UNIVERSIDADE DE SÃO PAULO

MUSEU DE ARQUEOLOGIA E ETNOLOGIA

PROGRAMA DE PÓS-GRADUAÇÃO EM ARQUEOLOGIA

\title{
OS VELHOS CAMINHOS DE CONGONHAS NUMA PERSPECTIVA DE EDUCAÇÃO PATRIMONIAL
}

VALBER SOUZA SILVA

Dissertação apresentada ao Programa de Pós-Graduação em Arqueologia do Museu de Arqueologia e Etnologia da Universidade de São Paulo, para obtenção do título de Mestre em Arqueologia.

"VERSÃO CORRIGIDA"

"A VERSÃO ORIGINAL ENCONTRA-SE NA BIBLIOTECA DO MAE"

Orientadora: Prof. ${ }^{a}$ Dr. ${ }^{a}$ Márcia Angelina Alves

Linha de pesquisa: Gestão do patrimônio arqueológico e Arqueologia Preventiva

São Paulo

Novembro 2014 



\section{Introdução}

Esta dissertação de mestrado é resultado da pesquisa em Arqueologia Histórica intitulada "Os velhos caminhos de Congonhas numa perspectiva de Educação Patrimonial”, que foi desenvolvida no município de Congonhas, Minas Gerais, Brasil.

O arraial de Congonhas do Campo teve origem no final do século XVII com a bandeira de exploração do paulista Bartolomeu Bueno. Os bandeirantes e aventureiros que chegaram de várias partes em busca do ouro na região do Rio Paraopeba adentraram seus afluentes e subafluentes, se fixando e fundando uma série de arraiais e povoados, em torno de uma igreja ou capela. Assim surgiu o arraial Redondo, que atualmente é o distrito de Alto Maranhão, o arraial de Soledade, que atualmente é o distrito de Lobo Leite e o arraial das Congonhas, que atualmente é a sede municipal. Estes arraiais, já no século XX, se uniram para formarem o que é hoje o município de Congonhas, que é o território ou a área histórica nuclear da pesquisa.

O município de Congonhas é ainda hoje muito conhecido nacionalmente e internacionalmente pelo seu nome anterior, Congonhas do Campo, que foi emprestado de uma planta existente nos campos da região que é a planta congonha (s.f. Luxemburgia polyandra), uma variedade de erva mate da família das arquifoliáceas, que possui propriedades diuréticas e é comumente consumida como remédio caseiro. O nome da planta vem do idioma Tupi e quer dizer: o que sustenta, o que alimenta (congõi) ou ainda, lugar onde o mato some.

Ao longo do século XVIII, as ricas minas auríferas de Congonhas do Campo foram largamente exploradas até que a exploração do metal precioso declinou, conforme diminuía a oferta do ouro de aluvião a partir da segunda metade do século XVIII, se agravando e acentuando durante o século XIX.

Conforme Celso Furtado (1980), o ouro explorado naquela região proporcionou as bases para a Revolução Industrial Inglesa. Também o desenvolvimento do Barroco Mineiro, estilo artístico predominante nas Minas Gerais dos tempos coloniais, se deu a partir da mineração do ouro.

Entre as igrejas barrocas remanescentes em Congonhas estão a Igreja de Nossa Senhora do Rosário, cujas obras tiveram início no final do século XVII, a Matriz de Nossa Senhora da Conceição, cujas obras tiveram início no século XVIII, a Igreja de Nossa Senhora da Ajuda, 
localizada no distrito de Alto Maranhão e a Igreja de Nossa Senhora da Soledade, ambas da primeira metade do século XVIII, a Matriz de São José Operário, que teve as obras iniciadas no século XIX e conclusão durante as primeiras décadas do século XX. Temos ainda em Congonhas o Conjunto Arquitetônico da Basílica do Senhor Bom Jesus de Matosinhos, construído durante os séculos XVIII, XIX e XX, com a participação de artistas renomados do Barroco Mineiro como os escultores Aleijadinho (Antônio Francisco Lisboa) e Francisco Vieira Servas e de pintores como José de Ataíde, João Nepomucemo e Burle Marx. O conjunto arquitetônico da basílica de Congonhas foi reconhecido pela UNESCO (Organização das Nações Unidas para a Educação, a Ciência e a Cultura) como Patrimônio Cultural Mundial no ano de 1985. Em Congonhas também se localiza a Romaria, cujas obras em estilo arquitetônico barroco tiveram início no final do século XIX e se estenderam até o início do século XX.

O município de Congonhas está localizado no limite sul do Quadrilátero Ferrifero, região de Minas Gerais onde se encontra uma das maiores jazidas de minério de ferro do planeta e que vem sendo explorada por diversas empresas mineradoras multinacionais e nacionais. Além do minério de ferro, outros minerais igualmente importantes para a fabricação dos mais variados produtos da indústria mundial são explorados no município de Congonhas. Entre eles destacamos o manganês e a bauxita, utilizados na fabricação de aço e de alumínio.

A exploração dos minérios e a siderurgia proporcionam uma demanda de mão de obra e de serviços especializados, tanto na mineração e na indústria quanto no comércio, o que por sua vez faz com que a cidade cresça econômica e demograficamente e que as obras de infraestrutura e habitação se tornem cada vez mais necessárias, assim como a expansão industrial e mineral.

Com isso, passado, presente e futuro se encontram em Congonhas, numa inter-relação nem sempre harmoniosa e organizada, já que nos últimos anos temos registrado alguns casos de incidências envolvendo o patrimônio arqueológico e sua consequente destruição. Portanto, nossa pesquisa em Arqueologia Histórica intitulada “Os velhos caminhos de Congonhas numa perspectiva de Educação Patrimonial” é uma pesquisa alternativa e originada em observações empíricas e em militância na defesa do patrimônio arqueológico histórico abandonado em Congonhas, Minas Gerais, ao mesmo tempo em que procuramos adaptá-la às correntes teórico-metodológicas e práticas desenvolvidas na Arqueologia ao logo de sua história, como o processualismo, o pós-processualismo e ao pós-pós-processualismo, o que se torna possível por meio de uma Arqueologia Histórica Interpretativa, que tem como referência a 
Arqueologia Interpretativa desenvolvida pelo arqueólogo Ian Hodder (1986, 1999 e 2003), que tem como características o fato de ser um método cumulativo e permitir intercalarmos informações proporcionadas pela documentação histórica escrita e pelo registro arqueológico. A arqueologia Histórica Interpretativa é também contextual, reflexiva e crítica.

Nossa pesquisa também está engajada junto ao Ministério Público de Minas Gerais, que procura viabilizar a elaboração de uma carta arqueológica para Congonhas, no intuito de minimizar os impactos negativos sobre o patrimônio arqueológico local. A carta arqueológica de Congonhas será a primeira do tipo a ser produzida em Minas Gerais e incluirá entre suas metas o georreferenciamento, a produção de informação arqueológica _arqueoinformação_e a criação de um sistema de informações por rede que possa auxiliar e orientar a população, empresários e poder público na preservação do patrimônio arqueológico em Congonhas.

Contudo, este trabalho precisa da interdisciplinaridade, porque, as ciências sociais ajudam principalmente a perguntarmos sobre os porquês, as finalidades de cada intervenção, a serviço de quem, para suprir quais necessidades e a quem ou o que afetam (Santomé, 1998). Desta forma, nos colocamos na empreitada de produzimos esta dissertação de mestrado em Arqueologia Histórica, que tem principalmente na História, na Antropologia, na Sociologia, na Museologia, no Direito e também na Educação, as disciplinas que formam o seu campo de diálogo teórico-metodológico e interdisciplinar, com vistas a proporcionarmos, além da identificação, georreferenciamento, mapeamento e interpretação dos vestígios arqueológicos, também um projeto de Educação Patrimonial que deve funcionar como uma forma de Arqueologia Preventiva, conforme os ensinamentos de José Luiz de Morais ${ }^{1}$, e buscarmos através de seus resultados, os referenciais proporcionados pela população detentora do patrimônio, que nos auxiliarão na construção de uma proposta para a preservação dos sítios arqueológicos de Congonhas, vislumbrando também a possibilidade de reutilização dos sítios arqueológicos para uma educação de forma permanente e duradoura e contribuindo para a formulação de meios adequados e coerentes de gestão do patrimônio arqueológico em acordo com a conjuntura atual do município de Congonhas, com a legislação patrimonial, numa perspectiva de futuro, contribuindo também com o Ministério Público de Minas Gerais na elaboração da carta arqueológica de Congonhas e realizando assim uma Arqueologia Pública.

Para lograrmos as metas desejadas, nosso projeto de pesquisa apresentado quando do ingresso no curso de mestrado do Programa de Pós-Graduação em Arqueologia do Museu de

\footnotetext{
${ }^{1}$ Aulas das disciplinas Métodos Arqueológicos (2010) e Arqueologia da Paisagem e Territórios Patrimoniais (2012).
} 
Arqueologia da Universidade de São Paulo (PPGArq-MAE/USP) foi organizado visando cumprir os seguintes requisitos:

\section{1 - Objetivos}

- Realizar uma pesquisa em Arqueologia Histórica Interpretativa [contextual, reflexiva, e crítica] (Hodder, 1986, 1999, 2003; Wilkie, 2009)², que por sua vez implica em:

- explicar as variações do objeto que chamamos velhos caminhos de Congonhas, e sua funcionalidade no contexto da região, considerando aspectos socioeconômicos e culturais naquela região desde a época do início da corrida do ouro nos tempos coloniais até os dias atuais;

- abordar relações de identidade e pertencimento da população local com o patrimônio arqueológico desde sua formação até os dias atuais;

- construir novas abordagens acerca da História da região e de seu povo;

- realizar uma Arqueologia Pública engajada com a sociedade, realizando trabalhos de Educação Patrimonial e coleta de referenciais junto à população de Congonhas, com vistas a buscar soluções para os seus problemas que envolvem o patrimônio arqueológico, numa perspectiva de futuro;

- discutir sobre aspectos da Arqueologia Preventiva, que devem gerar: discussões junto à população e Poder Público sobre critérios de preservação e gestão do patrimônio arqueológico empregados ao longo da história de Congonhas, e também sobre alternativas para preservação e musealização de remanescentes dos velhos caminhos para finalidades socioeducativas, visando o favorecimento da sociedade atual e das gerações futuras, considerando as possibilidades de formulação de um ecomuseu como alternativa principal de preservação, abrangendo assim, aspectos como a valorização do território da região formadora do município de Congonhas e sua paisagem única e exuberante, do seu patrimônio arqueológico,

\footnotetext{
${ }^{2}$ Em sua essência, a Arqueologia Histórica Interpretativa usa uma variedade de linhas de evidências para criar novas narrativas históricas em convergência com nossas experiências da sociedade contemporânea e fazer o passado acessível, relevante e até mesmo provocante. Ela trabalha também focada sobre os acasos, quando narrativas textuais e artefatuais contradizem uma a outra. Esta linha também busca perceber os registros documentais e arqueológicos intercalados e inseparáveis para as interpretações e narrativas arqueológicas.
} 
do seu patrimônio ambiental, do seu patrimônio imaterial, do seu patrimônio artístico e arquitetônico, todos vistos numa relação de interdependência e de importância fundamental para a compreensão da história da região e de seu povo.

\section{2 - Problemática}

$\mathrm{Na}$ pesquisa em Arqueologia Histórica produzida em Congonhas, a problemática se desenvolve principalmente a partir dos seguintes aspectos:

- crescimento industrial, urbano e adensamento populacional acelerados, por conta da extração de minérios e siderurgia, que sofrem pressão por conta de demanda mundial e possibilidade de destruição do patrimônio arqueológico que é desconhecido pela maioria da população. Neste sentido, também são impactados o patrimônio ambiental, o patrimônio artístico, o patrimônio arquitetônico e o patrimônio imaterial do município de Congonhas.

\section{3 - Hipóteses}

O que representam os vestígios arqueológicos encontrados na paisagem congonhense que denominados por "velhos caminhos", qual sua funcionalidade, e a que estariam eles associados?

- trilhas indígenas;

- trilhas abertas pelo colonizador;

- minas de ouro exploradas pela Coroa, nobres, senhores de escravos autorizados, homens livres ou faiscadores;

- às ruínas de igrejas, de sedes de fazendas de exploração de ouro;

- ao Caminho Velho da Estrada Real;

- às artes barrocas? 
O desenvolvimento desta pesquisa deve mostrar que os velhos caminhos de Congonhas passaram por diversos estágios e facetas, servindo desde trilhas para os nativos indígenas, até a chegada do colonizador português que as reutilizaram no transporte de ouro, mercadorias, animais e pessoas, fazendo parte também dos sistemas produtivos no interior das minas de ouro, influenciando no povoamento da região formadora do município de Congonhas, em suas vias de acesso e também em sua paisagem cultural, onde ganham destaque as igrejas barrocas, o casario colonial remanescente e os sítios arqueológicos que compõem a paisagem ao redor da cidade.

\section{4 - Pressupostos teóricos e metodológicos}

Uma pesquisa alternativa e originada a partir de observações empíricas e militância na defesa do patrimônio histórico deve, contudo, ser desenvolvida de acordo com paradigmas teóricometodológicos e práticos desenvolvidos no interior da disciplina Arqueologia Histórica.

Desta forma, para alcançarmos respostas arqueológicas e resultados satisfatórios, os trabalhos de pesquisa foram organizados de forma a cumprirem as seguintes etapas:

1 - pesquisa intensiva de campo com utilização do método indutivo e dedutivo, inspirado nos trabalhos etnográficos do antropólogo Ulrich Franz Boas (Alves, 2009 e 2013; Castro, 2004; Cuche, 1996; Fagundes, 2004; Stocking Jr, 2004);

2 - caminhadas sistemáticas para identificação, georreferenciamento e mapeamento de sítios arqueológicos;

3 - levantamento de dados envolvendo fontes documentais tais como sítios arqueológicos, sítios históricos, arte barroca, ou qualquer outra espécie de registro material que possam contribuir para o estudo arqueológico, documentos escritos como mapas, registros oficiais, cartas, e bibliografias variadas tais como livros, artigos, monografias, dissertações e teses, aproveitando e associando dados a informações oriundas de outras fontes como as fontes orais e outras acessíveis ao longo da pesquisa;

4 - análise do processo histórico de transformação da paisagem por aquela sociedade, inserida no tempo e espaço (Alves, 2009 e 2003; Fagundes, 2004; Leroy-Gourhan, 1965 e 1972) para chegar ao fato social total (Mauss, 1974); 
5 - reconhecimento da paisagem onde estão inseridos sítios arqueológicos e de sua de transformação histórica por processos antrópicos e naturais, de forma a compreender a formação dos sítios arqueológicos inseridos numa rede de relações interdependentes e de totalidade do tipo Wide Word Web (Morais, 2011);

6 - aproximação, discussão e coleta de dados junto à sociedade local: Poder Público, escolas, moradores e proprietários de áreas com potencial arqueológico; para realização de estudo de comunicação, recepção e avaliação e subsequente proposta de educação patrimonial e musealização de sítios arqueológicos que fará parte do corpo da dissertação.

Contudo, para prosseguimento deste trabalho interdisciplinar no campo da Arqueologia Histórica, é necessário também construir nossa abordagem à luz de subcampos da Arqueologia como a Arqueologia Urbana e a Arqueologia da Arquitetura, no intuito de fazermos a leitura da transformação da paisagem urbana do município e de sua paisagem cultural, considerando que o conjunto arquitetônico, escultórico e paisagístico do Santuário do Senhor Bom Jesus de Matosinhos foi tombado em 1938 e inscrito no Livro de Belas Artes e a cidade e seu conjunto arquitetônico e urbanístico em foram tombados e inscritos no Livro de Tombo Arqueológico, Etnográfico e Paisagístico em 1941, ambos em instância nacional, pela antiga Superintendência do Patrimônio Histórico e Artístico Nacional (SPHAN), tema relevante para a construção de uma abordagem contextual, reflexiva e crítica, porém complicado, porque pode ser facilmente confundido com ativismo ou denúncia, quando em Congonhas, destaca-se também a destruição sistemática de seu patrimônio arquitetônico, urbanístico, paisagístico, artístico e arqueológico ao longo de sua história.

Com efeito, reconhecemos que não se trata aqui de considerarmos o patrimônio arqueológico histórico como algo congelado no tempo e no espaço, ou que este deveria ser envolvido por uma espécie de campo de força a fim de que fossem evitadas quaisquer intervenções humanas ou da natureza sobre ele, mas também não é o caso para fecharmos os olhos para a realidade, deixando de lado as críticas e as reflexões acerca da efetividade de nossa legislação patrimonial e de como se comportam nossas instituições responsáveis pelo patrimônio cultural e assim, nosso conhecimento em Arqueologia é produzido em um lugar em que as políticas municipais são voltadas principalmente para o favorecimento e fortalecimento da indústria do ferro e aço, para o crescimento econômico, geração de empregos e por outro lado, na geração de pagamentos de pesados impostos sobre a indústria, comércio e cidadãos. 
Estes são fatores que interferem em nossa pesquisa tanto positivamente quanto negativamente, porque influenciam nossas decisões e geram consequências devastadoras sobre os sítios arqueológicos e outras manifestações culturais, o que justifica nossa escolha pela linha de pesquisa em Gestão do Patrimônio Arqueológico e Arqueologia Preventiva.

Portanto, em Congonhas, ao queremos fazer uma Arqueologia atualizada e preocupada em ajudar a construir a cidadania voltada ao patrimônio cultural daquela sociedade, a forma de Educação Patrimonial a que nos propomos a formular para o município deve, por isso, pretender ser permanente, abrangendo a rede de ensino local, para que alunos do ensino fundamental e médio possam ter acesso não somente aos sítios históricos e museus reconhecidos da cidade, mas também à arqueoinformação e ao patrimônio arqueológico, daí o vislumbre de buscarmos áreas para a preservação de vestígios arqueológicos para atividades educacionais. Os estudantes de agora serão os profissionais do futuro e nas mãos deles estarão decisões como as de que hoje nos responsabilizamos. Há também um grande receio, de muitos cidadãos, em se envolverem em questões relacionadas à Arqueologia, talvez pela falta de conhecimento sobre a disciplina, algo que temos tentado minimizar durante os trabalhos de Educação Patrimonial realizados no município.

Quanto ao público e população em geral, acreditamos que devem também receber informações acerca do patrimônio arqueológico do município por meio da educação, principalmente porque acreditamos que isso é a base para o conhecimento, para a formação intelectual dos cidadãos e para a preservação dos remanescentes do passado.

Outro fator que deve ser mencionado é sobre o termo velhos caminhos de Congonhas, empregado no título da dissertação de mestrado, e que surgiu de um universo hipotético, ao nos referirmos a marcas horizontais no solo, que muitas vezes se confundiam e se misturavam com trilhas, estradas, canais hidráulicos, galerias, muralhas, ruínas e grandes voçorocas abertas no solo, próximos a córregos e rios, formando o registro arqueológico.

Como apoio para a pesquisa, o minerador Wilhelm Ludwig Von Eschwege, engenheiro de minas e geólogo, foi responsável por grande parte de registros confiáveis sobre o garimpo a que podemos ter acesso ainda hoje. Também nos registros do padre jesuíta André João Antonil, buscamos subsídios escritos para orientar-nos em nossas prospecções, e desta forma, passamos a prosseguir por caminhos junto aos vestígios arqueológicos aflorados sobre o solo e que foram deixados pela mineração dos grandes veios auríferos que cortavam de sul ao norte e de leste a oeste, todo o solo de Congonhas. 
Contudo, entre as narrativas cientificas e as narrativas populares, acreditamos que no dever da Arqueologia, devemos considerar com cautela a todas elas, pois a Arqueologia é uma ciência social e histórica e nem sempre pode se apoiar na exatidão de dados, como é o caso de dados quantitativos provenientes de análises laboratoriais fornecidos pela Arqueometria, outro subcampo da Arqueologia mais ligado à processos fisioquímicos, principalmente.

Quanto aos sítios arqueológicos que conseguimos identificar, georreferenciar, mapear e divulgar, encontramos a Mina do Redondo, a fonte e a cadeia no distrito de Alto Maranhão, no antigo arraial Redondo, um dos primeiros povoamentos de garimpeiros da região, a Mina da Soledade, que fica às margens do Rio Soledade no distrito de Lobo Leite, antigo Arraial de Soledade, a Mina das Goiabeiras, mais próxima da sede municipal e chegamos próximos ao Morro de Santo Antônio, onde temos a Mina do Veeiro, que pertenceu à influente família dos Monteiro de Barros, que eram políticos e empresários na região de Congonhas e as ruinas abandonadas da Igreja de Santo Antônio, que por sua vez faziam parte de um conjunto que formava a Fazenda do Faria. Depois, no decorrer da dissertação, tratemos à parte de cada sítio e estudaremos caso a caso a viabilidade de cada um deles frente aos fins educacionais desejados.

Como foi mencionado anteriormente, buscamos realizar uma Arqueologia Pública engajada aos problemas por que passa o município atualmente, e por isso nos associamos e assumimos um posto no conselho fiscal da ONG Gota D'água do Alto Paraopeba, que abraçou e apoiou amplamente nossa pesquisa desde os primeiros dias. Esta ONG, no entanto, foi a entidade mais atuante na cidade na luta pela preservação do Morro do Engenho, tombado pela Câmara de Vereadores em 1997 como Patrimônio Cultural e Natural do Município de Congonhas, por fazer parte do conjunto paisagístico que compõe o entorno da Basílica do Senhor Bom Jesus de Matosinhos e também por ser reserva responsável por cerca de $50 \%$ do abastecimento hídrico do município.

A ONG Gota d'água do Alto Paraopeba também está envolvida em questões como o crescimento constante das barragens de contenção de rejeitos da mineração e passou, por nossa mediação, a fiscalizar também o tratamento dado ao patrimônio arqueológico do município de Congonhas e a se envolver nos trabalhos de Arqueologia Pública junto à população local.

Na cidade podemos ouvir expressões como: A serra é a moldura da obra do Aleijadinho em Congonhas. Apesar de expressões como esta, durante uma triagem de dados para nossa 
pesquisa de recepção e avaliação sobre a questão do abandono, gestão e preservação do patrimônio cultural que ocorreu durante nossos trabalhos de campo em Congonhas, temos notado, entre os cidadãos entrevistados em geral, uma grande dificuldade em compreender como diferentes fatores que se deram em diferentes contextos históricos se inter-relacionam sobre uma paisagem que se transforma constantemente.

Contudo, isto significou mais um desafio que se apresentou para a Arqueologia Histórica porque nos últimos anos, temos notado uma maior preocupação para a preservação dos recursos e dos remanescentes ligados ao passado. Contudo, é nosso interesse produzir uma Arqueologia Pública, engajados com a sociedade atual para buscarmos esclarecimentos e informações e com isso, há uma grande preocupação com as gerações de hoje e com as gerações futuras.

\section{5 - Procedimentos de campo, laboratório e gabinete}

No que diz respeito aos procedimentos de campo, laboratório e gabinete, empregamos princípios de estrutura organizacional próximos aos propostos por José Luiz de Morais em seu estudo intitulado "Perspectivas Geoambientais da Arqueologia do Paranapanema Paulista" (2011), às peculiaridades encontradas em nosso estudo de caso e às concepções teóricometodológicas e teóricas aplicadas à pesquisa, que por sua vez são organizados da seguinte forma:

\section{1 - Atividades de gabinete:}

1 - levantamento, aquisição, leitura, análise crítica, seleção de material bibliográfico para complementação do arcabouço teórico-metodológico e prático para desenvolvimento da pesquisa;

2 - levantamento, aquisição e produção de documentação cartográfica e aerofotogramétrica; 
3 - manipulação, comparação e interpretação de dados e de fontes variadas tais como elementos artísticos, arquitetônicos, culturais, geológicos, depoimentos orais e material historiográfico;

4 - produção de projeto de estudo de comunicação, recepção e avaliação;

5 - produção e seleção de material de apoio aos estudos de comunicação, recepção e avaliação tais como exposição fotográfica, questionários e 6 (seis) artigos para publicação no jornal Baruc, que é circulação regional no Alto Paraopeba e com tiragem quinzenal de 4.000 cópias (8.000 por mês) e 1 (um) artigo para publicação em livro sobre o patrimônio arqueológico de Congonhas;

6 - produção de uma proposta de Educação Patrimonial e musealização dos sítios arqueológicos identificados, georreferenciados e mapeados na pesquisa;

7 - finalização da composição do texto científico (dissertação de mestrado) em dois volumes.

\section{2 - Atividades de Campo:}

1 - reconhecimento e análise crítica de áreas de potencial arqueológico com caminhadas sistemáticas e prolongadas, considerando ambientação, vestígios arqueológicos, teorias, métodos e práticas desenvolvidos no campo da Arqueologia e da Arqueologia Histórica;

2 - aquisição de subsídios de estudo ambiental geral e observação do potencial arqueológico e museológico nas áreas pesquisadas;

3 - elaboração do detalhamento ambiental de setores delimitados e gerais, fotografando, levantando e mapeando sítios para registro junto ao IPHAN (Instituto do Patrimônio Histórico e Artístico Nacional) e outros órgãos estaduais e municipais responsáveis pela salvaguarda, curadoria e gestão do patrimônio cultural;

4 - prospecção sem coleta de superfície, utilizando a fotografia como elemento comprobatório do registro arqueológico;

5 - trabalho de coleta de referenciais junto à população local, envolvendo, escolas, ONGs, residências, órgãos públicos municipais (secretarias de meio ambiente, cultura, patrimônio, turismo) e museus. 


\section{3 - Atividades de Laboratório:}

1 - análise crítica e aproveitamento de documentação cartográfica e aerofotogramétrica referente à Congonhas e região;

2 - plotagem dos sítios registrados sobre documentação cartográfica;

3 - análise crítica e comparativa de material fotográfico produzido, a fim de revelar o registro arqueológico;

4 - restauração e recomposição de fotografias antigas de Congonhas.

\section{6 - A estrutura da dissertação}

Como forma de organização e trabalho, a dissertação de mestrado que apresentamos foi dividida em cinco capítulos, de forma que a redação pudesse abranger a problemática que envolve a pesquisa.

No primeiro capítulo, mais precisamente em sua primeira parte, à luz de autores principais como os historiadores Marc Bloch, Jean Glenisson e Jacques Le Goff, buscamos discutir acerca do termo "história", de sua abrangência, de seu entendimento e de seu emprego pela disciplina História e outras ciências sociais nos estudos acadêmicos, assim como do surgimento do movimento filosófico e metodológico ocorrido no campo da História, chamado pelos historiadores de História Nova, que buscava, entre outras coisas, compreender acerca da formação da disciplina História como ciência social, além de buscar aproximação interdisciplinar com outras ciências como a Arqueologia, que também é interessada nos estudos das sociedades pretéritas para a construção do conhecimento acerca da humanidade, acarretando em maiores interesses como a história problema no lugar da história conto, assim como os estudos relacionados à cultura material.

Para a abordagem acerca da cultura material, procuramos, à luz de autores principais como Jean-Marie Pesez, Richard Bucaille, Cesare De Seta e Carlos A. C. Lemos, construir uma abordagem acerca da importância de ciências como a Antropologia e a Arqueologia para os estudos e entendimento da cultura material, assim como de suas contribuições para a 
construção do conhecimento histórico. Também sob a luz dos autores supracitados, nos colocamos a buscar por uma definição do termo artefato, que é muito empregado pela Arqueologia, para abordarmos acerca do desenvolvimento da Arqueologia como ciência social.

Com base em autores arqueólogos como Pedro Paulo A. Funari e Bruce G. Trigger, o desenvolvimento paradigmático e epistemológico da Arqueologia é abordado da forma em que diferentes fases da disciplina, como ciência acadêmica, sejam considerados até chegarmos às concepções contemporâneas sobre a disciplina, com base em autores como Ian Hodder, Michael Shanks e David Witley, especializados em temas que abordam e elucidam sobre o papel do arqueólogo frente às comunidades com que trabalha e da importância do patrimônio arqueológico e de sua preservação para as gerações atuais e futuras, assim como para a própria Arqueologia.

A necessidade da interdisciplinaridade entre as ciências sociais, assim como a importância dos estudos sobre memória e memória coletiva foram abordados no primeiro capítulo, considerando autores principais como o educador Jurjo Torres Santomé, Jacques Le Goff, e Pedro Paulo de A. Funari.

A segunda parte do primeiro capítulo trata das abordagens construídas na área da Etnologia, da Antropologia e da Sociologia, mais precisamente com base em autores principais como André Leroi-Gourhan, Marceu Mauss, Denys Cuche, George W. Stocking Jr, Celso Castro e Márcia Angelina Alves, quando buscamos abordar acerca da aplicação do método dedutivoindutivo, a pesquisa intensiva de campo e o fato social total.

Com isso buscamos primeiramente mostrar como se deram alguns dos trabalhos antropológicos de Frans Uri Boas, que entre outras coisas, visitou e trabalhou entre povos indígenas como os KwaKiutl, os Chinook e os Tsimshiam, com interesse de estudar línguas, mitos nativos e reunir objetos para coleções museológicas, entre outros trabalhos. Depois, abordamos acerca da hipótese difusionista de Eduard Burnett Tylor e de sua elaboração do conceito científico de cultura. Mostramos porque o antropólogo Frans Boas é considerado o inventor da etnografia e o primeiro a fazer pesquisas in situ para observações diretas e prolongadas de culturas primitivas. Boas era crítico do método difusionista e o desconstruiu.

Procuramos mostrar que a questão social, objeto da análise de Frans Boas, ganhou impulso a partir da concepção de Marcel Mauss sobre o fato social, que ampliou o conceito do tio, 
Emile Durkheim para fato social total e que o conceito de fato social total tem como preocupação definir a realidade social ou, se preferimos, de definir o social como realidade.

No primeiro capítulo, procuramos também abordar temas relacionados à Arqueologia Histórica, seus inícios como disciplina no século XIX nos Estados Unidos, a institucionalização da disciplina e como a Arqueologia Histórica abarca sob seus olhares, os múltiplos aspectos ligados à questões de identidade e memória social. Buscamos definir a Arqueologia Histórica sob à luz de autores principais como Charles Orser Jr. e Pedro Paulo de Abreu Funari e com base em Russell J. Barber, procuramos mostrar que a Arqueologia Histórica expandiu seus campos de análises pós-processualistas e passou a se interessar por temas como as pessoas esquecidas no passado histórico, crescendo em interdisciplinaridade e em diálogos com subcampos auxiliares como a Arqueologia da Arquitetura, a Arqueologia da Paisagem, a Arqueologia Urbana e como a Arqueologia pode transcender os quadros estritos da historiografia assentada nas fontes escritas.

Com base em autores principais como Laurie A. Wilkie e Ian Hodder, analisamos a Arqueologia Histórica sob o olhar da teorização acerca dos métodos e práticas aplicados à Arqueologia Histórica Interpretativa, ramo recente da Arqueologia Histórica que tem conquistado diversos adeptos por todo planeta, influenciados por diferentes perspectivas teóricas que buscam através dela o comprometimento de construir interpretações arqueológicas empiricamente rigorosas, historicamente situadas e de relevância social, provindos de uma variedade de linhas de evidências para criar novas narrativas históricas que tenham ligações com nossas experiências da sociedade contemporânea e fazer o passado acessível, fazendo dos registros documental e arqueológico intercalados e inseparáveis para as interpretações e narrativas arqueológicas. Arqueologias Históricas Interpretativas são consideradas trabalhos fortemente empíricos porque convém que sejam feitos principalmente por aqueles pesquisadores que nasceram, viveram e possuem relações afetivas entre as populações pesquisadas e o patrimônio arqueológico em questão. Por isso são vistas como uma forma de Arqueologia caseira, ideais para o caso.

No primeiro capítulo, também abordamos acerca da Arqueologia da Paisagem, buscando analisa-la e compreendê-la dentro daquilo que autores principais como José Luiz de Morais, em seus estudos arqueológicos na Bacia do Paranapanema Paulista denominou integração $e$ interação ecossistêmica e holística. Buscamos, por meio desta metodologia, compreender a paisagem de Congonhas e sua transformação histórica por aquela sociedade como num 
sistema integrado em uma rede, ou melhor, numa wide word web, como propõe o próprio Morais.

Para o método de leitura da paisagem e a compreensão de sua transformação, nos apoiamos em autores principais como José Luiz de Morais, Filipe Criado Boado, e outros autores pontuais como Rossano L. Bastos e Marise Campos de Souza.

Com base em autores principais como Elizabeth A. Yentsch, Rebecca Yamin e Karen B. Metheny, focamos na interface da Arqueologia da Paisagem e seus laços interdisciplinares com a Arqueologia Urbana, a Arqueologia da Arquitetura, e a Geoarqueologia, ambas importantes no que diz respeito à compreensão da transformação humana do ambiente, do desenvolvimento das cidades e das sociedades que as formaram e que nelas vivem.

Em se tratando da Arqueologia da Paisagem em seu desdobramento urbano, a Arqueologia Histórica se aproxima da Geografia Urbana, do urbanismo e da Arquitetura. Arqueologia em meios urbanos nos remete à Arqueologia Urbana. Para tratarmos destes assuntos buscamos nos apoiar em autores principais como Fernanda Tocchetto, Beatriz Thiensen e José Luiz de Morais.

À luz de autores como Lewis R. Binford e Ana Luisa V. Bitencourt, discorremos acerca da importância para a abordagem de aspectos relacionados à Geoarqueologia para a compreensão dos vestígios arqueológicos resultantes da mineração de ouro, passiveis de serem examinados em cotas positivas e que se encontram ao longo do percurso dos velhos caminhos, associados aos veios de ouro explorados.

No segundo capítulo, abordamos o marxismo sob a ótica do arqueólogo Charles Orser Jr. e de sua importância para a Arqueologia Histórica e para os arqueólogos, assim como sob a ótica do historiador Eric Hobsbawm acerca da diferenciação entre o marxismo e o marxismo vulgar, já que a economia mundial e local e a forma como se desenvolveram são temas de grande importância para compreendermos a formação do registro arqueológico, da sociedade mineira e congonhense, assim como o tratamento dado ao seu patrimônio arqueológico e cultural numa visão geral.

Baseamo-nos em autores principais como Celso Furtado, Caio Prado Junior e Pierre Deyon, para abordarmos sobre o surgimento da sociedade mineira inserida num contexto mercantilista, num período quando a acumulação de ouro era a principal forma de riqueza nacional, ou, o metalismo. Assim, com base em outros autores principais como Laura 
Vergueiro (Laura de Mello \& Souza) e André João Antonil, adentramos na história do Ciclo do ouro em Minas Gerais, tratando de abordar acerca dos principais ciclos econômicos do Brasil até chegarmos ao século XX, quando da industrialização brasileira, até os dias atuais.

No terceiro capítulo, tratamos acerca da ambientação da área estudada. Desta forma iniciamos por discorrer acerca de dados geográficos e naturais do município de Congonhas, com suas características geológicas e geomorfológicas que são fatores importantes para sua compreensão socioeconômica desde os tempos coloniais até os dias atuais.

Tratamos também da formação de Congonhas, do ouro e toda exuberância que proporcionou a riqueza, a pobreza e o surgimento da sociedade mineira, representados principalmente em igrejas barrocas que ainda monumentalizam a paisagem congonhense, o jubileu, que com a fé no Senhor Bom Jesus de Matosinhos trouxe riquezas de fora, a chegada da ferrovia, que mudou as características urbanísticas e arquitetônicas do centro da cidade a partir do início do século XX e por fim, o minério de ferro.

Autores principais como Leonardo J. Silva e Bruno Milanez nos dão as bases para o levantamento historiográfico da cidade de Congonhas, inserida no contexto de um país mais industrializado, apoiados em produções oficiais como o Sumário de Dados de Congonhas, o informativo da Biblioteca Pública Municipal Dr. Djalma Andrade e o Atlas Escolar Histórico e Geográfico, além de utilizarmos de documentação primária escrita, cartográfica, aerofotogramétrica, entre outras.

No quarto capítulo, trabalhamos à luz dos relatos deixados pelo geólogo e engenheiro de minas alemão Wilhelm Ludwig Von Eschwege, com especial atenção aos trabalhos referentes à mineração de ouro. Também importantes para a compreensão da formação dos sítios arqueológicos históricos de Congonhas, são os registros do padre jesuíta André João Antonil, que conheceu as minas e seus caminhos durante a primeira metade do século XVIII, além dos trabalhos do arqueólogo brasileiro Carlos Magno Guimarães, que dedica boa parte de seu trabalho aos vestígios da mineração de ouro em Minas Gerais.

O geólogo alemão Wilhelm Ludwig Von Eschwege deixou por escrito diversos detalhes sobre suas pesquisas acerca da mineração, realizadas nos principais centros mineradores de Minas Gerais. Segundo ele, a mineração do ouro se deu em diferentes fases, em diferentes lugares de Minas Gerais, exigindo diferentes técnicas de extração e apuração do metal precioso, o que nos deixou diversos e diferenciados vestígios arqueológicos. Seus relatos são, por isso, considerados por nós fontes de informações relevantes que podem ser estudadas pela 
Arqueologia Histórica para a compreensão dos sítios envolvidos, pois a distribuição do ouro no solo influenciou a formação e a distribuição da população mineradora, a circulação de bens, serviços e cultura nas minas coloniais.

Durante o desenvolvimento do quarto capítulo, tratamos também de abordar temas como a legislação patrimonial no Brasil, aspectos relacionados à paisagem cultural, sua preservação e ao caso da paisagem de Congonhas, onde estão inseridos os sítios arqueológicos levantados com a pesquisa. Esta parte foi elaborada à luz de autores principais como José Luiz de Morais e Rossano Lopes Bastos e outros mais pontuais como Rafael W. Ribeiro.

Em seguida, tratamos de questões relativas às especificidades da paisagem cultural e de seus instrumentos de preservação legal, observando especificamente o caso da paisagem de Congonhas e nos apoiando em autores principais como Rossano Lopes Bastos, Wilson Rocha Assis, Rafael Winter Ribeiro e Ana Cristina Bandeira Lins e outros autores pontuais como Wagner Bornal e Cleyton Galdino.

Ao final do quarto capítulo, tratamos de especificar acerca dos sítios arqueológicos registrados no município de Congonhas. Das áreas de mineração aurífera que encontramos no território de Congonhas até o momento, podemos destacar sítios arqueológicos históricos que representam cinco grandes núcleos mineradores da região em que surgiu o município. São eles a Mina do Redondo, a Mina da Soledade, a Mina do Veeiro, a Mina das Goiabeiras e a Fazenda do Faria, além disso, existem estruturas arquitetônicas em ruínas próximas de alguns deles, como a capela de Santo Antônio, vizinha à Fazenda do Faria e a cadeia e a fonte do Alto Maranhão, localizadas no distrito onde havia a Mina do Redondo.

No quinto capítulo, com base em autores principais como Maria Cristina Oliveira Bruno e Natalia Tielve García e autores pontuais como Letícia Julião, Néstor García Canclini e Françoise Choay, tratamos de questões relacionadas aos resultados apresentados com a finalização da pesquisa, quando providenciamos um balanço da situação arqueológica encontrada no município de Congonhas, vislumbrando a realização de ações propostas para o futuro, que possam funcionar de forma positiva na preservação do patrimônio arqueológico e seu usufruto pela população local por meio de um ecomuseu.

$\mathrm{Na}$ última parte da dissertação de mestrado fazemos menção às considerações finais, proporcionando uma espécie de balanço da pesquisa de mestrado "Os velhos caminhos de Congonhas numa perspectiva de Educação Patrimonial”. 
Este trabalho também conta com um anexo, no segundo volume, onde trazemos o projeto de pesquisa de comunicação, recepção e avaliação, que é parte fundamental da pesquisa, porque reflete os resultados relacionados às questões de identidade e pertencimento da população de Congonhas frente seu patrimônio arqueológico histórico. Foi a partir deste estudo, junto às possibilidades encontradas no meio socioeconômico do município que buscamos referenciais para a formulação de uma proposta de educação patrimonial e musealização de sítios arqueológicos.

Fruto das transformações teóricas e metodológicas da Nova Museologia, a metodologia utilizada em museus conhecida como estudos de comunicação, recepção e avaliação, nos ajudaram a orientar-nos quanto aos aspectos mais relevantes e a considerarmos questões relacionadas à preservação, como suas probabilidades, potencialidades, viabilidades, relações de identidade e pertencimento da população frente ao seu patrimônio arqueológico e também suas fragilidades. Este estudo não ocorreu com o intuito de confirmarmos ou reforçarmos hipóteses previamente laçadas, mas sim para elucidarmos acerca de uma proposta coerente para o caso de Congonhas.

Com isso, buscamos integrar resultados conseguidos entre as práticas de campo e os trabalhos de gabinete e laboratório desenvolvidos no decorrer da pesquisa de mestrado intitulada "Os velhos caminhos de Congonhas numa perspectiva de Educação Patrimonial”, com a pesquisa de comunicação, recepção e avaliação, de forma participativa e em acordo com a conjuntura atual da cidade de Congonhas, e a partir de então, de posse dos referenciais coletados, nos direcionarmos rumo a uma proposta coerente que possa promover o patrimônio cultural pela Educação Patrimonial como desdobramento de Arqueologia Preventiva, e permitir a ressignificação do patrimônio arqueológico pela musealização de sítios arqueológicos e o manejo voltado para a educação, principalmente. O referido estudo foi desenvolvido sob a orientação da Prof. ${ }^{a}$ Dr. ${ }^{a}$ Márcia Angelina Alves e sob a coorientação da Prof. ${ }^{a}$ Dr. ${ }^{a}$ Marília Xavier Cury, ambas do PPArq-MAE/USP.

Também em anexo, no segundo volume, apresentamos diversas fotos, figuras, mapas e outros documentos organizados de forma a ilustrarmos de forma abrangente os diversos temas que foram tratados no decorrer da pesquisa como destruição e abandono de sítios arqueológicos, crescimento e problemas urbanos, transformação da paisagem cultural, entre outros.

Assim, tratamos de realizar um verdadeiro trabalho interdisciplinar em Arqueologia Histórica no município de Congonhas, em prol da identificação, preservação e usufruto do patrimônio 
cultural arqueológico pela sociedade que o detém, assim como de outras formas materiais e imateriais da cultura regional, visando o esclarecimento e a informação da população, resultando em uma Arqueologia Pública que visa a contribuir para a formação de uma cidadania voltada ao patrimônio. 


\section{Capítulo 1 - O universo teórico-metodológico}

\section{1 - História, cultura material e Arqueologia}

\subsection{1 - História}

Por se tratar deste nosso estudo uma pesquisa em Arqueologia Histórica, e em se tratando a Arqueologia de uma ciência histórica, temos o intuito de expandirmos a noção do conteúdo do termo História, iniciando nossa abordagem teórica-conceitual com os olhares voltados sobre a análise epistemológica que o historiador Marc Bloch (1976) desenvolveu acerca do conceito de História, nos fornecendo assim subsídios necessários para o entendimento acerca das direções sobre as quais os estudos históricos devem tomar.

Passando por uma análise das origens da palavra história, Bloch nos remeteu até os tempos mais remotos da etimologia do termo: “A palavra história é uma palavra velhíssima: [tão velha que houve quem se canse dela. É certo que foi raro chegar-se ao ponto de a querer riscar inteiramente do vocabulário]" (BLOCH, 1976, p. 85). Comparando o termo do ponto de vista de outras ciências sociais que fazem constante uso dele e que possuem, como os historiadores, o desejo de encontrar as melhores definições para o termo, Bloch descreveu:

Os próprios sociólogos da escola de Durkheim lhe dão guarida. Mas regam-na para um pobre cantinho das ciências do homem: espécie de refugo onde, reservado à sociologia tudo o que lhes parece susceptível de análise racional, precipitam os factos humanos considerados, simultaneamente, mais superficiais e mais fortuitos (BLOCH, 1976, p. 85).

Em contrapartida com a visão de história acima tomada como exemplo da noção do termo história, Bloch também nos ofereceu uma abordagem diferenciada, segundo sua ótica de historiador, o que ajuda para a compreensão do termo e seu direcionamento para a pesquisa e ainda nos convida a lembrar de diversas mudanças que o termo já sofreu e de suas diversas aplicações em outras ciências e em outros tempos: 
Nós lhe guardaremos aqui, pelo contrário, a sua mais larga significação. [A palavra não proíbe, de antemão, nenhuma direção de pesquisa, quer deva orientar-se de preferência para o indivíduo ou para a indagação de elementos mais duradouros; ela não contém em si nenhum credo; não obriga, consoante a sua etimologia primeira, a outra coisa além da 'investigação'.] Decerto a palavra, desde que apareceu, há mais de dois mil anos na boca dos homens, mudou muito de conteúdo. Tal é a sorte, na linguagem, de todos os termos realmente vivos. Se as ciências, a cada uma das suas conquistas, tivessem de procurar um nome novo para si - quanto batismo e quanto tempo perdido no reino das academias! (BLOCH, 1976, p. 87).

E ainda, conforme escreveu o historiador Jean Glenisson (1986), também existe uma diferenciação entre a história vivida e a história científica ou, se preferirmos, a história problema, que devem ser observadas de diferentes pontos de vista:

A palavra história assim é ambígua, e este traço encontra-se em todas as línguas e culturas: Em inglês, italiano, francês, português, espanhol, russo e mesmo em alemão, apesar dos esforços destinados a opor os dois vocábulos Geschichte [realidade histórica] e História [ciência histórica] (GLENISSON, 1986, p. 14).

Percebemos então que o termo história suscita diferentes interpretações e pode ser aplicado a diferentes campos do conhecimento humano, que por sua vez não podem dela se desvincular. Quanto ao seu alcance dentro do campo científico e da capacidade do pesquisador apreendêlo, o historiador ainda sugere:

Não é verdade que, perante a imensa e confusa realidade, o historiador é necessariamente levado a circunscrever nela, por conseguinte, uma escolha que, de toda evidência, não será a mesma do biologista, por exemplo; que será propriamente uma escolha do historiador. Trata-se de um autêntico problema de ação. Ele nos acompanhará ao longo de todo nosso estudo (BLOCH, 1976, p. 87).

Adiante, Marc Bloch nos questiona e ao mesmo tempo nos traz uma resposta: "Que aconteceu todas as vezes que houve que fazer imperioso apelo à intervenção da história? Surgiu o que era humano (BLOCH, 1976, p. 88)”. E ainda, sobre o objeto de estudo da História, assim ele afirmou: [...] "o objeto da história é por natureza o homem. Melhor, os homens. Mais do que o singular, favorável à abstração, convém uma ciência da diversidade o plural, que é o modo 
gramatical da relatividade" (BLOCH, 1976, p. 88). A história, para Marc Bloch, definitivamente, não é a ciência do passado.

Com isso, levando em consideração a abordagem de Marc Bloch sobre o termo história e a amplitude por ele alcançada, e com o intuito de abrangermos a noção do termo, dialogamos com a visão que outro historiador, Jackes Le Goff, apontou em sua obra "História e Memória" (1987) e assim, podemos proporcionar ao conhecimento produzido por historiadores uma confiabilidade, que o reserva o estatuto de trabalho científico: "A melhor prova de que a história é e deve ser uma ciência é o fato de precisar de técnicas, métodos, e de ser ensinada" (LE GOFF, 1987, p. 87).

Sobre este difícil problema teórico-metodológico sobre o qual nos colocamos a discutir, que é por sua vez objeto de obstinação das ciências sociais, e num sentido mais amplo, ciências gerais, destacamos o caminho apontado pela socióloga brasileira Regina Abreu (2009), que observou que a retroalimentação dialógica entre teoria e pesquisa é o ponto chave da produção do conhecimento e parâmetro de onde o pesquisador deve partir para formular boas questões. "O pesquisador é, sobretudo, um sujeito curioso que estabelece conexões de pensamento e formula questões" (ABREU in GONDAR \& DODEBEI, 2009, p. 29). E ainda, num processo que pode ser considerado coletivo pelas diversas interlocuções estabelecidas durante uma pesquisa, todo pesquisador dará também sua contribuição individual, contribuindo para a produção de conhecimentos, dialogando com outros autores dos quais utiliza os pensamentos, entre pesquisa e teoria (Abreu, 2009).

Neste sentido, podemos entender que o produto de uma construção que compromete sentido histórico das sociedades e validade de uma dita verdade histórica, o fundamento do trabalho histórico, e ainda, visando a construção do conhecimento científico no campo histórico, em sincronia com a multidisciplinaridade a que a história está obrigada a carregar consigo, o historiador Jacques Le Goff (1990) defendeu que historiadores devem estudar e colocar em prática todos os fenômenos da atividade humana, ou, dar forma cognitiva à história, de acordo com as condições históricas em que existiu. A presença do saber histórico é essencial no campo da ciência, da ação social, da política, da arte ou da religião. Como uma ciência também do tempo, a história se torna indispensável em toda atividade temporal, porém não como uma forma de memória manipulável e deformada, mas compreendendo que ela é uma forma de conhecimento falível, imperfeito, discutível, cujas normas de verdade e as condições profissionais que levam a sua elaboração e seu exercício permitam que sejam considerados científicos. 
Para o historiador Adam Schaff (1978), a História possui uma forma muito particular de lidar com o problema da objetividade da verdade histórica porque é dela que se tratará no contexto do conhecimento histórico, é um problema tipicamente filosófico, contudo, a história é construída pelo sujeito cuja realidade é percebida segundo uma espécie de mecanismo socialmente produzido, influenciado por um código de determinações sociais que penetram seu psiquismo pela linguagem com que pensa, pela mediação proporcionada pelas motivações conscientes ou subconscientes e principalmente pela mediação de sua prática social, ou seja, o conhecimento produzido sobre um determinado tema poderá variar muito de um pesquisador para outro.

E ainda, há perigos e surpresas dentre os quais o pesquisador envolvido pela pesquisa deve estar atento. Segundo o historiador Elias Thomé Saliba (1991), a confiança excessiva na força das ideias, a ansiedade em captar algum traço de regularidade num mundo convulsionado pelas revoluções, poderia conduzir alguns espíritos, como conduziu algumas vezes, a perderem-se nos meandros da subjetividade onírica, correndo, depois, o risco de verem-se estigmatizados como visionários. Numa linguagem mais popularizada, são os ossos do ofício.

Com isso, ao passo de que compreendemos a abrangência do complicado processo científico da pesquisa histórica, devemos também estar atentos às armadilhas existentes nos múltiplos caminhos que a pesquisa histórica científica pode trilhar, tanto do ponto de vista metodológico, quanto dos pontos de vista teórico-filosófico e prático.

Tais pontos elementares ao desenvolvimento paradigmático das ciências sociais tiveram um ponto fulminante com a fundação da revista "Annales" (Annale d'histoire économique ET sociale - 1922 e Annales. Écnomies, Societés, Civilization - 1945) ${ }^{3}$, obra de Lucien Febrev e March Bloch (apud. Le Goff, 1990), e com ela o surgimento do movimento que ficou conhecido por História Nova.

Foi nesse momento que a História buscou reforçar seus laços em direção a uma relação mais íntima com a Arqueologia, assim como com outros campos do conhecimento humano e

\footnotetext{
${ }^{3}$ Segundo Le Goff, as ideias da revista levaram à fundação, em 1947, por Lucien Febrev, de uma instituição de investigação e de ensino de investigação em ciências humanas e sociais. Em 1975 foi fundado a École des Hautes Études en Sciences Sociales, um instituto onde a história teria um lugar importante, ao lado da geografia, sociologia, antropologia, psicologia, linguística e semiologia e assegurou na França e em outros países a difusão das ideias que tinham estado na origem dos Annales. Fernand Braudel, decompôs a história em três planos sobrepostos, "o tempo geográfico", o " tempo social" e o "tempo individual", publicou ainda um artigo sobre "longa duração" (1958), que mais tarde influenciaria uma parte considerável da investigação histórica subsequente. Nos anos 70, diversas obras, em sua maioria coletivas, fariam balanços sobre as novas orientações em história. Novos objetos de estudo como o inconsciente, o mito, a mentalidade, a língua, o livro, os jovens, o corpo, a cozinha, a opinião pública, o filme, a festa, os marginais, tinham se fixado no clima (Le Goff, 1990).
} 
aconteceu a crítica ao fato histórico, à história positivista, a substituição da história conto pela história problema. Buscavam um maior tratamento interdisciplinar entre as fontes e aumentava a preocupação com a variada documentação produzida pelo homem (Le Goff, 1990) e os diferentes tipos de testemunhos dos pensamentos e ações humanas. "A diversidade dos testemunhos históricos é quase infinita. Tudo quanto o homem diz ou escreve, tudo quanto fabrica, tudo quanto toca pode e deve fornecer dados a seu respeito" (GLENISSON, 1986, p. 136).

Portanto, a busca interdisciplinar por novas fontes levaria os historiadores a se preocuparem e a observarem mais as questões relacionadas à cultura e cultura material, além disso, a aproximação da disciplina História com a Arqueologia se tornou mais fortalecida, constante e interdependente.

\subsection{2 - Cultura material}

O conceito de cultura passou a ser discutido com maior ênfase nas ciências sociais porque desde a introdução do conceito entre as ciências, estudiosos passaram a assistir a um notável desenvolvimento das pesquisas sobre a questão das variações culturais, particularmente nas ciências sociais americanas.

Desta forma, segundo Denys Cuche (1996): “Contrariamente à noção de sociedade, mais ou menos rival no mesmo campo semântico, a noção de cultura se aplica unicamente ao que é humano" (CUCHE, 1996, p. 13). Neste sentido, conforme apontou este mesmo autor: "E ela oferece a possibilidade de conceber a unidade do homem na diversidade de seus modos de vida e de crença, enfatizando, de acordo com os pesquisadores, a unidade ou a diversidade" (CUCHE, 1996, p. 13). E mais:

Pesquisas sobre sociedades extremamente diversas fizeram aparecer a coerência simbólica [jamais absoluta, no entanto] do conjunto das práticas [sociais, econômicas, políticas, religiosas, etc.] de uma coletividade particular ou de grupos de indivíduos (CUCHE, 1996, p. 13). 
Com isso, os intelectuais das ciências sociais passavam a perceber cada vez mais a importância da cultura material para os estudos históricos, e isso certamente se tornava tema de grande interesse para a Nova História:

(...) a expressão específica cultura material é apenas uma formulação muito restritiva dos múltiplos aspectos que compõem esta noção e não abarca a sua totalidade: a cultura material é composta por parte, mas não só, pelas formas materiais da cultura (BUCCAILLE \& PESEZ, 1989, p. 20).

A noção de fonte documental para a construção do conhecimento histórico foi então ampliada com o estudo da cultura material, não litando-se apenas ao estudo das fontes escritas. Os documentos escritos tornam-se cada vez mais raros na medida em que recuamos no tempo, daí a necessidade de recorrer às fontes materiais. A noção de cultura material surgiu nas ciências humanas, em particular, na História, depois da formação da Antropologia e da Arqueologia e da influência marxista do materialismo histórico, marcando distância em relação ao conceito de cultura e chamando atenção para aspectos não simbólicos das atividades produtivas do homem para produtos e utensílios, bem como para a variação das técnicas, para os materiais e objetos concretos no meio das sociedades humanas (Buccaille \& Pesez, 1989), e ainda, a ideia de cultura material sofreu mudanças e influências das modificações epistemológicas que assinalaram as ciências humanas contemporâneas, adaptando-se a uma conjuntura científica mutável, o que nos mostra sua adaptação às necessidades intelectuais de nosso tempo, ao mesmo tempo de forma estável e adaptável às exigências do momento, possivelmente correspondendo às necessidades constantes das ciências humanas e satisfazendo-as.

Segundo Jean Marie Pesez (1998), historiadores e arqueólogos são os que mais se utilizam da expressão cultura material, porém, geralmente não dão a ela uma definição nominal, que dê conta brevemente e de maneira adequada da significação da expressão, se limitando geralmente a empregar a noção como se os termos pelos quais é designada bastassem para defini-la. E ainda, observando o que supõe a materialidade associada à cultura, a cultura material tem relação evidente com as injunções materiais que pesam sobre a vida do homem e às quais ele opõe a resposta que é a cultura, porém, em se exprimindo a cultura de maneira abstrata, a cultura material faz parte das infra-estruturas mas não as recobre, pois se exprime no concreto, nos objetos e pelos objetos. 
Contudo, nenhuma outra ciência proporcionou melhor tratamento da cultura material que a Arqueologia. "Quem diz arqueologia diz vestígios de habitações e de edifícios, de objetos domésticos e de utensílios, etc., logo, de cultura material" (BUCAILLE \& PESEZ, 1989, p. 18). E ainda, segundo estes mesmos autores, devido à base epistemológica e metodológica dos arqueólogos, os historiadores confiam cada vez mais na documentação produzida, chegando a confundirem-se estes dois profissionais na mesma pessoa e ainda, [...] "colocando-a numa perspectiva cultural no sentido que dá a este adjetivo, o estudo da cultura material introduz nas ciências humanas, e particularmente no estudo da pré-história, a dimensão do maioritário e do coletivo" (BUCAILLE \& PESEZ, 1989, p. 21).

Tratando de cultura material, termos como artefato e objeto podem ser considerados sinônimos. Conforme sustentou Carlos A. C. Lemos (1987), os artefatos podem ser divididos em categorias e é necessário prestar atenção nas relações entre artefato e o meio ambiente, entre o saber e o artefato, entre o artefato e o homem e também entre o homem e a natureza.

Ainda segundo o mesmo autor, um objeto fora de seu contexto deve ser entendido como um fragmento, [...] "ou um segmento, de uma ampla urdidura de interdependências e entrelaçamentos de necessidades e de interesses satisfeitos dentro das possibilidades locais da sociedade a que ele pertence ou pertenceu” (LEMOS, 1987, p. 11). Assim, os artefatos podem ser encarados de diversas maneiras, e isso pode ser compreendido segundo sua utilidade imediata ou segundo sua durabilidade ou persistência, assim, eles possuem vida útil e sua durabilidade pode variar muito dependendo do material empregado ou sua utilidade.

Há também os artefatos utilizados para a fabricação de outros, e há também serventias diversificadas ou fins utilitários diversos e ainda, alguns artefatos podem ter seu uso comum substituído por outro tipo de uso, como uma casa de um barão dos tempos do Ciclo do Café que hoje em dia é utilizada como uma biblioteca pública, sendo assim, artefato de uso prolongado que teve que se adaptar a sucessivas alterações nos usos e costumes de um povo e desta forma, [...] "assistimos à saída de um artefato de seu meio original para começar a participar de outro contexto com outras relações e quase sempre com outras funções" (LEMOS, 1987, p. 19).

Existem os artefatos que podem ser divididos entre aqueles que são feitos em grande escala e repetidamente numa série, feitos à mão ou e à máquina, dependendo da sociedade que o produz ou da necessidade que ele venha a suprir. 
Há também artefatos de uso diário que podem se tornar diferenciados de seus iguais, dependendo das pessoas que os utilizaram ou dos eventos de que podem ter participado, ocorrendo uma sacralização do objeto (Lemos, 1987), muitas vezes acompanhada de afirmações sem comprovação e assim, uma espada utilizada numa batalha por um guerreiro de destaque pode se tornar objeto de veneração de um grupo ou de uma sociedade, assim como as cruzes ganharam destaque entre os cristãos, por ter ocorrido numa delas a morte de Jesus Cristo.

Contudo, para Cesare De Seta (1984), devemos evitar em nossas análises as armadilhas que as definições do termo objeto oferecem, segundo as quais objeto é considerado tudo aquilo que existe para o conhecimento, sendo o mundo inteiro não mais que representação.

Há também implícito na questão da cultura material, os problemas relacionados à sua fabricação e utilização, típicos nas discussões do mundo da Arqueologia, pois a história humana é também a história destes processos, perpassada por um número incalculável de objetos que surgem em momentos criativos muito diversos e também largamente numerosos, que nos diferencia dos programas únicos que as outras espécies animais podem executar em sua perfeição (Seta, 1984).

Contudo, os avanços da Arqueologia nos estudos da cultura material cresceram consideravelmente. Na Rússia, quando da guerra civil em 1919, Lênin assinou um decreto instituindo a Academia de História da Cultura Material da URSS (União das Repúblicas Socialistas Soviéticas).

Nesse acontecimento ficaram marcados fatos e conotações que concernem à noção de cultura material, como sua emergência tardia frente à necessidade de uma longa maturação epistemológica no âmbito da renovação do pensamento científico caracterizado na segunda metade do século XIX, sua colusão com o materialismo histórico e a importância atribuída a ela pelos marxistas, o seu aparecimento numa nação socialista e suas relações muito próximas da História, designando também o método arqueológico como melhor meio de acessar a história da cultura material.

Graças à arqueologia, o estudo da cultura material deu um salto. Por um lado, a arqueologia afirma-se como um caminho vantajoso para aceder à cultura material; por outro, esta última depara-se-nos como o melhor objetivo que a pesquisa arqueológica poderia propor-se (BUCAILLE \& PESEZ, 1989, p. 18). 
O desenvolvimento das ciências humanas não se concebeu fora da corrente evolucionista e nessa corrente, a Arqueologia, cujo desenvolvimento estaria para muitos na tomada de consciência da cultura material, já que importava para ela os aspectos materiais das civilizações e baseando neles, refletiu a própria definição das culturas e sua evolução: a Arqueologia pré-histórica.

O estudo da pré-história usa hoje a própria expressão 'cultura material' de modo mais limitado do que o da história; pode, no entanto, dizer-se que a pratica numa medida não inferior, como demonstram as numerosas escavações pré-históricas e os seus admiráveis resultados. Enumerá-los levaria muito tempo: limitar-nos-emos ao conhecidíssimo exemplo da escavação feita por Leroi-Gourhan em Pincevent, próximo de Paris, onde conseguiu reconstruir as tendas, as lareiras, o ambiente doméstico dos caçadores magdalenianos, bem como a estação de caça, as quantidades de carne disponíveis (com prudência, é certo) para cada indivíduo e algumas maneiras de cozinhar: não estará assim a arqueologia a desempenhar o papel atribuído por Marc Bloch à história da cultura material? (BUCAILLE \& PESEZ, 1989, p. 19-20).

A esta altura, historiadores já pesquisavam a história preocupados com a análise crítica da tecnologia, pois não dissociavam o estudo dos meios de trabalho do homem no processo de produção do estudo da própria produção. Influenciados por Karl Marx, historiadores marxistas da cultura material deveriam, portanto, colocar a cultura material em evidência.

Concluindo, o estudo da cultura material privilegiou as massas em detrimento das individualidades e das elites, dedicou-se a fatos repetidos como ciclos, hábitos e tradições e não ao acontecimento. Não se ocupou das supraestruturas, mas das infraestruturas, e tendo surgido nos países da Europa Ocidental entre investigadores predispostos a considerar de modo especial as economias e os modos de produção e desta forma, o homem como parte da cultura material, com seu corpo, seria considerado transmissor semiótico e igualmente importante para recompor o quadro geral de uma cultura ou de uma civilização, da mesma forma que partindo de farrapos e moedas para delinear uma cidade, a indústria, o comércio e a troca e assim, os tipos de consumo diferenciados de acordo com cada classe de uma população, de um determinado local, de um determinado tempo e desta forma, os objetos materiais passaram a trazer consigo muitas das marcas inerentes às artes, ao direito, à religião, ao parentesco, aos hábitos alimentares, à sexualidade, cuja Arqueologia aprendeu a valorizar 
em suas análises e somente considerando um quadro em conjunto é que se pode individualizar o estado de uma sociedade ou seu progresso e sua evolução, visualizados através dos utensílios que ela produz e assim, a cultura material tende a lançar uma ponte para a imaginação humana e sua criatividade e a considerar como suas três componentes fundamentais: o espaço, o tempo e o caráter social dos objetos e embora ainda pouco bem definido pelas ciências sociais e com algumas ambiguidades, o estudo da cultura material pertence à pesquisa histórica e com ela colabora através de métodos próprios para exame das espirais inerentes a todos os vestígios do passado humano (Bucaille e Pesez, 1989).

Enfim, a Arqueologia, mais que qualquer outra ciência, está disponível ao estudo dos objetos, da cultura material e com isso, cada vez mais aumentou seus laços interdisciplinares com a História e com ela produz conhecimentos inesgotáveis acerca da humanidade e seu passado.

\subsection{3 - Arqueologia}

A esta altura de uma busca epistemológica e paradigmática no seio das ciências sociais, a Arqueologia, disciplina acadêmica que por sua vez também passava por sua própria batalha intelectual entre as ciências sociais, podia ser considerada experiente quanto à difusão das teorias relacionadas à cultura material.

Segundo a etimologia, a palavra Arqueologia vem do idioma grego e muito reflete o significado atribuído a ela durante principalmente a maior parte de sua história (arque quer dizer antigo e logos quer dizer discurso, ciência) e com isso, a Arqueologia era vista como estudo do que é antigo, do passado, ou braço direito da História, porém, a forma de pensá-la e de exercê-la tem mudado ao longo de sua trajetória entre as ciências do homem.

A Arqueologia se desenvolveu sob uma série de conjunturas e tendências mundiais que a influenciaram desde sua formação até os dias atuais, refletindo em mudanças paradigmáticas. Com isso ocorreram mudanças teórico-metodológicas e também em seu campo prático.

Portanto, para entendermos sobre o desenvolvimento da Arqueologia e sobre seu papel no mundo de hoje, é preciso situá-la historicamente dentro do campo de forças em que se deu o processo de formação da disciplina. 
A Arqueologia, surgida na Europa, teve algumas de suas bases assentadas na História da Arte, na Arquitetura e nas formas, sendo desta maneira uma herdeira das tradições renascentistas. De início, em termos de teoria, a Arqueologia veio a ter difundido o modelo históricocultural, já que o nacionalismo do século XIX teria a influenciado bastante, sendo assim, cada nação ou país seria composto de um povo ou grupo étnico definido biologicamente, um território delimitado e uma cultura distinta das demais, manifestada por meio de uma língua e pelas tradições e práticas sociais.

Neste período formou-se o conceito de cultura arqueológica, que era entendido como um conjunto de artefatos semelhantes, de uma dada época, que seria a representação de um povo que tinha uma cultura diferente das demais e território demarcado e que buscava, contudo, orientações acerca das origens e da distribuição dos povos europeus. O modelo histórico cultural surgiu na Alemanha, pelo trabalho de Gustav Kossina e se generalizou por meio de Vere Gordon Childe, que desenvolveu o conceito de cultura arqueológica, adaptando-o ao evolucionismo materialista de origem marxista (Funari, 2007).

Apesar da proximidade com a História, principalmente por sua experiência em lidar com os mais diversos artefatos ou objetos produzidos pelas mãos dos homens, considerados fontes de fundamental importância para a pesquisa histórica, a Arqueologia ainda andou por muito tempo no campo da teoria até que, ao exemplo da História Nova, reconhecesse seu papel entre as ciências sociais e tomasse consciência de sua intrínseca natureza multidisciplinar para finalmente alcançar e reconhecer seu papel entre as ciências sociais.

A década de 1960 trouxe questionamentos ao histórico-culturalismo com o surgimento da Nova Arqueologia ou Arqueologia Processual. A Arqueologia Processual se desenvolveu no início de um período de mudanças intelectuais em filosofia, ciências e humanidades (Whitley, 1998). Segundo o arqueólogo Bruce Trigger, a América do Norte foi o local onde as mudanças no pensamento arqueológico foram mais profundas e ainda, as culturas arqueológicas já não eram consideradas mera soma dos respectivos tipos distintos de artefatos preservados passíveis de tratamento em bases estilísticas, como sendo independentes e de igual importância, em vez disso, elas tinham que ser analisadas como configurações ou mesmo como sistemas funcionalmente integrados. Neste sentido, o objetivo básico dos arqueólogos devia ser o de explicar as mudanças das culturas arqueológicas em termos de processos culturais (Trigger, 2004). 
Ainda segundo Bruce Trigger (2004), esses conceitos foram popularizados por Lewis Binford, que engajou-se em uma série de vigorosas polêmicas nas quais tentou demonstrar as vantagens da Nova Arqueologia sobre os enfoques tradicionais. A Arqueologia passava a ser entendida como Antropologia e disso surgiu o grito de guerra "A Arqueologia é Antropologia e nada mais". Enquanto que a história buscava eventos e culturas singulares, a Antropologia americana buscava leis transculturais de comportamento, ressaltando que existiam regularidades no comportamento humano (Funari, 2007).

A oposição de Lewis Binford ao enfoque histórico-cultural ainda influente nos Estados Unidos representou uma ruptura teórica com o passado não menos significativa que a metodológica e prática (Trigger, 2004). A década de 1960 também viu um grande aumento do que arqueólogos chamaram de Arqueologia dos Assentamentos, com seus estudos de demografia pré-histórica, mudança cultural, origens da agricultura e irrigação, uso humano do solo, plantas e animais. Os métodos arqueológicos associados com esse aumento eram filosoficamente positivistas e metodologicamente rigorosos, com pesada ênfase nos vestígios materiais e o compromisso com a noção de que o comportamento para a subsistência foi a infraestrutura dos sistemas culturais (Flannery \& Marcus, 1998). O que primeiro parecia ser meramente um período de reequipamento técnico produziu profundos problemas práticos, teóricos e filosóficos para os quais os novos arqueólogos tinham respondido com diversos novos métodos, novas observações, novos paradigmas e novas teorias (Clarke, 1973).

Uma nova onda de pensamento começou novamente a mudar a Arqueologia a partir da década de 70. Alguns arqueólogos reclamavam que o foco materialista da década de 60 desumanizava a história e que os caminhos deveriam ser seguidos para incluir mais dos valores, ideias, crenças e processos mentais que fazem da espécie humana uma espécie única (Flannery \& Marcus, 1998). Mas foi a partir da década de 1980 que começaram a surgir críticas mais contundentes ao Processualismo e nas ciências humanas em geral difundia-se o pós-modernismo e as críticas à crítica à ideia de verdade científica.

Alguns arqueólogos como Ian Hodder ressaltaram que havia uma dimensão simbólica na cultura e também que ela não podia ser deixada de lado (Funari, 2007). E ainda: “A partir da noção de que as ciências são construções discursivas, inseridas em contextos sociais, desmontou-se a lógica do processualismo: os homens não foram sempre e em toda parte capitalistas!" (FUNARI, 2007, p. 80-81). Este mesmo autor também fez a seguinte afirmativa: 
Os autores uniram as vertentes filológicas, históricas e filosóficas da crítica social às reflexões da Antropologia contextual, em um ataque devastador aos pressupostos histórico-culturais e processuais, caracterizados como discursos a serviço das potências imperialistas e da exploração. Já antes disso, Bruce G. Trigger contestava que a New Archaeology era uma forma de Arqueologia imperialista. A Arqueologia pós-processual ou contextual introduziu, de forma explícita, a dimensão política da disciplina, sua importância na luta dos povos pelo seu próprio passado e por seus direitos (FUNARI, 2007, p. 81).

Começava assim a surgir uma Arqueologia Pós-processual, que se desenvolveu sobre a base da Arqueologia Cognitiva de Renfrew (Trigger, 2004) e ganhou impulso com a publicação de "Reading the Past" (1986) de Ian Hodder, que afirmava que a Arqueologia não podia ser interpretada adequadamente de maneira fragmentada (Hodder, 1986).

A distinção convalidou o interesse por cosmologias, tradições astronômicas, estilos de arte, crenças religiosas particulares e outros tantos tópicos deixados à margem da Arqueologia Processual nas décadas de 1960 e 1970 (Trigger, 2004). Novas ideias junto com as antigas e também os arqueólogos passaram por um campo minado teórico e emergiram do outro lado com mais senso de como o social e o ideológico eram fatores significantes na formação do passado (Price \& Feinman, 2001), e desta forma, as diferentes especialidades dentro da disciplina $^{4}$ têm aumentado enormemente no que se refere às suas próprias perspectivas e métodos (Hodder, 1999).

E ainda, o debate processual/pós-processual tem centrado sobre as formas do conhecimento para uma ciência social, como a sociedade pode ser compreendida, harmonizando padronização ou estrutura e ação individual, intenção e agência, e sobre as atividades da disciplina da Arqueologia, suas ideologias e políticas culturais, seu lugar no presente [pós] moderno (Shanks \& Hodder, 1998).

Permaneceram ainda as preocupações que vinham sendo discutidas desde a década de 70 tais como o caráter da ciência e as intenções da explicação objetiva, o caráter da sociedade e o lugar dos valores na Arqueologia, as implicações sócio-políticas da disciplina e seu lugar atual como um modo de produção de conhecimentos (Shanks \& Hodder, 1998). Se tornaram acentuados os estudos dentro do próprio campo discursivo da Arqueologia e da formação de conceitos modernos que moldam os discursos possíveis e se multiplicaram os estudos sobre a invenção de quadros interpretativos com ênfase na História das Arqueologias, como

\footnotetext{
${ }^{4}$ Dentre as quais podemos destacar como exemplos a Geoarqueologia, Arqueologia Histórica, Arqueologia da Arquitetura, Arqueologia da Paisagem.
} 
procedimento heurístico para a crítica das práticas discursivas, no interior da disciplina (Funari, 2007).

Com isso passou a ocorrer maior intercâmbio entre as diversas correntes do pensamento arqueológico e a Arqueologia passou cada vez mais a se aproximar de outros ramos da ciência e do conhecimento humano, acompanhando uma tendência mundial nas academias:

A elaboração de políticas a favor da interdisciplinaridade obriga a prestar atenção a uma série de condições; de maneira especial, exige mudanças nas estruturas institucionais, novas relações entre os especialistas baseados na colaboração e não na hierarquização, e ainda menos nas tentativas de deslegitimar as especialidades rivais, e uma ligação cada vez mais íntima entre as instituições universitárias de pesquisa e ensino com o resto das esferas da sociedade (SANTOMÉ, 1998, p. $82)$.

Diante deste quadro apresentado, o compromisso da Arqueologia frente à sociedade se ampliou e ainda, o surgimento de especialidades aproximou a Arqueologia de diversas outras ciências, reforçando o seu caráter dinâmico e transdisciplinar que, como consequências, nas últimas décadas, foram observadas na aproximação cada vez maior da disciplina com questões relacionadas à memória social e ao patrimônio cultural (Peixoto, 2009). Além disso, ganhou destaque a aproximação com as sociedades detentoras do patrimônio arqueológico pela musealização e difusão de materiais arqueológicos oriundos de escavações, pela educação patrimonial e pela alternativa de uso da Arqueologia e de sua produção como estímulo para o turismo e geração de empregos e renda, um período que arqueólogos como José Luiz de Morais ${ }^{5}$ e Ian Hodder (2003) chamaram de Pós-pós-processualismo.

Portanto, era necessário que antes a Arqueologia descobrisse a si mesma e reconhecesse seu papel fundamental e único entre as ciências, para que uma definição mais específica do seu campo de ação pudesse ser formulada:

A Arqueologia é a ciência que estuda o passado da humanidade por meio de vestígios, artefatos, modos de fazer e criar que compõem a então chamada cultura material pelos estudiosos. Ao contrário do senso comum, a Arqueologia não se incumbe somente do estudo das sociedades do passado, mas das ainda existentes (MORAIS \& MORAIS, 2011).

\footnotetext{
${ }^{5}$ Aulas da Disciplina Métodos Arqueológicos e Arqueologia da Paisagem e Territórios Patrimoniais.
} 
Desta forma, na medida em que se alarga o campo dialógico da Arqueologia com outras ciências, ela transforma-se epistemologicamente, mantendo forte a noção de uma ciência voltada para o estudo das formas, da cultura material e das sociedades do passado, porém abrangendo cada vez mais o caráter humano da disciplina e sua importância para o conhecimento das sociedades vivas, com as quais os arqueólogos interagem e trabalham.

Com isso, a busca pelo papel científico entre as disciplinas acadêmicas História e Arqueologia está se definindo. A História Nova, fruto do amadurecimento da História frente às ciências sociais, não pôde associar de imediato suas perspectivas teóricas e metodológicas às da Arqueologia e por isso, teve que esperar o amadurecimento natural ocorrido no interior desta última para que cada uma pudesse então reconhecer seu papel único e se apoiarem na direção da construção do conhecimento acerca da humanidade.

\subsubsection{1 - Arqueologia Pública}

Nos últimos anos, os debates em torno da Arqueologia têm aumentado a ênfase pela participação das populações detentoras do patrimônio arqueológico e assim, uma Arqueologia da Herança Cultural tem crescido em todo o planeta porque muitos foram os fatores que contribuíram para o aumento na ênfase sobre a preservação de recursos e sítios arqueológicos, incluindo movimentos ambientalistas, uma maior consciência do rápido tempo da destruição de sítios, um interesse pelos direitos das pessoas nativas, a importância comercial da Arqueologia como um imã para turismo, e o renascimento na Arqueologia por motivações de fundos nacionalistas e políticos (Price \& Feinman, 2001).

A Arqueologia Pública ou Arqueologia Comunitária é um ramo recente da Arqueologia, que tem atraído principalmente arqueólogos interessados em questões como preservação de sítios arqueológicos e participação das populações detentoras do patrimônio arqueológico nas pesquisas.

Este ramo da Arqueologia emergiu nos anos 1970 e 1980, como resultado de ações políticas de numerosas comunidades indígenas e pós-coloniais e do crescimento da discussão sobre uma teoria crítica e ações sócio-políticas dentro da própria Arqueologia. Isso depende também de como é compreendido o termo comunidade entre os arqueólogos: "On a basic level the 'community' can be defined as the group of individuals living within the vicinity of the area 
being investigated" (TULLY, 2007, p. 158). Ou ainda, conforme apontam autores como Chip Colwell-Chanthaphonh e T. J. Ferguson (2008), uma comunidade descendente não se refere estritamente apenas ao fator biológico, mas também àqueles grupos de pessoas no presente que mantém ligações com os grupos de pessoas do passado pelas manifestações sociais, pela política ou pela economia.

Neste sentido, o trabalho do arqueólogo junto às comunidades tem se tornado também uma fonte de colaboração mútua entre profissionais e comunidades. Nos anos mais recentes, os arqueólogos tem se tornado mais engajados em levantar formas de colaboração e desenvolver projetos junto a comunidades descendentes que ajudam a transformar as fundações teóricas, metodológicas e éticas da Arqueologia. Isso é um fenômeno mundial e a colaboração é uma forma pela qual os pesquisadores tem se envolvido com parceiros locais, movendo os debates para além dos confrontos sobre a quem pertence o passado, enquanto mantém os princípios da investigação científica (Colwell-Chanthaphonh \& Ferguson, 2008).

Outro objetivo das práticas colaborativas na Arqueologia também é o de tentar criar um resultado positivo que talvez não pudesse ser atingido sem o compartilhamento de esforços de ambos os lados, tanto para a Arqueologia e o conhecimento produzido por ela, quanto para as comunidades envolvidas. Desta forma, uma Arqueologia Comunitária ou Pública pode diversificar as vozes na interpretação do passado. Esta subdisciplina é uma área em rápido crescimento no campo da Arqueologia e tem facilitado e proporcionado a educação entre arqueólogos e comunidades (Tully, 2007).

A colaboração é a chave para a prática (McGuire, 2008), contudo, esta prática colaborativa entre arqueólogos e comunidades não possui uma metodologia única e cada caso deve ser estudado de acordo com as especificidades e limitações locais, inclusive as do próprio arqueólogo pesquisador, quando entendemos que as investigações arqueológicas tem o potencial de impactar sobre uma diversidade grande de pessoas e quando elas decidem conscientemente estarem envolvidos no processo ou não (Tully, 2007).

Neste sentido, a colaboração não é uma prática ou ideia uniforme, mas um punhado de estratégias que devem ligar a pesquisa arqueológica com diferentes públicos trabalhando juntos e desta forma, enquanto cada projeto é único, todos movem a Arqueologia em direção a uma prática mais acurada, inclusiva e ética (Colwell-Chanthaphonh \& Ferguson, 2008).

Assim, os trabalhos em Arqueologia Pública também usam da aproximação e troca de experiências entre o arqueólogo e a população detentora do patrimônio arqueológico, ambos 
pesquisando na busca por alternativas e aproveitamento das potencialidades de fruição e manejo oferecidas pelo patrimônio arqueológico, criando bases para a preservação de sítios arqueológicos.

Autores da literatura arqueológica defendem a importância da realização de trabalhos comunitários e envolventes cujos arqueólogos têm cada vez mais se tornado interessados: "The importance of public archaeology is critical, and more effort has gone into such activities in recente years. It is essential to educate and envolve the public in the discipline" (FEINMAN \& PRICE, 2001, p. 485).

Tratando ainda de colaboração, aparece principalmente a interface da Arqueologia com a educação, em forma de Educação Patrimonial. A Educação Patrimonial tem também ganhado a cena e se tornado uma das principais ferramentas do trabalho arqueológico, quando aliada ao conhecimento que pode ser transmitido pelo patrimônio arqueológico.

Com isso, arqueólogos tem reconhecido cada vez mais que a disciplina não se restringe apenas ao campo de estudos de seus especialistas, já que a sociedade moderna tem criado uma grande demanda que os obriga a tornar públicas as ruínas, os objetos e outros dados de pesquisas, que atuam na educação dos cidadãos comuns pela Arqueologia (Marui, 2010).

Desta forma, a Arqueologia Pública tem sido significado também de preservação de sítios arqueológicos, que em longo prazo, pode trazer mudanças sociais significativas. Isto é o mínimo que a Arqueologia pode fazer em escolas de educação formal. Uma das alternativas para uso da Arqueologia em escolas ocorre no campo da Arqueologia para necessidades educacionais [Archaeology for education's need] (Jeppson \& Brauer, 2007).

Isso significa que a Arqueologia e sua produção podem atuar junto às práticas educacionais no intuito de preencher lacunas existentes, tanto no que se refere ao ensino da Arqueologia nas escolas, quanto ao uso da Arqueologia para apoio de ensino de outras disciplinas como a Geografia, a Biologia, a História, entre outras disciplinas.

Assim, nos últimos anos, a sociedade entre os arqueólogos, o público e as instituições educacionais como escolas e museus tem aumentado, e ainda, para a realização de um trabalho educacional, a Arqueologia Pública pode se aproveitar principalmente de sua interface com a Museologia, pois desta forma, os museus podem atuar como agentes de mudança social, já que podem proporcionar vias de acesso, interpretação e propriedade junto ao patrimônio arqueológico. Além disso, a comunidade pode participar das decisões a serem 
tomadas em relação aos museus e participar ativamente dos processos que envolvem as cadeias operatórias dos museus (Tully, 2007).

Desta forma, colocada em ação por meio de uma Educação Patrimonial voltada para o conhecimento sobre os sítios arqueológicos e a formação de uma cidadania voltada para o patrimônio, a Arqueologia Pública pode significar um agente de mudança social e ao mesmo tempo uma ferramenta na preservação do patrimônio arqueológico de Congonhas, contribuindo com a preservação de sítios arqueológicos e seus vestígios, assim como de outras formas materiais e imateriais de cultura, por meio de sua reutilização pela sociedade que os detém, podendo significar não apenas a produção de conhecimentos e informação, mas também podendo, num vislumbre mais positivo, chegar à geração de empregos e renda.

\section{2 - O método indutivo-dedutivo, a pesquisa intensiva de campo e a totalidade social}

\subsection{1 - O legado de Frans Boas}

Para compreendermos a natureza de nossa pesquisa em Congonhas, é preciso que antes sejam abordados também uma série de fatos e questões relacionadas ao desenvolvimento epistemológico no universo de outras ciências sociais tais como a Etnologia, a Antropologia e a Sociologia. É preciso então situar-nos no contexto histórico onde o desenvolvimento epistemológico e paradigmático dessas disciplinas, que passaram por amplas análises teóricas e práticas em seus campos, influenciariam a Arqueologia.

Sem deixar de lado as conquistas paradigmáticas alcançadas no campo da História (História Nova) e da Arqueologia Pós-Processual e Pós-pós-processual, e influenciados principalmente pelos trabalhos de Márcia Angelina Alves (2009 e 2013), com sua tese de livre docência intitulada "Assentamentos e cultura material indígena anteriores ao contato no sertão da Farinha Podre, MG e Monte Alto, SP”, nesta parte da pesquisa nossa metodologia de campo foi centrada nas abordagens construídas nas áreas da Etnologia, da Antropologia e da Sociologia, mais precisamente em Frans Boas e Marceu Mauss, tentando adequá-las à luz das conquistas paradigmáticas recentes no campo da Arqueologia Histórica. Esta parte da 
pesquisa trata também das bases teórico-metodológicas que nos deram sustentação durante os trabalhos de campo, principalmente no que se refere à observação participativa:

\begin{abstract}
A etnologia é constituída por várias disciplinas cuja complementaridade conduz, pelo menos em princípio, à compreensão dos laços que congregam os indivíduos em grupos étnicos particulares. Acima de tudo é a ciência da diversidade humana, e o seu campo de investigação não está limitado nem no espaço nem no tempo. Se é certo que o seu terreno predilecto são as populações não industrializadas no mundo atual, isso deriva de uma tradição científica normal que a levou a procurar a diversidade fora de nossas próprias culturas, ao contrário da sociologia que, por razões práticas, centrou primeiramente as suas preocupações no mundo moderno. Mas o homem do presente industrial fornece também matéria para uma análise da sua diversificação em macro-unidades étnicas, tal como o homem do passado préhistórico fornece um contributo precioso para o conhecimento das formas autenticamente primitivas da organização étnica (LEROI-GOURHAN, 1972, p. 11).
\end{abstract}

Ao longo do século XIX sistematizaram-se os estudos comparativos como a distribuição de moedas e monumentos megalíticos e os conjuntos de vestígios eram associados a povos. Óscar Montelius (1843-1921) desenvolveu o método tipológico e orientou a investigação para a comparação dos artefatos e estruturas na Europa, acreditando num evolucionismo não linear e baseando-se na estratigrafia, defendia a supremacia cultural do Mediterrâneo na PréHistória, portanto, era um difusionista, que defendia a ideia de relação entre centros produtores/inovadores e periferias consumidoras. A Arqueologia bebia nas fontes do antiquarismo e do nacionalismo e na transição para o século XX centrou-se na noção de cultura, nos artefatos e nas associações recorrentes com o objetivo de identificar etnias, nascendo então o difusionismo, que julgava improvável que uma mesma invenção tivesse lugar duas vezes, separadamente e assim, difusão e migração seriam os mecanismos dominantes da história. Paralelamente a isto, Frans Uri Boas se opôs ao evolucionismo cultural e defendeu que cada cultura era uma entidade única, apoiando o relativismo cultural e o particularismo histórico (Trigger, 2004; Oosterbeek, 2010).

No entanto, foi o antropólogo alemão Franz Uri Boas quem abriu os caminhos para a pesquisa sobre a dimensão histórica dos fenômenos culturais, retomada mais tarde por seus discípulos como Alfred Kroeber e Clark Wissler. Boas centralizou suas pesquisas nos fenômenos de contato cultural e depois em fenômenos de empréstimo. 
O antropólogo Franz Uri Boas nasceu na pequena cidade de Minden (Vestfália), Prússia, em 09 de julho de 1858, numa família de comerciantes judeus que viviam na Alemanha. Ele entrou para a universidade em 1877, cursando Física em três estabelecimentos diferentes: em Heidelberg, Bonn e Kiel. Em 1881, Boas concluiu seus estudos universitários e logo interessou-se por estudos de psicofísica, por sua vez desenvolvida por Gustav Fecher, disciplina esta interessada em compreender a relação entre sensações físicas e percepção psicológica. Logo ele mudou seu interesse para a geografia e foi influenciado em parte por Theobald Fischer, seu professor em Kiel. Depois de prestar o serviço militar, Boas mudou-se para Berlin, onde conheceu Adolf Bastian, considerado o patriarca da antropologia alemã e diretor do museu etnonológico Für Völkerkund (Museu do Folclore), ao qual Boas se ligou. Nessa época, Boas iniciou estudos em antropologia física, quando estudou técnicas de medições, com o médico anatomista Rudolf Virchow (Cuche, 1996).

Em 1883 ele foi para a Ilha de Baffin na Groelândia, com a expectativa de estudar os esquimós, levando um empregado da família, Wilhelm Weike, como companheiro e assistente de campo (Castro, 2004; Cuche, 1996).

Em sua estada em Arnarnitung, Boas escreveu uma célebre máxima ${ }^{6}$ acerca das noções que já havia formado durante o curto período em que já se encontrava na campanha da qual conseguiu extrair muitas informações sobre distribuição e mobilidade, rotas de comunicação e histórias sobre migrações.

Em 1886, Boas viajou para os Estados Unidos com interesses etnográficos. Ele visitou e trabalhou em tribos como KwaKiutl, Chinook e Tsimshiam. Seus maiores interesses de então eram estudar línguas, mitos nativos e reunir objetos para coleções museológicas. De volta para Nova York, ele se tornaria membro da então recente inaugurada revista Science como editor-assistente, onde passaria dois anos para depois se tornar professor de antropologia na Clark University (Worcester, Massachusetts), dedicando-se principalmente para a Antropologia Física.

Em 1896, Boas conseguiu um emprego estável no American Museum of Natural History, em Nova York. Daí veio a pesquisa intitulada Jesup North Pacific Expedition, que investigava

\footnotetext{
${ }^{6}$ Frequentemente me pergunto que vantagem nossa "boa sociedade" possui sobre aquela dos "selvagens" e descubro, quanto mais vejo seus costumes, que não temos o direito de olhá-los de cima para baixo. Onde, em nosso povo, poder-se-ia encontrar hospitalidade tão verdadeira quanto aqui? ... Nós, "pessoas altamente educadas", somos piores, relativamente falando. ...Creio que, esta viagem tem para mim (como ser pensante) uma influência valiosa, ela reside no fortalecimento do ponto de vista da relatividade de toda formação [Bildung], e que a maldade, bem como o valor de uma pessoa, residem na formação do coração [Herzensbildung], que eu encontro, ou não, tanto aqui quanto entre nós.
} 
afinidades e relações entre povos da Ásia com o noroeste dos Estados Unidos. Dessa expedição, Boas escreveu uma crítica contundente ao método do evolucionismo cultural, doutrina dominante na Antropologia da época.

Porém Frans Boas não fora o primeiro a adotar o conceito etnológico de cultura. Antes dele, outros, como o antropólogo britânico Eduard Burnett Tylor já fazia uso dele. Tylor formulou o conceito de cultura em 1871 como "um todo complexo que inclui conhecimentos, crenças, arte, moral, leis, costumes e outras capacidades e hábitos adquiridos pelo homem como membro da sociedade" (Oosterbeek, 2010).

Tylor, entre outras influências que recebeu, foi influenciado pelo etnólogo alemão Gustave Klemm, que utilizava a expressão Kultur com um sentido objetivo, principalmente por se referir à cultura material. Tylor, contudo, defendia uma visão universalista do que era a cultura. Para ele, a cultura era expressão da totalidade da vida social humana e se caracterizava por sua dimensão coletiva. Ela era adquirida e não dependia da hereditariedade biológica, sendo sua origem e seu caráter, em grande parte, inconscientes (Cuche, 1996).

Tylor, no entanto, não deixou de hesitar entre as noções de cultura e civilização, característica do contexto da época. Para ele, cultura e civilização eram conceitos totalmente distintos e só poderiam ser aplicados em diferentes situações. O termo civilização, para ele, não poderia ser aplicado aos povos ditos primitivos.

Ainda segundo Denys Cuche (1996), Tylor acreditava na capacidade de progresso do homem e partilhava dos postulados evolucionistas em voga na sua época. Tylor também não duvidava da unidade psíquica da humanidade, explicação que deu para as similitudes que eram observadas em sociedades muito diferentes, segundo ele, em condições idênticas, [...] "o espírito humano operava em toda a parte de maneira semelhante. Herdeiro do Iluminismo, ele aderiu igualmente à concepção universalista da cultura dos filósofos do século XVIII" (CUCHE, 1996, p. 37). Tylor seria então o primeiro etnólogo a abordar efetivamente fatos culturais em uma ótica geral e sistemática e a dedicar seus estudos da cultura em todos os tipos de sociedade e sob amplos aspectos, como materiais, simbólicos e corporais.

Após uma estadia no México, ele elaborou o método de estudo da evolução da cultura por meio do exame de sobrevivências culturais. Com um princípio metodológico generalizante, ele concluiu que a cultura dos povos primitivos contemporâneos representaria globalmente a cultura original da humanidade, uma sobrevivência das primeiras fases da evolução cultural 
pelas quais toda cultura civilizada teria um dia passado, uma caminhada obrigatória do selvagem para o civilizado. Este exame das sobrevivências levava então à utilização do método comparativo introduzido por Tylor na Etnologia, o qual era necessário para o estudo de culturas similares.

Denys Cuche (1996) acredita que, contudo, o evolucionismo de Tylor apresentava também traços da relatividade cultural e sua concepção evolucionista não era rígida, já que não era totalmente persuadido acerca do paralelismo absoluto da evolução cultural em sociedades diferenciadas. Considerava também a hipótese difusionista. Uma similitude entre traços culturais de culturas distintas não poderia provar que estavam em um mesmo nível de escala de desenvolvimento cultural, podendo ter ocorrido uma difusão. Tylor é considerado o inventor do conceito científico de cultura.

Já o antropólogo Frans Boas é considerado o inventor da etnografia e o primeiro a fazer pesquisas in situ para observações diretas e prolongadas de culturas primitivas. "O método indutivo e intensivo de pesquisa de campo tem como patrono Frans Uri Boas, que foi o primeiro pesquisador a fazer pesquisa in loco, ou seja, de campo, para observar diretamente e de maneira prolongada as culturas primitivas" (ALVES, 2009, p. 08).

A crítica de Boas era à suposição de que os fenômenos aparentemente semelhantes pudessem ser atribuídos às mesmas causas. Para ele era preciso antes perguntar, para cada caso, se eles não teriam se desenvolvido independentemente, ou se não teriam se transmitido de um povo para outro. Boas criticava ainda o determinismo geográfico e afirmava que o meio ambiente exercia um efeito limitado sobre a cultura humana, tese reforçada pela grande diversidade cultural de povos que vivem sobre as mesmas condições geográficas. De maneira geral, ele rejeitava qualquer teoria que pretendesse poder explicar tudo. "Preocupando-se com o rigor científico, ele recusava qualquer generalização que não pudesse ser demonstrada empiricamente" (CUCHE, 1996, p. 42). Boas seria então o criador do método histórico.

Boas também criticava o método difusionista, pois esse colocava o peso explicativo do problema da diversidade cultural na ideia de difusão. Os difusionistas repartiam a suposição de que a difusão de elementos culturais semelhantes em áreas geograficamente afastadas se dava por meio de comércio, guerras, viagens ou outros meios diversos. Alguns chegaram a defender a ideia de que existiu um único centro irradiador da cultura, o Egito antigo, do qual a civilização teria se difundido para diversas regiões do mundo (Trigger, 2004; Castro, 2004). 
Além do método histórico, Boas foi ainda responsável pela concepção antropológica do relativismo cultural. Ele queria, com isso, escapar do etnocentrismo no estudo de uma cultura particular e não compará-la prematuramente a outras, sem a priori e sem aplicar suas próprias categorias para interpretá-la.

Ele acreditava na complexidade de cada sistema cultural e afirmava que somente o exame metódico de cada sistema cultural poderia levar ao fundo de sua complexidade e para isso, eram necessários o uso da paciência, da prudência, e avançar com pequenos passos na pesquisa.

Boas ficou para a história das ciências sociais como o fundador do método indutivo e intensivo de campo. Boas descreveu e compreendeu culturas em uma perspectiva histórica e particularista. Ele é considerado também o patrono do particularismo cultural e inventor do método monográfico em antropologia centrado no método indutivo e intensivo de campo onde o empírico domina a cena - ele deve ser conhecido, revelado por pesquisa prolongada e direta até ser compreendido em sua totalidade (Alves, 2009 e 2013; Castro 2004; Cuche, 1996, Fagundes, 2004; Stocking Jr, 2004).

A Etnologia era para Frans Boas uma ciência da observação direta, que deveria então buscar o detalhe do detalhe, e o etnólogo, se ele quer conhecer e compreender uma cultura, deve aprender a língua em uso. Além disso, o pesquisador, durante as observações, [...] “deve estar atento principalmente a tudo o que se diz nas conversas 'espontâneas', e acrescenta, até 'escutar atrás das portas'. Tudo isso supõe que se permaneça por longo tempo junto à população cuja cultura está sendo estudada" (CUCHE, 1996, p. 43). Ou seja, nenhum detalhe deveria escapar da percepção do observador participante:

Os fenômenos chamados etnológicos resultam da natureza física e psíquica dos homens e de seu desenvolvimento sob a influência do meio ambiente; portanto, dois problemas devem ser estudados para atingir resultados científicos. O estudo preliminar é o do meio; o objetivo final da pesquisa é conhecer as leis e a história do desenvolvimento do caráter fisiológico e psicológico da humanidade. O "meio" são as condições físicas da região e os fenômenos sociológicos, isto é, a relação entre os homens. Além disso, o estudo do ambiente atual é insuficiente: devem-se considerar a história do povo, a influência das regiões pelas quais passou nas suas migrações e os povos com quem entrou em contato. Todos esses fenômenos podem ser diretamente levantados por um observador bem treinado, ou podem ser rastreados com maior ou menor precisão por pesquisas históricas (STOCKING JR., 2004, p. 88). 
Contudo, Stocking Jr. (2004) considera ainda mais difícil a segunda parte das pesquisas etnológicas.

O caráter físico e psíquico de um povo resulta da ação do meio e do modo como o caráter atual foi alcançado. Cada estágio no desenvolvimento de um povo deixa uma marca que não pode ser destruída por acontecimentos futuros. Assim, os elementos do caráter de um povo são extremamente complexos (STOCKING JR., 2004, p. 89).

Segundo este mesmo autor, esses problemas tem características notáveis como a ocorrência de invenções semelhantes em regiões diferenciadas e que não possuem origem comum. Um método empregado em seu estudo é comparar fenômenos e tirar conclusões por analogia, é o método dedutivo.

Outro método é estudar fenômenos que surgem de uma causa física comum entre todos os povos e que recebem influência do meio, ou seja, traçar a história do fenômeno em questão. Isto é o método indutivo.

O método dedutivo com valor científico e psicológico em analogia é eficaz em descobrir problemas, mas somente na medida em que os métodos indutivos possam ser aplicados no exame das ideias descobertas pela dedução. Desta forma, dedução e indução estarão em constante diálogo durante a pesquisa.

A tendência da ciência tem sido restringir cada vez mais o domínio dos métodos dedutivos e não se contentar com argumentos fundados na analogia, que são base da maioria dos erros da mente humana. A eles podem ser atribuídas as ideias religiosas e outros pensamentos do homem num estado antigo de cultura e, em certa medida, até num estado de civilização avançada. A ciência está constantemente invadindo o domínio dos argumentos baseados em analogia. Ela exige métodos indutivos (STOCKING JR, 2004, p. 90).

Boas ainda presidiu um comitê para criação da revista American Antropologist, inaugurada em 1899. Em 1905 Boas deixou o museu e se tornou professor em Columbia. Depois de um estudo feito através do método estatístico com imigrantes estrangeiros que chegavam dos Estados Unidos entre 1908 e 1810, Boas concluiu que as pretensas "raças humanas" não eram 
estáveis, podendo modificar traços físicos específicos de acordo com a pressão externa de um ambiente novo.

Então Boas se dedicou a mostrar o quanto absurda era a ideia de uma ligação entre traços físicos e mentais, ideia esta que era dominante na época e implícita na noção de raça. "Para ele não há diferença de 'natureza' biológica entre primitivos e civilizados, somente diferenças de cultura, adquiridas e logo, não inatas" (CUCHE, 1996, p. 41-42).

Boas seria, com isso, um dos primeiros cientistas sociais a abandonar o conceito de raça para dar explicação sobre comportamentos humanos.

Além do acúmulo de observações empíricas, a Antropologia Americana impulsionada por Frans Uri Boas deu sua colaboração às ciências sociais pelas contribuições teóricas. Daí o conceito de "modelo cultural" (cultural pattern), que designa o conjunto estruturado dos mecanismos pelos quais uma cultura se adapta a seu meio ambiente. Neste sentido, a Arqueologia seria também muito influenciada a partir de então.

\subsection{2 - A totalidade social}

A questão social, objeto da análise de Frans Boas, ganhou um forte impulso a partir da concepção de Marcel Mauss sobre o fato social, que ampliou o conceito do tio, Emile Durkheim para fato social total (Alves, 2009 e 2013). Mauss também anunciou as preocupações mais atuais da Antropologia Americana. A grande preocupação que se formou a partir de seus trabalhos foi com a questão da relação entre grupo e indivíduo, que inspirou a comunicação sobre as técnicas corporais.

Com isso Marcel Mauss percebeu a consequência mais significativa da nova orientação, a aproximação entre etnologia e psicanálise.

A empresa seria altamente capaz de enfrentar os preconceitos de raça, pois, diante das concepções racistas que querem ver no homem um produto de seu corpo, mostraria, ao contrário, que é o homem sempre e em toda parte, que soube fazer do seu corpo um produto de suas técnicas e de suas representações (LÉVISTRAUSS in MAUSS, 1974, p. 05). 
Esta prática elucidaria questões acerca de migrações, contatos culturais e empréstimos, onde os gestos, transmitidos de geração a geração teriam papel significante, dentro de uma Arqueologia dos hábitos corporais. E mais:

\begin{abstract}
É por intermédio da educação das necessidades e das atividades corporais que a estrutura social imprime sua marca aos indivíduos: "Adestram-se as crianças... a dominar reflexos... inibem-se os medos... selecionam-se pausas e movimentos". Esta procura da projeção social sobre o individual deve esquadrinhar o mais profundo dos costumes e das condutas; nesse domínio, não há nada fútil, nada gratuito, nada supérfulo: "A educação da criança está cheia do que chamamos de detalhes, mas que são essenciais". E ainda: "Quantidades de detalhes, inobservados, e dos quais é necessário fazer-se a observação, compõem a educação física de todas as idades e dos dois sexos" (LÉVI-STRAUSS in MAUSS, 1974, p. 03).
\end{abstract}

Já o conceito de fato social total tem como preocupação definir a realidade social ou, de definir o social como realidade, assim como apontou Alves (2009 e 2013). E ainda:

Que o fato social total não significa unicamente que tudo o que é observado faça parte da observação; mas também, e, sobretudo, que em uma ciência em que o observador é da mesma natureza que seu objeto, o observador é ele próprio uma parte de sua observação (LÉVI-STRAUSS, apud. ALVES, 1999, p. 10).

De acordo com Claude Lévi-Strauss em sua apresentação do "Ensaio sobre a Dádiva" (1974), para compreender um fato social é preciso apreendê-lo totalmente, isto é, de fora como uma coisa, mas como uma coisa de que, todavia faz parte integrante a apreensão subjetiva (consciente ou inconsciente) que dela tomamos se, homens, vivemos o fato como um indígena em vez de observarmos como um etnólogo. "A abordagem sistêmica de Mauss é centrada na reconstrução de todo social concebido como realidade com as partes aparentemente desconexas" (LÉVI-STRAUSS, apud. ALVES, 2009, p. 11). E ainda, segundo o próprio Mauss:

Nesses fenômenos sociais "totais", como nos propomos a chamá-los, exprimem-se, ao mesmo tempo e de uma só vez; toda espécie de instituições: religiosas, jurídicas e morais - estas políticas e familiais ao mesmo tempo; econômicas - supondo formas particulares de produção e de consumo, ou antes, de prestação e de distribuição, sem 
contar os fenômenos estéticos nos quais desembocam tais fatos e os fenômenos morfológicos que manifestam suas instituições (MAUSS, 1974, p. 41).

Lévi-Strauss propôs que a noção de fato social é dúbia: "A noção de fato social está em relação direta com a dupla preocupação de ligar o social e o individual por um lado, o físico ou fisiológico e o psíquico por outro" (LÉVI-STRAUSS, apud. AlVES, 2009, p. 10). E ainda, é por meio de uma série de reduções é que se pode compreender esta dupla questão:

1. diferentes modalidades do social (jurídico, econômico, estético, religioso, etc);

2. diferentes momentos de uma história individual (nascimento, infância, educação, adolescência, casamento, etc);

3. diferentes formas de expressão, desde fenômenos fisiológicos como reflexos, secreções, abrandamentos e acelerações até categorias inconscientes e representações conscientes individuais ou coletivas (LÉVI-STRAUSS, apud. ALVES, 2009, p. 10).

Após estudar diversos modelos de sociedade, Mauss não queria propor seu trabalho como modelo e o considerou todo indicações. Ele colocou questões a historiadores e etnógrafos e propôs objetos de investigação, em vez de tentar resolver o problema e dar respostas definitivas. Mauss não atingiu somente estes cientistas. Atingiu também linguistas, psicólogos, historiadores das religiões e orientalistas, além destes, no campo das ciências sociais e humanas, vários pesquisadores franceses e sul-americanos receberam suas influências (Levi-Strauss in Mauss, 1974).

Mauss se contentou em expor que na direção proposta por ele serão encontrados numerosos fatos sociais durante a realização de uma pesquisa.

Mas se isto é verdade, é porque há, nesta maneira de tratar um problema, um princípio eurístico que gostaríamos de aclarar. Os fatos que estudamos são todos, permita-me a expressão, fatos sociais totais, ou se se quiser - porém gostamos menos da palavra - gerais: isto é, põem em movimento, em certos casos, somente um certo número de suas instituições (potlach, clãs enfrentados, tribos que visitam, etc.), em particular quando essas trocas e contatos dizem respeito de preferência ao indivíduo (MAUSS, 1994, p 179). 
Mauss sugeriu que a sociedade exprime-se simbolicamente em seus costumes e em suas instituições, [...] "contrariamente, as condutas individuais normais jamais são simbólicas por elas mesmas: são os elementos a partir dos quais um sistema simbólico, que só pode ser coletivo, se constrói” (LÉVI-STRAUSS in MAUSS, 1974, p. 07).

E ainda, conforme Lévi-Strauss (1974), contrariamente ao simbolismo construído coletivamente estaria o simbolismo individual, que por sua vez se exprime em forma de condutas anormais dessocializadas e abandonadas a si mesmas, que realizam apenas no campo individual a ilusão de um simbolismo autônomo, uma espécie de simbolismo vagamente evocador de formas normais e realizadas na escala coletiva.

Portanto, é necessária a busca pela totalidade social, que deverá ser remontada pelas partes para chegarmos ao todo, no intuito de conhecermos melhor a sociedade estudada e construirmos sua história.

\section{3 - A Arqueologia Histórica e a Arqueologia da Paisagem}

\subsection{1 - Arqueologia Histórica}

Vimos que durante as últimas décadas a Arqueologia tem se tornado mais aberta ao campo interdisciplinar com outras ciências e dentro dela própria. As discussões ocorridas no interior da disciplina tem gerado espaço para novos subcampos, como a Arqueologia Histórica, a Arqueologia da Paisagem, a Arqueologia da Arquitetura e a Geoarqueologia, entre outros, que por sua vez, passam por suas próprias análises paradigmáticas em teoria, métodos e prática, acabando também por se expandirem em diversas linhas de pesquisa.

A Arqueologia Histórica teve seus inícios como disciplina no século XIX e ganhou maior atenção nos anos de 1960, principalmente nos Estados Unidos. Houve grande institucionalização da disciplina e muitos trabalhos foram realizados com rigidez metodológica em diversos sítios históricos importantes.

Como não podia deixar de ser diferente, a noção de Arqueologia Histórica irá depender de como definimos o termo. Por exemplo, a Assiriologia, a Egiptologia ou a Arqueologia 
Clássica, combinam estudos dos vestígios arqueológicos como utensílios domésticos, ruínas de palácios, casas, templos e armamentos, com estudos escritos gerados pelas sociedades que já possuíam o domínio da escrita, deixando registrados muitos dos fatos ocorridos, e também com a documentação produzida pelos muitos estudiosos que a estas ciências se dedicaram (Orser Jr, 2002). Isto pode ser entendido como Arqueologia Histórica.

A noção de Arqueologia Histórica, contudo, irá incluir outras interpretações sobre seu sentido, variando de acordo com a região e a época em que o arqueólogo se propõe a pesquisar. Destas concepções variadas derivam também diversas outras linhas de pesquisa e formas de fazer Arqueologia Histórica, por exemplo, a Arqueologia Bíblica em Israel, a Arqueologia Industrial voltada principalmente para os vestígios da Revolução Industrial na Inglaterra e suas implicações no mundo industrializado de hoje e a Arqueologia no mundo Pós-Colonial, termo este usado pelos primeiros interessados em Arqueologia Histórica nos Estados Unidos e que se dedicavam às sociedades colonizadas depois do século $\mathrm{XV}$, e sendo o primeiro termo o preferido em lugares como a China, que possui larga tradição escrita desde a antiguidade. "O termo Arqueologia Histórica, com tal definição, não é usado na Europa e na Ásia, já que se entende por históricas diversas arqueologias, como a Clássica e a Egípcia, para mencionar apenas duas delas" (FUNARI, 2002, p. 01).

Contudo, ainda existe um problema com essas definições do termo Arqueologia Histórica, e ainda, muito se discute acerca de seu papel como um subcampo autônomo da Arqueologia ou como uma ciência à parte, derivada desta última e apegada à História. O problema do termo gera discussões filosóficas que, se não conseguem definir um termo apropriado para uma Arqueologia Histórica global, pelo menos nos dão noção da riqueza da teoria envolta no estudo das sociedades letradas e da amplitude de métodos e técnicas que podem ser utilizados pelo arqueólogo historiador.

As diversas abordagens temáticas continuam a ganhar espaço e a Arqueologia Histórica abrange sob seus olhares os múltiplos aspectos ligados às questões de identidade e memória social. Em lugares como a Europa, a Arqueologia é considerada como estudo da civilização, seja ela as grandes civilizações antigas ou mesmo as pré-históricas inseridas em contexto histórico, não ocorrendo a diferenciação entre os termos Arqueologia e Arqueologia Histórica. A disjunção com a Pré-História nos Estados Unidos estaria ligada, segundo Pedro Paulo A. Funari (2002), com a sociedade americana e sua formação, que encarava o indígena como o "outro", selvagem, em contraposição à sociedade civilizada do branco, criando assim um lapso divisor entre as esferas de estudo no campo da Arqueologia, principalmente por ser 
conhecido o fato de que a muito na história da humanidade, sociedades letradas e de tradição oral convivem, comercializam, miscigenam-se, guerreiam.

Devemos considerar também que o termo Arqueologia Pós-Colonial difundiu-se primeiramente entre estudiosos que tinham específico interesse em um período histórico local. Os depósitos arqueológicos foram observados como simples objetos de curiosidades.

Essas explorações rudimentares, contudo, ilustraram pelo menos dois importantes pontos que deveriam ser relevantes para o futuro da Arqueologia Histórica: que sítios do período histórico existem, e que eles podem ser investigados utilizando métodos arqueológicos. Essas descobertas, tão óbvias hoje em dia, foram uma revelação do tempo porque, naqueles dias, a palavra "arqueologia" era sinônimo de Grécia clássica ou Roma, ou Egito dinástico (ORSER JR, 2002, p. 271).

Do início do período formativo, a Arqueologia Histórica herdou também uma forte influência da Arquitetura, apoiando trabalhos de Arquitetura Histórica e restaurações. A Arqueologia Histórica fornecia informações importantes sobre construções e fundações de edifícios. $\mathrm{O}$ problema é que a informação gerada pelo arqueólogo era muitas vezes considerada de menor importância. É que muitos ficavam presos aos limites dos artefatos apresentados pela Arquitetura, contribuindo com a diminuição da relevância dos trabalhos. "Um dos problemas desse período formativo - provavelmente por causa do forte papel que a informação da arquitetura representou - é que a arqueologia histórica como um corpo era incerta como o lugar acadêmico da disciplina” (ORSER JR, 2002, p. 271).

A Arqueologia Histórica, desta forma, tinha uma perspectiva particularista e passou para outro estágio, agora processualista (Barber, 1994). A Arqueologia se preocupava em resolver os problemas de construção de história cultural de alta escala em sociedades pré-históricas, podendo unir histórias em uma sequência.

Dentro do quadro que os pré-historiadores construíam sequências regionais que às vezes tinham grande profundidade de tempo - e geralmente terminando com a presença de Europeus numa área - não existia lugar para os arqueólogos históricos dentro da arqueologia acadêmica. Como resultado, muitos dos arqueólogos históricos condutores desse período viram que o que eles estavam fazendo como essencialmente um esforço 'histórico', no lugar de um enraizado em antropologia. As descobertas dos detalhes arquitetônicos ajudaram a definir o campo como um tipo de história (ORSER JR, 2002, p. 271). 
O período de formação da disciplina continuou com o desenvolvimento da Arqueologia Processual, quando os arqueólogos históricos experimentaram novas perspectivas e problemas. Os arqueólogos processualistas propunham que arqueólogos deveriam examinar, como antropólogos, processos culturais em todos os tempos e lugares. Isso abriu novas possibilidades para o campo da Arqueologia Histórica, que passou a se basear antropologicamente, ao invés de se preocupar com coleções arquitetônicas simplesmente. Lewis Binford, um dos mais renomados arqueólogos da época, se interessou por Arqueologia Histórica e a experimentou no Fort Michilimackinac, em Michigan. A Arqueologia Histórica de cunho antropológico passou então, depois da década de 1960 a figurar em diversos pontos, principalmente nos Estados Unidos, além de outros países como a Austrália.

Os arqueólogos interessados em Arqueologia Histórica se uniram em torno da American Anthropological Association, em reunião anual, mais precisamente a partir do ano de 1965, em St. Louis, e buscavam entre outras coisas uma organização futura para discutir o amplo terreno de problemas que giravam em torno da disciplina e conseguiram organizar a The International Conference on Historical Archaeology em 1967. Entre os tópicos debatidos buscaram a criação de uma associação à parte, The Society for Historical Archaeology e com ela a criação da revista Historical Archaeology (Allen e Michael, 2008), naquele mesmo ano, e de um jornal que estreou em 1968. A Arqueologia Histórica então ganhou confiança, maturidade intelectual e lugar acadêmico para estudar as dinâmicas sociais e culturais do passado, se fortalecendo nas décadas posteriores.

A Arqueologia Histórica expandiu seus campos de análises pós-processualistas (Barber, 1994) e passou a se interessar por temas como as pessoas esquecidas no passado histórico, grupos minoritários como escravos, trabalhadores de fábricas, mineradores e questões como agência ou simplesmente quem estava por trás do objeto. Também passou a fazer parte de seus objetivos revelar visões mais reais da história, em contraponto com narrativas tradicionais misteriosas e obscuras que se chocam com a realidade apresentada pelos vestígios arqueológicos e outras fontes. Outros fatores que ganharam relevância na disciplina foram os estudos acerca das relações de poder expressas na desigualdade, resistência e dominação entre colonizadores e colonizados (Funari, 2005).

A Arqueologia Histórica se aproveitou da ampla metodologia que tira proveito dos vestígios artefatuais, orais e escritos. Para conseguir objetivar suas perspectivas teóricas, o arqueólogo histórico precisa estar sempre atento às dicotomias presentes no seu objeto de análise. "Documentos são certamente validos, mas eles tem falhas, brechas, e distorções que 
demandam que eles sejam acessados, no lugar de simplesmente serem aceitos acriticamente" (BARBER, 1994, p. 06) ${ }^{7}$.

Elementos simbólicos, paisagens de feições amplas e jardins se tornaram objeto de interesse especial e o arqueólogo histórico passou a crer que, apenas um artefato pode ter diferentes significados, dependendo de quem o analisa e do cenário cultural de quem o analisa. "Os dados da Arqueologia Histórica são ricos o suficiente para suportar uma variedade de diferentes estilos em sua interpretação" (BARBER, 1994, p. 03) ${ }^{8}$.

Para arqueólogos como Martin Hall e Stephen Silliman (2006), a Arqueologia ajuda a formular o papel dessas histórias no mundo presente, não como precursores ou modistas, [...] "mas também como memórias públicas e heranças que são ás vezes esquecidas, ás vezes memorizadas, às vezes distorcidas, mas sempre mobilizadas por uma multidão de propósitos" (HALL \& SILLIMAN, 2006, p. 02) ${ }^{9}$.

Assim, com a aproximação dos debates atuais na Arqueologia, a Arqueologia Histórica procura adequar também as novas conquistas teóricas e metodológicas da primeira em seu interior. Um ramo novo tem surgido nas últimas décadas e é baseado principalmente nas ideias de Ian Hodder e sua obra "The Archaeological Process" (1999) ${ }^{10}$ e foi batizada como Arqueologia Histórica Interpretativa.

Apesar das aproximações teórico-metodológicas com as ideias desenvolvidas pelo arqueólogo Ian Hodder, é preciso lembrar-nos também que existem as diferenças de concepção entre as duas linhas, a Arqueologia e a Arqueologia Histórica.

Este ramo recente da Arqueologia Histórica, a Arqueologia Histórica Interpretativa, tem conquistado diversos adeptos por todo planeta e é dentro desta orientação que buscamos aplicar nossa pesquisa em Congonhas. Essa linha representa os resultados teóricos e metodológicos debatidos na formação da disciplina. Não existe, contudo, um movimento reconhecido para a criação de uma escola de Arqueologia Histórica Interpretativa. Esta linha veio de praticantes influenciados por diferentes perspectivas teóricas que buscam através dela o comprometimento de construir interpretações arqueológicas empiricamente rigorosas, historicamente situadas e de relevância social. Possui amplo aspecto interdisciplinar e busca,

\footnotetext{
${ }^{7}$ Tradução nossa.

${ }^{8}$ Tradução nossa.

${ }^{9}$ Tradução nossa.

${ }^{10}$ HODDER, Ian. The archaeological process. An introdution . Oxford, Blackwell publishers. 1999. 242 p.
} 
com isso, integrar um amplo alcance de evidências não arqueológicas e luta para subverter fronteiras disciplinares tradicionais.

Em sua essência, a Arqueologia Histórica Interpretativa usa uma variedade de linhas de evidências para criar novas narrativas históricas que tenham convergências com nossas experiências da sociedade contemporânea e fazer o passado acessível, relevante e até mesmo provocante. Neste sentido, ela também trabalha focada sobre os acasos, quando narrativas textuais e artefatuais contradizem uma a outra e consegue ver os registros documentais e arqueológicos intercalados e inseparáveis para as interpretações e narrativas arqueológicas (Wilkie, 2009; Hodder, 1999).

Em sua abordagem sobre a Arqueologia Histórica Interpretativa intitulada Interpretive Historical Archaeologies (2009), a arqueóloga Laurie A. Wilkie apontou quatro elementos que segundo ela definem essa linha de estudo da Arqueologia Histórica:

1. Praticantes da Arqueologia Histórica Interpretativa reconhecem que os atores representados no registro arqueológico são formados por, e de volta, formam os amplos contextos sociais históricos nos quais eles viveram. Para colocar isto mais brandamente, a história é importante. Arqueologias Históricas Interpretativas são Arqueologias Contextuais.

2. Na Arqueologia Histórica Interpretativa, documentos (incluindo fontes literárias e artísticas), histórias orais, arquitetura, cultura material, e vestígios arqueológicos são todos elementos significantes de um universo de evidência usados para nos informar sobre vidas sociais passadas. Cada um desses corpos de evidência é afetado por distintas e únicas histórias de vida e processos de curadoria e preservação. Usadas juntas, estas linhas evidenciarias oferecem o maior potencial para criação de narrativas históricas e interpretações holísticas. Por sua natureza, Arqueologias Históricas Interpretativas são empiricamente rigorosas, isto é, são condutoras de informação.

3. Interpretações arqueológicas feitas por praticantes de Arqueologias Históricas Interpretativas são situados no presente e formados pelas posições subjetivas do discurso arqueológico com comunidades descendentes contemporâneas.

4. Praticantes de Arqueologia Histórica Interpretativa são comprometidos em fazer a informação arqueológica acessível - pelo alcance dos modos de publicação e mídia (WILKIE, 2009, p. 338) ${ }^{11}$.

De certo, buscamos algo muito próximo das concepções da Arqueologia Histórica Interpretativa definidas por Wilkie, porém, acreditamos que essa metodologia não deva ser seguida como uma receita infalível. Acreditamos também que o ambiente de pesquisa e as outras abordagens teórico-metodológicas de que faremos uso possam modificar um pouco este quadro de relações, tendendo a relações mais fortes de um lado e menos de outro, na medida em que os problemas vão surgindo.

\footnotetext{
${ }^{11}$ Tradução nossa.
} 
No Brasil, os estudos de Arqueologia Histórica e sua cultura material iniciaram-se nos anos 1930, quando era crescente a preocupação em proteger o patrimônio arquitetônico e desta forma, surgiram as primeiras leis a este respeito, porém, os estudos interessados nessa cultura material brasileira se voltaram a ela a partir de estudos de Arqueologia Clássica nos anos 1960. A Arqueologia Histórica brasileira ganhou impulso por arqueólogos pré-historiadores entre 1960 e 1970 e seu interesse tem crescido muito a partir dos anos 1980, com estudos de missões católicas romanas que eram as missões jesuítas do sul do Brasil, em terras habitadas pelos índios guaranis. A Arqueologia Urbana tem se desenvolvido largamente e também a diversificação de trabalhos em diversos estados do país, principalmente em edificações de caráter vernacular, e em sítios como Canudos e Palmares (Orser Jr., 2002).

Um exemplo de caso de pesquisas em Arqueologia Histórica brasileira se deu na cidade de Piraju, no Estado de São Paulo, pela Prof. ${ }^{a}$ Dr. ${ }^{a}$ Daisy de Morais (2007). A estação ferroviária de Piraju tem arquitetura de Ramos de Azevedo e foi tema de pesquisas de mestrado, doutorado, dentre outras publicações em Arqueologia da Arquitetura.

E ainda, o fato de o Brasil ter boa parte dos arqueólogos formados na Europa e na América do Norte tem provocado debates com o objetivo de estabelecer definições e conceitos para a Arqueologia Brasileira e com isso, na Arqueologia Histórica, vem abrindo novas especialidades e frentes de trabalho que tem diferenciações teóricas e metodológicas de acordo com a área de abrangência da pesquisa, reforçando o caráter interdisciplinar da Arqueologia e aproximando-a de questões relacionadas à memória social e o patrimônio cultural (Peixoto, 2009).

Temas como colonialismo global, eurocentrismo, capitalismo e modernidade estão sempre presentes em Arqueologia Histórica e isso implica também que a Arqueologia Histórica no Brasil trabalhe em sintonia com uma perspectiva mundial, com base principalmente na proposição de Charles Orser Jr. (1996), que argumenta sobre uma definição da disciplina como um estudo do mundo moderno, caracterizado por uma economia singular que é considerada por ele como colonial, internacional e expandida, levantando questões relacionadas aos conceitos que ele define como chaves para esta realidade nova, os quais seriam colonialismo, eurocentrismo, capitalismo e modernidade, todos considerados formas de desenvolvimento inter-relacionados e de impossível separação (Funari, 1999), e ainda, muito próxima de disciplinas como a Antropologia e a História. 


\subsection{2 - Arqueologia da Paisagem}

Desde quando os arqueólogos tem estudado o passado humano, eles tem se interessado pelo espaço e consequentemente, em paisagens, e o pensamento arqueológico tem mudado quanto à natureza da paisagem e de seu papel nos questionamentos levantados pela Arqueologia. Assim, paisagem é o lugar onde os vestígios arqueológicos foram depositados e ela providencia, de uma perspectiva econômica e política, recursos, refúgio, riscos e facilita, dificulta, impede ou impacta sobre as ações humanas e as situações. As mais proeminentes noções de paisagem tem enfatizado suas dimensões sociais e simbólicas e desta forma, a paisagem é uma entidade que existe por sua virtude de ser percebida, experimentada e contextualizada pelas pessoas (Knapp \& Ashmore, 1999).

Para as arqueólogas María Nieves Zedeño e Brenda J. Bowser (2008), o lugar é uma conjuntura onde a natureza, as pessoas e os significados se convergem em múltiplas escalas e processos, criando um registro do comportamento humano, percepção e cognição e assim, o registro material da presença num lugar significa de fato, material de estudo para a Arqueologia ou, significados econômicos, sociais, políticos e simbólicos, uma vez gravados sobre a paisagem, que podem emergir no processo de reconstrução e interpretação do passado das pessoas pelo registro arqueológico.

$\mathrm{Na}$ Arqueologia Histórica, assim como na Arqueologia em geral, tem surgido novos subcampos como resultado dos desenvolvimentos interdisciplinares e multidisciplinares que se tornam cada vez mais frequentes. Mesmo antes, na Arqueologia, e agora também na Arqueologia Histórica, estudos mais recentes são realizados em conjunto com novas perspectivas abertas recentemente, como na interface com a Arqueologia da Paisagem, fortalecendo também os laços interdisciplinares com a Arqueologia Urbana, a Arqueologia da Arquitetura, e a Geoarqueologia, ambas importantes no que diz respeito à compreensão da transformação humana do ambiente, do desenvolvimento das cidades e das sociedades que as formaram e que nelas vivem.

Mesmo antes na Arqueologia e agora na Arqueologia Histórica, uma série de estudos tem se realizado em conjunto com novas perspectivas abertas recentemente, como na interface com a Arqueologia da Paisagem, fortalecendo também os laços interdisciplinares com a Arqueologia Urbana, a Arqueologia da Arquitetura, e a Geoarqueologia, ambas importantes no que diz respeito à compreensão da transformação humana do ambiente, do desenvolvimento das 
cidades e das sociedades que as formaram e que nelas vivem. Contudo, a Arqueologia da Paisagem tem se destacado como uma das novas ênfases em Arqueologia Histórica.

Alguns autores buscam também pela definição do termo Arqueologia da Paisagem e por isso, ocorrerão divergências e acordos a respeito do tema e assim, [...] "a noção de paisagem difere conforme o interesse daquilo que é objeto ou a maneira como se o encara" (MORAIS, 2012, p. 260).

Os enfoques da paisagem podem variar segundo o olhar dos diferentes profissionais que a usam como fonte de informações, sejam eles geógrafos, historiadores, arqueólogos ou antropólogos.

Alguns autores conseguem, contudo, chegarem a definições muito esclarecedoras desse conceito e colocando-o próximo do campo analítico da Arqueologia.

No caso da arqueologia da paisagem, o termo é preferencialmente visto sob a ótica da sociedade, ou seja, a paisagem é construída e continuamente reconstruída pela sociedade em evolução. Assim, é interessante reiterar que paisagem, enquanto resultado do processo de artificialização do meio, é objeto da arqueologia da paisagem, linha de pesquisa que estuda a regularidade, o arranjo e a distribuição das transformações do meio ambiente em uma área geográfica definida (MORAIS, 2012, p. 261).

Para Filipe Criado Boado (1999), uma série de fatores levam à organização da percepção, introduzem ordem ao entorno, produzindo uma paisagem cultural concreta fundamentada sobre uma conjunção de pontos, círculos, linhas e metades. Esta ideia vai de encontro com a de outro autor, José Luiz de Morais, que assim declarou a respeito da paisagem e sua articulação:

O processo de artificialização do meio resulta na sucessão de cenários plenamente articulados, reforçando a complexidade do conceito de paisagem construída. De fato, a paisagem analisada pelo arqueólogo não é apenas o ecossistema, mas sim o lugar pleno de assinaturas antrópicas que se sucedem no tempo. Pela forma e evolução da paisagem construída, procura-se chegar aos seus autores (MORAIS, 2012, p. 261). 
Portanto, para fazermos uma leitura arqueológica da paisagem construída, com vistas a chegar a seus autores, dependeremos antes de tudo de nossa própria percepção, por isso, devemos compreender também o seguinte:

[...] analisar o conceito de paisagem nos remete à nossa capacidade de ver, olhar. Quando circunscrevemos arbitrariamente um conjunto de bens naturais e culturais e a ele designamos o nome de paisagem, sejam esses bens designados através de sua naturalidade, entendida como natureza natural ou sua culturalidade, entendida como natureza transformada. Entretanto devemos assinalar que não existe natureza fora da cultura, então natureza a rigor, também é cultura. Desta forma, agora seria prudente então investigar a urbis, o urbano, a urbanidade e sua construção através do tempo e do espaço (BASTOS e SOUZA, 2010, p. 49).

Portanto, para fazer uma leitura da paisagem e buscarmos a compreensão da interação do homem e seu meio social, ambiental e cultural num processo histórico, é necessário antes de tudo conhecê-los, experimentando e vivenciando essa experiência interativa:

(...) el indivíduo es um punto, centro de percepción; desde ahí controla, mediante la visión, lo que le rodea, y así crea el espacio; después camina, aprehende el entorno y así comprende el espesor de esse espacio; después piensa, y dispone, divide y establece distinciones significativas, y así introduce sentido y orden en el espacio, lo transforma en paisage. (CRIADO BOADO, 1999, p. 25).

Arqueólogas como Rebecca Yaming e Karen B. Metheny (1996) consideram que a paisagem é o estágio para a ação humana, pois reflete ao mesmo tempo as atividades do passado e codifica a paisagem cultural sobre as quais as visões do mundo são formadas. Arqueólogos também devem buscar pelas interpretações da paisagem do passado e do presente que às vezes são construídas sobre fragmentos de história mítica ou ideologias contemporâneas (Yentsch, 1996).

Segundo RebbecaYaming e Karen B. Metheny (1996), é a Geografia Cultural que forma um número de pontos comuns e interesses com a Arqueologia da Paisagem, incluindo uma relação próxima com a Antropologia. 
Neste sentido, segundo José Luiz de Morais (2012), é principalmente na Geografia que a Arqueologia da Paisagem se casa interdisciplinarmente como estratégia de investigação de processos sociais em uma dimensão espacial, na tentativa de reconstrução de uma paisagem arqueológica e de padrões de assentamento a partir das expressões da cultura material. E ainda, segundo Morais (2012), a Arqueologia da Paisagem possui a qualidade de referenciar procedimentos, cenários ou sistemas regionais de povoamento, conferindo a ela a competência para tratar de assuntos relacionados ao design da arqueologia na dimensão do planejamento, gestão e manejo do patrimônio arqueológico, fatores estes que são de primeira importância quanto aos objetivos que pretendemos alcançar em nossa pesquisa de mestrado.

Em se tratando da Arqueologia da Paisagem em seu desdobramento urbano, a Arqueologia Histórica se aproxima da Geografia Urbana, do urbanismo e da Arquitetura, esta última segundo uma linha de investigação com relações com a disciplina História da Arquitetura, contudo:

\begin{abstract}
Convém reiterar que a arqueologia da arquitetura é definida como o estudo de edificações que compõem o registro arqueológico urbano da cidade, com o objetivo de reconstruir a sua história e inserção na sociedade que os construíram e os mantém. Nessa linha de pensamento, o patrimônio edificado deve ser estudado como documento material privilegiado pela sua condição de ator de um processo social complexo que resultou na cidade. Sua leitura e interpretação abrangendo projetos, construções, usos, alterações, abandono e recuperação permitem conhecer a história da sociedade onde ela se insere, em seus diversos aspectos (MORAIS, 2012, p. 263).
\end{abstract}

Nesse sentido, a Segunda Guerra Mundial e as reconstruções das cidades atingidas pelos bombardeios ocasionaram em uma série de intervenções arqueológicas submetidas aos ritmos das obras, estabelecendo uma relação entre Arqueologia Urbana, Arquitetura e salvamento. Já nas décadas de 1970 e 1980 começam a surgir trabalhos focados em Arqueologia Preventiva através de planejamento urbanístico substituindo as atividades de salvamento. Em 1992, na Conferência de Malta, os ministros europeus signatários da Convenção Europeia pela Proteção do Patrimônio Arqueológico recomendaram um plano europeu para a Arqueologia, que incluía um estudo comparativo acerca da Arqueologia Urbana no continente europeu, que resultou em trabalhos diferenciados no tema em diversos países do continente (Tocchetto e Thiesen, 2007). 
Nos Estados Unidos, entre as décadas de 1960 e 1970, houve um grande surgimento de projetos que tinham como temática a atribuição ao valor científico do patrimônio arqueológico urbano. Começaram assim a se reforçarem as relações e influências entre Arqueologia e Urbanismo, tratadas por Ulpiano Toledo Bezerra de Meneses (2006), que considerou a cidade como artefato, campo de força e campo de representações sociais, desta forma, consideramos que em uma cidade, em suas ruas, praças, ou igrejas, enfim, em sua paisagem, estão marcados todos os processos de sua transformação social, econômica e cultural, todos aptos para contribuir com as análises, e ainda, em se tratando da cidade como artefato e campo de forças de representações sociais.

E assim, no Brasil, ocorreram trabalhos em Arqueologia Urbana desde a década de 1960, porém, o tema começou a ser tratado criticamente a partir da década de 1990 (Tocchetto e Thiensen, 2007), demonstrando a defasagem da Arqueologia Brasileira em relação aos trabalhos em Arqueologia Urbana desenvolvidos em outros países.

Contudo, hoje em dia a Arqueologia Urbana no Brasil é realizada em alguns sítios arqueológicos pontuais estudados a partir de objetivos acadêmicos e em outros casos vinculados a projetos de restauração de bens edificados (Tocchetto e Thiesen, 2007). Esses trabalhos em Arqueologia Urbana têm crescido consideravelmente em quantidade e importância. Também estão imbricadas em seu meio as questões relacionadas às identidades e memória social, que vem ganhando espaço na Arqueologia Histórica nos últimos tempos.

E ainda, é necessário mais que a utilização de métodos hipotético-dedutivos ou que requerem as tridimensionalidades ou mesmo os métodos pós-processualistas (Criado Boado, 1999), porque devemos fazer o reconhecimento e desconstrução da paisagem onde estão inseridos sítios arqueológicos e de sua de transformação histórica por processos antrópicos e naturais e desta forma, com a leitura da paisagem histórica de Congonhas, buscamos compreender a sociedade e a transformação do espaço pela sociedade num determinado tempo através do que o arqueólogo José Luiz de Morais (2011) em seus estudos arqueológicos na Bacia do Paranapanema Paulista, o Projeto Paranapanema (PROJPAR), denominou integração e interação ecossistêmica e holística.

Segundo Morais (2011), o paradigma ecossistêmico subsidia a investigação arqueológica acompanhando a abordagem sistêmica do mundo, no qual todos os elementos e com eles as sociedades humanas interagem em uma imensa rede de relações em uma espécie de wide 
word web, ou, em integração total. Esta totalidade está vinculada ao paradigma holístico, que busca construir pontes sobre as fronteiras disciplinares e a tradição.

O paradigma holístico, entretanto, está vinculado à concepção sistêmica entendida como a maneira de ver todos os fenômenos ou eventos de um todo coordenados entre si, de modo que funcionem como uma estrutura organizada (Morais, 2011). E ainda: "Assim, natureza e sociedade fundem-se em uma totalidade organizada. Visão ecossistêmica e holística se integram e interagem na medida que tratam de relações e de totalidade" (MORAIS, 2011, p. 56).

Então, em nossa pesquisa de mestrado, a Arqueologia da Paisagem é o que nos proporciona os principais subsídios para a localização e identificação do registro arqueológico, assim como as estratégias de planejamento e gestão que considerem esse registro arqueológico. Neste sentido, ao exemplo dos estudos arqueológicos realizados pelo Projeto Paranapanema no município paulista de Piraju:

Registro arqueológico é um termo de conotação espacial, que privilegia o sentido de 'local' ou de 'sítio'. Nos estudos encaminhados pelo PROJPAR, registro arqueológico é um termo genérico que se refere aos objetos, construções e ambientes produzidos pelas sociedades do passado em seus respectivos contextos (MORAIS, 2007, p. 24).

Nos estudos de Arqueologia do Projeto Paranapanema, o patrimônio arqueológico foi definido como materialização da representação da memória constituída por objetos, construções e ambientes, que são expressões materiais da cultura potencialmente incorporáveis à memória local, regional ou nacional e que constituem parte da herança cultural deixada pelas gerações do passado às gerações futuras (Morais, 2007).

Desta forma, seguindo o pensamento de Morais José Luiz de Morais, compreendemos que o papel da Arqueologia da Paisagem nesta pesquisa significa compreender a transformação da paisagem de Congonhas numa totalidade. Este fator é essencial na busca por alternativas que possam possibilitar o georreferenciamento do registro arqueológico, assim como por alternativas de preservação e ressignificação do patrimônio arqueológico registrado durante a pesquisa para reutilização e usufruto dele pela sociedade local. 


\subsection{3 - Geoarqueologia}

Nesta parte da redação da dissertação de mestrado, tratamos de incluir aspectos relacionados à Geoarqueologia na compreensão da formação dos sítios arqueológicos pesquisados. "O termo geoarqueologia tem sido aplicado desde 1970 para designar variados tipos de pesquisas com utilização de técnicas das geociências na avaliação do registro arqueológico" (BITENCOURT, 2008, p. 45). Neste sentido:

\footnotetext{
$\mathrm{Na}$ relação interdisciplinar entre geociências e arqueologia, a geoarqueologia emergiu mais recentemente como uma disciplina distinta da arqueologia, possuindo, também, como rótulo alternativo 'Arqueologia Geológica'(BITENCOURT, 2008, p. 43)
}

No Brasil, com exceção de alguns casos como os do Museu Paraense Emílio Goeldi com as Terras Pretas da Amazônia (TPA), tanto a Arqueologia quanto a Arqueologia Histórica pouco exploram aspectos relacionados à Geoarqueologia, tão importantes para a contextualização de sítios arqueológicos, sendo este tipo de abordagem mais frequente no exterior (Silva; et al, 2008).

Para um dos grandes nomes internacionais da Arqueologia, o famoso arqueólogo Lewis R. Binford, o registro arqueológico é feito de coisas materiais e de matéria ordenada, o qual ele considera algo como uma língua não traduzida, que deve ser decifrada para passar de afirmações sobre a matéria e sua ordenação para afirmações acerca do passado e se queremos nos exprimir por palavras devemos compreender como as coisas materiais se formaram, se alteraram e adquiriram as características que possuem na atualidade, o que deve ligar as atividades humanas, às consequências dessas atividades que ficaram aparentes nas coisas materiais (Binford, 1991).

Neste sentido, em se tratando do estudo da paisagem de Congonhas, um fator que se torna evidente para nosso caso é o de compreendermos o papel do solo na formação dos sítios arqueológicos pesquisados. Como tratamos de pesquisar acerca de sítios históricos coloniais em Minas Gerais, é importante que possamos compreender o papel que teve o ouro e sua distribuição espacial na formação dos sítios arqueológicos encontrados, assim como em termos de cronologia histórica. "Os solos fazem parte de um ambiente dinâmico e 
heterogêneo, e podem ter suas características modificadas mediante alterações ambientais e/ou processos localizados" (SILVA; et al, in: RUBIN \& SILVA, 2008, p. 25). E ainda, o material arqueológico é encontrado dentro do perfil dos solos e são reflexos das características de seus materiais formadores, sob a ação do ambiente que influenciam a formação das paisagens nas quais estão inseridos, devemos estar atentos aos processos de formação ou da história da formação dos sítios para lograr o esclarecimento de fatos ligados à presença destes materiais (Silva, 2008).

Muito pertinente para o nosso caso, em termos de Geoarqueologia, a paisagem constitui uma unidade visual, podendo desta maneira ser observada e percebida de diversas formas, por múltiplas compreensões e interpretações, variando conforme o filtro da formação científica e da cultura do observador e assim, a análise da paisagem em Geoarqueologia é fundamental para a contextualização espacial ou ambiental da região onde está inserido um sítio arqueológico ou ainda, para a compreensão da estrutura ou das fontes fornecedoras de recursos naturais variados como fontes de matérias-primas para fabricação de artefatos diversos e alimentação. Neste sentido, a análise da paisagem pode ser feita com auxílio de fotografias aéreas e/ou imagens de satélites no intuito de caracterizarmos conjuntos de elementos, que podem ser naturais, como as formas de relevo, os solos, a hidrologia, os tipos de rochas e a vegetação, ou então os elementos antrópicos, que incluem formações ou sítios arqueológicos, incluindo áreas atuais como cidades, pastagens e culturas (Bitencourt, 2008).

Solos aluviais são aqueles formados sob sedimentos aluviais e podem ser tanto aqueles que ainda estão se formando na superfície quanto os que estão soterrados. No caso dos sítios pesquisados em Congonhas, Minas Gerais, tratam-se de sítios que se formaram devido à exploração do ouro de aluvião e neste caso, os solos que são formados em vales aluviais podem providenciar informações acerca dos contextos arqueológicos dos sítios, já que os dados presentes nos solos aluviais são importantes para reconstruirmos as histórias das formações dos sítios arqueológicos (Ferring, 1992).

Como nossa pesquisa trata do patrimônio arqueológico histórico, para a interpretação do registro arqueológico que se encontra na maior parte das vezes sobre a superfície do solo (cotas positivas), incluímos também observações por meio de técnicas não invasivas. 
As técnicas não invasivas são aquelas técnicas não destrutivas ${ }^{12}$, como observações espontâneas, levantamentos métrico-arquitetônicos, fotografias, mapas e outras fontes escritas (Morais, 2007) na interpretação da formação do registro arqueológico, georreferenciamento e registro.

Um dos trabalhos que consideramos mais importantes para apoiar-nos na análise da paisagem da região de Congonhas são os registros escritos pelo Barão de Eschwege, que relatou com detalhes acerca da mineração do ouro, suas fazes, métodos, técnicas, das estruturas construídas para a realização da mineração e ainda e tão importante quanto, das transformações na superfície da região mineradora, por conta dos trabalhos de extração do ouro.

\footnotetext{
${ }^{12}$ De acordo com Morais (2007), existem ainda as técnicas invasivas ou interventivas, que são aquelas mais comumente utilizadas quando a pesquisa atinge o subsolo (cota negativa). Essas técnicas invasivas desmontam os sítios arqueológicos, evidenciando e decompondo as partes dos sítios para serem lidas. Existem ainda os trabalhos realizados em cota zero, que consistem em limpeza e remoção do que possa comprometer a visibilidade da superfície do terreno estudado e também em levantamento planialtimétrico, permitindo determinar o modelado da superfície do terreno, chamado de módulo arqueológico, que contém o objeto de estudo e deve ser amarrado a coordenadas geográficas e cotas de altitude para permitir a locação dos elementos de interesse na pesquisa.
} 


\section{Capítulo 2: O sistema econômico mundial na época da colonização do Brasil}

\section{1 - Marxismo, Mercantilismo, colonização do Brasil e os ciclos econômicos do Brasil}

\subsection{1 - Marxismo e marxismo vulgar}

A região mineradora e a sociedade mineira, objetos de nosso estudo, formaram-se num período de grande convulsão econômica em todo planeta e principalmente na Europa, de onde partiu o colonizador que veio explorar e povoar a América. Para uma melhor compreensão da totalidade social, é necessário que façamos uma passagem pela história econômica da região onde a cidade de Congonhas teve sua origem, com a precaução para não tentarmos impor uma abordagem historiográfica determinista, principalmente no que diz respeito à economia, do contrário, ao estudar a sociedade mineira em sua complexidade, devemos observar fatores sociais, políticos, religiosos, artísticos, ambientais, entre outros que contribuíram para a formação da região e de seu povo, e desta forma, o fator econômico pode ser considerado uma orientação importante, mas que não deve ser observada separadamente das diversas outras empresas do espírito humano que levaram ao desenvolvimento da região mineradora e de seu povo, e que atualmente influenciam também a questão do tratamento dado ao patrimônio arqueológico.

Neste caso, é necessária uma abordagem acerca do marxismo, tema que exige muitos cuidados em seu tratamento e que segundo o arqueólogo Charles Orser Jr. (2002), além de uma rica tradição intelectual que examina a condição fundamental da desigualdade sobre as condições materiais das sociedades humanas, provando as raízes históricas dessas desigualdades e dos confrontos de significância política sobre todo conhecimento acerca do passado, os trabalhos desenvolvidos sobre esta ótica marxista podem e devem contribuir muito com a Arqueologia Histórica. O marxismo então pode, neste sentido, ser considerado como uma grande teoria que pode forjar um quadro filosófico compreensivo em teoria e prática. O marxismo também é distinguido por sua tentativa central de transformação da desigualdade vivida na sociedade atual. O marxismo deve ser visto então como uma forma de argumentarmos se podemos compreender as desigualdades objetivas e as contradições, e formularmos ações baseadas no que aprendemos com nossa prática acadêmica e por isso o 
marxismo ocupa um lugar especial na Arqueologia Histórica, outro fator importante é o fato de que o marxismo pode ser o caminho que o arqueólogo usa para se focar na desigualdade entre as classes, nas tensões sobre as trocas de mercadorias, nas contradições do capitalismo e das crises, ambos refletidos em coisas materiais.

Já no campo da História, o historiador Eric Hobsbawm explicou a respeito da abordagem marxista da história e as diferenças entre as concepções de Marxismo e Marxismo Vulgar, este último muito utilizado por historiadores contemporâneos que conduzem a pesquisa histórica tomando como base o fator econômico para explicação da mudança nas sociedades humanas.

Eric Hobsbawm (1997) mostrou em sua abordagem histórica que a disciplina acadêmica da História ficou fora das realizações intelectuais importantes da era burguesa, o século XIX. Para ele, excetuando-se as realizações técnicas no campo da disciplina, no mais ela teria obtido um considerável recuo naquele tempo, principalmente no que diz respeito a ensaios mal documentados, aos especulativos e genéricos, nos quais os que tentavam compreender as transformações na sociedade eram aqueles que teriam testemunhado a era mais revolucionária, com as revoluções Francesa e Industrial. Para ele, a história acadêmica nos finais daquele século estava correta em propor a generalização baseada em fatos insuficientes, ou respaldada por fatos não confiáveis. Porém, a história científica daquele tempo estava preocupada em estabelecer fatos, contribuindo pouco para a disciplina, com exceto por abordar um conjunto de critérios empíricos para avaliar alguns tipos de referências documentais, como por exemplo, registros manuscritos que envolviam decisões de indivíduos influentes e as técnicas necessárias para auxiliar nessa tentativa.

Para Hobsbawm, estes tipos de documentos e procedimentos só poderiam ser aplicados a uma classe limitada de fenômenos históricos, pois aceitava acriticamente certos fenômenos como sendo dignos de estudos especiais enquanto outros não, concentrando-se na história de eventos, com metodologia centrada imediatamente à narrativa cronológica.

A estrutura central dos eventos é que interessava os historiadores, que se concentravam nos estudos das guerras, das diplomacias, da política, relativa assim, como geralmente ensinado pelos professores, a batalhas, aos tratados e aos reis.

O que para Hobsbawm seria uma inocência em termos filosóficos e metodológicos, era o que as ciências naturais aceitavam, de forma controversa, e que fora batizado com o nome de "Positivismo". Isto supunha que, tal como a erudição científica poderia estabelecer o texto e 
sucessão definitivos dos documentos publicados em revistas reconhecidas, assim, ela poderia estabelecer a verdade exata da história.

A História, pelos padrões modestos das ciências sociais e humanas do século XIX, era considerada uma ciência deliberadamente retrógada. Por isso, suas contribuições para o conhecimento da sociedade humana, tanto passada quanto presente eram consideradas insignificantes e ocasionais. Mais cedo ou mais tarde, como veio ocorrer com a História Nova, viriam a encontrar maneiras alternativas e mais produtivas de investigação do passado humano, uma vez que o entendimento da sociedade requer o conhecimento da história.

A partir de 1910, as tendências que já se faziam notar na tentativa de introduzir um referencial materialista no lugar do referencial idealista, levam ao declínio da História Política e à ascensão da História Econômica e História Sociológica, isso sob o estímulo crescente do problema social que dominava a historiografia dos XIX. Já em 1914, poucos postos da História Econômica e da Sociologia com orientação histórica haviam sido conquistados nas universidades, sendo estes ainda derrotados e colocados para fora depois da Segunda Guerra Mundial, garantindo sucesso ao movimento anti-ranckeano.

A influência do Marxismo é, para Hosbawm, desde o início considerável, já que a única escola ou corrente de pensamento influente que visava a reconstrução da história no século XIX era o Positivismo. Filho do Iluminismo do século XVIII, ele não conseguiu conquistar admiração de forma irrestrita nos XIX. O Positivismo teria sua fragilidade na convicção de Comte de que a Sociologia era a mais adequada das ciências, mas tinha pouco a dizer sobre os fenômenos que caracterizavam as sociedades humanas, comparando com outros que poderiam ser diretamente derivados da influência de fatores não sociais, ou modelados pelas ciências naturais. Suas concepções sobre o caráter humano da história eram nada menos que especulativas e quando não, metafísicas. Por sua vez o principal para a transformação da História viria das ciências historicamente orientadas e principalmente de Marx, cuja influência o teria dado créditos para realizações que nem ele mesmo teria pretendido originar. O materialismo histórico seria então habitualmente definido como determinismo econômico.

As ideias marxistas penetraram de vez na França após a Segunda Guerra Mundial, na qual se introduziu de forma lenta na vida intelectual daquele país. Já nos anos 20 essas ideias já tinham penetrado o campo altamente político da historiografia da Revolução Francesa, porém a principal orientação dos historiadores franceses veio pela condução dos Annales, que segundo Hobsbawm não precisou que Marx chamasse sua atenção para as dimensões sociais e 
econômicas da história. Não somente o marxismo teve papel preponderante para modernização da historiografia como também demonstra que há uma grande dificuldade para se chegar a pretender a determinação de sua contribuição exata.

Hobsbawm ainda nos trouxe elementos que segundo ele, abarcavam a noção do que pode ser considerado o marxismo vulgar. São eles: 1 - A “interpretação econômica da história”, ou seja, a crença de que o fator econômico é o fator fundamental do qual dependem os demais. Nesse sentido essa interpretação se propunha ao: 2 - Modelo da "base e superestrutura" (utilizado mais amplamente para explicar a história das ideias), como uma simples relação de dominância e dependência entre a base econômica e a superestrutura, na maioria das vezes mediada pelo: 3 - Interesse de classe e luta de classes; 4 - Leis históricas e inevitabilidade histórica ou um desenvolvimento sistemático e necessário da sociedade humana na história, interpretado como uma regularidade rígida e imposta, como na sucessão das formações socioeconômicas, ou mesmo como um determinismo mecânico que às vezes se aproxima da sugestão de que não havia alternativas na história; 5 - Temas específicos de investigações históricas derivavam dos próprios interesses de Marx mas também, por vezes, de comentários mais ou menos casuais; 6 - Temas específicos de investigação não derivavam tanto de Marx quanto do interesse dos movimentos associados a sua teoria, por exemplo, nas agitações das classes oprimidas ou nas revoluções; 7 - Várias observações sobre a natureza e limites da historiografia derivavam principalmente do elemento número 2 e serviam para explicar as motivações e métodos de historiadores que afirmavam não estarem fazendo mais que a busca imparcial da verdade (Hobsbawm, 1997).

Eric Hobsbawm considerou que a escolha desses elementos acima não foi arbitrária. Para ele os itens 1, 4 e 7 representavam cargas concentradas de explosivo intelectual a detonar com os componentes cruciais das fortificações da história tradicional e desta forma, elas eram imensamente poderosas, talvez mais ainda que versões menos simplificadas do materialismo histórico e fortes o bastante para iluminar lugares ainda obscuros e de manter os historiadores satisfeitos por um período considerável. Se isso parece natural ou necessário, a escolha efetiva de elementos de Marx foi também histórica.

O grosso do que consideramos como influência marxista sobre a historiografia certamente foi marxista vulgar no sentido acima descrito. Consiste na ênfase geral sobre os fatores econômicos e sociais na história, dominante a partir do fim da Segunda Guerra Mundial apenas em uma minoria de países (por exemplo, até recentemente, a Alemanha Ocidental e os Estados Unidos), e que continua a ganhar 
terreno. Devemos repetir que esta tendência, embora sem dúvida produto da influência marxista, não tem nenhuma ligação com o pensamento de Marx (HOBSBAWM, 1997, p. 162).

As ciências sociais foram impactadas principalmente pela teoria da base e superestrutura, ou, uma sociedade composta de diferentes níveis de interação. Esta hierarquia de níveis ou o modo de sua interação não precisaria ser aceita para que o modelo geral fosse válido como uma contribuição valorosa, já que recebeu ampla e favorável acolhida entre historiadores, mesmo de não marxistas. Este modelo, contudo, deve ser debatido e os critérios usuais de verificação histórica devem ser aplicados a ele. O que Hobsbawm quer mostrar é que, o valor principal de Marx para os historiadores reside atualmente em suas proposições sobre a história, enquanto distintas de suas proposições sobre a sociedade em geral.

A influência marxista e marxista vulgar até agora mais eficaz veio de uma tendência geral de transformar a história em uma ciência social, tendência esta em vigor no século $\mathrm{XX}$, cuja principal contribuição do marxismo fora a crítica ao Positivismo, das tentativas de assimilação dos estudos das ciências sociais aos das ciências naturais, o humano ao não humano. Para tanto devemos reconhecer que as sociedades são sistemas de relações entre os homens, entre as quais as que são mantidas com a finalidade de produção e reprodução são de primordial importância para Karl Marx. O marxismo, que segundo Hobsbawm seria a primeira teoria estrutural-funcionalista da sociedade, difere das outras teorias de mesma natureza por dois aspectos: primeiro porque insiste em uma hierarquia dos fenômenos sociais tais como base e superestrutura e depois, porque acredita na existência de tensões internas na sociedade ou contradições, que levam ao contrabalanceamento do sistema que se mantém como um interesse vigente. E ainda, se a importância dessas peculiaridades do marxismo se encontram no campo da História, é porque elas permitem explicar porquê e como as sociedades mudam e se transformam, ou em outras palavras, seriam os fatos da evolução social.

Para Hobsbawm é preciso então, diante disso, implicar duas críticas específicas de teorias que se encontram em vigor dentro das ciências sociais. A primeira delas seria ao mecanismo que domina parte das ciências sociais, principalmente nos Estados Unidos, cuja força seria extraída da fecundidade de modelos mecânicos matemáticos sofisticados na fase do avanço científico atual, quando da busca por métodos de realização de mudanças sociais que não impliquem em revolução social, uma espécie de engenharia social implicada na riqueza proporcionada pelo acumulo de dinheiro e de tecnologias novas e adequadas ao uso na área social, tornada muito atraente em países industrializados, assim como as teorias nas quais 
esses métodos tomam base nesses países, teorias estas que funcionariam como soluções de problemas, o que Hobsbawm considera extremamente primitivas e grosseiras, mais ainda que suas congêneres do século XIX.

A partir desse modelo, muitos cientistas sociais, de propósito ou não, reduzem o processo histórico a uma única mudança de sociedade, da tradicional para a moderna ou industrial, considerando como modernas as sociedades definidas nos termos dos países mais avançados ou mesmo os Estados Unidos a partir da metade do século XX, e tradicionais aquelas sociedades que carecem de modernidade, o que operacionalmente poderia dividir a enorme etapa de mudanças em pequenas etapas, tais como as etapas do crescimento econômico de Rostow ou, aproximando um pouco mais, cada um dos ciclos econômicos no Brasil.

Assim, esses modelos eliminam a maior parte da história para se concentrar em períodos mais curtos, ainda que de forma crucial, e exagerar a minimização ou simplificação dos mecanismos de mudança histórica. Isso, segundo Hobsbawm, afetaria os historiadores principalmente porque a amplitude e o prestígio das ciências sociais que desenvolveram tais modelos dão coragem aos pesquisadores históricos a embarcarem em projetos influenciados pelos mesmos. Isso não poderia proporcionar nenhum modelo adequado de mudança histórica, mas sua popularidade faz importante que os marxistas constantemente se lembrem disso.

A segunda crítica a ser feita, segundo Hobsbawm, é a das teorias estruturais-funcionais, que ainda que possam parecer mais sofisticadas, são em alguns pontos mais estéreis, na medida em que podem negar a historicidade por inteiro ou transformá-la em outra coisa diferente do que é. Essas concepções seriam mais influentes na esfera de influência marxista porque parecem querer proporcionar meios de libertá-lo do evolucionismo característico do século XIX, com o qual muitas vezes este se articulava e ainda, embora à custa de também libertá-lo do conceito de progresso que caracterizou também o pensamento nos XIX, incluindo o próprio Karl Marx, que na verdade não pretendia fazê-lo. Hobsbawm contestou que ele não teria desejado dissociar o progresso da evolução e, em verdade, acusou Darwin por converter o primeiro em mero subproduto acidental da segunda.

Hobsbawm assegura que a hierarquia de níveis seria necessária então para explicar porque a história possui uma direção. Por isso uma hierarquia de níveis derivada de outro lugar que não seja da base das relações sociais de produção não teriam necessariamente essa característica e ainda, a sucessão dos sistemas socioeconômicos é implicada uma vez que processo e 
progresso do controle humano sobre a natureza não envolvem apenas mudanças nas forças de produção, como por exemplo as novas técnicas, mas sim nas relações sociais de produção. Isso requer que certos fenômenos sociais não possam ser concebidos na história como anteriores a outros e pelo mesmo motivo, requer que essa dimensão de sistemas não pode ser ordenada simplesmente em uma dimensão tecnológica, ou tecnologias inferiores precedendo as superiores, ou econômica, mas também deve ser ordenada em termos de sistemas sociais.

E ainda: 'Dada essa 'orientação' do desenvolvimento histórico, as condições internas dos sistemas socioeconômicos fornecem o mecanismo para a mudança que se torna desenvolvimento" (HOBSBAWM, 1997, p. 167). Neste sentido, Eric Hobsbawm nos alerta ainda sobre a existência simultânea de elementos estabilizantes e perturbadores que tal modelo deve refletir, e foi nela, que o modelo marxista se baseou, exceto em suas versões marxistas vulgares. É um modelo dual, dialético, difícil de montar e utilizar, pois na prática pode ocorrer a tentação de operá-lo conforme gosto ou ocasião, ora como modelo de funcionalismo estável, ora como modelo de mudança revolucionária, o interessante mesmo é que ele seja ambos. Assim, permanecemos ainda com os problemas históricos específicos da natureza e sucessão das formações socioeconômicas, e os mecanismos de seu desenvolvimento interno e interação. É asseverada a convicção de Hobsbawm de que a abordagem de Karl Marx é a única a nos habilitar a explicar toda amplitude da história humana e constitui o mais frutífero ponto de partida para uma discussão moderna, apesar de todas as suas limitações.

Ainda que cientistas sociais de orientação histórica possam se achar menos necessitados da importância dos elementos econômicos e sociais que os do início do século XX e ainda possam também se encontrarem mais estimulados por aspectos da teoria marxista que não produziram muitos impactos em historiadores das primeiras gerações pós-Marx, o pensamento de Marx se encontra em grande evidência, principalmente por conta das mudanças que ocorrem dentro das ciências sociais em geral.

A função principal do materialismo histórico foi, após o primeiro século da morte de Engels, a de trazer a História para mais perto das ciências sociais e evitar as simplificações exageradas do positivismo. Ele está enfrentando a própria historização no interior das ciências sociais. Por falta da historiografia acadêmica, essas ciências começaram cada vez mais a improvisar as suas, aplicando em seus estudos do passado procedimentos próprios, às vezes com resultados sofisticados, mas baseados em modelos de mudança histórica que poderiam, segundo Hobsbawm, serem ainda mais toscos dos que os utilizados no século XIX. 


\subsection{2 - O Mercantilismo e o início da exploração comercial do Brasil}

Na busca de uma melhor compreensão das causas que influenciaram na formação da sociedade mineira, devemos obrigatoriamente tratar de temas como o Mercantilismo. A definição de mercantilismo é controversa e extrapola o aspecto fortemente econômico ao qual o termo nos conduz prontamente a imaginar, por isso, o termo deve ser pensado sem querer reter seu aspecto comercial apenas, e assim, fugirmos de concepções pejorativas a seu respeito. O problema dessa força pejorativa que o termo contém teve início com a escola de História Econômica alemã da segunda metade do século XIX (Deyon, 1969), que acreditava, através da substantivação e idealização do adjetivo, na tentativa de maior dignidade filosófica.

É preciso olhar além dos interesses mercadores e financeiros e enxergar o sistema manufatureiro, as artes, a agricultura, o Estado, a religião, e por que não, as transformações culturais pelas quais estava interligada esta grande rede mundial de comércio.

Considerando as múltiplas abordagens a que o termo Mercantilismo pode levar, ainda, segundo Pierre Deyon (1969), ele pode ser encarado como o conjunto das teorias e das práticas de intervenção econômica que se desenvolveram na Europa moderna desde a metade do século XV. Deyon se propõe então a desdobrar os problemas das relações do sistema com os fatos, a conjuntura econômica, as realidades sociais e de sua influência sobre o advento do capitalismo moderno.

A herança medieval deixou para o Estado a tradição de intervenção na vida econômica e social. A política econômica dos Estados monárquicos encontraram aí seus primeiros elementos e as preocupações e práticas das cidades medievais foram estendidas aos limites das jovens monarquias nacionais e o Mercantilismo começou a se firmar na França e na Inglaterra.

As monarquias europeias colocaram imperativos à regulamentação das economias. A matériaprima era controlada pelos escabinos e pelos magistrados municipais e a concorrência externa era combatida em prol das manufaturas locais. Os estrangeiros eram obrigados a passarem por intermediários nativos. Já na Itália, os Sforza de Milão, os Médicis em Florença e os Bentivoglio em Bolonha protegiam comunidades de profissionais urbanos, financiavam inventores e ferreiros, vidraceiros, negociantes, artistas e fabricantes de tecidos. 
Mas os condados, ducados e cidades tinham seus limites territoriais e populacionais e as monarquias se beneficiaram de outras vantagens e possibilidades mais amplas. O Parlamento e a Coroa inglesa tomaram medidas a favor da indústria lanífera e proibiram a exportação de lã bruta já na metade do século XIII. Já na segunda metade do século XV proibiram produtos de lã estrangeiros e a instalação de fábricas estrangeiras de seda. As saídas de ouro e de prata passaram a ser cautelosas e observadas e os mercadores estrangeiros, vítimas do nacionalismo econômico que se encontrava em gestação, tinham que reinvestir em compras na Inglaterra.

Os italianos em Londres chegaram a ter suas casas e escritórios pilhados por londrinos. "A monarquia Tudor retomou, sistematizou todas estas iniciativas, substituíram as veleidades desordenadas por uma verdadeira política nacional. Com o mesmo arrojo, definiu o programa do absolutismo monárquico e do mercantilismo" (DEYON, 1969, p. 17). Na França de Luís XI, a Guerra dos Cem Anos trouxe progressos no poder central e com eles as necessidades financeiras que incitaram as intervenções mais regulares na vida econômica, como nas saídas de ouro e prata, os monopólios a companhias de comércio, o encorajamento na mineração, o favorecimento às manufaturas internas para evitar a compra do produto estrangeiro e favorecimento à expansão marítima, como na Inglaterra, investindo em sua marinha. Havia uma comunidade de interesses em uma política econômica e o sentimento no progresso e no reforço do Estado, uma ciência das riquezas que exprimia o voluntarismo renascentista. Com isso, podemos perceber aqui as três principais preocupações dentro da qual a economia mercantilista se baseava: o bulionismo ou metalismo ${ }^{13}$, o protecionismo e por fim, a balança comercial favorável.

A ocupação econômica da América constituiu um dos episódios dessa expansão comercial europeia, que no século XV alcançou um alto grau de desenvolvimento, quando as invasões turcas se tornam claramente um obstáculo às pretensões dos europeus. Uma grande realização dos europeus seria a retomada das linhas de comércio das mãos dos otomanos.

O desenvolvimento de Portugal no século XV - a exploração da costa africana, a expansão agrícola nas ilhas do Atlântico e finalmente a abertura da rota marítima das Indias Orientais - constituiu um fenômeno autônomo na expansão comercial europeia, em grande parte independente das vicissitudes crescentes criadas ao comércio do Mediterrâneo oriental pela penetração otomana. A produção de açúcar na Madeira e São Tomé alcançou seus pontos altos na segunda metade do século $\mathrm{XV}$, época em que os venezianos ainda conservavam intactas suas fontes de abastecimento nas ilhas do Mediterrâneo oriental. $\mathrm{O}$ mesmo se pode dizer do comércio das especiarias das índias, pois a ocupação do Egito - entreposto principal

\footnotetext{
${ }^{13}$ Retenção de metais preciosos, principalmente prata e ouro, como principal forma de acumulação de riquezas.
} 
- pelos turcos só ocorreu um quarto de século depois da viagem de Vasco da Gama. A imediata consequência da abertura da nova rota foi uma brusca queda dos preços das especiarias: os venezianos passaram a comprar pimenta em Lisboa pela metade do preço que pagavam aos árabes em Alexandria. $O$ grande feito português, eliminando os intermediários árabes, antecipando-se à ameaça turca, quebrando o monopólio dos venezianos e baixando o preço de produtos foi de fundamental importância para o subsequente desenvolvimento comercial da Europa (FURTADO, 1980, p. 05-06).

Dessa conjuntura derivou um novo conjunto de relações na Europa a abrir de vez os caminhos para a expansão marítima do continente. O europeu deixou a navegação interna no Mediterrâneo, deixando de lado uma navegação quase que de cabotagem para se lançar em águas mais distantes, cruzando o Estreito de Gibraltar e deixando em posição agradável aqueles países geograficamente de fronte ao mar, como Holanda, a Normandia, a Inglaterra, a Bretanha e a Península Ibérica. A descoberta da América pelos europeus veio nesse contexto e tornou no início algo secundário, principalmente por parte dos portugueses, que ao contrário dos espanhóis não puderam de imediato, colher seus frutos.

O ouro e a prata das antigas civilizações americanas eram a razão de ser da América espanhola e as lendas sobre tesouros a descobrir aumentavam o interesse de outras potências marítimas europeias que forçavam Portugal e Espanha a se lançarem em questões políticas, refletindo na ocupação inicial do território brasileiro e no Tratado de Tordesilhas. A Holanda já se preocupava com o estabelecimento e organizam uma expedição para colonizar a costa setentrional do Brasil e com isso Portugal teve que se esforçar para não perder as terras descobertas do Brasil, ocupando-as permanentemente. A Espanha aceitou diminuir a possessão de suas terras, estabelecida com o Tratado de Tordesilhas, para garantir o rico quinhão que lhe coube e se limitou em sua cobertura.

Coube a Portugal explorar economicamente as terras americanas sem contar com a exploração de ouro e prata, e tentar a empresa agrícola e exploratória que de início pareciam inviáveis em terras tão longínquas.

De início funcionou algo como o antigo sistema de feitorias, aproveitando produtos extrativos abundantes como as madeiras para construção e tintura, das quais cabe enaltecer o pau-brasil, ao qual se deve o que pode ser considerado como o primeiro ciclo econômico em terras brasileiras, além de animais exóticos, peles e as drogas do sertão. 
O pau-brasil que começou a circular na Europa teve ampla aceitação, principalmente por sua cor vermelha que fixava o tom purpúreo das vestes dos nobres, quando a cor nos trajes era de reconhecido valor e de uso privativo de algumas camadas sociais.

No início da colonização havia até uma simpatia entre o colono e o indígena e durante o sistema de feitorias, alguns brancos chegavam a ser tragados pela vida indígena, já que se misturava ao índio como meio de vencer a natureza nova e desconhecida. Assim não foi difícil o emprego da mão-de-obra indígena na exploração do pau-brasil, que se deu principalmente pelo escambo.

(...) o colono europeu não traria com ele a disposição de por-lhe a serviço, neste meio tão difícil e estranho, a energia do seu trabalho físico. Viria como dirigente da produção de gêneros de grande valor comercial, como empresário de um negócio tão rendoso; mas só a contragosto como trabalhador (PRADO JÚNIOR, 2000, p. 20).

Alguns dos mais conhecidos beneficiados com a exploração comercial do pau-brasil foi o armador bretão Ango, que acabou por se tornar banqueiro e financiador da própria Coroa portuguesa.

Porém, foi a experiência já iniciada na produção de açúcar nas ilhas do Atlântico que tornou a empresa portuguesa em terras brasileiras uma realidade. A aproximação com os holandeses, os flamengos, acostumados com o comércio no interior da Europa, dotados de capital e grande senso de organização comercial constituiu o fator de êxito na colonização portuguesa do Brasil, criando o mercado amplo para uma especiaria ainda pouco comum para os europeus como o açúcar.

Por trás de tudo, estava ainda o desejo e o empenho da coroa portuguesa em encontrar o tão sonhado ouro no interior das terras brasileiras. A utilização agrícola das terras brasileiras, que antes parecia inviável, tomou feição por meio das medidas políticas que, por pressão de outras nações, teve que fazer Portugal para garantir suas possessões americanas. De empresa espoliativa e extrativa como outras feitorias na África, o Brasil passou a fazer parte da empresa reprodutiva europeia. Teve assim seu início o Ciclo do Açúcar.

As empresas de açúcar nas ilhas do Atlântico proporcionaram um conhecimento técnico indispensável para a produção açucareira e para o problema da mão-de-obra, pois, Portugal 
tinha uma população pequena para permitir que a migração dos patrícios fosse ampla, problema que foi resolvido principalmente com a utilização do africano escravizado.

Neste cenário, destacou-se também o surgimento da pecuária, que veio em mão dupla para satisfazer as diferentes demandas de carne para alimentação e de animais de tração e carga que foram criadas em primeiro lugar pela empresa agromercantil e mais tarde, pela empresa mineradora:

\begin{abstract}
Essa demanda era considerável, pois as bestas de tração e transporte constituíam uma fonte de energia muito mais barata que o homem escravo, devendo substituí-lo sempre que possível. Mais barata e mais eficaz, pois o uso de animais permitia reduzir consideravelmente o tempo requerido para transportar lenha para os engenhos e carga para os portos. Dada a abundância de terras, a pecuária apoiava-se num mecanismo de acumulação natural, graças ao qual intensificou-se o processo de ocupação e povoamento do território (FURTADO, 1972, p. 95-96).
\end{abstract}

A pecuária flutuou entre as altas e baixas da atividade principal e de certa forma desempenhou um papel de estabilizador das atividades econômicas em seu conjunto, além de funcionar como uma forma de colonização e povoamento de terras ainda não exploradas pela empresa agrícola, por meio da abertura de novas fazendas para estabelecimento da criação de animais (Furtado, 1972). E ainda:

A importância da empresa agromercantil, no Brasil, está em que ela marcará decisivamente a estrutura da economia e da sociedade, que se formarão no país. Esta formação, é bem verdade, esteve longe de constituir um processo linear, pois irradiou de dois polos relativamente autônomos: a empresa agromercantil do século XVI e a empresa mineira do século XVIII. Esta, entretanto, fez-se em grande parte a partir de recursos acumulados pela primeira, da qual recebeu o instituto da escravidão. A economia mineira, surgindo como um parêntese num mundo essencialmente agrário, acelerou o processo de acumulação e de povoamento, sem modificar de forma perceptível o quadro institucional básico. A esses dois polos primários, que são as matrizes da economia brasileira, cabe acrescentar dois outros campos de atividade, que operam como mecanismos multiplicadores. Trata-se da caça ao indígena e da pecuária. A caça ao indígena, para utilizá-lo como mão-deobra escrava ou semiescrava, constitui o capítulo americano da obra de pilhagem que realizaram os portugueses para fundar o seu império colonial do Atlântico Sul. Essa pilhagem, cabe sublinhar, realizou-se essencialmente na África, de onde foram extraídos milhões de escravos, e nas Índias Orientais, onde o rendoso comércio das especiarias era imposto a tiros de canhão. A mão-de-obra indígena ocupou o primeiro plano na fase de instalação do europeu nas novas terras e de exploração florestal. Mas, seja que hajam sido simplesmente dizimados pelos rigores do trabalho imposto, a verdade é que a empresa agrícola necessitou para consolidar-se da mão de obra africana (FURTADO, 1972, p. 94-95). 
Contudo, os portugueses já conheciam o comércio africano de escravos e lá já praticaram o escambo em troca do cativo desde os tempos de Dom Henrique (1512-1580). Tornou-se então viável o emprego dessa mão de obra em terras brasileiras. O comércio de escravos africanos se tornou então uma das principais atividades econômicas na colônia, desenvolvendo-se paralelamente às outras atividades principais, como o plantio da cana, a extração do ouro em Minas Gerais e depois na economia do café, entre outras.

A luta pelo controle do açúcar foi uma das razões de ser da guerra entre Espanha e Holanda. De 1580 a 1540 a Coroa portuguesa foi reunida a da Espanha, que englobou o reino de Portugal sob sua monarquia. Portugal teve seus interesses desmoronados e teve ainda que ajudar na Guerra dos Habsburgos com dinheiro e pessoal.

Os Países Baixos e a Inglaterra ocuparam muitas das possessões portuguesas e em 1630 se instalaram desde Pernambuco até o Maranhão, somente saindo após a independência de Portugal do reino espanhol. Por outro lado, Portugal se empobreceu e com isso começou um êxodo de sua população para a colônia, que se espalhou pela costa brasileira.

\begin{abstract}
No que diz respeito à administração local, a centralização e reforçamento do poder real é sensível. Os antigos donatários das capitanias serão cada vez mais subordinados a governadores nomeados pelo rei. Já em 1584, diante do fracasso da maior parte dos donatários, se criara um governo geral, que, embora respeitando os direitos daqueles senhores feudais das capitanias, exercerá sobre eles uma supervisão geral e os auxiliará quando necessário. Este governo geral foi em épocas distintas separado em dois, repartindo-se entre eles o território da colônia; e reunindo novamente num só. Mas a partir dos fins do séc. XVII, os poderes e a jurisdição dos donatários serão cada vez mais restringidos e absorvidos pelos governadores reais. Aqueles ficarão aos poucos reduzidos unicamente aos direitos pecuniários que auferiam de suas capitanias. Quem administrava efetivamente a colônia eram os delegados do Rei. Aliás, os donatários desaparecerão logo completamente, pois a coroa lhes resgatará por compra os direitos hereditários de que gozavam. Compelindo-os muitas vezes a isto contra sua vontade. Em meados do séc. XVIII, todas as capitanias terão voltado ao domínio direto da coroa, e serão governadas por funcionários de nomeação real (PRADO JUNIOR, 2000, p. 51).
\end{abstract}

Ocorreu ainda o fracasso das Câmaras Municipais. As câmaras, que chegaram a legislar sobre amplos aspectos de interesse real, deveriam cuidar da difícil missão de manter a ordem numa terra de colonos e de administração longínqua, mas era representada aqui por donatários que eram indiferentes aos interesses reais e ariscos às causas de proveitos pecuniários próprios. 
Por essas razões não fica difícil entender os motivos do fracasso. As câmaras estavam se tornando simples executoras dos interesses próprios de quem por elas deveriam zelar em nome do Rei. Outro fator que tratou de cuidar Portugal diz respeito aos monopólios.

\begin{abstract}
Até então, a política metropolitana se caracterizara por um largo liberalismo. Afora o monopólio de certas atividades, como da extração do pau-brasil e de outras de somenos importância, os colonos não encontram embargo algum de ordem econômica. Seus trabalhos e seu comércio eram inteiramente livres, tanto dentro da colônia, como nas suas relações com o exterior (PRADO JÚNIOR, 2000, p. $52)$.
\end{abstract}

Alguns privilégios já tiveram que ser desfeitos anteriormente com a ocupação espanhola, que procurou impor suas políticas. Os colonos, acostumados com um certo liberalismo, não se acostumariam da noite para o dia com as novas imposições econômicas, desta forma, o contrabando ganhou condições e espaço para atuar.

Neste sentido, quando tratamos de monopólios nesse período podemos dizer "companhias privilegiadas", que já vinham sendo adotadas por holandeses e ingleses e consistiam em reservar para pessoas escolhidas o direito exclusivo de comércio externo da colônia. A primeira companhia privilegiada em 1647 teve amplos direitos de exploração comercial desde a costa do Rio Grande do Norte até São Vicente. Ela teve nas mãos todo comércio de vinho, azeite, farinha de trigo e bacalhau consumidos em terras brasileiras, mas foi abolida em 12 anos por conta de deficiências no abastecimento e protestos dos colonos. Em 1682 foi fundada a Companhia do Maranhão e Pará, com as mesmas concessões e que provocou consequências como a Revolta de Beckmann em1684.

Outras concessões provocaram também o descontentamento da população, como o monopólio do sal e a proibição de sua fabricação no Brasil em 1665, assim como a proibição da fabricação de aguardente em 1647, que acreditavam fazer concorrência aos vinhos portugueses. Essa medida forçava os pequenos produtores de cana a vender seu produto para os grandes senhores de engenho, que andavam aliados com a Coroa portuguesa.

À medida que a população colonial vai crescendo e procura por outras iniciativas em que aplicar suas atividades, a política de restrições se acentua. Procura-se impedir a produção de qualquer gênero que não interessasse diretamente à metrópole e seu 
A ruptura do sistema cooperativo estabelecido com a Holanda por conta da absorção de Portugal pela Espanha foi um fator preponderante que afetou a empresa agrícola portuguesa no Brasil. Os holandeses, antigos parceiros distribuidores do açúcar no mercado europeu, passaram a inimigos, por tabela, pela Espanha e se tornou um concorrente implacável.

Os holandeses haviam adquirido os conhecimentos técnicos e organizacionais para a produção açucareira e implantaram uma indústria concorrente forte no Caribe e com isso ocorreu a quebra do monopólio entre os produtores portugueses e os comerciantes holandeses. Para contribuir negativamente com os portugueses ocorreu a desvalorização do produto no mercado europeu na segunda metade do século XVII, reduzindo os preços pela metade e desvalorizando ainda mais adiante, durante o século XVIII. E para piorar, as exportações caíram para a metade do que eram em 1650. Com isso, a renda na produção açucareira caiu para um quarto do que foi no século XVII, levando também à depreciação da moeda portuguesa frente ao ouro.

Porém, Portugal ainda mantinha sua crença e esperança na descoberta do ouro. Em 1608, já havia instalado Portugal as suas casas de fundição em Taubaté e São Paulo para extrair o quinto do pobre ouro de lavagem que se esgotou com extrema rapidez. Mais uma vez o preço do sonho não valeu a pena:

O vicentino voltou ao cultivo do açúcar, do trigo e da vinha, e ao criatório; o paulista, ao plantio de sua mandioca; sem, contudo, desanimarem, ambos, de cresohedonismo. A guerra holandesa, interrompendo o fluxo do escravo negro para o Brasil, criou uma fome nacional de mão-de-obra escrava. O grande proprietário do litoral e o pequeno proprietário do planalto se viram, então, a braços com uma crise de sobrevivência. Começou a "preá do índio", a institucionalização do genocídio e que tinha como personagem principal um meio índio - o bandeirante - o qual falava tupi, de preferência ao português, tinha hábitos de bugre e era produto da mancebia de portugueses com caboclas (MELO, 1969, p. 86).

A empresa bandeirante não pouparia de artimanhas e maldades na captura do indígena para escravidão. Ateavam fogo em aldeias inteiras, queimavam homens e mulheres adultos e aprisionavam principalmente os adolescentes e as crianças (columís ou curumins), que se tornaram os preferidos no comércio humano do nativo brasileiro. Levados geralmente para 
São Vicente, Taubaté e São Paulo, custando um terço do preço pago pelo escravo africano. “Esse indígena 'assimilado' iria no futuro integrar expedições punitivas semelhantes, fazer com os outros o que se lhes fizera aos pais. Em São Paulo deviam sentir-se aclimatados, pois afinal os paulistas eram meio bugres como eles" (MELO, 1969, p. 87).

Porém, o índio não conseguiu suportar a estrutura de produção que estava se estabelecendo, já que, acostumados com sua economia natural, ficou difícil a adaptação forçada ao trabalho escravo: “A substituição do seu pelo adventício corresponde, assim, riscá-lo de zonas inteiras, a expulsá-lo para o interior, a dizimá-lo. Sua inadaptação ao trabalho escravo vai motivar a virada nas ideias a seu respeito" (SODRÉ, 1967, p. 44).

Então compreendemos um pouco da natureza das ideias preconceituosas e racistas que estamos acostumados a ouvir por toda parte, a respeito do indígena brasileiro, ainda nos dias de hoje:

\begin{abstract}
As que se generalizam, agora, dizem de sua preguiça, de sua tendência para o furto, de sua amoralidade - em suma de tudo aquilo que era o conjunto de sua cultura e fora do que qualquer interpretação ou julgamento estaria profundamente viscerado de falsidade. Essa compreensão é que vigorou, ao longo do tempo, chegando aos nossos dias quando, sob outras condições, prossegue, inexoravelmente, a destruição dos derradeiros stocks indígenas existentes. A aproximação do branco é o primeiro ato da destruição do indígena (SODRÉ, 1967, p. 44).
\end{abstract}

O genocídio indígena se justificava pelo lado português, que via no silvícola uma ameaça a seus padrões culturais, religiosos e também a seus interesses econômicos em terras brasileiras. A violência aplicada contra o indígena não se restringiria somente ao trabalho escravo e a violência física e moral. Para o sucesso da empresa era preciso ainda mais:

\footnotetext{
Primeiramente, negar aos indígenas e a seus descendentes inseridos na sociedade portuguesa suas identidades implicava negar-lhes a natividade nessas terras e a própria condição de seus verdadeiros donos (OLIVEIRA \& FERNANDES in OLIVEIRA \& OLIVEIRA, 2010, p. 109).
}

Quebrar com os referenciais culturais de sociedades de tradição oral foi uma estratégia de conquista que deu certo, e isso, também percebemos devido às escassas fontes de informação 
que nos chegaram, aliás, carregadas de preconceito e etnocentrismo em boa parte delas. “O índio vingava-se da escravidão não trabalhando, não dando rendimento, revoltando-se, quebrando os instrumentos, fugindo. Foi o pioneiro da operação 'tartaruga' no Brasill" (MELO, 1969, p. 88). Essa era sua defesa contra o opressor branco.

A caça ao indígena continuou como atividade principal do pequeno núcleo português que se havia instalado na atual região de São Paulo, cuja importância, mais que diretamente econômica, veio a ser de exploração e conhecimento do território que sob sua tutela conservariam os portugueses. Desse trabalho exploratório surgiu a descoberta, no final do segundo século da presença portuguesa na América, do ouro abundante acumulado em leitos de rios distantes do litoral (FURTADO, 1972, p. 95).

Portanto, a caça ao indígena e sua assimilação ao trabalho forçado foi um episódio de fundamental importância para as conquistas territoriais que fizeram com que o território do Brasil ampliasse suas divisas.

Foi em busca do indígena para a escravidão que o bandeirante paulista encontrou o tão sonhado ouro que os portugueses almejavam desde a época do descobrimento do Brasil e depois, Minas Gerais veio se tornar o principal centro econômico do Brasil colonial e um dos principais do mundo.

\subsection{3 - O ciclo do ouro em Minas Gerais}

As informações acerca dos primeiros habitantes que povoaram a região formadora do município de Congonhas ainda são um pouco controversas. Temos ainda, uma grande carência de informações a seu respeito que nos chegam pela historiografia e quando isso ocorre, na maioria dos casos, as informações se referem a grupos indígenas cativos e catequisados que eram levados de São Paulo para as Minas para o trabalho escravo.

Segundo as poucas informações que nos chegam, os grupos que povoaram a região do rio Paraopeba eram denominados Carijós, termo generalizante utilizado pela historiografia, porém, algumas evidências arqueológicas tem lançado luz acerca das origens dos povos indígenas próximos daquela região. Estudos de material arqueológico escavado na 
microrregião de Conselheiro Lafaiete associaram os vestígios encontrados com a tradição Aratu-Sapucaí, que tem produção material relacionada com a de grupos do tronco linguístico Macro-Jê.

Segundo a arqueóloga Ana Paula de Paula L. Oliveira (2010), pode ocorrer um contexto cultural mais diversificado entre os limites da pré-história e história na região e há indícios de organização sócioespacial e cultura material que podem indicar a presença de povos Jê, dados estes, porém, ainda sem validação por conta de falta de informações arqueológicas suficientes para confrontação de dados e verificação da dinâmica dos povos nativos que ocuparam a microrregião de Conselheiro Lafaiete, da qual o município de Congonhas faz parte.

Os paulistas, primeiros descobridores do ouro em Minas Gerais, encontraram o ouro por acaso, quando de suas entradas no sertão em busca dos índios para a escravidão. As entradas para aprisionamento indígena eram proibidas pela coroa portuguesa, provocando discórdias entre os paulistas, colonos e missionários jesuítas. Também movido pelo mito da serra de Sabarabussu, o bandeirante paulista Fernão Dias Pais em 1674 organizou uma bandeira que durou sete anos, da qual ele não voltaria vivo, sendo seguido depois por seu genro, Borba Gato, e seu filho Garcia Rodrigues Pais. Não sabemos com certeza quem foi o primeiro descobridor do ouro em Minas Gerais, [...] “_ fruto antes da descoberta de várias expedições mais ou menos simultâneas ou sucessivas do que do esforço de um só homem" (MELLO E SOUZA \& BICALHO, 2000, p. 26), no entanto, no ano de 1693 , o bandeirante ${ }^{14}$ taubateano $^{2}$ Antônio Rodrigues Arzão achou ouro em um ribeirão quando aprisionava índios. O ouro extraído foi levado para São Paulo e o achado foi comunicado ao concunhado Bartolomeu Bueno, que logo organizou uma bandeira e descobriu ouro na região de Itaverava ${ }^{15}$. A notícia do descobrimento chegou até Lisboa e o Rei Dom Pedro II de Portugal mandou que as informações fossem verificadas para estabelecer meios para a exploração (Vergueiro, 1986) ${ }^{16}$. Começava a corrida pelo tão sonhado ouro em terras brasileiras.

Os bandeirantes paulistas, descobridores e primeiros exploradores do ouro e das pedras preciosas em Minas Gerais também foram os fundadores dos primeiros arraiais daquela região. Antônio Dias de Oliveira, um paulista de Taubaté, chegou em 1698 na região onde pouco tempo depois seria fundada Vila Rica, atual cidade de Ouro Preto:

\footnotetext{
${ }^{14}$ Os bandeirantes, que no princípio das Bandeiras aprisionavam índios para a escravidão (Bandeiras de apresamento), passaram a organizar expedições voltadas para a prospecção mineral (Bandeiras de exploração).

${ }^{15}$ Itaverava: atualmente um município mineiro próximo à Ouro Preto.

${ }^{16}$ Os nomes Laura Vergueiro e Laura de Mello e Souza dizem respeito à mesma historiadora. A diferença na assinatura se deve a questões particulares da autora, que assinava o sobrenome Vergueiro quando casada, voltando em seguida a reassinar o sobrenome Mello e Souza.
} 
"Este primeiro momento das Minas de Ouro foi marcado por um sem-número de tumultos, de crimes, de convulsões de toda a sorte, contando entre elas as crises generalizadas de fome e de carestia de alimentos" (VERGUEIRO, 1986, p.16).

A notícia oficial do ouro naquela região, até então subordinada à capitania do Rio de Janeiro, levou a muitos colonos a se lançarem à caça do metal e foram se concentrando às margens dos ribeirões, onde se dava a exploração de aluvião. As sucessivas descobertas auríferas atraíam cada vez mais pessoas e com elas os problemas: "No mais, não há ministros nem justiças que tratem ou possam tratar do castigo dos crimes que não são poucos, principalmente dos homicídios e furtos" (ANTONIL, 1977, p. 168).

Mesmo assim, em cidades como o Rio de Janeiro e Santos, os navios passaram a ser abandonados pela tripulação, que corriam para as minas em busca do ouro. A guarda de infantaria deixava as guarnições e praças para tentar a sorte no garimpo e as leis cridas pela Coroa naquele momento de nada valiam para segurar os aventureiros em suas respectivas regiões. A sede insaciável do ouro estimulou a tantos a deixarem suas terras e a buscarem por caminhos ásperos e incertos como eram os das minas de ouro.

Com a febre pelo ouro, nas Minas Gerais setecentistas se concentraram uma grande diversidade de caminhos e estradas que conduziam os mineiros aos lugares mais remotos da capitania. No século XVIII, já existiam três caminhos mais conhecidos_as estradas reais_, que, em alguns casos, se aproveitavam de antigas rotas indígenas que ligavam povoações a outras e também ao interior do Brasil. Dessas primeiras estradas reais, o Caminho Geral do Sertão ligava São Paulo de Piratininga e as vilas do Vale do Paraíba, Serra da Mantiqueira e Rio das Velhas e foi este caminho que mais tarde ficou conhecido por Caminho Velho da Estrada Real. O Caminho Velho teria sido também a rota seguida por Fernão Dias entre os anos de 1674 e 1681, que percorreu uma grande parcela do território mineiro. Foi este também o caminho utilizado pelos primeiros garimpeiros quando da descoberta do ouro e por este caminho também circulou toda a diversidade de produtos que abastecia a região mineradora, ligando Minas Gerais aos portos de Paraty, Rio de Janeiro e as Vilas Paulistas (Santos, 2008).

Com as mentes voltadas para o enriquecimento rápido através do ouro e com o improviso de alojamentos numa região desconhecida, a carestia e a fome assolaram a região de 1697 a 1701, obrigando muitos garimpeiros a deixarem suas lavras sem terem o que comer, pois as roças de alimentos não eram suficientes para prover a carestia de alimentos. Algumas 
soluções como a plantação de roças e a criação de animais próximas das lavras foram utilizadas, porém, o problema da carestia de produtos alimentícios somente começou a ser resolvido com a construção do Caminho Novo por García Rodrigues, que passou a ser a nova rota comercial para as minas de ouro, ligando a região ao Rio de Janeiro, São Paulo e o Caminho da Bahia, que passaram a serem os novos núcleos fornecedores de mercadorias e alimentos para aquela região.

Por necessidade de uma via que encurtasse o caminho de Minas Gerais até a costa sul da colônia, foi aberto o Caminho Novo, entre os anos de 1700 e 1725, que em pouco tempo se tornou a principal via de acesso do Rio de Janeiro até Vila Rica e logo suas proximidades ficaram pontuadas de roças, povoados, arraiais e pontos de apoio aos viajantes, sendo que alguns deles se tornaram cidades como as atuais Barbacena, Juiz de Fora e Santos Dumont no Estado de Minas Gerais e Petrópolis e Paraíba do Sul no Estado do Rio de Janeiro (Mapa 01: Mapa da Estrada Real).

O outro caminho que dava acesso às Minas Gerais, o Caminho da Bahia, foi a rota por onde circulou boa parte da carne bovina que passou a ser consumida pelos mineiros e também por onde chegavam os escravos provenientes do nordeste. Também por esta rota circularam mercadorias das mais variadas e ficou conhecido também por ser a rota do descaminho do ouro, pois, por ela passava grande parte do ouro desviado das Minas por contrabandistas.

\footnotetext{
São Paulo fornecia milho, trigo, marmelada, frutas em geral, servindo ainda como entreposto do gado - bois, cavalos, muares - que vinha dos campos e coxilhas do sul da Colônia e da região platina. No Rio de Janeiro desembarcavam escravos africanos e artigos europeus, sobretudo produtos de luxo: veludos, pelúcias, vidros, louças. De Salvador vinham escravos provenientes da África e também das regiões açucareiras do Nordeste, que, conhecendo desde a segunda metade do século XVIII um período de estagnação, revendiam sua força de trabalho para o centro mais dinâmico da Colônia; a Bahia enviava ainda às minas o gado que criava nos currais do Rio São Francisco e as mercadorias provenientes da Europa, tais como tecidos, ferramentas, sal, ferro (VERGUEIRO, 1986, p. 19-20).
}

Havia nas Minas Gerais outras rotas regionais, como a que ligava Vila Rica ao Arraial do Tejuco, no Distrito Diamantino, ligando diversas localidades como Santa Bárbara, Catas Altas, Caeté e Sabará. 


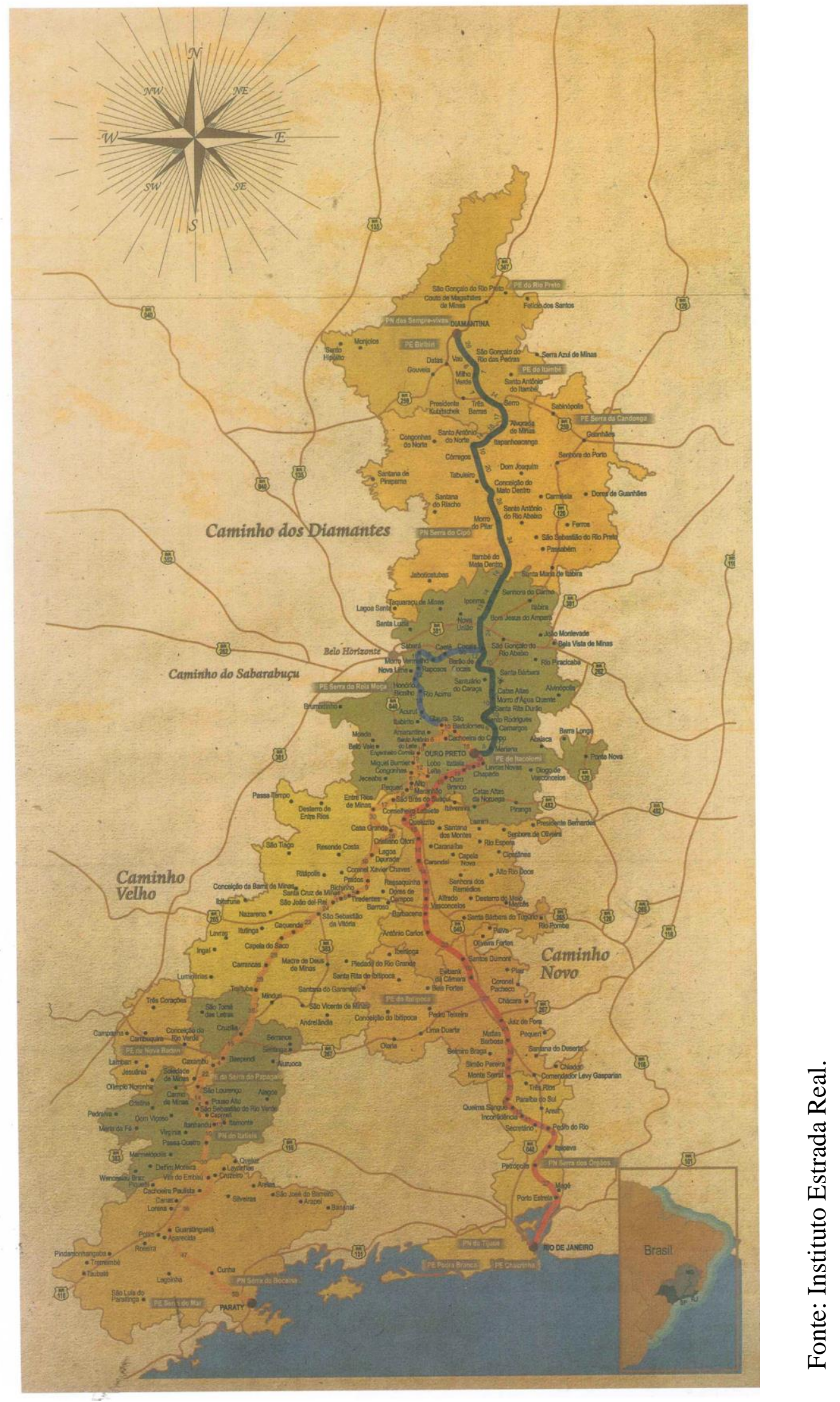

Mapa 1: Mapa da Estrada Real. Fonte: Instituto Estrada Real. 
Naquele tempo, começaram a se formar dois grupos rivais, um formado pelos paulistas, que por serem os descobridores se achavam os donos das lavras e hostilizavam qualquer outro grupo que chegava, fossem eles portugueses do Reino ou colonos de outras regiões que não fosse São Paulo, principalmente os que chegavam da Bahia. Estes grupos recebiam o nome de Emboabas ${ }^{17}$ e a hostilidade se tornou mútua entre os paulistas e os grupos Emboabas, o que tornava a região ainda mais tensa, longe das vistas das autoridades e da justiça.

Manuel Nunes Viana era um português que foi para a Bahia quando criança, viveu como mascate, administrava currais no São Francisco ${ }^{18}$ e intermediava o comércio de mercadorias para as Minas. Ele acabou se envolvendo em um duelo com o paulista Jerônimo Pedroso em junho de 1707 e não aceitou a ordem do Guarda-mor das Minas, Manoel Borba Gato, para deixar as Minas. Nunes Viana acabou sendo proclamado pelos próprios Emboabas o governador interino das Minas até que a Coroa enviasse outro governante. A maioria das lavras passou para o controle dos Emboabas, que confinaram os paulistas próximos ao Rio das Mortes, mas, ao saberem sobre a vinda do emboaba Bento do Amaral Coutinho, os paulistas deixaram a região em direção a São Paulo e Parati e foram massacrados depois que foram cercados no caminho pelos Emboabas, fato este que ficou conhecido como o encontro do Capão da Traição (Mello e Souza \& Bicalho, 2000).

O então governador do Rio de Janeiro, ao tentar intervir no conflito foi barrado próximo a Congonhas do Campo pelas tropas de Manuel Nunes Viana, logo depois de sair-se bem em negociações no Rio das Mortes. Voltou então para o Rio de Janeiro, onde foi trocado por Antônio de Albuquerque Coelho de Carvalho, que, com a experiência administrativa adquirida no Nordeste, pôs fim ao conflito que ficou conhecido como Guerra dos Emboabas, fazendo com que Manuel Nunes Viana deixasse a região das Minas. Antônio de Albuquerque também conseguiu, por meio de um aviso, barrar uma tropa de paulistas que marchava para as Minas em busca de vingança.

Toda essa gama de dissensões era apreendida pelo olhar metropolitano no seu nível mais abrangente: tratava-se de uma sedição que pusera em cheque o domínio da Coroa sobre a Colônia, desrespeitando os representantes oficiais, procurando soluções alternativas de mando, enfim, pondo em risco a integridade e a subordinação daquela que já surgia como a mais promissora região econômica do Império Colonial Português (VERGUEIRO, 1986, p. 29).

\footnotetext{
${ }^{17}$ Emboaba: Palavra de origem tupi que significa "os que não eram nascidos na região", forasteiros.

${ }^{18} \mathrm{O}$ gado de corte proveniente do Sul da Bahia tornou-se fonte indispensável de proteínas para os mineiros.
} 
Com o fim da Guerra dos Emboabas, Antônio de Albuquerque Coelho de Carvalho foi nomeado para governar a capitania. As Minas foram desmembradas do Rio de Janeiro, vinculadas com São Paulo e passaram a formar uma capitania separada.

\begin{abstract}
Albuquerque, que fora designado governador do Rio de Janeiro por carta datada de 9 de novembro de 1709 , passou, no ano seguinte, a dirigir a nova capitania de São Paulo e Minas do Ouro. A carta régia que o nomeou denotava duas preocupações principais: a necessidade de normalizar a população mineira, ordenando-a em núcleos urbanos a serem fundados (VERGUEIRO, 1986, p. 29).
\end{abstract}

A fundação de vilas ordenada pela Coroa tinha como finalidade alcançar as bases para a atuação da burocracia para a integração das Minas ao aparelho administrativo colonial. “Agora soubemos que Sua Majestade manda governador, ministros de justiça, e levantar um terço de soldados nas Minas, para que tudo tome melhor forma e governo" (ANTONIL, 1977, p. 169).

A primeira vila fundada nas Minas foi a Vila do Ribeirão de Nossa Senhora do Carmo, em 08 de abril de 1711 e que mais tarde seria chamada de Mariana e elevada à categoria de cidade.

A criação de uma vila - ou, muito raramente entre nós, de uma cidade - estava por
certo condicionada à ocupação anterior na região do novo município que a teria
como sede. Sem dúvida, importava o número de vizinhos naquelas terras, o de
moradores nos povoados porventura existentes e, particularmente, de maneira ainda
a ser mais bem conhecida, a distribuição das terras e das grandes glebas envolvidas,
diretamente interessados os seus detentores, como os demais, porém com um maior
poder de influir e obter a constituição do novo território autônomo. Tal interesse
preponderante interferia diretamente, por exemplo, sobre a determinação das novas
fronteiras municipais que passariam a circundantes ou terras inóspitas aguardando
um ulterior desbravamento (MARX, 1991, p. 67).

Logo depois foi fundada a Vila Rica de Albuquerque, que foi depois rebatizada de Vila Rica de Nossa Senhora do Pilar e logo a seguir veio a Vila Rica de Nossa Senhora da Conceição do Sabará, seguidas de outras que foram fundadas por Dom Brás Baltasar da Silveira, sucessor de Albuquerque, e por Dom Pedro de Almeida, o Conde de Assumar, sucessor de Baltasar da Silveira. 
O objetivo máximo da criação das vilas fora ordenar melhor a população, evitando o surgimento de novos conflitos e, caso voltassem a ocorrer, possibilitando a aplicação de medidas punitivas mais eficientes. Mas a mesma população que, sob os olhos vigilantes dos administradores coloniais, fora juntada nos núcleos urbanos com o objetivo de possibilitar um controle maior, começou, através do convívio mais intimo, a tomar consciência da situação colonial. Um deles, que logo assumiu proporções, foi o caráter extorsivo do aparelho fiscal (VERGUEIRO, 1986, p. $30)$.

Com a implantação das vilas, os impostos passaram a subir cada vez mais, com a finalidade de encherem os cofres da Coroa. As datas auríferas passaram a ser distribuídas aos seus descobridores, aos maiores proprietários de escravos e àqueles com maiores recursos financeiros para explorá-las e dessa forma, [...] "criavam-se impostos especiais sobre o comércio, casas de negócio, escravos, trânsito pelas estradas, etc.” (PRADO JUNIOR, 2000, p. 59).

A esta altura, Portugal já celebrara o Tratado de Methuen ${ }^{19}$ com a Inglaterra em 1703 e os impostos cobrados ajudavam no equilíbrio de sua balança comercial. "Com isto ganhou a Inglaterra em geral, como todos os mercadores da Europa, fornecedores das mercadorias que alimentavam o desvario dos portugueses" (ETZEL, 1974, p. 20). E ainda:

[...] ocorre, entretanto, que o ouro do Brasil começou a afluir exatamente quando entra em vigor o referido acordo. De início em volume e, uma dezena de anos depois, já em quantidades substanciais. Criam-se assim de imprevisto, as condições requeridas para que o acordo funcionasse (FURTADO, 1980, p. 81).

Com a fome da Coroa pelos impostos do ouro que pagavam suas despesas, foram instaladas nas Minas as Casas de Fundição, para onde ia o ouro em peso total extraído e o que restava era fundido em barras e recebia o carimbo real. $\mathrm{O}$ ouro não podia mais ser comercializado em forma de pó, de pepita ou em barras sem a marca real, o que provocou algumas revoltas, como o Levante de Vila Rica em 1720, conhecido também como a Revolta de Filipe dos Santos. A 28 de junho de 1720 ocorreram distúrbios e atos de desordem popular, então o governador Conde de Assumar mandou queimar o local onde residia um dos revoltosos, o

\footnotetext{
${ }^{19}$ Tratado de Methuem: conhecido como "Tratado dos panos e vinhos" que na época de sua assinatura satisfazia os interesses dos grupos dominantes, mas paralisou a industrialização portuguesa e canalizou o ouro e outras riquezas do Brasil para a Inglaterra. Segundo Furtado (1980), o ouro do Brasil seria fundamental para a Revolução Industrial Inglesa.
} 
comerciante Pascoal da Silva. O local conhecido como Morro de Pascoal da Silva ${ }^{20}$ foi queimado para dar exemplo aos moradores de Vila Rica e para confirmar o poder real perante a população. Filipe dos Santos, um dos principais envolvidos no levante, acabou condenado à morte e seu corpo feito em quartos e exposto nas estradas com sua cabeça colocada em um pelourinho de Vila Rica (Mello e Souza \& Bicalho, 2000). Como consequência do levante, São Paulo passou a ser capitania independente em 1720. Dom Lourenço de Almeida assumiu o governo de Minas Gerais em 1721no lugar do Conde de Assumar que observava:

[...] 'a terra parece que evapora tumulto; a água exala motins; o ouro toca desaforos; destilam liberdades os ares; vomitam insolências as nuvens; influem desordens os astros; o clima é a tumba da paz e o berço da rebelião' (VERGUEIRO, 1986, p. 36-38).

Outros tipos impostos passaram a valer na nova capitania e independentemente da vontade dos mineiros, era substituído por outro que a Coroa pensava ser mais conveniente, a exemplo da cobrança do quinto, que voltou a valer em 1725 e depois foi substituído por um imposto de capitação, novamente substituído pelo quinto após vinte anos. Em cada parte da comarca foi estabelecida uma Casa de Fundição e quando ocorria o excesso sobre 100 arrobas este cobria uma eventual falta no ano seguinte e quando um novo excesso era registrado seguidamente, o anterior passava para o poder do Rei. Somente a partir de 1763 que a arrecadação do quinto não atingiu mais a cota fixada de 100 arrobas.

O fato de desejar a Coroa completar a todo custo a cota prefixada fez com que criasse a derrama, mecanismo pelo qual a população deveria cobrir a diferença que faltava para completar as 100 arrobas. A insatisfação gerada por este procedimento teve sérias consequências, contando de forma decisiva na articulação da Inconfidência Mineira de 1789 (VERGUEIRO, 1986, p. 40).

No Distrito Diamantino, houve casos de arbitrariedade e violência por parte da Coroa. O território, que foi demarcado por volta de 1734, foi administrado diretamente por Lisboa e a organização militar ficou por conta do governo da capitania. O hábito de delatar era comum e estimulado pela Coroa, que acreditava assim, impedir o contrabando de diamantes, pois a

\footnotetext{
${ }^{20}$ O Morro de Pascoal da Silva também ficou conhecido após o incêndio que o devastou como Morro da Queimada e desta forma é conhecido até os dias atuais pelos moradores de Ouro Preto.
} 
extração e a comercialização das pedras eram negócios exclusivos da Coroa e às vezes eram arrendados para contratadores.

O contratador que ficou mais conhecido foi João Fernandes de Oliveira, que manteve um relacionamento amoroso com Francisca da Silva, uma mulata por ele alforriada e com quem teve treze filhos. O Distrito Diamantino era vasculhado pelos Dragões da Extração e os funcionários da Intendência dos Diamantes eram fiscalizados de forma rígida. Em 1771, o Contrato foi substituído pela Real Extração, uma companhia de caráter oficial.

\footnotetext{
Para melhor explorar o rico quinhão da Colônia que lhe fornecia ouro e diamantes, que lhe pagava as importações e o fausto, cuidou Portugal de fundar vilas e cidades, de impedir as desordens e os levantes, de reprimir e lançar mão da violência sempre que julgasse preciso. Essas medidas drásticas não puderam impedir a ocorrência de levantes sérios, não enriqueceram a Metrópole e contribuíram enormemente para lançar grande parte da população mineradora na mais negra miséria (VERGUEIRO, 1986, p. 43).
}

O enriquecimento de parte dos mineiros pela posse do ouro e pedras preciosas, o desenvolvimento de um comércio pujante e a organização social refletiram-se principalmente na arquitetura e nas artes, que por sua vez acabaram por entrar em decadência juntamente com a decadência na produção aurífera, quando ocorreu também uma ruralização para produção de artigos para subsistência.

\begin{abstract}
Na região de mineração, o declínio da atividade principal deu lugar não somente ao deslocamento de população para as frentes pecuárias, mas também à formação de uma agricultura principalmente de subsistência, a qual procurava localizar-se nas proximidades dos caminhos de tropas que comunicavam com os principais centros urbanos (FURTADO, 1972, p. 96).
\end{abstract}

A vinda da Família Real em 1808, que escapava do avanço dos exércitos franceses de Napoleão Bonaparte, fez do Rio de Janeiro a nova capital do Brasil e com isto, estabeleceu a decadência econômica e social nos centros mineradores. Os recursos humanos e econômicos também se transferiram para a nova capital. 
Observada de uma perspectiva ampla, a economia luso-brasileira do século XVIII se configurava com uma articulação - e articulação fundamental - do sistema econômico em mais rápida expansão na época, ou seja, a economia inglesa. O ciclo do ouro constitui um sistema mais ou menos integrado, dentro do qual coube a Portugal a posição secundária de simples entreposto (FURTADO, 1980, p. 34).

Com a transferência da corte portuguesa para o Brasil iniciou-se o processo de independência da América portuguesa, porém trazendo consigo as amarras econômicas e dependências do passado.

John Methuen, agente inglês que negociou o acordo em 1703, conseguiu ainda, para Portugal, uma posição privilegiada na Conferência de Utrecht, garantindo a renúncia da França aos direitos sobre a foz do rio Amazonas e os direitos de navegação na região. Portugal conseguiu também os direitos sobre Sacramento frente a Espanha, tudo sempre com a garantia inglesa.

Transferindo-se o governo português para o Brasil sob a proteção inglesa e operando-se a independência sem descontinuidade da chefia do governo, os privilégios econômicos de que se beneficiava a Inglaterra em Portugal transferiramse automaticamente para o Brasil independente (FURTADO, 1980, p. 36).

Depois da separação de Portugal em 1822, o Brasil precisou ainda de décadas para que ocorresse a eliminação da tutelagem à Inglaterra. Os brasileiros haviam recebido por tabela os interesses e privilégios ingleses pelo acordo de 1810, que davam garantias aos portugueses de que nenhum governo imposto por Napoleão em Portugal seria reconhecido.

Em 1827, o governo brasileiro teve que reconhecer a Inglaterra como nação privilegiada nas questões econômicas que envolvessem os dois países. Isso ocorreu no intuito de não receber retaliações da Inglaterra, parceira e protetora de Portugal, por conta da separação.

\subsection{4 - Do algodão à industrialização}

O algodão já havia se destacado como produto estimulante para a agricultura brasileira desde a metade do século XVIII. "O indígena chamava-o de maniu. Pero Vaz de Caminha ficou 
surpreso quando viu 'outra mulher moça com menino ou menina ao colo, atado com um pano não sei de que aos peitos"” (MELO, 1969, p. 105).

Em pouco tempo o algodão se comparou com o açúcar e não demorou, sua produção ultrapassou a açucareira. Ele já era usado pelos nativos indígenas brasileiros e com a colonização passou a constituir as roupas baratas e grosseiras com que vestiam os proprietários a seus escravos. Com a oferta de terras na América, o algodão estava reservado à produção em alta escala para o mercado mundial e o Brasil não ficou de fora dos interesses colonialistas.

O algodão trilharia outro caminho, diferentemente de outras culturas agrícolas até então implantadas aqui para se adequar a solos menos úmidos. $\mathrm{O}$ açúcar e o tabaco ficarão com as terras úmidas do litoral enquanto que o algodão procura ambientes mais secos. No Maranhão as culturas se internaram subindo as margens do Itapurucu, e se concentraram sobretudo em Caxias. No Ceará elas invadem a bacia do Jaguaribe, e seu principal centro se localizará no alto interior Icó (PRADO JÚNIOR, 2000, p. 83).

Pelo Nordeste, o algodão ocupou uma faixa intermediária entre o litoral e o agreste. Entre Minas Gerais e Bahia se concentrou e foi cultivado nas divisas destes Estados e assim também foi em Goiás.

As grandes regiões produtoras que se destacam foram Pernambuco e Maranhão, que se beneficiaram, junto com seus comerciantes, também da sua maior produtividade que as de outras culturas.

\footnotetext{
Verifica-se aí mais uma vez, o papel que representa na economia brasileira a função exportadora: é ela o fator único determinante de qualquer atividade de vulto. $\mathrm{E}$ isso se comprovará novamente neste mesmo setor da produção algodoeira, pouco depois do período que ora nos ocupa, quando vem o reverso da medalha e a fibra brasileira é desbancada e quase excluída do mercado internacional por seus concorrentes. A produção decairá logo em seguida, e as regiões produtoras que não contaram com um substituto encerram com um colapso sua brilhante e curta trajetória (PRADO JÚNIOR, 2000, p. 81).
}

Quando o Brasil, em 1842, teve expirado o último compromisso com a Inglaterra, outra cultura importante, o café, teve em iniciada sua produção, que fez dele o principal produto produzido aqui. "Embora o café tenha sido introduzido no Brasil no início do século XVIII, 
ele foi cultivado primeiramente como uma especialidade e era consumido principalmente nas residências e nos cafés nas mais importantes cidades europeias” (BAER, 1996, p. 34).

O cafeeiro também fugiu da baixada litorânea e partiu em direção das encostas da Serra do Mar, que dominava seu horizonte, se espalhando por São Paulo, Rio de Janeiro, Minas Gerais. Mesmo assim: "A estrutura econômica, baseada principalmente no trabalho escravo, se mantivera imutável nas etapas de expansão e decadência” (FURTADO, 1980, p. 38). E ainda:

\begin{abstract}
Durante o século XIX, o Brasil adaptou-se facilmente à ordem econômica controlada pela Grã-Bretanha, que se tornou o núcleo do centro industrial do mundo, trocando seus produtos manufaturados por alimentos e matérias-primas do exterior, ou seja, de países cujas economias eram completamente dependentes da exportação dos mesmos. O Brasil tornou-se um típico exemplo de tais países, pois sua economia dependia de um importante produto primário de exportação (café) e de alguns secundários (açúcar, algodão, cacau); durante quase todo esse período sua economia estava aberta ao capital e aos produtos manufaturados estrangeiros (principalmente ingleses), que fluíam para dentro do país e destinavam-se a formar uma infraestrutura financeira, comercial e de transportes que poderia ligar o país mais eficientemente à ordem econômica mundial do século XIX (BAER, 1996, p. $34)$.
\end{abstract}

O café também teve um período de grande consideração, porém curto. Além de outros fatores, o cultivo ficou implicado pelas técnicas rudimentares que foram, de início e sem muita mudança, aplicadas na produção. A queimada, que desgastava muito o solo, era aplicada nos desmatamentos que abriam espaço para a atividade, os restos da pecuária não eram usados na fertilidade da terra, assim como os restos da agricultura, não eram usados para tratamento animal, ou seja, não havia um manejo compartilhado dessas culturas que se disseminaram, gerando desperdícios em ambas as partes.

O café teve grande impulso, de início, no Vale do Paraíba, Norte, e Oeste do Rio de Janeiro, depois Nordeste e em 1880 migrou com força para o Vale do Paraíba paulista e depois, indo em direção ao oeste, centro e norte de São Paulo, região de Ribeirão Preto, onde era empregada a mão-de-obra livre e assalariada proveniente da Europa.

A expansão paulista em direção ao oeste ocasionou o desenvolvimento de imensas fazendas de café, visto que somente um pequeno número de pessoas possuía poder econômico e político necessários para estabelecer e defender propriedades e iniciar a produção em novas terras. Elas empregavam um crescente número de trabalhadores livres e, mesmo antes da abolição da escravatura, em 1888, fomentaram a imigração europeia. Depois da abolição, houve uma grande afluência de mão-de-obra 
imigrante, principalmente do Sul e do Leste da Europa (especialmente Itália) (BAER, 1996, p. 35).

Os produtores do café não tinham contra eles o exclusivismo do monopólio estrangeiro e estavam interessados no seu comércio. Logo, os fazendeiros paulistas assumiram importantes postos da política nacional, formando suas oligarquias. As políticas econômicas nacionais passaram a favorecer principalmente aos interesses da elite agrária. Já na primeira década do século XX, a produção de café no Brasil ultrapassou a capacidade de consumo mundial, ocasionando na queda dos preços e dando início, em 1907, num projeto de valorização do café com o Convênio de Taubaté. Este convênio primeiro proibiu o plantio por cinco anos e depois o governo passou a usar fundos próprios para comprar o excedente que era sonegado ao mercado, a fim de forçar a baixa dos preços, claramente com o objetivo de favorecer economicamente os produtores.

A proximidade com a política deixava os produtores ainda mais próximos do capital nacional e com isso, junto a fatores como o emprego de mão-de-obra livre e assalariada, investimentos de capital estrangeiro, infraestrutura de transportes, a região de São Paulo passou a figurar como o centro econômico mais poderoso do Brasil, posto este que não perdeu mais até os dias atuais, confirmando um período de transição econômica pelo qual o Brasil passou. “O dinamismo da economia brasileira nos anos 20 baseava-se em um setor cafeeiro em rápida expansão. A participação do café nas exportações aumentou de 56\% em 1919 para mais de 75\% em 1924" (BAER, 1996, p. 48). E mais:

\begin{abstract}
A expansão cafeeira da segunda metade do século XIX, durante a qual se modificam as bases do sistema econômico, constituiu uma etapa de transição econômica, assim como a primeira metade desse século representou uma fase de transição política. É das tensões internas da economia cafeeira em sua etapa de crise que surgirão os elementos de um sistema econômico autônomo, capaz de gerar o seu próprio impulso de crescimento, concluindo-se então definitivamente a etapa colonial da economia brasileira (FURTADO, 1980, p. 38).
\end{abstract}

A Primeira Guerra Mundial foi um fator importante para a queda nas importações brasileiras e o consequente desenvolvimento da indústria brasileira, que lentamente tomou feição a partir da instalação da indústria alimentícia e da indústria têxtil no país. "A crise do comércio exterior tradicional, que se anunciava desde começos do século assume 
características dramáticas a partir de 1929, pôs em marcha uma série de processos que convergiam no sentido de abrir o caminho à industrialização" (FURTADO, 1980, p. 20).

A crise de 1929 foi para a economia cafeeira um golpe mortal, porém, não era somente isso, a “Grande Depressão" dos anos 1930 causaram uma forte retração no mercado exportador brasileiro, [...] "cujo valor sofreu uma queda de US\$ 445,9 milhões em 1929 para US\$ 180,6 milhões em 1932" (BAER, 1996, p. 50). Com isso o governo brasileiro passou a se preocupar novamente com o setor cafeeiro e partiu para mais um plano protecionista.

Nem mesmo com a queda da hegemonia das oligarquias agrárias o país deixou de sofrer sua influência sobre o poder central. O próprio Getúlio Vargas estabeleceu alianças com a classe política tradicional, mesmo quando o café perdeu o poder de eleição de seus produtores, e as forças armadas, instaurando assim o Estado Novo. As políticas de Vargas vieram em contrapartida, favorecer novamente os agricultores com o ajustamento econômico que foi necessário devido à forte queda sofrida pelo café no mercado mundial, quando sua demanda foi reduzida por conta da Depressão e da grande safra que coincidiu com o momento, devido ao plantio que se deu nos anos 20. Além de ajuda aos produtores endividados, foi necessário proteger o setor cafeeiro da queda de mercados mundiais, ocorrendo a fundação do Conselho Nacional do Café em maio de 1931, que comprou todo o café e nele deu um fim, destruindo o que não pôde ser vendido ou estocado.

Outra economia, a pesca da baleia no sul do Brasil, teve grande importância na história econômica brasileira, assim como o foi o cacau na Bahia, a borracha para a Amazônia, a ervamate e a madeira de Santa Catarina, porém, para autores como Amaury Patrick Gremaud, Marco Antônio Sandoval de Vasconcellos e Rudinei Toneto Jr. (1999), a crise econômica dos anos 1930 também provocaram a ruptura do modelo econômico agroexportador e trouxe a consciência de que a industrialização era necessária para afastar o subdesenvolvimento e os constrangimentos vindos do exterior junto com a crise que se instalava. Somamos a isso o advento da Revolução de 30, que rompeu com o Estado oligárquico e descentralizado da República Velha, fortalecendo o Estado Nacional e ascendendo novas classes econômicas ao poder, que por sua vez priorizaram a industrialização como projeto nacional de desenvolvimento.

Desta forma, ocorreu o Processo de Substituição de Importações (PSI), passando para uma economia fechada e a industrialização voltada para o mercado interno e por partes, dando sequência à produção de bens de consumo leve, bens de consumo duráveis, bens 
intermediários e por fim os bens de capital e assim, ao longo de três décadas ocorreram mudanças sucessivas na economia, como a tendência ao desequilíbrio externo, que aparecia por razões diversas como primeiramente a transferência de renda da agricultura para a indústria pela política cambial adotada, que entre outras coisas, visava baratear os investimentos industriais e depois, por uma indústria sem competitividade que visava o mercado interno e a persistência do mercado consumidor quanto às importações. O Estado foi obrigado a aumentar sua participação, adequando o arcabouço institucional à indústria, como na criação da legislação trabalhista, gerando infraestrutura básica, captando poupança e gerando crédito e ainda, fornecendo insumos básicos. Destacaram-se a criação do Conselho Nacional do Petróleo (1938), a Companhia Siderúrgica Nacional (1941), a Companhia Vale do Rio Doce (1943) e a Companhia Hidrelétrica do São Francisco (1945).

Com efeito, foi dentro dessa conjuntura política e econômica que a indústria brasileira se desenvolveu no início do século XX e se aproveitou da mão-de-obra excedente pelo êxodo rural e das migrações nordestinas, auxiliadas pela diminuição das importações e da concorrência estrangeira, ambas forçadas pelo acontecimento da Segunda Guerra Mundial.

Contudo, a industrialização brasileira tomou um grande impulso com o Plano de Metas elaborado durante o governo de Juscelino Kubistschek, que tinha como objetivo principal estabelecer bases para a formulação de uma economia madura, principalmente com a instalação do setor de bens duráveis, cujos investimentos e geração de rendas estimularam outros setores da economia como a produção de bens intermediários e de bens não duráveis, o que obrigou o governo a investir em infraestrutura, como em transportes e energia elétrica, produção de bens intermediários como cimento, aço e carvão, além dos bens de capital. $\mathrm{O}$ governo de Juscelino Kubitschek também marcou o início de uma alta inflação de preços e logo depois o Brasil passou por uma crise política que dificultou as negociações a favor do crescimento econômico e industrial nacional, agravando-se durante os governos de Jânio Quadros e de João Goulart e culminando com o golpe miliar de 1964, quando o governo autoritário passou a elaborar reformas políticas e econômicas na tentativa de superação da crise, como o lançamento do Plano de Ação Econômica do Governo (PAEG).

No fim dos anos 1960, teve início o chamado Milagre Econômico Brasileiro (1968-73), que se caracterizou pelas maiores taxas de crescimento da história brasileira, na faixa dos $10 \%$ ao ano e inflação entre 15 e 20\% ao ano, e depois, durante os anos 1970 foi colocado em prática o II Plano Nacional de Desenvolvimento (II PND - 1974-79), que alterou as prioridades da industrialização, que passou a investir nos setores produtores de meios de produção, bens de 
capital e insumos, ambos com o apoio ou plena responsabilidade estatal, ficando marcado o período pela primeira crise do petróleo (1973-74) e pelo crescimento da dívida externa nacional.

No final da década de 1970 ocorreu a segunda crise do petróleo (1979), transformando o cenário econômico mundial que reagiu com o aumento das taxas de juros internacionais, quando o endividamento externo brasileiro crescia. Internamente, o Brasil vivia uma transição de governo, do Coronel Geisel para João Figueiredo, os Estados gastavam muito e estavam com as contas no vermelho, além de uma inflação alta, persistente e poderosa, contra as políticas ortodoxas que inutilmente tentavam freá-la.

A população insatisfeita e ameaçada pelo desemprego pedia por "Diretas já" ou seja, tudo encaminhava para uma nova crise econômica durante os anos 1980 e desta forma, o regime militar acabou e teve início a Nova República, que teve no combate à inflação a sua principal meta.

Nisso se deu a criação do Plano Cruzado, oriundo de uma conjuntura econômica favorável, aliada às correntes do pensamento econômico brasileiro, uma chamada de inercialistas, de pesquisadores ligados à Pontifícia Universidade Católica do Rio de Janeiro (PUC-RJ) e a outra camada por pós-keynesianos com ligações à Universidade de Campinas (UNICAMP). O Plano Cruzado (1986) tinha, entre as principais metas, o combate à tendência inflacionária crescente e normalizar as regras para a formação de preços. O plano, que de início obteve sucesso por conta da queda na inflação com o de congelamento de preços, troca de moeda nacional corrente e pelo apoio popular, em seguida entrou em colapso por conta das cobranças de ágio em produtos como a carne, o leite e os automóveis, excesso de consumo e a ilusão monetária causada pela despoupança. Não obstante, o Brasil decretou moratória para conter a saída de divisas e partiu para renegociações da dívida externa.

Após o Plano Cruzado, outras tentativas de tentar melhoras na economia brasileira não deram certo, como o Plano Bresser (1987), comandado pelo Ministro Bresser Pereira, e o Plano Verão (1989), com nova troca de moeda nacional corrente, desta vez de cruzado para cruzado novo. No final do Governo de José Sarney, o Brasil apresentava altas taxas de inflação, chegando a atingir $80 \%$ ao mês e além disso, houve descontrole nas dívidas públicas, aumento nas taxas de juros e aumento da dívida interna.

A nova promessa econômica, o Plano Collor I, veio então após as primeiras eleições diretas do país, quando foi eleito pelo voto direto o Presidente Fernando Collor de Mello em 1990, 
desta forma, as políticas econômicas do Brasil foram direcionadas para as reformas monetárias, que geraram descontentamentos por conta de bloqueios econômicos, administrativos, fiscais e patrimoniais, resultando em diversas privatizações de empresas e indústrias estatais de grande porte. Houve a abertura comercial com o processo de abertura do comércio exterior e mudança no regime cambial. Logo em seguida veio o Plano Collor II, que conseguiu atrair divisas do exterior com a reaproximação com o mercado financeiro internacional, porém acompanhadas de inflação e altas taxas de juros.

Com a inflação contínua e o impeachment de Fernando Collor de Mello, veio seu substituto Itamar Franco e o Plano Real, que ocorreu na gestão de Fernando Henrique Cardoso no Ministério da Fazenda. O Plano Real foi implantado em três fases, sendo a primeira fase considerada ortodoxa, por conta de ajustes fiscais na busca de um equilíbrio nas contas do governo, a segunda fase heterodoxa, por conta da criação da URV (Unidade Real de Valor) que intermediou a mais nova e última mudança na moeda nacional corrente, passando desta vez do cruzeiro real para o real, o que representava a fase final.

Ainda nos anos 1990, aproveitando a abertura comercial e a gradativa redução de impostos de importação, ocorreu a abertura do Mercosul (Mercado Comum do Cone Sul), acordo internacional que tem como objetivo principal aproximar e estimular as trocas e transações comerciais entre países como o Brasil, Argentina, Uruguai e Paraguai, entre outros. O governo do Presidente Fernando Henrique Cardoso defendeu a abertura comercial e manteve os compromissos estabelecidos no Mercosul. Outras preocupações constantes foram o controle das taxas baixas de inflação e a manutenção do real como moeda nacional estável. Por conta de pressões da indústria, principalmente a automobilística e as crises financeiras no México e na Ásia, a abertura de mercado diminuiu um pouco de ritmo.

Com a posse de Luiz Inácio Lula da Silva na presidência da república em 2003, o Brasil manteve o real como moeda forte e passou a adotar políticas assistencialistas como forma de diminuição da pobreza, do analfabetismo e em contrapartida, estimulando o consumo e a produção industrial. Com isso vislumbrou-se também a diminuição das taxas de desemprego.

O governo de Lula criou o PAC (Programa de Aceleração do Crescimento) em janeiro de 2007. O PAC teve como objetivo acelerar o crescimento econômico do Brasil. Entre suas prioridades estão os investimentos em infraestrutura, concentrados em áreas como saneamento, habitações, transportes, energia e recursos hídricos, a abertura de créditos e financiamentos e a desoneração tributária, além da melhoria do marco regulatório no setor 
ambiental. No ano de 2009 foi criado também o PAC- Cidades Históricas (Programa de Aceleração do Crescimento das Cidades Históricas), para a realização de obras como restauração de monumentos tombados, revitalização de praças e ruas e aterramento de fiações elétricas. No ano de 2010 foi lançado o PAC II (Programa de Aceleração do Crescimento II), que concentrou investimentos nas áreas de transportes, energia, cultura, meio ambiente, saúde e área social.

O Brasil também cresceu em importância para o calendário esportivo internacional, sediando eventos importantes como a Copa do Mundo de Futebol de 2014 e os Jogos Olímpicos do Rio de Janeiro 2016, forçando o país a investir em obras de infraestrutura e transportes.

A estabilidade econômica almejada por anos foi conquistada e com isso o Brasil conseguiu vencer a crise internacional que, começando pelos Estados Unidos, abalou a economia mundial, gerando desemprego e quebra financeira de instituições bancárias e indústrias, que vieram a recorrer a capitais estatais na tentativa de evitar demissões de funcionários e desemprego.

Com a posse de Dilma Vana Rousseff na presidência da república no ano de 2011, os Planos de Aceleração do Crescimento tiveram sua continuidade e também, com vitória da Presidenta Dilma nas eleições presidenciais, a mulher ampliou ainda mais sua participação no quadro político do Brasil, porém, o período recente tem sido marcado por manifestações e descontentamento de grande parte da população brasileira quanto às políticas e a economia do país, mas de qualquer forma, o Brasil atravessa um período de uma estabilidade econômica considerável, se comparada com outros tempos, com uma moeda ainda forte, uma preocupação de manutenção de inflação mais controlada que outrora e crescimento industrial relativamente baixo, mas com taxas de desemprego perto dos $7 \%$. 


\section{Capítulo 3: O município de Congonhas}

\section{1 - Congonhas: aspectos geográficos}

Nosso território ou área de pesquisa, corresponde ao município de Congonhas, Estado de Minas Gerais. Uma área, segundo o antropólogo Luis G. Lumbreras (1981), corresponde a grandes ou pequenos territórios onde se dão condições de articulação econômica e social coerentes. Mais importante que estabelecer fronteiras, uma área é onde se torna possível estabelecer pautas de conduta econômica e social dos povos no processo para dominar o meio ambiente.

Congonhas é atualmente um município conhecido mundialmente por seu patrimônio histórico tombado ou pelas obras do Aleijadinho ${ }^{21}$, e também por outros fatores, como sua recolocação no mercado econômico mundial, principalmente pela produção de minério de ferro (Mapa 02: Mapa de Áreas especiais do Município de Congonhas, Minas Gerais).

Viajantes que passaram por seu território deixando relatos escritos sobre os recursos naturais, sua exploração econômica e de seu desenvolvimento sociocultural são fontes de informações preciosas a seu respeito desde tempos coloniais. O padre jesuíta André João Antonil (1977) e o engenheiro de minas Wilhelm Ludwig von Eschwege (1979 a, b), são dois dos exemplos clássicos do testemunho sobre a vida na capitania das Minas Gerais, sendo o primeiro referente ao início do século XVIII e o início da mineração aurífera e o segundo no início do século XIX, já com a mineração aurífera declinando e a ruralização acentuando.

De acordo com bibliografia oficial e relatos da historiografia, o solo congonhense, recheado das mais diversas riquezas minerais, vegetais e animais, foi sempre objeto da cobiça do colonizador, e tem novamente se tronado palco das mais variadas concorrências econômicas no interior do município, lideradas pela exploração do minério de ferro por diversas companhias nacionais e multinacionais, entre as quais podemos destacar a CSN (Companhia Siderúrgica Nacional), a Vale, antiga Companhia Vale do Rio Doce (CVRD), a Gerdau Açominas, antiga Açominas S/A, a NAMISA (Nacional Minérios S/A), a Ferrous Resources do Brasil.

\footnotetext{
${ }^{21}$ Antônio Francisco Lisboa, considerado pela crítica da arte como o "Michelangelo Brasileiro", autor de obras como a Via Sacra e os Profetas de Pedra-Sabão em Congonhas e a Igreja de São Francisco de Assis em Ouro Preto, entre outras.
} 


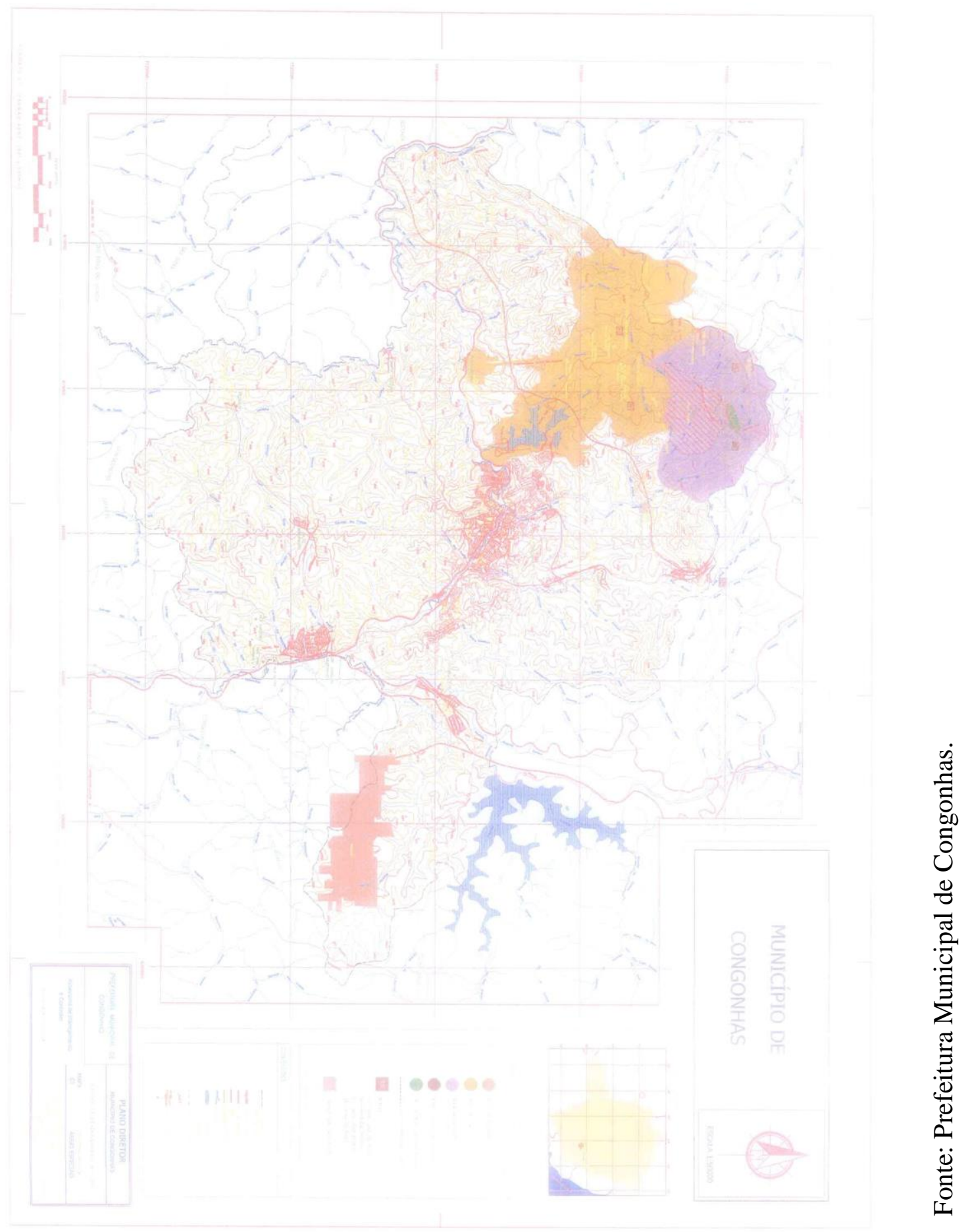

Mapa 2: Áreas especiais do município de Congonhas com escala 1:50000. 
Congonhas se situa na região macrorregião de Planejamento I de Minas Gerais, denominada Central, segundo a regionalização adotada no Estado a partir de 1995. "Tal área é formada por 13 microrregiões, localizando-se o Município na Microrregião de Conselheiro Lafaiete, constituída por 12 municípios" (SUMÁRIO DE DADOS DE CONGONHAS, 2002 p. 09). Atualmente a microrregião é conhecida por Alto Paraopeba.

A distância de Congonhas frente algumas grandes capitais do Brasil é a seguinte: Belo Horizonte, 78 km; Rio de Janeiro, 370 km; São Paulo, 580 km, Vitória, 565 quilômetros; e Brasília, $850 \mathrm{~km}$, com acesso pelas rodovias federais BR-040, BR-116, BR-383, BR-381 e BR 262 (Pironi, 2008).

Os municípios que fazem divisa com o território do município de Congonhas são os seguintes: [...] "ao norte, Itabirito e Ouro Preto, ao sul, São Brás do Suaçuí e Conselheiro Lafaiete, ao leste, Ouro Branco e ainda Ouro Preto, e ao oeste Belo Vale e Jeceaba" (SUMÁRIO DE DADOS DE CONGONHAS, 2002 p.10). Todos os municípios vizinhos de Congonhas são lugares que também surgiram e se desenvolveram a partir de povoados de garimpeiros durante o Ciclo do Ouro.

A área total do município de Congonhas corresponde a $305,5 \mathrm{Km}^{2}$, que é distribuída entre a área urbana da sede municipal, que possui $25,0 \mathrm{Km}^{2}$ e corresponde a $8,2 \%$ do total, áreas urbanas dos distritos, com 4,7 $\mathrm{Km}^{2}$ e correspondem a 1,5\% do total, agropecuária, que cobre $49 \mathrm{Km}^{2}$ ou $16 \%$ do total. Os $226,8 \mathrm{Km}^{2}$ restantes, que correspondem a 74,3\% da área total do município são cobertos pela atividade mineradora, pelas indústrias e por áreas de preservação de matas e mananciais (Biblioteca Publica Djalma Andrade, 20-??).

Sua população que no ano 2000 era de 35,4 mil habitantes, no ano de 2001 aumentou para 41,3 mil e no ano de 2010 chegou na casa de 48,6 mil habitantes (Milanez, 2011).

\section{2 - Congonhas: aspectos geológicos e geomorfológicos}

O município de Congonhas fica localizado no Quadrilátero Ferrífero, região rica em minériode-ferro. Congonhas está na fronteira sul e o rio Maranhão e o rio Paraopeba são considerados marcos que delimitam a fronteira sul do Quadrilátero Ferrífero. 
Os vértices do Quadrilátero Ferrífero são respectivamente os municípios mineiros de Itabira, a noroeste, Mariana a sudeste, Congonhas, a sudoeste e Itaúna, a noroeste.

Os mapeamentos geológicos produzidos na região do Quadrilátero Ferrífero têm como principal fundamento a pesquisa e descoberta de depósitos minerais ricos em minério-de-ferro e manganês, cuja procura na região teve grande impulso logo após a Segunda Guerra Mundial (Penha, 2012).

O relevo médio de Congonhas é de altitudes que variam entre 900 e 1000 metros. Congonhas apresenta conjunto de rochas altamente transformadas tectônica e metamorficamente e de idade pré-cambriana. Ao norte o afloramento é do tipo litológico mais antigo, pertencente ao Supergrupo Rio das Velhas ( $\mathrm{Pcr}$ ), que é constituído pelo Grupo Nova Lima, composto pelo micaxisto e pelas metavulcânicas. Ocorrem também as rochas pertencentes ao Complexo Barbacena $(P c b)$, dentre as quais destacamos gnaisses, granitoides e migmatitos, rochas intrusivas (granodioritos, granitos, piroxênio e serpentinito) e do Supergrupo Minas (Pcm), composto pelos grupos Piracicaba _ filitos, quartzito _, Itabira _Itabirito, dolomito e filito_e Caraça _ quartzito, filito e conglomerado _.

As principais ocorrências minerais são ferro, gnaisse (brita), algamatolito, amianto, cianita, grafita, pedra-sabão e quartzo (Pironi, 2008), que por sua vez ficam localizados na porção norte do município, onde temos a Serra da Moeda, do Esmeril e da Bandeira.

São encontrados elementos geológicos representativos de parte da evolução Pré-Cambriana, preservados em conjuntos de rochas onde está gravada a idade geológica, entre os quais podem ser relacionados o magmatismo, o tectonismo, mudanças na atmosfera, biosfera e nos sistemas de sedimentação (Azevedo, 2007).

O relevo de Congonhas pode ser considerado o mesmo do padrão do Quadrilátero Ferrífero, resultado de uma complexa natureza litológica e estrutural, nos quais as serras e os platôs são sustentados por quartzitos e Itabiritos proterozóicos do Supergrupo Minas e xistos de natureza diversificada do Grupo Nova Lima, ambos com idades superiores a 2,5 bilhões de anos.

Desta forma, a maior resistência oferecida pelos quartzitos e Itabiritos aos processos de intemperismo e de erosão atuantes nas últimas dezenas de milhões de anos resultou em um relevo, se extrapolando para todo o Quadrilátero, em que as camadas dessas rochas, integrantes do Supergrupo Minas, sustentam as serras do Curral, do Itatiaiuçu, da Piedade, da Moeda, do Caraça, do Ouro Branco, de Ouro Preto, dos Alemães e da Chapada (PENHA in BAETA \& PILÓ, 2012, p. 14). 
Como características que ocorrem com as rochas ferríferas e quartzíticas, os solos resultantes são arenosos, de pouca fertilidade e com elevado teor de acidez, fatores estes que contribuem com a formação de voçorocas e termiteiros.

A distribuição geográfica que se dá em função da declividade é organizada pelo tipo de terreno, correspondendo $95 \%$ de terreno montanhoso, $3 \%$ de terreno ondulado e de $2 \%$ de terreno plano. São em número de 3 (três), as unidades de relevo que se distinguem pelas altitudes médias e pelas formas de dissecação, sendo separadas da seguinte forma:

- leste: relevo menos dissecado, com altitudes médias de 1000 metros, com colinas suaves, compreendendo a área onde está instalada a Gerdau/Açominas até a rodovia BR 040;

- sul do Rio Maranhão: porção mais dissecada, com altitudes médias de 900 metros, composta por colinas e por morros;

- porção noroeste, ao norte do rio Maranhão e oeste da BR 040: altitudes médias de 800 a 1000 metros, correspondendo à área mais elevada, representada pelos cristais de direção sudoeste-nordeste da Serra da Moeda, com o ponto culminante do município (1630 metros) em Casa de Pedra.

Essas unidades de relevos, por sua vez, são determinadas por área A, área B e área C:

1 - área A: Regiões mais elevadas do município, com terrenos do Subgrupo Minas, abrangendo os grupos Itacolomi Indiviso, Itabira e Caraça, de limites externos que coincidem com a Serra da Moeda e prolongamentos conhecidos regionalmente como Serra do Esmiril e Serra da Bandeira.

Nesta área predominam os cristais de vertentes ravinadas, com altas declividades e rede de drenagem intensificada, que se desenvolve paralelamente aos alinhamentos de cristais. Esta área é muito rica em minério-de-ferro e é a que abriga a maior parte das empresas mineradoras. Por conta disso também, a área é pouco urbanizada.

2 - área B: equivale à região central do município de Congonhas e estende-se à leste na direção da Gerdau/Açominas. Esta área é composta por terrenos do Supergrupo Rio das Velhas que é representado pelo grupo Nova Lima, sendo intercalado com rochas do tipo intrusivas como os granodioritos, granitos e ultrabásicas. 
Quanto á sua geomorfologia, apresenta relevo de colinas associado a alinhamentos de cristais, principalmente no norte, através do Morro de Santo Antônio. É uma paisagem que apresenta relevo bem dissecado por conta do estabelecimento da rede de drenagem representada pela bacia hidrográfica do rio Maranhão e seus principais afluentes, o rio Santo Antônio, o córrego Casa de Pedra, o córrego dos Macaquinhos, o ribeirão Goiabeiras, o córrego Gurita e o ribeirão Soledade.

Esta é uma área que apresenta processos erosivos, com voroçocamentos e em lençol. Também apresenta poucas áreas propicias para o assentamento urbano, porém é nela que se encontra a sede do município, o distrito de Lobo Leite, além da BR 040 e as instalações da Gerdau/Açominas.

3 - área C: é a área localizada ao sul do município, formada por terrenos mais antigos e de idade pré-cambriana, representados pelo complexo Barbacena, onde predominam as rochas do tipo granito-gnaisse, em relevo de colinas com declividades médias.

As características geomorfológicas desta área tornam propícios os assentamentos urbanos, porém, o terreno possui amplas áreas com atividades erosivas em pleno desenvolvimento, principalmente nos fundos dos vales e nas declividades mais acentuadas. Nesta área está localizado o distrito de Alto Maranhão e também o bairro de Joaquim Murtinho, sendo que a maior parte da área apresenta características de zonas rurais.

\section{3 - Clima}

O clima do município de Congonhas ${ }^{22}$ é do tipo cwb _ clima tropical de altitude _, com características de temperaturas amenas ao longo do ano inteiro. O verão é brando e no inverno as temperaturas chegam a atingir números abaixo dos $15^{\circ} \mathrm{C}$.

Os níveis pluviométricos do município de Congonhas nos mostram uma precipitação anual de $1300 \mathrm{~mm}$, que é distribuída com sazonalidade pronunciada, sendo o verão o período mais chuvoso, principalmente entre os meses de dezembro a março, concentrando cerca de $60 \%$ a $70 \%$ do total. Os níveis pluviométricos menores ocorrem entre os meses de maio a agosto.

\footnotetext{
${ }^{22}$ Classificação de Köppen.
} 


\section{4 - Hidrografia}

A rede de drenagem de grande intensidade é parte da Bacia do Rio São Francisco, com o principal afluente o Rio Maranhão (Mapa 03: Mapa de bacias de contribuição para o abastecimento de água de Congonhas), sentido leste-oeste e desaguando no Rio Paraopeba, que limita os municípios de Congonhas, São Brás do Suaçuí e Jeceaba.

O município de Congonhas faz parte da bacia hidrográfica do rio São Francisco. A bacia do rio Paraopeba pertence a esta bacia e por sua vez recebe a sub-bacia do rio Maranhão. A rede de rios, córregos e ribeirões compõem 04 bacias hidrográficas. Duas dessas bacias ficam localizadas em áreas de mananciais, sendo uma a bacia do rio Paraopeba, que é um dos principais afluentes do Rio São Francisco no Estado de Minas Gerais. A outra bacia localizada em área de mananciais é a bacia do rio Soledade, que nasce no município de Ouro Preto e recebe águas do ribeirão Gurita e do ribeirão Ouro Branco.

Outras duas bacias encontram-se em área urbana e por isso são mais afetadas por agentes como poluição, assoreamentos e desmatamento de matas ciliares, são elas, a bacia do rio Maranhão e a bacia do rio Santo Antônio.

O rio Maranhão corta a zona urbana do município e no passado serviu como marco divisor do arraial de Congonhas do Campo. O rio Maranhão é também o que banha a maior parte do município, percorrendo da direção sul-norte a oeste, quando desagua no rio Paraopeba. Os afluentes do rio Maranhão são o córrego Monjolos, o ribeirão Gonçalo e o córrego Figueiredo, além das águas oriundas da bacia do rio Soledade e do ribeirão Bananeiras.

\section{5 - Vegetação e fauna}

A vegetação do município de Congonhas é constituída principalmente por campos cerrados e rupestres que ocupam as elevações das colinas e montanhas da região _ principalmente em trechos mais altos com elevações superiores a 900 metros de altitude em relação ao nível dos oceanos _, também de matas galerias, matas de encosta, gramíneas e ervas. A cobertura vegetal dos campos é caracterizada por uma cobertura herbácea contínua que eventualmente é interrompida pela presença de arbustos. 


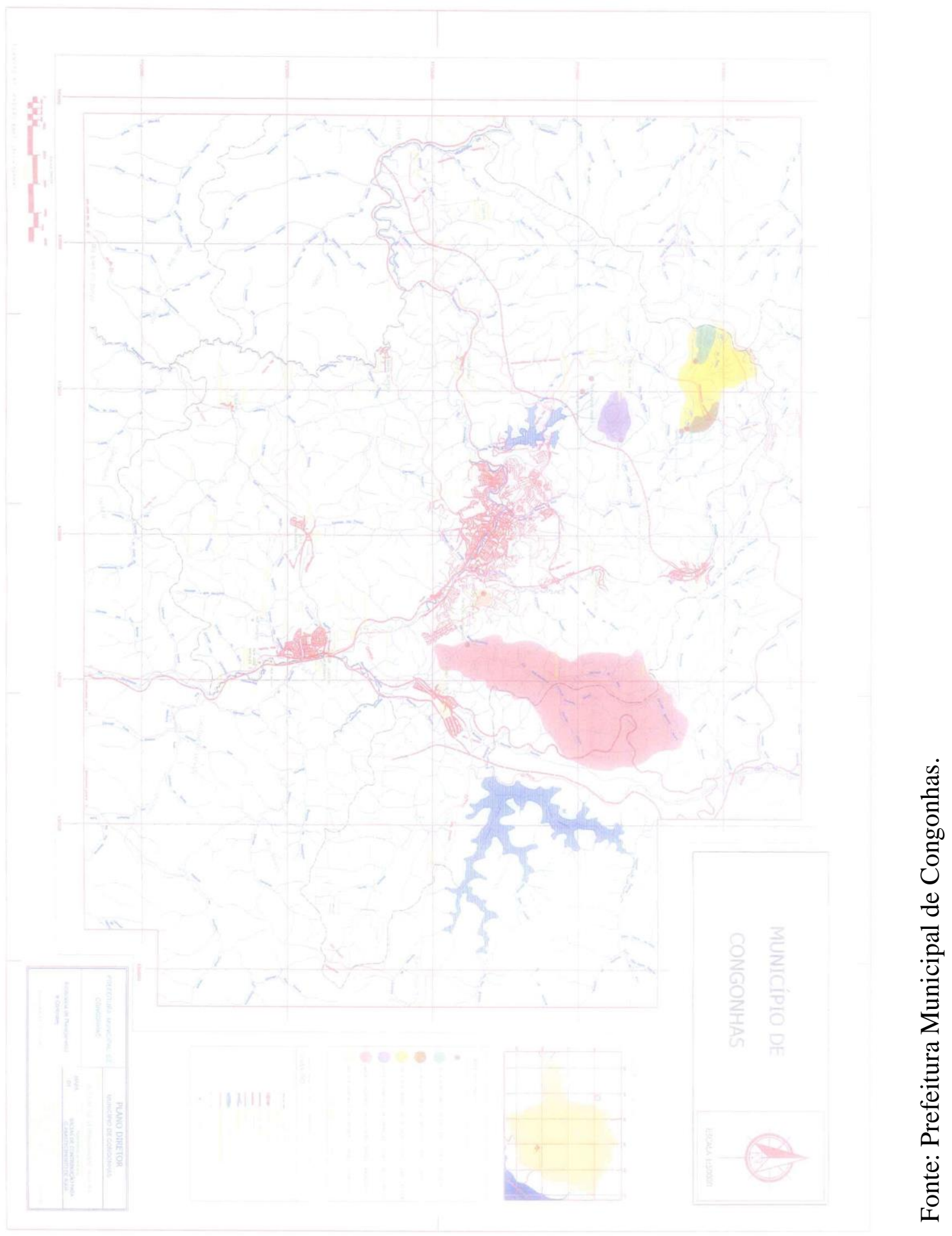

Mapa 3: Mapa de bacias de contribuição para o abastecimento de água de Congonhas. 
Nas imediações da Serra da Moeda, nas porções oeste e norte do município, existem trechos de Mata Atlântica preservada, mas boa parte das áreas ocupadas por florestas encontra-se modificada quase que por completo, notando ainda a presença de capoeira, que diz respeito a forrações secundárias, como consequência de queimadas ou desmatamentos por cortes anteriores.

A diversidade na vegetação do município de Congonhas pode ser considerada como resultado de uma combinação entre diferentes fatores que exercem influência sobre sua formação como a diversidade litológica, as formas diferenciadas de relevo, as variações topográficas e a pluviosidade.

Essa vegetação já foi bastante devastada pela atividade mineradora, tanto da extração do ouro no período colonial brasileiro, quanto no atual período de extração do minério-de-ferro e outros minerais como pedra-sabão, manganês, entre outros. Além disso, a expansão imobiliária e industrial, o acúmulo de lixo e entulho as queimadas também são responsáveis por uma parte do desmatamento no município.

Entre as várias espécies vegetais encontradas em Congonhas, podemos notar o desenvolvimento de gramíneas e capins perenes (poáceas) e samambaias (pteridófitas), e no estrato arbustivo existem espécies como as congonhas (arquifoliáceas), as quaresmeiras (melastomatáceas), os barbatimões (fabáceas), os coqueiros (arecáceas), chapéus-de-couro (volchisiácea) e ipês amarelos e jacarandás (bignoniáceas).

Dentre as espécies animais que habitam as matas do município de Congonhas podemos ver frequentemente as aves joão de barro (Furnarius rufus), o urubu (Coragyps spp), o bem-te-vi (Pitangus sulfuratus) e o tico-tico do campo (Zonotrichia capensis), os mamíferos paca (Agouti paca), gambá (Didelphis spp), capivara (Hidrochareris hydrochaeris), jaguatirica (Felis pardalis) e o lobo-guará (Chrysocyon brachyurus).

Entre os répteis encontramos diversas espécies de cobras como a cobra-cega (Siphonops annulatus), a jararaca (Bothrops jararaca) e o camaleão (Iguana iguana), além anfíbios como rãs (Rana spp) e sapos (Bufo spp).

Os rios e córregos de Congonhas são habitados por peixes como o acará (Geophagus brasiliensis), o mandi (Pimelodus maculatus) e o lambari (Astyanax bimaculatus). 


\section{6 - A formação de Congonhas}

O arraial de Congonhas do Campo começou a surgir no final do século XVII com desbravadores que povoaram antes outros arraiais, como a Vila Real de Queluz, que atualmente é a vizinha cidade de Conselheiro Lafaiete. Estes aventureiros procuravam por novos depósitos auríferos para serem explorados e terras férteis para plantio, pois a fome assolava a região naqueles primeiros anos de garimpo.

Os povoadores de Queluz faziam parte da Bandeira de Bartolomeu Bueno e seguiram margeando o rio Maranhão, se espalhando pelos afluentes e encontrando ouro no vale do rio Paraopeba, nas proximidades de Congonhas do Campo, onde fizeram um cruzeiro e chamaram o local de Arraial Redondo. Foram estes desbravadores também os responsáveis por darem início ao arraial de Soledade. O povoado vizinho que era conhecido como Freguesia de Nossa Senhora da Conceição. "Pode-se imaginar como eram rústicas essas vilas, com o aspecto alongado de caminhos que as casas de barro e de pau-a-pique costeavam" (MELLO E SOUZA, 1990, p. 105).

Em 1734 foi criada a Freguesia de Nossa Senhora da Conceição das Congonhas, elevada a distrito em 1746, ligado à São João Del Rei.

O nome de Congonhas do Campo foi emprestado de uma planta existente na região que é a planta Congonha ${ }^{23}$ (s.f. Luxemburgia polyandra), uma variedade de erva mate, da família das arquifoliáceas, com propriedades diuréticas e consumida como remédio para o intestino e bexiga. "Deram-lhe o nome que vem do Tupi e que quer dizer: o que sustenta, o que alimenta [Congõi]” (SUMÁRIO DE DADOS DE CONGONHAS, 2002, p. 06). Segundo outros estudos sobre a origem do nome da cidade, sua etimologia diz que vem do Tupi-Guarani: "Em outra versão, coa = mato; nhonha = sumido, o que significa 'zona onde o mato desaparece': campo. O nome Congonhas do Campo veio dessas duas versões” (PIRONI, 2008, p. 44).

O historiador Fernando Jorge, que pesquisou sobre a arte local e sobre o Aleijadinho, traz consigo a imagem mais popularizada e compartilhada sobre Congonhas:

\footnotetext{
${ }^{23}$ As variedades conhecidas desta planta são: congonha bate-caixa ou caixa de guerra, congonha bugre e congonha douradinha ou de folha miúda.
} 
A história desse arraial é pitoresca e interessante, devido ao Santuário do Senhor Bom Jesus de Matosinhos, cujo fundador foi o português Feliciano Mendes, um homem que certo dia viu desmoronarem todos os sonhos de felicidade, em conseqüência do seu fracasso na exploração das jazidas e da moléstia que quase o vitimou (JORGE, 1971, p. 169).

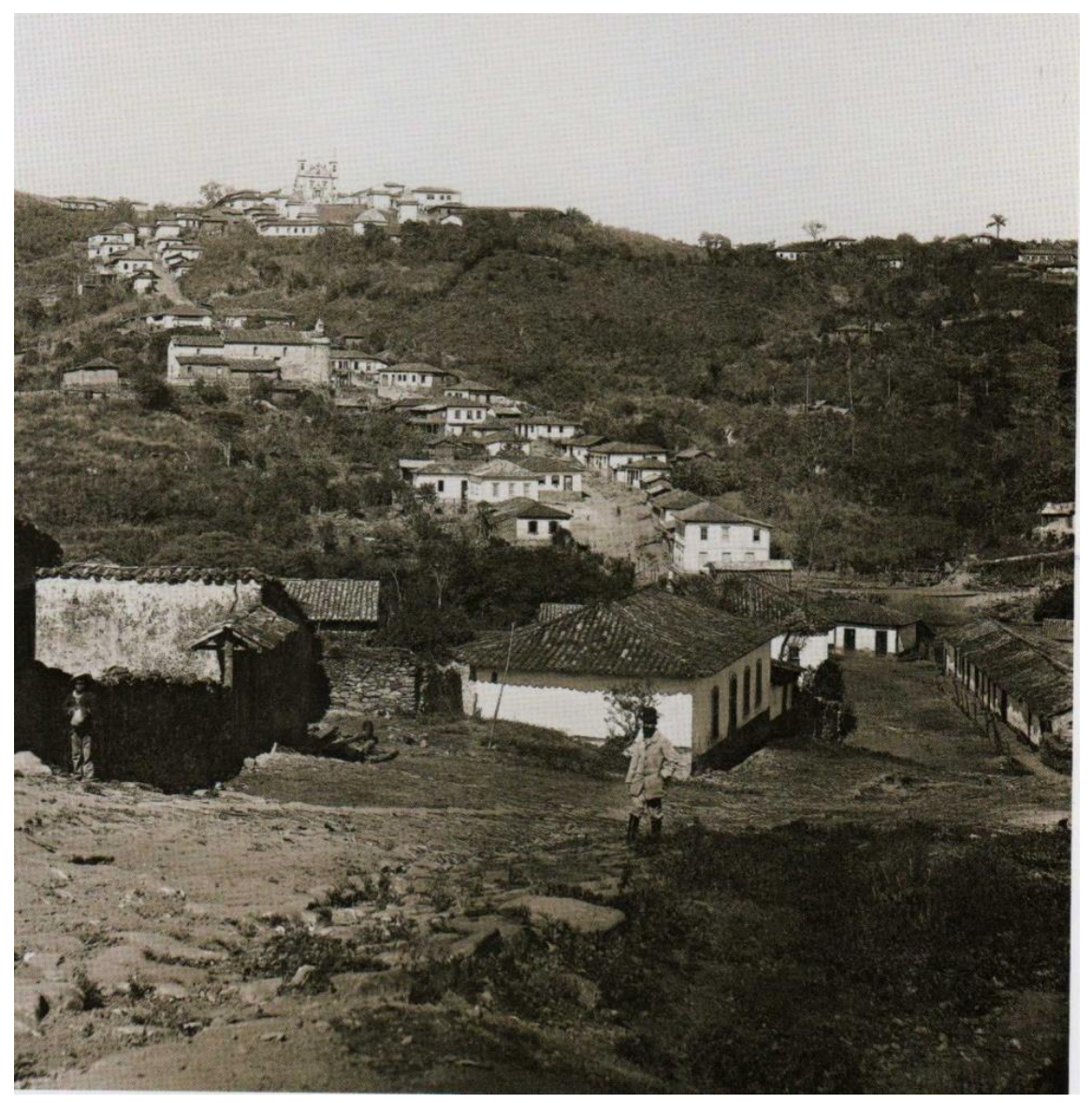

Figura 1: Congonhas, Minas Gerais, 1880.

Realmente, o templo do Senhor Bom Jesus de Matosinhos é uma edificação barroca digna de nota, porém, a cidade possui outros exemplares da arquitetura barroca que nos ajudam a compreender e a explicar como se deu a formação urbana e social de Congonhas, assim como a evolução de sua paisagem ao longo de sua história. Isso ocorre quando buscamos compreender correlações observáveis nos aspectos econômicos, sociais, civis e simbólicos que norteavam as mentes e as vidas dos mineiros, e também o papel político e burocrático da Coroa portuguesa, ambos refletidos nas edificações barrocas que monumentalizam as paisagens mineiras, como no caso das igrejas barrocas de Congonhas. 
As igrejas barrocas de Congonhas, assim como as igrejas de outras vilas e arraiais mineiros surgidos em tempos coloniais, de certa forma, refletem aquilo que Murillo Marx (1991) observou como obra do seguimento das precisas determinações eclesiásticas expressas importadas pelas práticas e costumes do reino, por cânones e constituições da religião oficial do reino, a Igreja Católica Apostólica Romana, constituindo em sua paisagem a relação Estado/Igreja, e a religiosidade da população humilde e longínqua dos principais centros de cultura e ainda, segundo as normas estabelecidas pelas Constituiçõens primeyras do acerbispado da Bahia ${ }^{24}$.

Nos primeiros anos de garimpo do ouro, os arraiais mudavam frequentemente de lugar e dessas primeiras construções pouco restou, principalmente por conta da fragilidade dos materiais empregados em sua construção e das precárias técnicas construtivas empregadas em construções improvisadas. "De fato, a empresa mineira era transitória e itinerante, caracterizando-se pelo baixo teor de capital fixo e pela capacidade de deslocamento em tempo relativamente curto" (MELLO E SOUZA, 1990, p. 66-67).

Neste sentido, o processo de desenvolvimento da arquitetura e da arte barroca em Minas Gerais foi gradativo. As igrejas mineiras durante o início da corrida pelo ouro foram feitas em taipa de pilão, que era um processo de construção tipicamente paulista, primeiros desbravadores e conquistadores da região mineradora, [...] "primitivas igrejas, chamadas 'igrejas de palha', feitas com barro e cobertura vegetal, pelos primeiros colonizadores e obedecem a uma planta simples de forma retangular" (CAMPIGLIA, 1957, p. 9).

Depois, na medida em que melhoravam as condições humanas, materiais e técnicas, paulistas e portugueses tentaram outros processos de construção até chegarem às construções de pedra, que foram surgindo aos poucos, na medida em que arraiais e vilas surgiam, cresciam e se desenvolviam pela região das minas de ouro. "A fixação do homem à terra só se estabilizava um pouco mais quando a exploração se fixava nos aluviões de meia encosta, as grupiaras ou catas altas" (MELLO E SOUZA, 1990, p. 67). E ainda:

\footnotetext{
${ }^{24}$ Segundo o próprio Murillo Marx (1991), são constituições primeiras porque, redigidas em 1707 e publicadas em 1719, foram as primeiras codificadas e aplicadas, com disposições que sucederam as outras do Brasil e as do mundo português, refletindo a orientação rigorosa do Vaticano em todo mundo, atentas à uniformidade de ritos necessários à Contra-Reforma, definidos pelo concílio de Trento (1545-1563), quando unida a Igreja aos Estados Nacionais europeus, passavam a representar as normas aceitas pelo poder temporal e pelo poder oficial. As constituições de números 683 a 686 tratam da ereção de ermidas, capelas, capelas curadas e das exigências para tal. A de número 1279 e seguintes tratam dos locais sacralizados, sagrados ou, locais "pios".
} 
Quando se fez o carnaval-religioso do 'Triunfo Eucarístico' em 1733, e as cerimônias se repetiram com o 'Áureo Trono Episcopal', em 1748, existia apenas uma minoria de nossas famosas construções barrocas (ETZEL, 1974, p. 85).

Então, o desenvolvimento do Barroco em Minas Gerais ganharia maior impulso somente durante a segunda metade do século XVIII, curiosamente, no mesmo período em que aconteceu o início da queda na produção aurífera.

A exploração aurífera e diamantífera na capitania das Minas Gerais atingiu seu apogeu antes da primeira metade do século XVIII, mas o ouro e os diamantes sozinhos não foram suficientes para o desenvolverem o Barroco naquela região, o que somente veio a acontecer da segunda metade do século em diante, após uma série de circunstâncias que podem esclarecer fatos paradoxais como estes:

\begin{abstract}
Podemos encarar o surto de construções religiosas da segunda metade do século XVIII em toda a colônia como uma espécie de amadurecimento das fortunas conseguidas na mineração de ouro e de diamantes. Com o impulso da retirada de fabulosos tesouros da terra houve uma dinamização da riqueza, menos pela posse do ouro do que pelas consequências que esta posse acarretou no giro do comércio e no desenvolvimento das propriedades urbanas e rurais. $\mathrm{O}$ comércio com as minas foi imenso na sua extensão e nos seus lucros exorbitantes. A necessidade de novas construções urbanas proporcionou o aumento de capitalistas vivendo à custa de suas rendas imobiliárias. Por outro lado, a agricultura adquiriu um grande impulso, pois era preciso muita produção para alimentar as dezenas de povoadores das regiões de mineração (ETZEL, 1974, p. 85).
\end{abstract}

No século XVIII, os preceitos religiosos eram incontestáveis e a Igreja Católica no Brasil colonial tinha o monopólio da evangelização, pregava e administrava os sacramentos, valorizando a vida celeste, mais do que a vida terrestre. A morte preocupava os brasileiros, o que era uma herança dos portugueses e visto que a preocupação com a morte e a vida no outro mundo era uma preocupação constante, é natural que as igrejas recebessem um cuidado especial por parte da população.

O dízimo que era cobrado pela Coroa geralmente tinha uma parte desviada e em geral não era usado para fins religiosos. O dinheiro para a construção dos templos vinha de uma minoria rica, pois a maioria da população era formada por marginalizados, mestiços, mulheres que tinham na prostituição a única fonte de renda e por famílias que viviam em meio a uma generalizada corrupção dos costumes, além de um grande número de escravos. 
O elemento que promoveu e levou adiante as obras da construção de igrejas teria que ser uma minoria que despontava no seio dessa população pobre. Esta elite surgiu nas organizações religiosas leigas, das irmandades e arquiconfrarias, que congregaram o que havia de melhor e mais representativo nos respectivos agrupamentos raciais e sociais de Minas Gerais. “Com a radicalização, consequência da discriminação racial e da luta pela sobrevivência entre as três raças ${ }^{25}$ que se amalgamavam na formação do brasileiro, criaram-se grupos que, todos, ambicionavam o melhor relacionamento com Deus" (ETZEL, 1974, p. 106).

A direção religiosa no Brasil durante o período colonial ficava a cargo do Rei de Portugal que por meio do Padroado ${ }^{26}$ conferido pela Santa Sé tinha plenos poderes para recolher os dízimos, construir igrejas, delimitar jurisdições territoriais, autorizar ou não o estabelecimento das Ordens Religiosas, conventos e mosteiros. Os negócios na Colônia eram comandados por ele através da Ordem de Cristo e da Mesa de Consciência e Ordem. "Foi com esta autoridade que proibiu o estabelecimento de ordens religiosas nas regiões das minas de ouro" (ETZEL, 1974, p. 105). E mais:

\begin{abstract}
As diversas formas de expressão da arte religiosa colonial para a orla litorânea estiveram subordinadas aos modelos europeus transplantados pelas ordens religiosas. Face à carência local, a formação e o adestramento de mão-de-obra especializada em determinados ofícios, desde os primeiros tempos, integrou o projeto colonizador português para o Brasil. Neste particular, salienta-se a ação dos Jesuítas, disseminadores de escolas de artes e ofícios pela Colônia. Em Minas foi diferente: a política restritiva e proibitiva da Metrópole em relação à fixação de clérigos na Capitania contribuiu decisivamente para o florescimento de expressões artístico culturais e artesanais próprias. A ausência de religiosos seculares e regulares na região abriu espaço para o desenvolvimento do espírito criativo e inovador dos leigos. A arte religiosa colonial mineira é obra essencialmente de artistas leigos e encomendada e consumida por leigos, portanto livre da rigidez, do formalismo e do hieratismo da arte produzida pelas congregações religiosas" (BOSHI, 1988, p. 26-27).
\end{abstract}

Com essa proibição, a atuação das irmandades e das arquiconfrarias passou a ser absoluta em Minas Gerais quanto à construção de templos religiosos. As poderosas ordens religiosas, que possuíam empresas comerciais e foram responsáveis pela construção de várias igrejas no litoral brasileiro ficaram proibidas de atuarem em Minas Gerais, principalmente pelo temor da Coroa, pois, aqueles homens de negócios poderiam se tornar pontes para o contrabando dos minerais.

\footnotetext{
${ }^{25}$ Brancos, negros e índios.

${ }^{26}$ Padroado: Direito de conferir benefícios eclesiásticos.
} 
Comerciantes ricos, intelectuais e os altos dignatários brancos criaram as Ordens Terceiras, que se desenvolveram a partir da segunda metade do século XVIII, porém, existiam alguns critérios de seleção, como na Ordem Terceira do Carmo, que reunia brancos ricos e negociantes, e as Ordens Terceiras Franciscanas, que preferiam os intelectuais, embora não desprezassem os ricos comerciantes. Existia também a seleção por raça, quando somente os brancos eram aceitos por essas instituições. Neste sentido, podemos perceber o domínio simbólico exercido por aquilo que Pierre Bourdieu (1994) chamou de habitus de classe. "O habitus descreve as mais profundas normas tácitas e valores que formam o modo que pensamos sobre o mundo, moldando nossas aspirações e ações por um período de vida de comportamento aprendido" (BURKE in HALL \& SILLIMAN, 2006, p. 133) ${ }^{27}$.

É importante lembrar que o conceito de habitus é usado por cientistas sociais para explicar a maneira pela qual as classificações étnicas subjetivas são baseadas em condições sociais que caracterizam domínios sociais particulares e assim, a construção de uma identidade étnica é baseada em disposições subliminares compartilhadas do habitus, que formam e são formadas por um conjunto de práticas, desta forma, as práticas e as crenças que se tornam concretizadas como símbolos de etnicidade são derivas de, e ressonam com práticas habituais e experiências pessoais, além de refletirem as condições imediatas e interesses que caracterizam situações particulares. Além disso, as categorias étnicas são produzidas, reproduzidas e também são transformadas através da comunicação sistemática de diferenças culturais com reação aos outros étnicos particulares. As orientações do habitus formam e são formadas pela prática social e assim, são ao mesmo tempo estruturas estruturantantes e estruturas estruturadas (Jones, 2005).

Assim, as construções religiosas que no início eram modestas foram ganhando cada vez mais suntuosidade, pois o fervor religioso e o status das irmandades que não mediam os recursos se associavam à vaidade e ao exibicionismo do indivíduo perante os seus semelhantes, o que acabava refletido diretamente nas edificações e na produção artística local.

As características apresentadas se juntam para identificar em Minas um acentuado espírito competitivo entre essas associações, que não só disputavam o concurso dos melhores artistas e artesãos para as suas encomendas, como, através deles, procuravam transformar a grandiosidade ou a beleza de suas obras em fator de prestígio, de autoafirmação e de destaque, se as compararmos a outras agremiações (BOSHI, 1988, p. 38).

\footnotetext{
${ }^{27}$ Tradução nossa.
} 
Agregado aos anseios dos mais ricos estava ainda o medo da inquisição, [...] "que foi apenas um eco da brutalidade com que agiu em Portugal" (ETZEL, 1974, p. 96). Mesmo assim, a inquisição deixava os católicos incomodados, já que estes sempre corriam o risco de serem delatados pelos seus semelhantes.

Um pouco de alívio para a população vinha da parte de que a inquisição em Minas Gerais acabou se concentrando na perseguição aos judeus e aos protestantes, que para se livrarem do seu julgo, acabavam se convertendo às práticas católicas, ao exemplo dos israelitas que se instalaram nas Minas e passaram a ser chamados de Cristãos Novos, por terem se convertido às práticas religiosas católicas. "Viver naqueles tempos era estar envolvido nas malhas do governo absoluto do rei e da religião também absoluta, regida pela prática impositiva e repressiva, consequência da Contrarreforma" (ETZEL, 1974, p. 53).

Por esta força simbólica exercida pela coroa portuguesa por meio de sua unificada Igreja/Estado, lembramo-nos novamente de Pierre Bourdieu (1994), que assim se referiu a respeito do alcance de ação do poder simbólico:

\footnotetext{
O poder simbólico como poder de constituir o dado pela enunciação, de fazer ver e fazer crer, de confirmar ou de transformar a visão do mundo; poder quase mágico que permite obter o equivalente daquilo que é obtido pela força (física ou econômica), graças ao efeito específico de mobilização, só se exerce se for reconhecido, quer dizer, ignorado como arbitrário. Isto significa que o poder simbólico não reside nos 'sistemas simbólicos' em forma de uma 'illocutionary force' mas que se define numa relação determinada - e por meio desta - entre os que exercem o poder e os que lhe estão sujeitos, quer dizer, isto é, na própria estrutura do campo em que se produz e se reproduz a crença (BOURDIEU, 1994, p. 14$15)$.
}

Outro fator social relevante para o desenvolvimento do Barroco em Minas Gerais foi o contingente de mão-de-obra livre que existia na região, já que muitos homens se aventuraram em direção às minas de ouro, movidos pelo sonho da fortuna rápida através do garimpo e assim, chegavam de todas as partes do Brasil e do mundo para inchar a massa humana cada vez mais.

Com gente vinda de todos os lados, a cosmopolita sociedade mineira que se formava passou então a ter mão-de-obra disponível para ser empregada nas construções religiosas, pois muitos daqueles que deixavam os locais onde viviam para se aventurarem nos garimpos de ouro 
acabavam frustrados, e assim, aprender um ofício de escultor, pedreiro ou pintor, em alguns casos era a garantia de sobrevivência, e também, a absorção da mão de obra livre excedente veio a coincidir com outras necessidades e demandas locais, como por exemplo, [...] “a implantação de um Estado fortemente centralizador e fiscalista, que incorporava aqueles primeiros elementos aos integrantes de seus aparelhos militar e burocrático" (BOSHI, 1988, p. 11).

Quanto à mão-de-obra escrava, ela estava presente em toda parte, pois o sistema era escravista, então, é natural que este tipo de trabalho estivesse por toda a Capitania. Os escravos exerciam diversas funções profissionais e podiam ser desde garimpeiros a jornaleiros ou artistas e estes últimos podiam exercer o ofício por meio de trabalhos forçados ou mesmo de forma livre, neste último caso por negros ou mulatos alforriados que assim, conseguiam algum prestígio social, como no caso do Aleijadinho.

\begin{abstract}
Colônia da época mercantilista, seu objetivo máximo era dar lucros à metrópole e nela propulsionar a acumulação de capital através do exclusivo de comércio e do tráfico negreiro, constituindo-se em 'retaguarda econômica da Metrópole' e lhe garantindo a autonomia. A adoção do trabalho escravo se deveu, à necessidade de maximizar os lucros através, por um lado, da superexploração de uma forma de trabalho compulsório limite - pois eram apropriados o trabalho e o trabalhador -, e, por outro, às grandes vantagens comerciais que advinham do tráfico (MELLO E SOUZA, 1990, p.61).
\end{abstract}

Os negros formavam também irmandades religiosas que foram responsáveis pela construção de diversas igrejas como as igrejas do Rosário, que se tornaram tradicionais redutos de negros como os escravos alforriados.

Ali, no reduto negro, ao exemplo dos brancos, podiam realizar casamentos, batismos e sepultamento de corpos, que neste último caso não eram poucos. $\mathrm{O}$ escravo, assim como o branco que se exibia através das irmandades, encontrava na arte uma forma de se expressar e de se igualar ao branco perante Deus e à sociedade.

É pela via de exercício de trabalhos manuais e artísticos que o mulato se imporá no quadro social de então. É pela destreza, habilidade, fino senso estético que ele rivalizará com o branco, e, dependendo da ótica, o suplantará na sociedade mineradora (BOSHI, 1988, p. 13). 
Para aqueles que podiam bancar as despesas, os sepultamentos também eram feitos com toda a pompa possível. Era dado dinheiro e velas aos pobres para que estes acompanhassem o cortejo e o maior número de padres disponíveis era chamado a carregarem as cruzes representativas das associações religiosas. Alguns velórios chegavam a demorar dias por causa das cerimônias religiosas e da quantidade de missas realizadas. Tudo era conferido por um visitador eclesiástico que poderia punir com excomunhão qualquer descumprimento dos desejos que o morto deixou em testamento. "O homem do barroco temia a morte e ambicionava para seu próprio enterro uma cerimônia que, em si mesma já continha algo de manifestação barroca" (ETZEL, 1974, p.103). Mais tarde, as igrejas tanto dos negros quanto as dos brancos ganhariam cemitérios atrás ou ao lado, já que o excesso de corpos sepultados no interior das mesmas começava a causar transtornos como o mau cheiro.

Outra característica barroca foi o costume das festividades, que se desenvolviam de acordo com as condições econômicas das populações locais de onde as festas eram realizadas. Uma das festas mais luxuosas em Minas Gerais no século XVIII foi o Triunfo Eucarístico, realizado em Vila Rica no ano de 1733, que foi a transladação do Santíssimo Sacramento da Igreja do Rosário dos Pretos para o novo templo da Senhora do Pilar. Outra festa que mobilizou a sociedade mineira foi o Áureo Trono Episcopal, festividade realizada em 1748 para a chegada do primeiro bispo de Mariana, Dom Frei Manoel da Cruz.

Depois da primeira metade do século XVIII, mesmo com a redução da produção aurífera, continuaram as construções barrocas por toda a capitania, [...] "isso mostra que havia um excedente econômico disponível para investimento em construção, arte e artesanato" (BOSHI, 1988, p. 36-37).

Mas o ouro não acabou de repente, foi aos poucos se tornando escasso, ao mesmo tempo em que as técnicas de garimpo eram apuradas e assim conseguiram encontrar e extrair ouro durante todo o século XVIII. Outro fator que é preciso ser levado em consideração é o contrabando, o qual tirava o ouro das mãos da Coroa para ser gasto como queriam os contrabandistas, e assim, o ouro podia ser investido nas construções religiosas.

A igreja tinha também um importante papel quanto à vida civil dos cidadãos das minas setecentistas. Compreender a respeito deste papel é também uma via que proporciona uma leitura arquitetônica e urbanística dos templos e dos largos e praças ao seu redor.

A igreja era então um organismo muito importante para a coroa portuguesa, também na organização das vilas e arraiais que surgiam, principalmente nos locais onde ocorria certa 
abundância aurífera, comércio intenso e populações que cresciam conforme as demandas locais.

A institucionalização da vida dessas tantas e tão dispersas comunidades se dava pela oficialização de sua ermida, de sua capelinha visitada por uma cura, pela sua elevação em matriz, elevação que significava a ascensão de toda uma região inóspita, ou de ocupação mais antiga e em expansão, ao no status de paróquia ou freguesia (MARX, 1991, p. 21).

A Igreja era acesso à assistência religiosa como o batismo e os sacramentos de morte e civil, com matrimônios, certidões de óbito. Por ela se resolviam as implicações jurídicas e querelas sociais e por ela se dava o reconhecimento da comunidade, de fato e direito, perante a Igreja oficial e desta forma, ao próprio Estado.

Esta posição de fundamental importância para controle e organização das cidades e da sociedade, das normas civis e da orientação e do controle espiritual pela Igreja/Estado ajudou então a influenciar sobre os traçados urbanos das vilas e arraiais mineiros, e consequentemente, em sua paisagem.

\begin{abstract}
O costume de se destacar o templo na paisagem transcendia, por isso, uma questão lógica, uma força de tradição, uma vontade plástica. Obedecia, na verdade, uma legislação clara a ser cumprida se se desejasse a sua aceitação e eventual promoção futura pela Igreja, que a reconhecia como tal; que lhe conferia, pelos seus estritos rituais, a qualidade de local onde se poderiam oferecer os sacrifícios e os sacramentos; que lhe indicaria um sacerdote, em caráter permanente ou não. 'A Igreja he cidade fabricada sobre o monte, patente a todos: he candea posta sobre o castiçal, que alumea a todos' (MARX, 1991, p. 22).
\end{abstract}

Ainda segundo o mesmo Marx, era preciso cumprir com o versículo bíblico de Mateus supracitado em destaque, como no primeiro livro editado nas Américas:

[...] era, portanto, atender a um preceito eclesiástico que conferia de imediato, na paisagem de qualquer lugar, o destaque almejado que o relevo sugerisse, se não a primazia absoluta ao edifício do templo. E, em boa parte, nosso território com seu relevo ensejou a exploração das colinas e das escarpas pelas capelas e igrejas de todo porte. Estava de saída garantida a forte presença, se não o incontrastável predomínio, desse elemento arquitetônico, pela sua posição topográfica (MARX, 1991, p. 18). 
Em termos de urbanidade, principalmente em vilas e arraiais mais desenvolvidos e com populações mais numerosas ${ }^{28}$, as igrejas deveriam ficar livres de casas de particulares junto a suas paredes, distantes de outras paredes de forma que as procissões pudessem andar ao seu redor, influenciando o conjunto de ruas e prédios a sua volta, com o passar do tempo transformando as redondezas e os caminhos para as casas mais espaçadas e longínquas em logradouros.

A igreja destacada pela altura no sítio urbano se valorizava visualmente também, pois, passava a contar com o espaço livre e amplo a sua volta, e ainda, disso muito se aproveitaria a famosa arquitetura colonial mineira para a volumetria dos templos religiosos e das detalhadas fachadas. E ainda, a presença do adro em muitos templos favoreceu a ambientação dos templos, contribuindo com sua área livre e a beleza, que em alguns casos merecem um destaque pelo apelo artístico recebido, como no caso do adro da Basílica do Senhor Bom Jesus de Matosinhos de Congonhas.

As igrejas de Congonhas, contudo, além de expressarem tais normas, refletem também um simbolismo característico dos valores constituídos no interior da sociedade mineira, estruturados e multiplicados sob a dura realidade vivida pelas primeiras populações que se aventuravam na busca pelo ouro até a decadência dos recursos materiais e humanos proporcionados pela dificuldade do garimpo e das mudanças sociais, econômicas e culturais decorrentes desta dinâmica.

Portanto, é possível inferir arqueologicamente acerca da disposição variante dos templos na paisagem porque muitas vezes, encontrarmos elementos simbólicos passíveis de leitura que nos permitem fazer correlações a este respeito. Por isso, devemos ficar atentos não somente às normas eclesiásticas e estatais e às devoções do povo, mas à questões socioeconômicas e culturais que muitas vezes estarão atreladas a fatores como os anseios, sonhos, ilusões, abismos sociais e mazelas constituídas e multiplicadas no seio da população mineira, que por sua vez, influenciaram na disposição dos templos na paisagem e no tratamento artístico e arquitetônico.

A Igreja de Nossa Senhora do Rosário foi construída por negros escravos no começo da mineração do ouro em Minas Gerais. Sua construção teve início no final do século XVII, quando os recursos materiais e humanos ainda eram escassos na região. Sua fachada seguiu tendência das pequenas construções barrocas mineiras do início do século XVIII, as paredes

\footnotetext{
${ }^{28}$ Murillo Marx (1991) cita como fonte a Constituição Primeira de número 687.
} 
são de pedra com quase um metro de espessura e a sineira foi colocada fora do templo, por causa da ausência de torres, que também revela o estilo das primeiras construções mineiras.

Fator importante a ser considerado para a leitura da inserção de uma igreja dedicada a Nossa Senhora é a conceituação referenciada de Murillo Marx (1991), que assim nos fornece elementos satisfatórios que justificam a presença de tantas igrejas dedicadas à mãe de Cristo nas comunidades do Brasil:

Ao discorrer sobre todo e qualquer templo com a invocação da mãe de Jesus, frei Agostinho de Santa Maria oferece um precioso retrato do mundo português no início dos setecentos. Seu monumental Santuário Mariano fornece incontáveis exemplos de dotações para ermidas, capelas e igrejas nos quatro continentes - e, portanto, também no nosso - que permitiram não somente a construção como, e acima de tudo, a ereção canônica de tantos templos dedicados a tantas Nossas Senhoras (MARX, 1991, p. 39).

A Igreja de Nossa Senhora do Rosário de Congonhas, no entanto, foi construída em um local elevado, que fica no topo de uma colina, o que faz com que possa ser vista de longas distâncias. Esta característica do templo é notada em outras igrejas do Rosário de Minas Gerais e em outras regiões do Brasil e pode significar uma forma de simbolizar, na paisagem, a maior proximidade com Deus, pois quem passa pelas ruas próximas à Igreja de Nossa Senhora do Rosário de Congonhas, precisa olhar para o alto para avistar o templo.

\begin{abstract}
As igrejas do Rosário são tradicionais redutos dos homens pretos, dos antigos escravos; em geral, as mais modestas, ainda que com honrosas exceções. Nas nossas andanças pelo país, notamos que muitas vezes estas igrejas se situam em partes mais afastadas do centro da povoação mas em lugar tão alto como a matriz ou mais alto do que ela. Seria uma coincidência, ou andou aqui o dedo do inconsciente coletivo de uma raça oprimida que escapava com este subterfúgio ao jugo de seus opressores, para se sentir mais próxima de Deus? (ETZEL, 1974, p. 78).
\end{abstract}

No teto do templo, os escravos pintaram no forro a imagem de Nossa Senhora do Rosário com querubins e utilizaram para este trabalho tintas feitas com clara de ovos, sumo de frutas, sangue de boi e óleos de flores. Este forro com a pintura original foi retirado em restauração recente e deve ser recolocado em outra restauração. 
Apesar da abundância de ouro em Congonhas, os trabalhos de douração foram modestos. No interior do templo foram instaladas algumas sepulturas, o que era costume nas construções do Barroco Mineiro, porém, foram retiradas em uma restauração do templo.

Na primeira metade do século XVIII, no arraial que depois veio a se tornar o distrito de Alto Maranhão foi iniciada a construção da Igreja de Nossa Senhora da Ajuda, no ano de 1746. O templo ganhou quatro altares laterais, pintura no forro do teto, além da imagem de Nossa Senhora da Ajuda esculpida em madeira e colocada no altar-mor.

A sacristia foi ornada com um altar e com as imagens de Nossa Senhora das Dores e do Senhor dos Passos, além de um chafariz em pedra-sabão, matéria prima utilizada na portada exterior. Também fora do templo foi colocada uma sineira ao lado, uma vez que o templo não possui as torres laterais.

Contudo, não foram encontradas informações a respeito dos artistas que trabalharam na construção da igreja, assim como também não foram encontradas informações mais detalhadas acerca da construção.

Lobo Leite, distrito de Congonhas criado junto com o município em 1938, também foi uma das primeiras povoações iniciadas na região pela bandeira de Bartolomeu Bueno. O local era conhecido antes da criação do distrito como Arraial de Nossa Senhora da Soledade, onde fica a igreja construída no século XVIII em homenagem à santa de mesmo nome:

\footnotetext{
Capela cuja documentação não é conhecida, mas cujas características permitem atribuí-la à segunda metade do século XVIII, tanto pelo aspecto externo, como pelos elementos interiores. Frontaria típica com o portal e duas janelas rasgadas ao nível do coro, vão com vergas em arco de círculo. O conjunto é enquadrado por 2 pilares com pedestal, base e capitel toscano; essas pilastras são terminadas com cunhais. Sobre esses elementos verticais corre um entablamento bem proporcionado, em cujas extremidades há dois coruchéus. Apoiado no entablamento, o frontão movimentado de curvas e contracurvas tem um óculo e é encimado pela cruz. A sineira apresenta-se lateralmente separada da igreja (SUMÁRIO DE DADOS DE CONGONHAS, 2002, p. 66).
}

As sineiras instaladas fora e a ausência de torres altas junto aos templos revelam uma tendência deste tipo de construção na área que faz parte do município de Congonhas, durante os primeiros anos da exploração do ouro, pois a Igreja de Nossa Senhora da Soledade segue o mesmo estilo arquitetônico das igrejas de Nossa Senhora do Rosário e de Nossa Senhora da 
Ajuda, possuindo apenas maior riqueza de acabamento e escultura que as demais, principalmente na parte externa. Ainda na parte externa, foi colocada uma espécie de pelourinho de frente para a porta frontal da igreja.

Um fator interessante é que, tendo o arraial surgido às margens do Rio Soledade, em um lugar de pouca visibilidade entre os morros, a Igreja de Nossa Senhora da Soledade foi construída com sua fachada voltada para terras onde outrora foi extraída boa parte do ouro daquela região e cujos vestígios da extração ainda se encontram pelas encostas dos morros e margens do rio.

Um exemplo para este tipo de correlação vem de outra igreja mineira, mas que não fica localizada em Congonhas é a Matriz de Santo Antônio de Catas Altas, que foi construída de frente para os garimpos auríferos, cujos vestígios da exploração do metal precioso ainda estão presentes e podem ser visualizados até os dias atuais.

No interior do templo de Nossa Senhora da Soledade, os altares entalhados em madeira ganharam trabalhos de douração e no arco da capela-mor dois anjos foram colocados ao centro sustentando um brasão com a figura do Sagrado Coração de Jesus. A imagem da santa que dá nome ao templo foi colocada no altar-mor, em elevação superior aos demais santos. Do lado esquerdo da capela-mor foi colocado um púlpito e foram feitas ainda pinturas de escrituras em latim no forro do coro, restaurado recentemente como o interior do templo.

No ano de 1734, ano do reconhecimento do povoado como freguesia, teve início em Congonhas a construção da Igreja Matriz de Nossa Senhora da Conceição.

Se prossegue a expansão da sede da nova freguesia, se o seu progresso se intensifica enquanto se expande a sua área construída, o número de seus lares e negócios, avantajam-se igualmente o seu templo principal (que os espanhóis chamam de iglesia mayor, significativamente) e o conjunto articulado do templo com seu adro. Este, quem sabe, será em si objeto de outra reforma ou ampliação, até mesmo à custa das casas vizinhas, visando recompor, regularizar, aumentar, embelezar o que já se tornou o largo mais central do antigo arraial. Não se dilui o conjunto religioso do edifício ou área livre - no lugar agora crescido; pelo contrário, todos os esforços comuns se voltarão para ele, para realçar o símbolo e a efetiva sede da nova categoria que reconhece e enaltece a comunidade em ascensão. Não mais um simples arraial ou capela, porém uma freguesia ou paróquia! (MARX, 1991, p. 28). 
A construção da matriz era um símbolo de prestígio e representava também novo status para a localidade e seus habitantes. A nave da igreja foi construída depois que a capela-mor funcionou por algum tempo como templo religioso.

\begin{abstract}
Ora, se o reconhecimento do arraial pelo Estado se iniciava através da Igreja, aumentava o significado do templo do clero secular, aquele diretamente dependente do bispado. A antiga capelinha, talvez agora já reformada ou mesmo totalmente refeita, transforma-se em sede paroquial, paróquia ou, na nossa expressão familiar, em igreja matriz do lugar. Ganha a sua nave outra expressão pelo seu novo status religioso; ganha mais ainda a sua sacristia, agora ponto obrigatório também para a cidadania. Cresce o prestígio, logo, talvez o tamanho e o tratamento de seu adro. Alterações dar-se-ão de imediato ou em breve para que o templo abrigue suas novas funções e dignidades devidamente. Se não o fora antes, certamente será agora refeito com outra lavra e tamanho, não só atendendo a uma gente mais numerosa, como também em função de muito mais recursos disponíveis. Os fregueses, os filii ecclesiae, os filhos da igreja, são agora muitos e, quem sabe, alguns abonados ou remediados (MARX, 1991, p. 27).
\end{abstract}

Este templo possui fachada em estilo Jesuítico do século XVIII, com duas torres laterais, frontais e com voluta e sineira, todos ligados ao corpo do templo. A portada possui escultura feita pelo Aleijadinho.

A portada é talhada em pedra-sabão, com ombreiras frisadas e sobrepostas em dois fragmentos de frontão centrado por medalhão representando a Arca de Noé e a Pomba Imaculada com ramo de oliveira no bico, pairando sobre o dilúvio do pecado, representando a pureza, a bonança e a aliança de Deus com o homem; tudo encimado pela coroa real da Imaculada Conceição, padroeira e princesa do reino de Portugal. A parte central desta portada leva a marca inconfundível da mão do Aleijadinho (BIBLIOTECA PÚBLICA MUNICIPAL DJALMA ANDRADE, 200-?, p. 38).

Uma das características do templo de Nossa Senhora da Conceição é sua nave, que é ampla e não possui colunas de sustentação. Ela chama a atenção pelo tamanho, que faz dela uma das maiores de Minas Gerais. Outro motivo para o amplo espaço da nave é a ausência de corredores laterais conjugados ao seu corpo, algo que é comum em igrejas mineiras da época.

No interior do templo foi construída uma balaustrada de jacarandá e no mesmo foram construídos altares laterais que levam imagens de santos esculpidos em madeira. A imagem de Nossa Senhora da Conceição de origem portuguesa foi colocada no altar-mor em posição mais elevada do que todas as outras imagens. 
No arco da capela-mor uma figura representa a Santíssima Trindade e no arco central, dois anjos que sustentam uma coroa e um escudo foram colocados no centro do mesmo, indicando a criação da vigaria por decreto real em 12 de fevereiro de 1743.

\begin{abstract}
Algo, entretanto, não mudará. O local da igreja matriz, ou da nova matriz, será o mesmo - aquele ponto geograficamente destacado de quando se iniciou um ajuntamento de moradas; aquele terreno então generosamente amplo que, sempre que possível, exibia de todos os lados a capelinha original, que possibilitava o seu entorno quando das procissões; aquele setor da povoação privilegiado pela concentração da gente, de atividades e negócios que a proximidade do templo estimulava. A presença diante do edifício religioso, de um espaço aberto, de seu adro, palco de tantos e tão variados agrupamentos, objeto de carinho e do gasto maior da comunidade, conservado, ampliado e composto sempre com o mais empenho e capricho, alcançará também outra dignidade e expressão. O mesmo espaço aberto, a mesma articulação, todavia, ou seja, o ponto focal, institucional permanecerá o mesmo num outro estágio de evolução social e institucional, que reflete - o que realmente importa - uma outra etapa da evolução urbana da localidade (MARX, 1991, p. 27-28).
\end{abstract}

Além do Aleijadinho, o seu pai, o artista português Manuel Francisco Lisboa e o escultor Manoel Francisco da Luz, trabalharam na construção da Igreja Matriz de Nossa Senhora da Conceição, que no século XX teve as torres reconstruídas.

A posição da Igreja Matriz de Nossa Senhora da Conceição de frente para a Basílica do Senhor Bom Jesus de Matosinhos e em local mais baixo, pode estar de acordo com Etzel (1974), no que diz respeito à construção do templo do Bom Jesus, que quando de sua ereção iniciada posteriormente e em local mais alto, buscavam refletir simbolicamente o tão ambicionado local mais próximo de Deus e também, o confronto entre as irmandades religiosas pelo templo de maior destaque e beleza.

A última das igrejas barrocas construídas em Congonhas foi a Igreja Matriz de São José Operário. As obras foram iniciadas no início do século XIX, no ano de 1817. Sua fachada foi construída em formato curvilíneo e as torres em formato circular, um dos poucos exemplares desse tipo de torre em Minas Gerais. A pedra-sabão foi largamente usada na construção do templo, como na confecção da portada com a imagem de São José ao alto, dos pilares e nos ornamentos das janelas.

No interior do templo, além do altar-mor, foram construídos dois altares laterais. O acabamento dos altares e das demais partes que compõem o interior do templo é bem 
simplificado se comparado com outras igrejas anteriores à igreja de São José, com detalhes menos extravagantes dos típicos do Barroco Mineiro.

O Barroco desta igreja é considerado um Barroco-Rococó, uma feição do Barroco que se generalizou no final do século XVIII e que caracteriza seu declínio, acompanhando a exaustão do ouro, a decadência econômica em Minas Gerais e a chegada do Neoclassicismo. Os altares da Igreja Matriz de São José Operário possuem ainda poucos detalhes com douração.

O tratamento minucioso, a simbólica mundana dos elementos decorativos, a par da definição nítida da composição, sugere na arquitetura mineira o estilo barrocorococó, de fins do século XVIII, e prenuncia o neoclássico dominante no século seguinte (CAMPIGLIA, 1957, p. 16).

O artista plástico Álvares de Meneses participou da construção do templo e pintou no forro do teto da nave no ano de 1880, uma figura de São José ensinando orações ao Menino Jesus e um anjo próximo aos dois com um ostensório nas mãos. O medalhão central foi pintado pelo artista plástico Rubens Ribeiro em 1915, porém, quanto ao projeto da igreja: "Não se tem notícia, no entanto, de quem a projetou, nem daqueles que trabalharam em sua obra, mas presume-se que os próprios integrantes da Irmandade de São José participaram diretamente da construção" (SUMÁRIO DE DADOS DE CONGONHAS, 2002, p.66).

Em sua correlação com a paisagem, além dos fatores institucionais impostos pela Igreja/Estado que influenciarão em sua arquitetura e posicionamento, a Igreja Matriz de São José Operário, construída em pleno período de estagnação econômica das Minas Gerais pela queda da produção aurífera, encontra-se posicionada de fronte às grandes montanhas de ferro da Serra da Moeda.

Desta forma, assim como podemos perceber em outros casos anteriores, quando a riqueza do ouro fornecia elementos simbólicos para o posicionamento do templo e sua constituição arquitetônica, neste caso, o posicionamento da igreja do santo operário parece fornecer um prenúncio a mais do que viria a ser a fonte de riqueza do homem das minas, o ferro.

No caso do Santuário do Senhor Bom Jesus de Matosinhos de Congonhas, com base nos estudos documentais feitos pelo historiador Edgard Cerqueira Falcão (1962), sabemos que a devoção ao Bom Jesus de Matosinhos foi levada de Portugal para as Minas junto com a ânsia pelo ganho material dos aventureiros que por lá se arriscavam, envolvidos em todo tipo de 
sorte, desde a fome que assolava a região até a segurança da riqueza proporcionada pelo ouro. Eles não tardavam em fazer promessas em nome dos objetivos a serem alcançados no garimpo do ouro e pedras preciosas e de proteção face um ambiente inóspito e constantemente perigoso: "Por tal forma implantou-se entre as alterosas montanhas da Serra do Espinhaço, e adjacências, ardente culto ao Bom Jesus de Matosinhos, glorioso patrono, sobretudo das populações setentrionais da metrópole lusa" (FALCÃO, 1962, p. 25).

O português Feliciano Mendes, devoto do Senhor Bom Jesus de Matosinhos que foi para Minas Gerais em busca do enriquecimento com o ouro, após ficar doente fez a promessa de dedicar-se ao serviço do Santo caso fosse curado da enfermidade, assim, satisfeito pela graça alcançada, assentou-se no Alto Maranhão, em um sítio perto do arraial de Congonhas do Campo e em fevereiro de 1757 fincou uma cruz na elevação do terreno e ergueu um oratório ao lado dela, onde colocou a imagem do Cristo Crucificado. Logo, procurou o Primeiro Bispo de Mariana, Dom Frei Manuel da Cruz com a intenção de conseguir uma autorização para erguer um templo para o culto ao santo de devoção e assim, cumprir a promessa feita em troca da cura conseguida.

A licença foi outorgada no dia 21 de julho de 1757, onde figurava o compromisso do devoto em construir por meio de esmolas o referido templo, desta forma, Feliciano Mendes se tornou eremita para que assim pudesse receber os recursos destinados à instituição em causa.

Após ser atendido em súplica pelo monarca português Dom José I, Feliciano Mendes tratou de trabalhar com as economias que conseguiu com o garimpo, comprou uma criança escrava de nome Sebastião para ajudar em sua missão e com a permissão em mãos e uma caixinha pendurada no pescoço, passou a pedir esmolas que logo se tornariam suficientes para a construção de uma capela.

A primeira providência tomada por Feliciano após juntar o montante necessário, foi abrir o Livro $1^{\circ}$ de Despesas do Santuário de Nosso Senhor Bom Jesus de Matosinhos de Congonhas do Campo, para nele registrar os pagamentos com materiais e mão-de-obra para a construção, depois, mandou fazer a planta da edificação e contratou os serviços de pedreiro, carpinteiro e seus respectivos auxiliares, mediante escritura pública lavrada no foro de Vila Rica.

O pedreiro Antônio Rodrigues Falcato e o carpinteiro Antônio Gonçalves Rosa, apoiados por seus auxiliares, deixaram a edificação em condições de receber cultos religiosos, antes mesmo do prazo estabelecido por Dom Frei Manuel da Cruz, a 23 de dezembro de 1759. 
Após o falecimento de Feliciano Mendes em 23 de setembro de 1765, assumiu o cargo de ermitão Custódio Gonçalves de Vasconcelos, no dia 4 de outubro daquele ano e depois oficializado em 10 de março de 1766 pelas autoridades eclesiásticas de Mariana, dando prosseguimento às obras até o ano de 1776, ano de sua morte, dando lugar a Inácio Gonçalves Pereira, que viu juntamente com a construção do adro, a conclusão das obras de pedreiro por Tomás da Maia Brito, responsável pelo plano de embelezamento exterior do templo.

Inácio Gonçalves Pereira iria ainda, entre suas realizações, adquirir um órgão para a capela, iniciar os alcatruzes, que formam um sistema de captação e canalização de água para o templo, construir um albergue para romeiros e concluir a Sala dos Milagres e a Capela do Sagrado Coração de Jesus. A Sala dos Milagres passou a receber pedidos de graças e agradecimentos em forma de $e x$-votos ${ }^{29}$ pelas graças alcançadas. Foi também sob a orientação de Inácio Gonçalves Pereira que em 1779 foi criada a Irmandade do Senhor Bom Jesus de Matosinhos de Congonhas do Campo.

Com a criação da Irmandade do Senhor Bom Jesus de Matosinhos de Congonhas do Campo, começaram os festejos ${ }^{30}$ do Jubileu a partir de 1780, que eram realizados a princípio em duas épocas do ano, em maio e em setembro, depois, diminuindo a frequência nos meses de maio por causa de chuvas que deixavam os caminhos da região intransitáveis e os rios transbordantes, passou a se realizar somente nos meses de setembro.

No ano de 1787, o Senhor Morto Jacente foi depositado na parte inferior e dianteira do altarmor, [...] "passando a venerar-se sob a invocação de Bom Jesus do Sepulcro, e tornando-se objeto de intenso culto pelas multidões de crentes" (FALCÃO, 1962, p. 56).

Após a morte de Inácio Gonçalves Pereira em 1790, a administração do Santuário passou para Tomás da Maia Brito, que cuidou da construção dos alcatruzes, que eram tubulações de água construídas em pedra-sabão e cuidou ele também da construção das casas adjacentes. Afastado do posto em 1794, foi substituído por Vicente Freire de Andrada, o $5^{\circ}$ ermitão. Os motivos para a troca de ermitão desta vez são desconhecidos.

O artista plástico Bernardo Pires da Silva foi parceiro de João Nepomuceno nas pinturas que ornam as paredes do templo e, junto com o também pintor Manuel da Costa Ataíde e o

\footnotetext{
${ }^{29}$ No local encontra-se atualmente uma coleção de ex-votos pintados, com 89 peças, tombadas pelo IPHAN em 29/01/1981, processo 1.039-T-80, inscritos no Livro de Belas Artes Vol. 2, folha n. $^{\circ}$ 04, $\mathrm{n}^{\mathrm{o}}$ de inscrição 548 e Livro Histórico Vol. 1, folha ${ }^{\circ} 84, n^{\circ}$ de inscrição 486.

${ }^{30}$ As festividades religiosas eram uma das práticas barrocas mais apreciadas pela sociedade mineira da época. Nota-se também as festividades do carnaval-religioso do 'Triunfo Eucarístico' em 1733 em Vila Rica, e as cerimônias se repetiram com o 'Áureo Trono Episcopal', em 1748 em Mariana.
} 
entalhador Francisco Vieira Servas fazem parte de um seleto grupo de artistas mineiros do século XVIII que em Congonhas deixaram o testemunho de sua arte.

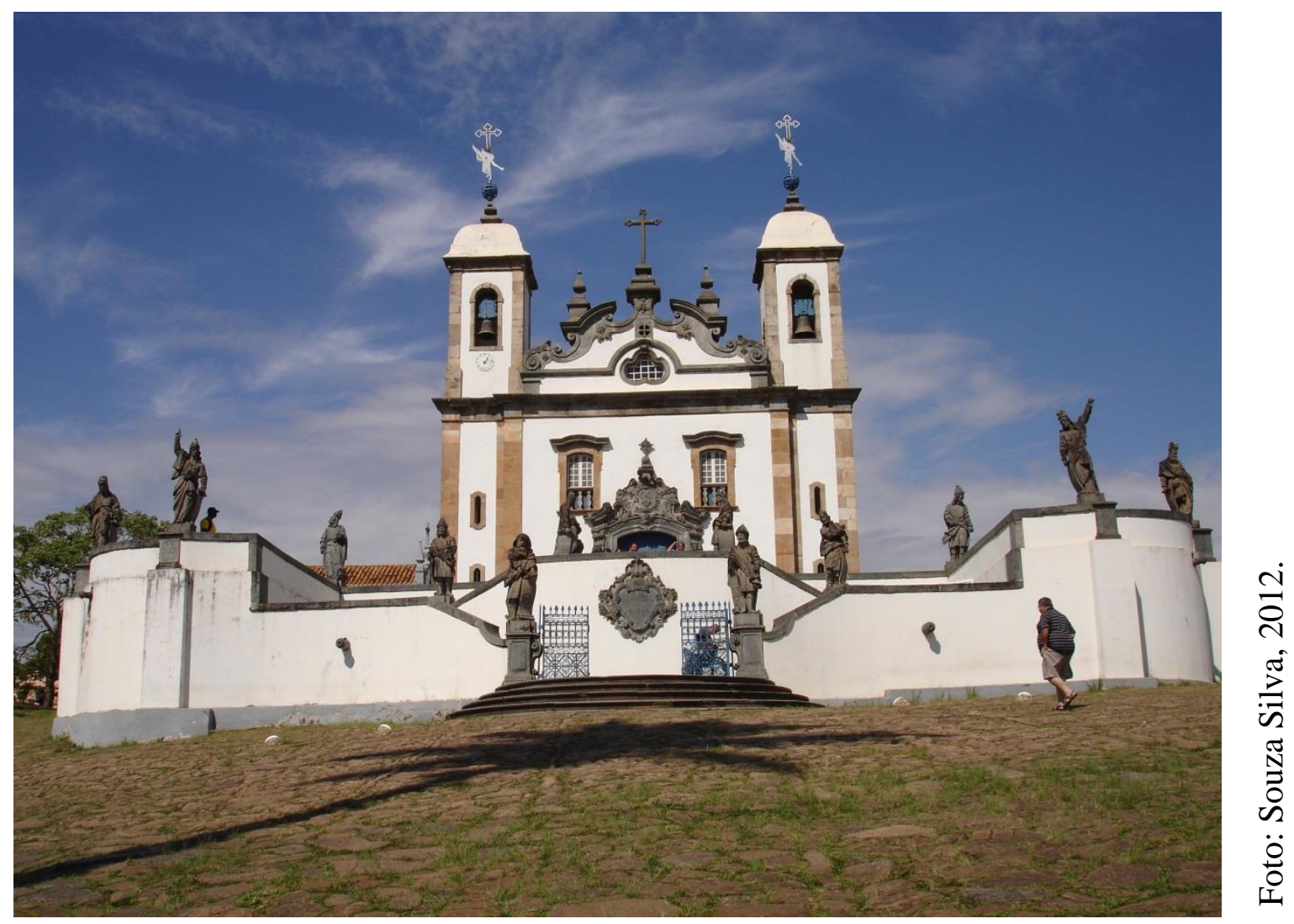

Figura 2: Fachada da Basílica do Senhor Bom Jesus de Matosinhos, Congonhas, Minas Gerais.

Outro artista, o Aleijadinho, iniciou os trabalhos no Santuário a partir de agosto de 1796, com o compromisso assumido com o ermitão Vicente Freire de Andrada de esculpir 66 estátuas de madeira cedro em tamanho natural e algumas em meio vulto, que teriam a função de traduzir as cenas da Paixão de Cristo para serem colocadas nas capelas dos Passos da Paixão. A tarefa do Aleijadinho terminou em 1799 e ganhou também a pintura de Manuel da Costa Ataíde. Aleijadinho trabalhou ainda durante o período em que esculpiu os profetas, iniciados em 1800 e na reforma do órgão da igreja com a ornamentação de uma nova caixa. 
No entanto, da mesma forma que toda a vida do Aleijadinho, os Profetas de Congonhas do Campo $^{31}$ se tornaram um mistério. Existem várias leituras que buscam dar sentido àquelas doze estátuas de pedra-sabão, assim como para as peças expostas nos passos da paixão.

Germain Bazin analisou os profetas e passos à luz de precedentes europeus, relacionando-os ao conceito de Sacro Monte que remontava à Renascença Italiana, ou seja, um jardim religioso na encosta de uma colina, desenvolvido em Portugal nos séculos XVII e XVIII Portugal, sendo templo mais complexo o de Bom Jesus do Monte, perto de Braga, Portugal (Bazin, 1963; Smith, 1973). Para a artista plástica Marilei Moreira Vasconcellos (1997), a obra tem simbologia referente à maçonaria, cujo sistema sacramental consiste em doutrinas e símbolos acessíveis somente aos maçons. Seria a representação de 12 inconfidentes.

Algumas leituras as interpretam de forma religiosa e tentam explicar as estátuas como vultos de mensageiros de Deus, desta forma, [...] "somente com espírito de fé se compreenderá o verdadeiro sentido da arte em Congonhas" (FALCÃO, 1962, p.145). Leitura que faz sentido, já que:

\begin{abstract}
Considerando-se que toda a iconografia do Santuário de Congonhas está centrada na figura do Cristo Redentor - que pelo sacrifício realizou enfim a tão almejada ligação entre a Antiga Lei e a Nova Aliança de Iavé com o seu povo escolhido, justifica-se plenamente a presença dos Profetas que pelas suas pregações e vaticínios prepararam esse acontecimento capital. Mas ainda, essa presença atesta a permanência, em terras americanas e já no alvorecer do século XIX, de uma das mais antigas tradições da arte cristã ocidental: a simbologia das harmonias e concordâncias entre o Antigo e o Novo Testamento, fonte viva de ensinamentos da doutrina cristã, e da qual acha-se impregnada toda a arte medieval (OLIVEIRA, 1985 , p. 55).
\end{abstract}

Outras leituras partem do campo científico e o exploram para explicar os Doze Profetas do Aleijadinho, tomando por base os acontecimentos sociais, políticos, econômicos e pessoais que nortearam a vida do artista, assim como os problemas que ocorriam nas Minas: “Antônio Francisco Lisboa pressentiu uma linguagem própria. Seria a primeira afirmação legítima da linguagem de uma nacionalidade que se formava. Caráter e unidade de concepção dão à sua obra condição fundamental no tempo e no espaço" (KELLY, 1960, p. 141).

\footnotetext{
${ }^{31}$ Os Doze Profetas que estariam representados em Congonhas são respectivamente Isaías, Jeremias, Baruc, Ezequiel, Daniel, Oséias, Joel, Abdias, Amós, Jonas, Habacuc e Naum.
} 
Testemunha do tempo, o Aleijadinho assistiu a revoluções, as exigências descabidas da Metrópole, aos desmandos das autoridades, as ameaças da derrama, aos pronunciamentos nacionalistas (Kelly, 1960). E ainda: "Inconfidência mineira - sonho e drama: fatos políticos, sociais e econômicos influíram em sua sensibilidade - de emancipado a rebelde" (KELLY, 1960, p.143). Ao mesmo tempo, sua obra parece demonstrar que o Barroco é o primado do visual e tudo incita os olhares (Ávila, 1980), e em se tratando da possível relação da obra do Aleijadinho com a Inconfidência mineira ${ }^{32}$ :

[...] em Congonhas, no adro do Santuário, o artista plasmou seu ato de adesão aos ideais republicanos, separatistas e abolicionistas da chamada Inconfidência Mineira, representado simbolicamente, naqueles doze vultos, os mártires e heróis da gloriosa conjuração, truncada oito anos antes (VENTURELLI, 1982, p. 27).

A construção das 06 Capelas dos Passos da Paixão ${ }^{33}$ que abrigam as 66 imagens de cedro do Aleijadinho foi iniciada por Tomás da Maia Brito no final do século XVIII e foi concluída em 1827, durante a administração de João Pedro Ribeiro da Costa, que assumiu o cargo de ermitão do Santuário em 1809, após a morte de Vicente Freire de Andrada.

Foi também no de 1827 que os Padres Lazaristas receberam um convite do Governo Imperial Brasileiro para fundarem um colégio de meninos no Santuário, o qual funcionou de 1828 a 1860 e durante esse período exerceram os Lazaristas a administração do Santuário de Congonhas do Campo e promoveram as práticas religiosas tradicionais como o Jubileu e as romarias. Em 1860, o Santuário voltou a ser administrado pela Irmandade de Nosso Senhor Bom Jesus até o ano de 1875, quando foi novamente reaberta a instituição de ensino e daí por diante, a administração passou a cargo de vários padres, a partir do Padre Antônio da Costa Machado.

\footnotetext{
${ }^{32}$ De acordo com a advogada e historiadora de artes Isolde Helena Brans Venturelli (1982), os profetas corresponderiam aos inconfidentes da seguinte forma: Isaías - Domingos de Abreu Vieira; Jeremias - TenenteCoronel Francisco de Paula Freire Andrade; Abdias - José Alvares Maciel; Habacuc - Domingos Vidal Barbosa; Naum - Coronel de Auxiliares Francisco Antônio de Oliveira Lopes; Ezequiel - Sargento Mor Luis Vaz de Toledo Piza; Baruc - Salvador Carvalho do Amaral Gurgel; Amós - Antônio Francisco Lisboa (Aleijadinho); Joel - Doutor Cláudio Manoel da Costa; Oséas - Inácio José de Alvarenga; Jonas - Joaquim José da Silva Xavier; Daniel - Tomás Antônio Gonzaga.

${ }^{33}$ As seis Capelas dos Passos da Paixão seguem a ordem cronológica dos fatos que marcaram os últimos dias de Jesus Cristo. São elas: Ceia, Horto, Prisão, Flagelação e Coroação de Espinhos, Cruz às Costas e por último a Crucificação.
} 


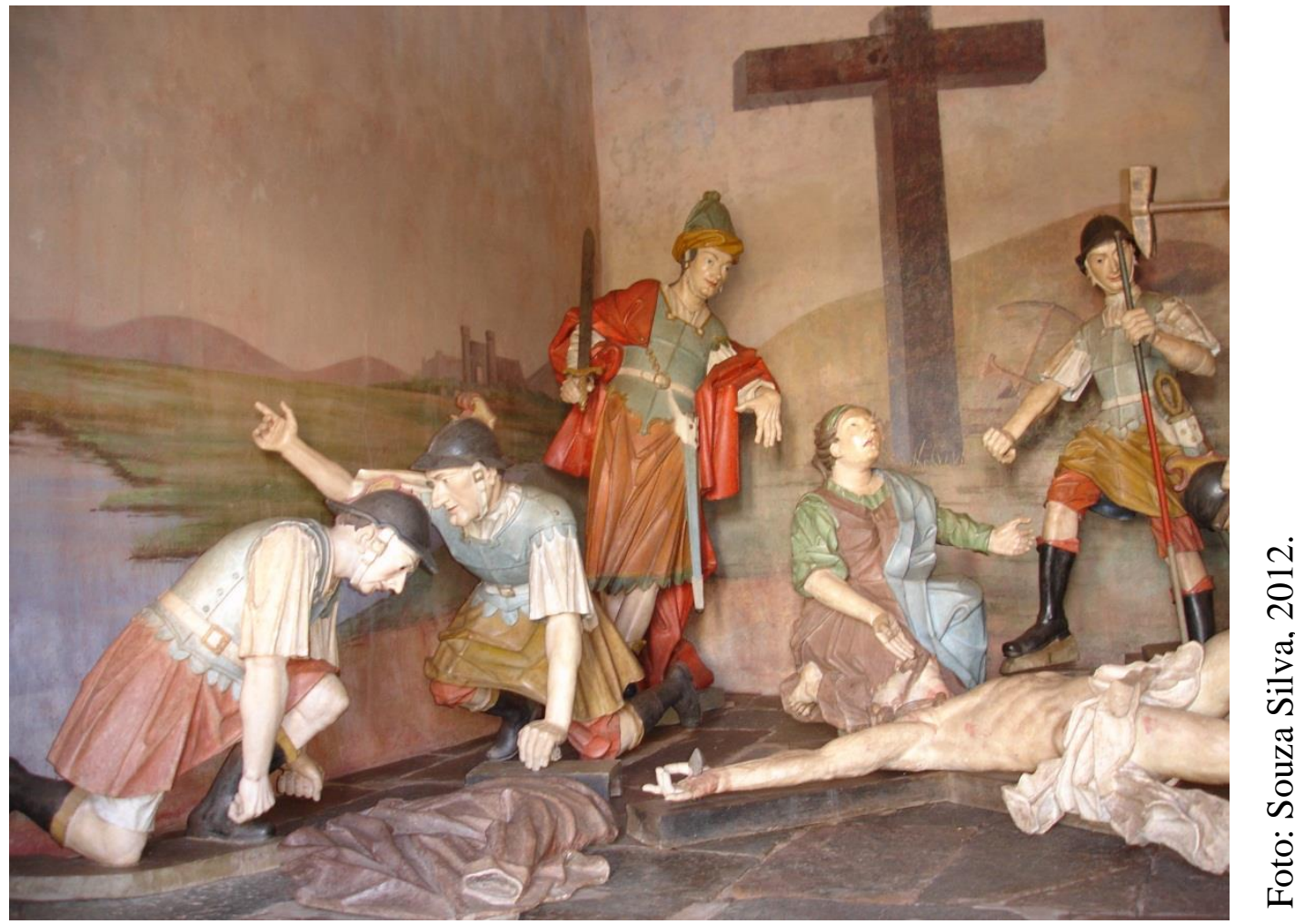

Figura 3: Aleijadinho (séc. XVIII) Cena da Crucificação, Congonhas, Minas Gerais.

De 1897 a 1903, o colégio passou para a direção dos Irmãos Maristas. Depois, com a posse de Dom Helvécio Gomes de Oliveira no sólio arquiepiscopal de Mariana em 1922, o Santuário foi entregue à guarda dos Padres Redentoristas, passando a funcionar dois estabelecimentos anexos, o Seminário São Clemente e o Juvenato Santo Afonso.

Em 26 de julho de 1957, o Santuário foi elevado à condição de Basílica Menor por meio de Breve Apostólico expedido pelo Papa Pio XII, com a proclamação efetivada em 03 de maio de 1958.

A Basílica do Senhor Bom Jesus de Matosinhos é um dos templos mineiros mais estudados pelos historiadores da arte e exerce um notável fascínio nestes estudiosos. Em Congonhas, ela é o templo mais visitado pelos turistas e o que recebe as maiores atenções por parte da população local, do poder público e também de empresas privadas como as do ramo das comunicações em geral, contudo, apesar das atenções para a história do Barroco de Congonhas, e porque não, de Minas Gerais, se voltarem para a Basílica, a cidade possui outros exemplares remanescentes do Barroco Mineiro de valor histórico inestimável. 
Ajudam a compor um conjunto arquitetônico e escultórico barroco nos arredores da basílica outras duas obras que avançaram pelos séculos XIX e XX. No século XIX, foram também entalhadas em pedra-sabão as portadas da fachada da Casa Paroquial situada atrás da Basílica do Senhor Bom Jesus. Essa fachada é o que restou da demolição do colégio que funcionava no local. Uma das portadas possui quatro pilares rebordados com esculturas de ramos de acanto e flores e no centro foi entalhado um escudo que leva a data de 1844, contornado por um arremate curvilíneo nas laterais e com uma coroa sobre o mesmo. A fachada da casa paroquial ainda possui mais três portadas de acabamento mais simples.

Como um centro religioso e de peregrinações, Congonhas do Campo viu ainda ser concluída no ano de 1922 a Romaria $^{34}$, local destinado a hospedar romeiros pobres que chegavam para o Jubileu do Senhor Bom Jesus de Matosinhos. A Romaria foi projetada por Floriano Blinder, arquiteto que se inspirou na arquitetura das Capelas dos Passos para erguer os dois torreões frontais que dão acesso ao local.

A inspiração de Floriano Blinder pode ser compreendida pela forte ligação do Barroco Mineiro com a Igreja Católica, tendo em vista que a religiosidade sempre foi uma marca da cidade, o que deu mais um sopro de vida ao estilo em Congonhas, que ao exemplo da Romaria, teve a Igreja Matriz de São José Operário terminada no início do século XX.

Na Romaria foram construídas 44 casas de 03 cômodos, unidas em uma construção de formato oval com uma área ao ar livre no centro. A Romaria deu lugar ao antigo abrigo dos pobres que existia onde hoje existe o salão onde celebram as missas, localizado ao lado esquerdo do templo da Basílica.

\section{7 - A cidade de Congonhas no contexto mundial atual}

Com a decadência da mineração aurífera que se acentuou na segunda metade do século XVIII, a economia na região de Congonhas tentou um novo impulso pelas ideias do Barão Wilhelm Ludwing Von Eschwege, coronel dos reais engenhos de Portugal e intendente geral das Minas. Eschwege teve a iniciativa, em 1811, de instalar próximo Congonhas do Campo a

\footnotetext{
${ }^{34}$ A Romaria foi desativada em 1968 e vendida para um grupo empresarial para a construção de um hotel. As casas da Romaria foram demolidas em anos posteriores e a construção do hotel não aconteceu. O terreno com os torreões originais foi comprado pela Prefeitura Municipal em 1993. Em 1994 foi iniciada a reconstrução das casas, concluída em 1995. A Romaria atualmente é utilizada para atividades socioculturais.
} 
Fábrica de Ferro do Prata, que ficaria conhecida com o nome de Fábrica Patriótica ${ }^{35}$. Esta fábrica foi a primeira usina de ferro a produzir industrialmente no Brasil, aproveitando do minério de ferro abundante na região, madeira, água, e mais, [...] "a vantagem de ficar a administração futura da fábrica sob fiscalização imediata dos acionistas mais importantes, que tinham suas propriedades nas cercanias" (ESCHWEGE, 1979, p. 247).

Porém, a Fábrica de Ferro do Prata funcionou até 1822, por conta de fatores como a pequena população consumidora da região, a falta de trabalhadores especializados e a concorrência europeia, que impossibilitaram o funcionamento da fábrica por pouco mais que uma década: "Dificuldades sem conta tornariam o produto manufaturado no Brasil dez vezes mais caro do que o similar europeu. A mais, o estabelecimento de empresas e a realização de planos de vulto tropeçariam em obstáculos invencíveis" (ESCHWEGE, 1974, p. 257). Em seguida, o mesmo autor comenta o fato de que, [...] "indiscutivelmente, no Brasil, sem aumento considerável da população, nenhuma grande fábrica se poderá manter” (ESCHWEGE, 1979, p. 261).

Com a mineração do ouro em constante queda e a impossibilidade de instalar uma indústria eficiente do ferro naquele tempo, Congonhas, ao exemplo de outros núcleos mineradores passou por uma estagnação econômica e por processo de ruralização. "Grande parte da província passou a concentrar suas atividades na agricultura de subsistência" (SILVA, 2003, p. 34). Passou ainda a exercer atividade econômica extraindo recursos econômicos com a festa anual do Jubileu do Senhor Bom Jesus de Matosinhos, iniciada no século XVIII, quando uma vez por ano, Congonhas se transforma num grande templo, numa grande pensão e num grande mercado a céu aberto:

Os proprietários alugavam quartos, quintais e até alpendres, que serviam de abrigo para os romeiros. Por décadas, essa atividade representou a principal fonte de renda de muitas famílias congonhenses durante o ano. Vinham de fora diversos artistas, e os mais famosos circos se apresentavam em Congonhas nessa época. Mesmo os que não comerciam ganham dinheiro indiretamente, pois as calçadas são alugadas pelos proprietários das casas aos barraqueiros (PIRONI, 2008, p. 46).

\footnotetext{
${ }^{35}$ Segundo relato do engenheiro de minas Wilhelm Ludving Von Eschwege (1833), "Fábrica Patriótica" era o nome dado à sociedade formada pelos acionistas que financiaram a construção do empreendimento. Este nome é atualmente utilizado na região para se referir à siderúrgica projetada por ele. O nome de batismo da fábrica é "Fábrica de Ferro do Prata", em alusão à região do Prata, local onde a siderúrgica foi instalada. Atualmente o sítio arqueológico pertence à Companhia Mineradora VALE e tem acesso restrito e controlado pela empresa.
} 
O arraial de Congonhas do Campo possuía, no ano de 1813, 2.412 habitantes e, em 1822, contava com 2.640 moradores. No ano de 1890, a população era estimada em 3.750 indivíduos e a cidade, por sua vez, se encontrava em ruínas por conta da economia em baixa. “A inauguração da Estação Ferroviária em 14 de novembro de 1914 representou naquele momento, um importante impulso para a urbanidade decadente” (SILVA, 2003, p. 35). E segundo o mesmo autor: "Com a chegada da ferrovia, intensifica-se a ocupação da faixa plana da cidade (fundo do vale do rio Maranhão), no sentido leste - oeste, até então ocupado de forma precária" (SILVA, 2003, p. 35). Nessa época, diversas lojas de comércio, pensões, hotéis e edifícios de uso institucional passaram então a ser construídos na área central e no entorno da estação ferroviária para se adaptarem à nova realidade econômica que a chegada da ferrovia trazia.

O distrito de Congonhas do Campo pertenceu a São João Del Rei até a criação da Vila Real de Queluz, que passou a abranger o território do distrito de Congonhas do Campo. O povoado de Bonfim, que fazia parte do distrito foi elevado à vila no ano de 1839 e com isso o território de Congonhas do Campo foi desmembrado.

Em 1891, o arraial de Congonhas do Campo foi ligado à comarca de Ouro Preto e depois, em 1923, um lado do arraial foi novamente transferido para Queluz. Neste momento, o arraial ficou dividido em duas partes, sendo uma de cada lado das margens do rio Maranhão. O lado chamado Matriz (Matriz de Nossa Senhora da Conceição) continuava pertencendo à Ouro Preto e o outro, chamado de Matosinhos (Santuário de Nosso Senhor Bom Jesus de Matozinhos), era a parte ligada à Queluz. Este é o motivo pelo qual a cidade possui duas igrejas matrizes. Reunificadas, passaram as duas partes a pertencerem somente ao território de Queluz.

Através do Decreto Lei Estadual no 148 de 17 de dezembro de 1938, foi criado o município de Congonhas do Campo, que incluía em seu território o distrito de Lobo Leite, também um dos primeiros arraiais de Minas Gerais e o arraial do Alto Maranhão, local antes chamado Redondo e onde começou o povoamento na região formadora do município de Congonhas do Campo, além da sede municipal.

Em 1939, o acervo escultórico, arquitetônico e paisagístico do Santuário do Senhor Bom Jesus de Matosinhos foi tombado pelo SPHAN (Serviço de Patrimônio Histórico e Artístico Nacional) e inscrito no Livro de Belas Artes. Em 1941, o SPHAN tombou o conjunto arquitetônico e urbanístico da cidade, de inscrição no Livro de Tombo Arqueológico, 
Etnonográfico e Paisagístico, processo n ${ }^{\circ}$ 238, T-41, inscrição número 12, fl.3 de 17 de março de 1941.

O primeiro prefeito de Congonhas foi Alberto Teixeira dos Santos Filho, um ex-vereador de Queluz que representava Congonhas do Campo e que governou o município de dezembro de 1938 a novembro de 1944. A primeira câmara de vereadores foi empossada no município no dia 08 de dezembro de 1947, já que foi eleita em 23 de novembro daquele mesmo ano. Seu primeiro presidente foi Lavínio Themóteo da Silva.

No ano de 1948, pela Lei Estadual no 336 de 27 de dezembro, Congonhas do Campo passou a ser chamada simplesmente Congonhas, mudança que ocorreu sem consulta prévia à população.

A produção industrial do ferro ganhou um novo impulso somente na primeira metade do século XX. Um investidor dinamarquês chamado Arn Kirstein Thun adquiriu uma fazenda de nome Casa de Pedra ${ }^{36}$, iniciando a extração do ferro em 1913, com técnicas ainda manuais. "Neste momento a produção de aço no Brasil ainda era bastante modesta tanto do ponto de vista qualitativo quanto técnica. O problema foi intensificado com a crise de 1929, que tornou a importação de aço muito mais difícil” (MILANEZ in FERNANDEZ; et al, 2011, p. 201). Com isso o Governo de Getúlio Vargas colocou a empresa Arn Thun sob intervenção e a desapropriou três anos depois, posteriormente colocando-a sob domínio da CSN (Companhia Siderúrgica Nacional) ${ }^{37}$, que passou a extrair de Congonhas o minério para os altos-fornos da usina da empresa estatal em Volta Redonda, no Rio de Janeiro. Em 1940 a CSN construiu cerca de 500 casas para seus funcionários. O Bairro Casa de Pedra ${ }^{38}$ contava com escola, hospital, igreja, cinema, mercado e clube recreativo para seus funcionários.

Em 1923 foi instalada outra mineradora em solo congonhense, a FERTECO S/A (Companhia de Mineração de Ferro e Carvão). Empresa com capital e direção de alemães, produziu ferro em forma de pelotas para o mercado nacional e o estrangeiro. Em 2001 sua usina e sua mineração foram vendidas para a Companhia Vale do Rio Doce. A FERTECO também

\footnotetext{
${ }^{36} \mathrm{O}$ nome Casa de Pedra se deve à uma gruta que havia no local e que foi destruída com a atividade mineradora.

${ }^{37}$ A CSN, fundada em 1941pelo Governo de Getúlio Vargas com apoio financeiro dos Estados Unidos, foi uma empresa estatal até o ano de 1993, quando foi privatizada pelo Governo Federal, através do PND [Plano Nacional de Desestatização], criado pelo Governo Collor, tendo como sócio majoritário o Grupo Vicunha [46, 48\% de participação] (SUMÁRIO DE DADOS DE CONGONHAS, s/d, p. 40).

${ }^{38}$ O Bairro Casa de Pedra, que contava com a Vila Rica, para os engenheiros e diretores e a Vila Operária, para os demais funcionários, existiu até o início dos anos 1980, quando sua área, que ficava no entorno da mineração e sobre uma grande jazida de ferro, foi tomada pela mineração e sua estrutura urbana foi completamente destruída para dar lugar à extração mineral.
} 
construiu em 1923 uma vila ${ }^{39}$ para seus funcionários, como era de costume ser feito pelas empresas.

Em 1976, foi iniciada a construção da Usina Presidente Bernardes ou simplesmente Açominas S/A, entre os municípios de Congonhas e Ouro Branco. Construída com recursos do Estado para ser uma das maiores siderúrgicas do país e abastecer tanto o mercado nacional quanto o externo, foi também privatizada em 1993.

No ano de 1985, a Basílica do Senhor Bom Jesus de Matosinhos, por sua importância no cenário histórico e artístico, foi tombada e declarada Monumento Cultural da Humanidade ${ }^{40}$ pela UNESCO (Organização das Nações Unidas para a Educação, a Ciência e a Cultura).

O turismo também é considerado um ponto importante para a economia local, porém, Congonhas recebeu muitos visitantes nos tempos do médium espírita José Pedro de Freitas, popularmente conhecido por Zé Arigó, que operou seus milagres através de cirurgias mediúnicas durante a década de 1960 e com isso, a cidade que já atraía multidões de doentes e romeiros para o Jubileu do Senhor Bom Jesus de Matosinhos, recebia milhares de pessoas de diversas partes do mundo em busca pela cura das mais variadas enfermidades. Em 15 de dezembro de 1968, o também médium espírita Chico Xavier, desta forma se referiu ao médium Zé Arigó na obra "A oitava maravilha" (1968), do jornalista argentino Reinaldo Comenale.

\begin{abstract}
Sinceramente, não sei o que deva ou possa escrever, no introito deste livro, já que devemos tanto à mediunidade de nosso caro irmão José Pedro de Freitas (José Arigó), que os Benfeitores Espirituais tomaram por bendito instrumento, em favor de todos nós, os espíritos doentes, reencarnados na Terra. Militando porém, na mediunidade, em pequenino setor de ação, e reconhecendo, conforme os ensinamentos do evangelho de Jesus, que toda benção procede do Alto e não de nós, rogo a Jesus amparar-nos e proteger-nos, para que nosso companheiro José Arigó e nós outros, seus companheiros na fé, possamos prosseguir fiéis aos nossos compromissos, diante da Espiritualidade Maior, procurando melhorar-nos para atender aos Desígnos do Senhor hoje e sempre (Chico Xavier) ${ }^{41}$.
\end{abstract}

Zé Arigó faleceu por conta de um acidente automobilístico em 1971 na BR-040. Depois de sua morte o movimento de visitantes na cidade caiu bruscamente. Em Congonhas ele ainda é

\footnotetext{
${ }^{39}$ A Vila da FERTECO funcionou até o início da década de 1990, quando seus moradores também foram obrigados a sair para dar lugar à instalação industrial.

${ }^{40}$ A denominação atual para o título concedido pela UNESCO em 1985 é "Patrimônio Cultural Mundial".

${ }^{41}$ Apud. COMENALE, 1968.
} 
muito lembrado pela população local e por visitantes e na cidade existe uma sala no Museu de Imagem e Memória de Congonhas dedicada a contar sua história por meio de fotografias e objetos relacionados ao seu cotidiano como médium espírita.

Outro ponto importante para atrair visitantes para Congonhas é o Jubileu do Senhor Bom Jesus de Matosinhos, que ainda atrai muitos romeiros à basílica da cidade com intenções de fazer orações, promessas e agradecer às graças cujos fiéis garantem que foram concedidas por intercessão do Santo. Contudo, o grande fluxo de pessoas ocorre entre os dias 07 e 14 de setembro durante todos os anos, quando oficialmente começam e terminam os festejos religiosos em homenagem ao Bom Jesus. Outro festejo religioso de notável importância para o turismo local é a Semana Santa, que atrai principalmente os turistas.

\footnotetext{
A estimativa realizada pela FUMCULT ${ }^{42}$ é de que o fluxo de visitantes em eventos na cidade foi de 855.000 pessoas no ano de 2002. Deste contingente, uma parcela estimada de 96.579 pessoas procuraram a cidade com interesse específico em seu Patrimônio Histórico (SILVA, 2003, p. 25).
}

Ou seja, a maior parte de visitantes está vinculada aos festejos religiosos e não à questão do turismo, como é comum nas cidades que compõem o chamado Circuito do Ouro, que abrange outros municípios como Ouro Preto, Mariana, Prados, São João Del Rei e Tiradentes. Uma parcela considerável dos visitantes também procura a cidade para um dia no Parque Ecológico da Cachoeira, que costuma atrair principalmente, nos finais de semana, um público volumoso vindo de cidades próximas como a capital Belo Horizonte e cidades vizinhas como Conselheiro Lafaiete, Jeceaba e Ouro Branco.

Outro fator de importante influência, porém negativo para o interesse dos turistas pelo Patrimônio Histórico do município é o fato de que a maior parte de seu conjunto urbanístico e arquitetônico tombado em 1941 pelo SPHAN foi cegamente destruído, dando lugar ao desordenamento urbano, à poluição visual, à desarmonia arquitetônica e à construções de aspecto visual contrastante com o conjunto arquitetônico e urbanístico tombado. "A promoção do Tombamento do núcleo histórico como um todo, contudo, não impediu a descaracterização e a destruição de grande parte do acervo da cidade" (SILVA, 2003, p. 36).

\footnotetext{
${ }^{42}$ FUMCULT: Fundação Municipal de Cultura Lazer e Turismo.
} 
O que vemos atualmente é apenas resquício de uma cidade tipicamente mineira dos tempos coloniais, o que por sua vez, acaba pesando na escolha dos visitantes, que dão preferência aos municípios mais preservados do ponto de vista arquitetônico.

Aliado a estes fatores está ainda o fato de que a cidade não organizou uma estrutura adequada para receber os turistas e fazê-los permanecer na cidade por mais de um dia. Os poucos leitos de hotéis e pousadas não oferecem hospedagem aos turistas, já que não conseguem oferecer hospedagem para os trabalhadores que chegam para a indústria local, que ficam em muitos casos, abarrotados nos alojamentos precários em casas de aluguel. Outro ponto importante para um turismo bem sucedido que é a gastronomia sofisticada também ficou em segundo plano e os restaurantes locais estão ocupados com a cozinha industrial. Nem mesmo a cozinha tradicional mineira é oferecida na maioria dos restaurantes.

$\mathrm{Na}$ realidade, a atividade econômica do turismo de forma satisfatória e lucrativa na Congonhas atual é uma alternativa e um potencial econômico desperdiçado que começa a incomodar e a preocupar alguns políticos e a população, que começam a olhar desconfiados para o futuro, frente à previsível exaustão do minério de ferro.

O grande número de pessoas que procuram a cidade por uma oportunidade de trabalho causa também transtornos inumeráveis aos antigos moradores acostumados com a vida aparentemente calma do interior. Tornaram-se comuns os conflitos por conta de vários alojamentos de funcionários de empresas que se espalham pela cidade, onde é comum o barulho causado por festas recheadas com álcool, drogas, música alta e gritaria acompanhada de palavras de baixo escalão.

Surgiram filas intermináveis nas agências bancárias, nos correios, nas casas lotéricas e nos caixas de supermercados. Há congestionamentos no trânsito e em um dia útil é quase impossível encontrar uma vaga de estacionamento nas ruas. Os pedestres se amontoam nas calçadas, que por vezes vêm sendo largueadas e quando velhos conhecidos param querendo saber as boas novas, logo a calçada se congestiona, estancando a passagem dos transeuntes. Situação que não parece incomodar os comerciantes, que se aproveitam inflacionando os preços de suas mercadorias e abrindo novas filiais de suas empresas de comércio, inflacionado também os serviços em geral, como os aluguéis de imóveis residenciais e comerciais e também, os preços para compra e venda de imóveis, cada vez mais supervalorizados, tal como veículos em geral. 
Diante desse quadro crescem também a criminalidade, com o aumento de furtos, roubos a residências e a veículos, consumo e tráfico de drogas, assassinatos, estupros, consumo de álcool e violência doméstica.

A poeira levantada pela atividade mineradora polui o ar e as ruas, deixando o rastro de sujeira por toda a cidade, incomodando os moradores e causando problemas de saúde pública. A mineração causa ainda diversos problemas ambientais como o desmatamento, a poluição das águas, problemas de abastecimento hídrico e interfere no aspecto visual, já que as montanhas no entorno da cidade são rapidamente devastadas, impactando até mesmo sobre a Basílica do Senhor Bom Jesus de Matosinhos e seu entorno paisagístico.

Tornou-se rotina o trabalho dos caminhões pipa que jogam água potável nas ruas e empresas, na tentativa de diminuir a poeira, numa cidade onde o abastecimento hídrico se torna cada vez mais comprometido por conta do avanço das mineradoras sobre nascentes, sobre o lençol freático e sobre a cidade. Os moradores contribuem lançando lixo, entulho e animais mortos em áreas de vertentes, poluindo a própria água que bebem e deixando os leitos dos rios com aspecto deplorável. Os moradores contribuem ainda com a péssima qualidade do ar, causando incêndios que se espalham na área urbana e pelas matas, ameaçando vidas na cidade e nas matas e colocando em risco o patrimônio arquitetônico e ambiental.

Quanto à vida nas propriedades rurais, esta vem se tornando difícil. Um dos maiores problemas é a busca das mineradoras por locais onde possam construir suas barragens de rejeitos de minérios e aumento de instalações industriais. Muito se fala sobre desapropriações de sítios, chácaras e fazendas para estes fins. Atividades como a agropecuária estão em constante baixa, concentrando-se na criação de gado de corte e de leite, criação de cavalos, suínos e galinhas. "A agropecuária em Congonhas, historicamente, caracterizou-se como uma atividade de subsistência, gerando pouco excedente para ser comercializado na cidade e menos ainda em outros municípios" (PIRONI, 2008, p.25).

A agricultura se mantém cambaleante com o baixo cultivo de hortaliças para subsistência e para o mercado interno do município e é praticado no sistema de agricultura familiar e ainda com técnicas manuais em sua maioria. Na verdade, a perspectiva de um futuro mais promissor tanto para os patrões quanto para os operários concentra-se principalmente na demanda de mão de obra e serviços crescentes na indústria: 
A crescente demanda mundial por minério de ferro faz com que as minas de Congonhas sejam cada vez mais exploradas. Impulsionada pela demanda da China e pelo aumento da demanda nacional, a CSN planeja novas expansões. Os projetos preveem a cisão dos ativos da empresa, tornando Casa de Pedra uma empresa independente. $\mathrm{O}$ cronograma de investimentos da mina estabelece um aumento de produção de 22 milhões de toneladas em 2010 para 70 milhões de toneladas em 2014. Além disso o grupo planeja a construção de uma usina siderúrgica em Congonhas para a produção de placas de aço (MILANEZ in FERNANDEZ; et al, 2011, p. 202).

Atualmente, o município se prepara para novos investimentos nas áreas de mineração e siderurgia. Além da Mina de Casa de Pedra, a Companhia Siderúrgica Nacional ainda possui outra empresa em Congonhas, num consórcio com acionistas japoneses e coreanos e curiosamente chamada de Nacional Minérios S/A (NAMISA). A empresa Vale também é uma das maiores empresas produtoras e fornecedoras de minérios da região para várias siderúrgicas. Outra grande empresa instalada em Congonhas, a Gerdau Açominas aumentou em 50\% da capacidade de produção de aço nos últimos anos e projeta com isso altos lucros econômicos. "Outro fato novo neste mercado é a recente tendência das siderúrgicas adquirirem suas próprias jazidas de minério de ferro, reduzindo a dependência em relação à Vale. Uma das empresas que adotou esta estratégia foi a Gerdau Açominas" (PIRONI, 2008, p. 28).

Enquanto a cidade cresce econômica e demograficamente, os sítios arqueológicos do município também sofrem as consequências. Tornaram-se comuns os casos de desrespeito à legislação vigente e o fato de trabalhar sobre um solo tombado não intimida as empresas, que destroem indiscriminadamente o que encontram pelo caminho dos tratores. O Ministério Público de Minas Gerais (MPMG), após receber uma série de denúncias feitas por ONGs e pelos moradores da cidade, embargou obras e tenta moralizar este quadro que se acentuava e atualmente tenta promover o engajamento entre órgãos da prefeitura municipal de Congonhas, empresas e pesquisadores numa busca pela solução deste problema.

Recentemente foi exigida a elaboração de uma carta arqueológica para o município, que tem como objetivos o mapeamento, a divulgação e a proteção do patrimônio arqueológico municipal. O trabalho é pago com dinheiro oriundo de um termo de ajuste de conduta (TAC) exigido à empresa mineradora Ferrous e executado pela empresa Artefactto Consultoria. A Carta Arqueológica de Congonhas também é produzida em engajamento com a pesquisa de mestrado "Os velhos caminhos de Congonhas numa perspectiva de Educação Patrimonial”. 


\section{Capítulo 4: Os velhos caminhos de Congonhas}

\section{1 - Relatos do Barão de Eschwege}

Buscando compreender mais sobre a disposição do ouro de aluvião como fator primordial na formação dos sítios arqueológicos pesquisados, temos em Congonhas um processo que, de acordo com os relatos do Barão Ludwig W. Von Eschwege (1979 a, b), trata-se de deposição do ouro causada principalmente pela ação das águas, que influenciaram desde as técnicas utilizadas em sua extração, assim como na formação do registro arqueológico que ocorre ao longo das áreas de exploração do ouro. Desta forma, os relatos deixados pelo geólogo e engenheiro de minas alemão serão nossa principal fonte de informações históricas quando abordarmos este assunto de fundamental importância para a interpretação da formação do registro arqueológico.

O engenheiro de minas e geólogo alemão buscava, entre outros trabalhos relacionados à mineração, o descobrimento do que chamou de "rocha matriz" ou "rocha mãe", o que segundo ele seria uma espécie de fonte localizada no subsolo, de onde todo o ouro da capitania de Minas Gerais, num tempo bem remoto, teria se removido, compartilhando o metal precioso que se espalhou por toda área em que foi mais tarde encontrado pelos bandeirantes e aventureiros. Porém a rocha matriz nunca foi encontrada e se tornou lenda.

Segundo o engenheiro de minas alemão Ludwig. W. Von Eschwege, em seus relatos feitos durante seus trabalhos pela capitania de Minas Gerais nas primeiras décadas do século XIX, a mineração do ouro se deu em diferentes fases, em diferentes lugares de Minas Gerais, exigindo diferentes técnicas de extração e apuração do metal precioso, de acordo com os recursos materiais e humanos de que o explorador mineiro dispunha para sua aquisição. Isso deixou, por sua vez, uma variedade enorme de vestígios arqueológicos decorrentes dessas atividades, que variavam de acordo o momento em que estas se desenvolveram e assim, primeiro foram explorados os leitos dos rios e córregos, depois foram exploradas suas margens e as encostas dos morros e por fim o explorador subiu os morros onde procurou escavar em busca dos veios auríferos, produzindo galerias.

Outros autores contribuem positivamente para as análises sobre a forma como ouro foi explorado e desta forma para a compreensão de seus vestígios nessa parte de nosso trabalho 
de pesquisa, porém, a preferência pelos relatos de Eschwege se deve ao fato de sua vivência profissional nas Minas e ao seu conhecimento técnico nas áreas de mineração e geologia, o que sem dúvida ele possuía com maior afinco do que qualquer outro viajante que deixou relatos sobre a atividade mineradora de Minas Gerais.

Os trabalhos de mineração do ouro eram realizados principalmente: nos leitos dos rios e córregos; nas margens dos rios e aluviões dos tabuleiros próximos; nos depósitos de aluvião das encostas das serras; nas massas friáveis, geralmente auríferas que continham veios de quartzo aurífero; nos depósitos dos vales; nos depósitos e veios das serras.

Os tabuleiros eram veios, chamados de madre pelo padre jesuíta André João Antonil (1977), eram os aluviões do leito menor dos córregos; tabuleiros eram os que ocupavam o seu leito maior; grupiaras, os depósitos das encostas, restos da ação erosiva das águas e da precipitação dos materiais transportados em períodos geológicos mais remotos; e finalmente, cascalho aurífero, que geralmente se encontrava rolado, com suas extremidades arredondadas pela ação das águas e atrito entre as rochas. O padre Antonil, outro autor importante que testemunhou e relatou sobre as Minas, também deixou em seus relatos a seguinte colocação a respeito do ouro e dos caminhos que encontrou ao longo dos veios auríferos:

\footnotetext{
Já se a terra tem vieiros, que é um caminho estreito, e seguido, por onde vai correndo o ouro; certamente não pinta mais pelas partes da cata, e se vai então seguindo o vieiro atrás do ouro, e estas de ordinário são as melhores lavras, quando o ouro pega em vieiros, onde se encontra com grandeza; e é sinal, que toda a data da terra, para onde arremate o vieiro, tem ouro (ANTONIL, 1977, p. 226).
}

O solo mais propício para a ocorrência do ouro se apresentava seguindo uma sequência geológica que se dava normalmente tendo o xisto argiloso sobre o itacolomito e o xisto hematítico. O xisto argiloso aurífero não é apresentado nas altas serras e em alguns casos, quando isso ocorre, ele não é aurífero. Em geral ele distribui-se em regiões mais baixas e entre elevadas cadeias, como ocorre em Congonhas. Da extração do ouro contido nesse tipo de terreno ficaram em Congonhas voçorocas presentes em Congonhas que se estendem desde os limites municipais com Conselheiro Lafaiete, aparecem no distrito do Alto Maranhão, passam pelas Minas da Soledade e Veeiro e chegam até a Fazenda do Faria, acompanhando também as curvaturas do relevo dos campos de Congonhas. 
Em geral, a atividade mineradora neste tipo de terreno deixou profundas voçorocas, em posição diagonal ou vertical, caracterizando o aprofundamento dos veios, que se imbricavam solo abaixo. A exploração desses veios de ouro levou muita lama para dentro dos rios e córregos, o que ocasionou a elevação de seus leitos, que, segundo Eschwege, eram muito mais profundos quando da chegada dos primeiros exploradores na região mineradora.

O itacolomito ou quartzito-itacolomi ocorre com propriedades auríferas em geral no primeiro membro da série, nos afloramentos do mesmo xisto argiloso e nos lugares onde ele se apresenta como xisto hematítico.

Os stock-werk eram sistemas de veios articulados. Os veios articulados também aparecem em Congonhas e em geral se encontram posicionados em sentido leste/oeste. Em geral, os sinais dos trabalhos de mineração desses veios ficaram gravados nos solo em forma de galerias, alguns com a presença de canga ou xisto argiloso.

Ao itacolomito segue o xisto hematítico. É um composto de hematita com quartzo, de estrutura xistosa granulada. "Essa rocha ocorre, segundo sua direção, em uma extensão de muitas milhas e é constante companheira da primeira camada aurífera do itacolomito, por sua vez, então, aurífero" (ESCHWEGE, 1979, p. 157).

O engenheiro alemão ainda relatou outros tipos de ocorrência de ouro em jazidas primárias, como a camada de talcoxisto subordinado ao xisto argiloso, no local chamado de Goiabeiras em Congonhas e também a ocorrências de jazidas secundárias, aparecendo em rochas compactas ou conglomerados, nas montanhas, disseminando em grãos soltos sobre a rocha e coberta de húmus, ás vezes em ambos os flancos dos vales, aos pés das montanhas, acompanhado de seixos e atingindo alturas consideráveis, chamadas de grupiaras, ora, enfim, no leito dos rios no cascalho virgem.

O nome tapanhoacanga ou canga era o que ele declarou como o mais considerável depósito dessas formações secundárias. Da extração desse ouro de canga restaram em Congonhas algumas galerias, como as existentes na face do morro que fica de frente ao distrito de Lobo Leite. Essas galerias representaram a fase terminal da atividade aurífera durante o Ciclo do Ouro, quando, sem perspectivas de encontrar mais ouro abundante nos rios e encostas, o mineiro passou a escavar o solo em busca de rochas matrizes, cavando na direção dos veios.

Os seixos rolados encontram-se em vales de rios e depressões. Com composição variada, compreendendo seixos rolados de quartzito, de xisto argiloso, de itacolomito e de hematita. 
Possui tamanhos variados, de uma ervilha até uma cabeça humana e são ligados por um cimento hematítico. Nesse conglomerado ocorre, além do ouro, o diamante, no Distrito Diamantino principalmente, embora com menor frequência. E ainda: "Essa camada aluvionar é explorada, quando rica em ouro e não muito compacta, caso em que os mineiros a denominam de cascalho duro" (ESCHWEGE, 1979, p. 159). Em Congonhas encontramos camadas de cascalho ou seixos rolados explorado em todas as minas. O solo de Congonhas possui uma camada extensa dessa formação, que se estende pelos municípios vizinhos.

O ouro que ocorre em grãos ou em pó, como produto de aluvião, é chamado de areias auríferas das montanhas, já que reveste as montanhas e suas encostas, coberto pelo húmus. São grãos pouco arredondados, com arestas e ângulos nítidos, sem vestígios de rolamentos. "São do mesmo tipo os poucos seixos de quartzo que ocorrem com ele e que, na maioria, possuem a mesma natureza da rocha subjacente. São igualmente angulares e não arredondados" (ESCHWEGE, 1979, p. 159). Da extração dessas formações originaram voçorocas presentes por toda parte que estivemos em Congonhas, além de outros sinais menos profundos espalhados pelos seus morros. Não é por acaso que o próprio Eschwege tenha se espantado quando chegou em Minas Gerais e encontrou, por toda parte, montanhas inteiras reviradas e devastadas, por conta das atividades mineradoras.

As areias auríferas se classificavam ainda como areias auríferas dos vales de rios e ribeirões e das encostas das montanhas, ou grupiaras. Situadas geralmente a cerca de 30 até 100 palmos do nível em que as águas se encontravam, onde aos pés das serras, estende-se uma camada aluvial de seixos facetados de quartzo e de formações primitivas.

Todas as minas em que estivemos em Congonhas apresentavam sinais profundos da atividade mineradora que recolheu o ouro dessas formações. A mineração desse ouro correspondeu à segunda fase da mineração intensa do ouro e também contribuiu profundamente para a elevação dos leitos por conta da quantidade de terra revirada e material lavado para apuração do metal, que terminou por assorear os leitos.

Ocorreu ainda o ouro extraído do cascalho virgem e areias auríferas dos leitos dos rios e ribeirões. Este tipo de ouro foi o que conduziu primeiramente à descoberta do metal em Minas Gerais e estimulou a exploração intensa nos rios e córregos da região. Seus depósitos foram formados com a cava e penetração dos rios em seus leitos mais profundos, ficando a areia, o cascalho e o ouro depositados pouco a pouco nos leitos. Com o passar dos séculos, o ouro, mais pesado, depositou-se nos locais mais profundos. 
Ainda, segundo Eschwege, o ouro desses rios, assim como da maioria das áreas por ele visitadas e analisadas em Minas Gerais não teria se esgotado. O que ocorre é que, pela ganância e pela pressa de enriquecer, e pela falta de técnicas e recursos adequados, os primeiros exploradores do ouro dos rios acabavam por entupir as camadas virgens com os rejeitos e entulhos da atividade mineradora, quando afundavam o leito do rio cavando desesperadamente.

Essa situação foi se agravando com a atividade nas margens e nas encostas, que, como vimos, contribuíram para a elevação dos leitos, tornando as camadas virgens que estavam intactas ainda mais profundas e dificultando ainda mais sua exploração, que acabou sendo transferida para os locais onde se tornava mais fácil a obtenção do metal. Isso quer dizer que, quantidades consideráveis de ouro ainda poderiam ser extraídas dos rios de Minas Gerais, porém sua localização se tornou incerta e dificilmente o homem daquele tempo, sem as condições tecnológicas de sondagem necessárias para encontrá-lo e explorá-lo, se arriscaria em uma busca difícil, perigosa e incerta.

Eschwege acreditava na ocorrência de uma rocha matriz e considerava que o todo ouro encontrado em Minas Gerais era apenas fragmentos espalhados dessa rocha matriz, que se depositou no alto das montanhas e morros, entranhas da terra, levados periodicamente durante milhões de anos pela água até as partes mais baixas. Para ele o ouro não havia acabado, foi apenas mal explorado, devido às técnicas rudimentares empregadas e à pressa dos primeiros garimpeiros em enriquecerem. Somente retiraram o que estava mais fácil e visível, muitas vezes encobrindo outras grandes quantidades que mais tarde acabariam por ficar esquecidas ou não eram mais exploradas devido à falta de tecnologia. Muitas vezes os senhores perdiam grande número de escravos e acabavam por falirem em empreitadas perigosas.

$\mathrm{Na}$ verdade, a cidade de Congonhas ficou rodeada por todos os lados de vestígios da mineração do ouro e não seria exagero destacar que os limites dos sítios arqueológicos coloniais se estendem por todo território do município, e que todos se encontram em estado de degradação e ameaçados de total destruição e perda dos contextos arqueológicos ainda remanescentes. 


\section{2 - Por que preservar? O patrimônio cultural, a legislação e as ameaças que perduram}

\subsection{1 - Algumas considerações acerca do patrimônio de Congonhas e de sua proteção}

Nesta parte da pesquisa, nos envolvemos em uma discussão sobre a noção de patrimônio, de como esta noção surgiu e tem se transformado ao longo da trajetória das ciências sociais e em especial, dentro da Arqueologia, em convergência com a situação do patrimônio de Congonhas e com os rumos que tomaram a pesquisa "Os velhos caminhos de Congonhas numa perspectiva de Educação Patrimonial”, que busca se desenvolver de forma a informar e estimular uma cidadania voltada para o patrimônio, contribuindo para amenizar os impactos negativos sobre os sítios arqueológicos de Congonhas, causados principalmente pela falta de conhecimento da população a respeito da existência dos mesmos e também por falta de observação da legislação patrimonial vigente no Brasil, assim como de acordos internacionais que resultaram na produção de cartas patrimoniais das quais o Brasil é signatário.

Desta forma, para iniciarmos esta discussão, abordamos o conceito de patrimônio atrelado a uma série de outros conceitos que se desenrolam junto a ele no campo da documentação.

Segundo o museólogo Mário Chagas (1996), é pela via do documento, visto como aquilo que ensina ou como suporte de informação ou bem cultural, é que somos levados ao conceito de patrimônio, considerado como: [...] "um conjunto de bens culturais sobre o qual incide uma determinada carga valorativa" (CHAGAS, 1996, p. 45). E ainda, segundo esse mesmo autor, o patrimônio é uma herança: “O termo patrimônio está vinculado à ideia de 'herança paterna', de alguma coisa que se transfere de uma geração para outra, de um tempo a outro" (CHAGAS, 1996, p. 45).

O termo patrimônio também se confunde com documento ou bem cultural, podendo ser os três ao mesmo tempo. Um documento se transforma em bem cultural ou patrimônio quando um indivíduo ou a coletividade o diz ou o valoriza de forma diferenciada, sendo preciso se manifestar e dizer para que um bem cultural possa ser reconhecido desta forma: "Nesta vereda se compreende o trânsito do bem cultural pelo sertão do arbítrio. A constituição do bem cultural passa através de um processo de atribuição voluntária de valores" (CHAGAS, 1996, p. 44). 
Documento e patrimônio podem ser considerados como arquivos de memória, prevenindo a memória do perigo do esquecimento, por conta disso, documento e patrimônio estão naturalmente atrelados à memória, sem a qual não existe aprendizagem e informação, pois a memória é o suporte para o novo, para a informação, para os excessos, ou ainda, é a partir da memória que percebemos o mundo e suas peculiaridades e desta forma, suas mudanças, suas transformações e permanências. É também a partir de nossa memória que distinguimos nossos referenciais culturais dos de outras pessoas e povos.

Documento, patrimônio e memória também colocam em evidência três outros conceitos para a construção teórica na área da documentação, os quais são preservação, investigação e comunicação. Compreendemos a preservação vinculada à ideia de ver antecipadamente o risco da destruição. Preservação significa então um esforço para o prolongamento da vida útil do documento ou bem cultural e desta forma, da memória. A preservação também possui caráter seletivo porque pode ser um ato de escolha, assim como de vontade. Ela é um meio e não um fim, e por conta disso, é necessário que seja instaurado o processo de comunicação, pois é a comunicação que confere sentido ao documento, dando origem para o novo, para o original, propiciando as bases para a produção de conhecimentos originais que partem do documento ou bem cultural preservado, ou seja, a investigação ou pesquisa, que por sua vez poderá ampliar as possibilidades de comunicação do documento ou bem cultural e dará sentido à preservação. Desta forma, a pesquisa também é uma forma de busca por uma visão crítica sobre a área da documentação, que envolve a relação homem-documento-espaço, além do patrimônio cultural, da memória, da preservação e da comunicação (Chagas, 1996).

Essa discussão sobre a noção de patrimônio não é muito recente. Foi depois da Revolução Francesa que o significado de patrimônio se estendeu do privado, particular, ou de um pequeno grupo para um grupo maior de pessoas, dos nobres, para o que pertence aos cidadãos, entendido como bem comum, e assim, a noção de patrimônio emergiu como bem coletivo associado ao sentimento de unidade nacional. As propriedades dos nobres passaram a ser apropriadas como herança do povo, assim como vestígios medievais até então recentes, e isso conduziu a noção de patrimônio ligada à produção artística e monumental, que somente em tempos mais atuais vem sofrendo explanação do sentido, abarcando outras categorias como as manifestações imateriais da cultura (Abreu, 2009; Sant'anna, 2009). E mais: "Uma história heroica das nações passou a ser construída, em que não mais os indivíduos reis, lideres, heróis - eram os sujeitos. A partir de então, o novo sujeito da história era o povo" (ABREU, 2009, p.35). 
Então, podemos compreender porque a busca por autenticidade e pela permanência fundou a prática de preservação ocidental que se fundamentava na escolha de obras de arte e edificações relacionadas à concepção de monumento histórico, aos ideais renascentistas de arte e beleza e à grande excepcionalidade, reconhecidos como sinônimo de riquezas das nações, da genialidade de seu povo e de sua história.

No ano de 1830 na França, foi criada a Inspetoria dos Monumentos Históricos, que se empenhou em fazer recenciamentos e inventários que não davam conta de garantir a preservação dos bens históricos. Somente no ano de 1913 foi instituído o classement, instrumento de proteção que muito se assemelha ao tombamento introduzido aqui no Brasil.

Contudo, a noção de patrimônio predominante focada nos objetos da cultura material e na monumentalidade excepcional das edificações mudou depois da Segunda Guerra Mundial e subsequente à mudança, os processos produtivos, as técnicas e as práticas começaram a ser vistos também como bens patrimoniais, frutos de uma expansão geográfica, cronológica e tipológica sofrida no campo do patrimônio que se espalhou pelo planeta.

Com isso, a apropriação do conceito antropológico de cultura no campo do patrimônio se alargou, abrangendo a esfera imaterial e a diversidade cultural. Isso influenciou a prática dos trabalhos antropológicos junto às populações diversas, inclusive os grupos que fazem parte do convívio do pesquisador, o que é o nosso caso.

No Brasil, entre os primeiros atos legais com vistas na proteção do patrimônio nacional de que temos notícia foram os tombamentos de cidades mineiras, que se deram a partir do ano de 1937. As primeiras cidades tombadas foram Ouro Preto, Mariana, Sabará, São João Del Rei, Tiradentes, Serro e Diamantina, todas inscritas no Livro de Belas Artes, escolhas estas que foram feitas pelo valor artístico, principalmente.

As cidades coloniais mineiras representavam o pensamento da época, no que diz respeito à escolha dos símbolos da identidade nacional e da construção do imaginário republicano nacional. Segundo as políticas do Estado Novo que eram implantadas, o Tiradentes, a Inconfidência Mineira e a arte do Aleijadinho deviam se tornar referências do nascimento político e artístico de uma identidade nacional, num Brasil que até então podia ser considerado recentemente independente de Portugal.

A princípio de caráter experimentalista, o tombamento visava preservar o cenário urbano daquelas cidades mineiras, consideradas pelo seu grande valor artístico e pela capacidade 
evocativa da cidade barroca setecentista, pronta, com paisagem homogênea que caracterizava o barroco mineiro no seu espaço de criação. As cidades mineiras tombadas passaram depois, a partir do final dos anos 1940, pelos tombamentos individuais de seus monumentos, tais como casas, chafarizes, pontes e igrejas e neste sentido, cidades como Prados passaram a incluir seus bens arquitetônicos e imateriais nos Livros de Tombo ${ }^{43}$. A pequenina Congonhas do Campo teve em 1941 o tombamento de seu conjunto arquitetônico e urbanístico, que diferente das outras cidades mineiras e não por acaso, foi inscrito no Livro Arqueológico, Etnográfico e Paisagístico, na tentativa de garantir a ambiência do conjunto Arquitetônico, Escultórico e Paisagístico do Santuário do Senhor Bom Jesus de Matosinhos, hoje Basílica, já tombado em instância nacional em 1938. Seu valor paisagístico já foi considerado de grande importância para a proteção do Santuário (Pessoa, 2011).

O SPHAN (Serviço do Patrimônio Histórico e Artístico Nacional) foi criado pelo governo de Getúlio Vargas pelo Decreto-lei $\mathrm{n}^{\circ} 25$, de 30 de novembro de 1937, quando definiu o Patrimônio Histórico e Artístico Nacional como sendo o conjunto dos bens móveis e imóveis existentes no país e cuja conservação seja de interesse público, quer por sua vinculação a fatos memoráveis da história do Brasil, quer por seu excepcional valor arqueológico ou etnográfico, bibliográfico ou artístico (Lemos, 1987).

Naquele tempo, Congonhas foi prontamente incluída na lista de bens tombados, mas atualmente, o seu valor arqueológico, assim como o paisagístico, o histórico, o arquitetônico e o urbanístico, tem sido claramente deixados de lado em prol de interesses múltiplos que se escondem por trás do nome do progresso e acabam por destruir o patrimônio arqueológico do município. Acreditamos, contudo, que o verdadeiro progresso deve acontecer com a economia em convergência com as tradições locais, mantendo vivos a história e o patrimônio cultural local.

Enquanto Congonhas dava início ao processo que dizimaria livremente seu patrimônio à vontade de seus moradores e autoridades, em Ouro Preto já havia ocorrido diversas discussões e debates que levaram a soluções para a instalação do Grande Hotel de Ouro Preto, o que levaria a outras discussões e buscas por soluções subsequentes que viriam a contribuir para a preservação e manutenção do patrimônio da antiga Vila Rica, atualmente muito prestigiado por turistas e estudiosos.

\footnotetext{
${ }^{43}$ Criados no mesmo ano de fundação do Serviço de Patrimônio Histórico e Artístico Nacional (SPHAN) em 1937, os Livros de Tombo, que tinham também a qualidade de classificar os bens tombados, se dividiam em quatro: O Livro de Belas Artes; o Histórico; o Arqueológico, Etnográfico e Paisagístico; e o das Artes Aplicadas.
} 
O tombamento do patrimônio arquitetônico e urbanístico da cidade de Congonhas, do conjunto escultórico, arquitetônico e paisagístico da Basílica do Senhor Bom Jesus de Matosinhos, além do tombamento como patrimônio cultural mundial do conjunto barroco da Basílica não foram suficientes para que a população e autoridades buscassem por melhores formas de manutenção dos bens tombados, que não fosse a destruição contínua que se instalou na cidade e se acentuou principalmente a partir da década de 1960, quando grandes construções modernas passaram a fazer parte da paisagem do pequeno arraial colonial, ganhando força com o crescimento urbano que se acelerou após a instalação da Açominas, na metade da década de 1970 e do crescimento das mineradoras locais que atraíram muitas pessoas em busca de emprego na cidade.

A partir da década de 1960, o moderno prédio do cinema Cine Leon, a moderna edificação da escola técnica da CSN e o novo prédio da Prefeitura Municipal de Congonhas se destacaram como significado de modernidade arquitetônica entre o casario colonial da pequena cidade mineira. Depois, no final da década de 1970, vieram centenas de casas modernas que a cidade recebeu após a chegada da Açominas S/A. Os pontos comerciais e os novos bairros que se instalaram na cidade passaram a dividir a paisagem com o casario colonial e na maioria dos casos, resultando em demolições e modernizações que não seguiram nenhuma forma de padrão ou preocupação com a manutenção das características coloniais de suas construções ou com a ambiência.

Buscamos, contudo, realizar uma leitura arqueológica da paisagem histórica de Congonhas, e para que isso ocorra de uma maneira eficiente, é necessário que estejamos atentos ao mesmo tempo, tanto para uma abordagem da sequência cronológica da transformação da paisagem cultural, quanto para a abertura de uma discussão sobre aspectos relativos à legislação patrimonial que reflitam sobre o patrimônio arqueológico e outras manifestações culturais materiais e imateriais e sobre o vislumbre da possibilidade de sua preservação legal, frente aos problemas que tem gerado sua destruição.

Neste sentido, temos prerrogativas legais que constam em acordos internacionais como na Carta de Veneza $(1987)^{44}$, artigo $6^{\circ}$, página $2^{\text {a }}$, que a respeito da conservação e da ambiência diz o seguinte:

\footnotetext{
${ }^{44}$ Disponível em: http://www.icomos.org.br/cartas/Carta_de_Veneza_1964.pdf
} 
A conservação de um monumento implica a preservação de uma ambiência em sua escala. Quando subsistir, a ambiência tradicional será conservada e toda construção nova, toda destruição e toda modificação que possam alterar as relações de volume e de cor serão proibidas.

Já o artigo $7^{\circ}$, página $2^{\mathrm{a}}$, da mesma Carta Patrimonial supracitada se refere da seguinte maneira quanto à importância do monumento para a compreensão da história e de seu deslocamento parcial ou por completo:

O monumento é inseparável da história de que é testemunho e do meio em que se situa. Por conseguinte, o deslocamento de todo o monumento ou de parte dele não pode ser tolerado salvo quando a preservação do monumento exigir ou quando o justificarem razões de grande interesse nacional ou internacional.

No caso de Congonhas, mais especificamente na parte que diz respeito ao produto da conservação do patrimônio tombado, a Conferência da UNESCO em Nova Delhi (1956) ${ }^{45}$ nos trouxe a seguinte colocação: "Estimando que a garantia mais eficaz de conservação dos monumentos e obras do passado reside no respeito e dedicação que lhes consagram os próprios povos" [...]. Isso nos lembra de que o que encontramos ao longo do processo de transformação histórica do município de Congonhas é algo muito próximo do que se referiu o educador Ulpiano Toledo Bezerra de Menezes (2006), acerca da questão do tratamento da cidade e da paisagem cultural urbana quando: [...] "bens declarados de valor universal não são percebidos como tais pelos habitantes, para quem eles podem constituir apenas ônus e, na maior parte das vezes, mera oportunidade de negócio" (MENEZES, 2006, p. 40). Opinião esta reforçada da seguinte forma:

\footnotetext{
Aliás foi sempre notória a miopia das gerações para o valor da cultura sua contemporânea; era necessária a seleção que as gerações faziam do espólio deixado por gerações anteriores para que o remanescente adquirisse valor cultural e pudesse ser considerado "Patrimônio" (PESSOA, 2001, p. 77).
}

Contudo, sabemos que a destruição dos referenciais históricos da nação ocorre no Brasil inteiro e normalmente a partir das mesmas causas. Todavia, nada há de confortante em sabermos que o problema da destruição sistemática dos referenciais do passado não ocorre

\footnotetext{
${ }^{45}$ Disponível em: http://portal.iphan.gov.br/portal/baixaFcdAnexo.do?id=234
} 
somente ou é exclusividade apenas de Congonhas. Desta forma, na realidade do patrimônio congonhense, uma palavra tem se destacado diante do quadro encontrado no município: destruição. Este foi o mesmo destino da maior parte dos casarões coloniais de Congonhas e é também o mesmo rumo que toma o patrimônio arqueológico. Para combater este problema é preciso conhecer os fatores que o causam.

Problemas como o baixo poder aquisitivo de ocupantes de monumentos, a indiferença quanto às questões de preservação do patrimônio cultural, a falta de investimentos na área do patrimônio e a falta de instrução da população que chega às vezes a atingir muitos dos ocupantes de cargos públicos de responsabilidade (Lemos, 1987) representam apenas parcelas de um problema maior.

Somamos a isso outros fatores como as mudanças políticas ocorridas no país e em instituições estatais, como o Serviço do Patrimônio Histórico e Artístico Nacional (SPHAN), que veio a se tornar Instituto do Patrimônio Histórico e Artístico Nacional (IPHAN), na educação do país, nos desastres naturais como as enchentes e alagamentos ocorridos no município de Congonhas e que até hoje provocam a destruição de casas nas partes mais baixas da cidade, mais propícias aos desastres naturais dessa ordem, nos eventos provocados pelas mãos do homem, sejam eles intencionais ou não, ou na própria fragilidade das construções coloniais e mais recuadas no tempo e das técnicas construtivas que utilizam normalmente elementos frágeis que se deterioram de forma fácil e rápida, como o pau-a-pique ou a madeira e ainda, os perigos para a manutenção dos bens culturais revelam uma causa subjacente comum, ou seja, [...] "a alienação da população, o divórcio entre o povo e as autoridades, a distância que separa as preocupações corriqueiras e o ethos e políticas oficiais" (FUNARI \& FUNARI in SOARES, 2007, p. 15). Porém, como afirmou o arquiteto Haroldo Gallo (2006):

\footnotetext{
Uma cidade, especialmente uma cidade histórica, é um organismo vivente submetido a inevitáveis transformações sem as quais não se viabiliza o dinamismo econômico e social. Mas ao mesmo tempo existem nela valores históricos e culturais que devem ser salvaguardados. Emerge aqui uma delimitação de sutil equilíbrio entre a autenticidade e a integridade do patrimônio em sua confrontação com a vida real e a evolução social (GALLO in MORI et al., 2006, p. 107).
}

Então, diante do quadro apresentado, por que preservar sítios arqueológicos em Congonhas, quando tudo parece guiar naturalmente para a destruição? Esta também é uma pergunta de 
difícil resposta, principalmente onde as relações de identidade e pertencimento da população com seus remanescentes do passado não tem demostrado ser das mais esclarecedoras.

Segundo Carlos A. C. Lemos (1987), a pergunta "por que preservar?" deve estar ligada a outras indagações tais como para quem se deve preservar e a que interesses devem se ater as intervenções preservadoras.

Desta forma, não se trata de abraçar o conformismo por sabermos que no Brasil as coisas deixam de funcionar pelos mesmos motivos, nem de culpar o povo ou apenas os governantes pela destruição do patrimônio, mas de entendermos no tratamento do patrimônio cultural do município e de seu processo de transformação a sua sociedade, a sua história e a sua cultura, como organismos dinâmicos, além de buscarmos por alternativas que conduzam em direção à promoção do patrimônio arqueológico, considerando os problemas específicos do município diante do descumprimento da legislação patrimonial, além das relações de identidade e pertencimento da população com seu patrimônio, com vistas a buscarmos o que for significativo para a sociedade dentre os elementos que compõem o seu patrimônio cultural.

Daí mais uma vez percebemos a necessidade de compreendermos o patrimônio de Congonhas numa perspectiva que nos permita dar conta da noção de paisagem em transformação, pois o patrimônio local deve ser compreendido como resultado da interação homem e natureza, a fim de chegarmos a uma totalidade, como numa wide word web. Isso também requer compreender o patrimônio e sua dinâmica atentos ao conceito formulado pelo sociólogo e antropólogo Marcel Mauss (1974) e batizado como fato social total ou, de uma forma mais simplificada por ele mesmo, como fatos sociais gerais.

Esta cumplicidade entre totalidade social e patrimônio foi observada pelo antropólogo brasileiro José Reginaldo dos Santos Gonçalves (2009), para quem a noção de patrimônio deve ser entendida como portadora do fato social total, e desta forma, de fatos sociais gerais, que nos permitem conhecer as mudanças culturais e até mesmo transitar entre diferentes culturas. Tratam-se de elementos de pesquisa que podem envolver arquitetura, arte, técnicas, regras jurídicas, estética, paisagem, entre outros elementos da produção cultural, que estão presentes no processo histórico de desenvolvimento da sociedade estudada, que por sua vez são subsídios que somam para sua compreensão, de sua história e de suas transformações:

A noção de patrimônio confunde-se com a de propriedade. A literatura etnográfica está repleta de exemplos de culturas, nas quais os bens materiais não são 
classificados como objetos separados dos seus proprietários. Esses bens, por sua vez, nem sempre têm atributos estritamente utilitários. Em muitos casos, servem a propósitos práticos, mas carregam, ao mesmo tempo, significados mágico-religiosos e sociais. Configuram aquilo que Marcel Mauss (1974) denominou "fatos sociais totais". Tais bens são, simultaneamente, de natureza econômica, moral, religiosa, mágica, política, jurídica, estética, psicológica e fisiológica. Constituem, de certo modo, extensões morais de seus proprietários, e estes por sua vez, são partes inseparáveis de totalidades sociais e cósmicas que transcendem sua condição de indivíduos (GONÇALVES in ABREU \& CHAGAS, 2009, p. 27).

Ainda, segundo o antropólogo José Reginaldo Gonçalves (2009), desta forma, podemos perceber a categoria de patrimônio residindo na ambiguidade da noção antropológica de cultura, que não se restringe apenas ao aspecto material da cultura humana, mas abarca também o que é imaterial e que, quando pensada etnograficamente, toma como ponto de vista a referência daquele povo que pesquisamos.

Outro ponto fundamental nessa questão é a compreensão de que a noção da abrangência do campo de estudos da Arqueologia tem mudado muito nos últimos tempos, desde os inícios da Arqueologia como ciência acadêmica até os dias de hoje. Teórica e metodologicamente metamorfoseada, o termo Arqueologia não condiz apenas com o sentido dado pela etimologia (arque quer dizer antigo e logos quer dizer discurso, ciência). Sendo assim, não é somente a cultura material que é considerada atualmente o objeto de pesquisa do arqueólogo, mesmo sendo ainda muito grande a ênfase dada às produções materiais humanas.

A Arqueologia, contudo, tem abrangido seu campo de atuação e seu objeto de pesquisa, o patrimônio arqueológico pode ser compreendido de forma mais abrangente, abraçando também a cultura imaterial, sendo assim, as formas de fazer e viver e também, os diferentes povos que de uma forma ou outra contribuíram ou ainda contribuem para com a formação das diferentes culturas da Terra e da nação brasileira. É igualmente importante observarmos o meio ambiente e a natureza das quais fazem parte os diferentes povos, que influenciam e contribuem para a sua formação e a diferenciação de sua identidade cultural entre os diferentes povos.

A Arqueologia é a ciência que estuda o passado da humanidade por meio de vestígios, artefatos, modos de fazer e criar que compõem então a cultura material pelos estudiosos. Ao contrário do senso comum, a Arqueologia não se incumbe somente do estudo das sociedades do passado, mas também das ainda existentes. Ora, se um arqueólogo realiza pesquisa em um assentamento quilombola, em uma missão jesuítica no Vale do Rio Paraná, em um engenho de cana de açúcar do século XVI ou em uma casa bandeirista, estará, certamente, estudando a civilização 
brasileira assim entendida como nação (MORAIS \& MORAIS in BASTOS \& SOUZA, 2011, p. 182).

Daí então a Arqueologia não pode ser vista ou compreendida apenas como sinônimo de estudo ou ciência do que é antigo ou da cultura material produzida pelo homem, mas de toda uma série de elementos que dizem respeito à existência e condição humana, dentre os quais a cultura material também faz parte:

\begin{abstract}
A metodologia da pesquisa consiste, em breves linhas, na busca de dados bibliográficos, levantamentos prospectivos e escavações, mas sem desprezar o fator social, conquanto a interação do arqueólogo com a comunidade é fundamental para o êxito do seu trabalho. Trata-se, portanto, de uma ciência social. Ademais, considerando que o estudo do passado condiciona as ações do homem para o futuro e que o traço cultural de uma sociedade possui o condão de criar uma identidade nacional, forçoso reconhecer o relevante papel desempenhado pela arqueologia. De tal assertiva, vislumbra-se, inclusive, que a arqueologia não cumpre função de natureza social somente, mas também política (MORAIS \& MORAIS in BASTOS \& SOUZA, 2011, p. 182).
\end{abstract}

Portanto, perceber o patrimônio dentro de sua interação social e política aproxima o arqueólogo com o imaterial e o termo patrimônio arqueológico mantém seu sentido como objeto da cultura material produzido pelo homem e ganha sentidos outros também que são o que é inerente ao ser humano, que diz respeito às pessoas e sociedades detentoras deste patrimônio, que são ao mesmo tempo produtoras da cultura material, dos sentidos e da vida.

Preservar é também elemento contribuinte para uma educação constante, já que os elementos fornecidos pela Arqueologia Histórica podem ajudar na compreensão da História do Brasil e de seu povo, pois entendemos que preservar não quer dizer imobilizar um elemento da cultura ou isolá-lo, mas dar sentido e significado à sua materialidade, e desta forma, utilizá-lo como elemento revelador da história do povo que o produziu.

Neste sentido, registro e preservação são sinônimos, pois buscam revelar informações que estão em acordo com as relações entre os diversos elementos culturais sem garantia de permanência e funcionam como meio de manter vivos usos e costumes. Fazer levantamentos de sítios arqueológicos e de ruínas variadas é uma forma de preservar remanescentes da 
história nacional condenados ao desaparecimento (Lemos, 1987), assim como de elementos imateriais da cultura.

Assim, após ser identificado e analisado pela Arqueologia Histórica, o patrimônio arqueológico histórico pode ser utilizado para contribuir com a educação dos estudantes e demais cidadãos, pois acreditamos que conhecer o patrimônio e atribuir valor a ele é uma forma de prevenir contra sua destruição. É também praticar uma forma de Arqueologia Preventiva.

Com efeito, acreditamos que a preservação dos sítios arqueológicos de Congonhas deve ser providenciada para usufruto de sua própria população, que deve reutilizá-lo para sua própria educação, criando assim um ciclo onde a educação dos cidadãos pode funcionar como uma forma de prevenção da destruição de seus referenciais do passado. Educar para conhecer, para informar e para estimular a cidadania voltada para o patrimônio, este é o motivo que justifica porque e para quem preservar.

\subsection{2 - Paisagem e legislação em Congonhas}

Para compreendermos a evolução histórica da paisagem em Congonhas ou o fenômeno de transformação da mesma, é essencial que ela seja situada numa wide word web, ou seja, devemos situá-la no paradigma ecossistêmico (Morais 2011). Para tanto, devemos compreender as mudanças, a história e o papel da região e daquela sociedade na história global, afastando a análise da perspectiva estática e conduzindo-a sob uma perspectiva dinâmica pela promoção do patrimônio arqueológico (Assis, 2011), pensando globalmente e agindo localmente (Bastos 2011).

Os velhos caminhos de Congonhas, forma pela qual chamamos nosso objeto de pesquisa, são na realidade, vias terrestres de transporte que influenciaram no traçado da Estrada Real, no trecho conhecido por Caminho Velho, cujo trecho em Congonhas às vezes se mistura às trilhas e vestígios de garimpo de ouro e desta forma, são também vestígios arqueológicos que formaram partes de minas de ouro desativadas, da exploração do ouro de aluvião das margens de rios e córregos, que se inserem na paisagem que se destaca diante da Basílica do Senhor Bom Jesus de Matosinhos e mais especificamente, dos Doze Profetas de Pedra-Sabão do Aleijadinho, integrando e compondo o entorno paisagístico. 
Este tipo de sítio arqueológico se enquadra em algumas definições estabelecidas, pois, dentre os sítios mistos e integrados podemos destacar os lugares notáveis ou paisagens notáveis:

\begin{abstract}
Os lugares notáveis, ou chamados sítios mistos, são as realizações humanas e ações da natureza. São também denominados bens mistos, culturais e naturais ainda paisagens culturais. Trata-se ainda de categoria com pequena representatividade na lista do patrimônio nacional e mundial. Entre os sítios mistos, onde podemos identificar o patrimônio cultural arqueológico e natural, podemos destacar as paisagens rurais, detentoras de fazeres, saberes, sabores e vestígios arqueológicos de grande magnitude e destacada significância (BASTOS E SOUZA, 2010, p. 48).
\end{abstract}

Desta forma, para nosso registro, a ampliação da noção de patrimônio é consequência da renovação das políticas públicas voltadas a essa área. O início do registro do patrimônio imaterial é um dos exemplos dessa mudança, quando a partir dos anos 2000 o Estado passou a reconhecer uma série de manifestações, ao mesmo tempo em que uma série de novos objetos passaram a ser considerados como patrimônio nacional (Ribeiro, 2011). Houve a implantação do INCR (Inventário de Referências Culturais) usado como inventário do patrimônio imaterial, o INBI (Inventário Nacional de Bens Imóveis-Sítios Urbanos) e o INCEU (Inventário de Configurações de Espaços Urbanos), além de outras ações como investimentos, contratações e reestruturações dentro do IPHAN, e ações de investimentos em políticas públicas de patrimônio nos Estados, que podem ter contribuído com a renovação do cenário em muitas instituições brasileiras, com isso:

Foi nesse contexto de ampliação da noção de patrimônio e de renovação das políticas públicas que a discussão sobre paisagem cultural emergiu no Brasil. Apesar de experiências anteriores de preservação da paisagem como patrimônio e da existência de um Livro de Tombo para a inscrição da paisagem, o Livro Arqueológico, Etnográfico e Paisagístico, a paisagem cultural surge no Brasil no início do século XXI pretendendo-se como uma coisa inteiramente nova (RIBEIRO in CUREAU; et. al., 2011, p. 257).

Neste sentido, a paisagem cultural foi primeiramente apropriada pela UNESCO para políticas de patrimônio em 1992, quando passou a incluir a categoria de paisagem cultural para inscrição de bens na Lista de Patrimônio Mundial, e desta forma, tentando quebrar também com a dicotomia presente nesta Lista de Patrimônio mundial, desde sua criação em 1972, na interpretação entre o patrimônio natural e o patrimônio cultural, e desta forma, 
[...] "a paisagem cultural para fins de inscrição na Lista de Patrimônio Mundial passou a ser entendida como aplicável àqueles sítios que expressavam a combinação de trabalhos da natureza e do homem, vistos em conjunto" (RIBEIRO in CUREAU; et. al., 2011, p. 257).

Temos ainda a Carta de Bagé, ou Carta da Paisagem Cultural, assinada entre 13 e 15 de agosto de 2007 como o marco no processo de busca e reconhecimento da paisagem cultural como patrimônio no Brasil e o reflexo da direção que a incorporação da categoria de paisagem, adotada no documento no art. $2^{\circ}$, começava a tomar, revelando, como na UNESCO, a ideia de que a paisagem cultural expressa a relação entre o homem e a natureza, o natural e o cultural:

Art. $2^{\circ}$. A paisagem cultural é o meio natural ao qual o ser humano imprimiu as marcas de suas ações e formas de expressão, resultando em uma soma de todos os testemunhos resultantes da interação do homem com a natureza e reciprocamente, da natureza com o homem, passiveis de leituras espaciais e temporais; $[. . .]^{46}$

Há destaque também para o art. $3^{\circ}$, porque traz uma concepção ampla da categoria de paisagem cultural quando inserida nos termos legais das políticas de patrimônio, mas que de certa forma, não definem claramente o que seja a paisagem cultural e deixa muito aberta a abrangência do termo:

Art. $3^{\circ}$. A paisagem cultural é um bem cultural, o mais amplo, completo e abrangente de todos, que pode apresentar todos os bens indicados pela Constituição, sendo o resultado de múltiplas e diferentes formas de apropriação, uso e transformação do homem sobre o meio natural ${ }^{47}$.

$\mathrm{O}$ art. $5^{\circ}$, que abarca a questão da preservação, pode apontar alguns caminhos no que diz respeito à uma proposta de ressignificação com a musealização de sítios arqueológicos para Congonhas:

Art. $5^{\circ}$. A preservação da paisagem cultural brasileira deve ser reconhecida mediante certificação concedida pelos órgãos de patrimônio cultural e aprovada por seus

\footnotetext{
${ }^{46}$ Disponível em: http://www.icomos.org.br/cartas/Carta_de_Bage_PaisagemCultural.pdf

${ }^{47}$ Ibid.
} 
conselhos consultivos, de forma conjunta com outros órgãos públicos, organismos internacionais, organizações não governamentais e a sociedade civil, sob forma de um termo de compromisso e de cooperação para gestão compartilhada de sítios de significado cultural; $[\ldots]^{48}$

No que diz respeito ao art. $5^{\circ}$, implementado na portaria da chancela da paisagem em 2009 , o mesmo autor argumentou que o mais importante é o trabalho de identificação da paisagem. "Este trabalho de seleção de alguns elementos e de uma determinada leitura e interpretação é que dará materialidade àquele espaço como uma paisagem" (RIBEIRO in CUREAU; et.al., 2011, p. 259).

Contudo, torna-se indispensável, diante de tais colocações, construir, por meio da Arqueologia da Paisagem, uma explicação contextualizada acerca da paisagem cultural em Congonhas, o que deve ser feito a partir do ponto zero (Marx, 1991) escolhido para georreferenciamento na pesquisa, que é a Basílica do Senhor Bom Jesus de Matosinhos, cujos sítios arqueológicos estão inseridos no entorno paisagístico. A este respeito, Lins (2011), diz o seguinte, quanto à representação artística da paisagem:

A representação artística da paisagem documenta o que é percebido pelo indivíduo artista, ao observar o meio. A escolha do que representar ou fotografar, por exemplo, evidencia o que se acredita digno de ser caracterizado. Desta forma, observar a produção artística local é o melhor modo de se conhecer a paisagem de um território (LINS in CUREAU; et. al., 2011, p. 271).

A mesma autora ainda destaca o seguinte, no tocante à observação da paisagem cultural pela arte: "Mas a arte não se limita apenas a representar a paisagem, ela a cria. Fontes literárias e de documentos iconográficos, entre outros, são agentes essenciais da formação de uma consciência coletiva, a qual construirá a paisagem" (LINS in CUREAU; et. al., 2011, p. 271).

Também, durante nossos trabalhos de observação participante, buscamos aguçar a percepção sobre a transformação da paisagem vivenciando o universo empírico, para a compreensão do fato social total (Mauss, 1974) na formação histórica da paisagem cultural de Congonhas:

\footnotetext{
${ }^{48}$ Disponível em: http://www.icomos.org.br/cartas/Carta_de_Bage_PaisagemCultural.pdf
} 
Primeiramente o olhar entra em contato com as coisas e os organismos externos. Após, a consciência subjetiva, composta de pensamentos, emoções, memórias, sonhos, imaginação, faz seu filtro. Por fim intervém o logos, formando a consciência objetiva, diretamente herdada da cultura. É a intersecção destes três momentos que forma a consciência da realidade externa, do que é percebido (LINS in CUREAU; et. al., 2011, p. 271).

Torna-se notável que a proposta colocada por Morais (2011) do paradigma ecossistêmico numa interação e integração holística funcionado como uma espécie de wide world web deve incluir os diversos elementos perceptíveis formadores da sociedade, sempre na direção de um continuиm, quando passado, presente e futuro parecem não ter fronteiras na transformação de um território por uma dada sociedade. A partir deste ponto de vista, fica impossível separar os fatos do presente dos fatos do passado e menos ainda, sem perceber sua inter-relação com os passos a dar no futuro. Deste ponto de vista, a ideia de trabalhar com a noção de transformação da paisagem no lugar de pequenos recortes temporais e temáticos congelados no tempo e no espaço casa-se melhor com o processo de promoção do patrimônio cultural.

Através da leitura da transformação da paisagem, considerando os aspectos históricos, sociais, econômicos, simbólicos, políticos e naturais do espaço em questão, podemos compreender o desenvolvimento daquela sociedade numa integração global. Assim podemos situar o objeto no paradigma ecossistêmico, considerando-o em uma escala global, ou melhor, no sentido de pensar globalmente e agir localmente, como numa wide word web, e ainda porque:

(...) entendemos que as pesquisas arqueológicas devem estar atreladas à história e à comunidade local, adotando o princípio da transdiciplinaridade, visando à compreensão da realidade a partir do estabelecimento de uma relação de complementaridade entre ciência e tradição (BORNAL \& GALDINO in BASTOS \& SOUZA, 2011, p. 133-134).

Sob este olhar de integração, podemos, ao exemplo do Programa de Gestão do Patrimônio Cultural de São Sebastião (2008), desenvolvido no município de São Sebastião, litoral do Estado de São Paulo, pelo arqueólogo Clayton Galdino Resende dos Santos, sob orientação da Prof. ${ }^{a}$ Dr. ${ }^{a}$ Maria Cristina Mineiro Scatamachia do MAE/USP, investir em ações e políticas públicas que priorizem a participação da comunidade de forma paritária, visando assim maior legitimidade no trato do patrimônio arqueológico (Bornal \& Galdino, 2011). 
O município de Congonhas em Minas Gerais tem se tornado um exemplo claro da falta de alcance e aplicabilidade dessas políticas públicas. Trataremos de explicar os problemas da cidade e de seu patrimônio arqueológico em seguida, porém antes, é preciso conhecê-la mais, adentrando em sua história.

\section{3 - O patrimônio arqueológico histórico e algumas considerações no âmbito da legislação nacional}

Temos na legislação brasileira diversos elementos que dão garantia de proteção ao patrimônio cultural do país, inclusive ao patrimônio arqueológico, a começar pelo Decreto-Lei $\mathrm{n}^{\mathrm{o}} 25$, de 30 de novembro de 1937, que organiza a proteção do patrimônio artístico nacional e já dispunha de prerrogativas no artigo $1^{\circ}$ de seu capítulo I, referentes aos bens vinculados aos fatos memoráveis da História do Brasil, dentre eles os bens de valor arqueológico, e ainda, os bens de valor etnológico, bibliográfico ou artístico (tabela 01: Tabela de prerrogativas e finalidades na legislação brasileira referentes ao patrimônio arqueológico e à paisagem cultural).

Já o artigo 216 da Constituição Federal de 05 de outubro de 1988, seção II, da Cultura, declara como patrimônio cultural brasileiro os bens de natureza material e imaterial, tomados em conjunto ou individualmente, os quais são portadores de referência à identidade, à ação, à memória dos diferentes grupos formadores da sociedade brasileira, incluindo os conjuntos urbanos e sítios de valor histórico, paisagístico, artístico, arqueológico, paleontológico, ecológico e científico, sendo que o Poder Público, com a colaboração da comunidade, deverá promover e proteger o patrimônio cultural brasileiro, por quaisquer das formas que sejam por meio de inventários, registros, vigilância, tombamento e desapropriação, e de outras formas de acautelamento e preservação (tabela 01: Tabela de prerrogativas e finalidades na legislação brasileira referentes ao patrimônio arqueológico e à paisagem cultural).

Os sítios e os vestígios arqueológicos georreferenciados ${ }^{49}$ em Congonhas remetem-nos aos tempos coloniais ou pós-contato. Eles são os seguintes:

\footnotetext{
${ }^{49}$ GPS marca Garmin GPS 12/12 Channel - precisão 3 metros.
} 
$1^{\mathrm{o}}$ - Fazenda do Faria

$20^{\circ} 27 ’ 30.0 ” \mathrm{~S}$

$43^{\circ} 51 ’ 27.1 ” \mathrm{~W}$

UTM - X: 607692

UTM - Y: 7720629

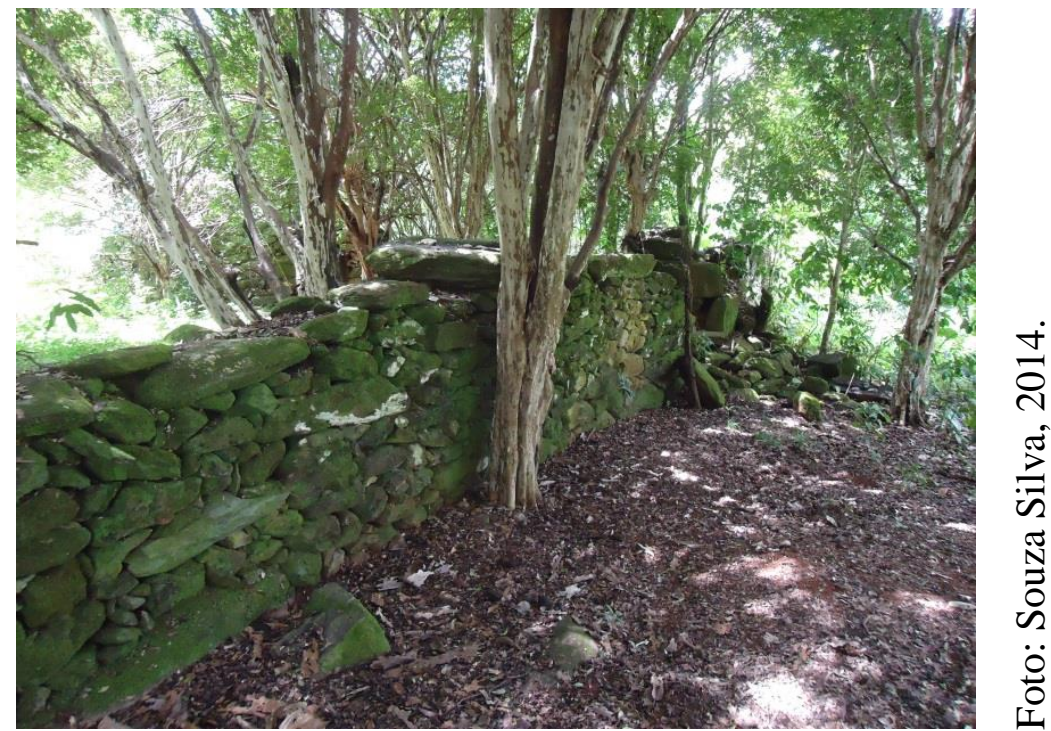

Figura 4: Muro da Fazenda do Faria.

A Fazenda do Faria guarda vestígios da atividade mineradora como canais hidráulicos e voçorocas. No local temos também vestígios relacionados à escravidão, como as ruínas de uma senzala, dos modos de vida, como área de serviços domésticos, com bica d'água, moinho, paiol e curral, todos feitos em pedras sobrepostas, além dos alicerces da casa grande. No local ainda podem ser encontradas diversas telhas cerâmicas coloniais, que possivelmente cobriram as estruturas que atualmente se encontram em ruínas, além de telhas francesas e ferramentaria e maquinaria de uso cotidiano como máquinas de moagem, selas de cavalos, arreios, carroças e carro de boi;

$2^{\circ}$ - Capela de Santo Antônio

$20^{\circ} 31 ' 24.6 ” \mathrm{~S}$ 
$43^{\circ} 48^{\prime} 53.8^{\prime \prime} \mathrm{W}$

UTM - X: 623555

UTM - Y: 7730131

A Capela de Santo Antônio fazia parte do conjunto da Fazenda do Faria e que atualmente se encontra em terreno desmembrado da fazenda, local este que pode revelar muitos vestígios relacionados à religiosidade da população mineira, além de possíveis enterramentos humanos, tanto em seu interior como nos arredores, que eram comuns na sociedade colonial mineira;

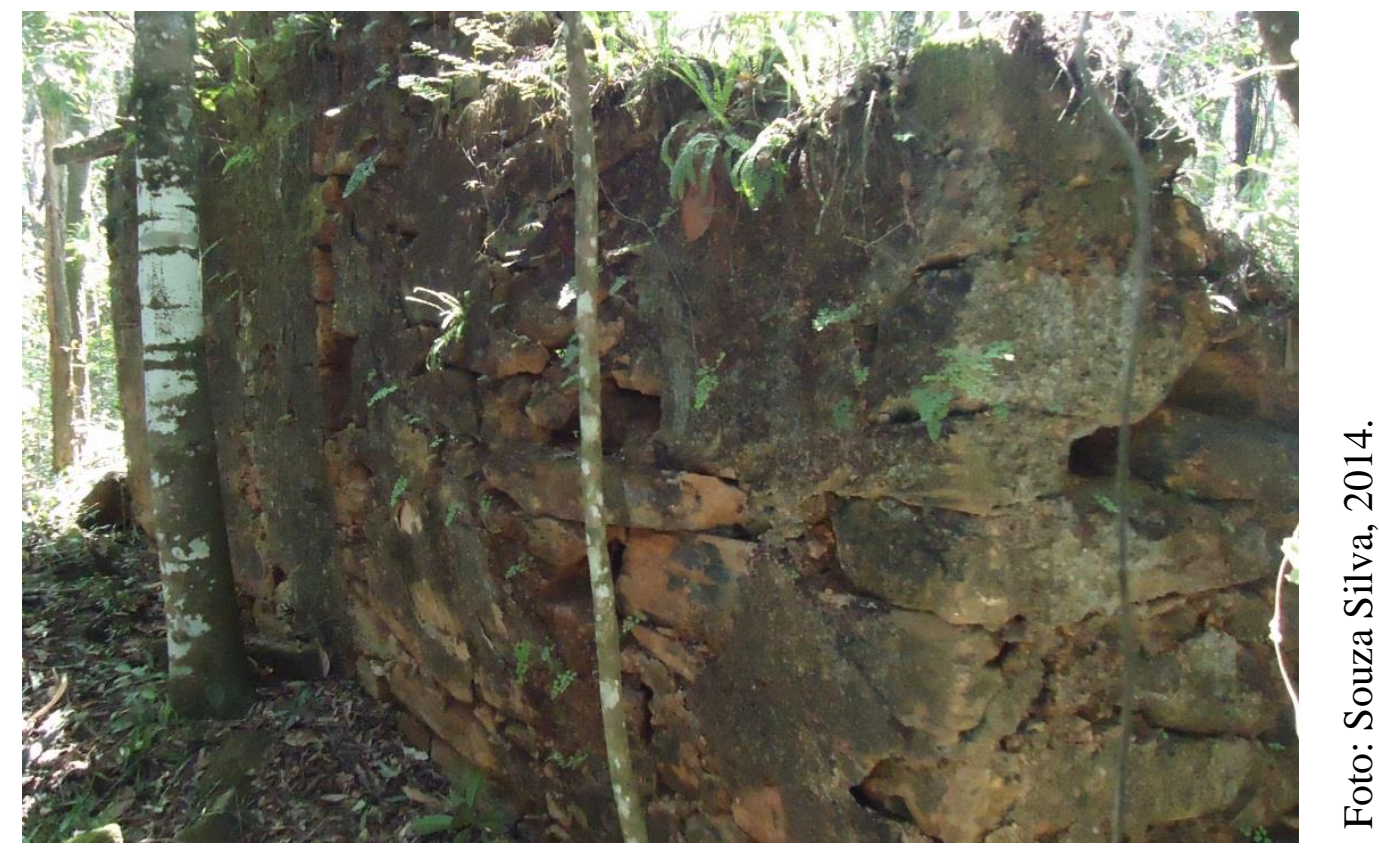

Figura 5: Parede frontal interna da Capela de Santo Antônio.

$3^{\circ}$ - Mina do Veeiro

$20^{\circ} 28^{\prime} 05.3 ” \mathrm{~S}$

4351'33.4” W

UTM - X: 618978

UTM - Y: 7736291 
A Mina do Veeiro ${ }^{50}$ pertenceu a nobres renomados em tempos coloniais, como o Barão e o Visconde de Congonhas. O local guarda vestígios da exploração aurífera como galerias subterrâneas, canais hidráulicos e mundéus;

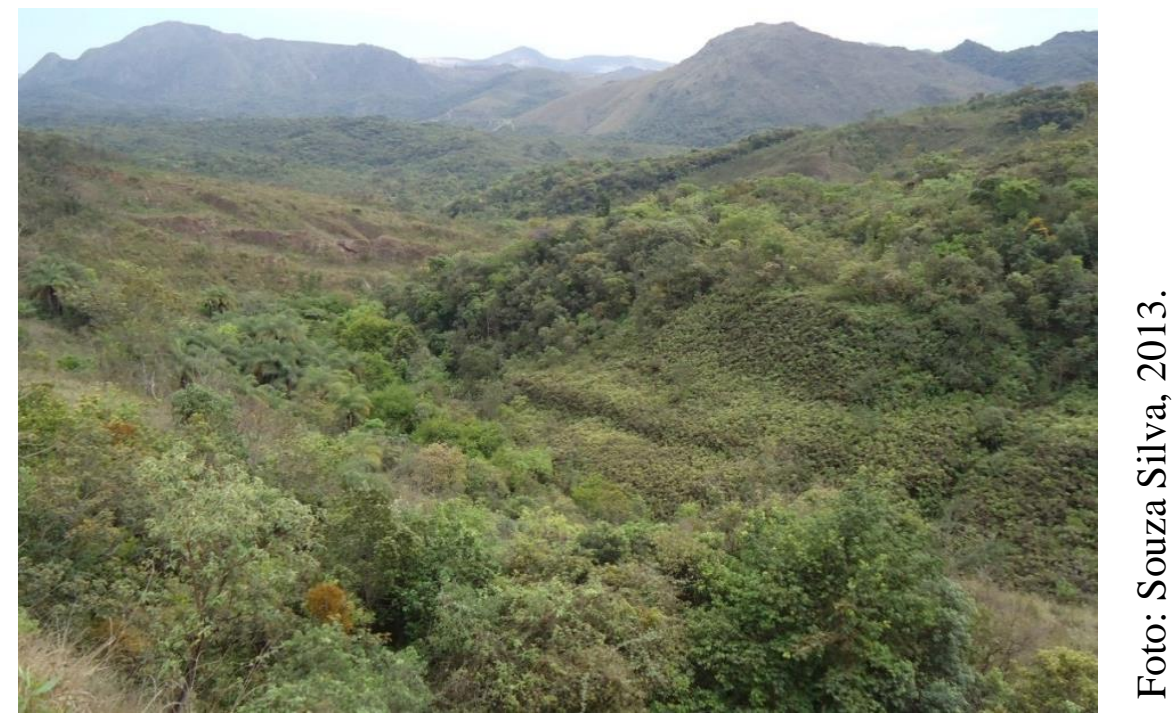

Figura 6: Mina do Veeiro.

$4^{\circ}$ - Mina da Soledade

$20^{\circ} 31 ’ 28.7 ” \mathrm{~S}$

$43^{\circ} 49^{\prime} 30.1^{\prime \prime} \mathrm{W}$

UTM - X: 622512

UTM - Y: 7730012

A Mina da Soledade guarda galerias subterrâneas, cavidades e voçorocas, resquícios da atividade mineradora que extraiu ouro em tempos coloniais. Também pode ser visualizada boa parte dos velhos caminhos de Congonhas que seguiam em direção sul/norte, acompanhando os veios de ouro e os vestígios de sua exploração. O local é o viveiro natural da planta congonha (s. f. Luxemburgia Polyandra), que empresta o nome à cidade e que pode ainda ser encontrada nas variedades bate-caixa, douradinha e bugre. Atualmente, o sítio onde

\footnotetext{
${ }^{50}$ A Mina do Veeiro é também conhecida pelo nome Mina do Vieiro.
} 
se encontra a mina passa por uma obra de terraplanagem para a construção de um condomínio residencial;

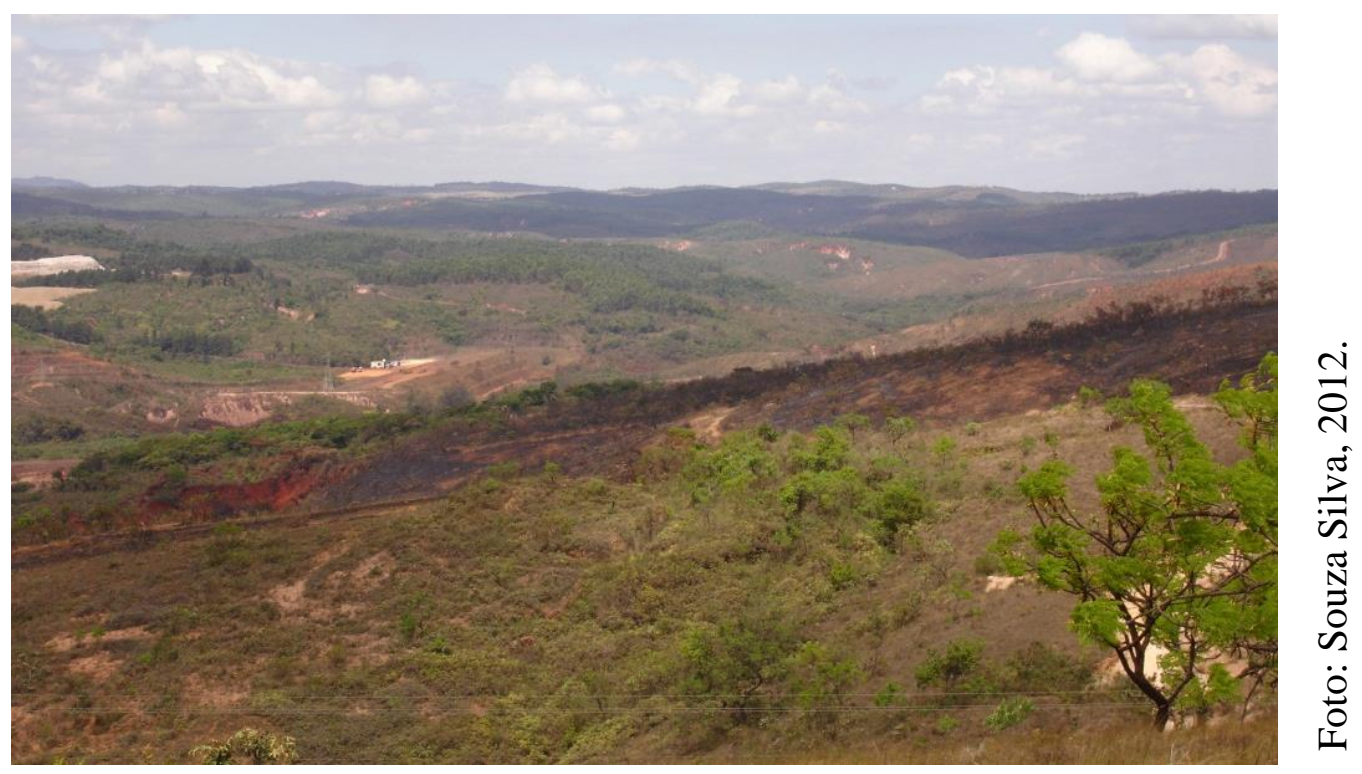

Figura 7: Mina da Soledade.

$5^{\circ}$ - Mina das Goiabeiras

$20^{\circ} 30^{\prime} 15.8^{\prime \prime} \mathrm{S}$

$43^{\circ} 50 ’ 16.7^{\prime \prime} \mathrm{W}$

UTM - X: 621160

UTM - Y: 7732257

A Mina das Goiabeiras é um sítio onde podemos encontrar fontes de pedra-sabão de atividade secular, de onde foram extraída boa parte da pedra utilizada para a tradicional produção de panelas, ornamentos e esculturas de pedra-sabão do município de Congonhas. A Minas das Goiabeiras foi também mina de ouro e de pedras preciosas, cujos sinais da exploração ainda podem ser visualizados, como voçorocas, canais hidráulicos e galerias subterrâneas. Parte da mina já sofreu pressão urbana e atualmente um condomínio residencial também está em construção no local, sobre uma das pedreiras de pedra-sabão. Próximo à Mina das Goiabeiras também existe um sítio arqueológico com uma galeria de extração de ouro, na propriedade do Sr. José Miguel Catharina; 


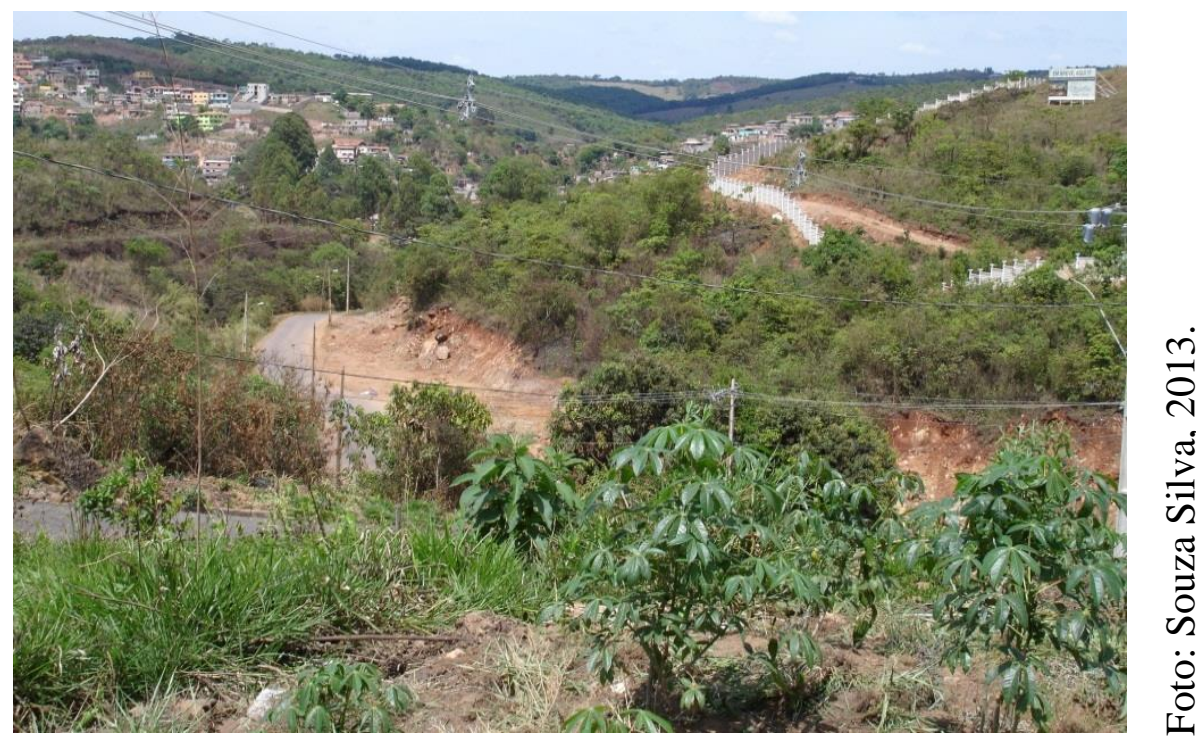

Figura 8: Mina das Goiabeiras.

$6^{\circ}$ - Mina do Redondo

$20^{\circ} 34 ' 17.3 ” \mathrm{~S}$

$43^{\circ} 50 ’ 24.6^{\prime \prime} \mathrm{W}$

UTM - X: 620884

UTM - Y: 7724840

Na Mina do Redondo ainda restaram grandes voçorocas, trechos de trilhas e estradas tropeiras do início do povoamento pelos bandeirantes, garimpeiros e outros tantos que deixaram diversas partes do Brasil e do exterior para buscarem riquezas nas minas.

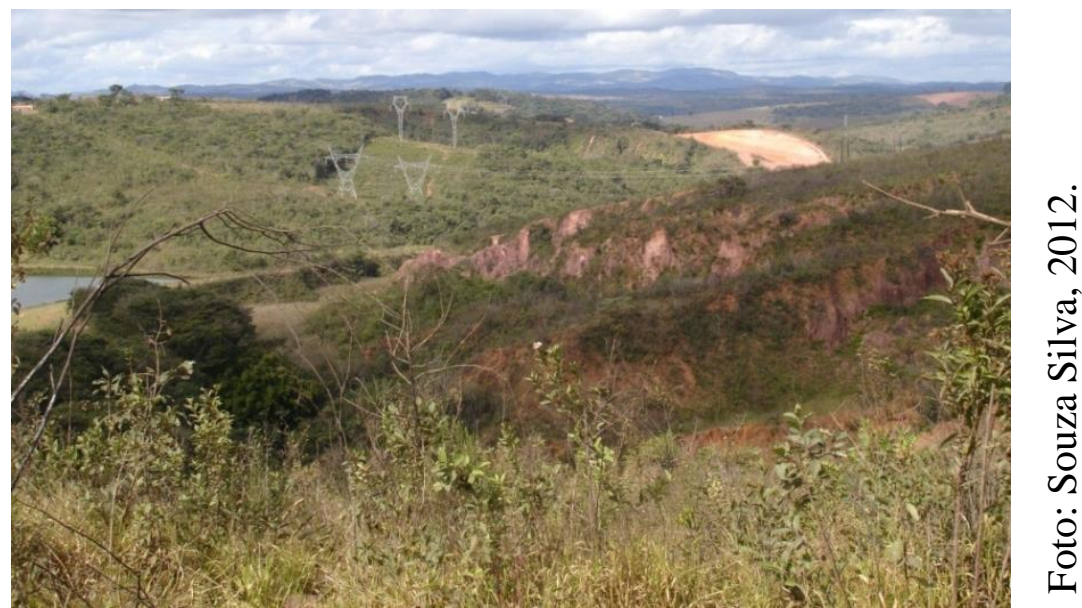

Figura 9: Mina do Redondo. 
$6^{\circ} \mathrm{A}$ - Cadeia do Alto Maranhão

O distrito de Alto Maranhão guarda, além dos vestígios do garimpo do ouro, as ruínas da cadeia, que segundo comentam os moradores da cidade, foi construída para prender indivíduos envolvidos na Guerra dos Emboabas (1707-1709). Há duas edificações:

$6^{\circ} \mathrm{A} 1$ - Edificação menor

$20^{\circ} 33^{\prime} 42.017^{\prime \prime} \mathrm{S}$

$43^{\circ} 51^{\prime} 29.598^{\prime \prime} \mathrm{W}$

UTM - X: 619013

UTM - Y: 7725935

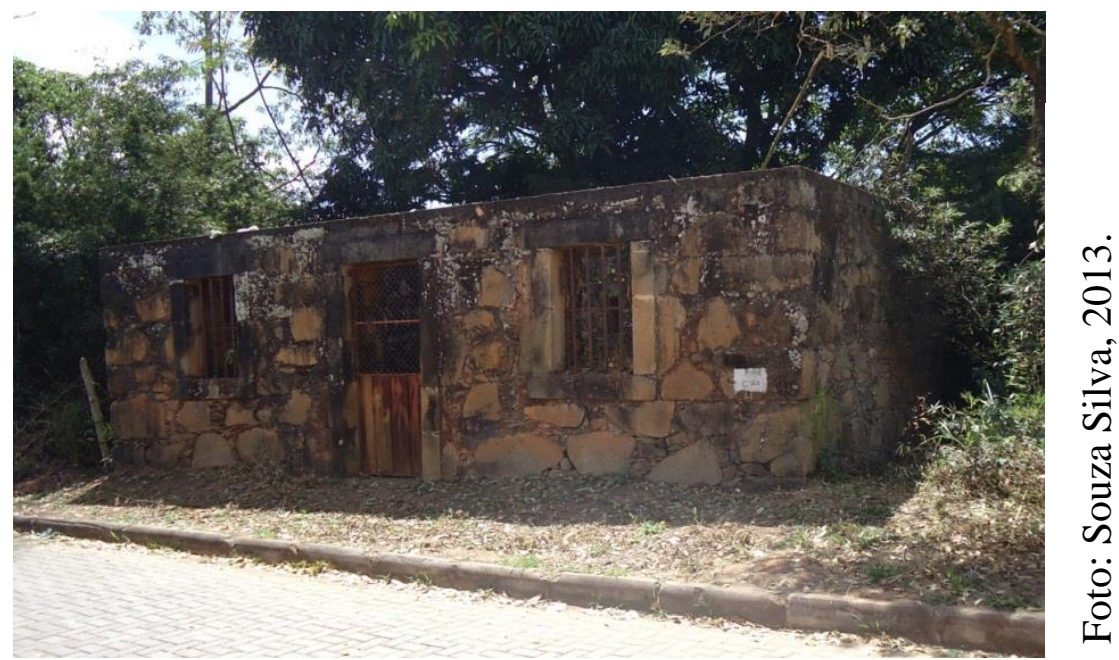

Figura 10: Cadeia do Alto Maranhão (Edificação Menor).

$6^{\circ}$ A 2 - Edificação maior

$20^{\circ} 33^{\prime} 39.150^{\prime \prime} \mathrm{S}$

$43^{\circ} 51^{\prime} 33.689$ ” W

UTM - X: 618895

UTM - Y: 7726028 


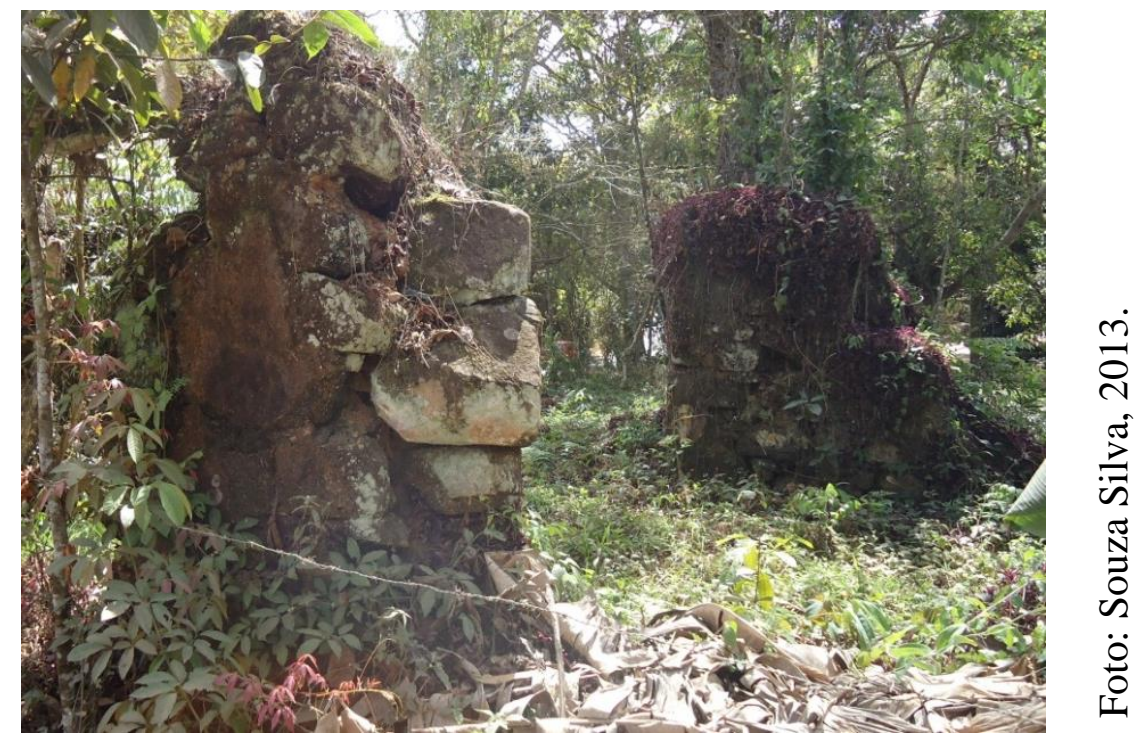

Figura 11: Cadeia do Alto Maranhão (edificação maior).

$6^{\circ} \mathrm{B}-$ Fonte

$20^{\circ} 33^{\prime} 49.959^{\prime \prime} \mathrm{S}$

$43^{\circ} 51^{\prime} 23.989$ ” W

UTM - X: 619170

UTM - Y: 7725691

Também no distrito de Alto Maranhão temos a fonte d'água, que abastecia a população do distrito nos tempos em que a água encanada ainda estava longe da realidade local.

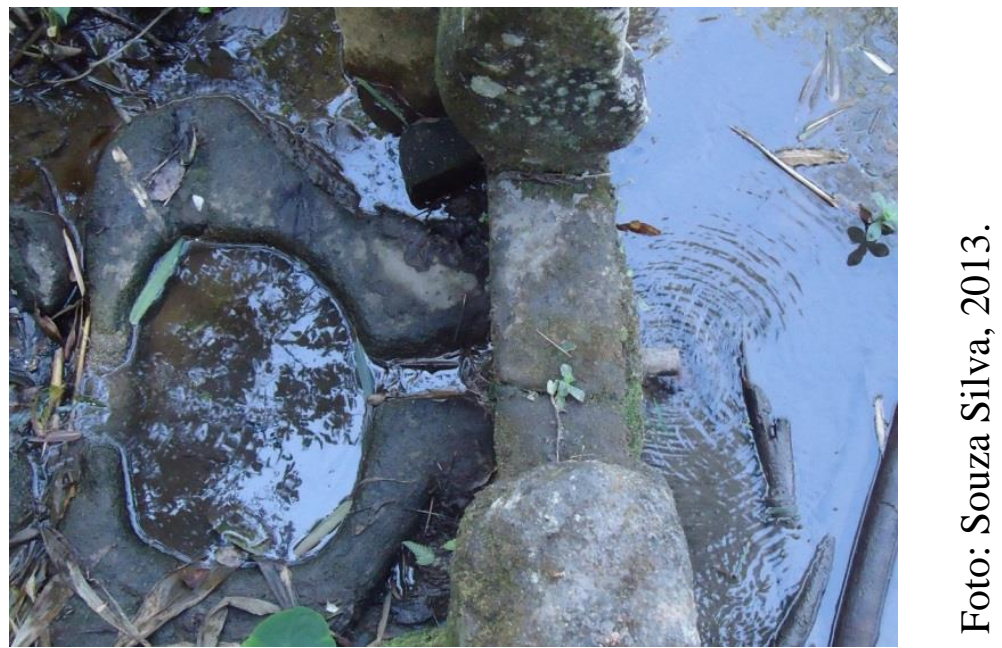

Figura 12: Bojo interno da Fonte do Alto Maranhão. 
Para conceituarmos os termos de lei que definem estes bens arqueológicos apresentados, temos prerrogativas na legislação brasileira na Resolução CONAMA nº 001/1986, no capítulo II, item 1 do Decreto-lei $n^{\circ}$ 25/37 do artigo $2^{\circ}$ da Lei Federal 3.924/61, da Portaria $n^{\circ}$ 07/88, na Portaria nº 28/2003, e também na Portaria IPHAN nº 230/02, as considerações que devem, contudo, ser observadas em Congonhas, definindo que sítios arqueológicos históricos em áreas urbanas são espaços geográficos delimitados pela presença de vestígios materiais oriundos dos processos de ocupação do território pós contato, incluindo estruturas, ruínas e edificações construídas com o objetivo de defesa ou ocupação, entre eles buracos, baterias militares, fortalezas e fortins; os vestígios da infraestrutura tais como as vias, as ruas, os caminhos, as calçadas, as ruelas, as praças, os sistema de esgotamento de água e esgotos, as galerias, os poços, os aquedutos, as fundações remanescentes das mais diversas edificações, dentre outras que fizeram parte do processo de ocupação iniciado nos núcleos urbanos e em outros lugares. Também se incluem dentre esses bens de valor arqueológico histórico os lugares e os locais onde possam ser identificados remanescentes de batalhas históricas e quaisquer outras dimensões que envolvam combates; também os antigos cemitérios, quintais, jardins, pátios e heras; estruturas remanescentes de processos industriais e manufatureiros; vestígios, estruturas e outros bens que possam contribuir na compreensão da memória nacional pós-contato (tabela 01: Tabela de prerrogativas e finalidades/definições na legislação brasileira referentes ao patrimônio arqueológico e à paisagem cultural).

Os itens de lei citados acima nos deixam claro de como a legislação brasileira poderia fazer avanços quanto ao patrimônio cultural, que no início dava maior ênfase aos monumentos e fatores memoráveis da história do Brasil, quando nos museus e livros ficavam marcados a história e a memória das classes dominantes tanto do ponto de vista econômico, político e cultural, enquanto que as classes dominadas e subordinadas no sistema social permaneciam excluídas da tutela jurídica de suas produções culturais (Assis, 2011). Tais avanços, que vieram mais tarde a ocorrer, passaram a abranger o patrimônio arqueológico histórico, incluindo uma diversidade ampla de bens remanescentes do passado colonial e pós-contato do Brasil, incluindo saberes, fazeres e modos de vida, incluídos na lista de bens imateriais.

No entanto, nesses tempos em que se desenvolveu a pesquisa "Os velhos caminhos de Congonhas numa perspectiva de Educação Patrimonial", buscamos construir um sentimento de valorização, informar, esclarecer e construir uma cidadania voltada para o patrimônio cultural de Congonhas e principalmente dos sítios arqueológicos, que por sua vez podem ser considerados uma parcela que compõe o entorno paisagístico da Basílica do Senhor Bom 
Jesus de Matosinhos, que é área de influência direta (AID), também afetada por qualquer empreendimento lesivo ao meio ambiente ou que ocorra sobre sítios arqueológicos no município de Congonhas.

Neste sentido, preservar também pode ser considerado um exercício de cidadania, que pode e deve ser exercido e estimulado entre os cidadãos de Congonhas, buscando maior conhecimento e aproximação da população com seu patrimônio arqueológico, com a finalidade de resguardá-lo de eventuais danos oriundos da falta de informação acerca da existência dos mesmos.

Envoltos neste intuito, acreditamos também que devemos nos lembrar de algumas considerações com a ênfase nos esforços de socializar as políticas públicas relacionadas com as atividades de educação patrimonial no âmbito das arqueologias preventiva e acadêmica, desta forma, temos o Termo de Referência para planejamento e execução de programa de Educação Patrimonial e inclusão social vinculado ao licenciamento ambiental de empreendimentos potencialmente lesivos ao meio ambiente, que tem suporte jurídico fundamentando-se na Constituição Federal (Bastos e Souza, 2010), promulgada em 5 de outubro de 1988, que além de considerar os sítios arqueológicos e pré-históricos no art. 20, X, considera também os sítios de valor histórico, paisagístico e científico no art. 216, V e ainda, no art. $225, \S 1^{\circ}, I V$, que deixa claro acerca da exigência dos estudos prévios de impacto ambiental e da publicidade a ser dada para estes estudos (tabela 01: Tabela de prerrogativas e finalidades/definições na legislação brasileira referentes ao patrimônio arqueológico e à paisagem cultural).

A preservação do patrimônio arqueológico também está na legislação brasileira de forma atrelada à questão ambiental. Não obstante, dois empreendimentos imobiliários foram embargados pelo IPHAN por falta dos procedimentos necessários para a realização dos estudos de Arqueologia Preventiva, conforme a Portaria IPHAN 230-02 (tabela 01: Tabela de prerrogativas e finalidades/definições na legislação brasileira referentes ao patrimônio arqueológico e à paisagem cultural).

Um deles é a obra de um condomínio residencial, cujo proprietário busca a liberação do empreendimento. Outra obra é um acesso da rodovia MG 030 para a BR 040, que esteve embargado em 2012 por conta da destruição de parte da Mina do Redondo, no distrito de Alto Maranhão, porém, já cumpridas as penalidades que couberam ao empreendedor, sendo a obra liberada pela justiça para seu término. 
Numa visão geral, a problemática em torno dos sítios arqueológicos de Congonhas e sua destruição, da destruição do casario colonial e de outros problemas mais recentes envolvendo o patrimônio cultural do município como a mineração de parte do Morro do Engenho que está de frente para a Basílica do Senhor Bom Jesus de Matosinhos, dos problemas ambientais como a poluição do ar, das matas e os incêndios e os problemas sociais de toda ordem pelos quais passa o município, estão perfeitamente na ordem do mundo globalizado, como o que hoje é vivido mais intensamente pelas sociedades das apressadas metrópoles modernas. É um problema pelo qual passa também pequenos municípios industrializados onde a pressa do diaa-dia já não permite mais que os habitantes percebam suas referências identitárias com seu lugar de origem. Há um abismo entre o território e a identidade de seus habitantes, sendo a formação do sujeito baseada em sinais e histórias de lugares diferentes dos de nascimento e criação (Lins, 2011) e às vezes confundindo-se com os referenciais culturais de outros lugares e povos que nos chegam, muitas vezes, por meio da mídia de massas, como a televisão, o jornal, as revistas e a Internet.

Acreditamos então que, para construirmos um sentimento de cidadania voltada para o patrimônio cultural de Congonhas, é preciso ainda que diminua a distância que separa o Poder Público e a legislação patrimonial do povo e de seu patrimônio arqueológico.

$\mathrm{Na}$ realidade, a problemática que envolve o patrimônio arqueológico de Congonhas e quaisquer providências que possam ser tomadas para que o problema seja resolvido, exige a observância da legislação brasileira por parte do Poder Publico e dos empresários, empreendedores e investidores, para que a Arqueologia não se torne um entrave para o desenvolvimento e nem que o desenvolvimento se torne a justificativa para destruir desnecessariamente o patrimônio arqueológico. Acreditamos, contudo, que a Arqueologia possa trabalhar de forma a providenciar meios para o progresso socioeconômico da região, considerando o bom funcionamento da legislação brasileira e com isso a preservação do patrimônio arqueológico para usufruto da sociedade que o detém.

Tão logo, ao pensar em preservação, devemos agir primeiramente na promoção do bem arqueológico, entendida aqui como forma de preservação, mas que a precede, pois pode significar a abertura dos caminhos e as ações que deverão ser tomadas de forma a minimizar os impactos negativos sobre o patrimônio arqueológico, de forma a produzirmos uma Arqueologia Preventiva (Souza \& Dimitriadis, 2011). 
Nesse sentido a Educação Patrimonial pode ser incluída neste processo como uma forma de Arqueologia Preventiva, pois, trabalhará na perspectiva de construção de uma coesão social e de integração entre Poder Público e sociedade, que são os meios condutores pelos quais a legislação funcionará e fruirá em direção a um desenvolvimento que considere a existência e a preservação dos referenciais culturais da nação brasileira.

Por isso, vislumbrar a preservação do patrimônio arqueológico em Congonhas e propor um programa de Educação Patrimonial permanente para sua ressignificação carece de percebermos sua integração com a paisagem e com outros referenciais culturais que contribuíram e ainda contribuem para com a formação da sociedade que o detém. O patrimônio arqueológico só poderá ser compreendido juntamente com os aspectos naturais e condicionantes sociais e históricos que o transformam e que influenciam sobre ele também na atualidade.

É de fundamental importância o papel da Arqueologia, da Arqueologia Histórica, da História, da Sociologia, da Antropologia, da Museologia, da Educação e do Direito, para a interpretação da paisagem cultural, para a identificação, registro e mapeamento de sítios arqueológicos e para apontar caminhos que nos conduzam a uma gestão legal e integrada do patrimônio arqueológico. É principalmente sobre o campo dialógico teórico-metodológico que envolve estas disciplinas acadêmicas que se desenvolve a ideia de promoção do bem arqueológico para a musealização e a Educação Patrimonial da população de Congonhas e este trabalho necessita de pensarmos as possibilidades oferecidas por cada uma dessas ciências acadêmicas.

Isso se faz necessário ainda porque temos diante de nós um desafio que requer o diálogo e a troca de experiências que envolvem as ciências no mundo globalizado de hoje (Santomé, 1998), e ainda mais porque quando tratamos de questões que envolvem as paisagens e a conservação da natureza e do meio ambiente, devemos ter os olhares voltados para a natureza da qual o homem faz parte e o vermos pelas lentes das disciplinas que se ocupam de sua existência, de sua evolução e de seu comportamento dentro se suas comunidades, resultando numa ação integrante que possibilite a compreensão da situação do homem no ambiente no qual ele vive (Pessoa, 2001) e desta forma, compreendermos a cultura material como resultado da interação entre o homem e a natureza, como numa wide word web (Morais, 2011). 
Nosso maior desafio então é conseguir unir as partes desconexas, ou seja, unir o patrimônio arqueológico, a população local, o Poder Público e a legislação. Para vencermos tal desafio, a promoção do patrimônio arqueológico significa o ponto de partida para um trabalho em conjunto com a sociedade e o Poder Público, aproximando-os do patrimônio arqueológico, nos utilizando da educação no caso da sociedade, e no caso do Poder Público, através do trabalho, utilizando-nos das disposições legais, fazendo com que se cumpram as normas estabelecidas pela legislação patrimonial em prol da preservação de sítios.

\begin{tabular}{|c|c|}
\hline prerrogativa & finalidades/definições \\
\hline $\begin{array}{c}\text { lei Federal } \\
3.924 \text {, de } 26 \\
\text { de julho de } \\
1961\end{array}$ & dispõe sobre os monumentos arqueológicos e pré-históricos. \\
\hline $\begin{array}{c}\text { lei Federal } \\
9.795 \text {, de } 27 \\
\text { de abril de } \\
1999\end{array}$ & institui a política nacional de educação ambiental. \\
\hline $\begin{array}{c}\text { portaria } \\
\text { IPHAN 07, } \\
\text { de } 1^{\circ} \text { de } \\
\text { dezembro } \\
\text { de } 1988\end{array}$ & $\begin{array}{l}\text { estabelece os procedimentos necessários à comunicação prévia, às permissões e autorizações } \\
\text { para pesquisas e escavações arqueológicas. }\end{array}$ \\
\hline $\begin{array}{c}\text { portaria } \\
\text { IPHAN 230, } \\
\text { de } 17 \text { de } \\
\text { dezembro } \\
\text { de } 2002\end{array}$ & $\begin{array}{l}\text { compatibiliza as etapas dos estudos de arqueologia preventiva com as fases do } \\
\text { licenciamento ambiental. }\end{array}$ \\
\hline $\begin{array}{c}\text { resolução } \\
\text { CONAMA } \\
\text { 001, de } 23 \\
\text { de janeiro } \\
\text { de } 1986\end{array}$ & $\begin{array}{l}\text { institui a obrigatoriedade de realização de EIA/RIMA para o licenciamento de atividades } \\
\text { poluidoras. }\end{array}$ \\
\hline
\end{tabular}




\begin{tabular}{|c|c|}
\hline $\begin{array}{c}\text { Constituição } \\
\text { Federal, } \\
\text { promulgada } \\
\text { em } 5 \text { de } \\
\text { outubro de } \\
1988\end{array}$ & $\begin{array}{l}\text { - Dos bens da União: art.20, X-as cavidades naturais subterrâneas e os sítios arqueológicos } \\
\text { e pré-históricos. } \\
\text { - Do patrimônio cultural brasileiro: art. } 216, \text { V-os conjuntos urbanos e sítios de valor } \\
\text { histórico, paisagístico, artístico, arqueológico, paleontológico, ecológico e científico. } \\
\text { - Do meio ambiente: art. } 225, \S 1^{o}, I V \text { - exigir, na forma da lei, para instalação de obra ou } \\
\text { atividade causadora de significativa degradação do meio ambiente, estudo prévio de } \\
\text { impacto ambiental, a que se dará publicidade. }\end{array}$ \\
\hline 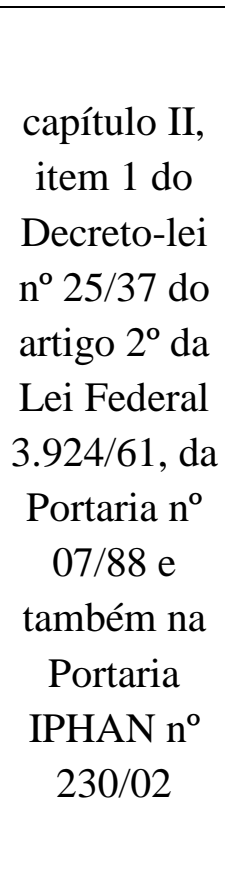 & $\begin{array}{l}\text { Sítio arqueológico histórico em áreas urbanas são espaços geográficos delimitados pela } \\
\text { presença de vestígios materiais oriundos dos processos de ocupação do território pós contato, } \\
\text { tais como: } \\
\text { Todas as estruturas, ruínas e edificações construídas com o objetivo de defesa ou ocupação } \\
\text { (buracos, baterias militares, fortalezas e fortins); } \\
\text { Vestígios da infraestrutura (vias, ruas, caminhos, calçadas, ruelas, praças, sistema de } \\
\text { esgotamento de água e esgotos, galerias, poços, aquedutos, fundações remanescentes } \\
\text { das mais diversas; } \\
\text { edificações, dentre outras que fizeram parte do processo de ocupação iniciado nos núcleos } \\
\text { urbanos e em outros lugares); } \\
\text { Lugares e locais onde possam ser identificados remanescentes de batalhas históricas e } \\
\text { quaisquer outras dimensões que envolvam combates; } \\
\text { Antigos cemitérios, quintais, jardins, pátios e heras; } \\
\text { Estruturas remanescentes de processos industriais e manufatureiros; } \\
\text { Vestígios, estruturas e outros bens que possam contribuir na compreensão da memória } \\
\text { nacional pós-contato. }\end{array}$ \\
\hline $\begin{array}{c}\text { Federal de } \\
05 \text { de } \\
\text { outubro de } \\
\text { 1988, seção } \\
\text { II, da } \\
\text { Cultura }\end{array}$ & $\begin{array}{l}\text { Art. } 216 . \text { Constituem o patrimônio cultural brasileiro os bens de natureza material e } \\
\text { imaterial, tomados individualmente ou em conjunto, portadores de referência à identidade, } \\
\text { à ação, à memória dos diferentes grupos formadores da sociedade brasileira, nos quais se } \\
\text { incluem: } \\
\text { I-as formas de expressão; } \\
\text { II - os modos de criar, fazer e viver; } \\
\text { III - as criações científicas, artísticas e tecnológicas; } \\
\text { IV-as obras, objetos, documentos, edificações e demais espaços destinados à } \\
\text { manifestações artístico-culturais; } \\
\text { V-os conjuntos urbanos e sítios de valor histórico, paisagístico, artístico, } \\
\text { arqueológico, paleontológico, ecológico e científico. } \\
\text { \$ 1. O Poder Público, com a colaboração da comunidade, promoverá e protegerá o } \\
\text { patrimônio cultural brasileiro, por meio de inventários, registros, vigilância, } \\
\text { tombamento e desapropriação, e de outras formas de acautelamento e preservação. } \\
\text { \$ 2. Cabem à administração pública, na forma da lei, a gestão da documentação } \\
\text { governamental e as providências para franquear sua consulta a quantos dela necessitem. } \\
\text { \$ 3. A lei estabelecerá incentivos para a produção e o conhecimento de bens e valores } \\
\text { culturais. (continua) }\end{array}$ \\
\hline
\end{tabular}




\begin{tabular}{|c|c|}
\hline & $\begin{array}{l}\text { §. Os danos e ameaças ao patrimônio cultural serão punidos na forma da lei. } \\
\text { §5. Ficam tombados todos os documentos e os sítios detentores de reminiscências } \\
\text { históricas dos antigos quilombos. }\end{array}$ \\
\hline $\begin{array}{c}\text { Decreto-Lei } \\
\mathrm{n}^{\circ} 25 \text {, de } 30 \\
\text { de } \\
\text { novembro } \\
\text { de } 1937\end{array}$ & $\begin{array}{l}\text { Art. } 1^{o} \text { - Constitui o patrimônio histórico e artístico nacional o conjunto dos bens móveis e } \\
\text { imóveis existentes no país e cuja conservação seja de interesse público, quer por sua } \\
\text { vinculação a fatos memoráveis da História do Brasil, quer por seu excepcional valor } \\
\text { arqueológico ou etnológico, bibliográfico ou artístico. }\end{array}$ \\
\hline $\begin{array}{c}\text { Carta de } \\
\text { Bagé }\end{array}$ & $\begin{array}{l}\text { Art. } 2^{\circ} \text { : A paisagem cultural é o meio natural ao qual o ser humano imprimiu as marcas de } \\
\text { suas ações e formas de expressão, resultando em uma soma de todos os testemunhos } \\
\text { resultantes da interação do homem com a natureza e reciprocamente, da natureza com o } \\
\text { homem, passiveis de leituras espaciais e temporais; } \\
\text { Art. } 3^{\circ} \text { : A paisagem cultural é um bem cultural, o mais amplo, completo e abrangente de } \\
\text { todos, que pode apresentar todos os bens indicados pela Constituição, sendo o resultado de } \\
\text { múltiplas e diferentes formas de apropriação, uso e transformaçâo do homem sobre o meio } \\
\text { natural; } \\
\text { Art. } 5^{\circ} \text { : A preservação da paisagem cultural brasileira deve ser reconhecida mediante } \\
\text { certificação concedida pelos órgãos de patrimônio cultural e aprovada por seus } \\
\text { conselhos consultivos, de forma conjunta com outros órgãos públicos, organismos } \\
\text { internacionais, organizaçôes não governamentais e a sociedade civil, sob forma de um } \\
\text { termo de compromisso e de cooperação para gestão compartilhada de sítios de significado } \\
\text { cultural; [...]. }\end{array}$ \\
\hline
\end{tabular}




\section{4 - Delimitação e função do patrimônio arqueológico: o que preservar?}

Do arraial colonial pouco restou e com o passar dos anos, conforme suas demandas, a cidade de Congonhas se viu rodeada por todos os lados de vestígios da mineração do ouro sobre os quais agora avança em busca de sua natural expansão urbana e industrial.

Não seria exagero destacar que os sítios arqueológicos coloniais se estendem por todo território do município, adentrando para além dos limites territoriais com seus municípios vizinhos e que, quando já não destruídos por completo, todos se encontram em estado de degradação e ameaçados de total destruição e perda dos vestígios arqueológicos ainda remanescentes. Desta forma, o que preservar em Congonhas, já que tudo parece ameaçado pela destruição ou já foi destruído?

Para responder a perguntas como estas, devemos encarar o problema a partir do presente, já que tratamos de uma questão ou de uma preocupação recente, pois ao exemplo de outros municípios brasileiros, Congonhas se transformou pela indiferença e pela vontade de todos que buscam alterá-la a partir de novas expectativas de programas ou necessidades decorrentes do progresso (Lemos, 1987), dos quais não somos contrários mas, que acreditamos que devam ocorrer em concordância com a legislação patrimonial brasileira.

Desta forma, entre os sítios arqueológicos que encontramos no território de Congonhas até o momento podemos destacar o que representou cinco grandes núcleos mineradores da região que deu origem ao município: a Fazenda do Faria, a Mina do Veeiro, a Mina de Soledade, a Mina das Goiabeiras e a Mina do Redondo. Além disso, existem estruturas arquitetônicas em ruínas próximas de alguns deles, como a capela de Santo Antônio, vizinha à Fazenda do Faria, e a cadeia do Alto Maranhão, localizada no distrito onde havia a Mina do Redondo, todos dignos de preservação notoriedade.

Devemos destacar também que a Basílica do Senhor Bom Jesus de Matosinhos não é objeto direto de nossa pesquisa de mestrado, mas foi escolhida como ponto 0 (ponto zero) por dois motivos, o primeiro é porque normalmente o ponto zero de uma cidade é a igreja matriz (Marx, 1991), porém, a cidade de Congonhas possui duas igrejas matrizes, fruto de quando a cidade esteve dividida entre as duas margens do rio Maranhão e por isso, optamos pela Basílica para evitarmos dar mais ou menos importância para esta ou aquela igreja matriz na escolha do ponto zero, e o segundo porque todos os sítios arqueológicos de que tratamos na 
pesquisa, a Mina da Soledade, a Mina das Goiabeiras, a Mina do Veeiro, a Fazenda do Faria e a Capela de Santo Antônio estão inseridos na paisagem cultural que compõe o entorno paisagístico do mais importante templo barroco da cidade e de cujo adro podem ser visualizados, exceto os que se encontram no distrito de Alto Maranhão como a Mina do Redondo, a fonte e as ruínas da cadeia, que não são visíveis do adro da basílica mas que são importantes para a compreensão da colonização da área onde foi gerado o município de Congonhas. Estas áreas, assim como a basílica, numa perspectiva histórica geral, são áreas de influência direta (AID), de qualquer empreendimento lesivo ao meio ambiente em Congonhas.

\subsection{1 - Fazenda do Faria}

$20^{\circ} 27^{\prime} 30.0 ” \mathrm{~S}$

$43^{\circ} 51 ' 27.1 ” \mathrm{~W}$

UTM - X: 607692

UTM - Y: 7720629

A distância geodésica em relação ao ponto 0 (Basílica do Senhor Bom Jesus de Matosinhos é 9460.873, e em quilômetros é 5,5 KM. A altitude em relação ao nível do mar é de 950 metros.

No sítio arqueológico Fazenda do Faria fomos muito gentilmente recebidos pelo proprietário, Sr. Ely de Freitas, irmão do falecido médium espírita Zé Arigó, este último nascido no local, e por sua família.

A Fazenda do Faria é o primeiro sítio arqueológico a merecer destaque, devido ao seu estado de conservação que pode ser considerado bom e com isso, há uma boa conservação do registro arqueológico.

É o sítio arqueológico mais preservado entre os que registramos em Congonhas, porém, não se encontra fora de risco de destruição total, pois, existe uma série de árvores frutíferas, especialmente jabuticabeiras, que crescem ao redor das ruínas ainda existentes no sítio, provocando e acelerando o processo de arruinamento de paredes, muros, calçadas e alicerces. 
Constatamos também a presença de arbustos e capim que somam para aceleramento neste processo, mas que vez ou outra são aparados pelo caseiro da fazenda, porém, sem qualquer cuidado no que se refere à manutenção das estruturas existentes no local.

Uma notícia boa é que, o proprietário da Fazenda do Faria, o Sr. Ely de Freitas e sua família disseram estarem dispostos e abertos a entrarem em negociações a respeito de uma possível venda a quem se interessar a preservar o local e abrir para visitação pública.

O Sr. Ely de Freitas é proprietário de alguns imóveis já tombados pelo IPHAN e pela Prefeitura Municipal de Congonhas e disse que não tem o interesse sobre o tombamento de sua fazenda porque não gosta muito das implicações impostas pelo processo de tombamento, os quais ele tem sofrido nos seus imóveis já tombados no centro histórico de Congonhas.

Em termos de funcionalidade, a Fazenda do Faria representou ao mesmo tempo o que foi uma fazenda cujo sistema de trabalho se dava de forma autossuficiente, um local para pratica religiosa, pois foi encontrada uma capela bem próxima e depois também um núcleo minador, fatores estes que podem ser classificados desta forma devido à disposição das estruturas, tanto da área da fazenda, da capela e quanto dos vestígios de mineração aurífera que se encontram próximos a ela, que destacaremos mais adiante.

A Fazenda do Faria também compõe atualmente o conjunto paisagístico da Basílica do Senhor Bom Jesus de Matosinhos e seus arredores podem ser observados do adro do templo barroco reconhecido como Patrimônio Cultural Mundial.

Dentre as estruturas registradas no sítio, temos a presença de ruínas de um moinho d'água, de uma bica d'água que se aproveitava da água do mesmo córrego que o moinho e uma área de serviços domésticos. 


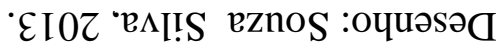

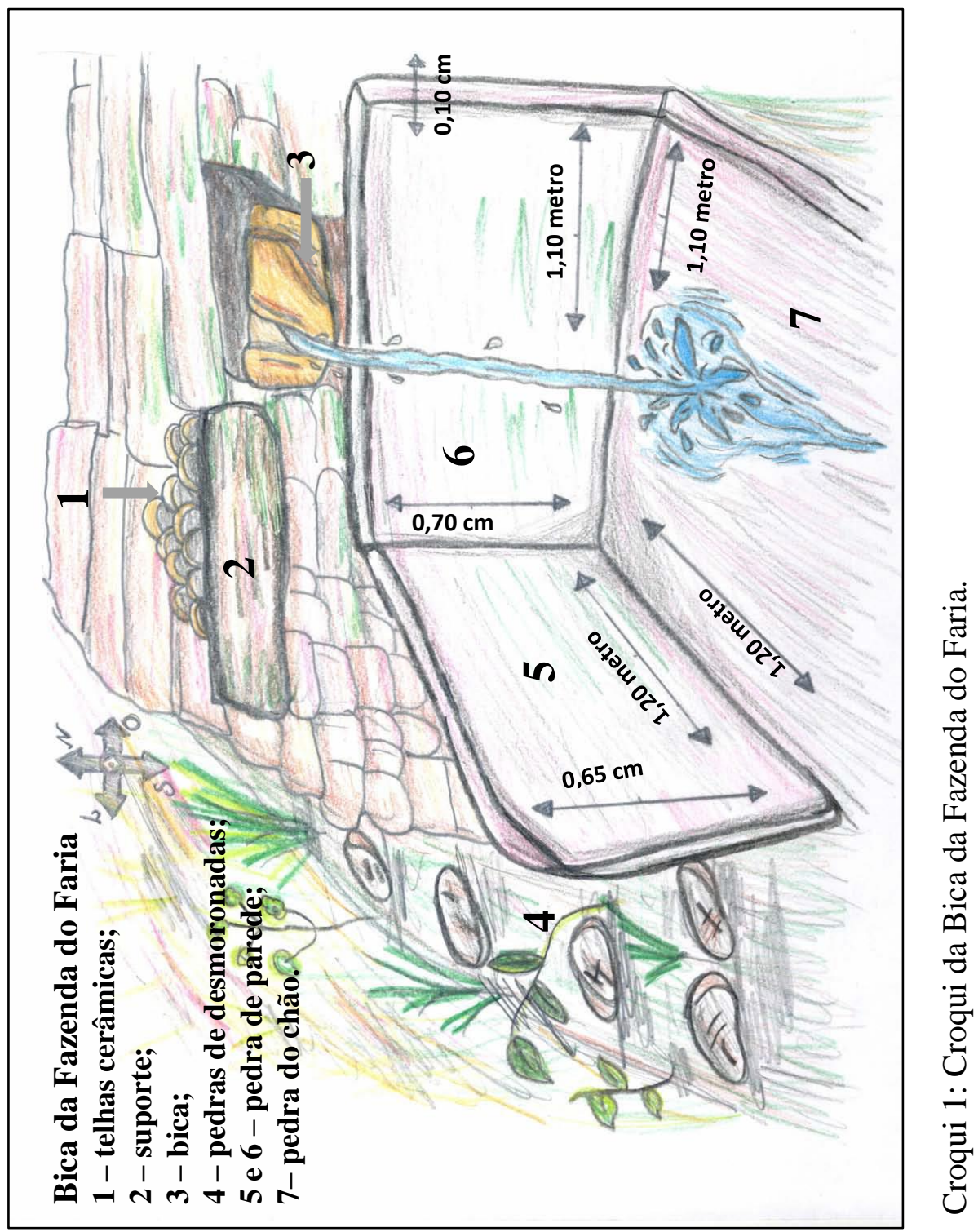


Registramos também, na Fazenda do Faria, nove pilares de pedras sobrepostas que individualmente medem de 1, 20 metros de altura por 74 centímetros de largura média em cada um de seus quatro lados, e formavam em conjunto a estrutura dos alicerces do que já foi possivelmente um paiol. Existem ainda, alicerces de uma casa cujo trabalho de pedraria os coloca no mesmo contexto histórico que os demais, porém, com uma casa reconstruída com características mais recentes.

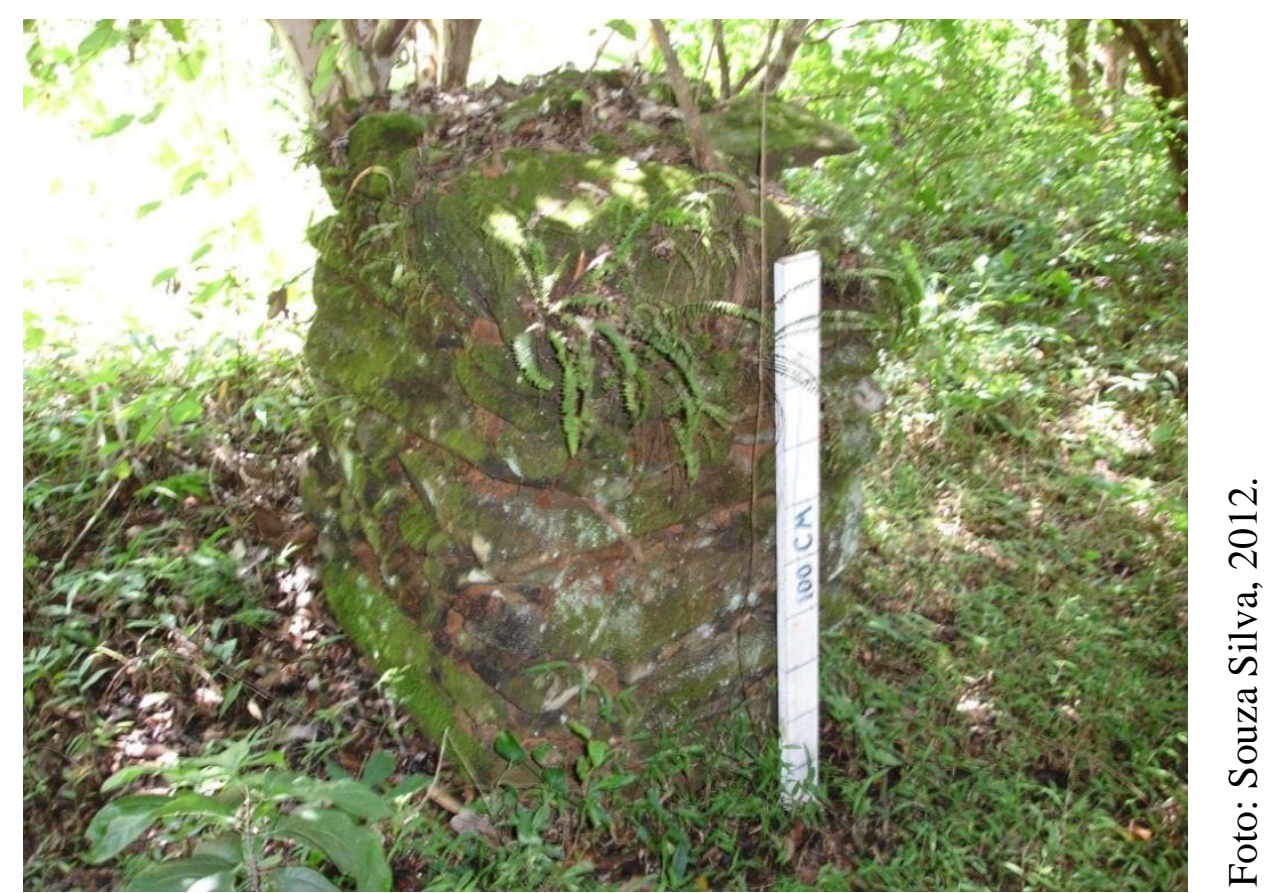

Figura 13: Pilar de paiol da Fazenda do Faria.

Existe também uma área murada com pedras sobrepostas que servia como curral para os animais da fazenda e um galpão construído em pedras sobrepostas que recentemente servia como chiqueiro de porcos e atualmente serve como depósito de materiais em desuso como balança, máquina manual para moagem de capim, moedor de carne, cela e arreio para cavalos $^{51}$, mas que na verdade, em tempos coloniais era a senzala da fazenda. A Fazenda do Faria, devido sua infraestrutura, sugere ter funcionado em regime de autossuficiência produtiva. Segundo os registros de Eschwege de 1814, a fazenda pertencia ao Alferes Joaquim José Faria, possuía 30 escravos e produziu uma média de 165 oitavas (Freitas \& Silva, 2008) $)^{52}$ de ouro naquele ano.

\footnotetext{
${ }^{51}$ Alguns desses objetos de uso no trabalho cotidiano da Fazenda do Faria são provenientes do século XVIII, do século XIX e do começo do século XX em diante, segundo o proprietário.

${ }^{52}$ Oitava: medida de peso utilizada nas regiões mineradoras. Equivalia a 72 grãos, aproximadamente 3,586 gramas. Válida para transações comerciais, a oitava era tão ou mais utilizada que o real, a unidade monetária portuguesa utilizada no período.
} 


\subsection{2 - Capela de Santo Antônio}

$20^{\circ} 31 ’ 24.6 ” \mathrm{~S}$

$43^{\circ} 48^{\prime} 53.8^{\prime \prime} \mathrm{W}$

UTM - X: 623555

UTM - Y: 7730131

A distância geodésica em relação ao ponto 0 (Basílica do Senhor Bom Jesus de Matosinhos) é 15554.502, e em quilômetros é 5,4 KM. A altitude em relação ao nível do mar é de 950 metros.

Próximo da Fazenda do Faria encontramos as ruínas da igreja que segundo o proprietário da fazenda, Sr. Ely de Freitas, se tratam da capela de Santo Antônio. Em estado de abandono, o templo, segundo ele, entrou em processo de arruinamento após a morte de seu pai, que era o zelador. Desde então, por mais de vinte anos a capela permanece abandonada e o mato e as árvores crescem ao seu redor, sobre as paredes de pedra e entre os vãos das mesmas, ajudando a reforçar o arruinamento das paredes, quase totalmente desabadas, e do teto, que desabou por completo. A capela possivelmente faz parte do conjunto da Fazenda do Faria, porém encontra-se em parcela de terreno pertencente à empresa Vale, onde a mesma mantém área de reserva ambiental APP (Área de Proteção Permanente).

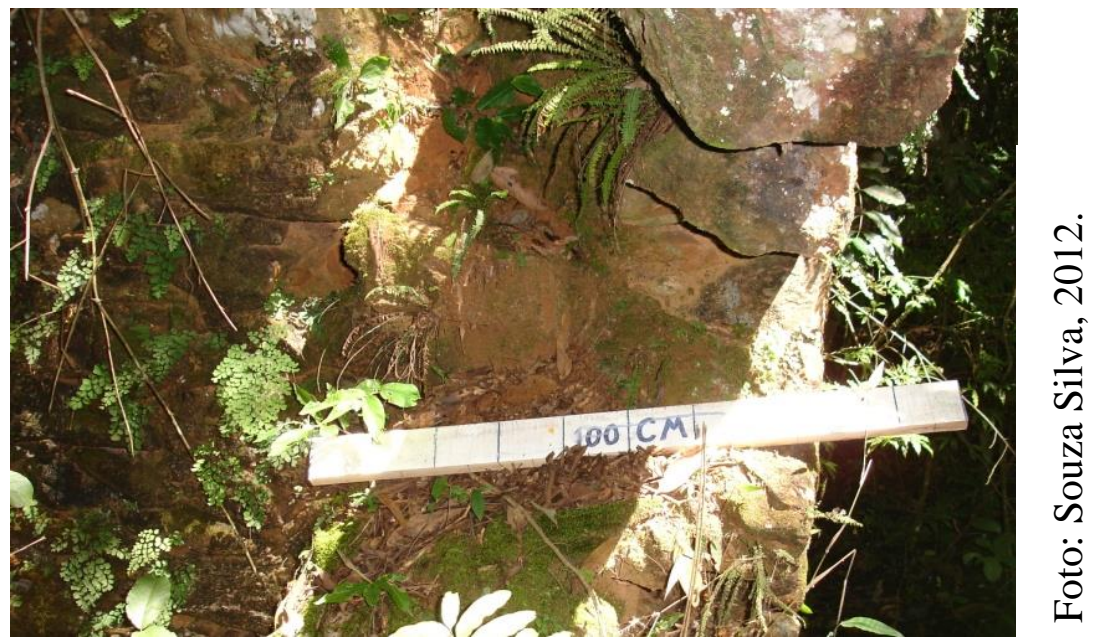

Figura 14: Espessura de parede da Capela de Santo Antônio. 
No que diz respeito à sua funcionalidade, o local era um templo para práticas religiosas. No local existem elementos de cultura material relacionados à prática da religião católica e às técnicas construtivas do templo, feito em pedras sobrepostas com a presença de reboco do lado externo, caimento do telhado em duas águas com cobertura de telhas cerâmicas feitas nas coxas. Também é possível que o local tenha sido utilizado para práticas mortuárias, com possíveis enterramentos humanos no que era o interior do templo religioso ou mesmo em seus arredores, já que a prática de enterrar corpos nas igrejas era comum do homem que viveu nas Minas coloniais, que, segundo o psicanalista e historiador de artes Eduardo Etzel (1974), se preocupava mais com a vida após a morte do que com a vida terrena e assim ambicionava um lugar mais próximo de Deus. Nos tempos do Barroco era comum que as igrejas fossem ao mesmo tempo o local de orações e enterramentos, como forma de encurtar o caminho entre a vida cheia de privações na Terra e o tão almejado lugar seguro próximo de Deus no céu.

Foram encontradas também, próximas à capela, estruturas feitas em pedras sobrepostas bem preservadas, oriundas do garimpo de ouro, tais como canais hidráulicos para condução da água utilizada na lavagem do ouro, assim como uma estrutura para roda de moinho d'água, utilizado para moagem mecanizada de rochas auríferas, além das voçorocas oriundas da exploração de materiais auríferos tais como rochas e areias.

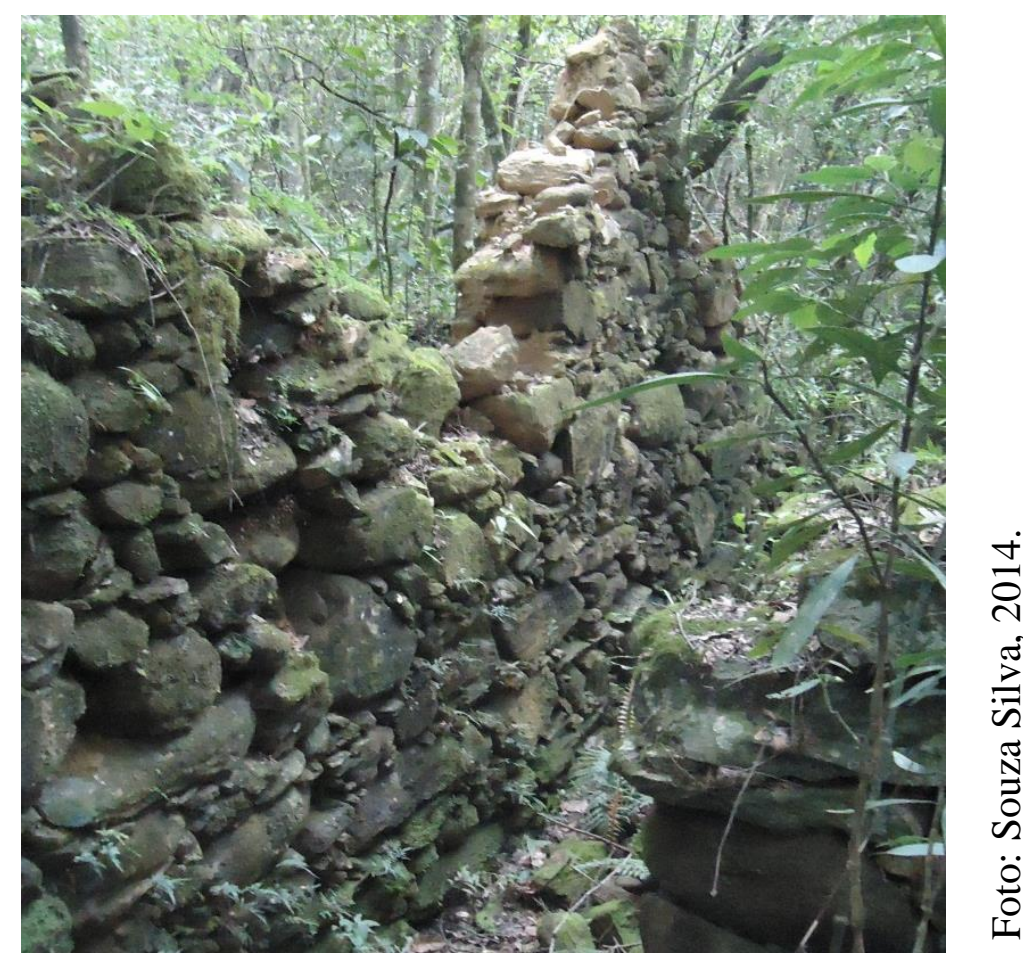

Figura 15: Estrutura para roda de moinho para moagem mecânica de material aurífero próxima à capela de Santo Antônio. 
Existe também outra estrutura, bem próximo a esta estrutura de roda de moinho, que por sua vez, foi construída em concreto maciço, possivelmente no século $\mathrm{XX}$, cuja funcionalidade ainda indefinida, pode estar relacionada com uma base para a sustentação de propulsores de cabo de aço, podendo ser obra desativada para o transporte de minério de ferro, ou ainda, para a exploração de uma mina subterrânea de ouro cujos cabos de aço movidos por uma máquina seriam puxados no intuito de transportar para a superfície o material aurífero extraído no interior da mina subterrânea.

Tanto a Fazenda do Faria quanto as estruturas de garimpo de ouro, assim como a capela de Santo Antônio, fizeram parte de um mesmo conjunto, pois, pertenceram ambos ao terreno da sede da fazenda, que foi ao longo do tempo sendo parcelado, vendido ou teve sua propriedade transferida, vindo a se tornar área de proteção permanente (APP) da empresa Vale e da prefeitura municipal de Congonhas.

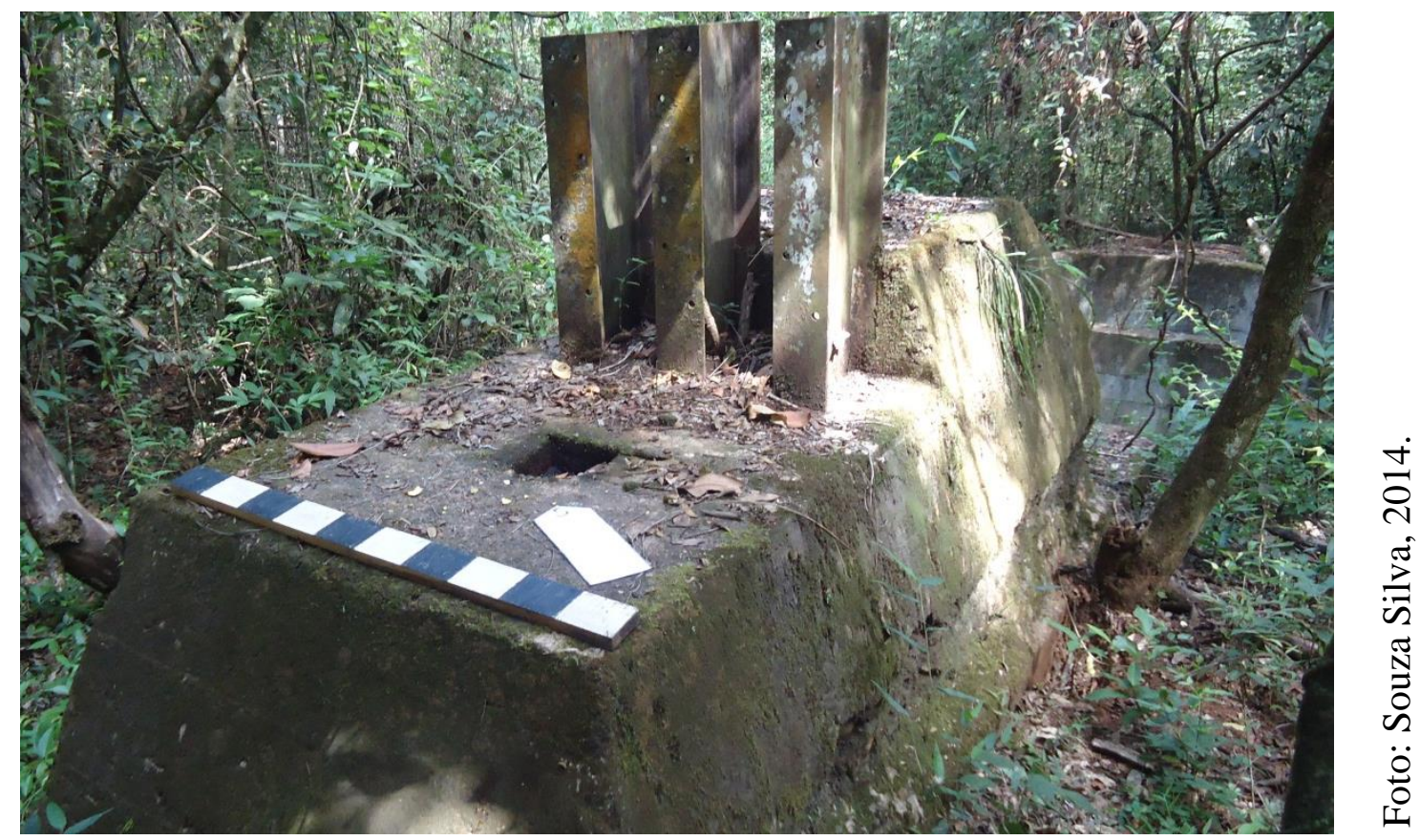

Figura 16: Estrutura de concreto de função indefinida. 


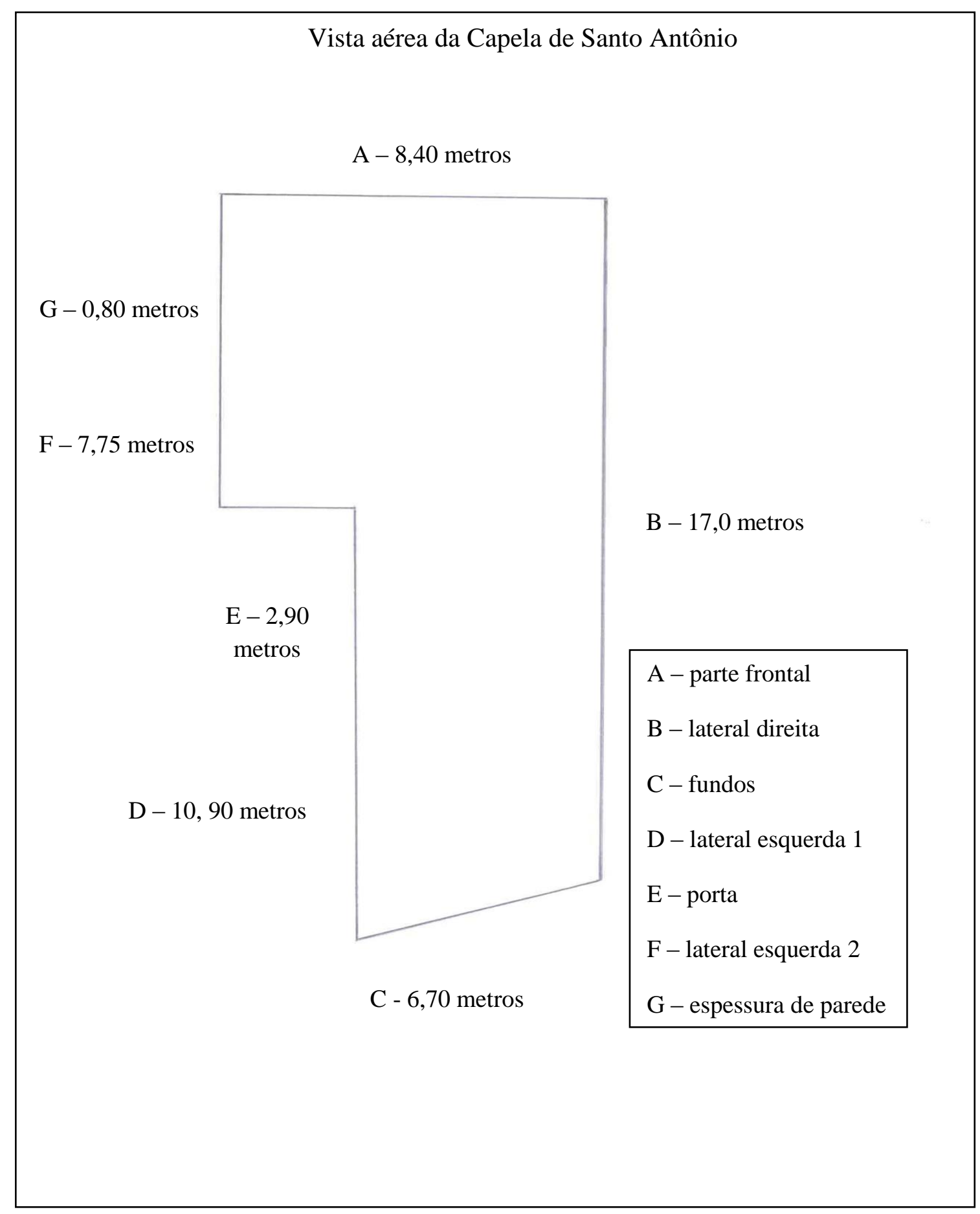

Croqui 2: Croqui da Igreja de Santo Antônio sem escala. 


\subsection{3 - Mina do Veeiro}

$20^{\circ} 28^{\prime} 05.3^{\prime \prime} \mathrm{S}$

$43^{\circ} 51$ '33.4” W

UTM - X: 618978

UTM - Y: 7736291

A distância geodésica em relação ao ponto 0 (Basílica do Senhor Bom Jesus de Matosinhos) é 10224.458 metros, e em quilômetros é 5,0 KM. A altitude em relação ao nível do mar é de 940 metros.

Seguindo a ordem em estado de conservação e contexto arqueológico está a Mina do Veeiro. A mina está próxima à Fazenda do Faria numa distância de 800 metros, ambas com acesso fácil, pela estrada municipal do Parque Ecológico da Cachoeira.

A Mina do Veeiro foi de propriedade da família Monteiro de Barros, cujo um dos membros de destaque mais elevado era Romualdo José Monteiro de Barros, o Barão de Paraopeba ${ }^{53}$, pessoa de grande prestígio na região. Outro membro da família Monteiro de Barros com expressivo destaque na história foi seu irmão Lucas Antônio Monteiro de Barros ${ }^{54}$.

A Mina do Veeiro pertence atualmente à mineradora Ferrous, que tem planos para preservar a mina. Em conversa com o dono anterior da Mina do Veeiro, Gualter Pereira Monteiro, exprefeito de Congonhas por três mandatos, ex-deputado estadual e descendente da família Monteiro de Barros, fomos convidados a conhecer o local e tivemos o acesso liberado. Monteiro, que é proprietário de uma imobiliária, ainda nos forneceu um antigo mapa da mina, sem data, e que mostra a presença de ouro e cascalho aurífero (Mapa 4: Mapa da Mina do Veeiro com escala 1:20000).

\footnotetext{
${ }^{53}$ Barão de Paraopeba: Dedicado à mineração, foi um dos sócios da Fábrica de Ferro do Prata, coronel de milícias e cavaleiro da Ordem de Cristo e exercia grande influência política na região.

${ }^{54}$ Lucas Antônio Monteiro de Barros (1765-1851): estudou Humanidades e formou-se em Leis em Coimbra, 1787. Ele trabalhou em diversos cargos públicos como os de intendente do ouro, ouvidor da comarca de Vila Rica, desembargador da Casa de Suplicação, superintendente geral dos contrabandos, juiz da Companhia de Vinhos do Alto Douro, desembargador da relação da Bahia, chanceler da Relação de Pernambuco e conselheiro da Ordem de Cristo, deputado pela província de Minas Gerais, conselheiro da Corte, senador por São Paulo e ministro e presidente do Supremo Tribunal de Justiça. Foi concedido a ele também os títulos de Barão de Congonhas em 1825, Visconde de Congonhas em 1826 e Visconde "com grandeza" em 1841, já pelo governo imperial. Também foi sócio na Fábrica de Ferro do Prata e seu nome fora envolvido na Inconfidência Mineira de 1789 como um dos conjurados favoráveis ao levante, porém, quando procurado pela devassa, já havia exercido vários cargos de confiança, inclusive o cargo de juiz no ano de 1790, em Portugal.
} 


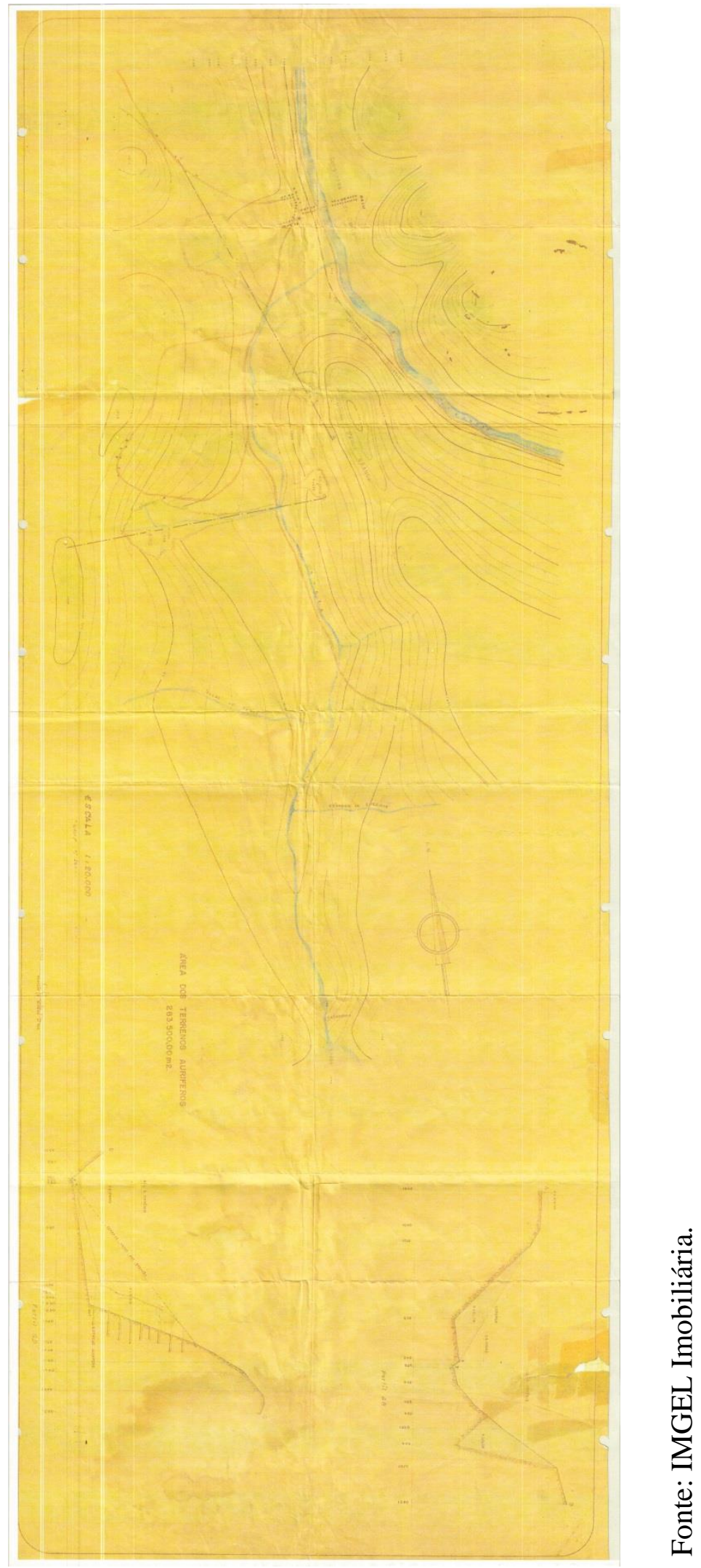

Mapa 4: Mapa do Veeiro. 


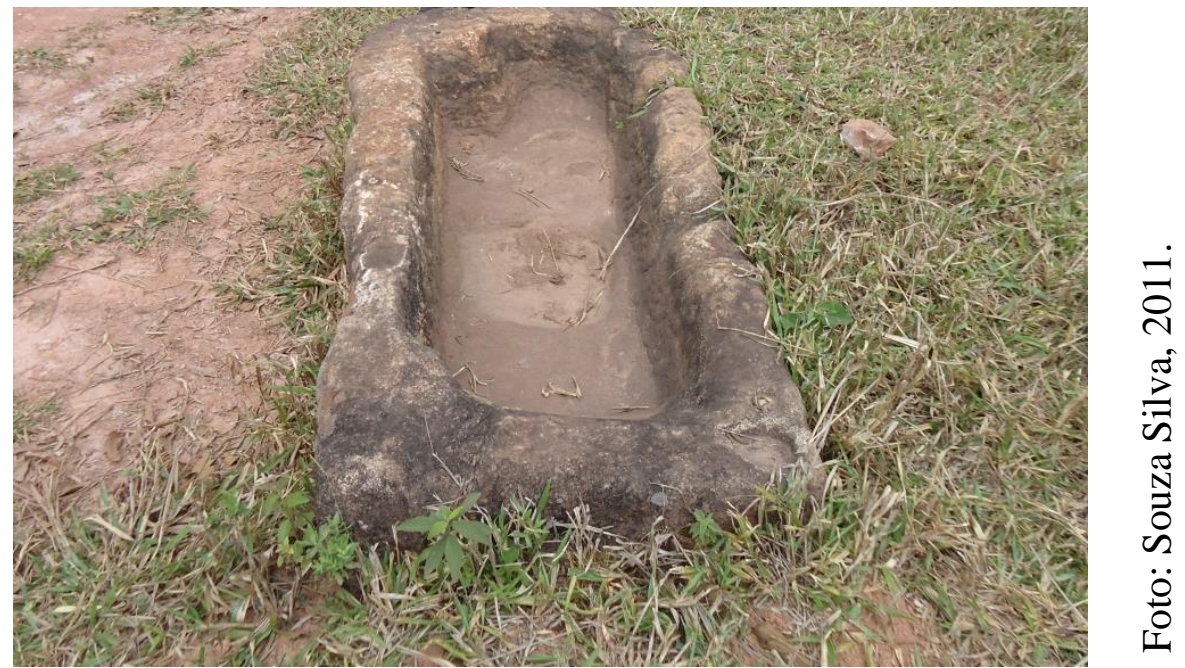

Figura 17: Bojo de hidroclassificação da Mina do Veeiro.

A Mina do Veeiro, atualmente é chamada de Sítio Beija-Flor. Uma parte do terreno da mina foi feito em chácaras, o chacreamento do Veeiro. A parte da mina, que funcionou como local para extração e beneficiamento de ouro no período colonial, ficou conservada e tem bem preservados muitos vestígios da mineração aurífera, tais como, galerias de extração subterrânea, voçorocas que são resultado da extração de areias e terras auríferas e do xisto argiloso aurífero, canais hidráulicos, bojo de hidroclassificação, tanque de hidroclassificação ou mundéu, onde a lama aurífera que descia pelos canais hidráulicos decantava e era apurada em bateias por escravos, além de carriola de transporte de terra e sinais de galerias que começaram a ser cavadas e tiveram os trabalhos interrompidos antes mesmo que tomassem forma subterrânea. A mina produziu em 1814 a quantia de 540 oitavas de ouro e contava com 40 escravos em suas atividades.

Os mundéus ${ }^{55}$ foram feitos em pedras sobrepostas rejuntadas com uma espécie de argamassa e eram usados para apuração mineral existentes no Veeiro. Eles caracterizam a existência de sistemas hidráulicos e estão passando por processo de arruinamento e de desmonte provocados pelo crescimento de mato e árvores em seu interior e em suas paredes e também pelos moradores próximos ao sítio, que utilizam as pedras do mundéu, misturando-as em concreto para as novas construções de casas e muros.

\footnotetext{
${ }^{55}$ Tanques de recebimento e decantação do material aurífero, que geralmente posicionado em partes baixas de relevos, recebia a lama produzida pela mistura da água e da terra cavada pelos escravos nos locais mais altos e trazida pelos canais hidráulicos para apuração com bateias pelos escravos.
} 
Na verdade o mundéu era dividido em quatro grandes tanques internos, sendo que uma parede interna foi parcialmente destruída, o que faz com que pareça 3 (três), o número de tanques internos do mundéu. Parte de uma parede derrubada do mundéu tornou-se passagem para um terreno vizinho e conduz até a mata vizinha. Um grande prejuízo, dada sua importância histórica: "Um sistema hidráulico implicava tanto um conjunto de elementos estruturais quanto um conjunto de trabalhadores que atuavam através de uma divisão do trabalho onde as fases se articulavam de forma coerente" (GUIMARÃES, 2007, p. 163). E ainda: "Esses sistemas geralmente estavam associados a outros tipos de construções como alojamentos, sedes administrativas, currais, etc." (GUIMARÃES, 2007, p. 163).

Exemplos disso estão também na já citada Fazenda do Faria, onde além de sistema hidráulico, foi encontrado todo um conjunto incluindo capela, senzala, casa, moinho, paiol, e curral.

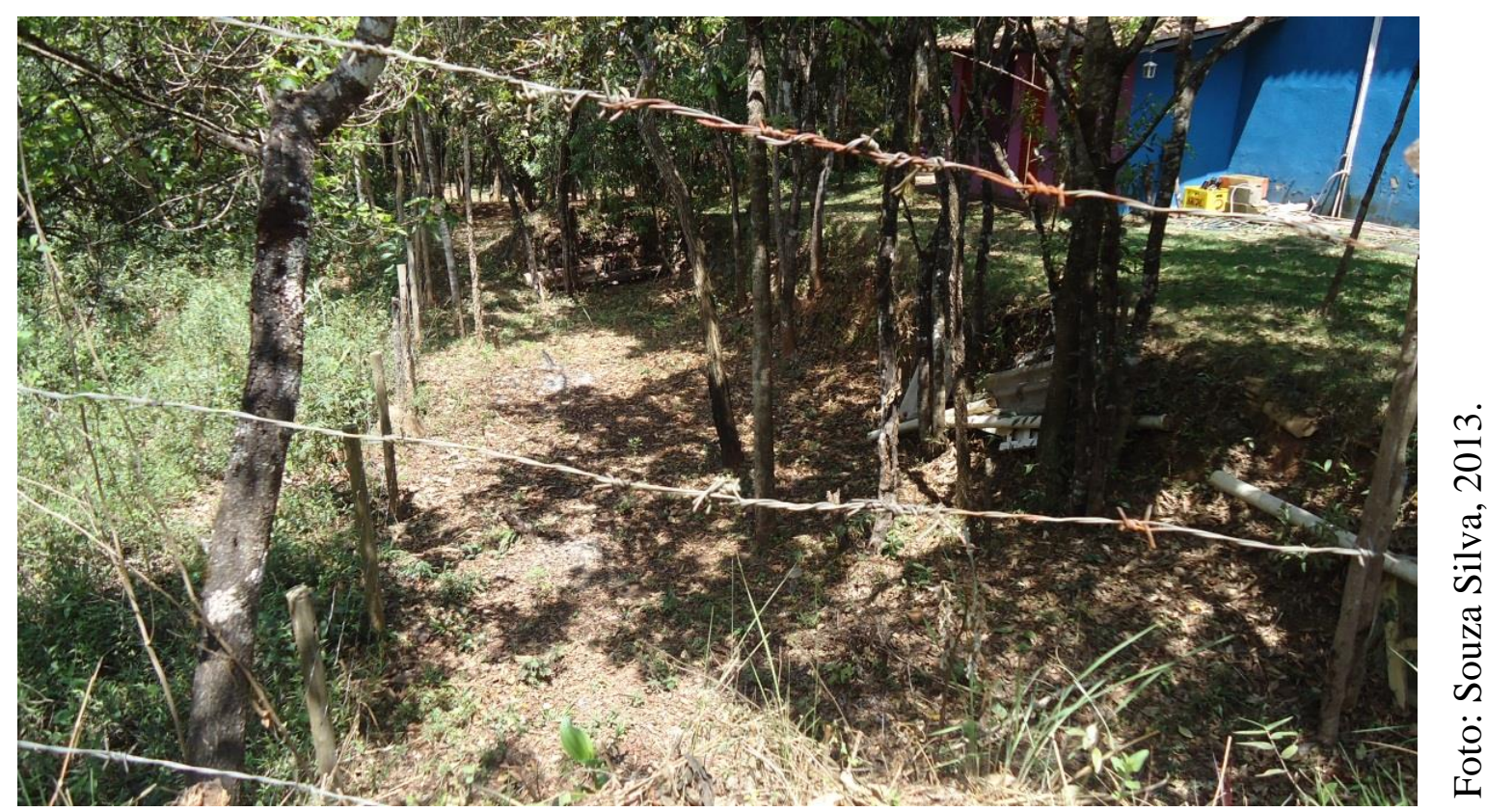

Figura 18: Parede destruída do mundéu da Mina do Veeiro. 
•EI0Z ' $\Lambda$ IIS eznos :oyuəsəC

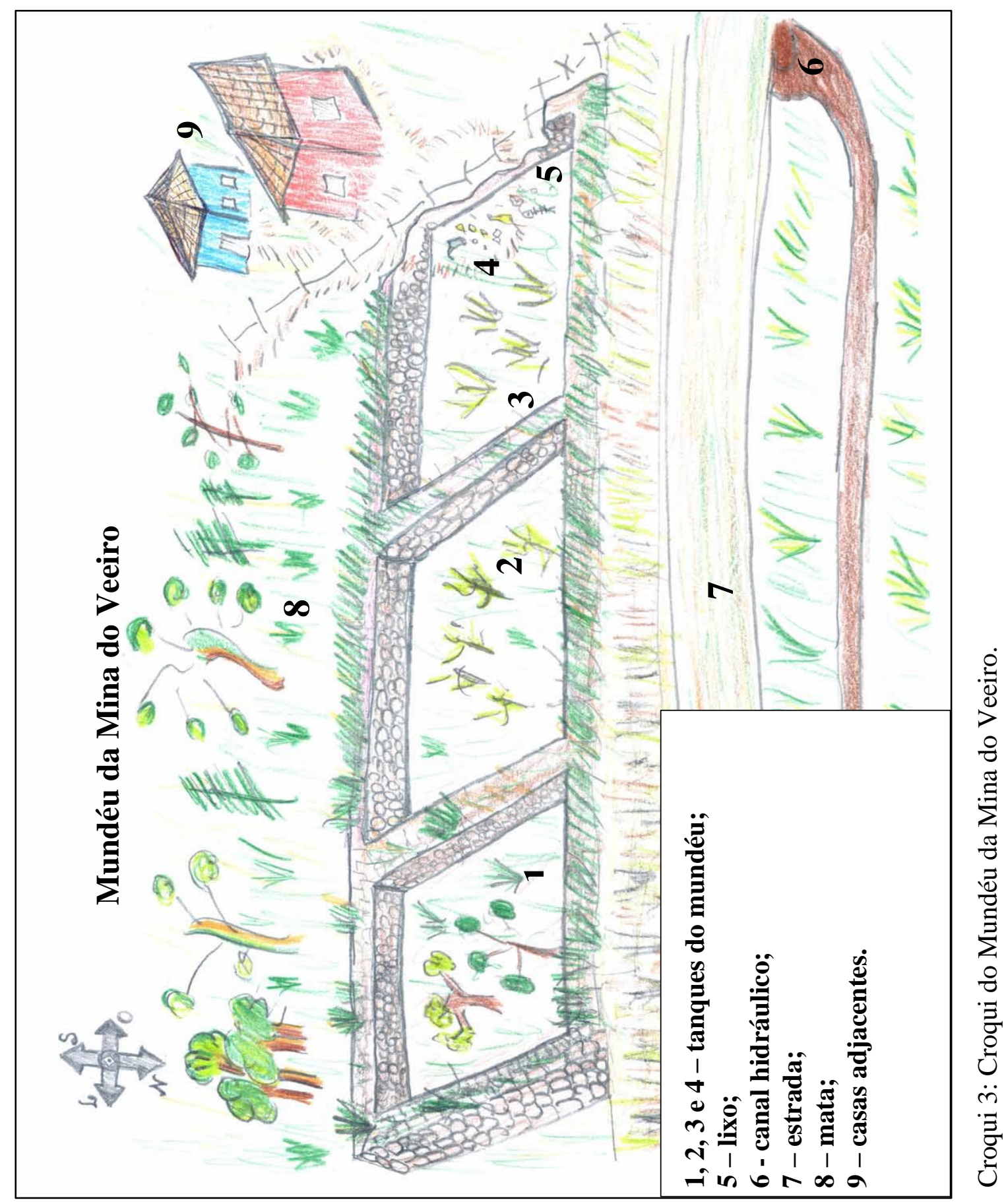




\subsection{4 - Mina da Soledade}

$20^{\circ} 31^{\prime} 28.7 ” \mathrm{~S}$

4349'30.1” W

UTM - X: 622512

UTM - Y: 7730012

A distância geodésica em relação ao ponto 0 (Basílica do Senhor Bom Jesus de Matosinhos) é 15427.115 metros, e em quilômetros é 4,2 KM. A altitude em relação ao nível do mar é de 1100 (mil e cem) metros.

Seguindo a ordem por estado de conservação está a Mina de Soledade. Próxima ao distrito de Lobo Leite, antigo Arraial da Soledade, onde temos a Igreja de Nossa Senhora da Soledade (século XVIII), que fica posicionada de frente para o morro onde está localizada a mina, que é chamado atualmente de Congonhas Acima.

Devido a este fator simbólico e pelo fato de estar localizada à margem direita do Rio Soledade, acreditamos se tratar da Mina da Soledade, sítio onde funcionava a extração e o beneficiamento do ouro.

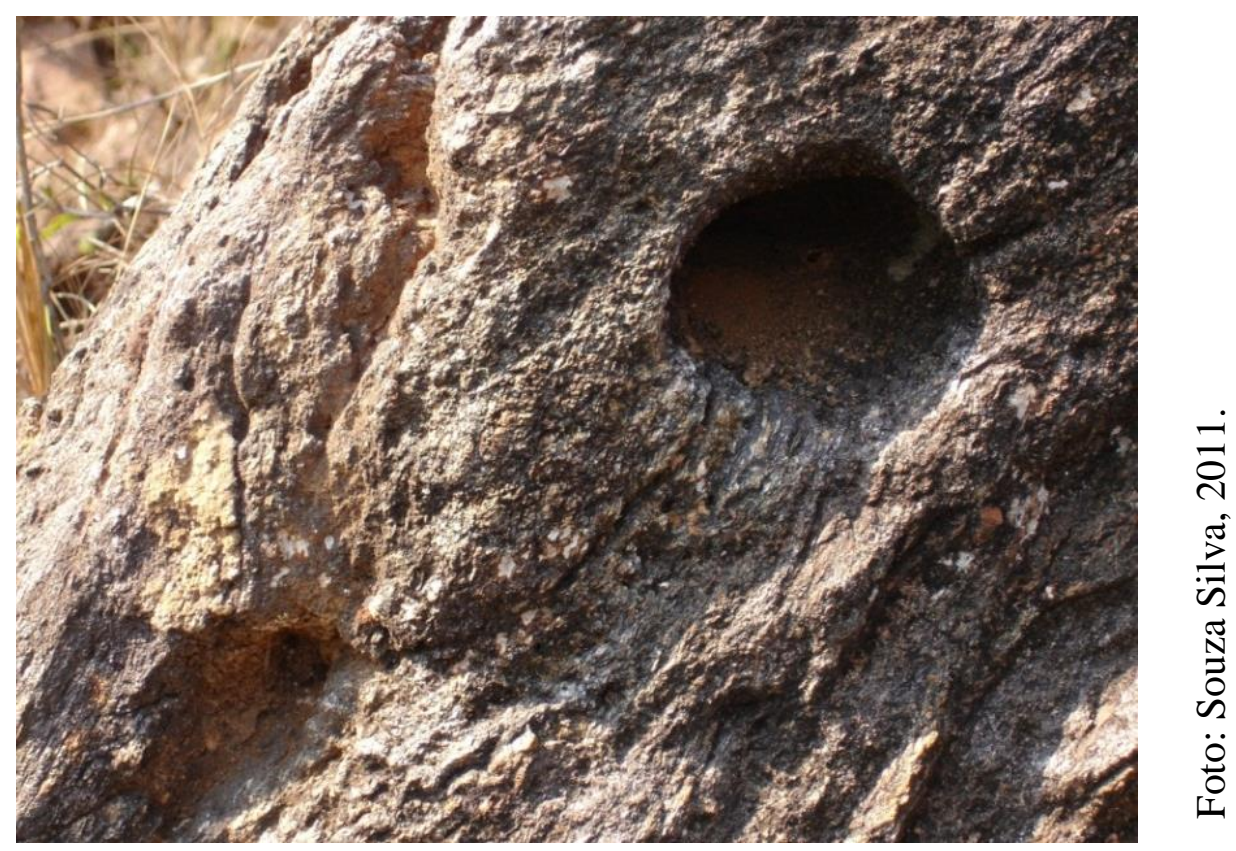

Figura 19: Furos de prospecção mineral na Mina da Soledade. 
No sítio arqueológico histórico ainda com vestígios de mineração de ouro bem preservados encontramos cinco galerias de exploração subterrâneas. A altitude dessas galerias é de 950 metros e existe a possibilidade de haver outras galerias na mata fechada.

Seguindo a trilha, chegamos a um valo aberto sobre o solo de canga que possui uma espécie de degrau, cuja parte superior tem 1,55 metros de altura da base até o nível do terreno. A forma com que se apresenta este valo sugere que os trabalhos foram interrompidos antes que adentrassem o solo e tomassem forma de galeria.

No terreno ainda existem vários sinais da exploração aurífera, inclusive voçorocas que ficam localizadas na parte mais baixa, próximas do leito do Rio Soledade e outras, na face contrária do morro que tem face voltada para o Rio Maranhão, que se estendem desde o Bairro Jardim Profeta e chegam até o trevo da Rodovia BR 040 com a MG 030, o trevo de Ouro Branco, e são resultados da exploração de veios profundos e extensos de areias auríferas dos vales dos rios e ribeirões e encostas, além do xisto argiloso aurífero.

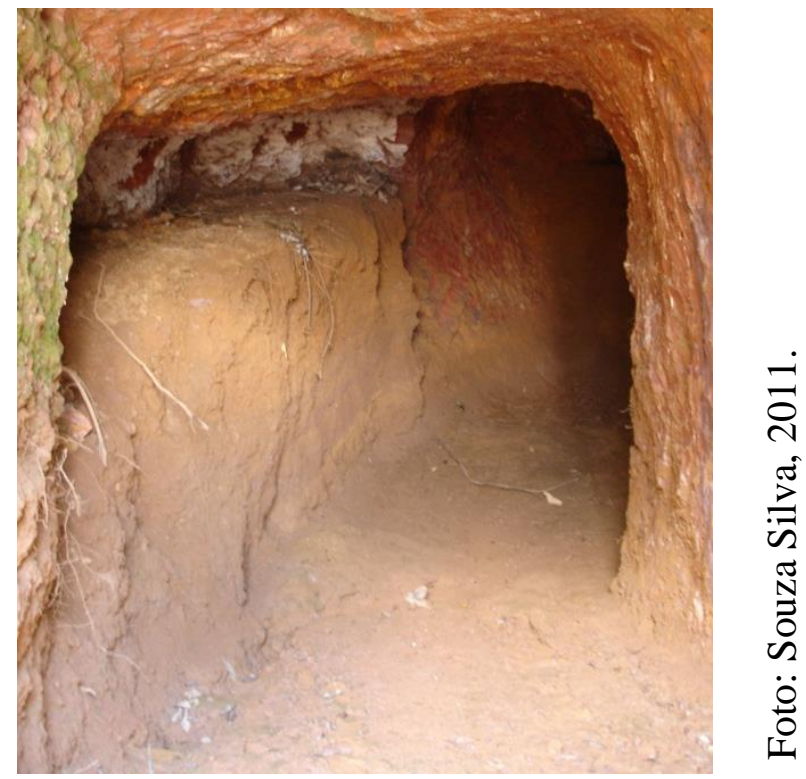

Figura 20: Galeria de exploração aurífera na Mina da Soledade.

Em 1814 a Mina da Soledade era dividida entre dois proprietários, sendo uma parte pertencente ao Coronel Mor Agostinho Lobo Leite, tinha 32 escravos e produziu 400 oitavas de ouro e a outra parte pertencente ao Coronel Nicolau Seabra, possuía 08 escravos e produziu 17 oitavas de ouro. 


\section{•EI0Z ' $\mathrm{B} \Lambda$ IIS eznos :oyuəsəd}

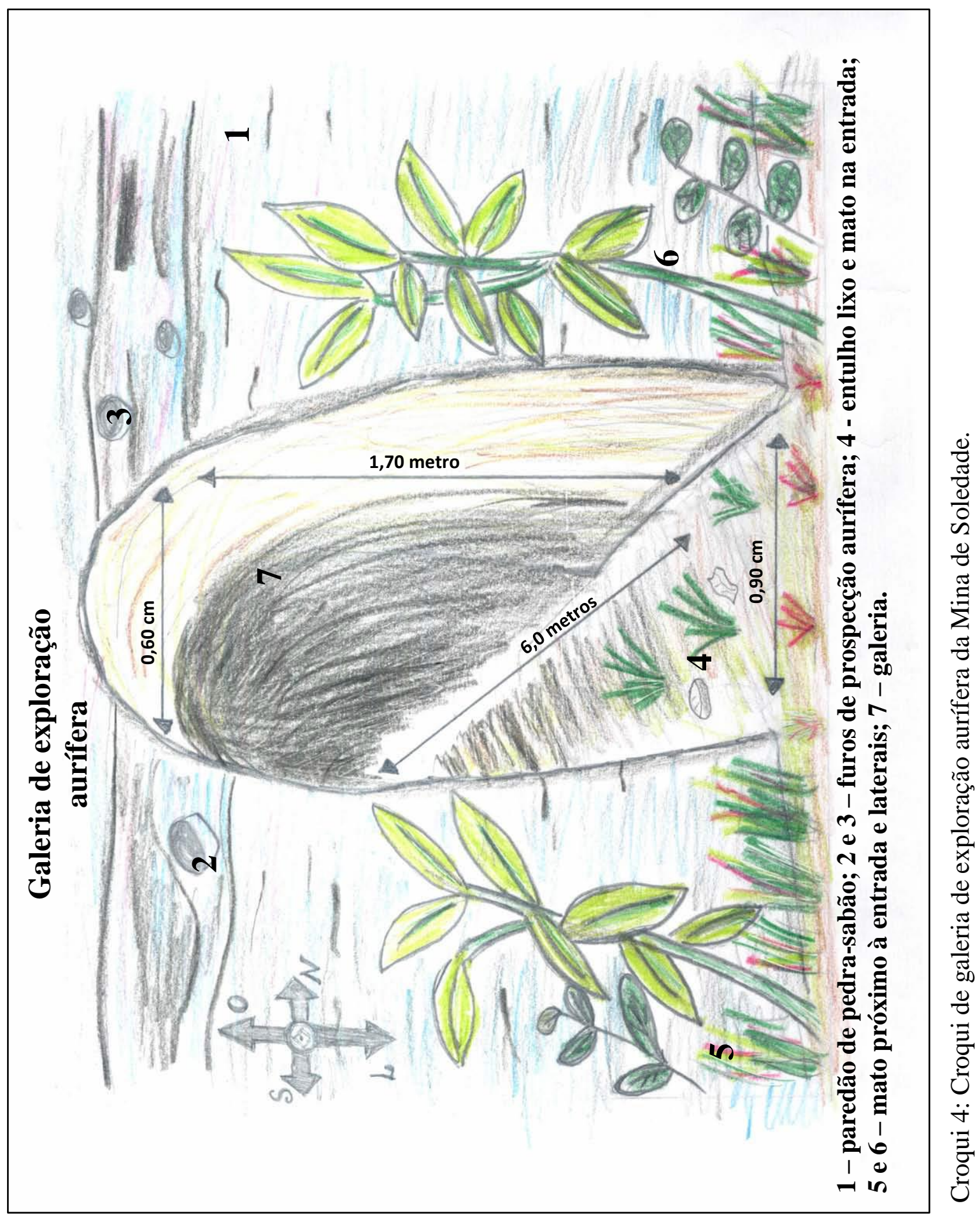




\subsection{5 - Mina das Goiabeiras}

$20^{\circ} 30^{\prime} 15.8^{\prime \prime} \mathrm{S}$

$43^{\circ} 50 ’ 16.7^{\prime \prime} \mathrm{W}$

UTM - X: 621160

UTM - Y: 7732257

A distância geodésica em relação ao ponto 0 (Basílica do Senhor Bom Jesus de Matosinhos) é 13396.504 metros, e em quilômetros é 2,5 KM. A altitude em relação ao nível do mar é de 1000(mil) metros.

Sítio arqueológico histórico que funcionou como mina de ouro, encontra-se em estado de conservação mais degradado e em grande risco, pois a Mina das Goiabeiras, que tem sido destruída principalmente pelo crescimento urbano da cidade que avança sobre o sítio arqueológico, fica muito próxima da área urbana do município de Congonhas. Alguns bairros como o Alvorada e o Santa Mônica já avançaram sobre a área da mina, além do bairro Água Boa, do terminal rodoviário de Congonhas e atualmente as obras do Condomínio Goiabeiras, que ocorre sobre uma mina de pedra-sabão de atividade secular, e de uma estrada municipal. A construção da BR 040 pelo governo federal também eliminou boa parte do contexto arqueológico da mina, que conta ainda com alguns vestígios remanescentes da mineração, resultado da retirada de areias auríferas da encosta do morro.

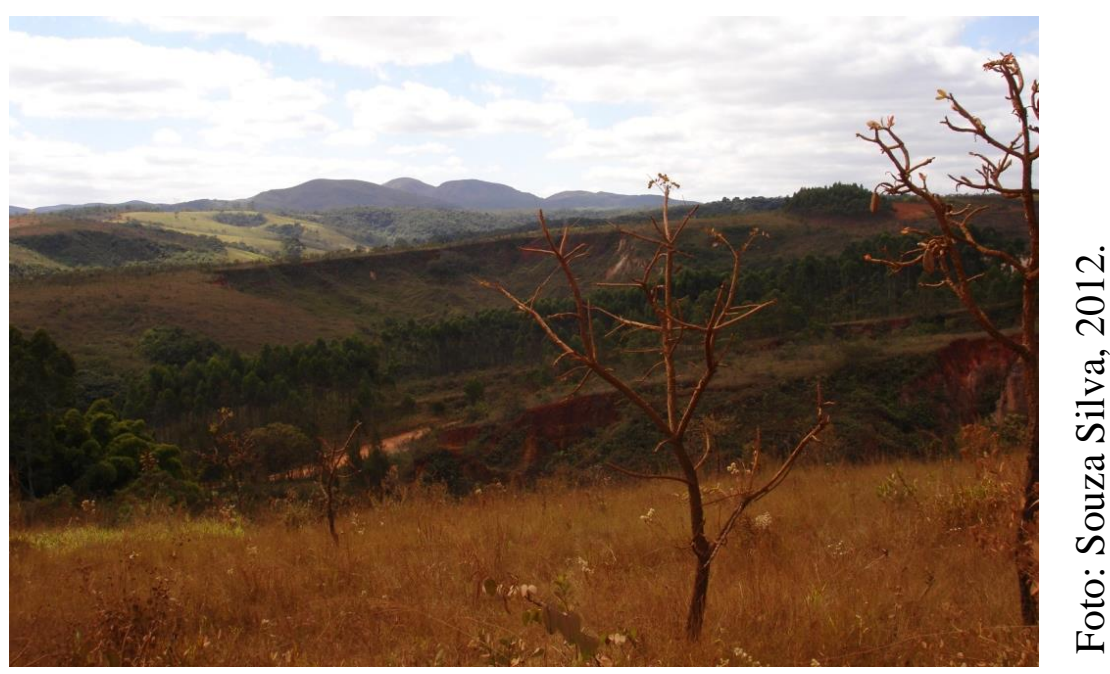

Figura 21: Mina das Goiabeiras. 
Dos vestígios arqueológicos encontrados, todas as galerias de exploração aurífera estão voltadas para a BR 040, na altura do km 612, e são resultados da exploração de veios auríferos. Existem sinais de mineração de ouro por todo o terreno.

Foram encontrados, além das galerias de exploração de ouro, voçorocas que são resultado da exploração de areias auríferas das encostas dos morros, um mundéu, utilizado na hidroclassificação ou beneficiamento do ouro, além de canal hidráulico, utilizado para desmontar as encostas com a água e levar o material aurífero para o mundéu, muros de contenção em caminhos internos da mina, além de muro de pedras sobrepostas.

De acordo com o registro de Eschwege, a Mina das Goiabeiras pertencia em 1814 a quatro diferentes mineradores. A parte que cabia ao Comandante João Ferreira da Cunha tinha 07 escravos no trabalho de garimpo e produziu 142 oitavas de ouro. A parte que cabia ao Coronel Manuel Gomes França tinha 06 escravos no trabalho de mineração e produziu em 1814 a quantia de 57,25 oitavas de ouro. As lavras do minerador Camilo Teixeira tinham 03 escravos e produziu 08 oitavas de ouro e por fim, as lavras de Dona Bárbara de Vasconcelos 07 escravos que produziram 11 oitavas de ouro e 25 faiscadores livres e 44 faiscadores escravos que produziram juntos 2.881 oitavas do metal dourado.

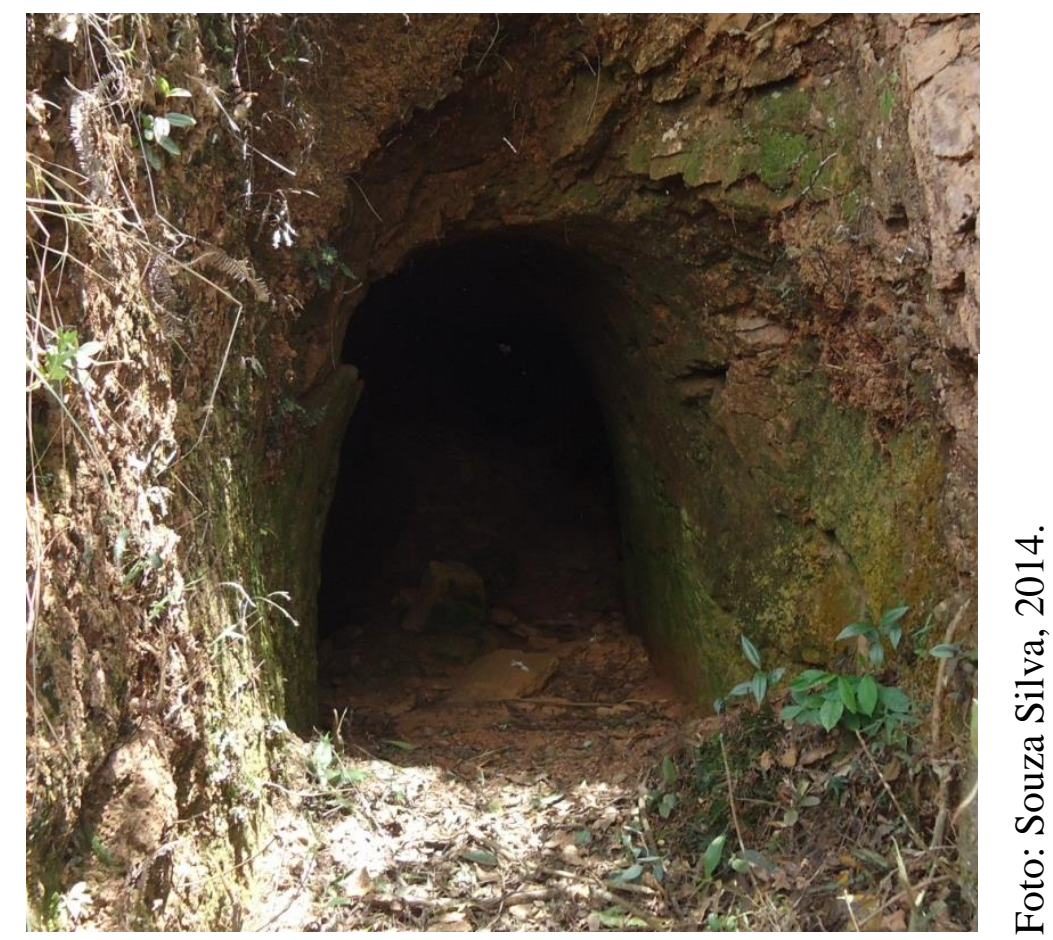

Figura 22: Galeria de exploração aurífera da Mina das Goiabeiras. 


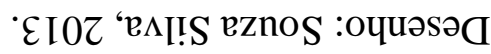

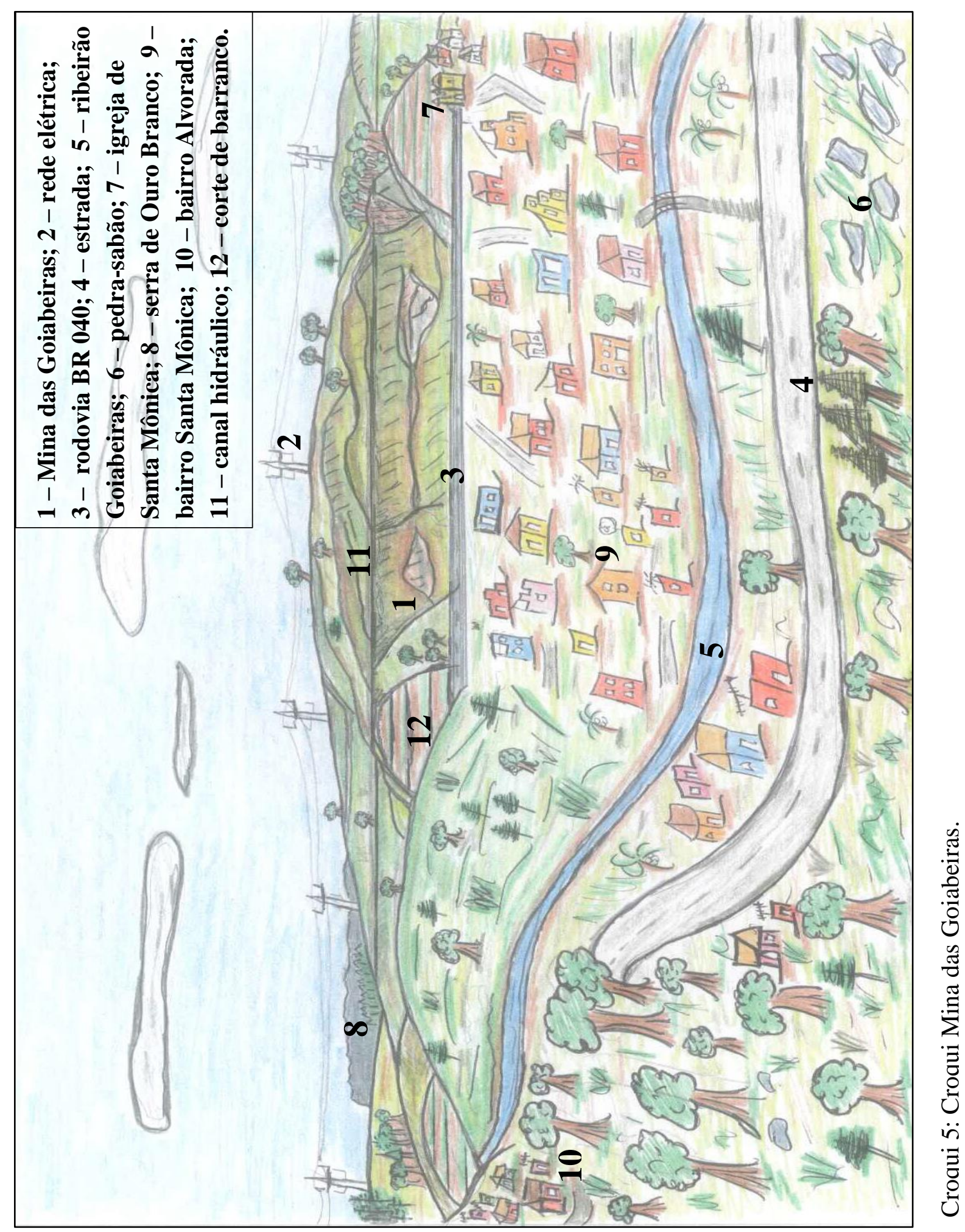




\subsubsection{1 - Galeria em propriedade do Senhor José Miguel Catharina}

$20^{\circ} 31 ' 24.6 " \mathrm{~S}$

$43^{\circ} 48^{\prime} 53.8^{\prime \prime} \mathrm{W}$

UTM X: 623555

UTM Y: 7730131

Dentre os sítios arqueológicos registrados em Congonhas, incluímos uma área de exploração aurífera no Bairro Jardim Profeta, de propriedade do Senhor José Miguel Catharina, onde existe uma galeria de exploração aurífera de 15 metros de comprimento, medindo 1,80 metros de altura e 0,90 centímetros de largura, que possui duas entradas e saídas, uma delas em parte assoreada por conta de desbarrancamento, sendo ainda possível atravessá-la de um lado a outro das extremidades. Foi encontrada também uma parte de um canal hidráulico, e uma voçoroca, resultado da extração de areias auríferas e uma cascalheira revolvida, ambos localizados na margem direita do Córrego dos Macaquinhos.

Na margem esquerda do Córrego dos Macaquinhos existe uma cava que acompanha toda a margem por uma distância de 330 metros, que se tornou um caminho onde ainda é possível ver os sinais das ferramentas que cavaram todo o terreno na tentativa de extrair o ouro misturado ao xisto argiloso aurífero.

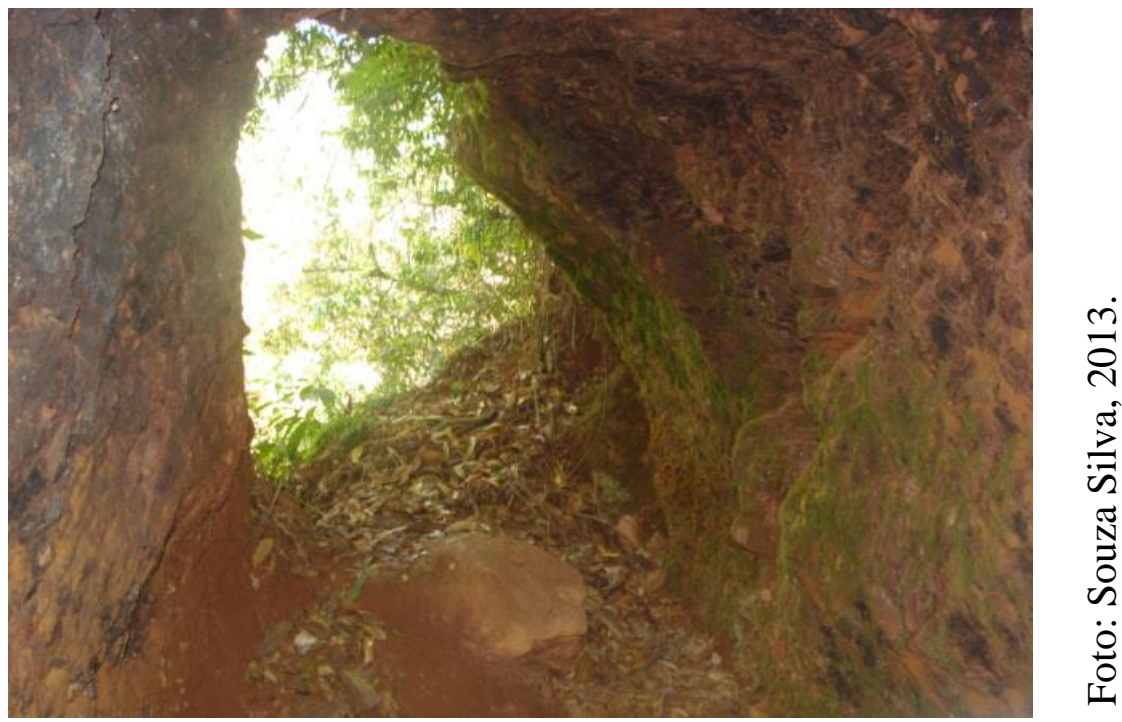

Figura 23: Entrada assoreada de galeria em propriedade do Senhor José Miguel Catharina. 
O sítio arqueológico, que fica em uma propriedade do Senhor José Miguel Catharina, que tem interesse em preservar ou vender o sítio para preservação, fica localizado bem próximo à Mina de Soledade, porém acreditamos que faz parte do sítio arqueológico Mina das Goiabeiras, porque está localizado ao lado do Córrego dos Macaquinhos, do lado direito de sua margem. Bem ao lado do sítio arqueológico existe também um trecho do Caminho Velho da Estrada Real, que em tempos coloniais ligava o Arraial das Congonhas do Campo ao Arraial de Soledade, ladeando a margem esquerda do Córrego dos Macaquinhos, na altura da Mina da Soledade.

O estado de conservação do sítio é razoável, tendo em vista que o Bairro Jardim Profeta surgiu e cresceu durante anos, sem que fosse feito algum trabalho no sentido de preservar os vestígios arqueológicos históricos coloniais do garimpo, porém, o sítio fica localizado em local estratégico, próximo à Estrada Real e ao bairro, sendo de fácil acesso para crianças, idosos, deficientes físicos, que geralmente têm maiores dificuldades de acesso a locais íngremes, terrenos irregulares e de grandes extensões territoriais.

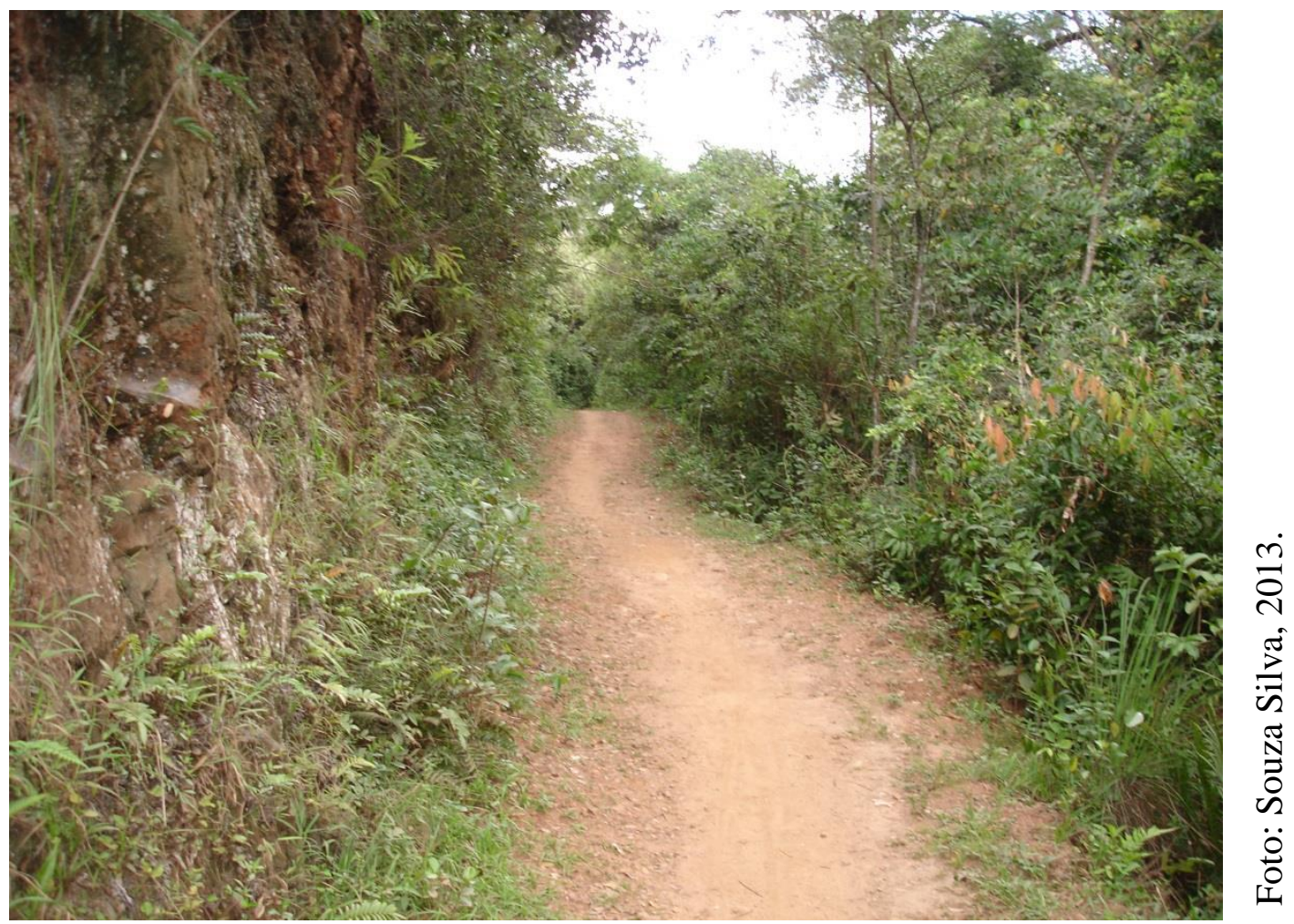

Figura 24: Caminho próximo à galeria de extração aurífera em propriedade do Senhor José Miguel Catharina. 


\subsection{6 - Mina do Redondo}

$20^{\circ} 34^{\prime} 17.3 ” \mathrm{~S}$

$43^{\circ} 50$ '24.6” W

UTM - X: 620884

UTM - Y: 7724840

A distância geodésica em relação ao ponto 0 (Basílica do Senhor Bom Jesus de Matosinhos) é 18694.422 metros, e em quilômetros é 6,9 KM. A altitude da mina em relação ao nível do mar é de 960 metros.

Em termos de funcionalidade, os vestígios arqueológicos como galeria de exploração de subterrânea e as voçorocas que resultaram da exploração de areias auríferas das encostas indicam que o local funcionou como mina de exploração e beneficiamento de ouro.

A Mina do Alto Maranhão ou Mina do Redondo já estava parcialmente destruída pela construção de uma rodovia estadual quando tivemos notícia de sua existência. No local foi destruída por completo uma galeria de cerca de 20,0 metros de comprimento e uma voçoroca resultante da extração das areias auríferas da encosta do morro foi parcialmente destruída pela obra, que também destruiu estradas e trilhas seculares naquela área, onde segundo a historiografia os mineradores do ouro atingiram primeiramente a região que deu origem ao município de Congonhas.

Não temos ainda informações mais precisas a respeito da mina, de seus proprietários, de quem nela trabalhou e tampouco a respeito da quantidade de ouro extraída nela. A grande voçoroca que ali ficou da exploração aurífera, com 1.000 metros de comprimento e chega a atingir 200 metros de largura sugere que foi grande a quantidade de ouro ali produzido e numeroso o número de trabalhadores escravos ocupados em sua cata.

\subsubsection{1 - Fonte do Alto Maranhão}

$20^{\circ} 33^{\prime} 49.959^{\prime \prime} \mathrm{S}$

$43^{\circ} 51^{\prime} 23.989 ” \mathrm{~W}$ 
UTM-X: 619170

UTM-Y: 7725691

No distrito de Alto Maranhão existe ainda um pequeno chafariz, chamado apenas de "fonte" pelos moradores do distrito.

A fonte está localizada numa altitude de 960 metros em relação ao nível atual do mar. A distância em quilômetros é de 5,5 KM em relação ao ponto 0 (Basílica do Senhor Bom Jesus de Matosinhos).

Esta fonte funcionou como um ponto de abastecimento hídrico, pois a água encanada ainda não era uma realidade nas Minas em tempos de colônia, cabendo aos escravos buscarem e carregarem a água sobre os ombros em tonéis, para suprirem essa necessidade de seus senhores, que a utilizavam para higiene diária e para os serviços domésticos.

É possível que na fonte também fossem feitos trabalhos como a lavagem de roupas e de outros tipos de peças de tecido, como as roupas de cama e de mesa, pertencentes às famílias do distrito de Alto Maranhão nos tempos da colônia.

As medidas das paredes da fonte variam entre 3,80 metros de largura por 1,0 metro de altura. O diâmetro da parede varia entre 20 centímetros na parte menos espessa a 50 centímetros na parte mais espessa.

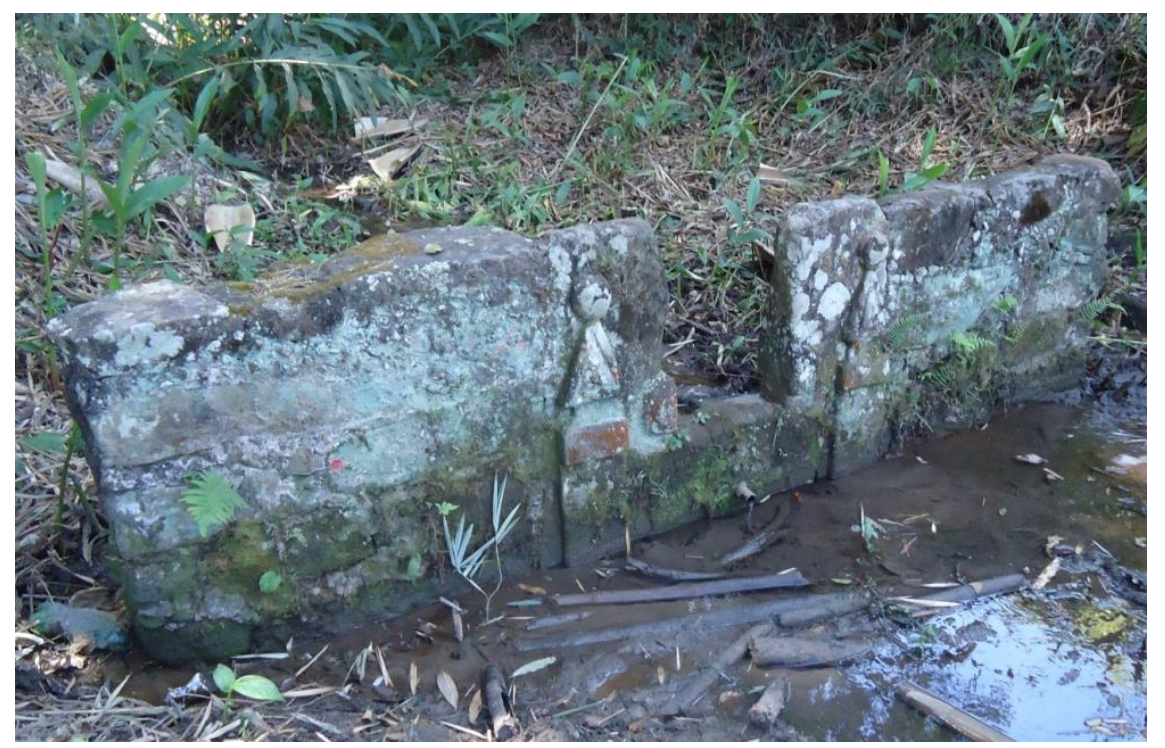

Figura 25: Fonte do Alto Maranhão. 
O chafariz é composto por uma parede que possui um rebaixamento central com duas esculturas laterais, com medidas de 80 centímetros e forma de triângulo sobre uma espécie de pedestal retangular e com uma espécie de esfera sobre a ponta do triângulo.

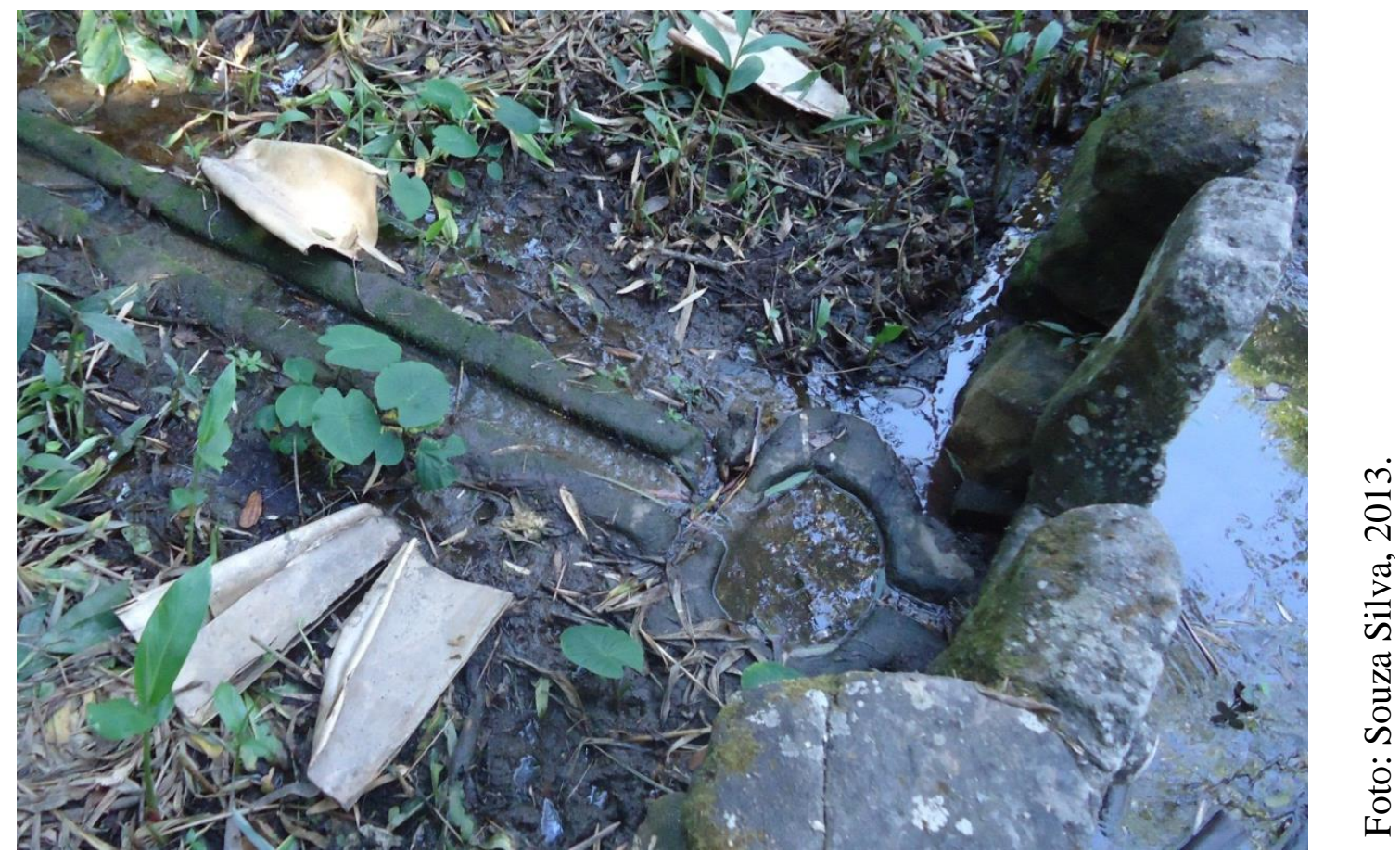

Figura 26: Parte interna da fonte do Alto Maranhão.

Do lado externo da parede, na parte central inferior da mesma, existe uma pequena saída d'água por um cano de 1/2 polegada e na parte inferior interna existe um bojo de pedra medindo $70 \mathrm{~cm}$ X $90 \mathrm{~cm}$ e 8 centímetros de profundidade, que concentra a água vinda da nascente, que fica a 20 metros da fonte e que chega por uma canaleta de 40 centímetros de largura e com 5 metros visíveis sobre o solo, com o restante da canaleta assoreado pela ação de lama, folhas de árvores e de um bambuzal que cresceram em seus arredores.

A mesma nascente também abastece atualmente as casas do distrito. A água é bombeada para cima por meio de bomba hidráulica elétrica, já que o chafariz está localizado 30 metros mais baixo do que as casas mais próximas. Seu acesso se dá por uma pequena estrada de inclinação considerável e sem pavimentação. 


\subsubsection{2 - Cadeia do Alto Maranhão}

\subsubsection{1 - Edificação menor}

$20^{\circ} 33^{\prime} 42.017^{\prime \prime} \mathrm{S}$

$43^{\circ} 51^{\prime} 29.598^{\prime \prime} \mathrm{W}$

UTM-X: 619013

UTM-Y: 7725935

A altitude da edificação da cadeia do Alto Maranhão em relação ao nível do mar é de 990 metros e a distância em quilômetros em relação ao ponto 0 (Basílica do Senhor Bom Jesus de Matosinhos) é de 5,1 KM.

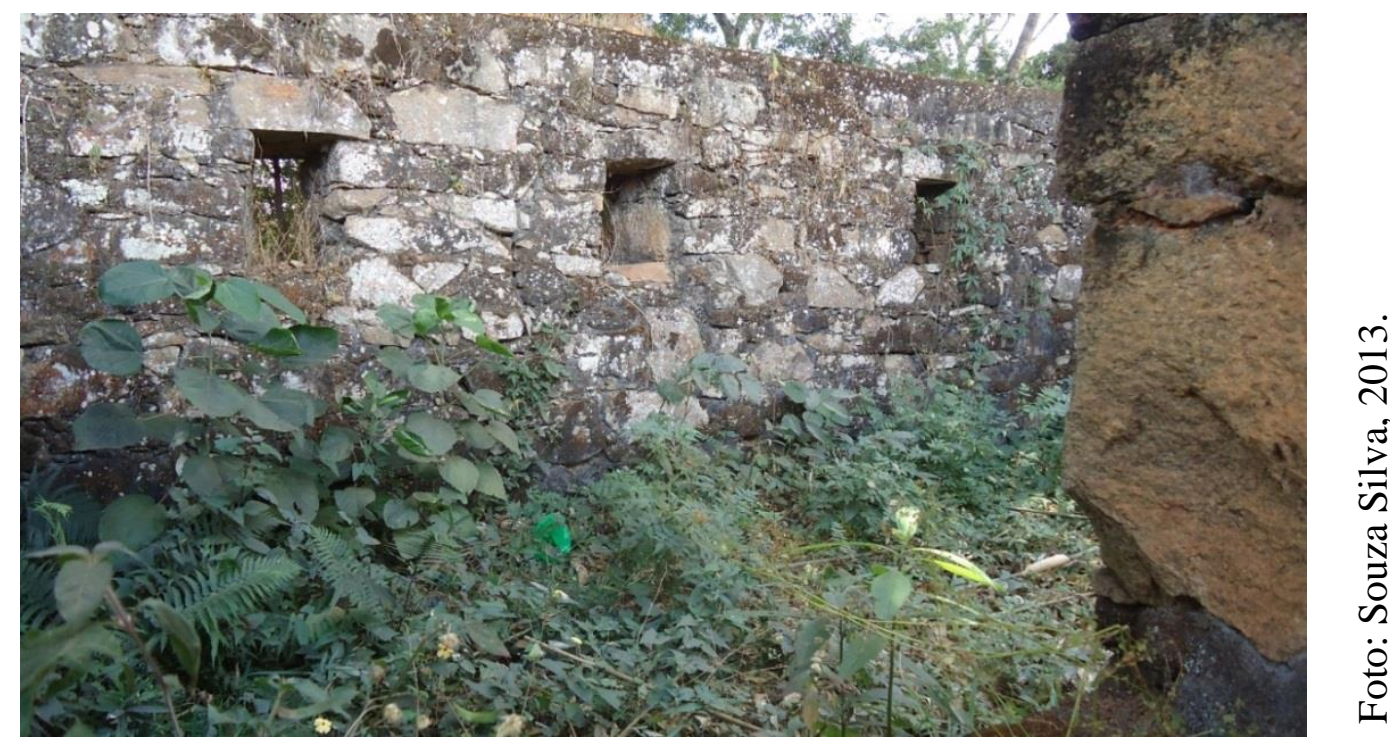

Figura 27: Interior da Cadeia do Alto Maranhão (século XVIII).

No distrito de Alto Maranhão também há ruínas de edificações, feitas em pedras sobrepostas. O local funcionou como cadeia e possivelmente, de acordo com moradores do bairro que não quiseram se identificar, foi construída para prender envolvidos na Guerra dos Emboabas (1707-1709), quando da ocorrência de batalhas na região de Congonhas do Campo. 
São duas edificações. A menor e mais conservada tem alturas que variam entre 2,63 metros na quina frontal esquerda e 2,50 metros na quina frontal direita e a mesma medida temos nas duas quinas esquerda e direita dos fundos. Suas laterais medem 5,70 centímetros enquanto a parte da frente e a dos fundos possuem medidas de 9,0 metros. As paredes de pedras sobrepostas tem 60 centímetros de espessura.

As janelas, no total de 9 (nove), ainda possuem as barras verticais de ferro colocadas para dificultarem a fuga dos presos que ali foram mantidos. A edificação possui apenas uma porta frontal, na qual foi colocado um portão de latão para impedir a entrada de curiosos.

\subsubsection{2 - Edificação maior}

$20^{\circ} 33^{\prime} 39.150^{\prime \prime} \mathrm{S}$

$43^{\circ} 51^{\prime} 33.689 ” \mathrm{~W}$

UTM-X: 618895

UTM-Y: 7726028

A distância em quilômetros em relação ao ponto 0 (Basílica do Senhor Bom Jesus de Matosinhos) é de 5,0 KM e a altitude em relação ao nível do mar é de 990 metros.

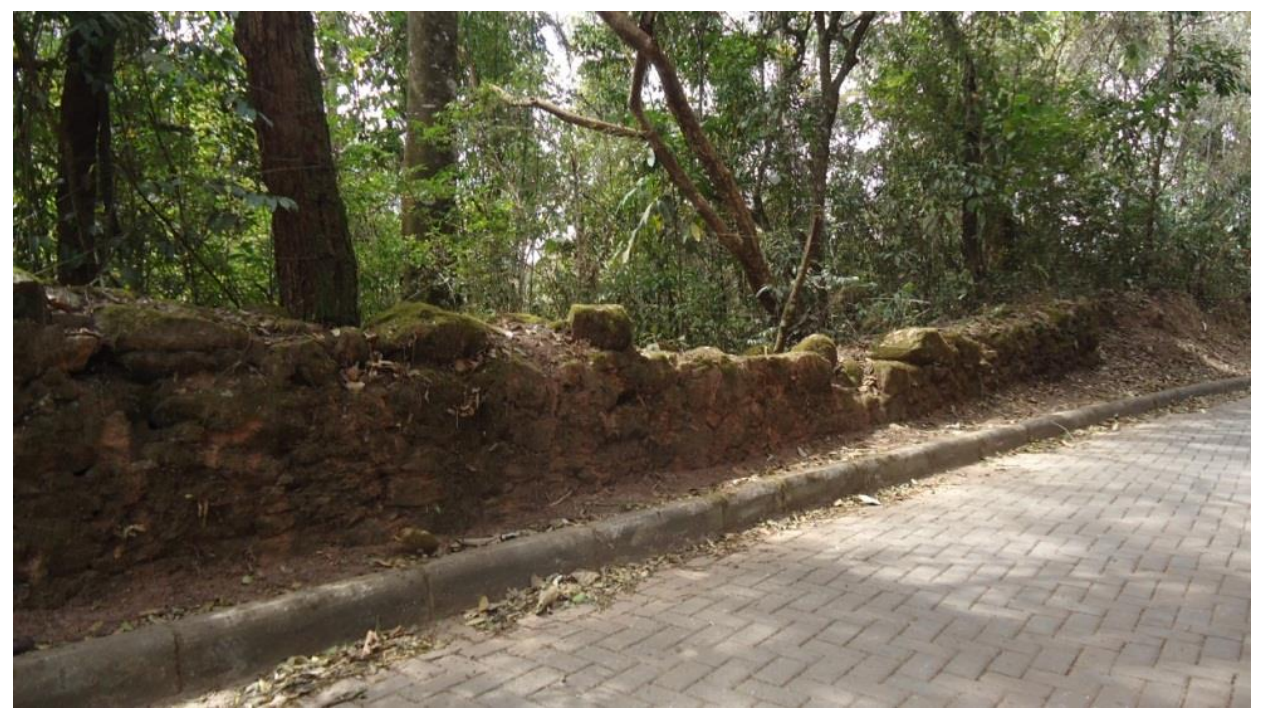

Figura 28: Muro da Cadeia do Alto Maranhão. 
A outra parte da cadeia está ligada à primeira por uma muralha de pedras sobrepostas quase que totalmente destruída, medindo 100 metros de cumprimento e chegando a 1,5 metros no ponto mais alto. A edificação encontra-se em processo de arruinamento por conta do mato e das árvores que crescem em seu interior e sobre suas paredes, fica numa bifurcação da Estrada Real e é um dos acessos mais antigos de Congonhas ao distrito do Alto Maranhão e à cidade vizinha de São Brás do Suaçuí.

A parte frontal da edificação em ruínas fica de frente para a mesma parte da Estrada Real que a edificação menor, tem medida de 12 metros enquanto que parte lateral tem medida de 17,5 metros. As paredes de pedras sobrepostas tem 80 centímetros de diâmetro. Sua altitude em relação ao nível atual do mar é de 990 metros.

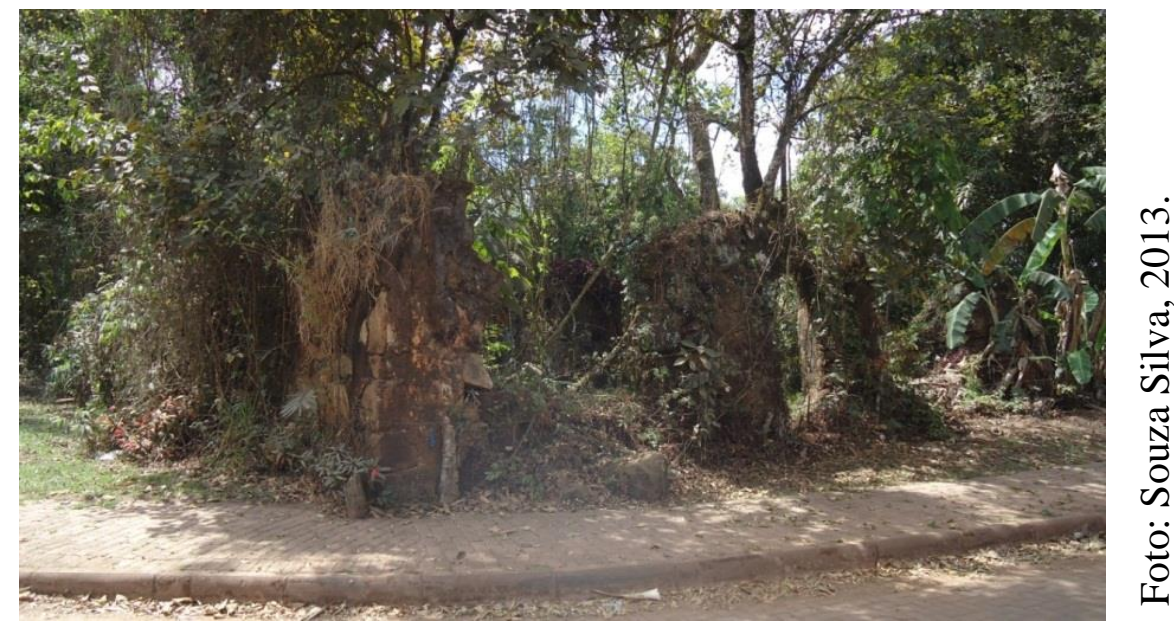

Figura 29: Ruínas da Cadeia do Alto Maranhão (século XVIII).

Este sítio arqueológico é bem conhecido pela população de Congonhas, pois fica localizado à margem da Estrada Real, no acesso entre a sede municipal de Congonhas e o distrito de Alto Maranhão. Este distrito é muito visitado pelos moradores da sede municipal, quando todos os anos, no dia 15 do mês de agosto, ocorre um feriado municipal e a tradicional festa do Alto Maranhão, em homenagem à padroeira do distrito que é Nossa Senhora da Ajuda.

Ainda não possuímos uma delimitação de área mais precisa de todos os sítios arqueológicos registrados na pesquisa. Para obtenção de limites precisos dos territórios das minas de Congonhas, será preciso ainda uma avaliação de documentação histórica e cartográfica da região para buscar por delimitações precisas. Este trabalho encontra-se em andamento e ainda 
não apresentou resultados que possam elucidar a respeito das divisas e medidas exatas dessas minas de ouro.

Dos sítios arqueológicos apresentados, nenhum deles escapa aos riscos de destruição rápida e silenciosa, o que de fato a história recente do município já apresenta com clareza, mostrando a urgência da organização de um meio de gestão do patrimônio arqueológico no município, capaz de ao mesmo tempo resolver os problemas que já ocorreram, prevenir das destruições futuras e cuidar para que o patrimônio arqueológico ainda existente seja manejado de forma que possa gerar educação e conhecimento para a população detentora do patrimônio.

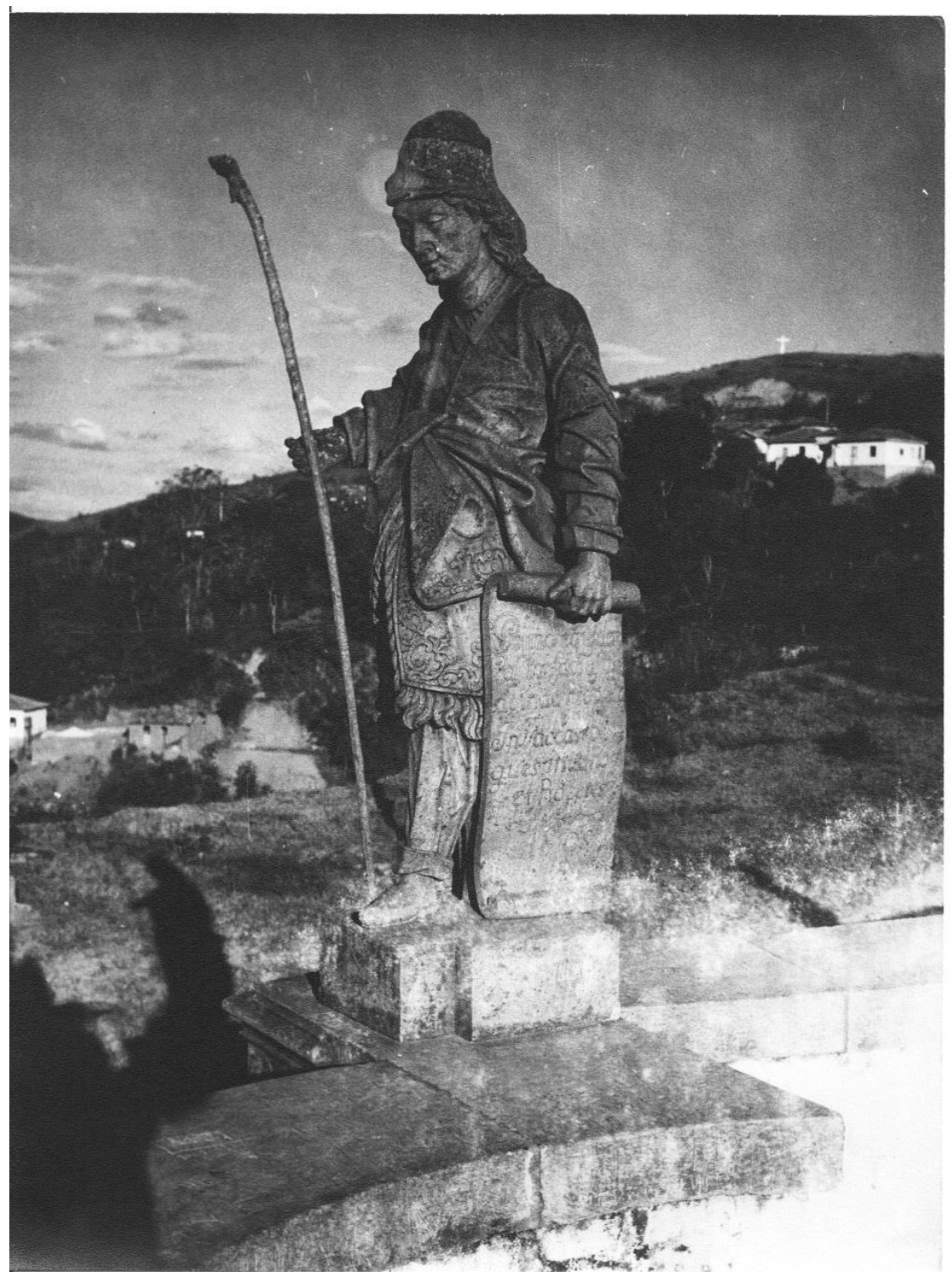

Figura 30: Aleijadinho: Profeta Amós (século XIX) e o Morro de Maranhão ao fundo. 
†t IOZ ' $\mathrm{k} \Lambda$ IIS eznos :oчuəsəd

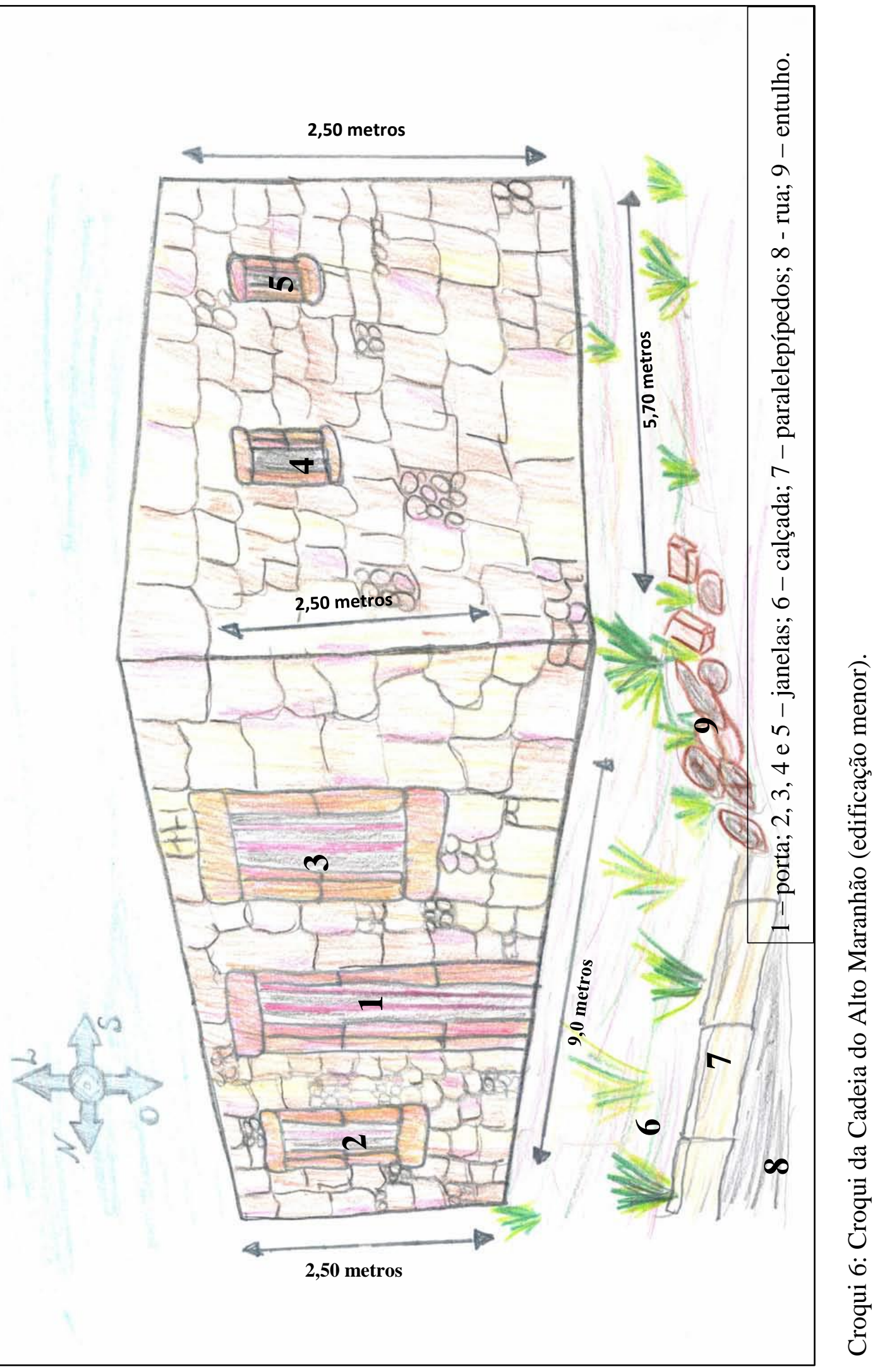




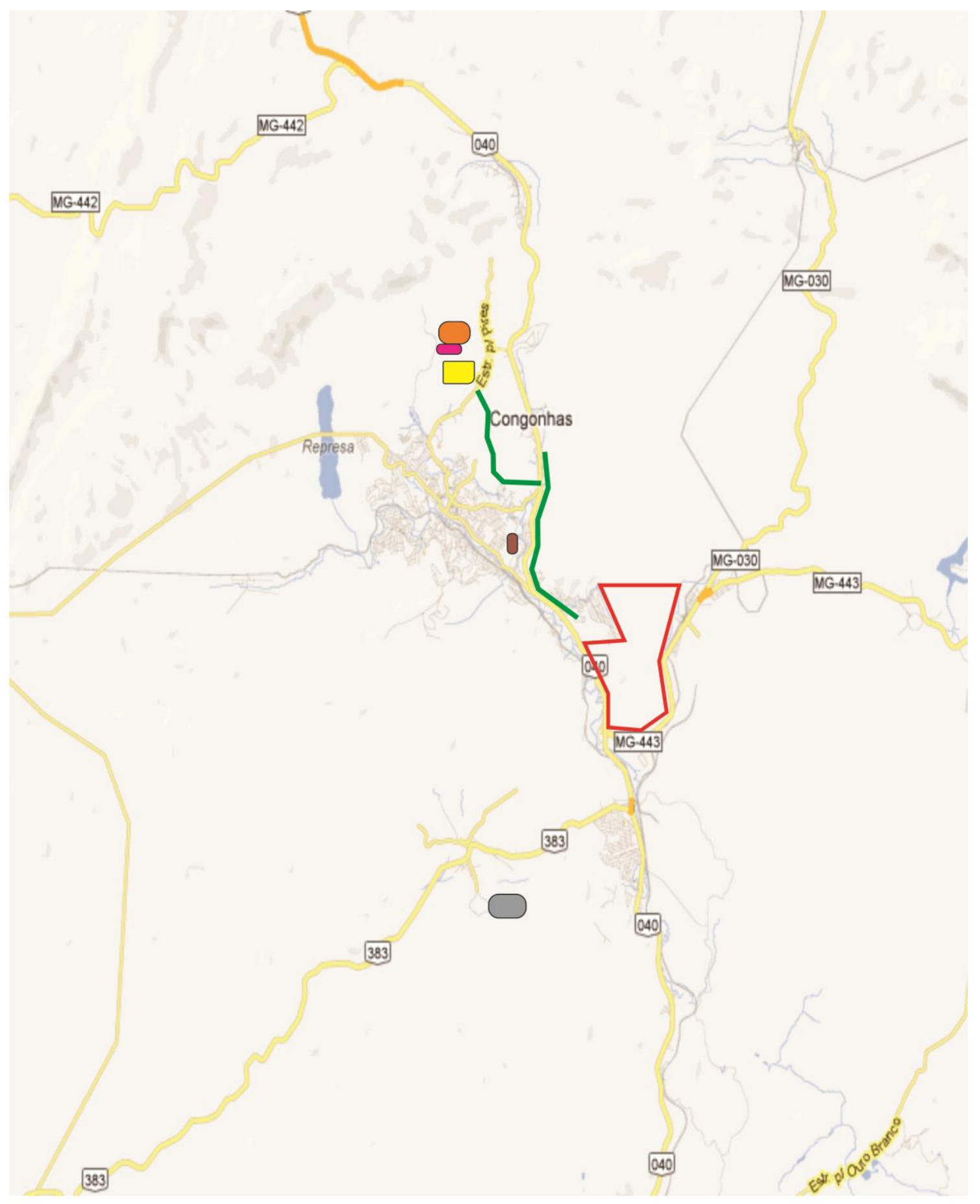

Mina do Alto Maranhão

Goiabeiras

- Igreja Santo Antônio

Fazenda do Faria

Mina do Veeiro

Velhos Caminhos de Congonhas (Rota do Ouro)

Mina da Soledade

Mapa 05: Sítios arqueológicos ao longo dos velhos caminhos de Congonhas, sobre mapa Google Maps. 
Papel vegetal com mapa de sítios plotados 


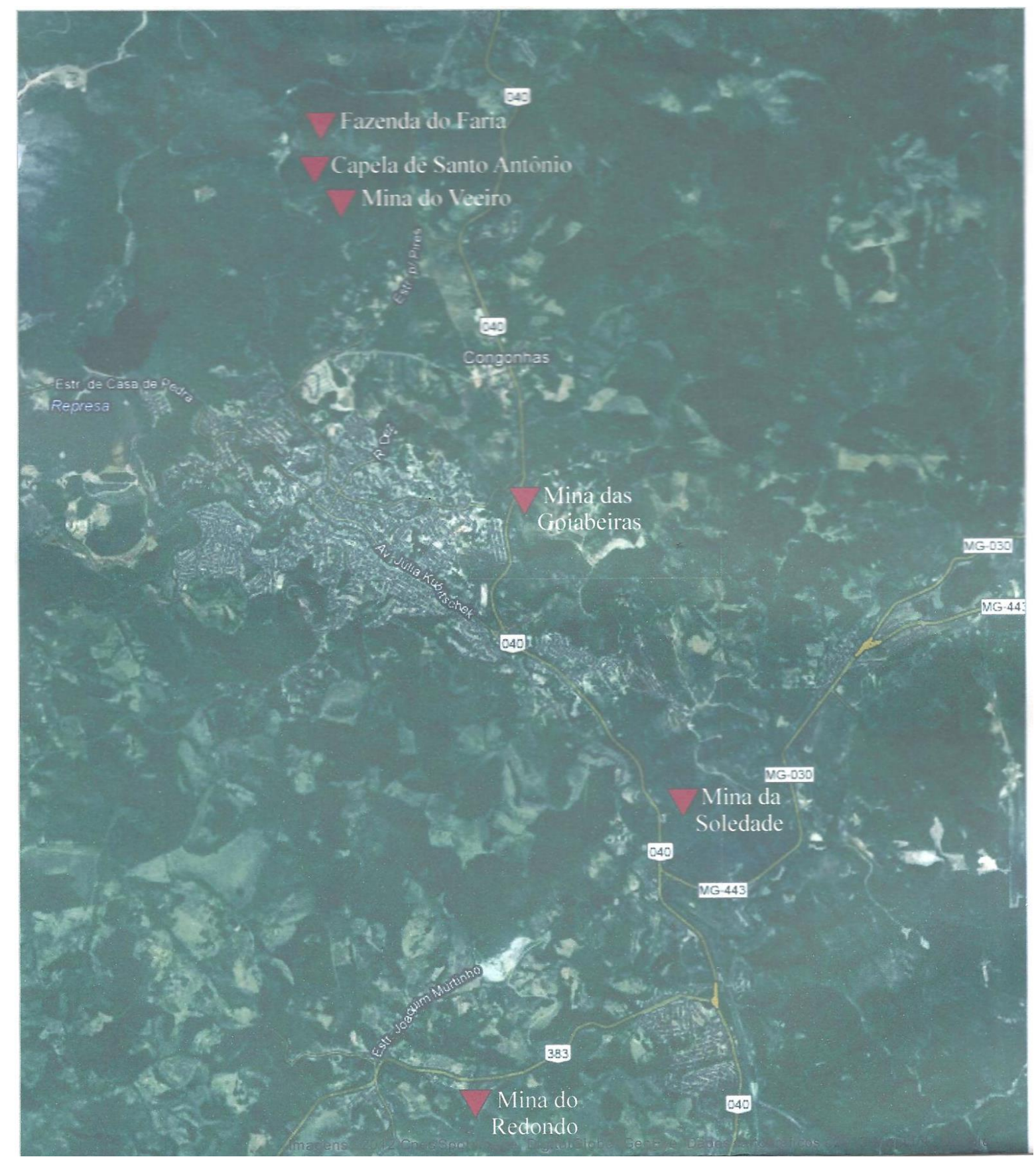

Mapa 06: Sítios arqueológicos registrados ao longo dos velhos caminhos de Congonhas sobre mapa Google Maps. 


\section{Capítulo 5: As perspectivas abertas com a pesquisa}

\section{1 - Sobre os referenciais coletados}

Com os trabalhos de coleta de referenciais considerados concluídos, apresentaremos os resultados que acreditamos que nos ajudarão a formular uma proposta de Educação Patrimonial e musealização dos sítios arqueológicos de Congonhas, levantados na pesquisa de mestrado intitulada "Os velhos caminhos de Congonhas numa perspectiva de Educação Patrimonial".

Durante os estudos de comunicação, recepção e avaliação realizados, foram levantadas algumas hipóteses acerca do alcance deste estudo como fonte de referenciais para a formulação da proposta, frente à realidade vivida no município de Congonhas quanto às questões como a destruição sistemática e a preservação de sítios arqueológicos para finalidades educacionais e usufruto da população local.

A primeira hipótese levantada foi quanto ao papel do Poder Público, e a pergunta feita foi a seguinte: como fazer com que as atenções se voltem para o patrimônio arqueológico de forma que diferentes órgãos e instituições possam trabalhar de forma integrada na sua promoção e proteção?

Neste sentido, o Poder Público tem atuado através da Secretaria Municipal de Patrimônio, que passou a exigir a inclusão dos estudos arqueológicos nos estudos de impacto ambiental e relatórios de impacto ambiental (EIA/RIMA) quando das obras que possam causar impactos negativos sobre o meio ambiente e sobre o patrimônio arqueológico.

Também o Ministério Público de Minas Gerais (MPMG) está atuando em consequência dos acontecimentos que causaram a destruição de sítios arqueológicos e mantém-se, por meio de sua Promotoria de Justiça, fiscalizando os acontecimentos e punindo as empresas responsáveis pela não observância da legislação.

O MPMG também contratou uma empresa que atua no ramo da Arqueologia de Contrato chamada Artefatto Consultoria, para trabalhar na elaboração de uma carta arqueológica para Congonhas, que será a primeira no Estado de Minas Gerais, com a finalidade de mapear, e também publicar na Internet a localização dos sítios arqueológicos de Congonhas para a 
informação de empresas, empreendedores e pelo próprio Poder Público, quando da realização de grandes obras impactantes ao patrimônio arqueológico do município. O MPMG passou a trabalhar em parceria com a pesquisa "Os velhos caminhos de Congonhas numa perspectiva de Educação Patrimonial" para a produção da Carta Arqueológica de Congonhas, no intuito de somar informações e ganhar tempo para a produção do referido documento.

Outra resposta muito positiva foi quanto à participação da Prefeitura Municipal de Congonhas, que tem policiado com mais firmeza nas questões envolvendo a Arqueologia e o patrimônio arqueológico do município, através de sua Diretoria Municipal de Patrimônio, que tem exigido a legalidade e o cumprimento da legislação patrimonial quando da execução das obras lesivas ao meio ambiente, refletindo em estudos arqueológicos, prevenção e preservação. A Diretoria Municipal de Patrimônio aumentou sua articulação e seu diálogo com outras secretarias municipais, apoiado as pesquisas, trabalhado nas três esferas do Poder $^{56}$ e formado parcerias _ inclusive conosco e com nossa pesquisa _, que possam resultar na preservação do patrimônio arqueológico, considerando sua importância para a educação dos cidadãos congonhenses e para as gerações futuras.

A outra parte que muito nos interessa para a produção desta proposta se refere às opiniões da população detentora do patrimônio arqueológico acerca de seu patrimônio e quanto ao destino que pode ser dado a ele. Uma das hipóteses levantadas foi quanto ao papel população na promoção participativa do patrimônio arqueológico: ela pode fornecer referenciais confiáveis e necessários que nos ajudem a formular uma proposta de Educação Patrimonial permanente que proporcione a preservação e ressignificação de sítios arqueológicos para finalidades educacionais como forma de Arqueologia Preventiva?

Acreditamos que a resposta que obtivemos da população congonhense foi muito positiva e satisfatória, tanto qualitativamente quanto quantitativamente. Tanto os trabalhos preliminares realizados na Escola Municipal de Ensino Fundamenta Conceição Lima Guimarães, quanto os trabalhos posteriores realizados na Escola Estadual Barão de Paraopeba, Escola Estadual Lamartine de Freitas e também os trabalhos de coleta de referenciais junto à população em parceria com a ONG Gota d'água do Alto Paraopeba, nos proporcionaram resultados positivos e os participantes demonstraram muito interesse pelo tema proposto.

Qualitativamente as respostas em geral nos agradaram porque as pessoas demonstraram grande desejo de conhecer mais a respeito do patrimônio arqueológico do município,

\footnotetext{
${ }^{56}$ Poder Legislativo, Poder Executivo e Poder Judiciário.
} 
demonstrando também que são favoráveis que o desenvolvimento socioeconômico de Congonhas ocorra com os cuidados necessários à preservação dos remanescentes do passado. Suas respostas foram bem contundentes e suas opiniões podem contribuir muito para futuros projetos na área de Arqueologia em Congonhas.

Quantitativamente, os números mostraram que os entrevistados são absolutamente favoráveis à preservação de seu patrimônio arqueológico para finalidades educacionais, números que, como o demonstrado pela pesquisa, chegaram a atingir os $100 \%$ (cem por cento) entre os participantes, como na participação dos alunos da turma $7^{\circ}$ ano Gentileza, nas respostas das questões 1, 2, 3, 4 e 5, da turma $8^{\circ}$ ano Amor, nas respostas das questões 2, 3, 4 e 5, ambas da Escola Estadual Barão de Paraopeba e da turma $3^{\circ}$ ano E da Escola Estadual Lamartine de Freitas, nas respostas das questões 2, 3, 4, e 5 .

No que diz respeito aos dados quantitativos levantados nas escolas, o ponto negativo se deve à falta de frequência dos alunos na escola, já que muitos alunos que participaram ou desenvolveram atividades não responderam ao questionário porque faltaram à aula. Em outros casos, alunos que responderam o questionário não participaram ou desenvolveram atividades porque faltaram à aula no dia de atividades, porém, estes são problemas comuns nas escolas. Isto também influenciou qualitativamente nas respostas.

Ainda tratando dos dados quantitativos, o que chamou atenção também foi quanto ao envolvimento reduzido da população de Congonhas fora da escola, que muitas vezes se omitiu em responder o questionário, às vezes se negando a respondê-lo durante as abordagens e na maioria dos casos se comprometendo a respondê-lo, levando-o consigo, porém, não devolvendo para a avaliação das respostas.

E ainda, em se tratando da participação da população de Congonhas, levantamos outras hipóteses das quais surgiram a seguinte questão: será possível, com a aplicação deste estudo de comunicação, recepção e avaliação, contribuirmos no processo educacional dos participantes de forma a conseguirmos outros resultados que não sejam somente a participação e coleta de referenciais que apoiem na formulação da proposta de Educação Patrimonial e reutilização de sítios arqueológicos para a educação?

Acreditamos que esta tenha sido a parte mais satisfatória de todo a pesquisa de comunicação, recepção e avaliação porque em geral, todos os alunos e professores, além dos cidadãos que responderam ao questionário, demonstraram muito contentamento ao terem o patrimônio 
arqueológico incluído entre os referenciais que explicavam a história de Congonhas, de seu povo e da paisagem local.

No geral, os alunos demonstraram grande interesse pela Arqueologia e pela Arqueologia Histórica, o que segundo os professores que participaram das atividades educativas desenvolvidas nas escolas, se refletiu em mais atenção dos alunos em sala de aula, interesse em trabalhar com as disciplinas parceiras e em desenvolverem atividades relacionadas ao patrimônio arqueológico e outros referenciais culturais e históricos. Tudo isso acabou se refletindo em melhores notas e numa educação qualitativamente melhor.

Quanto à população em geral, todos que tiveram a oportunidade de participar dos trabalhos realizados na sede da ONG Gota d'água do Alto Paraopeba, mesmo os que não responderam ou devolveram o questionário respondido, teceram muitos elogios à nossa atitude de enfrentamento da situação arqueológica de Congonhas e demostraram muita satisfação em perceberem a história local pela via proporcionada pelo patrimônio arqueológico, se tornando também cidadãos mais conscientes quanto à importância de sua participação na história e de seu direito e dever de proteger os referenciais do passado.

Contudo, estivemos atentos ao longo da realização desta pesquisa para tentarmos responder às questões e hipóteses previamente levantadas e também elencar e incluir dados inesperados que viriam a surgir no decorrer do processo e que poderiam de alguma forma prestar sua contribuição com o processo educativo.

Neste sentido, o que mais nos surpreendeu foi a recepção que teve a equipe de pedagogos, professores e alunos da Escola Estadual Barão de Paraopeba, que se envolveram de forma profunda no estudo de comunicação, recepção e avaliação, ao ponto de envolverem toda a escola por todo o segundo bimestre escolar, com atividades ainda adentrando o terceiro bimestre. A equipe da escola envolveu toda a sociedade congonhense, convocando também os pais dos alunos a prestigiarem e participarem das atividades, que foram finalizadas com a Feira de Educação Patrimonial.

A equipe da Escola Estadual Barão de Paraopeba também foi responsável por conseguir a parceria com a empresa Vale, que abriu o sítio arqueológico Fábrica Patriótica para visitação dos alunos e proporcionando desta forma o contato dos alunos com a Arqueologia Histórica in situ. A equipe da escola também conseguiu uma visitação à Gerdau Açominas, que abriu suas portas para visita dos alunos à empresa para tratar de assuntos relacionados ao meio ambiente e à preservação da água. O tema foi trabalhado junto com alunos do curso de formação de 
técnicos em meio ambiente, do IFMG (Instituto Federal de Minas Gerais), que estudam no campus de Congonhas.

Dos trabalhos realizados na Escola Estadual Lamartine de Freitas, o que mais nos surpreendeu, além da seriedade com que a Arqueologia Histórica foi recebida e tratada pelos alunos formandos do $3^{\circ}$ ano $\mathrm{E}$ turma 2013, foi a forma como se deram os primeiros contatos com a escola, porque a professora de História Ivone da Conceição Cordeiro, que passava pela porta da sede da ONG Gota d'água do Alto Paraopeba quando do desenvolvimento da pesquisa junto à população de Congonhas resolveu adentrar para conhecer o trabalho realizado em parceria com a ONG, trabalho do qual ela gostou e fez o convite para fazermos juntos um trabalho na Escola Estadual Lamartine de Freitas, o qual contou também com uma palestra do presidente da ONG, Hélvio Vitarelli ${ }^{57}$.

Quanto às respostas das questões feitas aos professores das escolas participantes, todas seguiram na mesma direção, que é a de acreditarem na potencialidade do patrimônio arqueológico como ferramenta pedagógica importante para apoiar não somente a disciplina de História, mas também as outras disciplinas da grade escolar como Geografia, Biologia, Artes, além de outras, para o conhecimento da história da formação da sociedade congonhense e da transformação da paisagem e da natureza ao seu redor.

Quanto às respostas dos professores, as únicas queixas foram acerca da falta de tempo para o desenvolvimento de atividades e a falta de afinidade e interesse que foi demonstrada pelos alunos no início dos trabalhos, em parte por não conhecerem a respeito da Arqueologia.

Quanto à falta de tempo, isso pode ser sanado na fase de planejamento do ano escolar, quando as escolas estiverem preparadas para lidarem com a Educação Patrimonial, de uma forma menos improvisada como foi feito, ou se estendendo mais durante o ano escolar. Quanto ao interesse dos alunos frente ao tema, isso somente poderá ser incentivado a partir do momento em que a Educação Patrimonial se tornar um elemento constante na educação dos cidadãos congonhenses e desta forma, com maior participação da Arqueologia na grade escolar.

Quanto à desconfiança frente à Educação Patrimonial demonstrada inicialmente pelos alunos de Congonhas, a partir do momento em que as atividades educacionais romperam com as grades e muros da escola e passaram a ser desenvolvidas in situ, como nas visitas aos museus, à Basílica do Senhor Bom Jesus de Matosinhos e à Fábrica Patriótica, os alunos em geral

\footnotetext{
${ }^{57}$ Em memória.
} 
foram se tornando cada vez mais interessados e participativos no desenvolvimento de atividades e isso também se refletiu em maior interesse pelo aprendizado em sala de aula.

No entanto, creditamos que de forma geral, os trabalhos e os resultados do estudo de comunicação, recepção e avaliação foram muito surpreendentes e satisfatórios, contando com estudantes e cidadãos de todas as faixas etárias e visões de mundo. Os trabalhos envolveram instituições não governamentais, órgãos públicos, empresas privadas, profissionais variados e escolas, numa corrente que demostrou que bastava darmos um incentivo e uma instrução inicial para que a sociedade congonhense agisse e se manifestasse em prol da preservação de seu patrimônio arqueológico, assim como de outras formas de patrimônio material e imaterial.

Os trabalhos foram de uma forma ou outra, como mostramos, ganhando em participação, interesse e envolvimento, onde cada participante buscou contribuir, buscando, encontrando e envolvendo novos parceiros que deram sua contribuição pela promoção e preservação do patrimônio arqueológico, além de outras tantas formas de manifestação cultural, tais como, o ballet, a capoeira, a culinária, o teatro, a dança, as artes plásticas, a semana santa, que fizeram parte na formação da sociedade congonhense ao longo de sua história.

\section{2 - Um balanço crítico sobre a situação arqueológica de Congonhas}

O Brasil possui mecanismos constitucionais que dão garantia de direito de expressão de sua cultura a todos os povos constituintes da nação brasileira. Aqui, inserido na legislação legal como uma parcela do direito ambiental, o patrimônio arqueológico é considerado bem público, está sob tutela da União Federativa e é direito e dever do Estado e de todo cidadão brasileiro zelar pelos bens arqueológicos, que são portadores de referências da identidade nacional. Destruir o patrimônio arqueológico é considerado crime contra o Patrimônio Nacional e crime ambiental, além de crime irreversível contra a ciência e dano sem reparo ao conhecimento científico.

O que muita gente não entende, ou não sabe, é que a Arqueologia no mundo se desenvolveu e ganhou espaço a tal ponto que hoje em dia ela não pode mais ser entendida como uma ciência que se restringe apenas aos estudos das sociedades e coisas do passado, mas sim, como ciência voltada para o estudo da humanidade e de tudo que diz respeito ao homem, não 
importando se tratamos de uma sociedade morta, já extinta, ou viva, em pleno estágio de desenvolvimento cultural.

Por conta disso, devemos entender o patrimônio arqueológico por diferentes olhares, que não somente a face material_artefatos produzidos pelo homem_, mas também pela sua face imaterial _modos de fazer, produzir e viver_e sua face humana, que são os próprios indivíduos, as sociedades, o humano cuja ausência não permitiria gerar coisa alguma _sociedades indígenas, comunidades de pescadores, quilombolas ou mesmo comunidades modernas surgidas sobre os valores modernos e capitalistas_. Patrimônio arqueológico, portanto, se refere também á vida e não somente aos vestígios materiais encontrados sob camadas de sedimentos na profundidade do solo e do tempo.

E assim, com a aceleração do crescimento econômico, industrial e demográfico do Brasil, tem se tornado cada vez mais frequentes os casos em que, empreendimentos de todo tipo, ocorridos sobre velhas ruínas de casas, vilarejos coloniais, cemitérios indígenas ou minas desativadas, se convertem em problemas para empresas, Estados, municípios e para as populações diretamente afetadas pelo impacto das grandes obras. Geralmente, quando uma obra é embargada por conta de problemas envolvendo a Arqueologia é sinal de que os estudos de impacto ambiental ou o cumprimento da legislação ambiental estão incorretos, incompletos ou insuficientes. Nestes casos, a Arqueologia e o patrimônio arqueológico acabam por serem vistos como entrave para o desenvolvimento, ou seja, uma visão enganosa a este respeito.

Para que isto não ocorra, cabe ao empreendedor responsável pelo financiamento das obras impactantes providenciar os estudos arqueológicos corretos, promover trabalhos de mitigação e/ou compensação do bem destruído e arcar com as despesas de custo dos mesmos, além de ter a responsabilidade de publicação dos resultados junto à população porque afinal de contas patrimônio arqueológico é sinônimo de patrimônio público.

Não é objetivo da Arqueologia que as grandes obras não possam ser feitas, pelo contrário, ela tem como ninguém a noção de que evolução, desenvolvimento e progresso são condições naturais da vida e da espécie humana sobre o planeta Terra. Tanto é verdade que o IPHAN discute junto aos arqueólogos brasileiros alguns meios de tornar a instituição mais eficaz quanto às políticas publicas que dizem respeito à Arqueologia, ao patrimônio arqueológico e sua preservação, como ocorrido no último Congresso da Sociedade de Arqueologia Brasileira (SAB) “Arqueologia sem Fronteiras", em agosto de 2013, na cidade de Aracajú, Estado de Sergipe. 
Enquanto discutimos e esperamos por alternativas que visem melhorar o alcance dos estudos arqueológicos, temos obras paradas onde atrasam os prazos de entrega e os pagamentos, descumprem compromissos de toda ordem e isso não pode significar outra coisa senão prejuízos para todos os lados da cadeia produtiva envolvida em projetos em que a inobservância da legislação vigente sobre a Arqueologia e ao patrimônio arqueológico está em questão.

Por outro lado, quando praticada de forma consciente e correta, observando a legislação, a Arqueologia pode significar geração de empregos e renda, produção de conhecimento científico, melhorias na educação e desta forma o desenvolvimento econômico, social e humano, quando nações, sociedades, empresas e homens podem se engrandecer ao considerarem a Arqueologia e seus benefícios.

Na história da humanidade temos casos como o de Thomas Jefferson, terceiro presidente dos Estados Unidos e grande político na história, que praticava a Arqueologia. Já o famoso cientista Albert Einstein, foi arqueólogo antes de se tornar físico nuclear e de transformar o mundo. Mais próximo de nós, aqui no Brasil, temos Dom Pedro II, que foi um pioneiro na pesquisa brasileira. Países que deram importância para o conhecimento produzido pela Arqueologia como a Inglaterra, os Estados Unidos e a França, somente para citar alguns, encontram-se no topo do ranking das principais potencias mundiais e seus cidadão geralmente são muito orgulhosos de suas origens.

Em países como o México e o Egito, a Arqueologia é um dos principais atrativos para os turistas, e com isso, ela é uma das principais fontes geradoras de renda, que movimenta toda a economia daqueles países. No Brasil, em cidades como Monte Alto, no Estado de São Paulo, a Arqueologia ajudou a incrementar o turismo local e atua junto à Paleontologia na divulgação do nome da cidade no Brasil e no exterior, tornando-se referência para estudantes do ensino básico e secundário, além de atrair pesquisadores e curiosos pelo passado préhistórico do Brasil. Também temos o exemplo do parque da Serra da Capivara no Estado do Piauí, referência na preservação do passado pré-histórico brasileiro.

Em Congonhas, quando o Brasil republicano buscava referenciais para se firmar como nação, durante o advento do Estado Novo, um fator que pode ser considerado de grande importância para a Arqueologia e para a história dessa ciência no Brasil e que parece ter sido deixado de lado é o de que a cidade teve seu conjunto urbanístico e arquitetônico tombado e a cidade foi inscrita no Livro de Tombo Arqueológico, Etnográfico e Paisagístico em 1941, por conta de 
sua excepcional monumentalidade e importância para a compreensão da história e da sociedade nacional. O Santuário do Senhor Bom Jesus de Matosinhos e seu conjunto arquitetônico, paisagístico e escultórico já tinham sido tombados em 1939 e inscritos no Livro de Belas Artes.

Assim como em outras cidades mineiras, o Barroco, o Aleijadinho, a Inconfidência Mineira e o Tiradentes se tornaram referências para um país que acabava de nascer e almejava o desenvolvimento. No entanto, escolhas como estas não foram feitas por obra do acaso e não devem ser desconsideradas em nome do progresso da economia, num município onde passado, presente e futuro parecem estar em constante confronto.

Numa região em que a base da economia foi e é a mineração, uma das consequências negativas do desenvolvimento econômico é a degradação ambiental e com isso, a do patrimônio arqueológico, que além da cultura material, abrange faces como a humanidade e a vida, por isso, crescimento econômico não pode significar o detrimento silencioso dos referenciais culturais do povo e da nação, da história, da memória, do respeito às pessoas, porque assim não caminhamos para frente como colocam os meios midiáticos que costumam divulgar projeções de futuro promissor, mas estaremos apenas andando de lado, fora do que determina a ordem natural das coisas, desenvolvendo a economia para um lado e perecendo socialmente para o outro. O ideal é que as coisas andem juntas e se desenvolvam mutuamente.

Enfim, quando a Arqueologia é praticada de forma responsável e consciente, ela é propulsora de progresso, de desenvolvimento e de ordem. Quando do contrário, é crime, entrave, prejuízos incalculáveis por toda parte. Por isso, um município como Congonhas, que se encontra na mira de grandes empresas multinacionais do ramo da mineração e da siderurgia, não pode mais deixar de perceber a presença de seu patrimônio arqueológico e de sua importância para a população local.

E assim, devido à atual situação arqueológica do município de Congonhas e dos resultados apresentados pela pesquisa de comunicação, recepção e avaliação, acreditamos que um ecomuseu é uma boa alternativa para musealização de sítios arqueológicos que antes, em tempos coloniais, formavam um conjunto de grandes minas de ouro e que agora estão fragmentados e parcelados, transformados em sítios rurais, fazendas pecuaristas, chácaras recreativas, bairros residenciais, indústrias ou pequenas reservas ambientais que escondem remanescentes do passado, que poderiam ser reutilizados para a educação e usufruto dos cidadãos. 


\section{3 - O ecomuseu: uma proposta coerente para Congonhas}

A palavra museu teve origem na Grécia antiga, mais especificamente do Mouseion, o templo das nove musas filhas de Zeus com Mnemosine, que era a divindade da memória. As nove musas por sua vez eram ligadas aos distintos ramos das ciências e das artes e o Mouseion era um local reservado à contemplação e aos estudos científicos, artísticos e também os literários. O museu é comumente compreendido na sociedade ocidental como sinônimo de instituição permanente, basicamente dedicada ao estudo, conservação, documentação e exibição de materiais do homem e do seu ambiente, visão de museu originada no pensamento do homem europeu e divulgada pela literatura, com a ênfase dada ao colecionismo renascentista.

Durante os séculos XV e XVI, as coleções principescas que começaram a se formar a partir do século XIV passaram a ser enriquecidas por conta de um colecionismo que tomava conta do continente europeu, estimulado pelas obras de arte da antiguidade, das curiosidades e tesouros oriundos dos continentes americano e asiático e também da própria produção local, feita por artistas que despontavam com suas obras valorizadas e financiadas pelos ricos e nobres (Sanjad \& Brandão, 2008).

Deste período, temos conhecimento do surgimento dos primeiros gabinetes de curiosidades e de coleções científicas, que aos poucos foram se especializando e se organizando, acompanhando a mentalidade e as concepções científicas entre os séculos XV e XVIII e que se transformaram em museus, mais próximos da forma atual, porém, sem o acesso público, algo que aconteceu somente no final do século XVIII, com o surgimento dos grandes museus nacionais.

O ponto de ebulição foi a Revolução Francesa, quando ocorreu a necessidade de criação de um aparato técnico e jurídico para proteção do patrimônio francês, que se desenvolveram um pouco mais tarde, já no século XIX, como resultado de dois processos diferentes, que foram a transferência dos bens da Coroa, do clero e dos povos emigrados para a nação e também pela destruição ideológica de parte desses bens sob o Terror e o governo do Comitê de Salvação Pública, que suscitaram uma reação de defesa imediata para o patrimônio (Choay, 2001; Julião, 2002). Com isso, novas funções foram atribuídas aos bens que passaram a pertencer aos cidadãos, instruindo a nação e difundindo o civismo e a história, difundindo a criação dos museus e traçando os contornos de sua forma moderna, que se acentuou durante o século XIX. Com isso, em 1793 aconteceu a abertura do Louvre e o acesso de seu acervo artístico 
para o público. Outros museus ${ }^{58}$ surgiram buscando formar cidadãos por meio do conhecimento de seu passado e de sua participação na construção da nacionalidade e com isso, legitimando simbolicamente os Estados nacionais emergentes (Julião, 2002).

Neste mesmo período, ocorreu o surgimento das primeiras instituições museológicas no Brasil, no século XIX, com a criação em 1818 do Museu Real ${ }^{59}$, por iniciativa de Dom João VI, e depois o Museu do Exército em 1864 e o Museu da Marinha, em 1868, o Museu Paraense em 1876, o Instituto Histórico e Geográfico da Bahia em 1894 e dois museus etnográficos, sendo o primeiro o Museu Paraense Emilio Goeldi, de 1866, construído com recursos privados e transferido para responsabilidade do Estado 1871 e reinaugurado em 1891 e o Museu Paulista ${ }^{60}$, em 1894. Tivemos ainda, a criação do Serviço do Patrimônio Artístico e Histórico Nacional (SPHAN), em 1937, que vinha marcar a institucionalização de uma política para o patrimônio cultural no país, como reflexo do ideário de construção de uma identidade nacional, formulado nos anos 1920, pelos intelectuais modernistas (Julião, 2002). Neste período do século XX foram criados também os livros de tombo.

Porém, a ideia ocidental de museu tem mudado no mundo todo, assim como no Brasil. Se por um lado existem visões de museu como uma máquina de classificar objetos e diferenciá-los de outros objetos (Canclini, 2008), por outro lado as mudanças nos museus apontam para os diferentes modos de organização e atuam de acordo com objetivos e estratégias dos mais variados, que por sua vez podem ser adaptados ao passo do contexto político no lugar onde surgem e de avanços conceituais na compreensão e prática museológicas (Sanjad \& Brandão, 2008).

Observando a grande variedade de instituições e propostas museológicas, nos últimos meses visitamos diversos museus e circuitos culturais, buscando por alternativas que nos auxiliem na tentativa de encontrarmos uma solução coerente para o caso de Congonhas e seus sítios arqueológicos. Estivemos em instituições mineiras como o Inhotim, no município de Brumadinho, visitamos o circuito cultural da Praça da Liberdade ${ }^{61}$ e o Instituto Estrada Real e o Museu de Artes e Ofícios, ambos na capital Belo Horizonte, a Escola de Minas, o Museu da Inconfidência, o Museu do Aleijadinho, o Museu do Oratório, o Museu de Arte Sacra e a

\footnotetext{
${ }^{58}$ Em 1808, surgia o Museu Real dos Países Baixos, em Amsterdã; em 1819, o Museu do Prado, em Madri; em 1810, o Altes Museum, em Berlim, e em 1852, o Museu Hermitage, em São Petesburgo, antecedidos pelo Museu Britânico, em 1753, em Londres, e o Belvedere, 1783, em Viena.

${ }^{59} \mathrm{O}$ Museu Real é atualmente chamado de Museu Nacional.

${ }^{60}$ O Museu Paulista é também conhecido por Museu do Ipiranga.

${ }^{61} \mathrm{O}$ circuito cultural da Praça da Liberdade em Belo Horizonte, Minas Gerais inclui, entre outros atrativos, o Palácio da Liberdade, antiga sede do governo estadual mineiro, o Memorial Vale, o Museu das minas e do metal e o Arquivo Público Mineiro.
} 
mina de ouro Santa Rita ${ }^{62}$, ambos no município de Ouro Preto. Estivemos também em cidades mineiras como Prados, Tiradentes, Mariana, São João Del Rei, Santa Bárbara, Catas Altas e também no Bichinho, distrito do município de Prados, onde em ambos tivemos a oportunidade de conhecer e conversar com cidadãos, moradores e turistas, a respeito do papel da preservação do patrimônio histórico da região para a educação e geração de renda e ainda, verificarmos o papel da cultura imaterial, representada no artesanato e na música para o desenvolvimento local.

Segundo Maria Cristina Oliveira Bruno, [...] "não só os museus têm uma íntima vinculação com a Arqueologia, mas a Museologia - enquanto disciplina - apresenta uma acentuada cumplicidade com esta área de conhecimento" (BRUNO, 1995, p. 141).

Neste sentido, as mudanças sofridas pelos museus já não nos conduzem apenas aos museus vistos como lugares de coisas consideradas por muitos como antiquadas, velhas ou mortas. Os museus tem se tornado pontos de referência cultural, de interpretação, centros de estudo, educação e recreação, onde as funções antigas como conservar, expor e investigar possam ser agregadas a outras como comunicar, difundir conhecimento, considerando o caráter pedagógico e o sentido lúdico como partes essenciais do sentido mais atualizado de museus (García, 200-?).

Contudo, tem ocorrido um universo de mudanças por que passa a Museologia contemporânea, um movimento intelectual denominado Nova Museologia, quando a própria Museologia passou a ser reconhecida como área de conhecimento científico, compreendendo o museu não apenas como um espaço destinado aos objetos de raridade, beleza ou curiosidade consideráveis e atraentes, mas sim como uma instituição que vai além de seus limites físicos, com o patrimônio visto não somente por sua dimensão material, mas também pela dimensão imaterial.

\footnotetext{
${ }^{62}$ A mina de ouro Santo Rita, em Ouro Preto já havia sido visitada por nós anteriormente, no ano de 2010, com os alunos da Escola Estadual Noemi Nogueira, do município de Itaverava, Minas Gerais, onde lecionamos a disciplina de História para o ensino fundamental. $\mathrm{Na}$ oportunidade da visita às cidades históricas de Mariana e Ouro Preto, os alunos recebiam conteúdo sobre história de Minas Gerais e a visita in situ proporcionou aos alunos maior interesse pela disciplina de História, melhorou a atenção dos mesmos em sala de aula e consequentemente ocorreram melhoras no aproveitamento escolar que se refletiu em melhoria nas respostas das provas e nos trabalhos, assim como nas notas finais. Além da mina de ouro, foram visitados outros pontos históricos importantes como igrejas, praças, chafarizes, pontes, museus e casas de personalidades mineiras.
} 


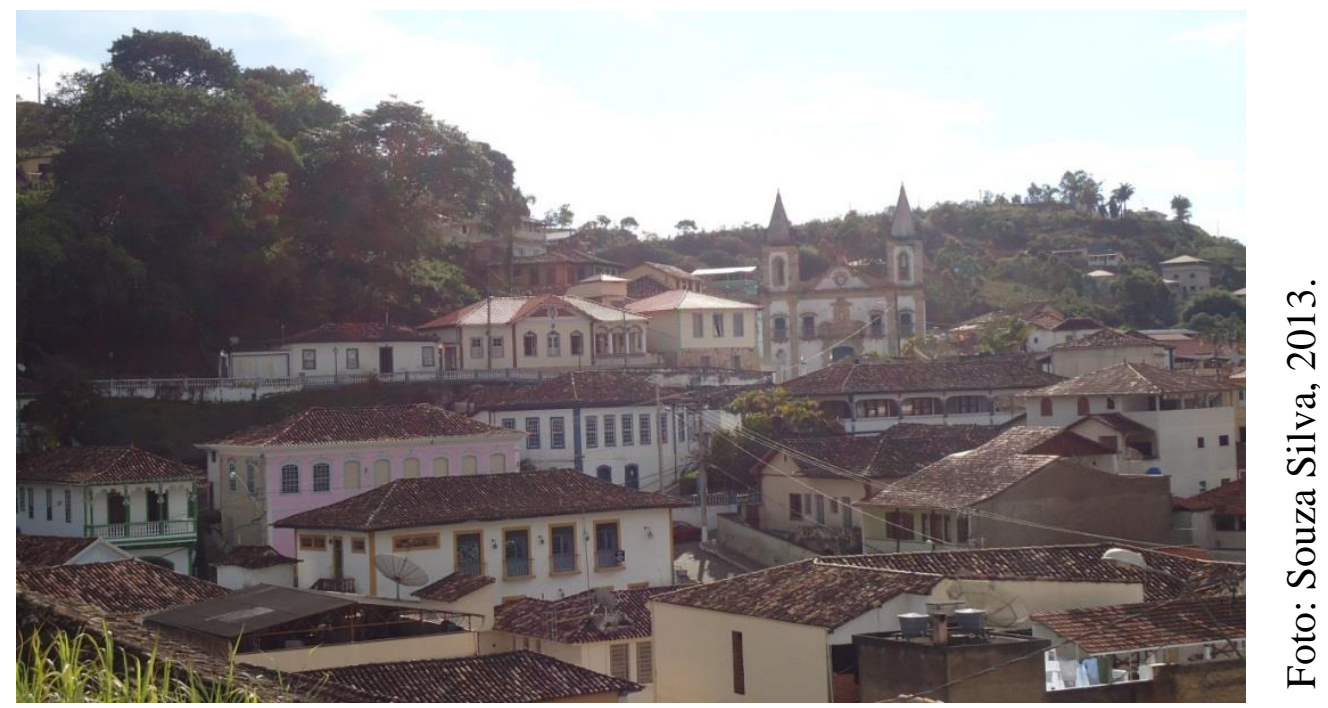

Figura 31: Vista parcial do centro histórico de Prados, Minas Gerais.

Dentro das concepções mais atualizadas de museus, temos algo que vem de encontro aos problemas sofridos pelos sítios arqueológicos de Congonhas, ou seja, o ecomuseu, que foi idealizado principalmente pela inspiração dos museólogos Hugues de Varines-Bohan e George-Henri Rivière, sendo este último ex-diretor do (ICOM) International Council of Museums, da UNESCO, e pôde fomentar em todo o mundo a criação de museus regionais de história, artes e ciências, imprimindo a marca de ligar o passado com o presente numa perspectiva de futuro. Em 1946 ele impulsionou durante o propósito de reformulação do Museu de História de Rennes o que mais tarde veio a se tornar um ecomuseu (Pessoa, 2001; Julião, 2002).

O museu de uma cidade ou região pode ensinar a cronologia e ao mesmo tempo, a simultaneidade dos fenômenos que podem revelar os elos que existem entre a realidade dinâmica do mundo, o passado e o presente, e da mesma forma, o ecomuseu pode revelar a história de uma região desde sua formação geológica, das suas explicações para a formação da vida ou como a cultura local foi desenvolvida, em harmonia com ecossistemas naturais que os próprios homens transformam ao longo do tempo (Pessoa, 2001). Desta forma, o ecomuseu é um tipo de instituição museológica que se enquadra nas concepções atuais de museu.

Contudo, acreditamos que a viabilização de um ecomuseu possa ser uma alternativa coerente para o momento que o município de Congonhas atravessa em sua história. O ecomuseu pode ao mesmo tempo dar conta de educar pelo patrimônio arqueológico e preservar para a educação. 
Desta forma, podemos compreender que o ecomuseu pode também abrir os olhares não somente para o patrimônio arqueológico, mas também para outras formas de patrimônio, como o ambiental, o arquitetônico, o ambiental, o geológico, o artístico e o imaterial, ambos tendo no patrimônio arqueológico seu elemento balizador e todos compreendidos numa relação de interdependência e relevância para a história da região formadora do município de Congonhas e de seu povo. Ao tentarmos definir o que é um ecomuseu, temos a seguinte afirmativa:

Ecomuseu seria a reunião de elementos e de bens culturais inter-relacionados, dispostos de variadas maneiras, em diversos lugares apropriados à visitação e dentro do próprio "habitat" de uma determinada sociedade de modo que se possa apreender todo o seu processo evolutivo cultural (LEMOS, 1987, p. 12).

Desta forma, ecomuseu pode ser considerado uma entidade onde tudo é vivo, fluído e dinâmico. É onde o patrimônio cultural é compreendido não pela característica de objeto semióforo, quando objetos e coleções de museus são expostos ao olhar e não sofrem a usura característica. "A amplitude das ações que podem se desenvolver a partir do termo ecomuseu é tão vasta que pode afirmar-se só encontrar limites na capacidade de realização que os meios disponíveis consentem" (PESSOA, 2001, p. 42).

Neste sentido, George-Henri Rivière tinha a preocupação de traduzir a ligação entre o substrato físico do território, a película biológica que o cobre, e o homem que está integrado nessa realidade biofísica.

Enfim, o ecomuseu é uma instituição museológica que pode receber componentes como o museu do tempo e o museu do espaço. O museu do tempo se liga à história e cultura locais e pode utilizar de um local onde a génese e a evolução da paisagem é relatada. Nele são criadas as motivações para que o visitante aprecie e estude os valores da natureza e da cultura locais. No museu do espaço o visitante tem acesso aos elementos que influenciam a cultura da região, como a mineração e suas relações com os acidentes geomorfológicos, fauna e flora, sítios e objetos arqueológicos, monumentos históricos ou resumindo, tudo o que é representado no espaço cujos visitantes aprendem no museu do tempo.

Assim, se podemos dar uma finalidade para um ecomuseu, ele estará voltado à população de um determinado lugar, principalmente aquelas cujas pressões do mundo moderno tendem a 
apagarem ou diminuírem a importância das culturas próprias e tradicionais, ou seja, [...] "com o ecomuseu as populações reaprendem a amar o que é seu, a sua tradição, os seus conhecimentos seculares, a sua maneira peculiar de estar no mundo" (PESSOA, 2001, p. 35). O ecomuseu é um tipo de instituição museológica que cabe como meio de enfrentamento da realidade por que passa a sociedade de Congonhas frente ao problema da destruição de sítios arqueológicos no município e é uma via que direciona para uma musealização de sítios arqueológicos, voltada para a informação, a educação permanente dos cidadãos desejosos de estudarem e conhecerem os seus referenciais culturais e desta forma, proporcionar um sentimento de cidadania por meio do patrimônio local.

Assim, com a participação da sociedade e do poder público, os sítios arqueológicos de Congonhas podem ser preservados para sua valorização contínua pela educação. Empresas e moradores podem ser estimulados a cuidarem e perceberem o território, a natureza, a história e a sociedade de forma integrada e interdependente.

Hoje, temos localizados sobre os sítios arqueológicos de Congonhas diversas propriedades como fazendas em atividade, mineradoras, chácaras para uso recreativo, bairros residenciais ou áreas de proteção ambiental mantidas por empresas privadas, fatores que não impede a formulação de um ecomuseu.

Por isso podemos afirmar que Congonhas possui uma grande quantidade de elementos que podem ser integrados para a formulação de um ecomuseu. A formação geológica e a questão do ouro e do minério de ferro, a interação do indígena com a região, a chegada do colonizador e do garimpeiro, a Guerra dos Emboabas, as implicações e transformações paisagísticas oriundas da forma com que o ouro se encontrava e como isso influenciou a ascensão e o declínio da extração do ouro e das artes barrocas, a importância do ouro para a economia mercantilista, a religiosidade nos tempos do garimpo e a economia proporcionada pelo Jubileu do Senhor Bom Jesus, a influência da religião sobre a permanência do Barroco até o século XX, a mineração do ferro integrada a uma economia global e sua importância para a manutenção do sistema capitalista, o tratamento ao meio ambiente tanto no passado colonial quanto atualmente, o patrimônio arquitetônico, o patrimônio arqueológico, as festas, as manifestações imateriais e as arte do Aleijadinho, integrados em uma dimensão histórica com perspectiva de futuro, com vistas à preservação e que possam realizar a promoção continuada pela e para a educação patrimonial, permitindo ao morador da cidade e ao visitante vislumbrarem uma história em perspectiva de sistema em processo, do local ao global, numa wide word web. 
Compreendido como museu do homem em seu meio ambiente natural e cultural, o ecomuseu representa a relação da população de um determinado território com a sua história e com a natureza que a cerca, prestando-se como meio de autoreconhecimento da comunidade na qual está inserido. Sua coleção é constituída pelo patrimônio vivo pertencente aos habitantes do território, abrangendo bens materiais, imateriais, móveis e imóveis. A população participa de maneira decisiva na gestão do museu como sujeito e objeto de conhecimento público e curador do ecomuseu (JULIÃO in TRINDADE; et. al., 2002, p. 23-24).

Um estudo de caso que podemos citar como exemplo de trabalho em criação de ecomuseus foi o que levou os cuidados e a colaboração de George-Henri Rivière com a proposta de organização do Ecomuseu da Serra da Estrela em Portugal (Pessoa, 2001; Julião, 2002).

Esta proposta museológica do Ecomuseu da Serra da Estrela em Portugal elucida e ajuda-nos a respeito de como aproveitar os remanescentes históricos e arqueológicos em Congonhas e as manifestações populares locais, trabalhando de forma integrada aos processos históricos da região e da cidade, considerando o aspecto global em integração, junto de outros locais que o município já possui e que já recebem as atenções do Poder Público e da população de Congonhas.

Congonhas possui a Romaria, principal centro de atividades culturais da cidade. No local funcionam as secretarias de Turismo, Patrimônio e Cultura do município de Congonhas. O local é aberto para visitação turística e nesse sentido, possui ainda um ponto de informação turística para apoio aos visitantes e banheiros públicos. Na Romaria estão instalados ainda o Museu de Mineralogia e o Museu de Arte Sacra de Congonhas.

A localização da Romaria pode ser considerada privilegiada porque ela fica próxima à Basílica do Senhor Bom Jesus de Matosinhos e já funciona como local reservado para práticas culturais como shows musicais, apresentações de artistas cênicos e festivais tradicionais da cidade como o Festival da Quitanda, que ocorre todo ano no mês de maio e o encontro de motociclistas Motofest, que é uma das atividades do Festival de Inverno de Congonhas, que ocorre no mês de julho de cada ano.

Os festivais tradicionais que ocorrem anualmente podem se tornar estímulos para a prática cultural e promoção e divulgação do ecomuseu, pois estes locais e eventos recebem visitantes da própria cidade de Congonhas, de diversas partes de Minas Gerais, do Brasil e do exterior.

Contudo, a Romaria pode ser pensada funcionando como um ponto de referência, administração e apoio técnico. Lá poderá funcionar a célula principal do Ecomuseu, onde as 
visitas poderão ser agendadas, pois o local já possui pessoal treinado para recepção de visitantes, promoção de festas e eventos e de processos administrativos cujos funcionários das secretarias atuantes no local possuem larga experiência.

A Romaria também chegou a ser cogitada em reuniões das que tivemos oportunidade de participar no ano de 2011 junto ao Conselho de Patrimônio de Congonhas para abrigar um museu de Arqueologia e desta forma receber material arqueológico oriundo de resgates arqueológicos ocorridos na região.

A Secretaria de Patrimônio da cidade informou que o museu de Arqueologia poderá sair do papel em breve, mas não informou quando, pois os trabalhos museográficos estão em andamento e ainda sem uma perspectiva exata para conclusão do museu.

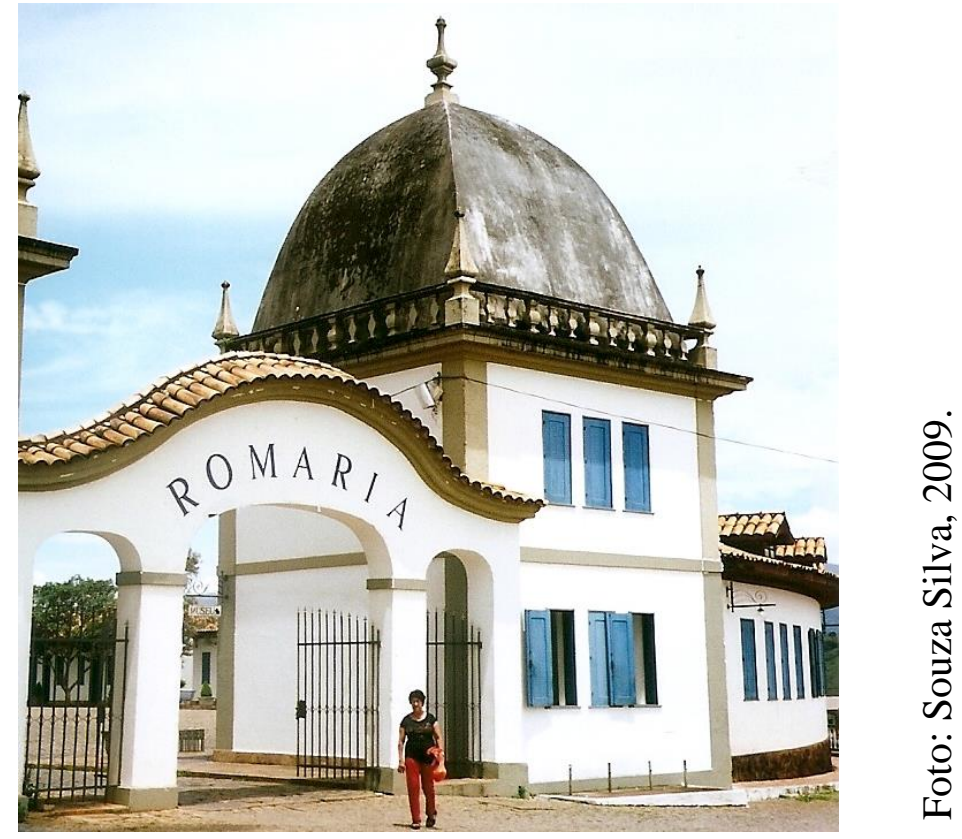

Figura 32: Romaria, Congonhas, Minas Gerais.

Acontece ainda no município de Congonhas que, diante dos casos de destruição mais recentes do patrimônio arqueológico, o MPMG (Ministério Público de Minas Gerais) requisitou a produção de uma carta arqueológica, com a finalidade de localizar e mapear os sítios arqueológicos do município, para que a documentação produzida sirva como uma base de dados para consulta por gestores públicos, empreendedores e moradores, funcionando principalmente de forma preventiva a evitarem os danos ao patrimônio arqueológico nos 
empreendimentos lesivos ao meio ambiente, quando normalmente é alegada a falta de conhecimento do patrimônio arqueológico como justificativa para a destruição.

Para este fim, tomamos conhecimento e procuramos divulgar o estudo de caso do Programa de Gestão do Patrimônio Arqueológico de São Sebastião, litoral do Estado de São Paulo, onde procuraram criar um Sistema de Informações Geográficas (SIG) para manipulação de dados do patrimônio cultural da cidade com um banco de dados geográficos _coleção de dados georreferenciados_. Outra proposta interessante que parte dos trabalhos realizados na cidade de São Sebastião, é o SIGWeb, que disponibiliza dados na rede mundial de computadores para uso técnico para gestores públicos e empreendedores, com vistas a divulgar e disponibilizar a arqueoinformação neste meio, fazendo também com que o usuário possa ter acesso a informações como hidrografia, topografia, limites administrativos, posicionamento de sítios arqueológicos e diversas outras ferramentas de apoio:

Diante das especificidades dos registros arqueológicos o SIGWeb permite a utilização de pontos, linhas e polígonos. Esta facilidade permite a utilização de pontos, linhas e polígonos. Esta locação permite a ocorrências isoladas (pontos), perímetros presentes em manchas, limites de sítios e suas subdivisões (polígonos) e traçados, como por exemplo, antigas estradas, córregos relacionados, etc., (linhas). Dentre outras funções, o SIGWeb permite a geração de arquivo PDF e oferece link com os produtos Google, Googlemaps e Google Earth (SANTOS, 2011, p.63).

Em Congonhas temos ainda diversas outras opções patrimoniais que podem ser agregadas ao roteiro de um ecomuseu e que foram lembrados pelos alunos da Escola Estadual Barão de Paraopeba, como o Parque Ecológico da Cachoeira, que fica próximo ao sítio arqueológico Fazenda do Faria a uma distância de 800 metros, perto das ruinas da igreja de Santo Antônio a uma distância de 700 metros, e perto da Mina do Veeiro a uma distância de 500 metros. Todos estes sítios arqueológicos e inclusive o Parque da Cachoeira, ficam posicionados no Morro de Santo Antônio e bem próximos ao Morro do Engenho, que do parque ecológico podem ser visualizados, proporcionando uma bela visão da paisagem.

Avistamos ainda, do interior do parque ecológico, uma bela porção de mata atlântica parcialmente preservada e a cachoeira de Santo Antônio com seu véu de noiva, patrimônios naturais de valor inestimável para o município, seus cidadãos e todos que visitam o parque.

O parque, cujo nome e localização já nos lembram sobre a questão ecológica, é um parque ecológico, turístico e balneário e costuma receber público variado que chega a alcançar 
milhares de visitantes, turistas e moradores de Congonhas todos os anos. O Parque Ecológico da Cachoeira possui também campo de futebol, quadras de voleiball, futsal, basqueteball, peteca e piscinas para adultos e crianças e desta forma, pode ser utilizado para o estímulo de práticas esportivas variadas, como as que foram lembradas pelos cidadãos que responderam aos questionários propostos.

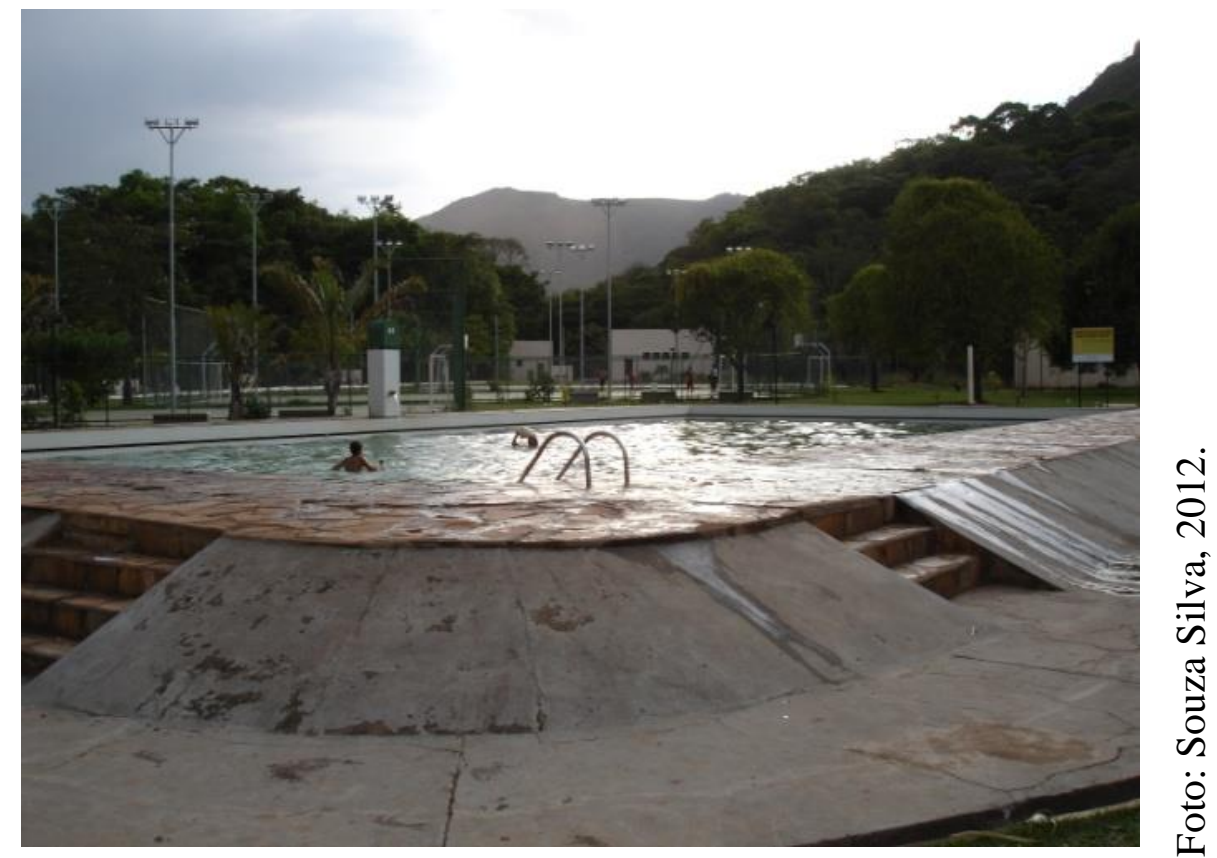

Figura 33: Parque Ecológico da Cachoeira.

Além disso, o principal acesso ao parque se dá por uma estrada municipal que possui calçada para pedestres. $\mathrm{O}$ trajeto é quase todo arborizado, proporcionando sombra para o pedestre por durante parte do dia. Podemos sugerir a estrada como ótimo local para o estímulo às caminhadas, corridas e ciclismo. A estrada de acesso ao parque também passa diante das entradas da Mina do Veeiro, Fazenda do Faria e da Igreja de Santo Antônio, que não por acaso, tem o mesmo nome da cachoeira e do morro onde se localiza. Estes locais podem fazer parte um trajeto de caminhada e ciclismo ecológico e histórico.

O parque ecológico da cachoeira ainda possui concha acústica, que pode ser usada para o estímulo às atividades artísticas, tais como exposição de artes plásticas, de artesanato regional, de eventos voltados para a música, a dança e o teatro, em parceria com artistas locais que podem utilizar o espaço e se aproveitarem do movimento de pessoas que circulam pelo parque para divulgarem seus trabalhos. 
Eventos dessa natureza também poderão ser organizados no Parque Ecológico da Cachoeira pela equipe já existente na Romaria, que possui ampla experiência na organização de eventos culturais e esportivos por todo o município de Congonhas.

A inclusão do Parque da Cachoeira no roteiro do ecomuseu se deve principalmente pela estrutura já existente para recepção do público visitante. A ideia funciona da seguinte maneira: o parque funcionará como um ponto de recepção dos alunos que podem visitar os sítios arqueológicos que estão próximos, pagando uma taxa extra que pode ser incluída na entrada do parque. A visitação do público aos sítios arqueológicos nas áreas próximas ao parque poderá ser feita acompanhada por guias treinados pela prefeitura e os visitantes serão guiados e inspecionados enquanto caminham nas belas estradas arborizadas, até chegarem aos sítios, tomando os cuidados ambientais necessários como guardarem o próprio lixo, não retirar plantas, animais, minerais ou objetos nativos como lembrança e respeitar os limites estabelecidos no roteiro que deverá ser criado.

Os valores cobrados poderão ser negociados e divididos com os proprietários das áreas de ocorrência dos sítios arqueológicos, que poderão aplicar a renda na manutenção dos sítios arqueológicos. Porém, isto é uma ideia que pode sofrer contribuições e alterações para que se torne melhor.

Tendo definido o ecomuseu como o tipo de museu que cabe à conjuntura atual do município de Congonhas e sua situação arqueológica, cabe agora definirmos ações que possam conduzir o ecomuseu rumo a um papel educativo para a sociedade local.

Enfim, a partir da ideia de um ecomuseu, podemos visualizar uma série de ações fundamentais que devem ser tomadas para proporcionar a promoção do patrimônio cultural e a ressignificação para uso do patrimônio arqueológico pela população de Congonhas, detentora dos bens arqueológicos.

\subsection{1 - Planejamento e ações administrativas}

As ações administrativas são compreendidas como os primeiros passos para a formulação do ecomuseu. É a partir dessas ações que serão proporcionadas as bases para as atividades que serão desenvolvidas no âmbito da museografia e da educação patrimonial. 
1 - constituição de um grupo gestor interdisciplinar ou equipe especializada de profissionais, munidos dos equipamentos necessários para a realização dos trabalhos necessários a seguir;

2 - criação de seção de Cadastramento dos proprietários de áreas que tenham ocorrência de sítios arqueológicos que queiram incluir suas propriedades ao ecomuseu, assim como empresas e a própria Prefeitura Municipal de Congonhas;

3 - Criação de um sistema de siglas para os sítios arqueológicos e artefatos arqueológicos provenientes de escavações e evidenciações de estruturas arqueológicas;

4 - criação de seção administrativa do Ecomuseu, que pode ser vinculada à FUMCULT (Fundação Municipal de Cultura, Lazer e Turismo) para organização e agendamento de atividades, distribuição de pessoal e organização de visitações, que deverão ser agendadas previamente;

5 - criação de seção de monitoramento arqueológico de sítios (tipo SIGWeb), também atrelado à seção administrativa, que deve se manter acessível às secretarias municipais de patrimônio, obras, meio ambiente, administração, gestão urbana e FUMCULT;

6 - Contratação de um profissional arqueólogo pela Prefeitura Municipal de Congonhas para apoio e monitoramento.

\subsection{2 - Planejamento e ações museográficas}

As ações museográficas deverão ser desenvolvidas por profissionais habilitados, de acordo com as necessidades decorrentes do processo e partem da seguinte ordem:

1 - levantamento territorial e preenchimento de inventários arqueológicos, antropológicos e arquitetônicos detalhados das áreas do ecomuseu, por respectivos profissionais habilitados;

2 - levantamento cultural, fotográfico, faunístico, botânico, geográfico, topográfico e geológico detalhados das áreas do ecomuseu por respectivos profissionais habilitados;

3 - providenciar sinalização para identificação de áreas por meio de painéis informativos ou placas, à prova d'água, com textos informativos, fotos, mapas ou croquis, para serem instalados nas alamedas e proximidades dos sítios arqueológicos; 
4 - providenciar proteção por cerca de áreas potencialmente arqueológicas para evitar acessos que possam causar invasões indesejadas que podem gerar saques, vandalismo ou qualquer tipo de destruição que possam prejudicar futuros trabalhos arqueológicos;

5 - providenciar a escavação arqueológica e evidenciação de estruturas em todos os sítios arqueológicos;

6 - providenciar a criação de um museu de Arqueologia com laboratório, reserva técnica para depósito de material arqueológico proveniente de escavações e de evidenciações arqueológicas, espaço para exposição temporária e espaço para exposição permanente de material arqueológico;

7 - criação de um roteiro de visitação, que será o espírito do ecomuseu, considerando e incluindo as áreas levantadas e cadastradas em união por meio do roteiro de ação educativa, este, por sua vez, deverá ser atrelado ao cronograma de atividades de cada escola e obedecer seu tempo estabelecido.

\subsection{3 - Planejamento e ações educacionais}

As ações educativas no âmbito da Educação Patrimonial podem ser iniciadas sem que necessariamente tenham concluído as ações anteriores, pois, podem se aproveitar dos bens culturais arquitetônicos, arqueológicos, históricos, ecológicos e ambientais já conhecidos, preservados e que ofereçam condições de segurança aos visitantes.

Os referenciais coletados indicam que a Educação Patrimonial pode também ser feita nos sítios arqueológicos remanescentes da cidade, aliando educação às práticas esportivas variadas, aos saberes do povo e ao turismo cultural, integrando áreas e sítios desmembrados e aproximando o homem da natureza pelos múltiplos aspectos e possibilidades de um ecomuseu.

A Educação Patrimonial pode tomar como base, indicação ou modelo as ações que foram desenvolvidas na Escola Estadual Barão de Paraopeba e pode ser desenvolvida em todas as escolas municipais, estaduais e particulares de Congonhas, se destinando principalmente aos alunos do ensino fundamental de $6^{\circ}$ ao $9^{\circ}$ ano, podendo ser adaptado para qualquer faixa etária ou ano escolar, inclusive para o ensino médio, respeitando a grade escolar das 
respectivas turmas e as limitações e capacidades intelectuais de cada faixa etária, seguindo os seguintes passos:

1 - organização de reunião junto ás escolas municipais no início do ano escolar, na fase de planejamento escolar que se dá no inicio do ano letivo, com palestra para professores e equipes pedagógicas com tema que considere a Arqueologia e o objetivo da Educação Patrimonial;

2 - organização e agendamento de reuniões em cada uma das escolas do município de Congonhas, junto a cada escola, de acordo com a disponibilidade de cada escola e obedecendo a fase de planejamento escolar;

3 - planejamento estratégico e agendamento de um "Plano de Educação Patrimonial" junto às equipes de cada escola do município de Congonhas, obedecendo a fase de planejamento escolar;

4 - execução do Plano de Educação Patrimonial pelas escolas municipais, que pode ter duração de 1 (um) bimestre escolar e pode ser aplicado no $2^{\circ}$ bimestre escolar, integrando o conteúdo das disciplinas da grade curricular transversalmente à disciplina de História, de forma interdisciplinar. Nesta fase devem ser desenvolvidos trabalhos que podem ser inspirados nos trabalhos realizados na Escola Estadual Barão de Paraopeba, a saber:

$4 \mathrm{~A}$ - atividades na escola: palestra para alunos com arqueólogo, apresentação de filmes com temas relativos à Congonhas e à Arqueologia, realização de debates e atividades que considerem temas interdisciplinares e transversais à disciplina de história, realização de feira de Educação Patrimonial com temas e trabalhos sobre Congonhas, produzidos pelos alunos, como dança, teatro, produção de filmes, painéis informativos, desenhos artísticos, entre outros.

4 B - atividades fora da escola, feitas com auxilio de transporte escolar: Visitas técnicas aos sítios históricos de Congonhas: Basílica do Senhor Bom Jesus de Matosinhos e demais igrejas barrocas do município, assim como de seus distritos históricos de Alto Maranhão e Lobo Leite. Visitas técnicas ao Museu de Mineralogia e ao Museu de Imagem e Memória de Congonhas. Visita técnica e recreativa ao Parque Ecológico da Cachoeira. Visitas técnicas aos sítios arqueológicos que ofereçam condições de segurança. Visitas técnicas às siderúrgicas e mineradoras; 
5 - avaliação dos resultados em cada escola, feita pela equipe de professores e respeitando suas respectivas disciplinas e turmas em que o Plano de Educação Patrimonial foi aplicado;

6 - entrega dos resultados por cada escola participante para a Secretaria Municipal de Educação;

7 - divulgação dos resultados obtidos pela Secretaria Municipal de Educação de Congonhas.

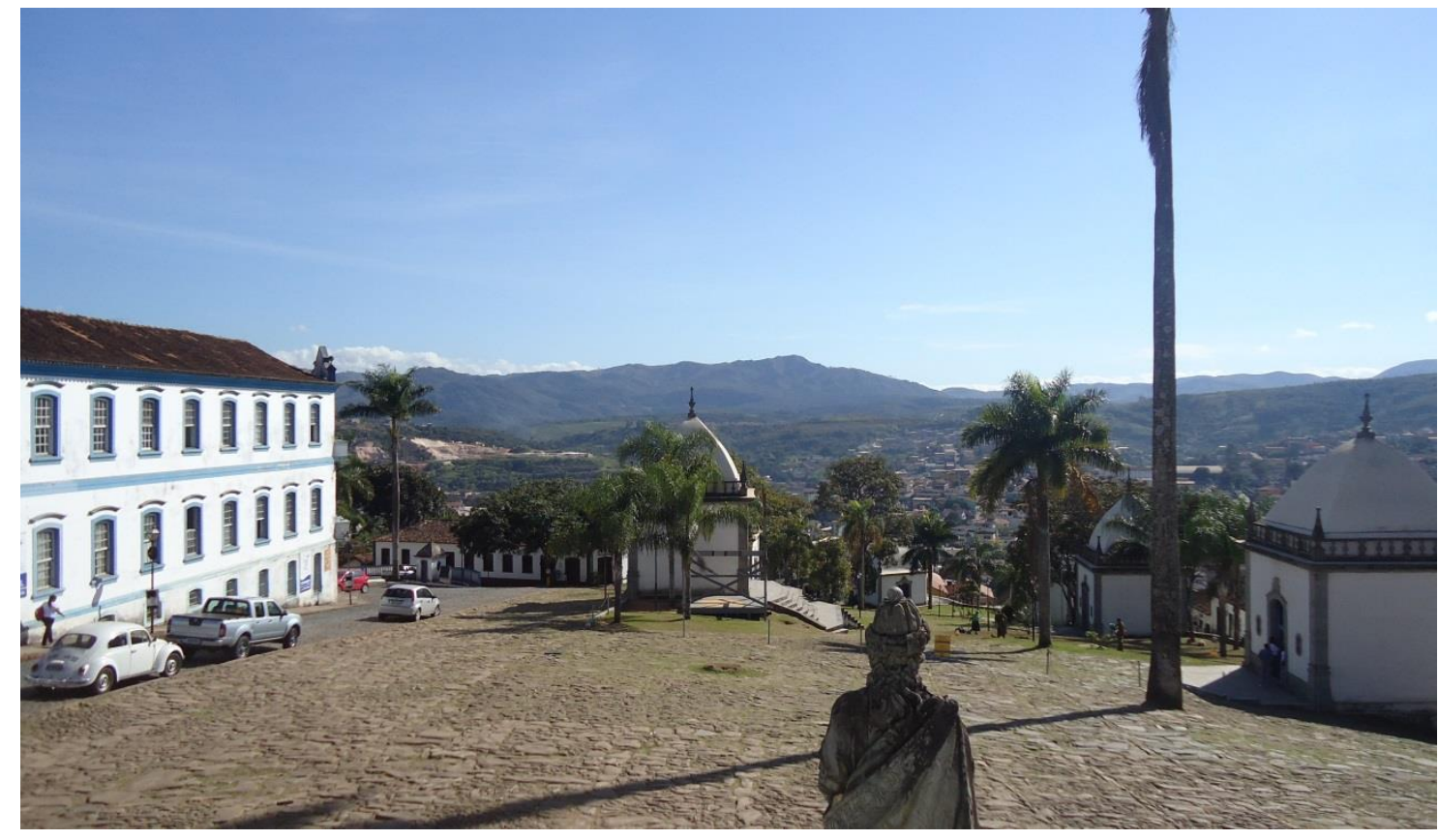

Figura 34: Obras de Aleijadinho (Antônio Francisco Lisboa, século XIX) diante da paisagem onde estão os sítios arqueológicos Fazenda do Faria, Capela de Santo Antônio, Mina do Veeiro, Mina das Goiabeiras e Mina da Soledade. 


\section{Considerações Finais}

Para a realização da pesquisa de comunicação, recepção e avaliação, os trabalhos preliminares ocorridos na Escola Municipal de Ensino Fundamental Conceição Lima Guimarães foram importantes porque ajudaram a construir a metodologia a ser utilizada na Escola Estadual Barão de Paraopeba.

Os trabalhos de comunicação, recepção e avaliação realizados na Escola Estadual Barão de Paraopeba ocorreram até o mês de setembro do ano de 2013, quando terminamos por avaliar o processo e agregar os dados coletados na escola junto aos outros dados coletados junto a população do município e aos dados coletados na Escola Estadual Lamartine de Freitas.

Outras formas de coleta de dados que ocorreram pela promoção do patrimônio cultural se deram através da reedição ampliada de uma exposição fotográfica didática feita na Escola Estadual Barão de Paraopeba, reapresentada na sede da ONG Gota D’água do Alto Paraopeba, no centro da cidade de Congonhas, por onde milhares de pessoas circulam todos os dias. Com isso, nos aproveitamos da circulação intensa de pessoas para fazermos a distribuição dos questionários junto aos populares que transitavam e que adentraram na sede da ONG para conhecer a exposição em formato de linha do tempo.

O mesmo tipo de ação ocorreu nas ruas, com ajuda da ONG, utilizando também pastas de arquivos contendo material fotográfico organizado em forma de linha do tempo, abordando a história de Congonhas desde sua fundação, passando pelos dias atuais até abordarmos as preocupações com o futuro do meio ambiente e de seu patrimônio arqueológico.

No que diz respeito aos trabalhos de Educação Patrimonial de uma forma geral, os resultados apresentados nos dão a entender que um programa de Educação Patrimonial pode ser desenvolvido para outras escolas do município de Congonhas, segundo a metodologia e padrões com que foi aplicada na Escola Estadual Barão de Paraopeba, e depois, de forma sucinta na Escola Estadual Lamartine de Freitas. Desta forma, a educação formal pode se tornar uma aliada na promoção do patrimônio cultural do município, pois consegue abordar o patrimônio cultural de forma transversal aos estudos de História, inserindo o patrimônio arqueológico como meio importante para a compreensão da história e da transformação da sociedade, assim como para a construção de um sentimento de cidadania voltada para o patrimônio. 
Os trabalhos realizados em Congonhas nos proporcionaram conhecer e ao mesmo tempo ampliar o potencial da Arqueologia, em especial da Arqueologia Histórica e do patrimônio arqueológico histórico como uma maneira quase que recreativa de aprender e de formar cidadãos conscientes da importância de seu patrimônio e de sua preservação para as gerações futuras.

Em geral, as pessoas que participaram e deram suas opiniões a respeito da preservação de sítios arqueológicos e sua reutilização para finalidades educacionais foram bem comunicativos, receptivos e parceiros, principalmente no que diz respeito à ideia de um desenvolvimento socioeconômico que considere a presença dos vestígios do passado brasileiro presentes em solo congonhense e sua preservação para finalidades educacionais.

A sociedade, que às vezes parece inerte frente aos problemas ambientais do presente mostrou que percebe os problemas em sua volta e considera importante uma mudança de postura do Poder Público quanto às decisões que possam colocar o patrimônio arqueológico em risco de destruição.

O Poder Público, por outro lado, tem se colocado à disposição da sociedade na tentativa de amenizar e até mesmo solucionar os problemas relativos à destruição do patrimônio arqueológico de Congonhas. A principal mudança tem se refletido na produção da Carta Arqueológica de Congonhas e no salvamento parcial de áreas potencialmente arqueológicas como a Mina da Soledade, que atualmente tem seu solo parcelado em lotes para a construção civil, mas de qualquer forma considerando a existência do patrimônio arqueológico e proporcionando o salvamento in situ de parte dos vestígios arqueológicos deixados pela atividade mineradora do ouro, e também as ruínas da fonte e da cadeia do Distrito de Alto Maranhão.

De qualquer forma, os trabalhos realizados para a produção da pesquisa de comunicação, recepção e avaliação diminuíram sensivelmente a distância entre o Poder Público e a população de Congonhas, e destes com o patrimônio arqueológico, mostrando que é necessário apenas um incentivo para que o patrimônio arqueológico voltasse a ser percebido e valorizado da forma tal como deve ser, ou seja, como meio de educar e proporcionar um desenvolvimento socioeconômico equilibrado.

O que é preciso ainda é que a proposta elaborada como resultado deste estudo de comunicação, recepção e avaliação se torne uma realidade no dia-a-dia da sociedade congonhense. De qualquer forma, a materialização desta proposta contará com o apoio da 
população, que deseja que seu patrimônio arqueológico seja estudado, preservado, reutilizado e de forma alguma destruído.

Os trabalhos realizados mostraram que unidos, todos os entes que formam a sociedade podem trabalhar juntos pela preservação dos remanescentes do passado, de forma que os resultados possam aparecer em forma de uma sociedade, de um Poder Público, de um desenvolvimento socioeconômico onde o patrimônio arqueológico e a economia local seguem na direção de um futuro melhor e mais equilibrado.

Neste sentido, um ecomuseu será um meio de mantermos ativa a união entre Poder Público, sociedade e a legislação, por meio do patrimônio arqueológico e de outros referenciais materiais e imateriais da cultura.

Quanto à relevância da pesquisa para a Arqueologia, acreditamos que nossa maior contribuição tenha ocorrido no campo prático, pois a promoção do patrimônio arqueológico junto à população nos mostrou que apesar da importância das palavras, as atitudes formam os principais elementos para tentarmos preservar o pouco que nos resta de nosso patrimônio arqueológico, sobre os qual ainda estamos aos poucos aprendendo a conhecer, a respeitar, a valorizar, a preservar e reutilizar. 


\section{Referências Bibliográficas}

ABREU, R. A emergência do patrimônio genético e a nova configuração do campo do patrimônio. In: ABREU, R.; CHAGAS, M. (Orgs). Memória e Patrimônio: Ensaios Contemporâneos. Rio de Janeiro: Lamparina, 2009. pp. 34-48.

Chicletes eu misturo com bananas? Acerca da relação entre teoria e pesquisa em memória social. In: GONDAR, J. \& DODEBEI, V. O que é memória social? Rio de Janeiro: Contra Capa, 2009. pp. 27-54.

ALLEN, R. \& MICHAEL, R. L. Forty Years of Historical Archaeology, 1967-2007. In: Journal of Society for Historical Archaeology. Vol. 42. No 2. Stone Mountain: Society for Historical Archaeology, 2008. pp. 08-15.

ALVES, M. A. Assentamentos e cultura material indígena anteriores ao contato no Sertão da Farinha Podre, MG e Monte Alto, SP. 2009. 324 p. Tese (concurso de provas e títulos para a livre-docência) Museu de Arqueologia e Etnologia da Universidade de São Paulo - Área de Arqueologia Brasileira. São Paulo: MAE/USP, 2009.

Assentamentos e cultura material indígena anteriores ao contato no Sertão da Farinha Podre, MG e Monte Alto, SP. Erechim: Habilis, 2013.

ANTONIL, A. J. Cultura e Opulência do Brasil. $3^{\text {a }}$ ed. Rio de Janeiro: Itatiaia, 1977.

ASSIS, W. R. O Patrimônio Cultural e a Tutela Jurídica das Identidades. In: CUREAU, S.; et. al.(Orgs). Olhar Multidisciplina Sobre a Efetividade da Proteção do Patrimônio Cultural. Belo Horizonte: Forum, 2011. pp. 63-78.

ÁVILA, A. O lúdico e as projeções do mundo barroco. São Paulo: Perspectiva,1980.

AZEVEDO, Ú. R. de. Patrimônio Geológico e Geoconservação no Quadrilátero Ferrífero, Minas Gerais: Potencial para a criação de um Geoparque da UNESCO. 2007. 211 p. Tese (Doutorado) Instituto de Geociências da Universidade Federal de Minas Gerais. Belo Horizonte: Instituto de Geociências/UFMG, 2007.

BAER, W. A Economia Brasileira. Trad. Edite Sciulli. São Paulo: Nobel, 1996.

BARBER, R. J. Doing Historical Archaeology: Exercises Using Documentary, Oral, and Material Evidence. New Jersey. University of California, 1994.

BAZIN, G. O Aleijadinho e a escultura barroca no Brasil. $2^{\text {a }}$ ed. Mariza Murray (Trad.) São Paulo: Record, 1963.

BASTOS, R. L.; SOUZA, M. C. de. Normas e Gerenciamento do Patrimônio Arqueológico. $3^{\text {a }}$ ed. São Paulo: IPHAN, 2010.

BASTOS, R. L. As novas transformações da Arqueologia: Paisagens Culturais e Biopolíticas. In: BASTOS, R. L.; SOUZA, M. C. de (Ed.). Patrimônio Cultural Arqueológico: Diálogos, Reflexões e Práticas. São Paulo: IPHAN, 2011. pp. 74-86. 
BIBLIOTECA PÚBLICA MUNICIPAL DJALMA ANDRADE. Congonhas: Prefeitura Municipal de Congonhas, 20-??.

BINFORD, L. R. Em Busca do Passado: A descodificação do registro arqueológico. Lisboa: Europa-América, 1991.

BITENCOURT, A. L. V. Princípios, métodos e algumas aplicações da Geoarqueologia. In: RUBIN, J. C. de. \& SILVA, R. T. da (Orgs). Geoarqueologia: Teoria e prática. Goiânia: UCG, 2008. pp. 41-70.

BLOCH, M. A História, os homens e o tempo. In: BLOCH, M. Introdução aos estudos históricos. Cap. 1. Sintra: Europa-América, 1976. pp. 85-102.

BORNAL, W.; GALDINO, C. Ações de Arqueologia Pública no município de São Sebastião no Estado de São Paulo. In: BASTOS, R. L.; SOUZA, M. C. de (Ed.). Patrimônio Cultural Arqueológico: Diálogos, Reflexões e Práticas. São Paulo: IPHAN, 2011. pp. 133-147.

BOSHI, C. C. O Barroco Mineiro: Artes e Trabalho. São Paulo: Brasiliense, 1988.

BOURDIEU, P. O Poder Simbólico. Coleção Grandes Cientistas Sociais. Renato Ortiz (Org). Ática, 1994.

BRUNO, M. C. O. Musealização da Arqueologia. Um estudo de modelos para o Projeto Paranapanema. 1995. 382 p. Tese (Doutorado). Museu de Arqueologia e Etnologia da Universidade de São Paulo. São Paulo: FFLCH/USP, 1995.

As marcas do empreendedorismo no Brasil: Alguns desafios para a musealização. In: BRASIL. MINISTÉRIO DA CULTURA. Pioneiros e empreendedores: a saga do desenvolvimento no Brasil. Os caminhos do processo de musealização. MARCOVITCH, J. \& BRUNO, M. C. O. (Orgs.) São Paulo, 2012.

Museologia para professores: os caminhos da educação pelo patrimônio. São Paulo: Centro Estadual de Educação Tecnológica Paula Souza, 1998.

BUCAILLE, R. \& PESEZ, J-M. Cultura material. In: Enciclopédia Einaudi. HomoDomesticação/Cultura Material. Vol. 16. Portugal: Casa da Moeda, 1989. pp. 11-47.

BURKE, H. Ideology and the Material Culture of Life and Death. In: HALL, M. \& SILLIMAN, S. W. (Eds). Historical Archaeology. Cornwall: Blackwell, 2006. pp. 128-145.

CAMPIGLIA, G. O. O. Igrejas no Brasil - Fontes para a História da Igreja no Brasil. São Paulo: Melhoramentos, 1957.

CANCLINI, N. G. Leitores, espectadores e internautas. São Paulo: Iluminuras, 2008.

CASTRO, C. Frans Boas: Antropologia Cultural. Rio de Janeiro: Jorge Zahar, 2004.

CHAGAS, M. Museália. Rio de Janeiro: JC Editora, 1996.

CHOAY, F. A Alegoria do Patrimônio. Trad. Luciano Vieira Machado. São Paulo: Estação Liberdade, 2001. 
CLARKE, D. The loss of innocence. Antiquity/vol.47/Issue 185. Antiquity Publications. 1973. pp. 6-18.

COLWELL-CHANTHAPHONH, C. \& FERGUSON, T. J. Introduction: The Collaborative Continuum. In: COLWELL-CHANTHAPHONH, C. \& FERGUSON, T. J. Collaboration in Archaeological Practice: Engaging Descendant Communities. Lanham: Altamira Press, 2008. pp. 1-32.

COMENALE, R. Zé Arigó: La Octava Maravilla. Belo Horizonte: Boa Imagem, 1968.

CRIADO BOADO, F. Del Terreno al Espacio: Planteamientos Y Perspectivas para la Arqueología Del Paisaje. Santiago de Compostela: CAPA, 1999.

CUCHE, D. A noção de cultura nas ciências sociais. Bauru: EDUSC, 1996.

CURY, M. X. Exposição: Análise metodológica do processo de concepção, montagem e avaliação. 1999. 134 p. Dissertação (Mestrado). Escola de Comunicação e Artes da Universidade de São Paulo. São Paulo: ECA/USP, 1999.

DEYON, P. O Mercantilismo. São Paulo: Perspectiva, 1969.

ESCHWEGE, W. L. von. Pluto Brasiliensis. Vol. 1. Trad. Domício de Figueiredo Murta. São Paulo: USP, 1979. a.

. Pluto Brasiliensis. Vol. 2 Trad. Domício de Figueiredo Murta. São Paulo: USP, 1979. b.

ETZEL, E. O Barroco no Brasil. Psicologia - Remanescentes em São Paulo, Goiás, Mato Grosso, Paraná, Santa Catarina, Rio Grande do Sul. São Paulo: Melhoramentos/EDUSP, 1974.

FAGUNDES, M. Sitio Resende: Das cadeias operatórias ao estilo tecnológico. Um estudo de dinâmica cultural no médio vale do Paranaíba, Centralina, Minas Gerais. 2004. 554 p. Dissertação (Mestrado) Museu de Arqueologia da Universidade de São Paulo. São Paulo: MAE/USP, 2004.

FALCÃO, E. C. A Basílica do Senhor Bom Jesus de Congonhas do Campo. Vol.3. São Paulo: Revista dos Tribunais, 1962.

FERRING, C. R. Alluvial Pedology and Geoarchaeological Research. In: HOLLIDAY, Vance T. (Ed.). Soils in archaeology: Landscape evolution and human occupation. Smithsonian Institution, 1992. pp. 1-39.

FLANNERY, K. V., MARCUS, J. Cognitive Archaeology. In: WHITLEY, D. S. Reader in Archaeological Theory: Post-Processual and Cognitive Approaches. London: Routledge, 1998. pp. 35-48.

FREITAS, D. D. \& SILVA, V. C. da. Dicionário Ilustrado da Inconfidência Mineira. Belo Horizonte: 2008. 
FUNARI, P. P. A.; FUNARI, R. S. Educação Patrimonial: teoria e prática. In: SOARES, A. L. R. Educação Patrimonial: Teoria e Prática. Santa Maria: UFSM, 2007. pp. 11-21.

FUNARI, P. P. A. A Arqueologia histórica em uma Perspectiva Mundial. In: FUNARI, P. P. A. Arqueologia e Patrimônio. Erechim: Habilis, 2007. pp. 27-34.

. Arqueologia e Patrimônio. Erechim: Habilis, 2007.

Apresentação. In: FUNARI, P. P. A. \& FOGOLARI, E. P. (Orgs.). Estudos de Arqueologia Histórica. Erechim: Habitus, 2005. pp. 03-07.

A Arqueologia Histórica em uma Perspectiva Mundial. In: Anais SAB 2001. Campinas: UNICAMP, 2002. pp. 1-8.

Historical archaeology from a word perspective. In: FUNARI, P. P. A. \& JONES, S. (Eds.). Historical Archaeology: Back from the edge. London \& New York: Routledge, 1999. pp. 37- 63.

FURTADO, C. Análise do "Modelo" Brasileiro. $3^{\mathrm{a}}$ ed. Rio de Janeiro: Civilização Brasileira, 1972. 1980.

Formação Econômica do Brasil. 11ª ed. São Paulo: Companhia Editora Nacional,

GALLO, H. Arqueologia, Arquitetura e a cidade: a preservação entre a identidade e a autenticidade. In: MORI, V. H., SOUZA, M. C. de; BASTOS, R. L. \& GALLO, H. Patrimônio: atualizando o debate. Instituto do Patrimônio Histórico e Artístico Nacional. São Paulo: IPHAN, 2006. pp. 91-116.

GARCÍA. N. T. Un modelo participativo em la gestión del património: el ecomuseu. In: MASACHS, R. C. \& MERILLAS, O. F. (Coords.). Comunicación educativa del patrimônio: referentes, modelos y ejemplos. (200-?). pp. 137-149.

GLENISSON, J. Iniciação aos Estudos Históricos. $5^{\text {a }}$ ed. São Paulo: Bertrand Brasil/DIFEL, 1986.

GONÇALVES, J. R. S. O patrimônio como categoria de pensamento. In: ABREU, R. \& CHAGAS, M. (Orgs). Memória e Patrimônio: Ensaios Contemporâneos. Rio de Janeiro: Lamparina, 2009. pp. 25-33.

GREMAUD, A. P. G.; VASCONCELlOS, M. A. S. de \& TONETO JR, R. Economia brasileira contemporânea. $3^{\text {a }}$ ed. São Paulo: Atlas, 1999.

GUARNIERI, W. R. C. Conceito de cultura e sua inter-relação com o patrimônio cultural e a preservação. Cadernos Museológicos, Nº 3. IBPC. São Paulo, 1990.

GUIMARÃES, C. M.: Arqueologia Histórica em Minas Gerais: um universo de possibilidades. In: OLIVEIRA, A. P. de P. L. (Org.). Arqueologia e Patrimônio de Minas Gerais. Juiz de Fora: Editar, 2007. pp. 163-169.

GUTIERRES, G. L. \& CATANI, A. M. Participação e Gestão Escolar: Conceitos e potencialidades. (199-?). pp. 59-75. 
HALL, M. \& SILLIMAN, S. W. Introduction: Archaeology of the Modern Word. In: HALL, M. \& SILLIMAN, S. W. (Eds.). Historical Archaeology. Oxford: Blackwell, 2006. pp. 01-17.

HOBSBAWM, E. O que os historiadores devem a Karl Marx? In: HOBSBAWM, E. Sobre História: Ensaios. Trad. Cid Knipel Moreira. 5a ed. São Paulo: Companhia das Letras, 1997. pp. 155-170.

HODDER, I. Archaeological Reflexivity and the "local” voice. In: Anthropological Quartely. Washington, v.76, $\mathrm{n}^{\circ} 1,2003$.

The archaeological process. An introdution . Oxford, Blackwell publishers. 1999.

Reading the past: Current approaches to interpretation in archaeology. New York: Cambridge Univrsity Press, 1986.

HORTA, M. de L. P.; GRUMBERG, E. \& MONTEIRO, A. Q. Guia Básico de Educação Patrimonial. Instituto do Patrimônio Histórico e Artístico Nacional, Museu Imperial. Brasília, 1999.

JAMESON JR, J. H. \& BAUGHER, S. Public Interpretation, Outreach and Partnering: An Introduction. In: JAMESON JR, J. H. \& BAUGHER, S. Past Meets Present: Archaeologists Partnering with Museum Curators, Teachers and Community Groups. New York: Springfield, 2007. pp. 3-17.

JEPPSON, P. L. \& BRAUER, G. Archaeology for Education Needs: An Archaeologist and an Educator Discuss Archaeology in the Baltimore County Public Schools. In: JAMESON JR, J. H. \& BAUGHER, S. Past Meets Present: Archaeologists Partnering with Museum Curators, Teachers and Community Groups. New York: Springfield, 2007. pp. 231-248.

JONES, S. Categorias históricas e a práxis da identidade: a interpretação da etnicidade na arqueologia histórica. Trad. Solange Nunes de Oliveira Schiavetto. In: FUNARI, P. P. A. et al. (Orgs). Identidades, discurso e poder: Estudos da arqueologia contemporânea. São Paulo: Annablume, 2005. pp. 27-43.

JORGE, F. O Aleijadinho: Sua Vida, Sua Obra, Seu Gênio. $5^{\text {a }}$ Ed. São Paulo: Divisão Européia do Livro, 1971.

JULIÃO, L. Apontamentos sobre a História do Museu. In: TRINDADE, S. C.; et al. Cadernos de diretrizes museológicas I. Belo Horizonte: Secretaria de Estado da Cultura. Superintendência de Museus. Associação dos Amigos do Museu Mineiro, 2002. pp. 15-28.

KELLY, C. O Profeta Aleijadinho. São Paulo: São José, 1960.

KNAPP, A. B. \& ASHMORE, W. Archaeologycal Landscapes: Constructed, Conceptualized, Ideational. In: ASHMORE, W. \& KNAPP, A. B. (Eds). Archaeologies of Landscape: Contemporary Perspectives. Oxford: Blackwell, 1999. pp. 1-31.

LE GOFF, J. (Org.) A Nova História. São Paulo: Martins Fontes, 1998. História e Memória. Trad. Bernardo Leitão. Campinas: UNICAMP, 1990. 
LEMOS, C. A. C. O que é Patrimônio Histórico. $5^{\text {a }}$ ed. São Paulo: Brasiliense, 1987.

LEROI-GOURHAN, A. Evolução e Técnicas: I - O Homem e a Matéria. Trad. Fernanda Pinto Basto. São Paulo: Martins Fontes, 1972. O gesto e a palavra: 2 - Memória e ritmos. São Paulo: Edições 70, 1965.

LÉVI-STRAUSS, C. Introdução. In: MAUSS, M. Sociologia e Antropologia: Com uma Introdução à obra de Marcel Mauss de Claude Lévi-Strauss. Vol. 2. Trad. Mauro W. B. de Almeida. São Paulo: EDUSP, 1974. pp. 1-36.

LINS, A. C. B. A Paisagem Ameaçada. In: CUREAU, S.; et. al. (Orgs). Olhar Multidisciplina Sobre a Efetividade da Proteção do Patrimônio Cultural. Belo Horizonte: Forum, 2011. pp. 269-281.

LUMBRERAS, L. G. Arqueologia de la América Andina. Carlos Milla Batres (Ed.). Editorial Milla Batres, 1981.

MCGUIRE, R. H. Archaeology as Polical Action. Berkley: University of California Press, 2008.

MARUI, M. Cultural Heritage and Communities Coexisting: Public Archaeology in Cambodia, 1999-2009. In: Publique Archaeology. vol. 9. n 4. 2010. pp. 194-210.

MARX, M. Cidade no Brasil: terra de quem? São Paulo: Nobel/EDUSP, 1991.

MAUSS, M. Sociologia e Antropologia: Com uma Introdução à obra de Marcel Mauss de Claude Lévi-Strauss. Vol. 2. Trad. Mauro W. B. de Almeida. São Paulo: EDUSP, 1974.

MELLO E SOUZA, L. de \& BICALHO, M. F. B. 1680-1720: o império deste mundo. Laura de Mello e Souza \& Lília Moritz Schwarcz (coords.). São Paulo: Schwarcz, 2000.

MELLO E SOUZA, L. de. Desclassificados do Ouro: A pobreza mineira no século XVIII. $3^{\text {a }}$ ed. Rio de Janeiro: Graal, 1990.

MELO, C. Os Ciclos Econômicos do Brasil. Rio de Janeiro: Guanabara, 1969.

MILANEZ, B. Grandes Minas em Congonhas (MG): mais do mesmo? In: FERNANDES, F. R. C.; ENRÍQUEZ, M. A. R. da S. \& ALAMINO, R. de C. J. (Eds.). Recursos Minerais \& Sustentabilidade Territorial. Vol. 1. Grandes Minas. Juiz de Fora: UFJF, 2011. pp. 199-228.

MORAIS, D. de. Arqueologia da Arquitetura: Estação Ferroviária de Piraju. Ensaio de Arqueologia da Arquitetura de Ramos de Azevedo. Erechim: Habilis, 2007.

MORAIS, F.; MORAIS, J. L. A finalidade constitucional da $n^{\circ} 230-02$. In: BASTOS, R. L. \& SOUZA, M. C. de. Patrimônio Cultural Arqueológico: Diálogos, Reflexões e Práticas. São Paulo: IPHAN, 2011. pp. 181-197.

MORAIS, J. L.; VASCONCELLOS, C. de M. \& HATTORI, M. L. Gestão estratégica do patrimônio arqueológico na área de influência de gasodutos da Petrobrás: Gasoduto 
Caraguatatuba - Taubaté \& Gasoduto Paulínia - Jacutinga. Guia de Educação Patrimonial. MAE/USP. São Paulo, 2009.

MORAIS, J. L. de. Arqueologia da Paisagem. In: SCHEUNEMANN, I. \& OOSTERBEEK, L. (Orgs.). Gestão Integrada do Território: Economia, Sociedade, Ambiente e Cultura. Rio de Janeiro: IBIO, 2012. pp. 255-292.

Habilis, 2011.

Perspectivas Geoambientais da Arqueologia do Paranapanema Paulista. Erechim: Patrimônio: atualizando o debate. São Paulo: IPHAN, 2006.

MENESES, U. T. B. de. Premissas para a formulação de políticas públicas em Arqueologia. In: Revista do Patrimônio Histórico e Artístico Nacional. Nº 33. IPHAN. São Paulo, 2007.

A cidade como bem cultural: Áreas envoltóreas e outros dilemas, equívocos e alcance da preservação do patrimônio ambiental urbano. In: MORI, V. H.; et. al. Patrimônio: atualizando o debate. Instituto do Patrimônio Histórico e Artístico Nacional. São Paulo: IPHAN, 2006. pp. 35-76.

O museu na cidade X A cidade no museu: Para uma abordagem histórica dos museus de cidade. Revista Brasileira de História. Vol. 5, nº 8/9. São Paulo, 1984. pp. 197-205.

NETO, J. A. N. A transversalidade e a renovação no ensino de História. In: KARNAL, L. (Org). História na sala de aula: conceitos, práticas e propostas. São Paulo: 2003.

OLIVEIRA, A. P. de P. L. \& FERNANDES, R. S. Arqueologia, história e novas fontes: os indígenas de Minas Gerais nas trincheiras do passado colonial. In: OLIVEIRA, A. P. de P. L. \& OLIVEIRA, L. M. (Orgs.). Arqueologia e Patrimônio de Minas Gerais: Ouro Preto. Juiz de Fora: UFJF, 2010. pp. 105-117.

OLIVEIRA, A. P. de P. L. Arqueologia e história indígena de Minas Gerais: os Carijós de Vila Rica. In: OLIVEIRA, A. P. de P. L. \& OLIVEIRA, L. M. (Orgs.). Arqueologia e Patrimônio de Minas Gerais: Ouro Preto. Juiz de Fora: UFJF, 2010. pp. 155-164.

OLIVEIRA, M. R. de . Aleijadinho: Passos e Profetas. São Paulo: Itatiaia, 1985.

OOSTBERBEEK, L. Um século e meio de conflitos na Arqueologia Preventiva em Portugal: entre o dever e o esquecimento. In: SOUZA, M. C. de. Arqueologia Preventiva: Gestão e mediação de conflitos. Estudos Comparativos. São Paulo: IPHAN, 2010. pp. 95-112.

ORSER JR, C. E. A Historical Archaeology of the Modern Word. New York: Plenum Press, 1996.

Encyclopedia of Historical Archaeology. London: Routledge, 2002.

PEIXOTO, L. da S. Cultura Material e Memória Social. In: FUNARI, P. P. A.; et.al. Arqueologia Histórica, Memória e Patrimônio em Perspectiva Multidisciplinar: Contribuições da Arqueologia, História, Literatura, Arquitetura e Urbanismo. Pelotas: Instituto de Memória e Patrimônio - IMP; Laboratório de Antropologia e Arqueologia - 
LEPAARQ/UFPEL; Programa de Pós-Graduação em Memória Social e Patrimônio Cultural UFPEL, 2009. pp. 91-103.

PENHA, U. C. Miguel Burnier: Geologia e Paisagens. In: BAETA, A. \& PILÓ, H. (orgs.) Marcas Históricas: Miguel Burnier - Ouro Preto. Belo Horizonte: Gerdau, 2012. pp. 12-27.

PESEZ, J-M. História da cultura material. In: LE GOFF, Jacques. (Org.) A Nova História. São Paulo: Martins Fontes, 1998.

PESSOA, F. S. Reflexões sobre a ecomuseologia. Porto: Afrontamento, 2001.

PESSOA, J. Reflexões sobre a Preservação de Áreas Urbanas no Brasil. In: CUREAU, S.; et. al (Orgs). Olhar Multidisciplinar sobre a efetividade da Proteção do Patrimônio Cultural. Belo Horizonte: Fórum, 2011. pp. 51-62.

PIRONI, R. Atlas Escolar Histórico e Geográfico de Congonhas. Belo Horizonte: Acervo Cultural Brasileiro, 2008.

PRADO JUNIOR, C. História Econômica do Brasil. 44ª ed. São Paulo: Brasiliense, 2000.

PRICE, D. T. \& FEINMAN G. M. The Archaeology of the future. In: FEINMAN, G. \& PRICE, D. (Eds). Archaeology at the millennium. New York: Kluwer Academic/Plenum Publishers, 2001. pp. 475 - 496.

RIBEIRO, R. W. Possibiliades e Limites da Categotia de Paisagem Cultural para Formação de Políticas de Patrimônio. In: CUREAU, S.; et. al (Orgs). Olhar Multidisciplinar sobre a efetividade da Proteção do Patrimônio Cultural. Belo Horizonte: Fórum, 2011. pp. 255-267.

SALIBA, E. T. As Utopias Românticas. São Paulo: Brasiliense: 1991.

SANJAD, N. \& BRANDÃO, C. R. F. A exposição como processo de comunicação. In: BITTENCOURT, J. N. (Coord.). Cadernos de diretrizes museológicas 2. Belo Horizonte: Secretaria de Estado da Cultura de Minas Gerais. Superintendência de Museus. 2008. pp. 2433.

SANT'ANNA, M. A face imaterial do patrimônio cultural: os novos instrumentos de reconhecimento e valorização. In: ABREU, R. \& CHAGAS, M. (Orgs). Memória e Patrimônio: Ensaios Contemporâneos. Rio de Janeiro: Lamparina, 2009. pp. 49-58.

SANTOMÉ, J. T. Globalização e interdisciplinaridade: O currículo integrado. Trad. Cláudia Schilling. Porto Alegre: Artmed. 1998.

SANTOS, C. G. R. dos. Programa de Gestão do Patrimônio Arqueológico de São Sebastião. 2011. 131 p. Dissertação (Mestrado). Museu de Arqueologia e Etnologia da Universidade de São Paulo. São Paulo: MAE/USP, 2011.

SANTOS, M. Estrada Real: O presente ilumina o passado (Le présent éclair le passé). Belo Horizonte: Santa Marta, 2008.

SCHAFF, A. História e verdade. São Paulo: Martins Fontes. 1978. 
SETA, C. De. Objecto. In: Enciclopédia Einaudi. Artes - Tonal/atonal. Vol. 3. Portugal: Casa da Moeda, 1984.pp. 91-112.

SHANKS, M. \& HODDER, I. Processual, Postprocessual and Interpretive Archaeologies. In: Whitley, David, S.: Reader in Archaeological Theory: Post-Processual and Cognitive Approaches. London: Routledge, 1998. pp. 70-95.

SILVA, L. J. da. Espaço e centralidade no centro histórico de Congonhas. 2003. 128 p. Monografia (especialização em Arquitetura). Escola de Arquitetura. Belo Horizonte: UFMG, 2003.

SILVA, R. T. da; et. al. Aspectos pedológicos aplicados à pesquisa arqueológica: considerações teóricas. In: RUBIN, J. C. R. de. \& SILVA, R. T. da (Orgs). Geoarqueologia: Teoria e prática. Goiânia: UCG, 2008. pp. 23-40.

SMITH, R. C. Congonhas do Campo. Rio de Janeiro: Argir, 1973.

SODRÉ, N. W. O que se deve ler para conhecer o Brasil. Rio de Janeiro: Civilização Brasileira, 1967.

SOUZA, M. C. de; DIMITIADIS, G. Arqueologia Preventiva como veículo de coesão social. In: BASTOS, R. L. \& SOUZA, M. C. de (Eds.). Patrimônio Cultural Arqueológico: Diálogos, Reflexões e Práticas. São Paulo: IPHAN, 2011. pp. 87-96.

STOCKING JR., G. W. Frans Boas: A Formação da Antropologia Americana 1883-1911 Antologia. Rio de Janeiro: Contraponto/UFRJ, 2004.

SUMÁRIO DE DADOS DE CONGONHAS. Congonhas: Prefeitura Municipal de Congonhas, 2002.

TIRADO SEGURA, F. Contribuciones de la Evaluación al Desarrollo de la museologia. In: Encontro de Profissionais de Museus. A comunicação em questão: exposição e educação, propostas e compromissos. São Paulo; Brasília: MAE, USP: STJ, 2003. pp. 19-42.

TOCCHETTO, F. \& THIESEN, B. A memória fora de nós: A preservação do Patrimônio Arqueológico em Áreas Urbanas. In: LIMA, T. A. Patrimônio Arqueológico: o desafio da preservação. Revista do Patrimônio Histórico e Artístico Nacional. N³3. São Paulo: IPHAN, 2007. pp. 174-199.

TRIGGER, B. G. História do Pensamento Arqueológico. São Paulo: Odysseus, 2004.

TULLY, G. Community archaeology: general methods and standards of pratice. In: Public Archaeology, vol. 6. No 3. 2007. pp. 155-187.

VASCONCELLOS, C. de M. O papel social e educacional dos museus: um estudo de caso do projeto girassol do Museu de Arqueologia e Etnologia da USP. In: NASCIMENTO, S. S. do \& BOSSLER, A. P. (Orgs.) Museu e escola. UFMG/FaE/LEME. Belo Horizonte, 2010. pp. 113.

VASCONCELLOS, M. M. Aleijadinho: Iconografia Maçônica. São Paulo: Radhu, 1997. 
VENTURELLI, I. H. B. Profetas ou Conjurados? São Paulo: Edição da autora, 1982.

VERGUEIRO, L. Opulência e miséria das Minas Gerais. São Paulo: Brasiliense, 1986.

WHITLEY, D. S. New Approaches to Old Problems. In: WHITLEY, D. S. (Org). Reader in Archaeological Theory: Post-Processual and Cognitive Approaches. London: Routledge, 1998.pp. 1-25.

WILKIE, L. A. Interpretive Historical Archaeologies. In: MAJEWSKI, T. \& GAIMSTER, D. International Handbook of Historical Archaeology. New York: Springer, 2009. pp. 333-34.

YAMING, R. \& METHENY, K. B. Preface: Reading the Historical Landscape. In: YAMING, R. \& METHENY, K. B. Landscape Archaeology: Reading and Interpreting the American Historical Landscape. Knoxville: University of Tennessee, 1996. pp.13-20.

YENTSCH, E. A. Introduction: Close Attention to Place - Landscape Studies by Historical Archaeologists. In: YAMIN, R. \& METHENY, K. B. Landscape Archaeology: Reading and interpreting the American Historical Landscape. Knoxville: University of Tennessee, 1996. pp. 23-37.

ZEDEÑO, M. N. \& BOWSER, B. J. The Archaeology of Meaningful Places. In: BOWSER, B. J. \& ZEDEÑO, M. N. The Archaeology of Meaningful Places. Salt Lake City: The University of Utah Press, 2008. pp. 1-14. 


\section{Bibliografia}

Anthropological Quartely. Washington, v.76, nº1, 2003.

Antiquity. vol. 47. Antiquity Publications. 1973.

ASHMORE, W. \& KNAPP, A. B. (Eds). Archaeologies of Landscape: Contemporary Perspectives. Oxford: Blackwell, 1999.

BAETA, A. \& PILÓ, H. (Orgs.) Marcas Históricas: Miguel Burnier - Ouro Preto. Belo Horizonte: Gerdau, 2012.

BASTOS, R. Lopes \& SOUZA, M. C. de (Ed.). Patrimônio Cultural Arqueológico: Diálogos, Reflexões e Práticas. São Paulo: IPHAN, 2011.

BITTENCOURT, J. N. (Coord.). Cadernos de diretrizes museológicas 2. Belo Horizonte: Secretaria de Estado da Cultura de Minas Gerais. Superintendência de Museus. 2008.

BLOCH, M. Introdução aos estudos históricos. Sintra: Europa-América, 1976.

BOWSER, B. J. \& ZEDEÑO, M. N. The Archaeology of Meaningful Places. Salt Lake City: The University of Utah Press, 2008.

BRASIL. MINISTÉRIO DA CULTURA. Pioneiros e empreendedores: a saga do desenvolvimento no Brasil. Os caminhos do processo de musealização. MARCOVITCH, J. \& BRUNO, M. C. O. (Orgs.) São Paulo, 2012.

Cadernos Museológicos, No 3. IBPC. São Paulo, 1990.

CAMPOS, F. S. P. de A. A última ceia: uma análise crítica da visualidade na obra de Antônio Francisco Lisboa - O Aleijadinho. 2009. 222 p. Dissertação (mestrado) Niterói: Universidade Federal Fluminense. Programa de Pós-Graduação em Ciência da Arte, 2008.

CARVALHO, C. S. R. de; et al. (Orgs.) Um olhar contemporâneo sobre a preservação do patrimônio cultural material. Rio de Janeiro: Museu Histórico Nacional, 2008.

CHAGAS, M. de S.; BEZERRA, R. Z. \& BENCHETRIT, S. F. (Orgs.) A Democratização da Memória: A Função social dos Museus Ibero-Americanos. Rio de Janeiro: Museu Histórico Nacional, 2008.

COLWELL-CHANTHAPHONH, C. \& FERGUSON, T. J. Collaboration in Archaeological Practice: Engaging Descendant Communities. Lanham: Altamira Press, 2008.

Enciclopédia Einaudi. Homo-Domesticação/Cultura Material. Vol. 16. Portugal: Casa da Moeda, 1989. Artes - Tonal/atonal. Vol. 3. Portugal: Casa da Moeda, 1984. 
Encontro de Profissionais de Museus. A comunicação em questão: exposição e educação, propostas e compromissos. São Paulo; Brasília: MAE, USP: STJ, 2003.

FERNANDES, F. R. C.; ENRÍQUEZ, M. A. R. da S. \& AlAMINO, R. de C. J. (Eds.). Recursos Minerais \& Sustentabilidade Territorial. Vol. 1. Grandes Minas. Juiz de Fora: UFJF, 2011.

FEINMAN, G. \& PRICE, D. (Eds). Archaeology at the millennium. New York: Kluwer Academic/Plenum Publishers, 2001.

FUNARI, P. P. A.; et.al. Arqueologia Histórica, Memória e Patrimônio em Perspectiva Multidisciplinar: Contribuições da Arqueologia, História, Literatura, Arquitetura e Urbanismo. Pelotas: Instituto de Memória e Patrimônio - IMP; Laboratório de Antropologia e Arqueologia - LEPAARQ/UFPEL; Programa de Pós-Graduação em Memória Social e Patrimônio Cultural - UFPEL, 2009.

FUNARI, P. P. A.; et al. (Orgs). Identidades, discurso e poder: Estudos da arqueologia contemporânea. São Paulo: Annablume, 2005.

FUNARI, P. P. A. \& FOGOLARI, E. P. (Orgs.). Estudos de Arqueologia Histórica. Erechim: Habitus, 2005.

FUNARI, P. P. A. \& JONES, S. (Eds.). Historical Archaeology: Back from the edge. London \& New York: Routledge, 1999.

FUNARI, P. P. A. Arqueologia e Patrimônio. Erechim: Habilis, 2007.

MASACHS, R. C. \& MERILLAS, O. F. (Coords.). Comunicación educativa del patrimônio: referentes, modelos y ejemplos. (20-?).

GONDAR, J. \& DODEBEI, V. O que é memória social? Rio de Janeiro: Contra Capa, 2009.

HALL, M. \& SILLIMAN, S. W. (Eds). Historical Archaeology. Oxford/Cornwall: Blackwell, 2006.

HALL, S. A identidade cultural na pós-modernidade. Trad. Tomaz Tadeu da Silva e Guacira Lopes Louro. 11 ${ }^{\mathrm{a}}$ ed. Rio de Janeiro: DP\&A, 2006.

HERNÁNDEZ HERNÁNDEZ, F. Manual de Museología. 2ª reimp. Madrid: Síntesis, 2008.

HOBSBAWM, E. Sobre História: Ensaios. Trad. Cid Knipel Moreira. $5^{\mathrm{a}}$ ed. São Paulo: Companhia das Letras, 1997.

HODDER, I.; et al. (Orgs) Interpreting Archaeology: Finding meaning in the past. London/New York: Routledge, 1995.

HOLLIDAY, V. T. (Ed.). Soils in archaeology: Landscape evolution and human occupation. Smithsonian Institution, 1992.

INSOLL, T. (Ed.) The Archaeology of Identities: A reader. London: Routledge, 2007. 
JAMESON JR, J. H. \& BAUGHER, S. Past Meets Present: Archaeologists Partnering with Museum Curators, Teachers and Community Groups. New York: Springfield, 2007.

JORGE, V. O. Arqueologia, Patrimônio e Cultura. Lisboa: Instituto Piaget, 2000.

Journal of Society for Historical Archaeology. Vol. 42. $N^{\circ}$ 2. Stone Montain: Society for Historical Archaeology, 2008.

KARNAL, L. (Org). História na sala de aula: conceitos, práticas e propostas. São Paulo: 2003.

LAYTON, R. (Ed.) Who needs the past? Indigenous values and archaeology. New York: Routledge, 1994.

LIMA A. P. S. de. Academia, contrato e patrimônio: visões distintas da mesma disciplina. 2010. 145 p. Tese (doutorado) Museu de Arqueologia e Etnologia da Universidade de São Paulo. São Paulo: MAE/USP, 2010.

LIMA, T. A. Patrimônio Arqueológico: o desafio da preservação. Revista do Patrimônio Histórico e Artístico Nacional. N³3. São Paulo: IPHAN, 2007.

LEMONNIER, P. (Ed.). Tecnological Choices: Transformation in Material Culture since the Neolithic. London: Routledge, 1993.

LONGACRE, W. A. (Ed.). Ceramic Ethnoarchaeology. Tucson: The Arizona University Press, 1991.

MAJEWSKI, T. \& GAIMSTER, D. International Handbook of Historical Archaeology. New York: Springer, 2009.

MARTÍN-BARBERO, J. Os exercícios do ver: hegemonia audiovisual e ficção televisiva. São Paulo: SENAC, 2001.

MORAIS, D. de. Teyqué pé: integrando as referências patrimoniais. 2010. 261 p. Tese (doutorado) Universidade Lusófona de Humanidades e Tecnologias. Lisboa: Departamento de Museologia, 2010.

MORI, V. H.; et al. Patrimônio: atualizando o debate. Instituto do Patrimônio Histórico e Artístico Nacional. São Paulo: IPHAN, 2006.

NASCIMENTO, S. S. do \& BOSSLER, A. P. (Orgs.) Museu e escola. UFMG/FaE/LEME. Belo Horizonte, 2010.

OLIVEIRA, A. P. de P. L. \& OLIVEIRA, L. M. (Orgs.). Arqueologia e Patrimônio de Minas Gerais: Ouro Preto. Juiz de Fora: UFJF, 2010.

OLIVEIRA, A. P. de P. L. (Org.). Arqueologia e Patrimônio de Minas Gerais. Juiz de Fora: Editar, 2007.

PEARSON, M. P. \& RICHARDS, C. (Orgs). Architecture and order: Approaches to Social Space. London/New York: Routledge, 1994. 
PRESTES, M. P. Arqueologia e Patrimônio: revitalização e uso de sítios arqueológicos em área urbana. 2004. 139 p. Dissertação (mestrado). Universidade de São Paulo. São Paulo: Faculdade de Filosofia, Letras e Ciências Humanas da Universidade de São Paulo, 2004.

Public Archaeology, vol. 6. No 3. 2007.

Public Archaeology. vol. 9. $n^{\circ}$ 4. 2010.

Revista Brasileira de História. Vol. 5, nº 8/9. São Paulo, 1984.

Revista do MAE-USP. Anais da II Semana de Arqueologia. Suplemento n. ${ }^{\circ}$ 11, 2011.

Revista do Patrimônio Histórico e Artístico Nacional. Nº 33. IPHAN. São Paulo, 2007.

RUBIN, J. C. R. de. \& SILVA, R. T. da (Orgs). Geoarqueologia: Teoria e prática. Goiânia: UCG, 2008.

SANTOS, M. Pensando o espaço do homem. São Paulo: Hucitec, 1982.

SÃO PAULO. IPHAN: Patrimônio: atualizando o debate. São Paulo: 2006.

SCARRE, C. \& SCARRE, G. The Ethics of Archaeology: Philosophical Perspectives on Archaeological Practice. Cambridge: Cambridge University Press, 2006.

SCHEUNEMANN, I. \& OOSTERBEEK, L. (Orgs.). Gestão Integrada do Território: Economia, Sociedade, Ambiente e Cultura. Rio de Janeiro: IBIO, 2012.

SHIFFER, M. B. (Ed.). Social Theory in archaeology. Salt Lake City: University of Utah Press, 2000.

SILVA, F. F. da. As cidades brasileiras e o patrimônio cultural da humanidade. São Paulo: EDUSP, 2003.

SOARES, A. L. R. Educação Patrimonial: Teoria e Prática. Santa Maria: UFSM, 2007.

SOUZA, M. C. de. Arqueologia Preventiva: Gestão e mediação de conflitos. Estudos Comparativos. São Paulo: IPHAN, 2010.

STARK, M.; BOWSER, B. \& HORNE, L. (Eds.) Cultural transmission and material culture: Breaking down boundaries. Tucson: The University of Arizona Press, 2008.

STARK, M. (Ed.). The Archaeology of Social Boundaries. Washington/London: Smithsonian Institution Press, 1998.

TILLEY, C.; et al. (Eds.). Handbook of Material Culture. London: SAGE Publications INC, 2006.

WALSH, K. The representation of the past: museums and heritage in the post-modern world. London/New York: Routledge, 2001. 
WHITLEY, D. S. Reader in Archaeological Theory: Post-Processual and Cognitive Approaches. London: Routledge, 1998.

UCKO, P. J. (Ed.). Theory in Archaeology: A world perspective. London/New York: Routledge, 1995.

VASCONCELLOS, C. de M. Representações da Revolução Mexicana no Museu Nacional de História da Cidade do México (1940-1982). 2003. 255 p. Tese (doutorado) Universidade de São Paulo. São Paulo: Departamento de História da Faculdade de Filosofia, Letras e Ciências Humanas da Universidade de São Paulo, 2003.

YAMING, R. \& METHENY, K. B. Landscape Archaeology: Reading and Interpreting the American Historical Landscape. Knoxville: University of Tennessee, 1996. 


\section{Sítios pesquisados na Internet}

http://portal.iphan.gov.br/portal/baixaFcdAnexo.do?id=234 acessado em 24 de outubro de $\underline{2012 .}$

http://www.icomos.org.br/cartas/Carta_de Bage_PaisagemCultural.pdf acessado em 28 de outubro de 2012.

http://www.icomos.org.br/cartas/Carta_de_Veneza_1964.pdf acessado em 29 de outubro de 2012. 


\section{Anexo 1}

\section{Estudo de comunicação, recepção e avaliação}

\section{1 - Projeto de pesquisa de comunicação, recepção e avaliação para os velhos caminhos de Congonhas}

Este projeto é considerado parte importante da pesquisa de mestrado porque procura coletar referenciais junto à população da cidade para apoiar em nossas ações futuras quanto à preservação e ressignificação de sítios arqueológicos para fins educacionais. Ele foi elaborado para que fosse aplicado como uma forma de comunicação nas escolas do município de Congonhas e seus resultados ajudarão a definir o modelo de Educação Patrimonial a ser proposto para todo o município, assim como formas possíveis de musealização de sítios arqueológicos que possam ser incluídos na de reutilização de sítios arqueológicos ameaçados de destruição no processo de educação de cidadãos congonhenses.

Com efeito, acreditamos que o sucesso do processo comunicativo a ser desenvolvido e o alcance de seus resultados dependerão de como faremos o processo funcionar e de como os receptores das informações receberão a mensagem a ser transmitida e assim, como o patrimônio arqueológico e sua preservação para fins educacionais estão em questão, trataremos de aliar propostas educacionais desenvolvidas nas áreas da comunicação em museus e na área da educação formal brasileira.

Neste sentido, o museólogo Jesús Martin-Barbero (1994) sustentou que a recepção é uma parte das mais importantes no processo de comunicação museológica:

Parto do princípio de que a recepção não é somente uma etapa no interior do processo de comunicação, um momento separável, em termos de disciplina, de metodologia, mas uma espécie de um outro lugar, o de rever e repensar o processo inteiro da comunicação (MARTÍN-BARBERO in SOUZA, 1994, p. 40). 
O processo de comunicação, desta forma, estaria ligado a um modelo mecânico que, por sua vez, é condutista ${ }^{63}$. É o modelo hegemônico nos estudos de comunicação, em que comunicar é fazer chegar uma informação pronta, do comunicador ao receptor.

Este modelo condutista está fundido em outra epistemologia, que é a iluminista, que desde o século XIX concebeu o processo de educação como um processo de transmissão de conhecimento de quem conhece para quem não conhece e o receptor considerado um recipiente a receber as coisas prontas produzidas por outros indivíduos. Neste sentido, concepções como estas seguem contrárias ao que declarou o educador Ulpiano Toledo Bezerra de Meneses (2007), para quem a memória não pode ser objeto de resgate, pois se trata de um processo mutável dentro de uma perspectiva histórica, um trabalho contínuo, ao contrário de algo objetivado ou de um pacote fechado de recordações induzidas. Há, então, uma espécie de contraponto, uma contradição ou antagonismo na forma de pensarmos a educação por meio da herança cultural e então, surge uma necessidade de resolvermos esta questão dúbia antes de tudo. Mas como resolvermos esta questão, no sentido de formarmos um pensamento único ao invés de uma ideia de duplo sentido?

Acreditamos, então, que a forma de resolver esta questão dúbia está num método de educação transversal e interdisciplinar, já que a transversalidade no ensino de História é uma ferramenta pedagógica que permite, por um lado, estimularmos o pensamento crítico do aluno, do receptor da informação, e por outro, nos permite incluir num processo educacional os vestígios levantados pela Arqueologia Histórica, de forma a trabalharmos interdisciplinarmente, junto com outras disciplinas da grade escolar, considerando temas como a pluralidade cultural do Brasil, o meio ambiente, a ética, ou até mesmo a saúde.

Essa postura não implica provocar aberturas nesse modelo, já que não temos outro para colocar em seu lugar, mas sim começarmos a descobrir um mapa noturno (como os que orientam os pilotos à noite), que corresponderia a instituições, vislumbres, indicadores para se avançar rapidamente (MARTÍN-BARBERO in SOUZA, 1994, p. 42).

Resolvida a querela epistemológica levantada, acreditamos que após o desenvolvimento dos trabalhos educativos sob uma proposta transversal e interdisciplinar, os dados resultantes

\footnotetext{
${ }^{63}$ Este modelo é considerado condutista porque ao trazer uma informação pronta, do comunicador ao receptor da informação, o processo de comunicação é conduzido, guiado, orientado pelo transmissor da informação até o receptor, que muitas vezes é considerado como um recipiente vazio a ser cheio com informação.
} 
desta pesquisa de comunicação, recepção e avaliação irão ajudar fundamentar a proposta de musealização de forma mais fundamentada e confiável, pois é com a análise deste dados é que iremos definir um plano de ações concretas a ser aplicado na cidade.

Os resultados desta pesquisa serão aliados a outros tipos de coletas de referenciais que se deram entre diferentes entes da sociedade, proporcionado uma coleta diversificada com as mais diferentes pessoas, faixas etárias, classes sociais e visões de mundo. Desta forma, participarão deste projeto todos os cidadãos interessados, de forma livre e espontânea, estudantes dos ensinos fundamental e médio, além de cidadãos que não se encontram nessa fase do aprendizado, como trabalhadores em geral, aposentados, estudantes universitários, entre outros.

Os referenciais fornecidos pela própria sociedade serão amplamente considerados para a formulação de ações a serem feitas e assim, acreditamos que a aplicação deste projeto é a via de abertura para a elaboração de uma proposta de Educação Patrimonial e musealização de sítios arqueológicos, de forma participativa e democrática.

Contudo, este projeto tem a forma de um projeto de pesquisa porque nosso objetivo principal é realizarmos uma pesquisa concreta de comunicação, recepção e avaliação. Tratamos aqui de uma pesquisa que vem para apoiar a outra, intitulada "Os velhos caminhos de Congonhas numa perspectiva de Educação Patrimonial", pois, ao mesmo tempo em que busca proporcionar uma educação pela herança cultural, também avaliará os resultados do processo e de sua importância para a população, no intuito de buscar a musealização de sítios arqueológicos para uma educação permanente em Congonhas.

Segundo a Professora Doutora Marília Xavier Cury ${ }^{64}$, coorientadora deste projeto, a comunicação é fator primordial da Educação Patrimonial porque o conhecimento arqueológico e os sítios que pretendemos que recebam ações preservacionistas devem ser, antes de tudo, promovidos e divulgados entre o público que queremos atingir e beneficiar, o que vai de encontro com outras ideias a respeito da herança cultural e de sua apropriação pelas comunidades detentoras: "Herança significa um passo além do patrimônio cuja transformação em herança se dá a partir da consciência de sua existência" (BRUNO, 1998, p. 19).

\footnotetext{
${ }^{64}$ Além da coorientação deste projeto de pesquisa de comunicação, recepção e avaliação, a Prof. ${ }^{a}$ Dr. ${ }^{a}$ Marília Xavier Cury tratou de abordar sobre esta metodologia de pesquisa durante as disciplinas "Comunicação e Expografia" e "Público de Museus e Pesquisa de Recepção", que a mesma lecionou no MAE/USP durante o $1^{\circ}$ semestre de 2013.
} 
A recepção é entendida como a forma com que o público recebe a mensagem que pretendemos passar. Ela acontece durante todo o processo comunicativo até o seu final, e assim, deveremos fazer aplicação de questionários aos participantes e por fim, a avaliação dos resultados e dos referenciais coletados será incluída entre os dados elencados para propormos as ações concretas no sentido de musealizarmos sítios arqueológicos e ressignificá-los para usufruto da população local, objetivando a Educação Patrimonial permanente e duradoura, no lugar da destruição do patrimônio arqueológico.

Outra consideração a ser feita, tem como base as afirmativas do museólogo Jesús MartínBarbero (1994), que nos alerta de que deve ocorrer um cuidado com as avaliações da palavra do receptor, que deve ser considerada sem que seja algo como uma palavra de ordem, mas sim, no sentido de participação. Além disso, o receptor e sua opinião são considerados muito importantes neste processo, mas temos que considerar também o meio e sua concentração econômica e política.

Por isso os estudos de recepção devem considerar questões como a vida quotidiana, o consumo, a leitura semiótica do ambiente e a história. Para que isso ocorra, a paisagem local onde estão inseridos os sítios arqueológicos que apresentaremos ao público deve ser incluída no processo comunicativo de forma em que os cidadãos, estudantes ou não, possam compreendê-la numa dinâmica que considere sua transformação como resultado da interação entre a sociedade que a transforma e a natureza, em um processo histórico e de acordo com as conjunturas que provocam as respectivas mudanças, inseridas numa rede de relações que funcione como uma wide word web (Morais, 2011).

Com isso, a paisagem congonhense deverá ser compreendida segundo a história local, e isso significa observá-la desde a ocupação da região pelas populações indígenas, passando pela chegada do colonizador, que segundo a historiografia local, teria vindo de Queluz, atual Conselheiro Lafaiete, pelas margens do rio maranhão e adentrando seus afluentes, ocupando as regiões do Alto Maranhão _Arraial Redondo_, Lobo Leite _Arraial de Soledade_e Congonhas do Campo _Arraial das Congonhas_, passando também pelo período de estagnação econômica provocada pelo esgotamento do ouro e das dificuldades de extraí-lo do solo, pelas transformações urbanas trazidas pela ferrovia, pelas siderúrgicas e mineradoras de ferro, quando finalmente abordaremos a transformação da paisagem segundo a conjuntura socioeconômica atual, até chegarmos a uma perspectiva de futuro que considere a preservação dos remanescentes do passado local como parte dos referenciais da nação brasileira. 
As ações concretas no sentido de musealizar e ressignificar sítios arqueológicos serão apresentadas somente após apresentação dos resultados, que serão conhecidos apenas com a avaliação desta pesquisa, ou seja, depois de todo o processo de comunicação, recepção e avaliação.

\section{1 - Introdução e Justificativa}

A cidade de Congonhas, Estado de Minas Gerais, vive atualmente diversos conflitos envolvendo seu patrimônio cultural. Um deles, e que mais nos interessa, é a destruição contínua de sítios arqueológicos por conta de obras de infraestrutura urbana e mobilidade, como a abertura de loteamentos, condomínios residenciais, estradas municipais e rodovias, além de um impasse que se tornou motivo de disputa na justiça entre grandes empresas mineradoras, ONGs e sociedade civil. O impasse gira em torno da oferta de empregos gerada pela indústria de mineração do ferro, a exploração mais sustentável do meio ambiente e a preservação do patrimônio cultural, que inclui situada diante das cobiçadas montanhas de ferro, a obra prima do artista brasileiro Antônio Francisco Lisboa, o Aleijadinho, conhecida como "Os Doze Profetas", cujos sítios arqueológicos ameaçados ajudam a compor o cenário entre tais obras e as montanhas ferríferas.

Tema de interesse público, a partir de nossa participação em audiências públicas realizadas pela Câmara de Vereadores de Congonhas para sua discussão, tornou-se consenso entre os envolvidos e interessados na querela, dos quais destacamos estudantes, trabalhadores, políticos como deputados estaduais e vereadores, representantes de empresas mineradoras multinacionais e juristas, o reconhecimento da dificuldade de compreensão da inter-relação dos fatores geradores do impasse na cidade e de como os implicadores da questão se intercalam num processo histórico.

Problemas desta ordem já foram apontados pela museóloga e professora Maria Cristina Oliveira Bruno (1995) do MAE/USP (Museu de Arqueologia e Etnologia da Universidade de São Paulo), em sua tese de doutorado, onde afirmou que são falhos e ausentes os estudos das sociedades pretéritas do Brasil para a compreensão da história do país e suas explicações. 
Considera-se que a ausência de um olhar interpretativo, capaz de identificar e resgatar da vivência de grupos pré-coloniais os elementos que deveriam colaborar com a compreensão da identidade nacional, pode ser uma das razões da posição estranha que ocupa o conhecimento produzido por meio de estudos arqueológicos. Estudos, estes, sempre respeitados, mas nem sempre inseridos nas explicações sobre o Brasil (BRUNO, 1995, p. 7).

Contudo, a Arqueologia pode atuar sobre diversas possibilidades de inserção de uma Educação Patrimonial que pode ajudar a esclarecer a população local acerca da importância da preservação de seu patrimônio. A Educação Patrimonial é entendida aqui como uma forma de educar por meio da herança cultural, ou por meio dos referenciais culturais da nação e de seu povo, e um meio que ofereça ao cidadão a possibilidade de inclusão e capacitação de uma consciência crítica sobre o meio no qual ele vive, e de como questões ambientais e culturais se inter-relacionam sobre a paisagem que se transforma pela ação humana e natural em um processo histórico, pois o patrimônio arqueológico, assim como a cidade de hoje e toda a rede de relações em sua volta, [...] "por sua vez, só é inteligível dentro de uma perspectiva histórica” (MENESES, 1984, p. 200).

Compreender a importância do patrimônio arqueológico para a história da sociedade local se tornará possível por meio de sua promoção pela Educação Patrimonial, pois entendemos que educar é formar cidadãos conscientes da importância de seu papel na sociedade da qual ele é herdeiro de tradições e costumes e também sujeito transformador e reprodutor dessas mesmas tradições e costumes, os quais serão herdados pelas gerações futuras.

Com efeito, utilizando-nos da legislação brasileira, aplicamos à Educação Patrimonial e inclusão social os princípios definidos para a educação ambiental, nos termos da Lei Federal 9.795, de 27 de abril de 1999 (Bastos e Souza, 2010). Existem ainda outras considerações que devem constar entre os princípios básicos estabelecidos para a educação ambiental nos programas de educação patrimonial e inclusão social tais como:

\footnotetext{
- o enfoque humanista, holístico, democrático, participativo e emancipador;

- a concepção patrimonial em sua totalidade, considerando a interdependência entre os meios natural, socioeconômico e cultural;

- o pluralismo de ideias e concepções pedagógicas, na perspectiva da inter, multi e transdiciplinaridade;

- a vinculação entre a ética, a educação, o trabalho e as práticas sociais;

- a continuidade e a permanência do processo educativo;

- a avaliação crítica do processo educativo;

- o reconhecimento e o respeito à pluralidade e à diversidade individual e cultural;
} 
- a abordagem articulada de assuntos e questões patrimoniais locais, regionais, nacionais e globais (BASTOS e SOUZA, 2010, p. 217).

Com isso, acreditamos que a educação é um dos requisitos básicos para dar aos cidadãos o acesso aos diversos bens e serviços produzidos pela sociedade e também um direito fundamental para o homem, que deve ser garantido e respeitado, e de forma alguma ser negligenciado. Educar, no que diz respeito a este projeto principalmente, é um meio pelo qual os cidadãos poderão se tornar estimulados a participarem com olhar crítico nas questões do dia-a-dia, principalmente onde o patrimônio cultural arqueológico estiver inserido, já que o município de Congonhas cresce tomando impulso na mineração, que por sua vez sofre a pressão externa de um mercado global em constante expansão, causando uma destruição deste patrimônio, que ocorre de forma silenciosa e sistemática, não dando a oportunidade aos cidadãos de participação nas decisões que muitas vezes tem terminado na devastação parcial ou senão completa do patrimônio. Assim, os cidadãos serão convidados a identificarem problemas e participarem de decisões relacionadas ao patrimônio arqueológico do município de Congonhas, entendido aqui como bem ou cultura material portadora dos referenciais constitutivos da nação brasileira e de seu povo, presentes na paisagem que se transforma pela ação contínua do homem no mundo.

Consideremos ainda que, subjacente aos meandros do processo museológico existe uma engrenagem pedagógica constituída pelas articulações entre procedimentos de salvaguarda e comunicação que é orientada para o conhecimento e valorização da herança cultural, ou, uma pedagogia voltada para a educação da memória, que permite a compreensão sobre a importância de gestos preservacionistas, possibilitando o uso qualificado do patrimônio e que potencializa a singularidade desses processos e nos ajuda a entender a transitoriedade humana (Bruno, 2012).

Desta forma, o patrimônio cultural arqueológico inserido numa paisagem em transformação é também Fato Museal e ferramenta pedagógica para entender embates como a necessidade de espaço para o crescimento e expansão da mineração e da urbanização e também, fonte de conhecimento para o enfrentamento dos problemas de seu cotidiano, dos quais os cidadãos serão instigados a participarem e tomarem decisões, se distanciando das tomadas de decisões autoritárias e negligentes das quais eles são excluídos. 


\section{2 - Objetivos gerais e específicos}

Este trabalho tem como objetivo promover o patrimônio cultural arqueológico por meio de ações educativas, inserindo-o na interpretação da história local, como vestígios para a interpretação da paisagem cultural, resultado da interação homem/natureza. Ele visa também proporcionar maior aproximação do patrimônio arqueológico entre educadores, estudantes e outros seguimentos da sociedade e de órgãos públicos como escolas do município de Congonhas, realizando experiências educativas que possam fornecer referenciais que venham ajudar a formular uma proposta que visa ao mesmo tempo uma Educação Patrimonial permanente para o município de Congonhas e a musealização de sítios arqueológicos para serem reutilizados para atividades educacionais.

A promoção do patrimônio cultural se dará pela Educação Patrimonial, entendida aqui como uma forma de Arqueologia Preventiva e para tanto, buscaremos desenvolver, por meio de atividades educativas sob uma abordagem de ensino transversal e interdisciplinar, variadas formas de comunicação museal que auxiliem o processo educativo, para explicar o processo histórico de transformação da paisagem no município de Congonhas inserindo o patrimônio arqueológico nas explicações, propiciando por meio da Educação Patrimonial a emergência de uma consciência crítica sobre a ação transformadora do homem no mundo em que vivemos e atuamos como agentes transformadores, proporcionado condições e diretrizes para promover socialmente o patrimônio arqueológico e sua ressignificação como referencial histórico para as explicações sobre a cidade e região e seu povo, contribuindo para a inteligibilidade do fenômeno da transformação da paisagem cultural, a partir de uma ideia de patrimônio arqueológico inserido numa paisagem em transformação como Fato Museal.

\section{3 - Problemática e hipóteses}

O município de Congonhas se desenvolve socioeconomicamente e cresce demograficamente, mas temos notado que, diante de tal realidade, o patrimônio arqueológico tem ficado de lado perante aos interesses econômicos gerais e às políticas públicas que tentam impulsionar e destacar a participação da cidade na economia globalizada. 
Diante disso, como proporcionar meios de garantir que a legislação patrimonial seja respeitada, acompanhando o crescimento socioeconômico e demográfico, sem que o patrimônio arqueológico se torne uma pedra no sapato do desenvolvimento local ou viceversa?

Inseridos na paisagem cultural que compõe o conjunto arquitetônico, escultórico e paisagístico da Basílica do Senhor Bom Jesus de Matosinhos, os sítios arqueológicos Fazenda do Faria, Capela de Santo Antônio, Mina do Veeiro, Mina de Soledade e Mina das Goiabeiras encontram-se abandonados e em risco de destruição, assim como a Mina do Redondo e as ruínas da fonte e da cadeia do Distrito de Alto Maranhão, que não são visíveis do templo do Bom Jesus, mas que também possuem importância fundamental na compreensão do povoamento da região que atualmente é o município de Congonhas.

Diante desse quadro, uma questão que se levanta é a seguinte: seria possível incluir os sítios arqueológicos nas explicações sobre a transformação da paisagem local de forma que os mesmos se tornem referenciais para estudos históricos?

Outro problema a ser resolvido é de que o município de Congonhas não possui um programa de gestão do patrimônio arqueológico que leve à sua promoção e proteção. Por isso, quanto ao papel do Poder Público, como fazer com que as atenções deste se voltem para o patrimônio arqueológico de forma que diferentes órgãos e instituições possam trabalhar de forma integrada na sua promoção e proteção?

Quanto ao papel população, uma promoção participativa do patrimônio arqueológico entre ela pode fornecer referenciais confiáveis e necessários que nos ajudem a formular uma proposta de Educação Patrimonial permanente que possa contar com a preservação e ressignificação de sítios arqueológicos para finalidades educacionais como forma de Arqueologia Preventiva?

E ainda, será possível, com a aplicação deste estudo de comunicação, recepção e avaliação, contribuirmos no processo educacional dos participantes de forma a conseguirmos outros resultados que não sejam somente a participação e coleta de referenciais que apoiem na formulação da proposta de Educação Patrimonial e reutilização de sítios arqueológicos para a educação?

Contudo, estaremos atentos ao longo da realização desta pesquisa para tentarmos responder às questões e hipóteses previamente levantadas e também elencar e incluir dados inesperados 
que venham a surgir no decorrer do processo educativo e que possam de alguma forma prestar sua contribuição com o processo educativo.

\section{4 - Pressupostos teóricos e metodológicos}

Conforme apontou o educador Ulpiano Toledo Bezerra de Meneses (2007), a Arqueologia Histórica pode trabalhar com objetos fora de contexto e vestígios, artefatos e estruturas que se encontram sobre do solo, aparentes, somando positivamente à informação escrita para a construção de abordagens históricas para serem transmitidas na área educativa junto à Arqueologia, tornando-se materiais que a Arqueologia fornece para a inteligibilidade do fenômeno de transformação da sociedade, o que por sua vez nos permite trabalhar com a ideia de um patrimônio arqueológico inserido numa paisagem em transformação em Congonhas, de forma a explicar as relações do homem, sujeito transformador, com o patrimônio arqueológico presente na paisagem, natureza transformada, fenômenos que se dão em forma de processo histórico.

Neste sentido, em convergência com a análise metodológica de exposição museológica desenvolvida pela museóloga e comunicóloga Marília Xavier Cury e empregada na área da educação em museus, também entendida como uma forma de Educação Patrimonial, a musealização é entendida como valorização do objeto, que se inicia com o olhar crítico sobre as coisas materiais. "No entanto, musealização é um processo que se inicia na valorização seletiva, mas continua no conjunto de ações que visa a transformação do objeto em documento e sua comunicação" (CURY, 1999, p. 8). Desta forma, [...] "podemos dizer que é através da musealização de objetos, cenários e paisagens que constituam sinais, imagens e símbolos, que o Museu permite ao homem a leitura do mundo" (GUARNIERI, 1990, p. 8).

Como parte da abordagem interdisciplinar, a Museologia, inserida neste projeto, trabalhará também na perspectiva de uma Museologia como estudo da relação específica do homem com a realidade, assim definida por Waldisa Russio Camargo Guarnieri (1990), que também definiu a Museologia como estudo do Fato Museal ou Museológico:

(...) 'é a relação profunda entre o Homem, sujeito que conhece, e o Objeto, parte da Realidade à qual o Homem também pertence e sobre a qual tem o poder de agir’, 
relação esta que se processa 'num cenário institucionalizado, ou o museu'(GUARNIERI, 1990, p. 9).

Nosso Fato Museal a ser estudado durante a realização desta pesquisa é o patrimônio arqueológico inserido na paisagem que se transforma, enquanto que o cenário institucionalizado será a escola, a rua, ou qualquer outro local de que nos dispusermos para a realização de trabalhos educativos.

Tendo definindo o patrimônio arqueológico inserido na paisagem em transformação como nosso Fato Museal_Fato Musealizável_, nossas ações educativas de promoção do patrimônio arqueológico entre a população de Congonhas se darão conduzidas pela noção abrangente do que é o processo de musealização e de suas diversas possibilidades de abordagens práticas no campo da Museografia. Nesse sentido, consideraremos a definição do termo muselização apresentado por Marília Xavier Cury:

\footnotetext{
Entende-se o processo de musealização como uma série de ações voltadas sobre os objetos, quais sejam: aquisição, pesquisa, conservação, documentação e comunicação. O processo inicia-se ao selecionar um objeto de seu contexto e completa-se ao apresenta-lo publicamente através de exposições, de atividades educativas e de outras formas. Compreende, ainda, as atividades administrativas como pano de fundo desse processo (CURY, 1999, p. 8-9).
}

Partindo deste ponto de vista acerca do que é a musealização, de início serão produzidos slides, palestras, exposições fotográficas, pastas com imagens de Congonhas e dos sítios arqueológicos Fazenda do Faria, Capela de Santo Antônio e Mina do Veeiro, que ficam próximos ao Morro de Santo Antônio, a Mina das Goiabeiras, que fica localizada mais próxima do município, a Mina de Soledade, que fica no Distrito de Lobo Leite e a Mina do Redondo e ruínas da cadeia e fonte, que ficam no Distrito de Alto Maranhão, todos detentores de vestígios arqueológicos para serem explorados junto aos educandos por meio de filmagens, fotografias e apresentações de slides. Estudaremos também sobre a possibilidade de realizarmos até mesmo visitas in situ, caso estas não representem falta de segurança para os participantes da pesquisa.

Isso também nos lembra de que as ações educacionais devem, contudo, se adaptarem às possibilidades oferecidas pelo meio em que se realiza, ou seja, o município de Congonhas, em Minas Gerais, já que o princípio da participação é exercício do diálogo entre as partes 
envolvidas, o que nem sempre poderá ocorrer e ainda, porque somos constantemente advertidos sobre as possibilidades, interferências e surpresas do meio e do cotidiano que influenciam sobre a pesquisa: "Toda e qualquer organização que tente implantar e desenvolver práticas de natureza participativa vive sob a constante ameaça de reconversão burocrática e autoritária de seus melhores esforços” (GUTIERRES \& CATANI, (199-?), p. $71)$.

Isso diz respeito, por exemplo, de nos vermos forçados a nos enquadrar às agendas dos possíveis parceiros, às suas disponibilidades de fornecimento de pessoal e material, de espaços ou quaisquer outros recursos que eles possam vir ou não a providenciar. Desta forma, fica claro que não é interessante nesse projeto tentar impor que atividades de promoção do patrimônio arqueológico sejam realizadas a qualquer custo, em detrimento dos interesses dos participantes e parceiros, pois isso nem de longe se aproximaria de um processo participativo e democrático. Pretendemos, contudo, nos aproximar da ideia de uma educação como a proporcionada pelos museus como ferramenta para promover mudanças na direção do desenvolvimento social, para propormos uma agenda alicerçada também nas demandas da sociedade (Vasconcellos, 2010). O patrimônio arqueológico deve ser encarado como parte da vida das pessoas e os problemas de destruição do patrimônio como os que atualmente são vividos em Congonhas são também reflexos de uma educação deficiente, porém, acreditamos que e é pela via da educação é que devem ser enfrentados os problemas de uma sociedade.

Acreditamos também que as principais causas dos problemas que levam ao desconhecimento e desinteresse das pessoas pelo patrimônio arqueológico estão na forma como a História do Brasil é ensinada. Um dos problemas relacionados aos estudos de História no Brasil é o de que a disciplina só trata de coisas antigas e de que nada tem a ver com a realidade atual ou nosso dia-a-dia ou com a inserção do indivíduo como agente de mudança e transformação. "De fato, um modelo de ensino histórico que lida com uma narrativa feita apenas com heróis e sujeitos fundadores da civilização é algo que se separa do universo dos alunos e os exclui desse processo" (NETO, 2003, p. 66). Portanto, o ideal é que possamos despertar o interesse dos alunos por uma história da qual eles façam parte e na qual está inserido seu patrimônio arqueológico, fazendo com que os alunos possam perceber processos e intercessões entre o patrimônio arqueológico e a sua própria história, a do povo brasileiro e do povo congonhense.

Por isso, acreditamos também que por meio de um ensino transversal e interdisciplinar, a Arqueologia, como ciência histórica, pode, através do conhecimento que constrói acerca da civilização, funcionar como um agente participativo nesse processo educacional de 
exploração da realidade do mundo pelo sujeito que dele faz parte e o ajuda a transformar e assim, professores de diversas disciplinas, os alunos e demais participantes serão instigados a entrarem em debates e discussões acerca do cotidiano do município, de sua importância na história mundial, principalmente no que diz respeito ao dia-a-dia de seus moradores, à sua economia, à questão da transformação histórica da paisagem ao seu redor e desta forma, dos sítios arqueológicos que a compõem.

Com efeito, acreditamos que, ao contrário dos métodos condutistas normalmente utilizados nos estudos de recepção que trazem a informação pronta do condutor ao receptor, a melhor forma de trabalho para dar aos participantes uma maior capacidade de visão crítica neste campo da Educação é o método de ensino transversal ou transversalidade.

A transversalidade é uma proposta que pode ultrapassar a fragmentação dos conteúdos e disciplinas, promovendo um trabalho cujo conhecimento possa ser construído em função de temas e propostas de ensino apresentados mas, que ao mesmo tempo, podem estimular o pensamento e a visão crítica do mundo. É um método de ensino que está atrelado aos Parâmetros Curriculares Nacionais (PCN) do Ministério da Educação, onde são apresentados temas que devem nortear a elaboração de objetivos, programas e conteúdos em escolas brasileiras por professores e alunos, envolvendo temas transversais para a educação nacional, dentre os quais podem constar temas como ética, pluralidade cultural, saúde, orientação sexual e meio ambiente, desta forma:

(...), a partir da constatação da necessidade de discutir questões presentes no cotidiano dos brasileiros, como, por exemplo, os permanentes casos de corrupção e de desrespeito à pessoa e à noção de cidadania, o preconceito contra grupos étnicos, de gênero e de orientação sexual, as precárias condições de saúde de parte considerável da população, a desinformação sobre a educação sexual, visível em muitas escolas no alto número de adolescentes grávidas e na necessidade de preservação do meio ambiente, como forma de garantir a própria sobrevivência (NETO, 2003, p. 59).

No caso de nossa pesquisa, questões como a pluralidade cultural e meio ambiente serão os temas de maior ênfase, podendo incluir também os temas ética e saúde, já que tratamos de questões relacionadas ao patrimônio arqueológico, sua destruição e sua preservação, apresentando e debatendo acerca do destino que pode ser dado a sítios como a Fazenda do Faria, a Capela de Santo Antônio e a Mina do Veeiro, no Morro de Santo Antônio, a Mina de Soledade em Distrito de Lobo Leite e a Mina do Redondo e ruínas da cadeia e fonte de Alto 
Maranhão, todos ricos em vestígios arqueológicos e histórias para serem exploradas junto aos educandos.

Contudo, os resultados deste processo devem ser avaliados. A avaliação é uma parte importante desta pesquisa porque as opiniões e respostas de alunos, professores e demais cidadãos serão consideradas no intuito de observarmos múltiplas possibilidades de formulação de uma proposta de Educação Patrimonial e musealisação dos sítios arqueológicos de Congonhas, em convergência com a conjuntura atual do município.

Desta forma, como afirmou o museólogo Felipe Tirado Segura (2003), não pretendemos com a pesquisa fazer planos ou expressões de supostas verdades universais, mas se trata de incitar a reflexão crítica em torno do tema proposto, com vistas a contribuir com a formação de ideias e critérios, que possam eventualmente se traduzir em práticas que possam melhorar o tratamento e a informação acerca do patrimônio arqueológico. Portanto, a avaliação deste processo é de certo o canal que deve nos ajudar a nos conduzir rumo a uma proposta cujos sítios arqueológicos do município de Congonhas possam ser valorizados por um processo inclusivo, democrático, participativo.

Desta forma, avaliar significará uma forma de perguntar, de gerar atitudes críticas, de revisar o que foi produzido e de superar limitações, pois os resultados da avaliação podem retroalimentar o alcance dos objetivos, podem não só modelar orientar como também orientar a práxis, entendida como a integração teórica explicativa refletida nas ações práticas, que por sua vez poderão nos fornecer elementos para os trabalhos referentes à museografia (Tirado Segura, 2003).

Neste sentido, essa experiência participativa é o que poderá permitir ou valorizar o êxito de uma exibição ou montagem, tanto a exposição montada para o ambiente escolar quanto para o ambiente externo, ou também as futuras mudanças ou introduções que um trabalho deste tipo pode sofrer e ainda, promover o estabelecimento de diagnósticos e prognósticos.

Ainda sobre esta questão da avaliação do processo educativo, outros autores como Horta, Grumberg e Monteiro (1999) trazem a Educação Patrimonial como fundamental na coleta de referenciais da opinião pública e lembram da importância dela para a tomada de decisões em um trabalho conduzido de forma a considerar a participação do público na promoção do patrimônio cultural ou ainda, uma experiência que pode enriquecer a metodologia aplicada e permitir a verificação do nível de envolvimento e compreensão dos alunos com o tema explorado durante a pesquisa. 
Faremos, portanto, com base em Felipe Tirado Segura (2003), avaliação quantitativa e avaliação qualitativa. A primeira, quantitativa, é baseada em dados e operações estatísticas para que o pesquisador possa validar seus instrumentos e fundamentar suas observações e sustentar suas inferências. A avaliação qualitativa é identificada com a que se sustenta mais nas tradições da investigação etnográfica, que sugere ser de trabalho de campo, em narrativa, com entrevistas diretas e baseada em análise de casos. São procedimentos e métodos diferentes, porém importantes para abordar a avaliação, pois não são antagônicos nem excludentes.

Portanto, para alcançarmos o êxito, as perguntas a serem feitas aos alunos devem se referir ao patrimônio arqueológico do município de Congonhas, com o intuito de conhecermos e avaliarmos os conhecimentos deles sobre os sítios arqueológicos da cidade de Congonhas e sobre as possibilidades de musealização e reutilização dos mesmos para finalidades educacionais. A outra parte da pesquisa será feita com entrevistas junto à população, aleatoriamente, devendo as perguntas seguirem o mesmo tema proposto.

Serão aproveitados também os resultados do questionário preliminar aplicado junto aos alunos do ensino fundamental da Escola Municipal Conceição Lima Guimarães. Os trabalhos avaliativos podem envolver também aspectos relativos ao trabalho dos professores e desta forma, poderemos proporcionar também um balanço dos resultados obtidos junto aos professores, no intuito de buscarmos por fragilidades e potencialidades do processo educativo.

\section{5 - Plano de trabalho e cronograma de execução do estudo de comunicação, recepção e avaliação}

Para o desenvolvimento desta pesquisa, trabalharemos na direção de desenvolver atividades educativas buscando incluir o patrimônio arqueológico numa educação transversal, sob uma perspectiva inter, trans, multidisciplinar e participativa, junto ao público do ensino formal, em parceria com a escola formal de ensino, e ao ensino informal, em parceria com ONGs, associações, proprietários de áreas com ocorrência de sítios arqueológicos, agremiações e empresas e grupos privados com sede ou filiais na cidade de Congonhas e demais agentes interessados em participar de forma espontânea, levando em conta as diversas possibilidades e potencialidades de que o meio nos disponibilizará. 
Buscaremos adequar as necessidades apresentadas pelo meio com atividades propostas contidas no Guia Básico de Educação Patrimonial do IPHAN (1999), desenvolvido por Maria de Lourdes Parreiras Horta, Evelina Gutemberg e Adriane Queiroz Monteiro e também ao conteúdo do Guia de Educação Patrimonial (2009), desenvolvido pelos pesquisadores do MAE/USP, José Luiz de Morais, Camilo de Mello Vasconcellos e Márcia Lika Hattori.

Para organizarmos o desenvolvimento de diferentes atividades de forma a resolvermos a problemática que nos foi apresentada, propomos as seguintes etapas:

1 - busca por parcerias _escolas, ONGs, associações, empresas privadas_ e análise das potencialidades e possibilidades de oferecidas pelo meio, ou seja, definição de plano museológico que permita a explicação da evolução histórica da paisagem de Congonhas por meio de uma abordagem educativa, para a realização das demais etapas;

2 - etapa de Produção de material informativo/educativo _fotográfico, cartográfico, discursivo, entre outros_;

3 - etapa de observação, explorando recursos e exercícios visuais/sensoriais tais como: manipulação, experimentação, comparação, dedução, jogos e questionários para identificação de objetos, função, significado com o intuito de desenvolver a percepção visual e simbólica;

4 - etapa de registro, explorando desenhos, descrições verbais como palestra, ou escritas, como pôsteres, gráficos, fotografias, linhas de tempo, mapas;

5 - etapa de exploração, com análise dos problemas que ocorrem no município, apresentação de hipóteses, discussões em grupo, investigações em locais como em sítios arqueológicos, centros históricos, bibliotecas, jornais e revistas, com o intuito de desenvolver a capacidade de análise e juízo crítico, além da interpretação de evidências e significados;

6 - etapa de apropriação, com criação, releitura, dramatização e diferentes meios de expressão como pinturas, esculturas, peças teatrais, redação escrita, desenvolvendo assim a capacidade de expressão, apropriação e participação criativa;

7 - etapa de avaliação do processo, a se realizar junto dos demais participantes, com o intuito de buscar pontos positivos e negativos do processo;

8 - propor diretrizes para um modelo de Educação Patrimonial para o município de Congonhas, que envolva formas de musealização dos velhos caminhos de Congonhas com base nas experiências adquiridas. 
Tabela 1 (Anexo 1): Cronograma de Atividades da pesquisa de comunicação, recepção e avaliação

\begin{tabular}{|l|l|l|l|l|l|l|l|l|l|l|l|l|l|}
\hline Ano & Etapa & Jan & Fev & Mar & Abr & Mai & Jun & Jul & Ago & Set & Out & Nov & Dez \\
\hline 2013 & 1 & & & X & & & & & & & & & \\
\hline 2013 & 2 & & & & X & & & & & & & & \\
\hline 2013 & 3 & & & & & X & & & & & & & \\
\hline 2013 & 4 & & & & & X & & & & & & & \\
\hline 2013 & 5 & & & & & & X & & & & & & \\
\hline 2013 & 6 & & & & & & & $X$ & & & & & \\
\hline 2013 & 7 & & & & & & & & X & & & & \\
\hline 2014 & 8 & & & & & & & & & $X$ & & & \\
\hline
\end{tabular}




\section{2 - A coleta de referenciais}

Os resultados do estudo de comunicação, recepção e avaliação é considerado por nós de grande relevância para a formulação de uma proposta de Educação Patrimonial para Congonhas e para a ressignificação e musealização dos sítios arqueológicos.

Nossa principal missão de início foi convencer as pessoas, professores, pedagogos, alunos e cidadãos em geral de que nosso trabalho de nada tem a ver com a denúncia ou com a batalha partidária e política e sim, com um fim científico e social, sem interesses lucrativos e que não visa afetar o trabalho das empresas nem a administração municipal. Pelo contrário, buscamos nos aproximar dos órgãos públicos como o Ministério Publico, secretarias da prefeitura, ONGs, pessoas e empresas que podiam assumir parcerias.

Conseguimos para esta pesquisa de recepção e avaliação os seguintes parceiros:

1 - ONG Gota D’água do Alto Paraopeba;

2 - Escola Municipal Conceição Lima Guimarães;

3 - Escola Estadual Barão de Paraopeba;

4 - Secretaria Municipal de Turismo;

5 - Ivone da Conceição Cordeiro, professora de História.

\section{1 - A escola Municipal Conceição Lima Guimarães}

A escola parceira para a aplicação do primeiro questionário aos estudantes foi a Escola Municipal Conceição Lima Guimarães, que trabalha com a educação infantil e o ensino fundamental. O questionário foi aplicado de forma preliminar, no ano de 2010, e serviu como base para elaboração das atividades e questionários seguintes, fator que consideramos muito pertinente no desenvolver das atividades relacionadas à promoção do patrimônio arqueológico para a população do município de Congonhas.

O Bairro Residencial Gualter Monteiro é considerado um bairro de classe baixa, possui infraestrutura básica como coleta de esgotos, água encanada, luz e asfalto. São muitos os 
casos de alcoolismo, uso e tráfico de drogas como o crack, maconha e cocaína. Estão presentes também no bairro a violência doméstica, roubos e assassinatos, entre outros crimes e delitos. Contudo, a maioria da população do bairro é formada por cidadãos trabalhadores e honestos que exercem dignamente as mais variadas profissões, desde os empregados das mineradoras, passando pelos profissionais liberais e funcionários públicos.

Os alunos da escola são na maioria, filhos de funcionários das mineradoras, de empreiteiras que prestam serviços na área de mineração ou são filhos de profissionais como pedreiros, pintores, carpinteiros, empregadas domésticas e alguns são moradores de áreas e bairros rurais e seus pais são pequenos agricultores ou pecuaristas.

O trabalho de aplicação do questionário foi proposto para a pedagoga Vanete Cristina da Silva, que trabalhava como supervisora na escola e gentilmente aceitou a nossa proposta. Para a aplicação do questionário, a diretoria da escola providenciou uma sala de informática, onde foi preciso alguns improvisos, porém, sem interferir no rendimento do trabalho.

Participaram do questionário alunos do $6^{\circ}$ ao $9^{\circ}$ anos e alunos do programa de adiantamento escolar chamado PAV. Para a amostragem foram escolhidos em média três alunos de cada turma, fora de critérios como o rendimento escolar e procurando um equilíbrio entre meninos e meninas. No total foram 19 alunos participantes, com idades entre 11 e 17 anos, que foram monitorados pela pedagoga Vanete Silva, enquanto realizávamos os trabalhos em sala de aula.

Os trabalhos foram iniciados no dia 19 de novembro de 2010, com uma palestra sobre Arqueologia e sobre a natureza de nossa pesquisa em Congonhas. Foram introduzidos temas como Arqueologia Pré-Histórica, Arqueologia Histórica, patrimônio cultural arqueológico, de forma a prepara-los para as atividades que seriam feitas em seguida. A palestra foi intitulada "Conhecendo nosso passado pela Arqueologia".

Em seguida foram aplicados os dois questionários propostos, sendo um para avaliarmos o conhecimento dos alunos sobre os sítios arqueológicos de Congonhas, até então, a Mina do Veeiro, a Mina da Soledade e a Mina das Goiabeiras, e outro questionário aplicado após apresentação e visualização de uma seção de imagens dos sítios arqueológicos, seguido de explicação e contextualização histórica das mesmas, com a finalidade de avaliarmos as opiniões e o interesse dos alunos pelos locais visualizados. 


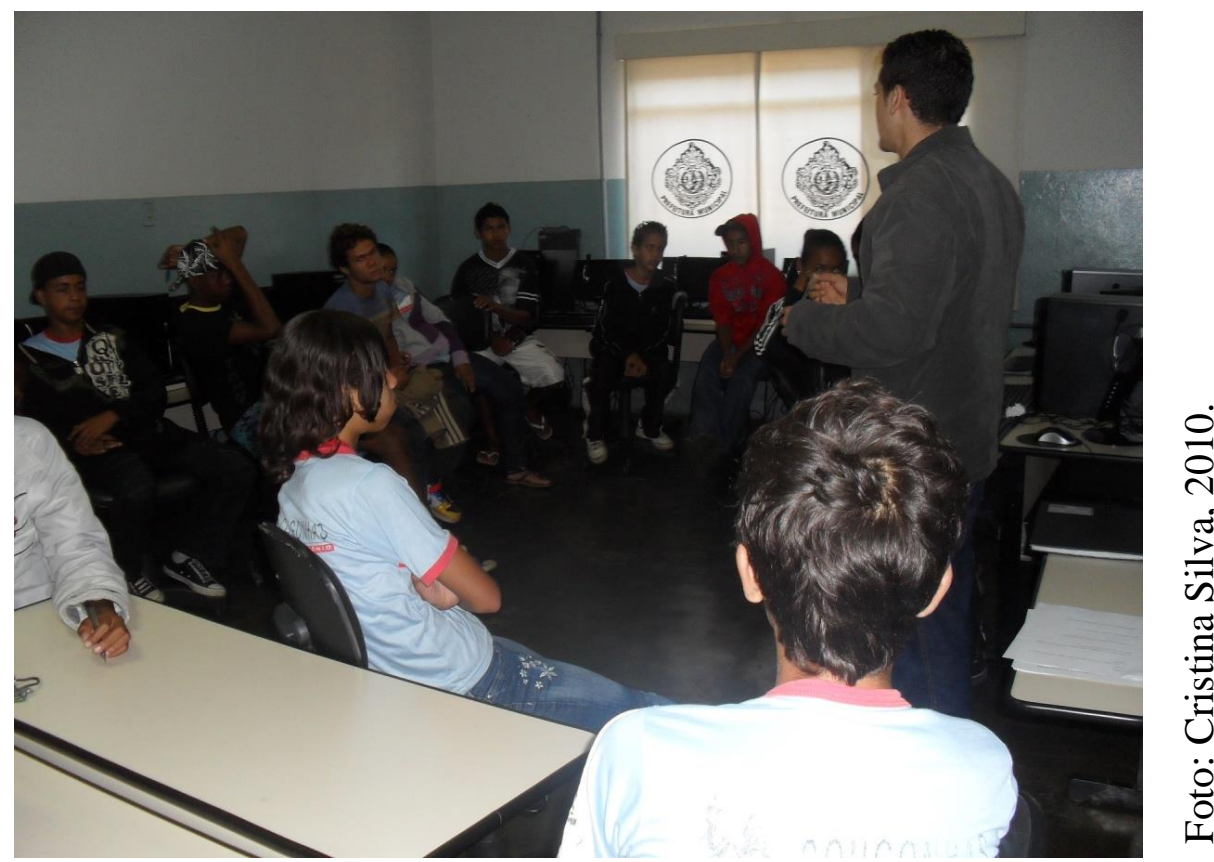

Figura 1 (Anexo 1): Palestra para alunos da Escola Municipal Conceição Lima Guimarães em Congonhas, Minas Gerais.

Este trabalho foi produzido como trabalho final da disciplina de pós-graduação em Arqueologia pelo MAE/USP, Arqueologia, Comunicação, Educação e Recepção, lecionada pela coorientadora desta proposta, a Prof. ${ }^{a}$ Dr. ${ }^{a}$ Marília Xavier Cury, no segundo semestre de 2010 e seus resultados ajudaram a nortear muitos dos passos seguintes que deram origem ao projeto de pesquisa em Arqueologia apresentado a esta mesma instituição intitulado "Os velhos de Congonhas numa perspectiva de Educação Patrimonial". Segundo a própria Prof. ${ }^{\text {a }}$ Dr. ${ }^{a}$ Marília Xavier Cury, nada impede que este trabalho e seus resultados sejam acrescentados nesta pesquisa porque foi a partir desta atividade e de seus resultados que o projeto de pesquisa, assim como outros questionários e as ações de Educação Patrimonial seriam planejados, cabendo assim inclui-lo entre os demais dados e referenciais levantados junto à população de Congonhas e ao público estudantil. 


\section{2 - Questionário preliminar}

Para a primeira parte do questionário preliminar, nos utilizaremos de conhecimento empírico envolvendo o objeto de pesquisa de nosso projeto, objetivando na direção de informar acerca do conhecimento dos alunos da rede pública municipal sobre o mesmo.

O questionário a ser aplicado possui duas partes, sendo que na primeira, os alunos serão questionados sobre os velhos caminhos de Congonhas, com o objetivo de avaliarmos o conhecimento dos mesmos sobre o patrimônio arqueológico da cidade.

A segunda parte do questionário é focada nas potencialidades do patrimônio arqueológico. Os alunos serão levados a visualizarem imagens fotográficas e filmagens do patrimônio arqueológico e depois disso responderão às questões e poderão opinar sobre as potencialidades do patrimônio arqueológico. Com base nas repostas e opiniões dos alunos, apresentaremos algumas das perspectivas educacionais para o patrimônio arqueológico em Congonhas.

\subsection{1 - Primeira parte: antes de visualizarem as imagens (para conhecimento)}

A - Você conhece ou já ouviu falar nas velhas trilhas e túneis que existem em Congonhas?

B - Existe alguém em sua família ou algum amigo (a) seu (a) que conhece as trilhas e túneis ou que já esteve em algum desses locais?

C - Você sabe onde fica alguma dessas trilhas ou algum dos túneis?

D - Faz ideia de quem utilizava as velhas trilhas e túneis?

E - Para qual finalidade você acha que serviam aquelas trilhas e túneis? 


\subsection{2 - Segunda parte: depois de visualizarem as imagens (potencialidades)}

Nesta parte do trabalho os alunos foram estimulados a visualizarem imagens fotográficas dos sítios arqueológicos que tínhamos levantado até então, que eram a Mina das Goiabeiras, Mina do Veeiro e a Mina da Soledade ${ }^{65}$, respondendo em seguida ao seguinte questionário:

A - Agora, depois de visualizar as imagens responda: O que você acha que são aquelas trilhas e túneis que você viu? Para que serviam e quem as utilizava?

B - Quando você acredita que foram construídos?

$\mathrm{C}-\mathrm{O}$ que você acha que acontecia naqueles lugares?

D - Você sentiu vontade de conhecer aqueles lugares? Por quê?

E - O que você acha que pode acontecer caso aquelas trilhas e túneis sejam destruídos, como por exemplo, para a construção de uma casa ou uma estrada sobre eles?

$\mathrm{F}$ - $\mathrm{O}$ que você acredita que pode ser feito com os lugares que você acabou de ver? Existe alguma forma de utilizá-los em favor da sociedade atual?

Deste questionário preliminar tiramos os referenciais a respeito do conhecimento prévio sobre o local eram escassos. Depois de visualizarem as imagens as respostas se tornaram mais amplas e consistentes.

\subsection{3 - Respostas do primeiro questionário aplicado na Escola Municipal Conceição Lima Guimarães para conhecimentos}

Dos 19 alunos que participaram das atividades na Escola Municipal Conceição Lima Guimarães, todos responderam ao primeiro questionário aplicado e à todas as questões levantadas.

\footnotetext{
${ }^{65}$ Os outros sítios arqueológicos levantados durante a realização da pesquisa que são a Mina do Redondo, a Capela de Santo Antônio e a Fazenda do Faria, ainda não haviam sido prospectados até o dia das atividades ocorridas na Escola Municipal Conceição Lima Guimarães e por isso não poderiam ser mostrados aos alunos naquele momento.
} 


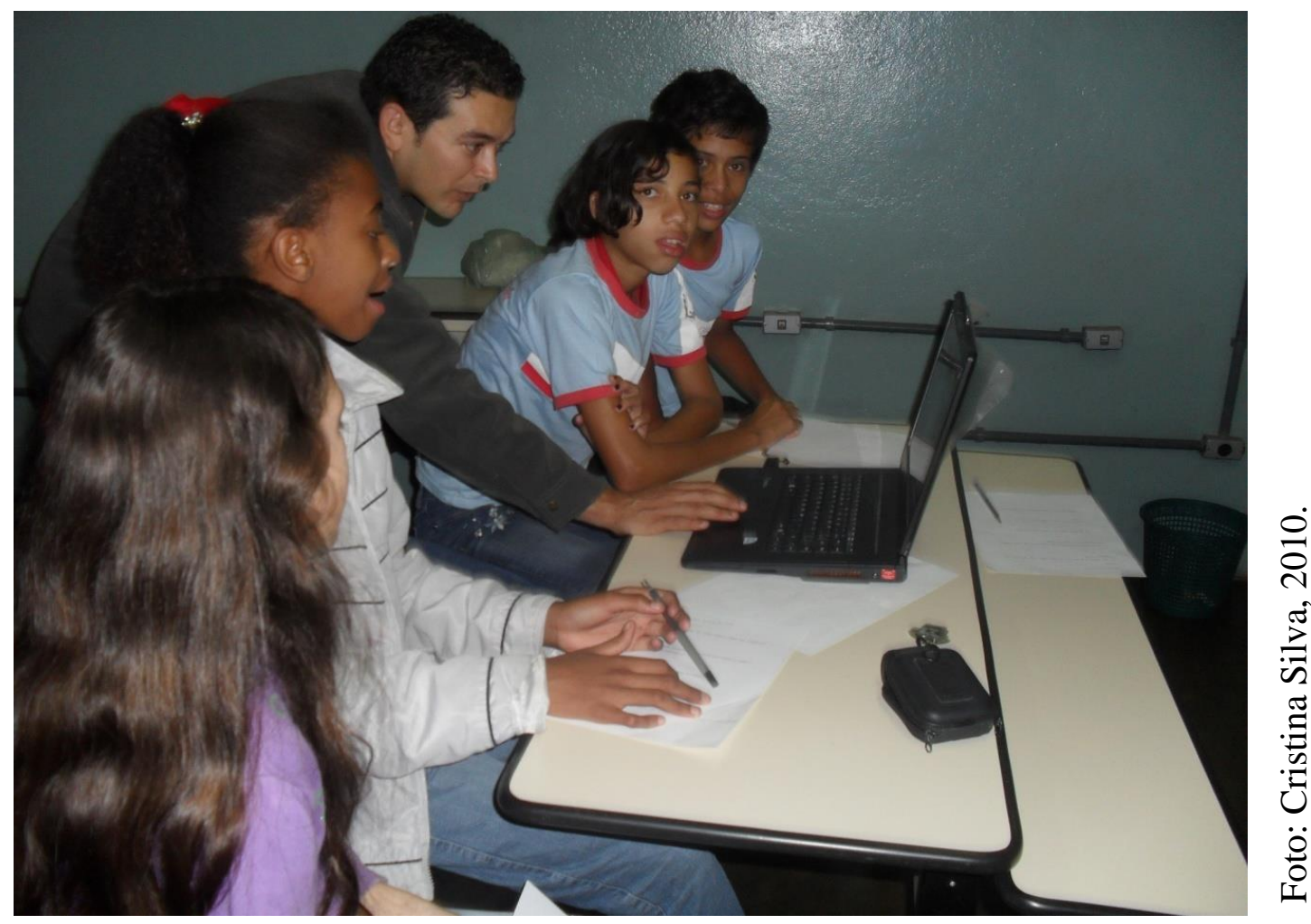

Figura 2 (Anexo 1): Alunos da Escola Municipal Conceição Lima Guimarães durante a visualização de imagens dos sítios arqueológicos.

Na questão A, obtivemos um total de 12 respostas negativas e 7 positivas, no que diz respeito ao conhecimento dos alunos sobre a existência de antigas trilhas e túneis em Congonhas. Vejamos algumas das respostas:

“_ Não” (Ana Clara Jorge Santos, $9^{\circ}$ ano).

“_ Não conheço” (Michel Santos Pinheiro, $8^{\circ}$ ano).

Na questão $\mathrm{B}$, foram obtidas 8 respostas negativas e 11 positivas, quando perguntados se conhecem alguém que saiba da existência de antigas trilhas e túneis em Congonhas. Vejamos algumas das respostas:

“_ Sim, o meu irmão, ele conhece e já me contou” (Mariane Caroline Alves Silva, $7^{\circ}$ ano).

“_ Tenho um amigo que já explorou as trilhas de Congonhas” (Thais Cristine da Silva Moreira, $8^{\circ}$ ano).

Na questão $\mathrm{C}$, obtivemos 18 respostas negativas e 1 positiva quando os alunos foram perguntados se sabiam onde ficavam as trilhas e túneis. Vejamos algumas das respostas: 
“_ Não. Eu nunca vi mais (mas) sempre tive curiosidade de conhecer” (Mariane Caroline Alves Silva, $7^{\circ}$ ano).

“_ Aqui em Congonhas não. Mais (Mas) já ouvi o meu amigo faça (falar) que já foi nas trilhas de Miguel Burnier" (Thais Cristhine da Silva Moreira).

Nas respostas da questão $\mathrm{D}$, obtivemos 12 respostas negativas e 7 negativas, quando perguntados se faziam idéia de quem utilizava as trilhas e túneis de Congonhas. Vejamos algumas das respostas:

“_ Para garimpeiros, escravos, etc.” (Michel Santos Pinheiro, $8^{\circ}$ ano).

“_Escravos e/ou garimpeiros” (Sharon Agata B. Santos, $8^{\circ}$ ano).

Finalizando o primeiro questionário, obtivemos na questão $F$ respostas negativas e 13 respostas positivas quando perguntados acerca da finalidade de uso das trilhas e túneis de Congonhas. Vejamos algumas das respostas:

“_Transportar mercadoria e garimpar ouro" (Sharon Agata B. Santos, $8^{\circ}$ ano).

“_ para (Para) facilitar o trabalho de empresas que trabalham na área, e para pessoas que estudam sobre história. Mas a finalidade delas eram facilitar a passagem de pessoas onde se gravaria o caminho sem se perder. Quando eles estavam trabalhando em busca do ouro" (Roselita Maria Santos Nogueira, $9^{\circ}$ ano).

\subsection{4 - Respostas do segundo questionário aplicado na Escola Municipal Conceição Lima Guimarães para potencialidades}

Dos 19 alunos da Escola Municipal Conceição Lima Guimarães que participaram das atividades de Educação Patrimonial, todos responderam ao segundo questionário e todas as questões levantadas, excluindo apenas na questão A, quando um aluno não respondeu.

Na questão A, obtivemos 18 respostas positivas e 1 aluno não respondeu, quando, depois de visualizarem as imagens, foram perguntados novamente se sabiam sobre o que eram as trilhas e túneis que tinham acabado de ver, para que serviam e quem as utilizava. Vejamos então algumas das respostas da questão A do segundo questionário:

“_Eles olhavam se tinha ouro" (Letícia T. Dutra Gonçalves, $6^{\circ}$ ano). 
“_Eles olhavam se tinha ouro, para construir casas e cavacavam (cavavam) para procurar ouro" (Núbia Nayara Gonçalves, $7^{\circ}$ ano).

Na questão B, quando perguntados sobre a época da construção das trilhas e túneis, 18 alunos responderam e apenas 1 aluno alegou que não sabia. Vejamos algumas das respostas:

“_A 200 anos atrás” (Rafael Oliveira Santos, 9ªno).

“_ Na época dos escravos” (Ana Clara Jorge Santos, $9^{\circ}$ ano).

Na questão C, obtivemos 18 respostas positivas e 1 resposta negativa quando os alunos foram perguntados se sabiam o que acontecia nos lugares que tinham acabado de visualizarem. Vejamos então algumas das repostas:

“_Eu acho que eles tiravam ouro de lá e mineração" (Mariane Caroline Alves Silva, $7^{\circ}$ ano).

“_ Os escravos garimpavam ouro, transportar e lavar o ouro" (Sharon Agata B. Santos, $8^{\circ}$ ano).

Já na questão $\mathrm{D}$, obtivemos 18 respostas positivas e 1 resposta negativa quando os alunos foram questionados se gostariam de conhecer os lugares que tinham visto nas imagens. Vejamos algumas das respostas da questão D:

“_ Sim. Para conhecer mais minha cidade e ter oportunidade de explorar mais os lugares que eu não conheço" (Thais Cristhine da Silva Moreira, $9^{\circ}$ ano).

“_ Sim, porque é muito importante conhecer um pouco mais sobre a história de Congonhas" (Roselita Maria Santos Nogueira, $9^{\circ}$ ano).

Ainda tratando do segundo questionário aplicado na Escola Municipal Conceição Lima Guimarães, obtivemos na questão E 13 respostas coerentes com o tema proposto, 3 ruins ou fora do tema em questão e 2 alunos responderam que não sabem, quando questionados sobre as consequências de possíveis obras que possam atualmente acontecer sobre as trilhas e túneis de Congonhas. Vejamos algumas das respostas da questão E:

“_ Eu acho que a beleza daquilo tudo iria sumi (sumir) (,) fora a cultura e memória da cidade" (Carlos Alexandre A. Ferreira, PAV II).

“_ Acabará com uma história de Congonhas” (Rafael Oliveira Santos, $8^{\circ}$ ano). 
Finalizando o segundo questionário aplicado na Escola Municipal Conceição Lima Guimarães, obtivemos para a questão F 15 respostas positivas, sendo que 12 delas estavam bem formuladas e de acordo com o tema proposto e 3 estavam fora do tema e por isso ruins. Também foram 3 as respostas cujos alunos alegaram não saber responder à questão levantada. Vejamos então algumas das respostas da questão F:

“_ Devia ser mantido em estado de observação de estudiosos e cuidar para que pessoas possam visitar sem destruir, pois é um patrimônio que temos aqui” (Roselita Maria Santos Nogueira, $9^{\circ}$ ano).

“_Eu acredito que podem cuidar e manter. Sim (,) mostrando esses lugares para a sociedade ia despertar a vontade de cuidar e manter natureza" (Thais Cristhine da Silva Moreira, $9^{\circ}$ ano).

\subsection{5 - Resultados preliminares da Escola Municipal Conceição Lima Guimarães}

O tempo gasto para a aplicação do questionário, resposta, debate e explicações foi de quarenta e cinco minutos. Os resultados obtidos com a aplicação da primeira parte do questionário não nos surpreenderam, salvo em alguns casos, a maioria dos alunos mostrou não fazer ideia do que poderiam ser as trilhas e túneis sobre os quais perguntamos. Alguns entraram em contradição em suas respostas.

Quanto às respostas da segunda parte do questionário, aplicado logo após mostrarmos as imagens do sítio arqueológico, as crianças mostraram não somente interesse em conhecerem o local, mas também o desejo de que o local seja preservado para trabalhos escolares, pesquisas e também para o turismo, reconhecendo que o local é um importante aspecto de sua cultura e sua história. Muitos demonstraram preocupação acerca do objeto e com sua possível destruição, conscientes de que seria um dano irreparável.

Uma das perguntas mais frequentes depois da aplicação do segundo questionário foi "Como é que a gente não conhecia isso antes?" Muitas daquelas crianças não se seguravam de curiosidade, queriam visitar o local no mesmo dia e se frustraram ao saberem que o local ainda não se encontra em vias de ser visitado por uma excursão escolar. "Quando poderemos ir até lá para vermos aqueles túneis?" Esta foi a pergunta mais frequente em nossas explicações depois do encerramento do questionário. 


\section{3 - Os trabalhos de Educação Patrimonial na Escola Estadual Barão de Paraopeba}

A Escola Estadual Barão de Paraopeba fica instalada no bairro Vila Andreza. O bairro é considerado de classe média e uma grande parte dos estudantes da escola residem próximos a ela. Por ficar próxima à área central da cidade, a escola recebe estudantes de diversos outros bairros como Vila São Vicente, Rosário e Alvorada, que são bairros onde a pobreza e a criminalidade são maiores.

Na Escola Estadual Barão de Paraopeba nosso trabalho teve ótima receptividade da parte da direção, professores e dos funcionários, que ainda em fase de planejamento, aderiram à ideia de desenvolvermos e realizarmos juntos uma série de atividades programadas de Educação Patrimonial, em diversas disciplinas e trabalhadas transversalmente com a disciplina de História.

A direção da escola nos reuniu com os professores e das reuniões surgiram várias ideias para trabalhos de Educação Patrimonial. Foi preciso orientar e coordenar os professores e para isso nos aproveitamos de reuniões e de material didático referente à teoria, método e prática da Educação Patrimonial. Alguns professores já haviam feito trabalhos voltados para o patrimônio cultural da cidade e do Estado de Minas Gerais, porém, de forma isolada e curta, diferentemente da proposta de trabalho em conjunto e com duração de um bimestre escolar.

Deveríamos trabalhar no intuito de comunicar para promover o conhecimento e questionar para potencializarmos as possibilidades. As ideias principais que surgiram das reuniões foram rediscutidas e chegamos ao seguinte acordo quanto à promoção do patrimônio cultural na E.E. Barão de Paraopeba e a busca por suas potencialidades:

$1^{\circ}$ - trabalhar durante o $2^{\circ}$ bimestre de 2013 os temas das variadas disciplinas curriculares transversalmente com a disciplina de História, considerando aspectos histórico-culturais da cidade de Congonhas e levando em conta os estudantes como agentes responsáveis e participantes num mundo em transformação constante;

$2^{\circ}$ - iniciarmos os trabalhos com palestra com conteúdo sobre o que é Arqueologia, o papel da Arqueologia no mundo de hoje, a Arqueologia Histórica e nossa pesquisa em Congonhas, a Ecomuseologia, sempre considerando e abordando a paisagem em transformação e o papel dos estudantes como agentes participantes transformadores do mundo e da história; 
$3^{\circ}$ - os alunos deveriam fazer visita guiada à Basílica do Senhor Bom Jesus de Matosinhos e a museus da cidade como o Museu de Mineralogia e o Museu de Imagem e Memória de Congonhas;

$4^{\circ}$ - caminhada com pesquisa empírica de campo na área urbana, abordando aspectos relativos à paisagem em transformação, observando as diferenças entre a arquitetura colonial e moderna e fatores e causas históricas e sociais de mudanças e o meio ambiente relacionado aos diferentes ciclos de mineração como o ouro e o ferro, quando as minas e o resultado da atividade mineradora destes minerais podiam ser visualizados da Basílica;

$5^{\circ}$ - os alunos deveriam visitar as ruínas da Fábrica de Ferro do Prata ou Fábrica Patriótica, como é popularmente conhecido o sítio arqueológico musealizado e mantido pela mineradora Vale. No local estão as ruínas da primeira fábrica que aproveitou a riqueza do ferro na região;

$6^{\circ}$ - a direção da E.E. Barão de Paraopeba nos reservou um espaço no pátio da escola para uma exposição fotográfica didática com o tema "Paisagem em Transformação", que viria a apoiar atividades desenvolvidas transversalmente à disciplina de História durante o bimestre escolar;

$7^{\circ}$ - uma feira de Educação Patrimonial que pode acontecer no final do bimestre escolar, considerado pela equipe pedagógica da escola como o ponto culminante dos trabalhos, quando os alunos poderão apresentar temas relacionados à paisagem cultural, como produção de maquetes e desenhos, e participarão de atividades como apresentação de congado, capoeira, experimentação do chá feito da planta congonha, entre outros.

$8^{\circ}$ - o último dos trabalhos junto à escola se refere aos questionários aplicados aos alunos, professores e à equipe pedagógica, no mês de setembro de 2013, com vistas a avaliarmos os pontos positivos e negativos do processo e que nos conduzirão finalmente a uma proposta de Educação Patrimonial que possa ser aplicada em outras escolas do município na promoção de seu patrimônio cultural e de ressignificação com a musealização para os sítios arqueológicos.

As atividades na Escola Estadual Barão de Paraopeba estiveram em andamento durante o $2^{\circ}$ bimestre escolar e algumas atividades continuaram a serem trabalhadas até o $3^{\circ}$ bimestre, como as visitas técnicas a sítios como a Fábrica Patriótica e aplicação do questionário, como já constava no cronograma de atividades.

A maioria dos professores estive trabalhando temas transversalmente em sala de aula. A visita ao sítio arqueológico Fábrica Patriótica foi marcada para o mês de setembro de 2013, por 
conta de problemas de agendamento junto à empresa Vale, fazendo com que as atividades se estendessem um pouco mais além do esperado, adentrando o $3^{\circ}$ bimestre.

Das atividades que foram feitas em parceria com a Escola Estadual Barão de Paraopeba:

$1^{\circ}$ - no dia 13 de maio de 2013 a apresentação de palestra sobre Arqueologia para professores e alunos, introduzindo temas como Arqueologia Pré-histórica, Arqueologia Histórica, patrimônio arqueológico e a pesquisa "Os velhos caminhos de Congonhas numa perspectiva de Educação Patrimonial”.

$2^{\circ}$ - no dia 16 de maio de 2013 com visita técnica guiada à Romaria e ao Museu de Mineralogia da Romaria ${ }^{66}$, à exposição artística na Romaria dos trabalhos do artista plástico local Jomadi, visita técnica à Basílica do Senhor Bom Jesus de Matosinhos guiada por dois guias da Prefeitura Municipal, sendo uma parte referente às Capelas dos Passos da Paixão e a outra referente ao templo e aos Doze Profetas e depois, caminhada pelo centro histórico para observação da paisagem urbana;

$3^{\text {o }}$ - no dia 17 de maio de 2013 com início de exposição fotográfica didática com o tema Paisagem em Transformação, cujo conteúdo didático foi explorado transversalmente. As fotografias ficaram expostas durante 30 dias;

$4^{\circ}$ - feira de Educação Patrimonial, realizada no dia 20 de julho, com a participação de alunos, funcionários, professores, convidados, pais de alunos e demais moradores da cidade e do bairro Vila Andreza, onde se localiza a escola. Para a participação na feira de Educação Patrimonial, os alunos da E. E. Barão de Paraopeba produziram:

1 - painéis com fotografias e informações sobre as obras do Aleijadinho em Congonhas;

2 - desenhos artísticos lembrando a arte barroca local;

3 - vídeos com explicações sobre a história da cidade e suas mais conhecidas personalidades, apresentados na feira de Educação Patrimonial em atividade intitulada "Guia por um dia"; 4 - apresentação de dança de ballet em homenagem à Prof. ${ }^{a}$ Victória Fischer de Parcus, a "Tia Vick" (1907-1994), que foi professora de Inglês e de Educação Moral e Cívica na cidade e

\footnotetext{
${ }^{66}$ A Romaria, antes uma pensão destinada a receber romeiros que visitavam a cidade no Jubileu do Senhor Bom Jesus de Matosinhos, é atualmente um centro cultural onde fica instalado o Museu de Mineralogia. No local também funcionam as secretarias municipais de cultura, turismo e patrimônio de Congonhas, além de receber atividades culturais como shows musicais, peças teatrais, mostras de cinema, palestras, reuniões, entre outras.
} 
também foi fundadora da Escola da Ballet de Congonhas ${ }^{67}$ na década de 1960, além de criadora e organizadora do figurino da semana santa da cidade, muito apreciado por turistas, visitantes e moradores que todos os anos se vestem de personagens bíblicos para encenarem a Paixão de Cristo;

5 - apresentação teatral com o tema "A Paixão segundo o Barão", quando os alunos representaram a Paixão de Cristo segundo relatos do Barão de Eschwege, retirados de arquivos da Biblioteca Pública Municipal;

6 - roda de capoeira, com a presença do mestre de capoeira "Pacato" e seus pupilos. Pacato é um professor de capoeira muito conhecido na cidade e região e um dos poucos capoeiristas a dominar com afinco a técnica da Capoeira de Angola, que exige muita elasticidade do corpo humano. Os alunos participaram livremente da roda e o momento foi de muita descontração e diversão. A capoeira é uma atividade muito apreciada e praticada por jovens da cidade de Congonhas;

7 - exposição de estátuas de gesso representando os "Doze Profetas do Aleijadinho";

8 - apresentação de dança de quadrilha ou Festa Junina, adiada para julho especialmente para a Feira de Educação Patrimonial. Neste momento tivemos distribuição gratuita da tradicional canjica de festa junina, a todos os presentes;

9 - painéis com desenhos e fotografias retratando a fauna urbana e a fauna selvagem do município;

10 - painéis com informações geográficas como localização do município no mapa mundial, aspectos econômicos, população, riquezas minerais e recursos hídricos.

Algumas atividades que estavam no planejamento, como a experimentação do chá da planta congonha (s. f. Luxemburgia polyandra) e apresentação de grupo de congado não ocorreram por conta de problemas de agenda dos convidados.

A visita técnica à Fabrica Patriótica ocorreu ao longo do $3^{\circ}$ bimestre, por conta de problemas de agendamento junto à empresa.

A direção da escola julgou que os questionários para aplicação na escola deveriam ser feitos somente depois que todas as atividades fossem encerradas, pois seria inconveniente traçar

\footnotetext{
${ }^{67}$ A Escola de Ballet de Congonhas funciona até os dias atuais e é muito procurada por mães que levam principalmente suas filhas para aprenderem os primeiros passos do Ballet.
} 
planos e produzir questões antecipadamente, por se tratar de um trabalho dinâmico que envolve pessoas e interesses e disciplinas diversas.

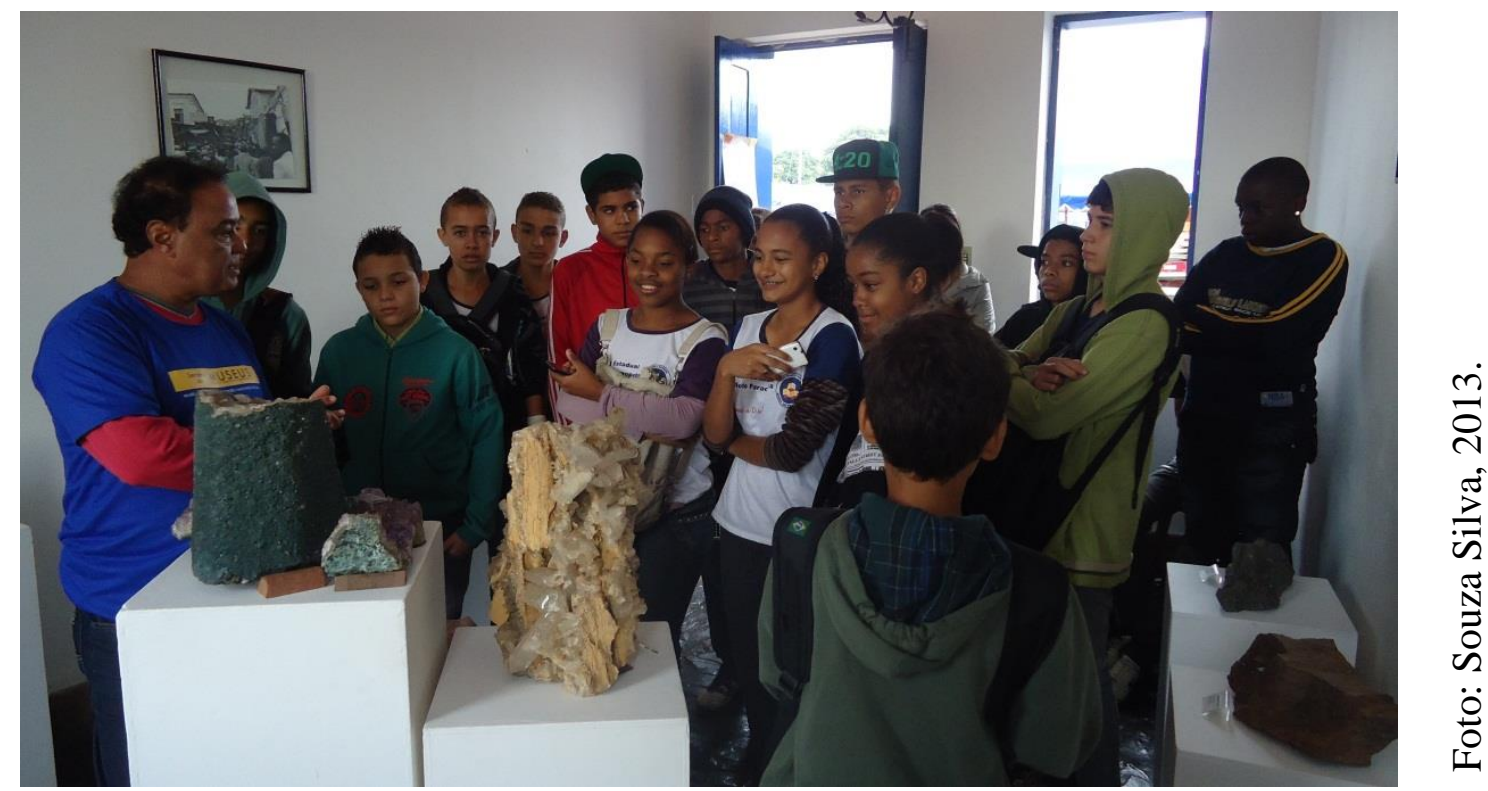

Figura 3 (Anexo 1): Alunos da Escola Estadual Barão de Paraopeba no Museu de Mineralogia da Romaria em Congonhas, Minas Gerais, durante visitação.

\section{4 - Questionário aplicado aos alunos da Escola Estadual Barão de Paraopeba}

O questionário aplicado aos alunos da Escola Estadual Barão de Paraopeba procurou abordar o tema trabalhado, quando procuramos apresentar os sítios arqueológicos junto aos alunos, numa perspectiva dinâmica, para em seguida buscar suas opiniões a respeito da preservação e ressignificação para uso em atividades educacionais, principal objetivo desta pesquisa, além de outros temas, como o turismo cultural, tema este colocado em discussão por alunos de escolas e moradores da cidade de Congonhas.

Foram feitas as seguintes questões aos alunos:

Questão $n^{\circ} 1$ - Durante os trabalhos de Educação Patrimonial realizados na E. E. Barão de Paraopeba, quais foram as atividades de que você participou dentro e fora da escola?

Questão $\mathrm{n}^{\mathrm{o}} 2$ - Dos locais que você visitou com a escola, qual deles você gostou mais e por quê? 
Questão no 3 - Das atividades de que você participou, qual delas você gostou mais e por quê?

Questão no 4 - Durante os trabalhos de Educação Patrimonial, o que você gostaria de ter feito ou qual local histórico/arqueológico você gostaria de ter visitado junto com a escola e não pôde fazê-lo? Justifique:

Questão $n^{\circ} 5$ - Durante os trabalhos de Educação Patrimonial realizados na E. E. Barão de Paraopeba, foram apresentados aos alunos e professores, por meio de palestras e exposição didática fotográfica, alguns dos sítios arqueológicos do município de Congonhas como a Mina do Redondo (Alto Maranhão), Mina da Soledade (Lobo Leite), Mina das Goiabeiras (Bairro Santa Mônica e proximidades), Mina do Veeiro e Fazenda do Faria (próximos ao Parque da Cachoeira), que guardam ruinas e vestígios arqueológicos como a capela de Santo Antônio, senzala, moinho, paiol, diversos vestígios da mineração do ouro como galerias e caminhos centenários.

O que você pensa a respeito da criação de um Ecomuseu, que vise a preservação de sítios arqueológicos como estes e de sua utilização para atividades educacionais, estudos científicos e até mesmo o turismo?

Questão $n^{\circ} 6$ - Faça um desenho ou redação sobre a atividade que você mais gostou de participar:

\section{5 - Resultados do questionário aplicado aos alunos da Escola Estadual Barão de Paraopeba}

Os alunos da E. E. Barão de Paraopeba se mostraram satisfeitos, tanto quanto à participação nas atividades de Educação Patrimonial quanto na oportunidade de responder o questionário, que foi de respostas individuais, de escolha livre e levou em conta apenas as opiniões dos mesmos.

As turmas que responderam o questionário são as seguintes, segundo ordem por ano das turmas:

$1-6^{\circ}$ ano Bondade;

$2-6^{\circ}$ ano Solidariedade; 
$3-6^{\circ}$ ano Fraternidade;

$4-7^{\circ}$ ano Gentileza;

$5-7^{\circ}$ ano Caridade;

$6-8^{\circ}$ ano Amor;

$7-9^{\circ}$ ano Confiança.

Os resultados do questionário aplicado aos alunos foram os seguintes:

\section{1 - Resultados do $6^{\circ}$ ano Bondade:}

Questão no 1 - Durante os trabalhos de Educação Patrimonial realizados na E. E. Barão de Paraopeba, quais foram as atividades de que você participou dentro e fora da escola?

A turma do $6^{\circ}$ ano Bondade possui 26 alunos. Desse montante 17 alunos responderam o questionário, sendo que 13 deles responderam a questão no 1 e 4 deles não responderam. Dos 13 que responderam a questão $\mathrm{n}^{\circ} 1,9$ alunos participaram das atividades e 4 não participaram. Vejamos algumas das respostas:

“_ A visita a vale, a quadrilha e a capoeira” (Riarlley Júnio Santos, 12 anos).

“_ Visita a vale e quadrilha” (Lucas Fonseca da Paz, 12 anos).

Questão $n^{\circ} 2$ - Dos locais que você visitou com a escola, qual deles você gostou mais e por quê?

A turma do $6^{\circ}$ ano Bondade possui 26 alunos. Desse montante, 17 alunos responderam o questionário, sendo que 13 deles responderam a questão $\mathrm{n}^{\mathrm{o}} 2$ e 4 deles não responderam. Dos 14 que responderam a questão $\mathrm{n}^{\circ} 2,9$ alunos citaram os locais preferidos e 5 não participaram das atividades. Vejamos algumas das respostas:

“_ A Vale, porque tudo lá é encantador e tudo excelente” (Fabíola Soares Souza, 11 anos).

“_ A Vale porque lá foi muito legau (legal) lá é lindo de mais (demais)” (Gabriela Arruda, 11anos).

Questão $n^{\circ} 3$ - Das atividades de que você participou, qual delas você gostou mais e por quê? 
Do total de 17 alunos 10 citaram as atividades, 4 não citaram e 3 não responderam sobre a $3^{\mathrm{a}}$ questão. Algumas das respostas:

“_ O teatro porque é muito divertido e muito engraçado" (Fabiola Soares Souza, 11 anos).

“_ balé (Ballet) porque nós tivemos o trabalho de inventar a coreografia” (Luiza Oliveira S. Sobral, 12 anos).

Questão no 4 - Durante os trabalhos de Educação Patrimonial, o que você gostaria de ter feito ou qual local histórico/arqueológico você gostaria de ter visitado junto com a escola e não pôde fazê-lo? Justifique:

Sobre a questão $\mathrm{n}^{\circ}$ 4, 11 dos 17 alunos que responderam o questionário fizeram declarações, 1 aluno não declarou e 5 alunos não responderam. Vejamos algumas das respostas:

“_ O museu nunca fui no museu” (Fabiola Soares Souza, 11 anos).

“_Eu gostaria de ter feito um piquenique na parte das ruinas e gostaria de ter ido aos campos e áreas de mineração" (Vitória Regina Martins Melo, 12 anos).

Questão $n^{\circ} 5$ - Durante os trabalhos de Educação Patrimonial realizados na E. E. Barão de Paraopeba, foram apresentados aos alunos e professores, por meio de palestras e exposição didática fotográfica, alguns dos sítios arqueológicos do município de Congonhas como a Mina do Redondo (Alto Maranhão), Mina da Soledade (Lobo Leite), Mina das Goiabeiras (Bairro Santa Mônica e proximidades), Mina do Veeiro e Fazenda do Faria (próximos ao Parque da Cachoeira), que guardam ruinas e vestígios arqueológicos como a capela de Santo Antônio, senzala, moinho, paiol, diversos vestígios da mineração do ouro como galerias subterrâneas e caminhos centenários.

O que você pensa a respeito da criação de um Ecomuseu, que vise a preservação de sítios arqueológicos como estes e de sua utilização para atividades educacionais, estudos científicos e até mesmo o turismo?

Dos 17 alunos que responderam ao questionário, 4 alunos opinaram, um respondeu mas não opinou e 12 não responderam. Vejamos algumas das respostas:

"_ Acho muita boa a ideia e acho também que deveriam criar mais locais de visitação para mais atividades educacionais e visitas" (Caroline Stephane Moreira B., 13 anos).

“_Eu acho bem legal” (Juan Fialhos de Siqueira Carneiro, 11 anos). 
Questão $n^{\circ} 6$ - Faça um desenho ou redação sobre a atividade que você mais gostou de participar:

Dos 17 alunos que fizeram responderam o questionário, 10 fizeram desenhos e os demais não se manifestaram.

\section{2 - Resultados do $6^{\circ}$ ano Solidariedade:}

Questão $n^{\circ} 1$ - Durante os trabalhos de Educação Patrimonial realizados na E. E. Barão de Paraopeba, quais foram as atividades de que você participou dentro e fora da escola?

A turma do $6^{\circ}$ ano Solidariedade possui 17 alunos. Desse montante 16 alunos responderam o questionário, sendo que 14 deles responderam a questão $\mathrm{n}^{\circ} 1$ e 2 deles não responderam. Dos 14 que responderam a questão $\mathrm{n}^{\circ} 1,4$ alunos participaram das atividades e 10 não participaram. Vejamos algumas das respostas:

“_ Quadrilha, capoeira e teatro” (Marcos Vinícius, 12 anos).

“__ Sim, a quadrilha” (Íris, 12 anos)

Questão $n^{\circ} 2$ - Dos locais que você visitou com a escola, qual deles você gostou mais e por quê?

A turma do $6^{\circ}$ ano Solidariedade possui 17 alunos. Desse montante 14 alunos responderam a questão $\mathrm{n}^{\mathrm{o}} 2$, sendo que apenas 1 aluno citou o local, 13 alunos não citaram e 2 alunos não responderam a questão. Vejamos algumas das respostas:

“_ Não visitei nenhum lugar” (Franciele A. de Souza Costa, 11anos).

“_ Nenhum local” (Monalisa T. F. Arruda, 11 anos).

Questão $n^{\circ} 3$ - Das atividades de que você participou, qual delas você gostou mais e por quê?

Do total de 16 alunos 3 citaram as atividades, 11 não citaram e 2 não responderam sobre a $3^{\text {a }}$ questão. Algumas das respostas:

“_ Das atividades fora da escola porque fomos todos mais juntos” (Isadora Gonçalves F., 11 anos). 
“_ Capoeira, porque eu aprendi” (Marcus Vinicius, 12 anos).

Questão $n^{\circ} 4$ - Durante os trabalhos de Educação Patrimonial, o que você gostaria de ter feito ou qual local histórico/arqueológico você gostaria de ter visitado junto com a escola e não pôde fazê-lo? Justifique:

Sobre a questão $\mathrm{n}^{\circ}$ 4, 7 dos 16 alunos que responderam o questionário fizeram declarações, 4 alunos não declararam e 5 alunos não responderam. Vejamos algumas das respostas:

“_ Vale e Cachoeira pois esses dois locais ajudam também a escola a nos ensinar sobre a água, o minério, etc.”, (Isadora Gonçalves F. 11 anos).

“_ Ir no parque da cachoeira” (Ranya Luriene M. Santos, 12 anos).

Questão n ${ }^{\circ} 5$ - Durante os trabalhos de Educação Patrimonial realizados na E. E. Barão de Paraopeba, foram apresentados aos alunos e professores, por meio de palestras e exposição didática fotográfica, alguns dos sítios arqueológicos do município de Congonhas como a Mina do Redondo (Alto Maranhão), Mina da Soledade (Lobo Leite), Mina das Goiabeiras (Bairro Santa Mônica e proximidades), Mina do Veeiro e Fazenda do Faria (próximos ao Parque da Cachoeira), que guardam ruinas e vestígios arqueológicos como a capela de Santo Antônio, senzala, moinho, paiol, diversos vestígios da mineração do ouro como galerias subterrâneas e caminhos centenários.

O que você pensa a respeito da criação de um Ecomuseu, que vise a preservação de sítios arqueológicos como estes e de sua utilização para atividades educacionais, estudos científicos e até mesmo o turismo?

Dos 16 alunos que responderam ao questionário, 2 alunos opinaram, 11 responderam mas não opinaram e 3 não responderam. Vejamos algumas das respostas:

“_ Enteresante (Interessante), pois conhecemos o passado" (Bianca Tamires M. Costa, 11 anos).

“_Enteressando (Interessante), pois conhecemos o passado" (Ranya Lariene M. Santos, 11 anos).

Questão $n^{0} 6$ - Faça um desenho ou redação sobre a atividade que você mais gostou de participar: 
Dos 16 alunos que fizeram responderam o questionário, nenhum deles fez desenhos, redação ou se manifestaram.

\section{3 - Resultados do $6^{\circ}$ ano Fraternidade:}

Questão n ${ }^{\circ} 1$ - Durante os trabalhos de Educação Patrimonial realizados na E. E. Barão de Paraopeba, quais foram as atividades de que você participou dentro e fora da escola?

A turma do $6^{\circ}$ ano fraternidade possui 14 alunos. Desse montante 6 alunos responderam o questionário, sendo que 6 deles responderam a questão $\mathrm{n}^{\circ} 1$. Dos 6 que responderam o questionário, todos participaram das atividades. Vejamos algumas das respostas:

“_ Na Vale aprendemos as coisas da ruina e outras coisas como capoeira, casamento na roça e outras coisas" (Rafaela Balbino, 12 anos).

“_ As ruinas, como se faz o minério, toda a Vale. O casamento na roça, capoeira, quadrilha, a ressurreição de Jesus" (Rafaela Carolina, 11anos).

Questão $\mathrm{n}^{\circ} 2$ - Dos locais que você visitou com a escola, qual deles você gostou mais e por quê?

A turma do $6^{\circ}$ ano Fraternidade possui 14 alunos. Desse montante de 14 alunos, 6 alunos responderam o questionário e a questão $\mathrm{n}^{\circ} 2$, sendo que os 6 alunos citaram o local. Vejamos algumas das respostas:

“_ Não visitei nenhum lugar” (Franciele A. de Souza Costa, 11anos).

“_ Nenhum local” (Monalisa T. F. Arruda, 11 anos).

Questão $\mathrm{n}^{\circ} 3$ - Das atividades de que você participou, qual delas você gostou mais e por quê?

Do total de 6 alunos que responderam o questionário, todos citaram as atividades. Algumas das respostas:

“_ da (Da) Vale porque tem muita comida e minério e onibos (ônibus)" (Gustavo Henrique Ferreira Guedes, 13 anos). 
“_ da (Da) capoeira porque aprendei (aprendi) como ela e (é) importante no nosso dia-a-dia" (Isabela Cristina Santos Silva, 13 anos).

Questão $n^{\circ} 4$ - Durante os trabalhos de Educação Patrimonial, o que você gostaria de ter feito ou qual local histórico/arqueológico você gostaria de ter visitado junto com a escola e não pôde fazê-lo? Justifique:

Sobre a questão $n^{\circ}$ 4, 6 dos 6 alunos que responderam o questionário fizeram declarações. Vejamos algumas delas:

“_ AEA (Associação dos Empregados da Açominas) porque tem piscina e campo, o (os/ou) museus" (Douglas Luan Soares Mendes, 14 anos).

“_ Eu gostaria de ir no parque aquático porque muita gente fala que lá é muito bom e divertido" (Isabela Cristina dos Santos Silva, 13 anos).

Questão n ${ }^{\circ} 5$ - Durante os trabalhos de Educação Patrimonial realizados na E. E. Barão de Paraopeba, foram apresentados aos alunos e professores, por meio de palestras e exposição didática fotográfica, alguns dos sítios arqueológicos do município de Congonhas como a Mina do Redondo (Alto Maranhão), Mina da Soledade (Lobo Leite), Mina das Goiabeiras (Bairro Santa Mônica e proximidades), Mina do Veeiro e Fazenda do Faria (próximos ao Parque da Cachoeira), que guardam ruinas e vestígios arqueológicos como a capela de Santo Antônio, senzala, moinho, paiol, diversos vestígios da mineração do ouro como galerias subterrâneas e caminhos centenários.

O que você pensa a respeito da criação de um Ecomuseu, que vise a preservação de sítios arqueológicos como estes e de sua utilização para atividades educacionais, estudos científicos e até mesmo o turismo?

Dos 6 alunos que responderam ao questionário, 5 alunos opinaram, 1 respondeu mas não opinou. Vejamos algumas das respostas:

“_ Muito Bom para todos conhecerem melhor as coisas de Congonhas" (Rafaela Carolina, 11 anos).

“_ Seria importante para as pessoas que querem conhecer melhor a cidade" (Isabela Cristina Santos Silva, 13 anos). 
Questão $n^{\circ} 6$ - Faça um desenho ou redação sobre a atividade que você mais gostou de participar:

Dos 6 alunos que fizeram responderam o questionário, 2 escreveram frases. Nenhum escreveu redação ou se manifestou com desenhos.

\section{4 - Resultados do $7^{\circ}$ ano Gentileza:}

Questão no 1 - Durante os trabalhos de Educação Patrimonial realizados na E. E. Barão de Paraopeba, quais foram as atividades de que você participou dentro e fora da escola?

A turma do $7^{\circ}$ ano Gentileza possui 20 alunos. Desse montante 11 alunos responderam o questionário, sendo que 11 deles responderam a questão $n^{\circ} 1$. Dos 11 que responderam o questionário, todos os alunos (100\%) participaram das atividades. Vejamos algumas das respostas:

“_ Fomos na Romaria, no museu e na Basílica” (Ester Silva Martins, 12 anos).

“_ Fomos na Romaria, no museu, na Basílica e fizemos um projeto na escola” (Stéphane Cristina R. D., 12 anos).

Questão $n^{\circ} 2$ - Dos locais que você visitou com a escola, qual deles você gostou mais e por quê?

A turma do $7^{\circ}$ ano gentileza possui 20 alunos. Desse montante de 20 alunos, 11 alunos responderam o questionário e a questão $\mathrm{n}^{\circ} 2$, sendo que os 11(100\%) dos alunos citaram o local. Vejamos algumas das respostas:

“_ na (Na) basílica porque fiquei sabendo de coisas que eu não sabia ” (Eduarda S. Souza, 12anos).

“_ No museu porque gostei de conhecer as coisas antigas" (Stéphane Cristina R. D., 12 anos).

Questão $\mathrm{n}^{\mathrm{o}} 3$ - Das atividades de que você participou, qual delas você gostou mais e por quê?

Do total de 11 alunos que responderam o questionário, todos (100\%) citaram as atividades. Algumas das respostas: 
“_ Do projeto, porque (porque) (nos) nós fizemos vários trabalhos” (Eduarda S. Souza, 12 anos).

“_Poemas que apresentamos com a Professora Elisa” (Ester Silva Martins, 12 anos).

Questão $n^{\circ} 4$ - Durante os trabalhos de Educação Patrimonial, o que você gostaria de ter feito ou qual local histórico/arqueológico você gostaria de ter visitado junto com a escola e não pôde fazê-lo? Justifique:

Sobre a questão $\mathrm{n}^{\circ}$ 4, 11 dos 11 alunos (100\%) que responderam o questionário fizeram declarações. Vejamos algumas delas:

“_ Cachoeira, porque la (lá) a gente ver (vê) a paisagem” (Ester Silva Martins, 12 anos).

“_ Na Cachoeira, pois lá na minha opinião é um lugar mais bonito de Congonhas” (Tainara Aline G. Lima, 12 anos).

Questão n ${ }^{\circ} 5$ - Durante os trabalhos de Educação Patrimonial realizados na E. E. Barão de Paraopeba, foram apresentados aos alunos e professores, por meio de palestras e exposição didática fotográfica, alguns dos sítios arqueológicos do município de Congonhas como a Mina do Redondo (Alto Maranhão), Mina da Soledade (Lobo Leite), Mina das Goiabeiras (Bairro Santa Mônica e proximidades), Mina do Veeiro e Fazenda do Faria (próximos ao Parque da Cachoeira), que guardam ruinas e vestígios arqueológicos como a capela de Santo Antônio, senzala, moinho, paiol, diversos vestígios da mineração do ouro como galerias subterrâneas e caminhos centenários.

O que você pensa a respeito da criação de um Ecomuseu, que vise a preservação de sítios arqueológicos como estes e de sua utilização para atividades educacionais, estudos científicos e até mesmo o turismo?

Dos 11 alunos que responderam ao questionário, 11 alunos (100\%) opinaram a respeito. Vejamos algumas das respostas:

"_ acho (Acho) muito legal os aluno (alunos) iriam gosta (gostar) bastante (,) muito interessante" (Ericles Rogerio Sales Rocha, não declarou idade).

“_ Boa, isso pode ajudar alguns alunos a ficarem mais informados sobre alguns desses sítios..." (Tainara Aline G. Lima, 12 anos). 
Questão $n^{\circ} 6$ - Faça um desenho ou redação sobre a atividade que você mais gostou de participar:

Dos 11 alunos que responderam o questionário, 10 alunos desenharam e 1 aluno não desenhou. Nenhum aluno se manifestou por escrito.

\section{5 - Resultados do $7^{\circ}$ ano Caridade:}

Questão $n^{\circ} 1$ - Durante os trabalhos de Educação Patrimonial realizados na E. E. Barão de Paraopeba, quais foram as atividades de que você participou dentro e fora da escola?

A turma do $7^{\circ}$ ano Caridade possui 23 alunos. Desse montante, 15 alunos responderam o questionário, sendo que todos eles responderam a questão $n^{\circ} 1$. Dos 15 que responderam o questionário, 13 alunos participaram das atividades e 2 não participaram. Vejamos algumas das respostas:

“_ Fomos à Romaria, no museu de mineralogia, Basílica” (Camila Aparecida, 13 anos).

“_ Feira na escola, palestra com o arqueólogo e uma visita a igreja dos 12 profetas, aos passos da paixão e ao museu de mineralogia" (Ester Maria Rocha Clemente, 13 anos).

Questão $n^{\circ} 2$ - Dos locais que você visitou com a escola, qual deles você gostou mais e por quê?

A turma do $7^{\circ}$ ano Caridade possui 23 alunos. Desse montante de 23 alunos, 15 alunos responderam o questionário e a questão $\mathrm{n}^{\circ} 2$, sendo que 13 dos alunos citaram o local, 1 aluno respondeu mas não citou e 1 não respondeu. Vejamos algumas das respostas:

“_ Ir a (à) basílica, romaria, museu de mineralogia” (Adriana de Jesus da Silva, 12 anos).

“_ Do museu de mineralogia. Porque despertou meu interesse quanto as riquezas do nosso patrimônio municipal” (Ester Maria Rocha Clemente, 13 anos).

Questão $n^{\circ} 3$ - Das atividades de que você participou, qual delas você gostou mais e por quê?

Do total de 15 alunos que responderam o questionário, 13 citaram as atividades, 1 aluno não citou e 1aluno não respondeu. Algumas das respostas: 
“_ O museu, por causa das pedras por tudo que tinha lá” (Ana Paula Semião, 12 anos).

“_ As ruinas da Vale. Pois não pudemos ir e é um lugar bonito e acolhedor que conta o princípio da nossa mineralogia" (Ester Maria Rocha Clemente, 13 anos).

Questão n ${ }^{\circ} 4$ - Durante os trabalhos de Educação Patrimonial, o que você gostaria de ter feito ou qual local histórico/arqueológico você gostaria de ter visitado junto com a escola e não pôde fazê-lo? Justifique:

Sobre a questão $\mathrm{n}^{\circ}$ 4, 12 dos 15 alunos que responderam o questionário fizeram declarações, 2 alunos responderam mas não declararam e 1 aluno não respondeu. Vejamos algumas das respostas:

“_ Museu da memória, porque eu queria saber mais o que tinha” (Ana Paula Semião, 12 anos).

“_ A tudo que eu tive vontade de fazer eu fiz” (Camila Aparecida, 13 anos).

Questão $n^{\circ} 5$ - Durante os trabalhos de Educação Patrimonial realizados na E. E. Barão de Paraopeba, foram apresentados aos alunos e professores, por meio de palestras e exposição didática fotográfica, alguns dos sítios arqueológicos do município de Congonhas como a Mina do Redondo (Alto Maranhão), Mina da Soledade (Lobo Leite), Mina das Goiabeiras (Bairro Santa Mônica e proximidades), Mina do Veeiro e Fazenda do Faria (próximos ao Parque da Cachoeira), que guardam ruinas e vestígios arqueológicos como a capela de Santo Antônio, senzala, moinho, paiol, diversos vestígios da mineração do ouro como galerias subterrâneas e caminhos centenários.

O que você pensa a respeito da criação de um Ecomuseu, que vise a preservação de sítios arqueológicos como estes e de sua utilização para atividades educacionais, estudos científicos e até mesmo o turismo?

Dos 15 alunos que responderam ao questionário, 10 alunos opinaram a respeito e 5 não responderam. Vejamos algumas das respostas:

“_ Muito Bom, que daí os alunos também participam” (Adriana de Jesus da Silva, 12 anos).

“_ Seria ótimo mais um ponto turístico da cidade.” (Adrielly Ap. da Silva G. Martins, 12 anos). 
Questão $n^{\circ} 6$ - Faça um desenho ou redação sobre a atividade que você mais gostou de participar:

Dos 15 alunos que responderam o questionário, 8 alunos desenharam, 1 aluno produziu redação e seis não se manifestaram.

\section{6 - Resultados do $8^{\circ}$ ano Amor:}

Questão $n^{\circ} 1$ - Durante os trabalhos de Educação Patrimonial realizados na E. E. Barão de Paraopeba, quais foram as atividades de que você participou dentro e fora da escola?

A turma do $8^{\circ}$ ano Amor possui 30 alunos. Desse montante 14 alunos responderam o questionário, sendo que 1 deles respondeu a questão $\mathrm{n}^{\circ} 1$. Dos 13 que responderam a questão n. ${ }^{\circ} 1,11$ alunos participaram das atividades e 2 não participaram. Vejamos algumas das respostas:

“_Eu participei fora da escola (,) foi (fui) até a basílica do Senhor Bom Jesus e no museu e também (,) eu fiz um trabalho sobre o jubileu” (Graciele Gonçalves dos Reis, 14 anos).

“_ Na igreja aprendi sobre os profetas” (Arthur Eduardo de S. Silva, 13 anos).

Questão $n^{\circ} 2$ - Dos locais que você visitou com a escola, qual deles você gostou mais e por quê?

A turma do $8^{\circ}$ ano Amor possui 30 alunos. Desse montante de 30 alunos, 14 alunos responderam o questionário e a questão $\mathrm{n}^{\circ} 2$, sendo que 14 dos alunos (100\%) citaram o local. Vejamos algumas das respostas:

“_ De ir no museu da Basílica e ver as pedras preciosas, porque eu acho legal saber mais sobre as pedras" (Pamella Tamara A. Alves, 13 anos).

" _ No museu da romaria por causa de algumas pedras que estavam no museu e tudo que aprendi sobre elas" (Luisa Alice Silva Souza, 14 anos).

Questão $n^{\circ} 3$ - Das atividades de que você participou, qual delas você gostou mais e por quê?

Do total de 14 alunos que responderam o questionário, 14 alunos (100\%) citaram as atividades. Seguem algumas das respostas: 
“_ Do trabalho sobre o Jubileu, porque eu fiquei sabendo da história e o primeiro jubileu de Congonhas" (Graciele Gonçalves dos Reis, 14 anos).

“_ Na Basílica, porque eu gostei da história da Basílica” (Paola Amorim Lima, 13 anos).

Questão $n^{\circ} 4$ - Durante os trabalhos de Educação Patrimonial, o que você gostaria de ter feito ou qual local histórico/arqueológico você gostaria de ter visitado junto com a escola e não pôde fazê-lo? Justifique:

Sobre a questão $\mathrm{n}^{\circ}$ 4, 14 dos 14 alunos (100\%) que responderam o questionário fizeram declarações. Vejamos algumas das respostas:

“_ De ir no sítio da vale ou algum sítio arqueológico” (Nayara Silva Martins, 13 anos).

“_ De ir no sítio da Vale ou ir em algum sítio de arqueologia, pois adoro saber mais sobre essas coisas" (Pamella Tamara A. Alves, 13 anos).

Questão n ${ }^{\circ} 5$ - Durante os trabalhos de Educação Patrimonial realizados na E. E. Barão de Paraopeba, foram apresentados aos alunos e professores, por meio de palestras e exposição didática fotográfica, alguns dos sítios arqueológicos do município de Congonhas como a Mina do Redondo (Alto Maranhão), Mina da Soledade (Lobo Leite), Mina das Goiabeiras (Bairro Santa Mônica e proximidades), Mina do Veeiro e Fazenda do Faria (próximos ao Parque da Cachoeira), que guardam ruinas e vestígios arqueológicos como a capela de Santo Antônio, senzala, moinho, paiol, diversos vestígios da mineração do ouro como galerias subterrâneas e caminhos centenários.

O que você pensa a respeito da criação de um Ecomuseu, que vise a preservação de sítios arqueológicos como estes e de sua utilização para atividades educacionais, estudos científicos e até mesmo o turismo?

Dos 14 alunos que responderam ao questionário, 14 alunos (100\%) opinaram a respeito. Vejamos algumas das respostas:

“_É muito interessante fazer com que seja preservado nosso patrimônio" (Graciele Gonçalves dos Reis, 14 anos).

"_ Auxiliava nas aulas de Geografia e História. Geraria renda com turismo para a cidade. Ajudaria na preservação do patrimônio." (Priscila Soraia, não declarou idade). 
Questão $n^{\circ} 6$ - Faça um desenho ou redação sobre a atividade que você mais gostou de participar:

Dos 14 alunos que responderam o questionário, 12 alunos desenharam e dois alunos não se manifestaram

\section{7 - Resultados do $9^{\circ}$ ano Confiança:}

Questão $n^{\circ} 1$ - Durante os trabalhos de Educação Patrimonial realizados na E. E. Barão de Paraopeba, quais foram as atividades de que você participou dentro e fora da escola?

A turma do $9^{\circ}$ ano Confiança possui 18 alunos. Desse montante, 10 alunos responderam o questionário, sendo que os 10 responderam a questão $n^{\circ} 1$. Dos 10 que responderam o questionário, 7 alunos participaram das atividades e 3 não participaram. Vejamos algumas das respostas:

“_ Ajudei a falar sobre os profetas e o Aleijadinho. Fizemos pesquisas sobre eles, linhas do tempo e um mural com suas fotos" (Firmino da Silva Coelho, 15 anos).

“_ Fiz um trabalho sobre a vida do Aleijadinho e sobre os profetas" (Everton, 14 anos).

Questão $n^{\circ} 2$ - Dos locais que você visitou com a escola, qual deles você gostou mais e por quê?

Do montante de 18 alunos, 10 alunos responderam o questionário e 9 responderam a questão $n^{\circ} 2$, sendo que 4 alunos citaram o local e 6 não citaram. Vejamos algumas das respostas:

“_Visitar ao Bom Jesus, porque eu acho essa visita muito interessante” (Anderson, 15 anos).

“_ Basílica e AEA” (Pollyana Santos Lobo, 16 anos).

Questão $n^{\circ} 3$ - Das atividades de que você participou, qual delas você gostou mais e por quê?

Do total de 10 alunos que responderam o questionário, 4 alunos citaram as atividades, 2 responderam mas não citaram e 4 alunos não responderam a questão $n^{\circ} 3$. Seguem algumas das respostas: 
“_Eu gostei muito da Educação Patrimonial. Os assuntos chamavam muita atenção" (Firmino da Silva Coelho, 15 anos).

“_ Do mural dos Profetas, pois foi interessante e divertido" (Jenifer Indiana Braga Gonçalves, 14 anos).

Questão no 4 - Durante os trabalhos de Educação Patrimonial, o que você gostaria de ter feito ou qual local histórico/arqueológico você gostaria de ter visitado junto com a escola e não pôde fazê-lo? Justifique:

Sobre a questão $\mathrm{n}^{\circ}$ 4, 7 dos 10 alunos que responderam o questionário fizeram declarações, 2 alunos responderam mas não fizeram declarações e 1 aluno não respondeu a questão. Vejamos algumas das respostas:

“_Eu gostaria de visitar a Ouro Preto porque é um lugar de coisas antigas e história” (Anderson, 15 anos).

“_ Ir em Belo Vale no museu dos escravos e em Ouro Preto (...)” (Bruna Ap. Silva Pereira, 15 anos).

Questão $n^{\circ} 5$ - Durante os trabalhos de Educação Patrimonial realizados na E. E. Barão de Paraopeba, foram apresentados aos alunos e professores, por meio de palestras e exposição didática fotográfica, alguns dos sítios arqueológicos do município de Congonhas como a Mina do Redondo (Alto Maranhão), Mina da Soledade (Lobo Leite), Mina das Goiabeiras (Bairro Santa Mônica e proximidades), Mina do Veeiro e Fazenda do Faria (próximos ao Parque da Cachoeira), que guardam ruinas e vestígios arqueológicos como a capela de Santo Antônio, senzala, moinho, paiol, diversos vestígios da mineração do ouro como galerias subterrâneas e caminhos centenários.

O que você pensa a respeito da criação de um Ecomuseu, que vise a preservação de sítios arqueológicos como estes e de sua utilização para atividades educacionais, estudos científicos e até mesmo o turismo?

Dos 10 alunos que responderam ao questionário, 7 alunos opinaram a respeito e 3 não responderam a questão. Vejamos algumas das respostas:

“_Eu acho que na opinião um Ecomuseu seria muito bom para Minas Gerais tanto para os turistas quanto para moradores, isso seria muito bom para a preservação da natureza" (Kelly Samilly M. Corrêa, 16 anos). 
“_ Muito importante, pois acho muito interessante para nossa geração e para a próxima conhecer um pouco mais de nossa cultura e da nossa origem" (Sara Marques Oliveira, 14 anos).

Questão $n^{\circ} 6$ - Faça um desenho ou redação sobre a atividade que você mais gostou de participar:

Dos10 alunos do $9^{\circ}$ ano Confiança que responderam o questionário, 4 alunos desenharam e os demais não se manifestaram nem com desenhos quanto com redações.

Quanto aos trabalhos realizados na Escola Estadual Barão de Paraopeba, eles tendem para uma escola mais próxima da história da cidade e do seu patrimônio. Durante a caminhada, foi possível conversar com os alunos acerca do patrimônio arquitetônico da cidade e escutar expressões tais como: "A gente devia ter mais aulas desse tipo, dá para aprender muito"; "Tinha que ter aula assim pelo menos uma vez por mês"; ou expressões tais: "Seria bom se a gente pudesse conhecer um sítio arqueológico de perto". Entre os alunos alguns que ainda não conheciam a Basílica.

Os guias contratados pela Prefeitura Municipal de Congonhas acharam interessante o fato da Basílica do Senhor Bom Jesus de Matosinhos receber um grupo considerável de estudantes da cidade num mesmo dia, fato que consideram muito incomum na cidade, mesmo em muitos anos de trabalho como guias.

Os professores participantes em geral, têm mostrado satisfação em trabalhar com o tema proposto e também destacaram a importância de uma forma de ensino agregada aos aspectos histórico-culturais do município de forma que possa refletir positivamente no interesse dos alunos pelas disciplinas ensinadas pela própria herança cultural.

A direção da escola ressaltou a importância de trabalhar com alunos do ensino fundamental por estarem mais amadurecidos que os alunos dos anos iniciais básicos e mais susceptíveis a este tipo de aprendizado que os do ensino médio, que já estão com as personalidades mais formadas.

Alguns dos professores que participaram resolveram trabalhar o em parceria com outros, rendendo com isso trabalhos intercalados dentro da temática das disciplinas. 


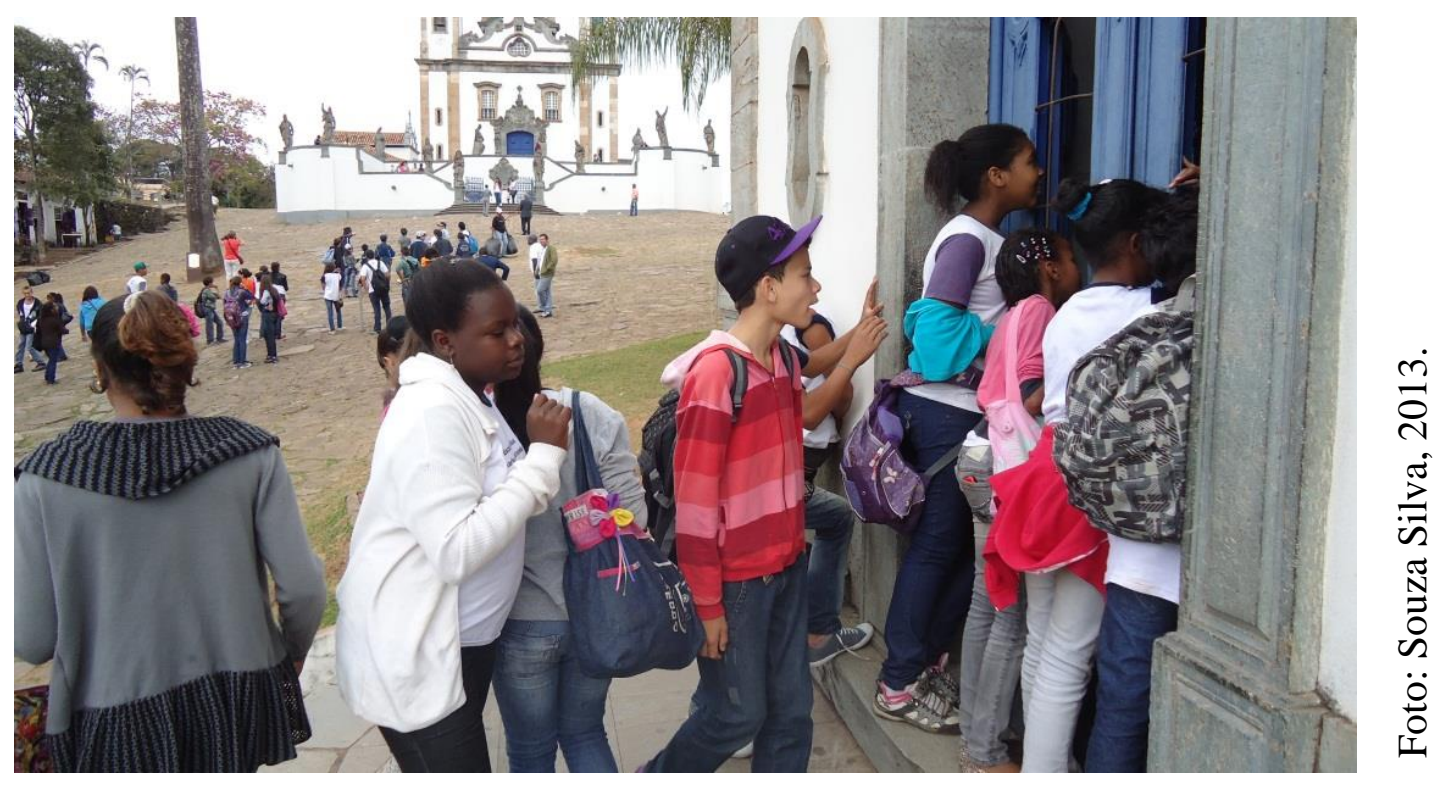

Figura 4 (Anexo 1): Visitação guiada dos alunos da E. E. Barão de Paraopeba à Basílica do Senhor Bom Jesus de Matosinhos, Congonhas, Minas Gerais. 
2.6 - Desenhos de alunos da Escola Estadual Barão de Paraopeba

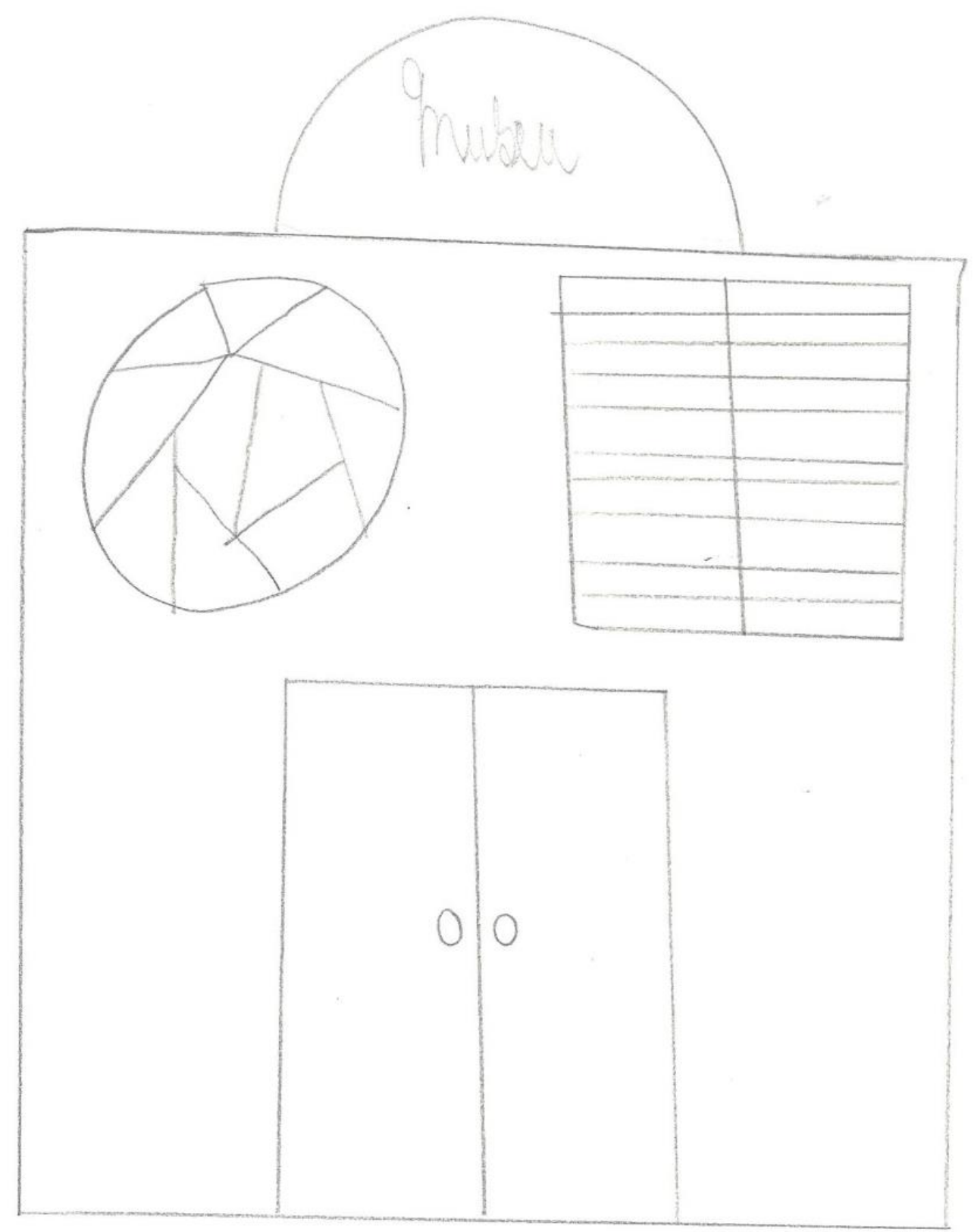




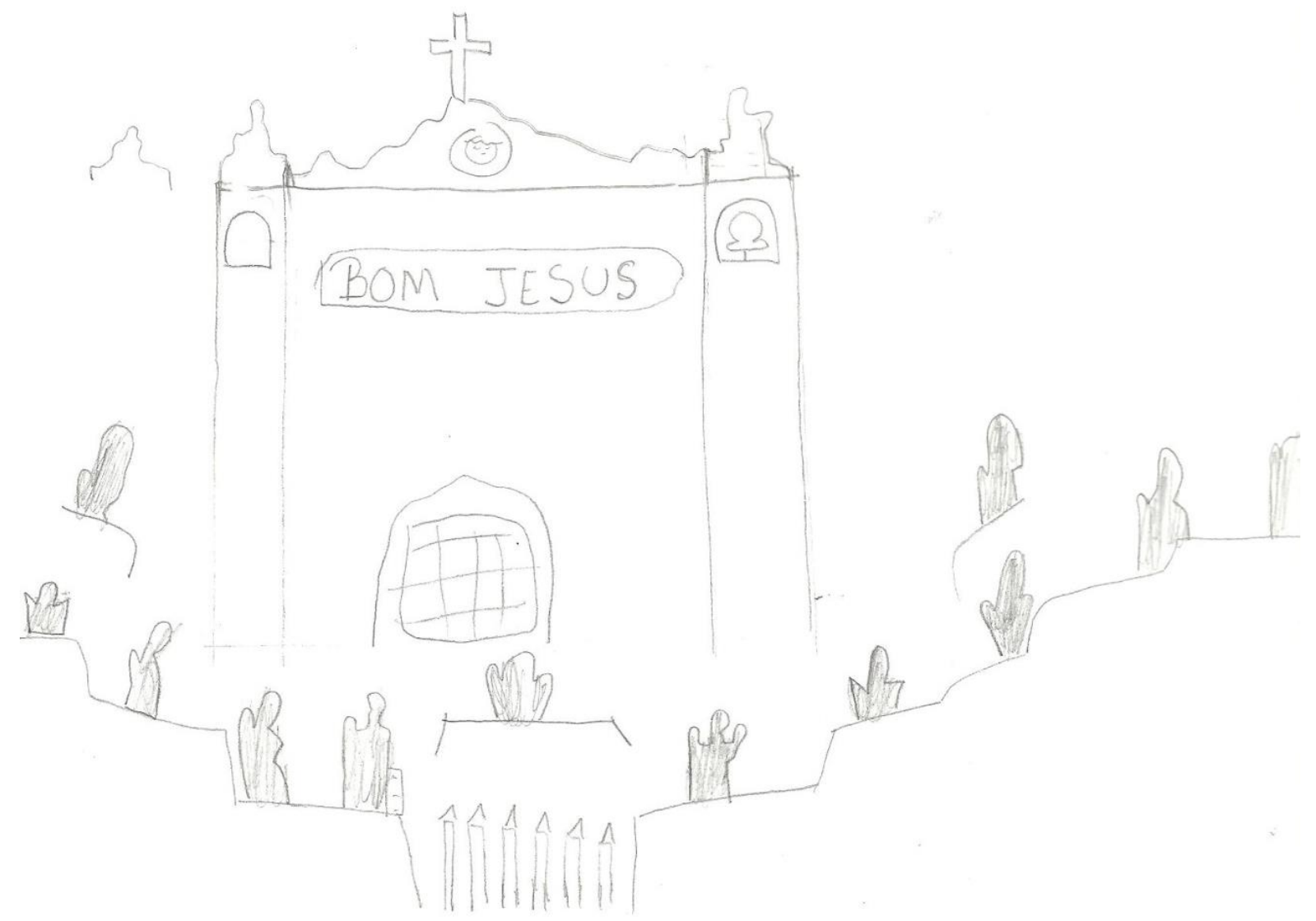




\section{7 - Coleta de referenciais junto aos professores da Escola Estadual Barão de Paraopeba}

O questionário respondido pela equipe de professores no dia 06 de setembro de 2013 contou com a colaboração dos mesmos em sua elaboração e procurou enfatizar temas como dificuldades dos professores em aplicar o projeto, desempenho e satisfação dos alunos, resultados diretos no processo de aprendizado, possibilidades de reaplicação em outras unidades escolares da cidade, importância do trabalho para o aprendizado e a preservação dos sítios arqueológicos apresentados.

A equipe pedagógica e demais funcionários da escola também foram convidados a responder o questionário, porém, somente os professores que participaram do projeto responderam as questões.

Questionário dos professores e equipe pedagógica da E. E. Barão de Paraopeba:

Questão $n^{\circ} 1$ - Durante os trabalhos de Educação Patrimonial realizados na E. E. Barão de Paraopeba transversalmente com a disciplina de História, quais foram as atividades que você trabalhou com as turmas ou participou?

Questão $n^{\circ} 2$ - Quais foram as maiores dificuldades encontradas e por quê?

Questão no 3 - Você acha que os trabalhos de Educação Patrimonial ajudaram no processo de aprendizado, melhorando fatores como interesse dos alunos pela disciplina, atenção em sala de aula, interesse pelo tema proposto ou nota final? Neste sentido, quais foram os principais resultados alcançados?

Questão $\mathrm{n}^{\mathrm{o}} 4$ - O que você acha que faltou ser feito durante o tempo em que as atividades de Educação Patrimonial foram realizadas e que ser feito em outras ocasiões?

Questão $n^{\circ} 5$ - Em sua opinião, a Educação Patrimonial, da forma em que foi realizada na E. E. Barão de Paraopeba, pode ser feita em outras escolas do município? Por quê?

Questão $n^{\circ} 6$ - Durante os trabalhos de Educação Patrimonial realizados na E. E. Barão de Paraopeba, foram apresentados aos alunos e professores, por meio de palestras e exposição didática fotográfica, alguns dos sítios arqueológicos do município de Congonhas como a Mina do Redondo (Alto Maranhão), Mina da Soledade (Lobo Leite), Mina das Goiabeiras (Bairro Santa Mônica e proximidades), Mina do Veeiro e Fazenda do Faria (próximos ao 
Parque da Cachoeira), que guardam ruinas e vestígios arqueológicos como a capela de Santo Antônio, senzala, moinho, paiol, diversos vestígios da mineração do ouro como galerias subterrâneas e caminhos centenários.

O que você pensa a respeito da criação de um ecomuseu, que vise a preservação de sítios arqueológicos como estes e de sua utilização para atividades educacionais, estudos científicos e até mesmo o turismo?

Vejamos algumas das respostas selecionadas dos professores da E. E. Barão de Paraopeba ao questionário a eles aplicado:

\section{1 - Professora Angela e Professora Delaine - História e Educação Física}

Resposta da questão n’ 2 - “_Aceitação de alguns alunos em realizar algumas atividades”.

Resposta da questão $\mathrm{n}^{\mathbf{o}} 3$ - “_ Interesse por parte dos alunos em conhecer as festas culturais da cidade, um desempenho satisfatório pela maioria dos alunos nas atividades realizadas".

Resposta da questão $\mathrm{n}^{\circ} 5$ - “_ Sim, a partir do Momento que as escolas estejam abertas a aceitação da proposta".

Resposta da questão $\mathrm{n}^{\circ} 6$ - “_Seria ótimo, pois estaria enriquecendo ainda mais o conhecimento e a conscientização da preservação dos sítios arqueológicos".

\section{2 - Professora Elisa Cristina - Português}

Resposta da questão $\mathrm{n}^{\circ} 1$ - “_Criamos eu e meus alunos uma apresentação de textos que de alguma forma apresentavam "Congonhas". Nosso trabalho chamou-se Guia por um dia".

Resposta da questão $n^{0} 3$ - “_ Todos se empenharam, estudaram e fizeram bela culminância (Feira de Educação Patrimonial)”.

Resposta da questão $n^{\circ} 5$ - “_ Sim. Afinal o objetivo de conhecer ainda mais a cidade em que mora e até mesmo a "Terra Natal" para muitos causa orgulho e prazer".

\section{3 - Professora Célia Beatriz Guerra Gonzaga - Ciências}

Resposta da questão no 2 - “__ Pouco tempo para realizar as atividades”. 
Resposta da questão n 3 - “__ Os trabalhos com projetos despertam o interesse dos alunos e permitem que sejam trabalhadas várias habilidades e competências".

Resposta da questão no 4 - “_Visita a um sítio arqueológico (Mina de ouro)”.

Resposta da questão n ${ }^{\circ}$ - “_ _ Sim, desde que haja envolvimento dos professores”.

\section{4 - Professora Suely Maria - Geografia}

Resposta da questão no 1 - “_Em Geografia mostrei Congonhas antes e depois, através de slides e localização da cidade no mundo".

Resposta da questão $\mathrm{n}^{\circ} 2$ - “_ O maior vilão responsável pelas dificuldades foi o tempo, pois dedico as minhas atividades a duas escolas e confesso que fiquei sobrecarregada, mas foi muito produtivo".

Resposta da questão no 3 - “__ Os alunos estão mais interessados, lendo mais, acho que preservando mais o patrimônio da escola, mantendo mais limpas as salas, entre outros".

Resposta da questão n ${ }^{\circ} 4$ - “__ Acho que seria muito interessante a visita dos alunos a um sítio arqueológico para saber o que é o objetivo dessa preservação”.

Resposta da questão $\mathrm{n}^{\circ} 5$ - “_ Sim, quanto maior o número de pessoas envolvidas maior seria a conscientização da preservação do Patrimônio "sítios arqueológicos", que deixaram marcas, vestígios de vidas passadas e caracterizando seus modos de vida, costumes, etc.”.

Resposta da questão $n^{\circ} 6$ - “_ O trabalho de Educação Patrimonial contou com a participação de alunos de várias idades da escola Barão de Paraopeba e teve como consequência um grande aprendizado. Os alunos demonstraram muito interesse em participar das atividades propostas. Com relação a criação de um Ecomuseu na cidade, é uma excelente ideia, pois sem dúvida uma atividade onde as pessoas além grande aprendizado (conhecimentos), momentos de diversão, contam também com atividades relacionadas às questões turísticas”. 


\section{8 - Entrevistas e coleta de referenciais junto à população}

Além destes trabalhos pontuais apresentados aqui, temos levantado dados de forma aleatória, com entrevistas feitas a diversos moradores da cidade de Congonhas e das mais variadas faixas etárias e classes sociais. No entanto, muitos se sentem constrangidos por responderem questionários escritos, uns porque não sabem como começarem a escrever, outros porque não gostam da própria letra e outros porque nem mesmo o sabem. Esta forma de entrevista é feita como uma conversa informal porque assim os entrevistados se sentem mais à vontade para falar e dar opiniões a respeito dos sítios arqueológicos da cidade e da possibilidade de musealização e reutilização para a Educação Patrimonial, mas quando pedimos para que informem nomes e documentação, no geral eles ficam constrangidos e se negam a deixar que seus depoimentos e nomes sejam convertidos para a forma escrita e acrescentados na pesquisa. O mesmo ocorre com fotografias, pois os entrevistados acabavam por não se deixarem ser fotografados porque a maioria se sentia envergonhados diante da câmera.

Um fato curioso e importante ocorrido durante a pesquisa foi o de que com a destruição de parte da Mina do Redondo no Alto Maranhão, muitas pessoas nos procuraram para saber a respeito da Arqueologia e do patrimônio arqueológico da cidade. Aproveitamos momentos como estes para levantar dados e opiniões junto às pessoas e oferecê-las o questionário para responderem sobre a situação arqueológica do município de Congonhas.

\subsection{1 - Entrevista com o engenheiro civil e arquiteto Leonardo J. da Silva}

Uma das entrevistas que foi autorizada a ser publicada na pesquisa foi feita com Leonardo o engenheiro civil especializado em arquitetura e autor de um projeto de revitalização arquitetônica do centro histórico de Congonhas, Leonardo J. da Silva, que gentilmente nos recebeu em sua residência.

A entrevista ocorreu em forma de conversa, onde os assuntos relacionados à preservação e destruição do patrimônio arqueológico foram debatidos anteriormente às perguntas que seguem: 
Pergunta $\mathbf{n}^{0}$ 1: Leonardo, em sua opinião, quais as razões da destruição sistemática do patrimônio cultural da cidade de Congonhas, aqui incluindo o arquitetônico, o arqueológico, o histórico, o artístico e o ambiental?

Resposta da pergunta no 1: “_ O problema é que Congonhas é refém e sofre pressão do modelo civilizatório atual."

Pergunta $\mathbf{n}^{0}$ 2: Qual é a principal deficiência na cidade, em relação à gestão do patrimônio cultural?

Resposta da pergunta no 2: “_ $\mathrm{O}$ que ocorre aqui é uma ausência dos valores ligados à preservação, portanto, o patrimônio não é considerado valor, como ocorre em outros lugares como Tiradentes e Ouro Preto em Minas Gerais ou Paraty, no Rio de janeiro.”

Pergunta $\mathbf{n}^{0}$ 3: E porque você acha que isso acontece?

Resposta da pergunta $\mathbf{n}^{\mathbf{0}}$ 3: “_ Ocorre que na cidade de Congonhas há uma supervalorização do econômico focado na mineração, em detrimento de seu patrimônio cultural".

Pergunta $n^{\mathbf{0}}$ 4: "Estou mostrando imagens no computador de sítios arqueológicos da cidade: a Fazenda do Faria, a Igreja de Santo Antônio, a Mina do Veeiro, a Mina das Goiabeiras, a Mina da Soledade, a Mina do Redondo, a cadeia e a fonte do Alto Maranhão. Você acredita que é importante preservá-los para as gerações futuras"?

Resposta da pergunta $\mathbf{n}^{\circ}$ 4: “ $\quad$ Acho importantíssimo que seja preservado, mas não acredito que na cidade não haverá vontade política para tanto. Estão mais preocupados com a mineração e o histórico está descartado. Eu mesmo produzi em minha especialização em Arquitetura pela Universidade Federal de Minas Gerais (UFMG) um projeto de revitalização arquitetônica para o centro histórico de Congonhas que nunca saiu do papel.’

Pergunta no 5: O que você acha da ideia de um Ecomuseu em Congonhas?

Resposta da pergunta $\mathbf{n}^{0}$ 5: “_C Como proposta museológica eu não acho que o Ecomuseu seja uma boa, verdadeiramente não gosto. Mas acredito que para o ponto a que chegamos aqui, com muita destruição e áreas fragmentadas e parcelas, o Ecomuseu pode ser a melhor solução quando falamos em preservação de sítios arqueológicos." 


\subsection{2 - Entrevista com a Diretoria Municipal de Patrimônio de Congonhas}

Ocorreu também, durante o decorrer da pesquisa de comunicação, avaliação e recepção realizada como parte da pesquisa de mestrado "Os velhos caminhos de Congonhas numa perspectiva de Educação Patrimonial”, uma entrevista com a Diretoria Municipal de Patrimônio de Congonhas.

A entrevista foi concedida pela diretoria em grupo, durante uma reunião ocorrida na sede da Diretoria Municipal de Patrimônio de Congonhas, e contou com a participação de Luciomar Sebastião de Jesus, diretor municipal de patrimônio, Maurício Geraldo Vieira, presidente do Conselho Municipal de Patrimônio de Congonhas, Ronaldo José Silva de Lourdes, engenheiro civil da Prefeitura Municipal de Congonhas e coordenador do Programa Monumenta do Governo Federal em Congonhas e Cristiano Oliveira Silveira Costa, arquiteto da Prefeitura Municipal de Congonhas.

Durante a reunião foram debatidos temas como as ações que a Prefeitura Municipal de Congonhas tem feito para conter a destruição de sítios arqueológicos no município, assim como os fatos, providências e repercussões envolvendo os últimos casos de destruição de sítios arqueológicos em Congonhas. Do debate surgiram as seguintes perguntas.

Pergunta $\mathbf{n}^{\mathbf{0}}$ 1: Quais foram as obras paralisadas em Congonhas por conta da destruição de sítios arqueológicos históricos e qual é a situação de cada obra no momento?

Resposta da pergunta $\mathbf{n}^{\circ}$ 1: “_ As obras paralisadas até o momento foram a estrada MG 383, cujo embargo foi suspenso por conta do cumprimento das penalidades, a obra do Condomínio Goiabeiras, cuja liberação do projeto da obra depende da realização e conclusão dos estudos arqueológicos, a obra de loteamento do bairro Nova Congonhas, cujos estudos arqueológicos foram feitos e parte do sítio arqueológico preservado in situ, sendo consequentemente suspenso o embargo e liberado o projeto e a outra obra foi a estrada municipal contorno norte, cuja contratação de arqueólogo foi realizada e o embargo suspenso para realização da obra".

Pergunta $\mathbf{n}^{\mathbf{0}}$ 2: Quais são as ações que a Diretoria de Patrimônio tem proporcionado para evitar a destruição de sítios arqueológicos em Congonhas? 
Resposta da pergunta $n^{\circ}$ 2: “__ Caso seja notada a presença de vestígios arqueológicos na obra ou nas proximidades, a Diretoria Municipal de Patrimônio suspende a aprovação do projeto e o envia para o IPHAN (Instituto do Patrimônio Histórico e Artístico Nacional). É exigida a contratação de empresa de arqueologia para fazer os estudos necessários, buscando sempre acatar as decisões do IPHAN, no sentido de preservar os sítios, considerando questões afetivas da população com o patrimônio. Também temos feito parcerias que resultam no apoio ao MPMG (Ministério Público de Minas Gerais) na produção da Carta Arqueológica de Congonhas, assim como na pesquisa de mestrado "Os velhos caminhos de Congonhas numa perspectiva de Educação Patrimonial”, com objetivo de formarmos uma grande equipe e reforçar parcerias que possam somar na melhor produção da referida carta arqueológica, que pode resultar em prevenção contra a destruição e consequentemente a preservação do patrimônio arqueológico de Congonhas. Também temos buscado maior diálogo e articulação com a Secretaria Municipal de Obras, com a Diretoria de Meio Ambiente, assim como a Secretaria Municipal de Educação, para a realização, num futuro breve, de trabalhos em Educação Patrimonial”.

Pergunta no 3 - Além destas ações que os Senhores citaram, existem outras ações em andamento?

Resposta da pergunta $n^{\mathbf{0}} 3$ - “_ Temos trabalhado também no sentido de sensibilizar as autoridades e mostrar o quanto os sítios arqueológicos são importantes para o município. É uma tarefa difícil, mas acreditamos que temos conseguido alcançar resultados satisfatórios nas três esferas do Poder, ou seja, o Poder Executivo, o Poder Legislativo e o Poder Judiciário, que tem nos dado apoio total. Tanto é verdade que conseguimos um passo importante que é a Carta Arqueológica. O próximo Plano Diretor terá o patrimônio arqueológico como meta. Outro passo que já está em andamento para contribuir com a Arqueologia em Congonhas é o tombamento, em instância municipal, das ruínas da cadeia e da fonte do Distrito de Alto Maranhão".

Pergunta $\mathbf{n}^{\mathbf{0}} 4$ - Além das ruínas da cadeia e da fonte do Alto Maranhão, existem planos para o tombamento dos sítios arqueológicos do município de Congonhas?

Resposta da pergunta $n^{0} 4$ - “_Nossa intenção é proporcionar o tombamento dos sítios arqueológicos também, mas para que isso ocorra, aguardaremos a realização dos estudos que estão acontecendo em Congonhas e a conclusão da carta arqueológica. A princípio estamos debatendo junto às autoridade e pesquisadores a respeito da viabilização de um parque, que 
unirá a questão da preservação do meio ambiente, principalmente da planta congonha (s.f. Luxemburgia Polyandra) à questão da preservação do patrimônio arqueológico".

\subsection{3 - Questionário aplicado junto à população de Congonhas}

O questionário foi produzido com ajuda da ONG Gota D’água do Alto Paraopeba e após discussão com seus membros, chegamos ao consentimento de que seria melhor abordarmos o problema da destruição dos sítios arqueológicos da cidade como resultado da conjuntura atual do município de Congonhas, que passa acelerado o crescimento econômico, industrial e urbano.

Para esta atividade, a ONG Gota D’água do Alto Paraopeba abriu suas portas para a população de Congonhas durante o mês de agosto de 2013 para que fossem realizadas pesquisa de opinião pública, estampando na entrada o lema "Sítios arqueológicos de Congonhas: destruição ou preservação?” e a ONG também ajudou a produzir duas pastas com material fotográfico, contendo as fotos da exposição fotográfica didática apresentada na E. E. Barão de Paraopeba, acrescidas de outras fotografias feiras pela própria ONG, nas quais estavam os trabalhos ambientais feitos pela entidade.

Na sede da ONG, agora aberta diariamente para a aproximação da população com a entidade, produzimos uma linha do tempo intitulada "Túnel do Tempo", onde os visitantes viajavam no tempo dentro de uma galeria subterrânea de mineração de ouro por diferentes momentos históricos da cidade, desde chegada do colonizador no final do século XVI, passando pela escassez do ouro no século XIX, pelo século XX e as transformações arquitetônicas e paisagísticas até chegar ao século XXI, com a mineração do ferro, a siderurgia, o crescimento populacional, o impacto ambiental, a degradação da natureza e com ela a destruição dos sítios arqueológicos, tudo feito com imagens fotográficas da cidade.

O questionário levava em conta a preservação dos sítios arqueológicos da cidade e a possível criação de um parque que pudesse preservá-los e ressignificá-los para usufruto da população local. Questões como o turismo e a exploração turística dos sítios arqueológicos foram colocadas em pauta, apesar de não se tratar do objetivo principal desta proposta, que é a musealização para a Educação Patrimonial, porém, os membros da ONG julgaram conveniente levantarmos questões a este respeito, pois Congonhas é um município minerador 
e o minério é um recurso natural finito e assim, a discussão sobre o potencial turístico dos sítios arqueológicos deveria ser acrescentada como uma alternativa para o futuro. O tema turismo foi levantado anteriormente por alunos da Escola Municipal Conceição Lima Guimarães e também por isso o acrescentamos no questionário, assim como nos questionários de alunos e professores da Escola Estadual Barão de Paraopeba.

A ONG também nos ajudou a distribuir o questionário pelas ruas da cidade, em bairros residenciais e até mesmo em municípios vizinhos. Foram feitas 300 cópias que foram distribuídas durante todo o mês de agosto de 2013. Geralmente as pessoas, alegando pressa ou falta de tempo no momento das abordagens mas, se interessando pelo tema, levavam consigo os questionários para responderem em casa ou no trabalho, se comprometendo a entrega-los na sede da ONG, situada na avenida Júlia Kubitschek n ${ }^{\circ} 1066$, centro, principal rua da cidade e principal acesso de chegada e saída da sede municipal.

Numa abordagem geral, as opiniões das pessoas tendem para que o patrimônio arqueológico da cidade seja manejado de forma que leve à sua musealização e uso para a educação, ao contrário da destruição que tem aparecido e aumentado nos últimos anos e quem chamado a atenção das pessoas para o patrimônio arqueológico e para problemas de sua gestão.

Questionário aplicado junto à população de Congonhas:

Questão no 1 - Você conhece algum sítio arqueológico em Congonhas? Qual?

Questão no 2 - Você acredita que é importante desenvolver ações que possam prevenir a destruição ou preservar sítios arqueológicos em Congonhas?

Questão $\mathbf{n}^{\mathbf{0}} 3$ - O que você pensa a respeito de preservar sítios arqueológicos para utiliza-los em atividades voltadas para a Educação e para o Turismo? Por quê?

Questão $\mathbf{n}^{\mathbf{0}} 4$ - Você considera justo que a sociedade atual trabalhe no sentido de preservar nossas heranças do passado para estas e para as gerações futuras? Comente:

Questão no 5 - O que você pensa a respeito da possibilidade de criação de um Parque Natural, Monumento Natural ou Ecomuseu que possa dar conta de cuidar do patrimônio arqueológico aqui nessa cidade? Do que mais um parque poderia cuidar aqui em Congonhas?

Questão no 6 - Você gostaria de sugerir atividades culturais, ecológicas ou esportivas que poderiam fazer parte deste parque? Caso queira sugerir, cite a atividade e justifique a opinião: 
Questão no 7 - Além deste questionário, você gostaria de deixar outros comentários, considerações ou sugestões sobre questões desta natureza? Caso queira, redija um texto livre:

Dos 300 questionários distribuídos entre a população de Congonhas e moradores de outros municípios vizinhos como Conselheiro Lafaiete, Ouro Branco, Belo Vale e Jeceaba, um total de 27 retornaram respondidos para a sede da ONG Gota D'água do Alto Paraopeba. Vejamos então os resultados e algumas das respostas proporcionadas pelos cidadãos em geral:

\section{Questão n⿳ 1 - Você conhece algum sítio arqueológico em Congonhas? Qual?}

Do total de 27 questionários, obtivemos para a questão $n^{\circ} 1,17$ pessoas responderam sim e 10 responderam não. Vejamos algumas das respostas:

Resposta da questão ${ }^{\circ} 1$ por José Miguel Catarina, 53 anos, comerciante:

“_Sim, na rua José Moreira n 679, Jardim Profeta."

Resposta da questão $\mathrm{n}^{\circ} 1$ por Dolores Rosângela Vartuli, 61 anos, turismóloga:

“_Sim. Alto do Maranhão, região da Joana Vieira."

Questão no 2 - Você acredita que é importante desenvolver ações que possam prevenir a destruição ou preservar sítios arqueológicos em Congonhas?

Do total de 27 questionários, obtivemos para a questão $\mathrm{n}^{\circ} 2,27$ pessoas responderam que sim e 0 (zero) que não. Vejamos algumas das respostas:

Resposta da questão $n^{\circ} 2$ por Rafael Senra Coelho, 31 anos, estudante:

“_Creio que a preservação é de vital importância em Congonhas, cidade de vocação histórica, isso se faz ainda mais necessário e urgente. Estamos falando de nossa história, dos traços culturais que, caso não forem preservados, se perderão para sempre.”

Resposta da questão $\mathrm{n}^{\circ} 2$ por Ivan Barros Moreira, 31 anos, radialista:

“_Sim, educação ambiental nas escolas.”

Questão $n^{0} 3$ - O que você pensa a respeito de preservar sítios arqueológicos para utiliza-los em atividades voltadas para a Educação e para o Turismo? Porque?

Do total de 27 questionários, obtivemos para a questão $\mathrm{n}^{\circ} 3,27$ pessoas foram favoráveis à preservação e 0 (zero) contra. Vejamos algumas das respostas: 
Resposta da questão $\mathrm{n}^{\circ} 3$ por Ysamara Alice Silveira Catarina, 19 anos, Auxiliar administrativa:

“_Creio que seria ótimo, porque a sociedade daria mais valor a nossa cidade."

Resposta da questão $n^{\circ} 3$ por Francisco Pereira Trindade 64 anos, aposentado:

“_Especialistas devem descobri-los e preservá-los para no futuro quando acabar este minério que daqui é extraído a cidade ter a visão voltada para o turismo."

Questão $n^{0} 4$ - Você considera justo que a sociedade atual trabalhe no sentido de preservar nossas heranças do passado para estas e para as gerações futuras? Comente:

Do total de 27 questionários, obtivemos para a questão $\mathrm{n}^{\circ}$ 4, 27 pessoas responderam sim e 0 (zero) não. Vejamos algumas das respostas:

Resposta da questão no 4 Sirlene P. Pereira, 29 anos, auxiliar contábil:

“_Sim. Devemos manter e preservar para que nossos filhos e netos tenham a oportunidade de conhecer e poder também zelar pelos bens que possuímos e fazem parte de nossa identidade cultural."

Resposta da questão $\mathrm{n}^{\text {o }} 4$ por Marlene A. Rodrigues Silva Maia, 39 anos, empregada doméstica:

“_Sim , para que a história não se perca."

Questão $n^{0} 5$ - O que você pensa a respeito da possibilidade de criação de um Parque Natural, Monumento Natural ou Ecomuseu que possa dar conta de cuidar do patrimônio arqueológico aqui nessa cidade? Do que mais um parque poderia cuidar aqui em Congonhas?

Do total de 27 questionários, obtivemos para a questão $n^{\circ}$ 5, 26 pessoas concordam, 0 (zero) não concorda e 1 não respondeu. Vejamos algumas das respostas:

Resposta da questão $\mathrm{n}^{\circ} 5$ por Maria Regina Morais Souza, 51 anos, comerciante:

“_Um Ecomuseu seria muito importante para a preservação do patrimônio ecológico, bem como um parque natural."

Resposta da questão n ${ }^{\circ} 5$ por Antônio Maria Reis, 69 anos, Professor aposentado: 
“_Ótima ideia. Poderia educar o povo para as questões patrimoniais históricas. Talvez seja uma solução, pois nossas escolas estão mais preocupadas em formar o jovem para disputar o mercado de trabalho."

Questão n⿳0 6 - Você gostaria de sugerir atividades culturais, ecológicas ou esportivas que poderiam fazer parte deste parque? Caso queira sugerir, cite a atividade e justifique a opinião:

Do total de 27 questionários, obtivemos para a questão $\mathrm{n}^{\circ} 6$ o total de 23 pessoas que sugeriram atividades, 0 (zero) não sugeriram e 4 não responderam. Vejamos algumas das respostas:

Resposta da questão n 6 por Marcelo Sabará, 40 anos, atendente de farmácia:

“_São várias as atividades que podem ser incluídas a esta causa, como: caminhadas ecológicas, passeios ciclísticos, acampamentos, etc."

Resposta da questão $n^{\circ} 6$ por Regina Magda Corrêa, 58 anos, aposentada:

“_Incentivo ao conhecimento, à cultura de nossa região, esquecida por muitos e desconhecida de nossos jovens."

Questão $n^{0} 7$ - Além deste questionário, você gostaria de deixar outros comentários, considerações ou sugestões sobre questões desta natureza? Caso queira, redija um texto livre:

Do total de 27 questionários, obtivemos para a questão $\mathrm{n}^{\circ}$ 7, 18 pessoas não comentaram, e 9 fizeram comentários. Vejamos algumas das respostas:

Resposta da questão $\mathrm{n}^{\circ} 7$ por Mario Sales Maia, 51 anos, aposentado:

“_ Vemos em Congonhas um verdadeiro descaso com o nosso patrimônio material, cultural e natural. Acho justo que fosse implantadas em Congonhas mais iniciativas sobre a preservação do nosso passado."

Resposta da questão $n^{\circ} 7$ por Isabela Mendes Freitas, 30 anos, doutoranda (não informou a disciplina) na Universidade Estadual do Rio de Janeiro (UERJ):

“_Considero importante que esta questão dos sítios arqueológicos de Congonhas seja amplamente divulgada com fins de esclarecer a população sobre sua relevância, considerando 
também que Congonhas carece de um arquivo Público Municipal que contenha material para pesquisa histórica e antropológica sobre nossa cidade."

\section{9 - Coleta de referenciais junto à Escola Estadual Lamartine de Freitas}

A Escola Estadual Lamartine de Freitas fica localizada no bairro da Praia, numa área bem próxima do centro de Congonhas. Nas proximidades da escola fica o principal ginásio de esportes da cidade, a Policlínica Municipal, que atende casos de enfermidades variadas de pacientes de todo município, o quartel da Polícia Militar de Minas Gerais e ainda, um clube com estádio de futebol. O bairro da Praia é uma área em pleno desenvolvimento urbano e econômico e nele estão instalados colégios particulares, supermercados, oficinas mecânicas, padarias, bares, restaurantes, salões de beleza e diversas outras lojas de comércio variado.

A Escola Estadual Lamartine de Freitas oferece ensino fundamental e médio e recebe estudantes da sede municipal, dos distritos, área rural e inclusive estudantes de outros municípios que fazem divisa com Congonhas e que vivem mais próximos da sede deste.

Os trabalhos de Educação Patrimonial e coleta de referenciais junto à Escola Estadual Lamartine de Freitas tiveram início a partir dos trabalhos de coleta de referenciais realizados na sede da ONG Gota D’água do Alto Paraopeba, quando a Professora Ivone, que é professora de História da escola, conheceu e se interessou pelos trabalhos voltados para a divulgação e preservação do patrimônio arqueológico, nos fazendo então um convite para desenvolvermos trabalhos junto a seus alunos de ensino médio.

Depois de algumas visitas à escola, decidimos, junto à sua diretoria sobre a forma de trabalho e metodologia a serem adotados e ficou definido então que a disciplina de Arqueologia seria tema de trabalho transversal junto à disciplina de História, ou seja, um trabalho parecido com o que foi feito na Escola Estadual Barão de Paraopeba, porém de forma a estimular a pesquisa e preparar os alunos para o vestibular, o ENEM (Exame nacional do Ensino Médio) e universidade.

Como nosso prazo era curto, já que estávamos no $4^{\circ}$ e último bimestre escolar, não dispúnhamos de tempo e recursos humanos naquela altura do ano e nossa opção foi reproduzir 
alguns dos trabalhos já realizados nas escolas Conceição Lima Guimarães e Barão de Paraopeba, de forma mais objetiva e intensiva, respeitando a idade e o ano escolar dos alunos.

A Professora Ivone e a diretoria da escola escolheram a turma do $3^{\circ}$ ano E, a qual, de acordo com suas opiniões e experiências na escola, tinha melhor aproveitamento escolar e maturidade para tratar com seriedade do tema Arqueologia e patrimônio arqueológico. A turma do $3^{\circ}$ ano E constava de 30 alunos e estudava no turno da manhã.

As atividades de Educação Patrimonial e coleta da referenciais que foram realizadas na Escola Estadual Lamartine de Freitas foram as seguintes:

1 - reunião com a professora de História e a diretoria, com apresentação do projeto de Educação Patrimonial e coleta de referenciais aprovado pela direção da escola e pela Superintendência Regional de Educação;

2 - realização de palestra de 2:30 horas (duas horas e trinta minutos), intitulada "Conhecendo os sítios arqueológicos de Congonhas", quando trabalhamos temas introdutórios como a História da Arqueologia, seu papel entre as ciências, sua proximidade e a interdisciplinaridade com a disciplina de História e outras ciências, patrimônio arqueológico, tipos de sítios arqueológicos, tipos de vestígios e artefatos arqueológicos e suas funcionalidades, métodos de datação de vestígios, trabalhos de campo e de curadoria de artefatos. Também foram divulgados sítios arqueológicos envolvidos na pesquisa em Congonhas como a Fazenda do Faria, a Capela de Santo Antônio, a Mina do Veeiro, a Mina da Soledade, a Mina das Goiabeiras e a Mina do Redondo, incluindo as ruínas da cadeia e da fonte do Alto Maranhão. A palestra contou também com a participação do presidente da ONG Gota D’água do Alto Paraopeba, Hélvio Vitarelli, que discursou sobre a importância da preservação dos recursos naturais do município, entre eles a água, os minerais, o patrimônio arqueológico e a própria planta congonha que empresta o nome para a cidade (s.f. Luxemburgia polyandra). Os alunos tiveram tempo de trinta minutos para debate e formulação de questões relacionadas à Arqueologia e aos demais assuntos abordados. A palestra contou também com a presença de pedagogos, professores de outras disciplinas e funcionários, todos curiosos por Arqueologia, no final da palestra ocorreu um debate entre os palestrantes e os alunos;

3 - apresentação de duas pastas de arquivo fotográfico com linha do tempo representada por 50 fotografias, sendo 25 fotografias em cada pasta, que mostravam a cidade de Congonhas desde os tempos coloniais até os dias atuais, relacionando passado, presente e futuro por meio do patrimônio arqueológico, arquitetônico e ambiental do município; 
4 - visita técnica ao Museu da Imagem e Memória de Congonhas, ao Museu de Mineralogia e ao Museu de Arte Sacra, passando pela rua do Aleijadinho, com sua arquitetura colonial em parte preservada e com destaque para a Igreja Matriz de São José Operário;

5 - visita técnica à Basílica do Senhor Bom Jesus de Matosinhos, com guia providenciado pela Prefeitura Municipal de Congonhas (Secretaria de Turismo), passando pelas capelas dos passos da paixão, pelo adro e os 12 Profetas, pela portada do templo, onde puderam expandir seus conhecimentos acerca das histórias e dos mistérios envolvendo estas obras artísticas e pela sala dos milagres, onde tiveram contato com a história do Jubileu do Senhor Bom Jesus de Matosinhos, das pessoas que por lá passaram em busca de milagres e bênçãos, além da coleção de ex-votos tombada como patrimônio nacional pelo IPHAN. Os alunos tiveram oportunidade de visualizarem do adro da basílica alguns dos sítios arqueológicos do município como a Mina de Soledade, a Mina das Goiabeiras, a Mina do Veeiro, além da região onde se encontra a Fazenda do Faria e a capela de Santo Antônio, fazendo questionamentos acerca da preservação do patrimônio arqueológico e recebendo explicações acerca da importância dos sítios arqueológicos que compõem aquela paisagem cultural para a explicação da história daquela região e de seu povo;

6 - os alunos foram estimulados a desenvolverem pesquisas acerca de um tema de escolha livre, que tivesse relação com os trabalhos anteriores. Por exemplo, eles podiam escolher entre pesquisar sobre a Arqueologia, o Barroco Mineiro, o Aleijadinho, a Romaria, a planta congonha (s.f. Luxemburgia polyandra), a arquitetura colonial. A pesquisa foi feita em grupos, que tinham que debater acerca do tema escolhido e teriam direito a nota bimestral;

7 - prova final com questões relacionadas os temas desenvolvidos;

8 - a Professora Ivone agregou outras atividades ao projeto de Educação Patrimonial como apresentação da peça teatral intitulada "Dom Silvério, o poeta negro", do grupo de teatro congonhense chamado Dez pras oito. A peça trata da vida e obra de Dom Silvério Gomes Pimenta, nascido em Congonhas em 1840 e que foi o primeiro Arcebispo de Mariana;

9 - aplicação dos questionários para avaliação e coleta de referenciais junto aos alunos e à professora da disciplina de História, Professora Ivone;

10 - avaliação dos referenciais coletados na Escola Estadual Lamartine de Freitas. 


\subsection{1-Questionário aplicado junto aos alunos da Escola Estadual Lamartine de Freitas}

Para obtenção de dados referenciais à questão da Educação Patrimonial e da preservação de sítios arqueológicos de Congonhas, foram aplicadas as seguintes questões, junto aos alunos da Escola Estadual Lamartine de Freitas:

Questão no 1 - Você conhece sítios arqueológicos em Congonhas? Quais?

Questão $\mathrm{n}^{\mathrm{o}} 2$ - Você acredita que é importante desenvolver ações que possam prevenir a destruição ou preservar sítios arqueológicos em Congonhas?

Questão $\mathrm{n}^{\mathrm{o}} 3$ - O que você pensa a respeito da preservação de sítios arqueológicos para utiliza-los em atividades voltadas para a Educação? Justifique:

Questão n ${ }^{\circ} 4$ - Você acredita que a sociedade atual deve trabalhar no sentido de preservar nossas heranças do passado para estas e para as gerações futuras? Comente:

Questão $n^{\circ} 5$ - O que você pensa a respeito da possibilidade de criação de um Ecomuseu como alternativa de preservação do patrimônio arqueológico aqui nessa cidade? Do que mais um parque poderia cuidar aqui em Congonhas?

Questão $n^{\circ} 6$ - De quais trabalhos de Educação Patrimonial você participou durante o $4^{\circ}$ bimestre? De qual atividade você mais gostou e o que faltou?

Questão $n^{o} 7$ - Além deste questionário, você gostaria de deixar outros comentários, considerações ou sugestões sobre questões desta natureza? Caso queira, redija um texto livre:

\subsection{2 - Resultados do questionário aplicado aos alunos da Escola Estadual Lamartine de Freitas}

Como já era esperado pela Professora Ivone da disciplina de História, e pela direção da Escola Estadual Lamartine de Freitas, os alunos do $3^{\circ}$ ano E se mostraram muito atentos às questões relacionadas à Arqueologia no município de Congonhas e trabalharam de forma muito produtiva. No geral, estiveram muito atentos, curiosos e desinibidos durante as atividades e para formular questões. Alguns alunos demostraram interesse e estavam informados acerca 
dos temas trabalhados e de problemas relacionados à Arqueologia e à destruição de sítios arqueológicos ocorrida no município recentemente, que foi divulgada de forma ampla pela mídia mineira em jornais, televisão e Internet.

Desta forma, vejamos algumas das respostas dos alunos do $3^{\circ}$ ano $\mathrm{E}$ sobre as questões que lhes foram apresentadas:

\section{Questão no 1 - Você conhece sítios arqueológicos em Congonhas? Quais?}

Do montante de 30 alunos, 19 alunos responderam o questionário e 09 alunos responderam a questão $\mathrm{n}^{\circ} 1$, sendo que 06 alunos citaram que conhecem algum sítio arqueológico em Congonhas e 13 alunos citaram que não conhecem.

“__ Sim, os que foram apresentados pelo arqueólogo durante a visita até a Basílica” (Sabrina Emanuelli Dias Silva, 17 anos).

“_Não. Não tive a oportunidade de ver algum mas gostaria muito de conhecer.” Denize L. Marques, 17 anos).

Questão $n^{\circ} 2$ - Você acredita que é importante desenvolver ações que possam prevenir a destruição ou preservar sítios arqueológicos em Congonhas?

Dos 19 alunos que responderam o questionário, 19 deles (100\%) responderam acreditam que ações deste tipo podem ser importantes e ninguém foi contra.

“_Sim, pois isso tem que ser preservado para que as gerações futuras possam conhecer o quão grande era a riqueza da cidade" (Viviane Justino Oliveira, 17 anos).

“_É importante prevenir a destruição pois o estudo desses sítios arqueológicos é muito importante para nossa cidade" (Iêda Denise de Souza, 17 anos).

Questão $n^{\circ} 3$ - O que você pensa a respeito da preservação de sítios arqueológicos para utiliza-los em atividades voltadas para a Educação? Justifique:

Dos 19 alunos que responderam a questão $\mathrm{n}^{\circ}$ 3, 19 deles (100\%) consideraram que preservar para educar é importante e ninguém foi contrário.

“__Isso é muito bom pois preservando os sítios arqueológicos os alunos poderão conhece-los, ter a visão da história, do conhecimento, e saberem que tem que colaborar com a preservação" (Eduarda Carolina Rezende, 18 anos). 
“_Eles podem ser ótimos para incentivar e despertar o interesse dos alunos na história de nossa cidade e aumentar os conhecimentos gerais" (Paola Aparecida Dias, 18 anos).

Questão $n^{o} 4$ - Você acredita que a sociedade atual deve trabalhar no sentido de preservar nossas heranças do passado para estas e para as gerações futuras? Comente:

Dos 19 alunos que responderam o questionário, 19 deles (100\%) consideraram que é dever preservar para as gerações futuras e ninguém foi contrário.

“_Sim. Temos que deixar resquícios do passado para que a geração futura saiba sobre sua origem" (Paola Aparecida Dias, 18 anos).

“__Sim, pois muitas coisas já se passaram e com o tempo isso foi se perdendo, então com essa preservação as pessoas vão poder conhecer a riqueza da cidade.” (Viviane Justino de Oliveira, 17 anos).

Questão $n^{\circ} 5$ - O que você pensa a respeito da possibilidade de criação de um Ecomuseu como alternativa de preservação do patrimônio arqueológico aqui nessa cidade? Do que mais um parque poderia cuidar aqui em Congonhas?

Dos 19 alunos que responderam o questionário, 19 deles (100\%) considerou que um ecomuseu pode funcionar bem como alternativa de preservação de sítios arqueológicos.

"_Penso que seria ótimo, pois iria preservar muitas coisas, e as pessoas poderiam conhecer tudo que há aqui em Congonhas, com isso, as pessoas iriam conhecer melhor a cidade e iriam se interessar mais" (Viviane Justino Oliveira, 17 anos).

“_Seria interessante a criação de um Ecomuseu, para a população de Congonhas passar a se interessar mais pela Arqueologia” (Dábyla Luma Romão de Moura, 17 anos).

Questão $n^{\circ} 6$ - De quais trabalhos de Educação Patrimonial você participou durante o $4^{\circ}$ bimestre? De qual atividade você mais gostou e o que faltou?

Dos 19 alunos que responderam a questão $\mathrm{n}^{\circ}$ 6,17 deles citaram os trabalhos que mais gostaram e 2 deles não citaram.

“_Da visita ao museu, gostei bastante” (Igor Luiz Lobo de Souza, 17 anos).

“_Eu visitei os museus e o Alto do Bom Jesus de Congonhas. Gostei de todos" (Paola Aparecida Dias, 18 anos). 
Questão $n^{\circ} 7$ - Além deste questionário, você gostaria de deixar outros comentários, considerações ou sugestões sobre questões desta natureza? Caso queira, redija um texto livre:

Dos 19 alunos que responderam ao questionário, 7 deles fizeram um texto e 12 deles não fizeram.

“_Acho que poderia trazer a arqueologia para as escolas, seria uma maneira de nós alunos entender e aprender mais sobre nosso passado" (Iêda Denise de Souza, 17 anos).

“_Foi muito bacana ter participado desse projeto, pois tive grandes conhecimentos sobre o que há aqui e que precisa ser preservado, pois nós que moramos, às vezes não ficamos muito interessados a conhecer a fundo do que há aqui, de como foi, da história. Me acrescentou muito no meu dia-a-dia" (Viviane Justino Oliveira, 17 anos).

\subsection{3 - Questionário aplicado à Professora de História Ivone da Conceição Cordeiro da Escola Estadual Lamartine de Freitas com as respostas}

Questão $n^{\circ} 1$ - Você conhece sítios arqueológicos em Congonhas? Quais?

“_Não. Conheço somente por ouvir falar ou por leitura, mas nunca fui em nenhum”.

Questão $n^{\circ} 2$ - Você acredita que é importante desenvolver ações que possam prevenir a destruição ou preservar sítios arqueológicos em Congonhas?

“ Sim."

Questão $n^{\circ} 3$ - O que você pensa a respeito da preservação de sítios arqueológicos para utiliza-los em atividades voltadas para a Educação? Justifique:

“_Muito importante. A teoria estará integrada com a prática.”

Questão $n^{\circ} 4$ - Você acredita que a sociedade atual deve trabalhar no sentido de preservar nossas heranças do passado para estas e para as gerações futuras? Comente:

“__ Sim, porque preservando as heranças culturais a história se torna sempre voltada para a ligação entre passado, presente e futuro." 
Questão $n^{\circ} 5$ - O que você pensa a respeito da possibilidade de criação de um Ecomuseu como alternativa de preservação do patrimônio arqueológico aqui nessa cidade? Do que mais um parque poderia cuidar aqui em Congonhas?

“_Preservação das heranças culturais e preservação do meio ambiente que é o habitat do homem."

Questão $n^{\circ} 6$ - De quais trabalhos de Educação Patrimonial você participou durante o $4^{\circ}$ bimestre? De qual atividade você mais gostou e o que faltou?

“_Palestras voltadas para o tema proposto e visita ao acervo histórico da cidade.”

Questão $n^{\circ} 7$ - Além deste questionário, você gostaria de deixar outros comentários, considerações ou sugestões sobre questões desta natureza? Caso queira, redija um texto livre:

“_Contribuiu muito para o aprimoramento dos conhecimentos." 
Anexo 2 - Figuras, mapas e outros documentos
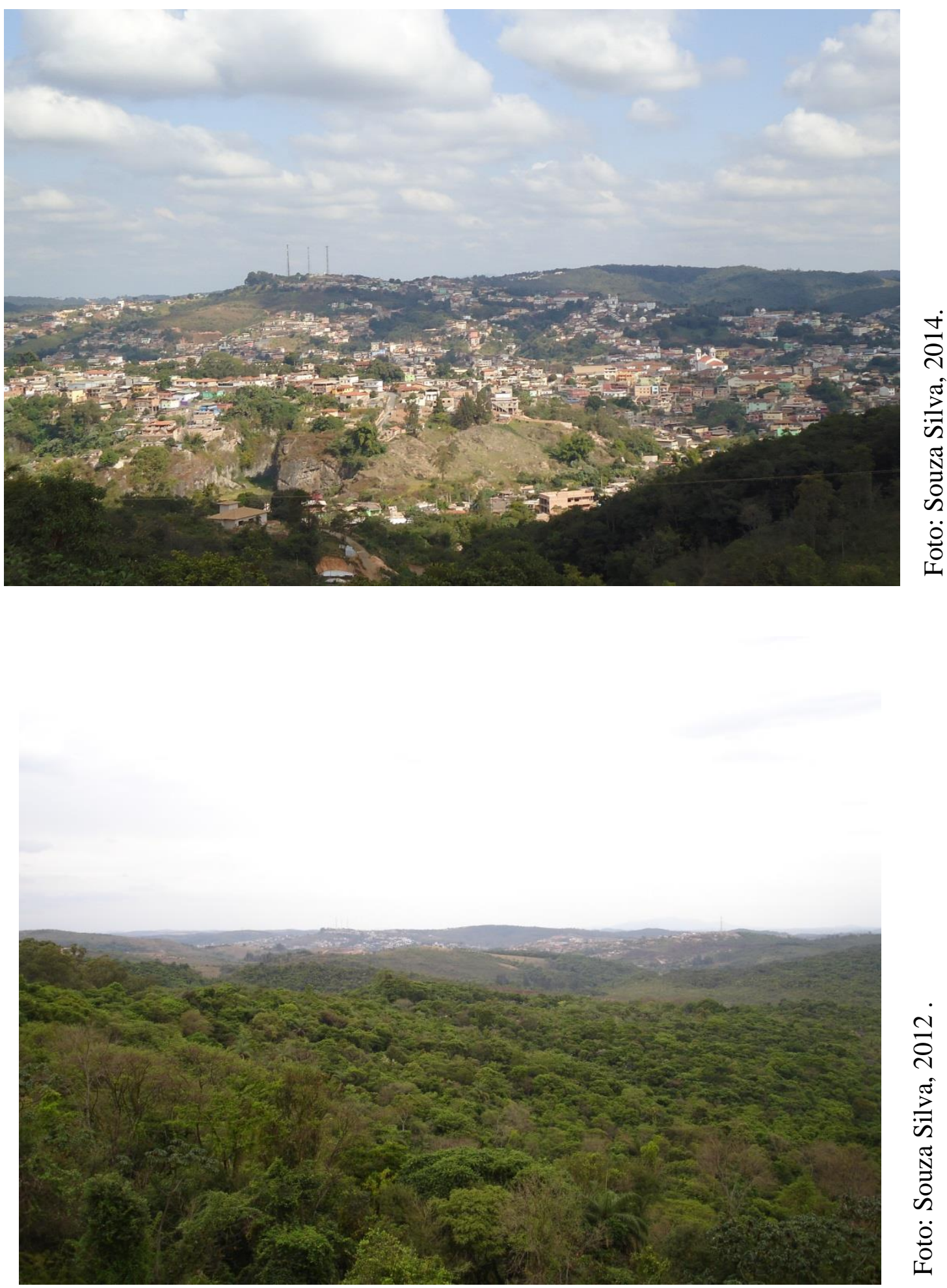

Figura 1 (Anexo 2): Congonhas - Vista Parcial do município. 

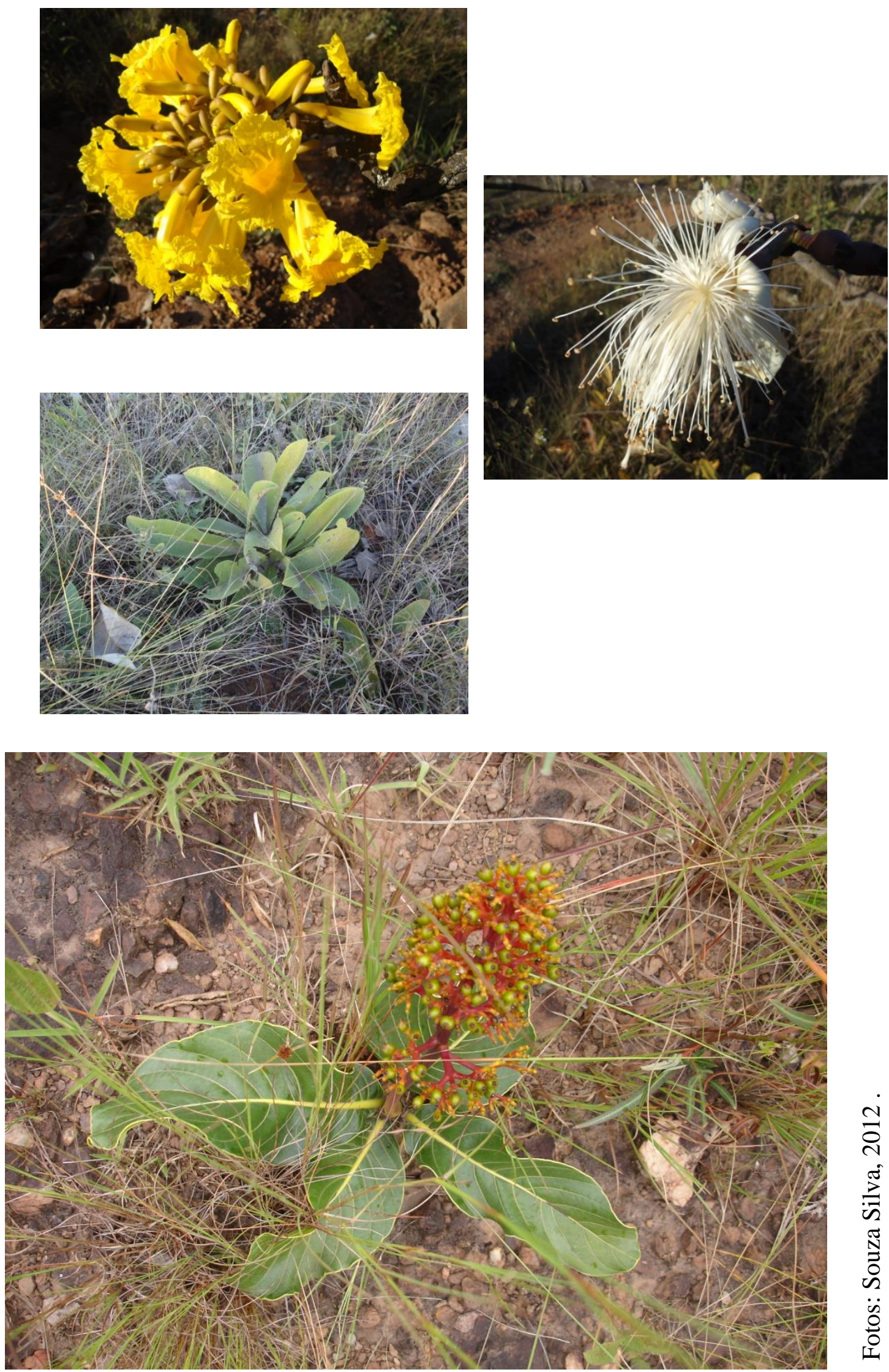

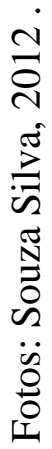

Figura 2 (Anexo 2): De cima para baixo: congonhas bate-caixa floridas, congonha bugre e congonha douradinha. 

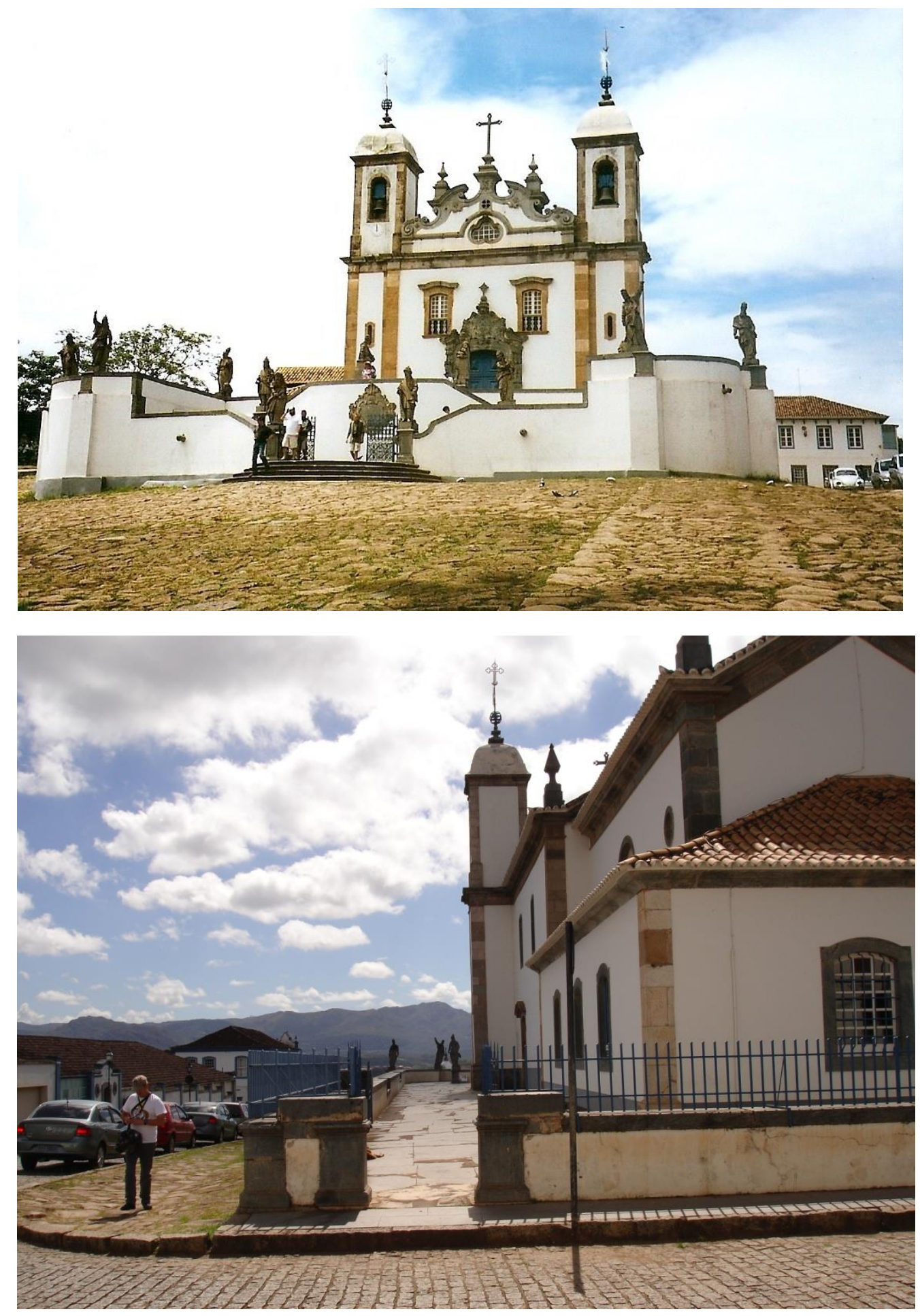

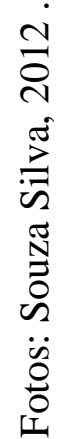

Figura 3 (Anexo 2): Basílica do Senhor Bom Jesus de Matosinhos. 

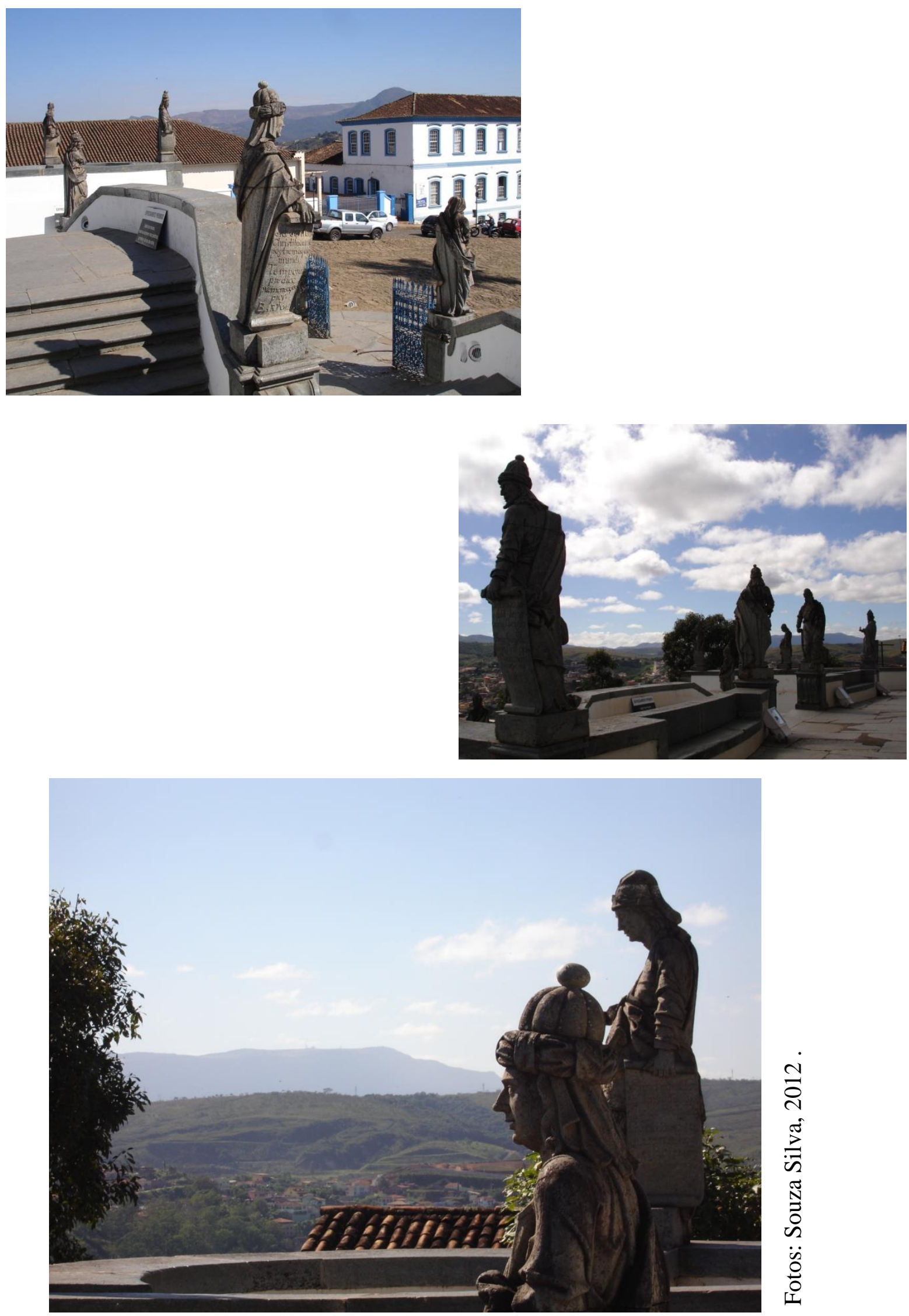

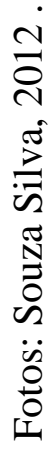

Figura 4 (Anexo 2): Aleijadinho (Antônio Francisco Lisboa): Os Doze Profetas. Pedra-sabão, século XIX. 

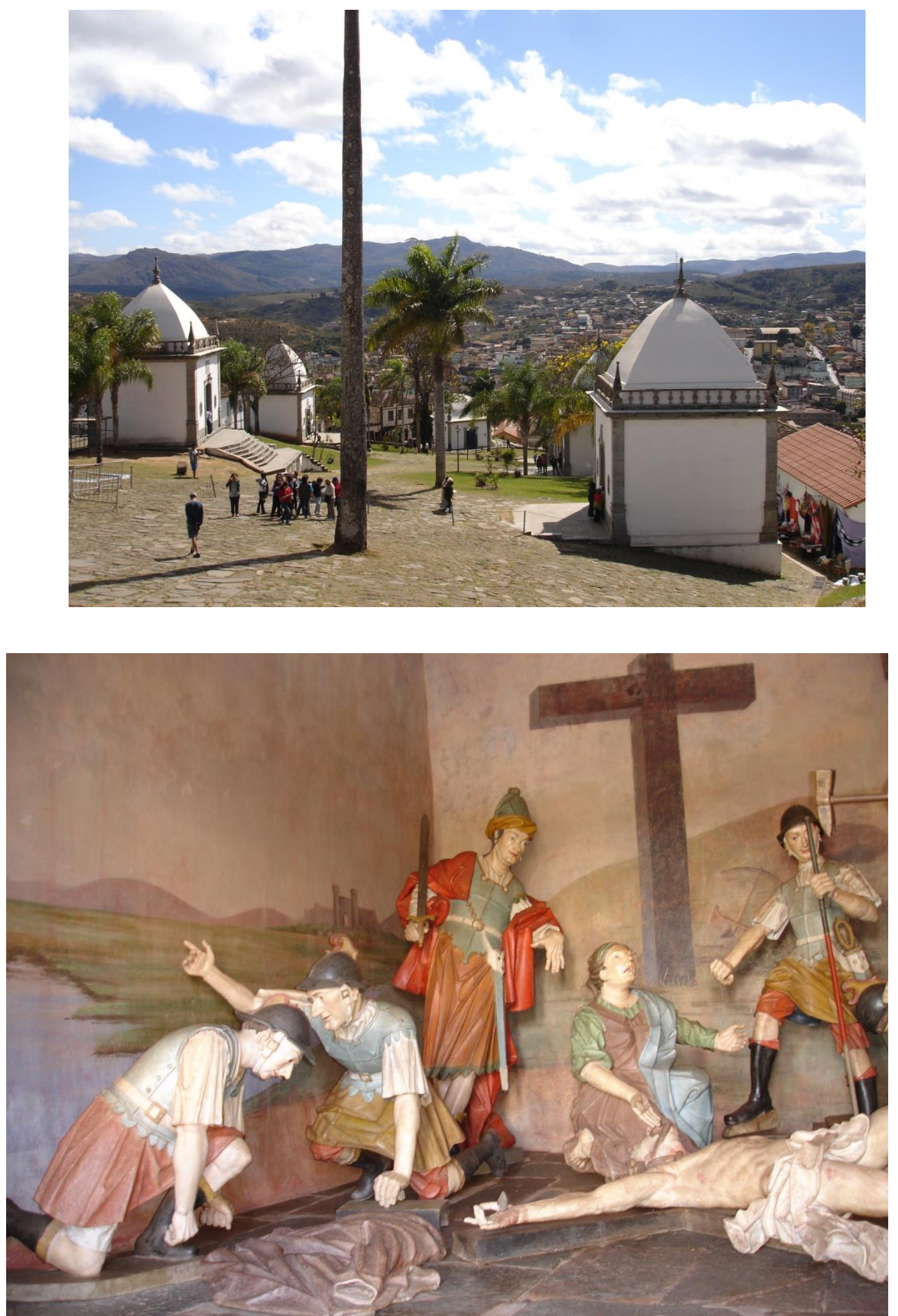

$\frac{1}{2}$

ิㅗㅇ

ڤ̊

苍

Figura 5 (Anexo 2): Capelas dos Passos e cena da Crucificação. 

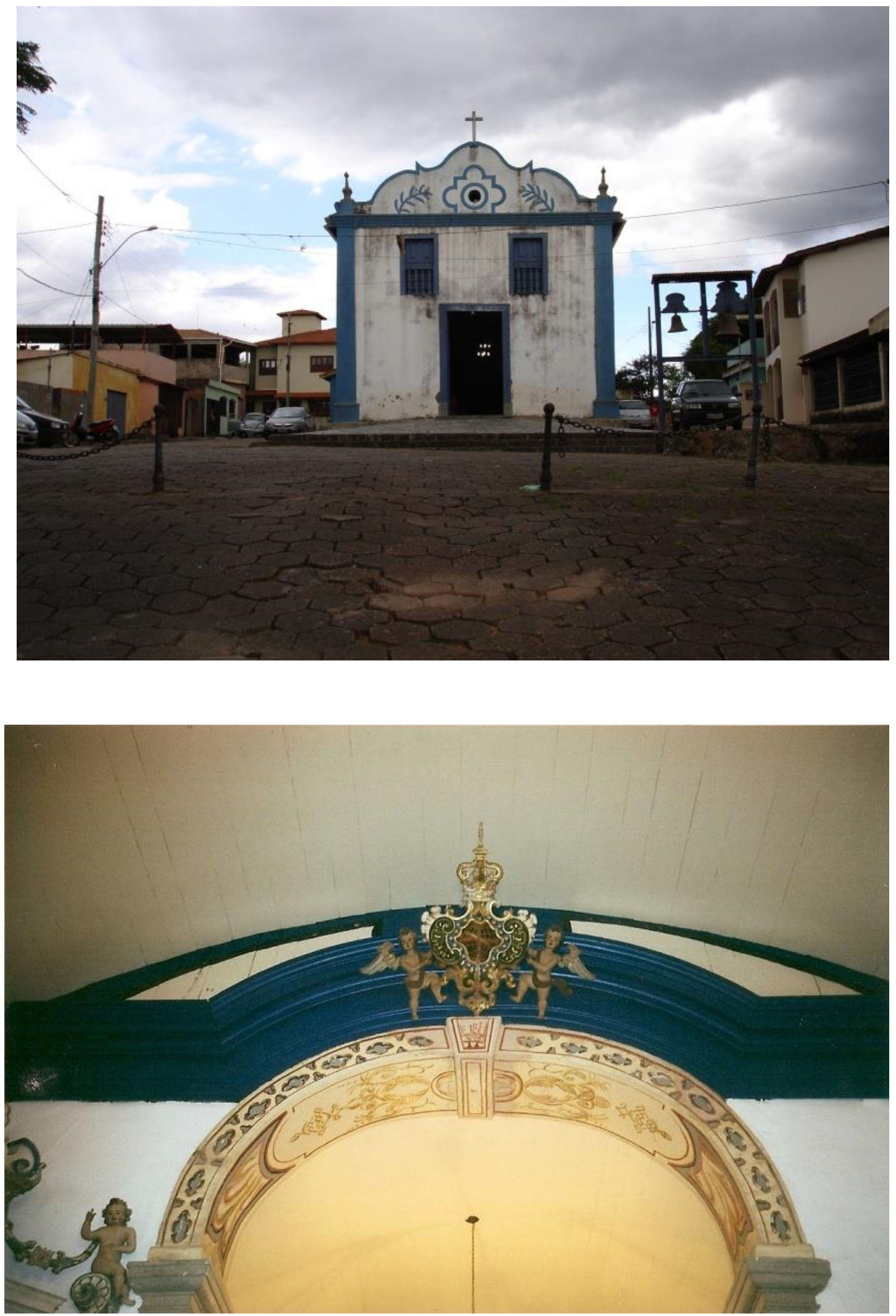

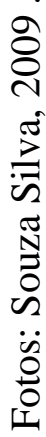

Figura 6 (Anexo 2): Igreja de Nossa Senhora do Rosário: fachada e brasão da nave. 


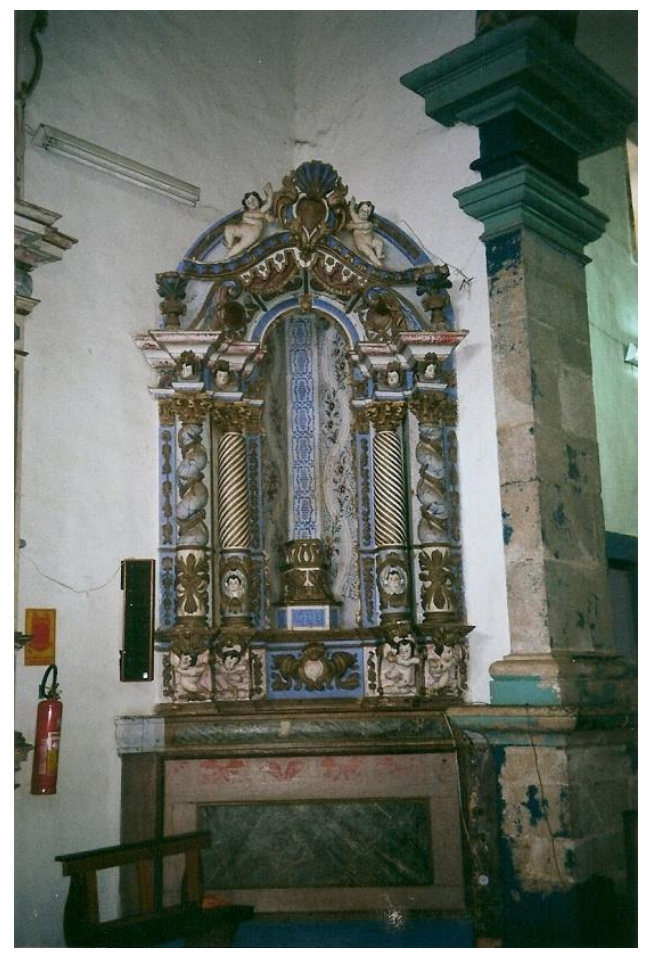

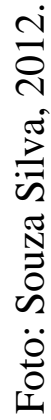

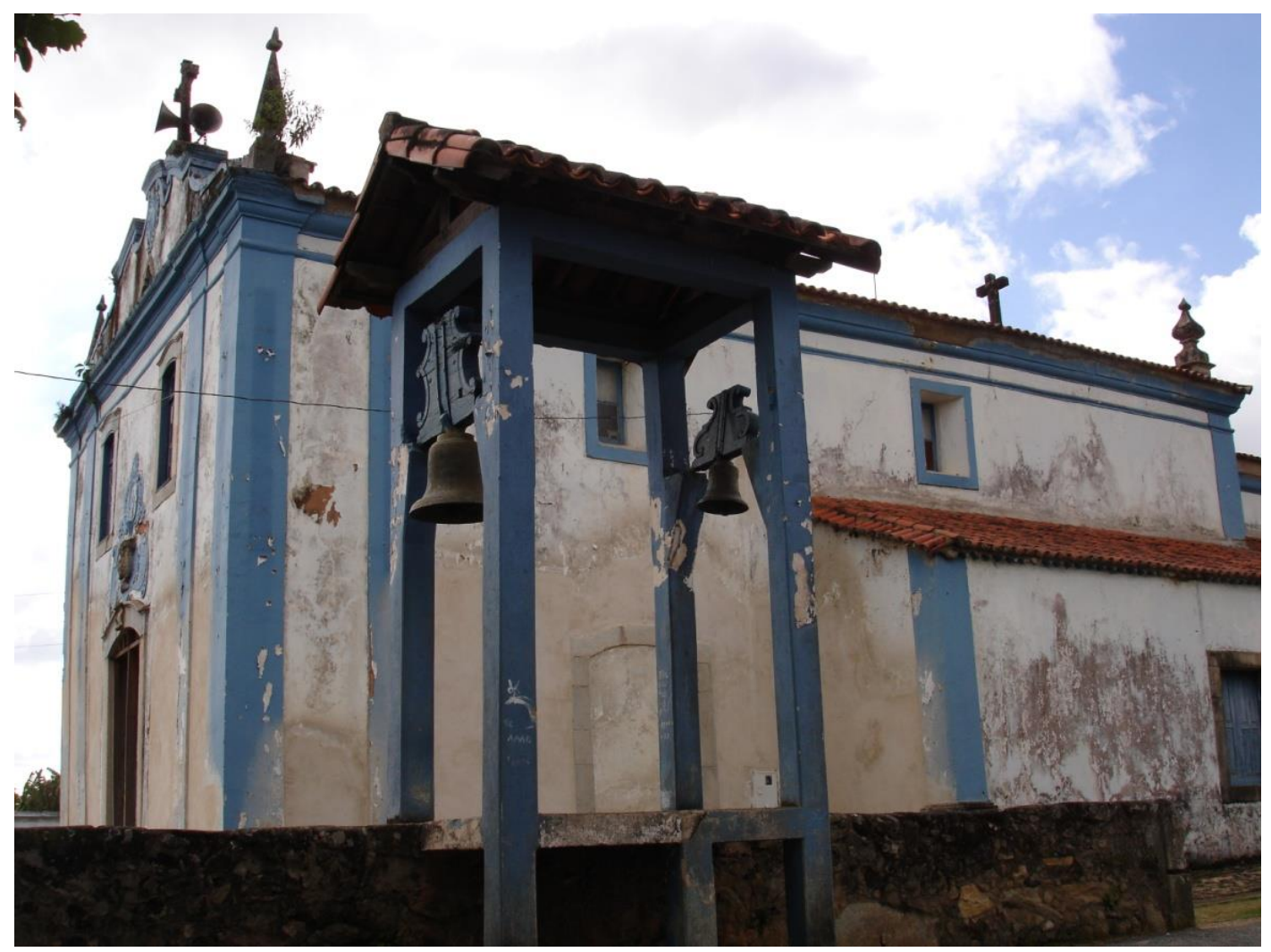

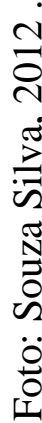

Figura 7 (Anexo 2): Igreja de Nossa Senhora da Ajuda (Século XVIII): Altar em restauração e sineira lateral. 

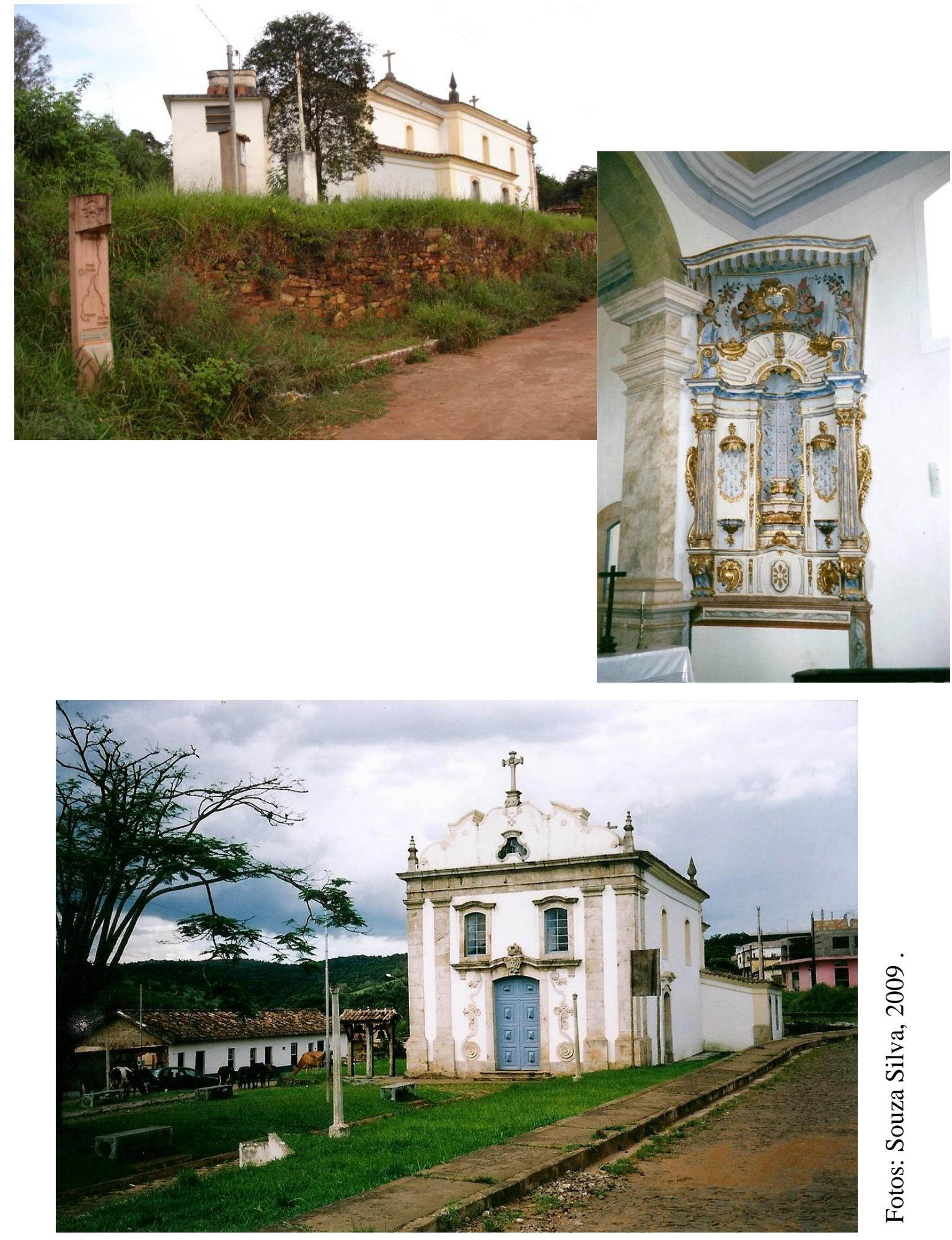

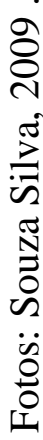

Figura 8 (Anexo 2): Igreja de Nossa Senhora da Soledade: vista de trás, altar em restauração e fachada com sineira lateral. 

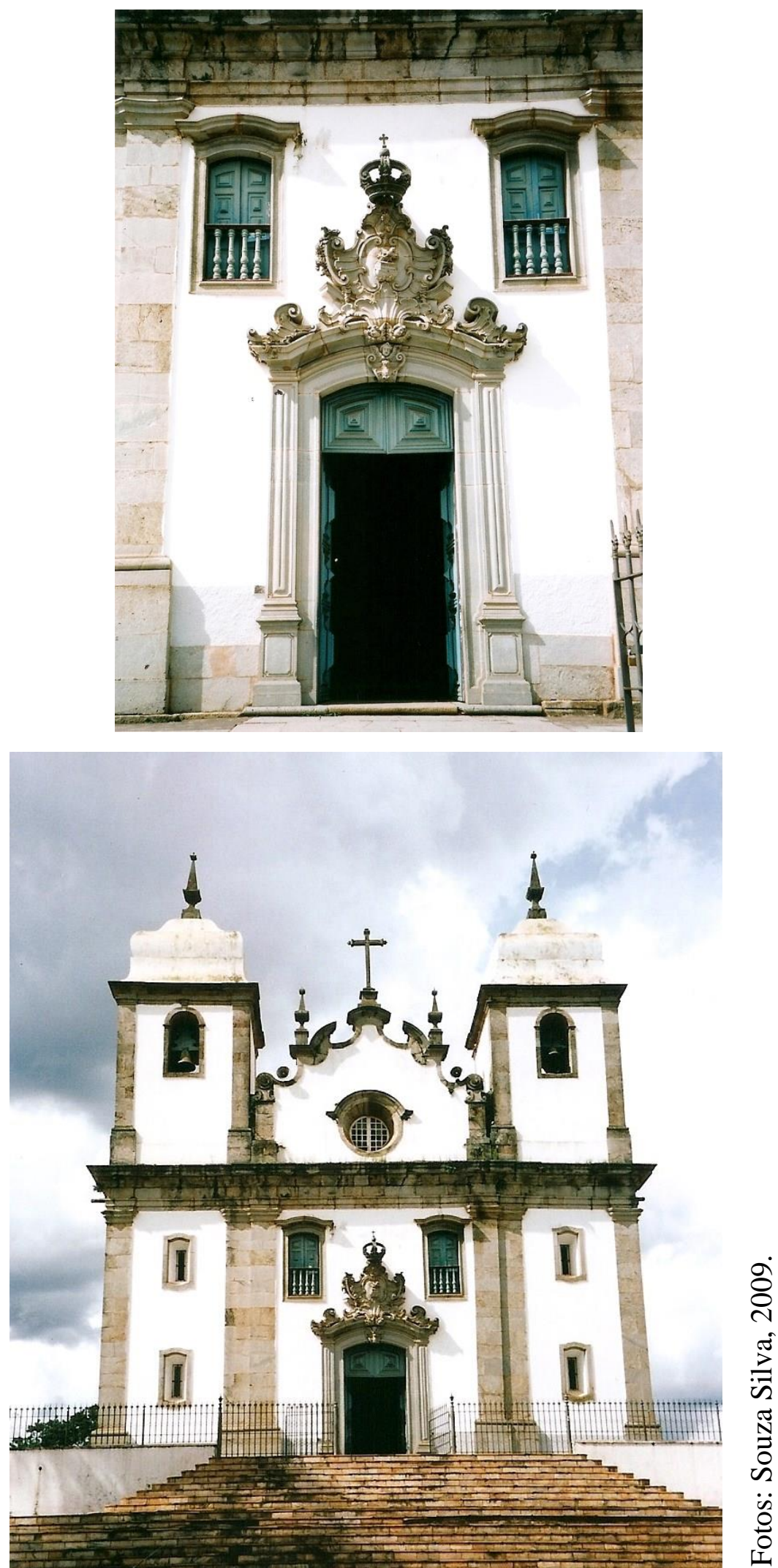

Figura 9 (Anexo 2): Igreja Matriz de Nossa Senhora da Conceição - portada do Aleijadinho e fachada (século XVIII). 

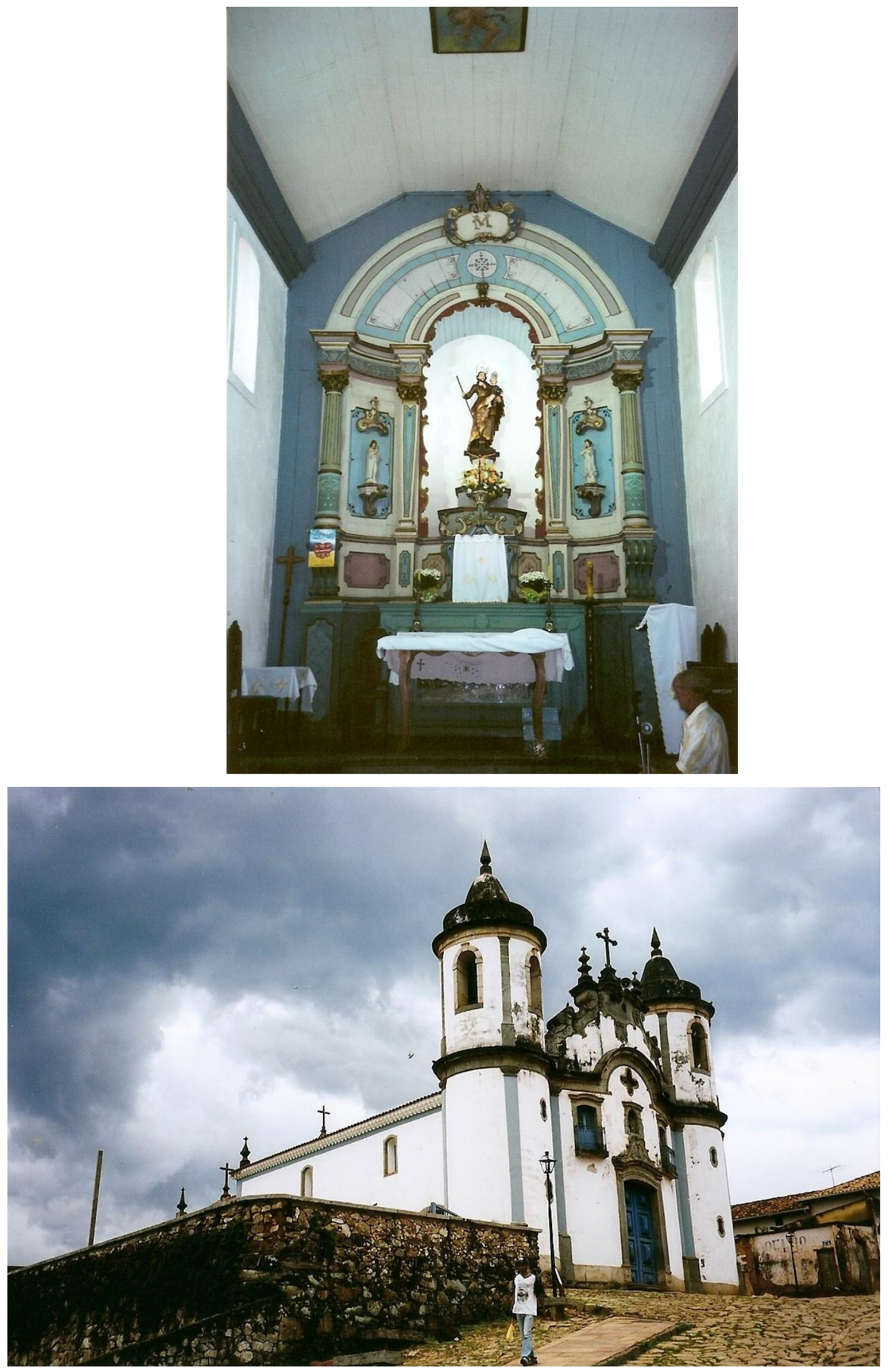

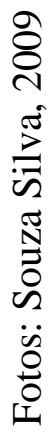

Figura 10 (Anexo 2): Igreja Matriz de São José Operário - altar mor e fachada. 

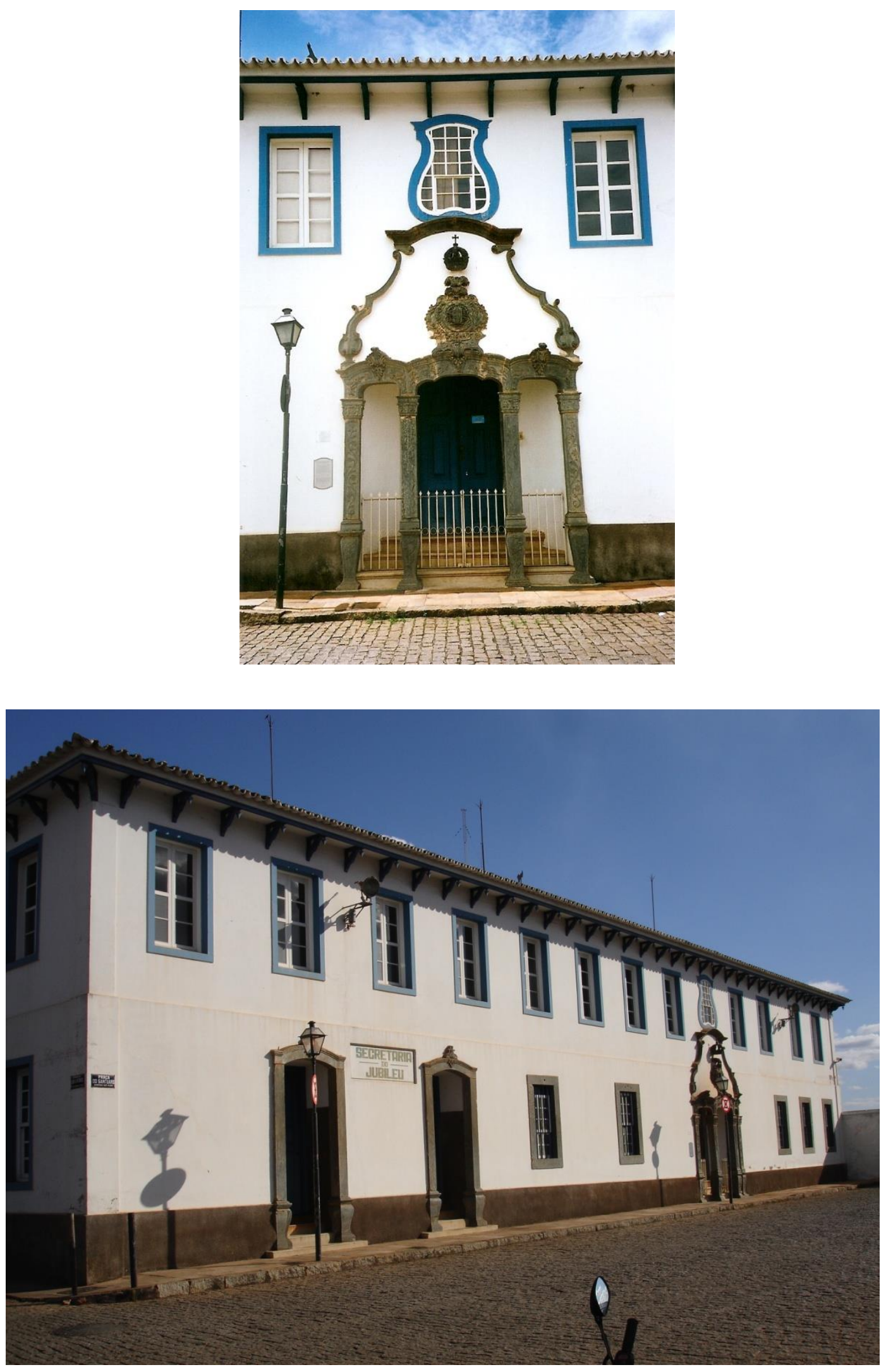

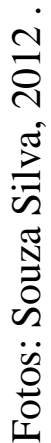

Figura 11(Anexo 2): Casa Paroquial da Basílica do Senhor Bom Jesus de Matosinhos - portada e fachada. 


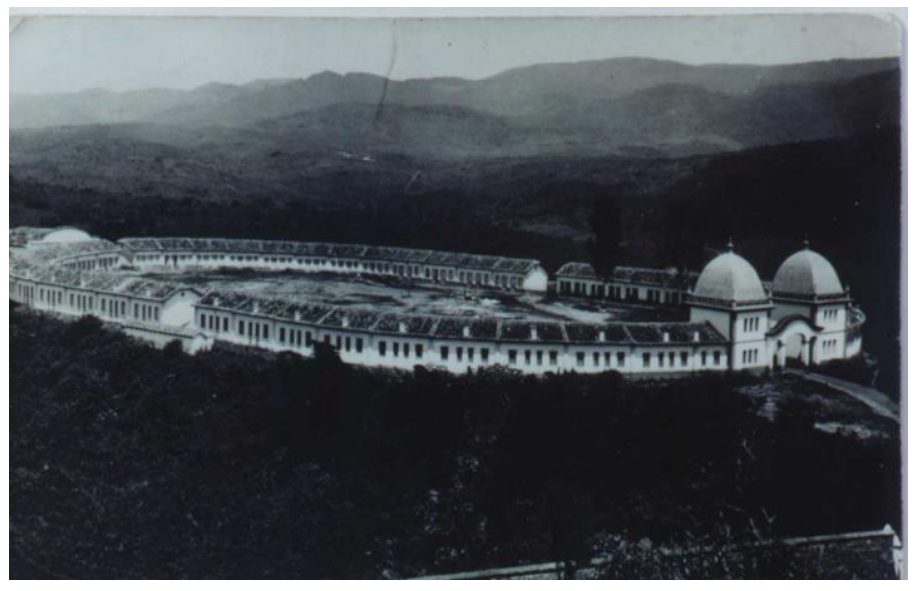

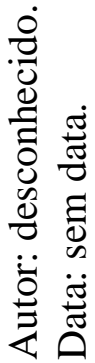
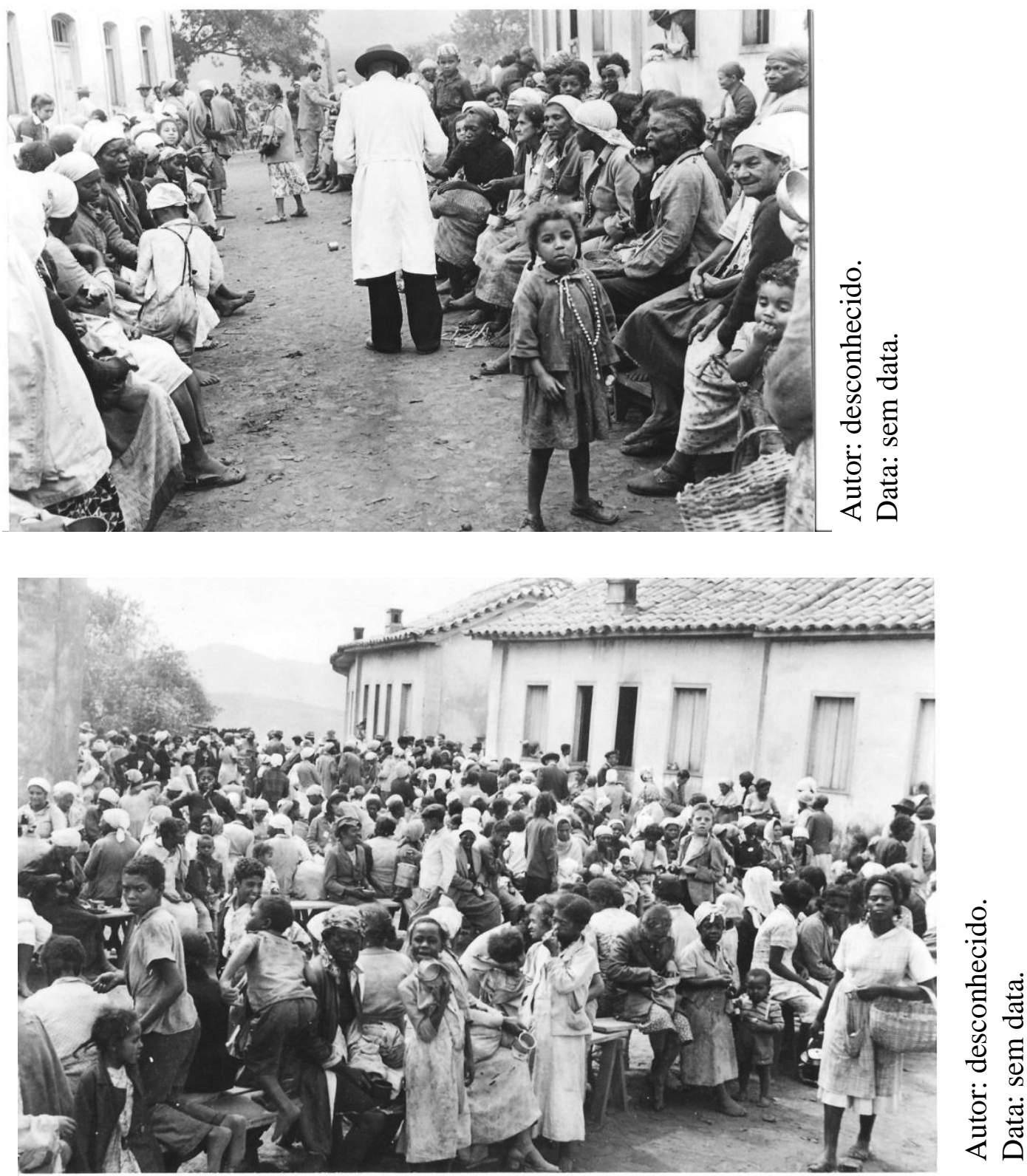

Figura 12 (Anexo 2): Romaria e romeiros antes da demolição parcial das instalações originais. 

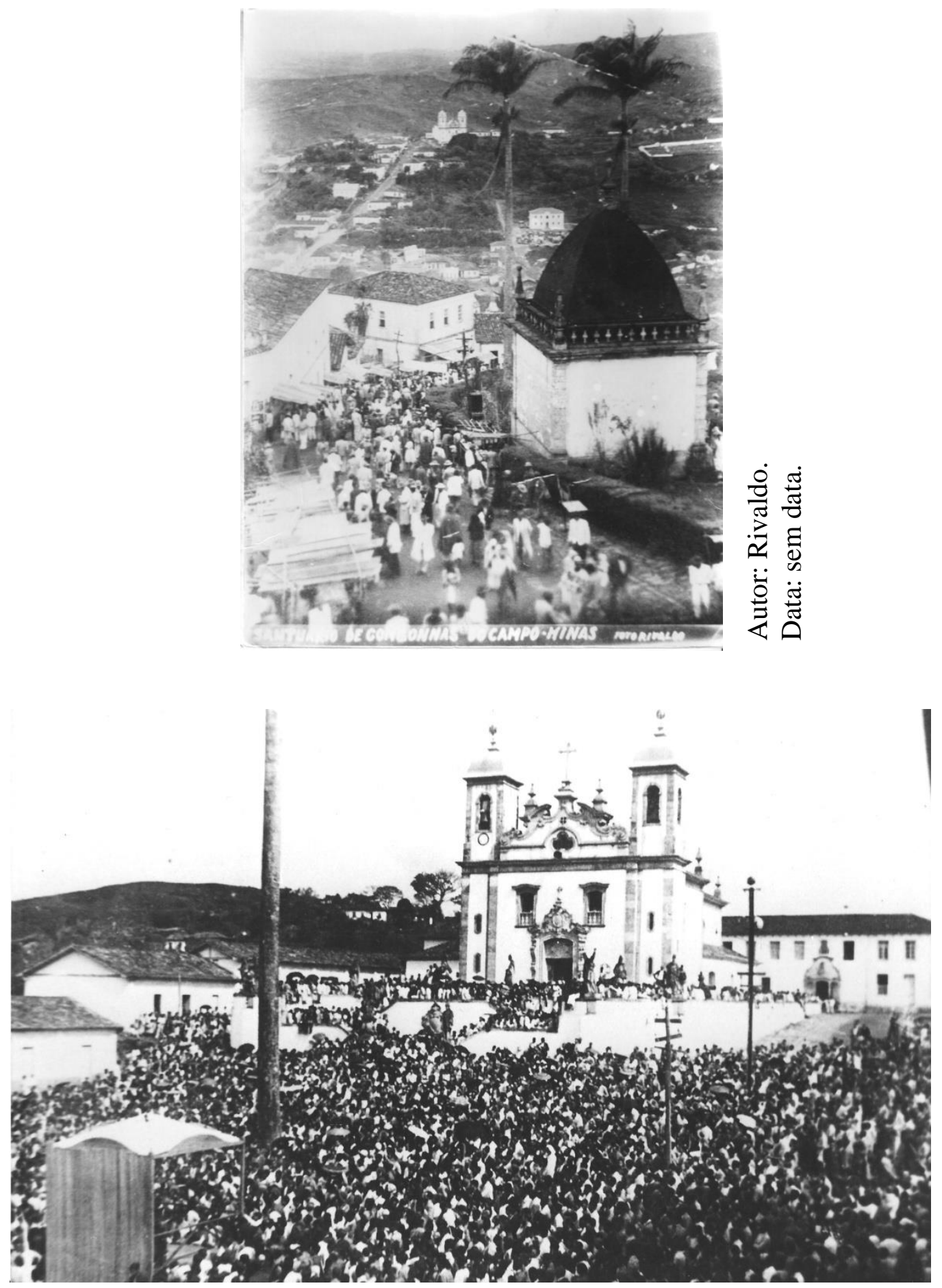

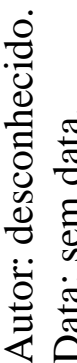

Figura 13 (Anexo 2): Tradicional Jubileu do Senhor Bom Jesus de Matosinhos. 

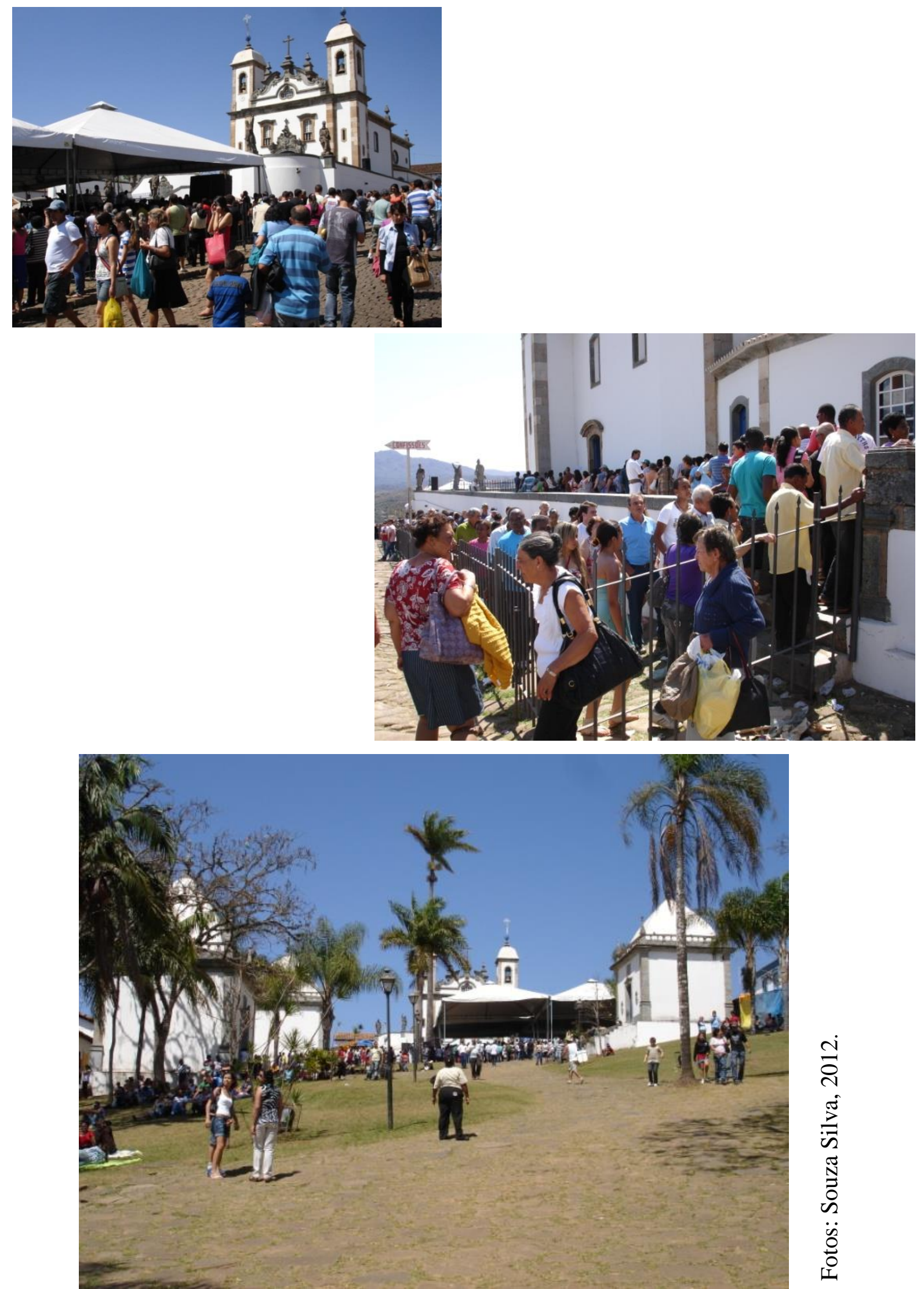

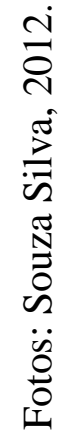

Figura 14 (Anexo 2): Jubileu do Senhor Bom Jesus de Matozinhos. 

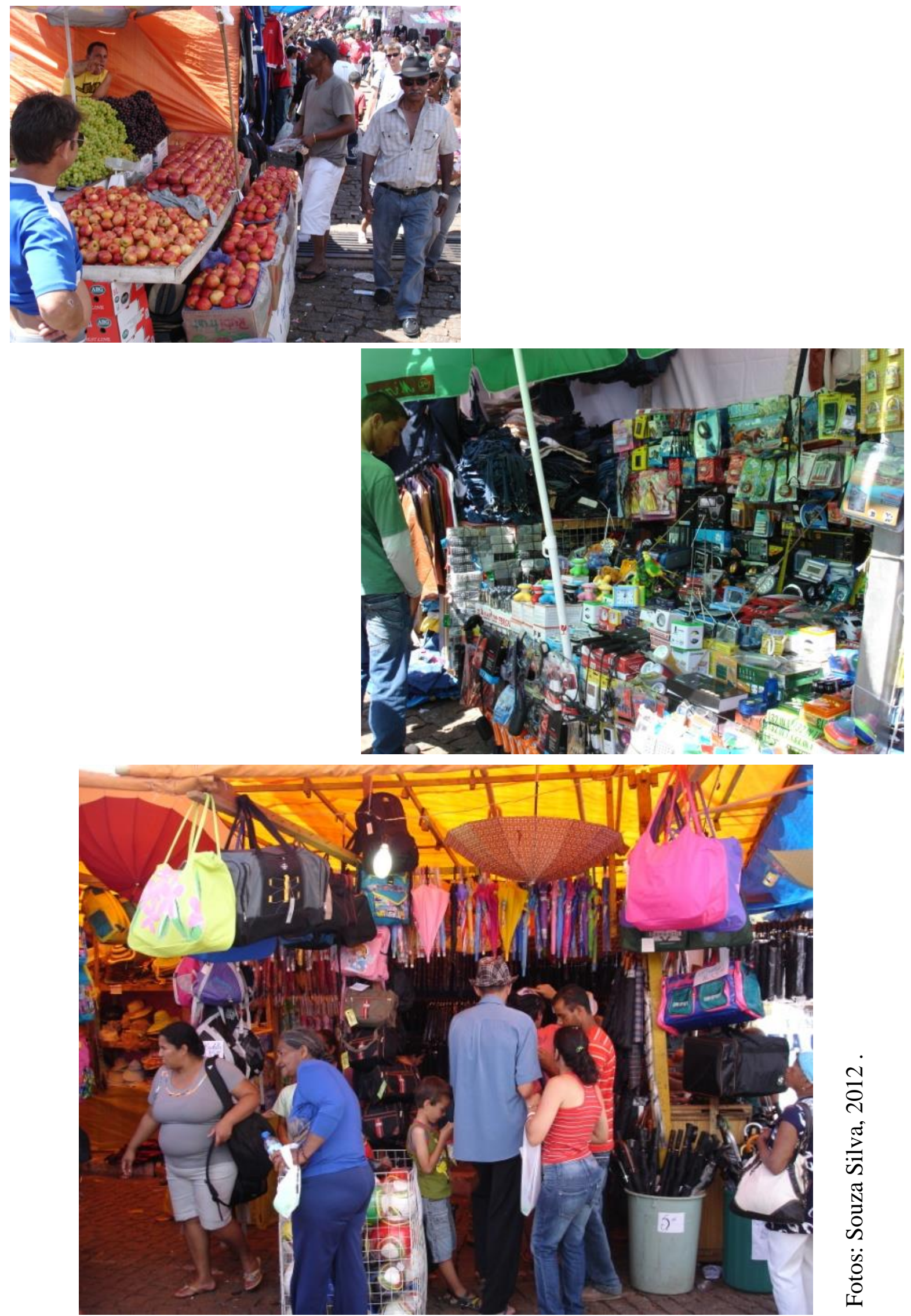

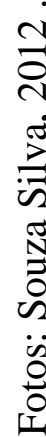

Figura 15 (Anexo 2): Comércio durante os festejos do Jubileu do Senhor Bom Jesus de Matozinhos. 

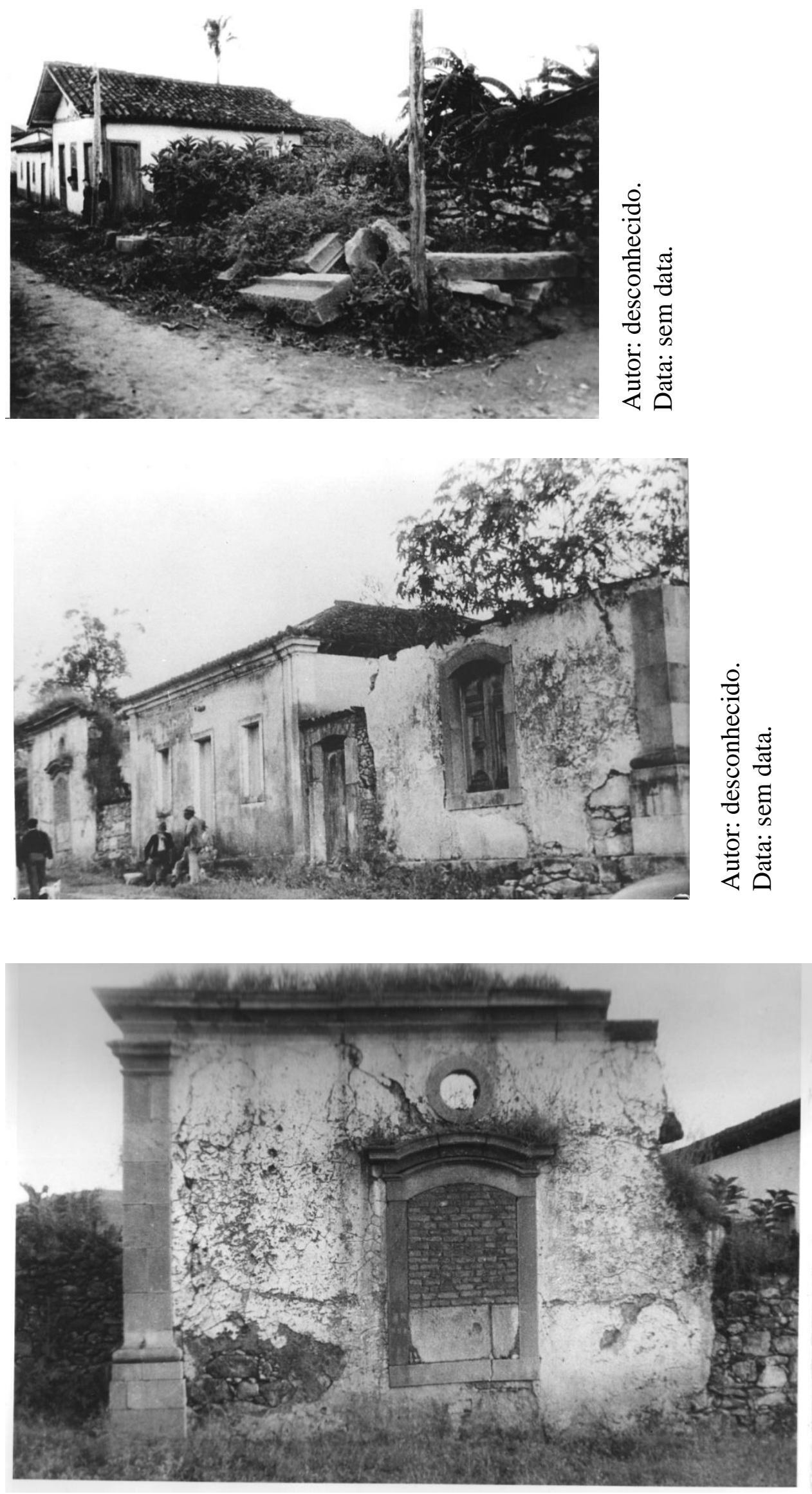

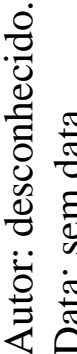

Figura 16 (Anexo 2): Casario colonial de Congonhas em ruínas. 

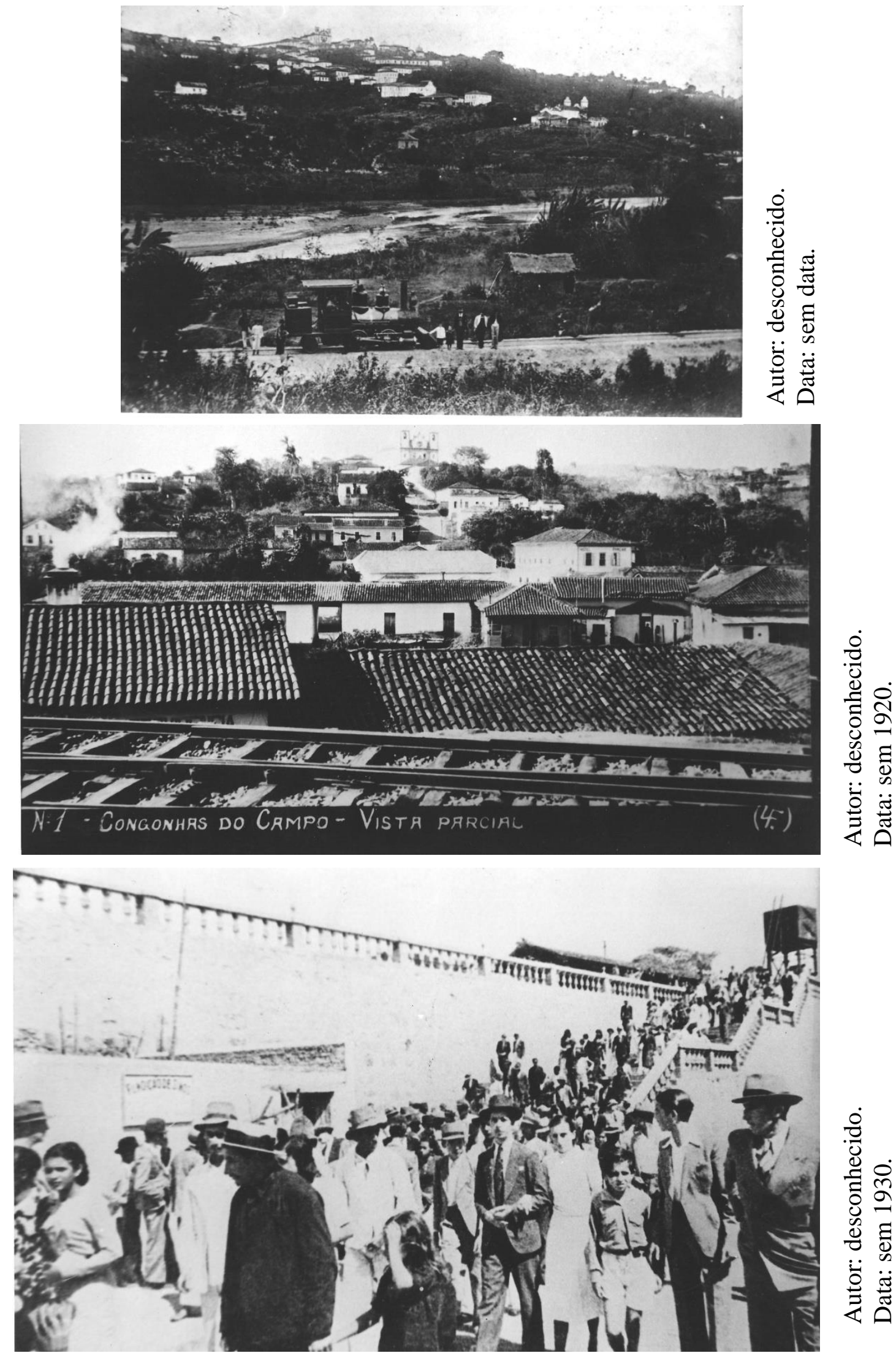

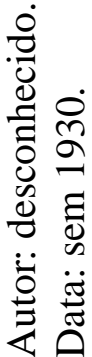

Figura 17 (Anexo 2): Ferrovia e saída de passageiros da estação ferroviária de Congonhas. 

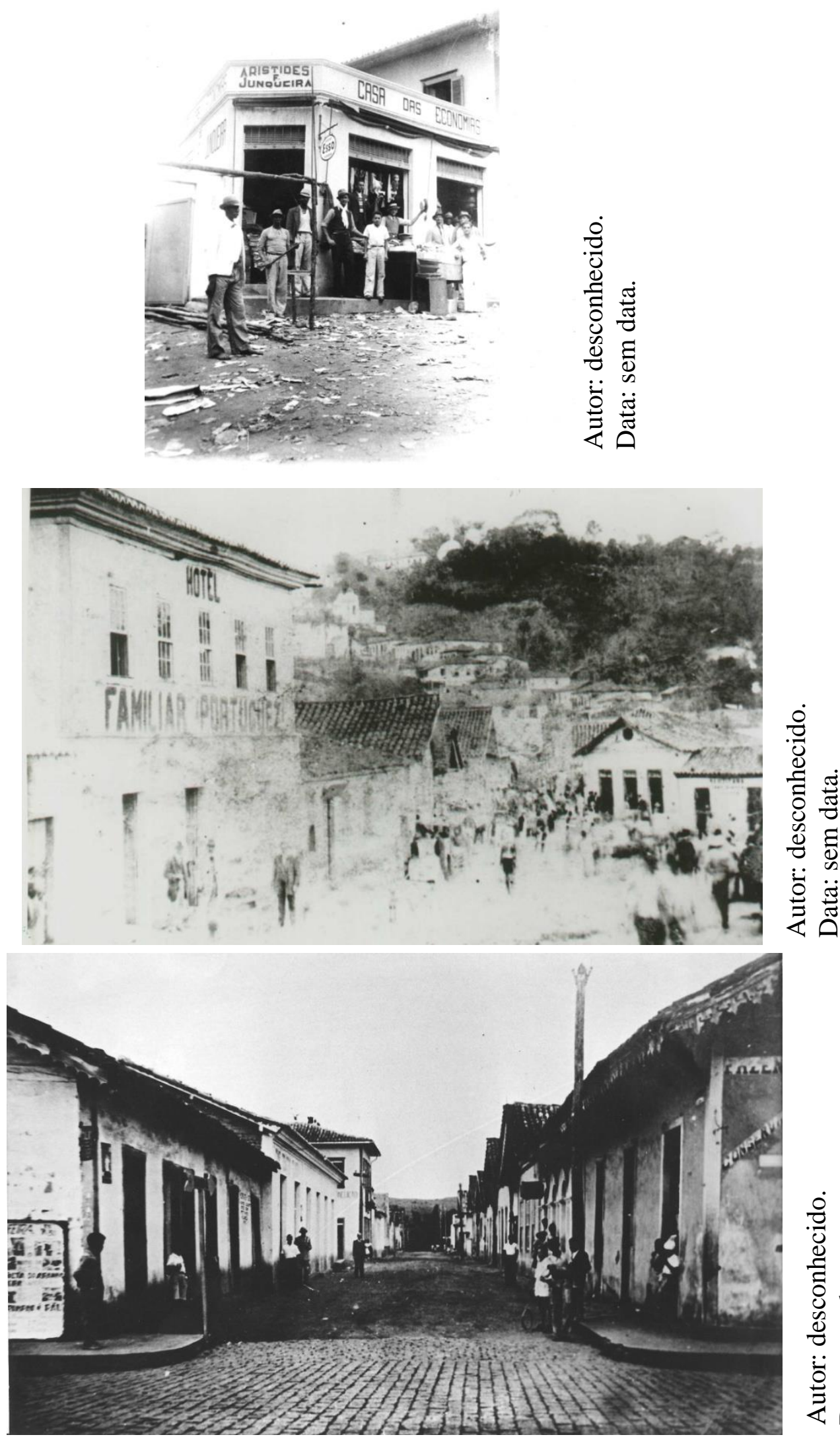

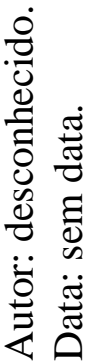

Figura 18 (Anexo 2): De cima para baixo: casa de comércio na área central, Praça Mário R. Pereira e Rua Marechal Floriano. 


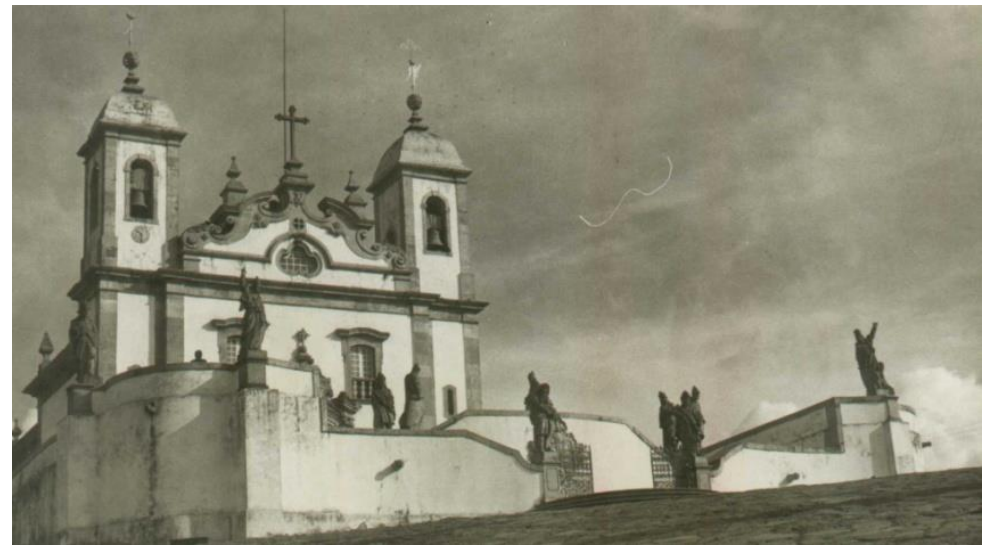

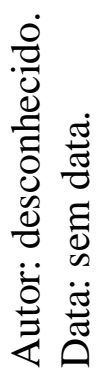

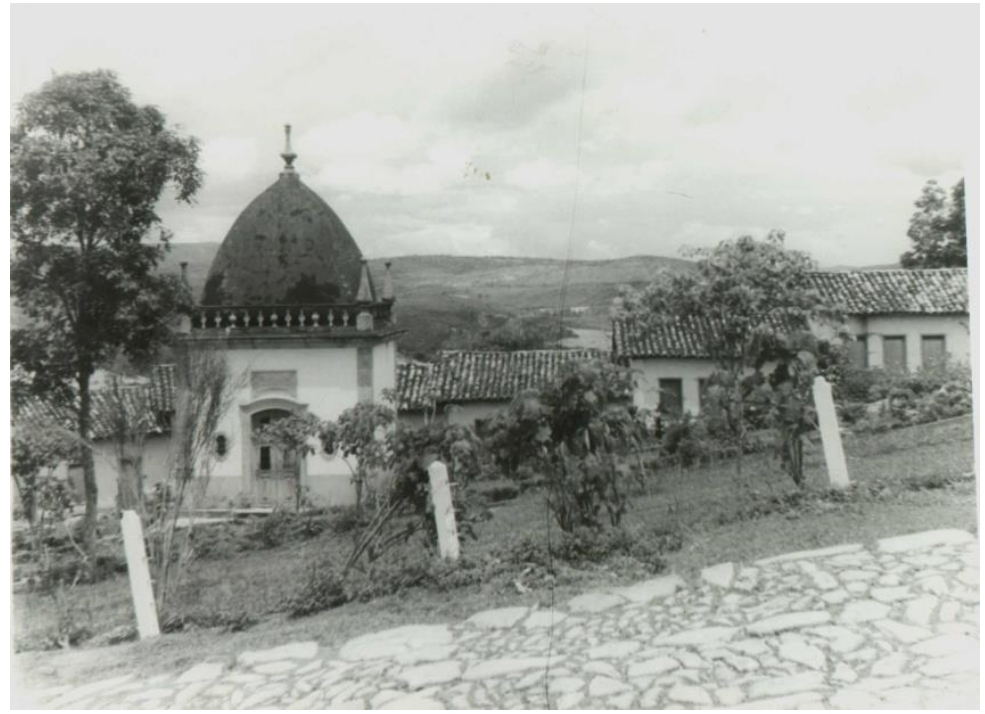

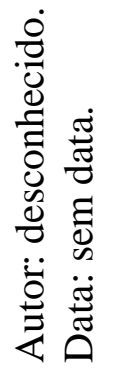

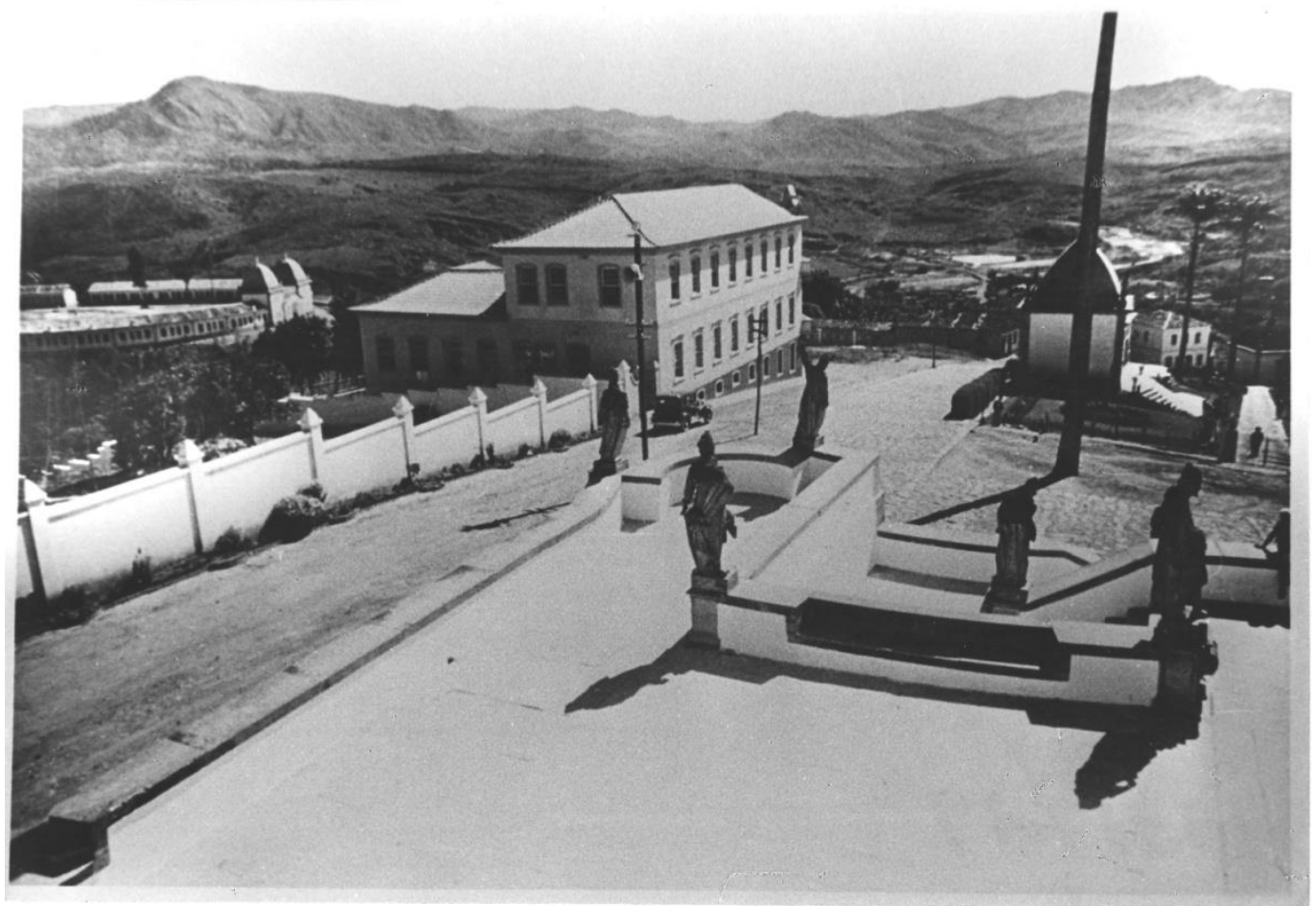

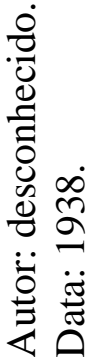

Figura 19 (Anexo 2): Conjunto estatuário, arquitetônico e paisagístico da Basílica do Senhor Bom Jesus de Matosinhos. 


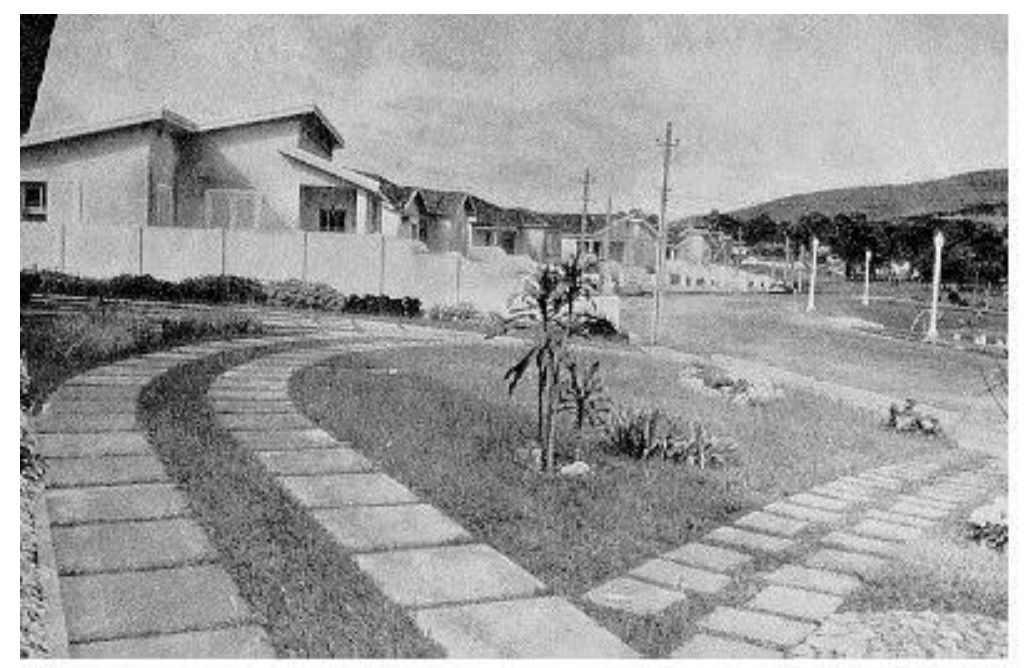

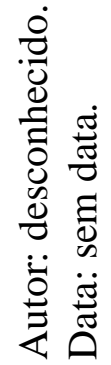

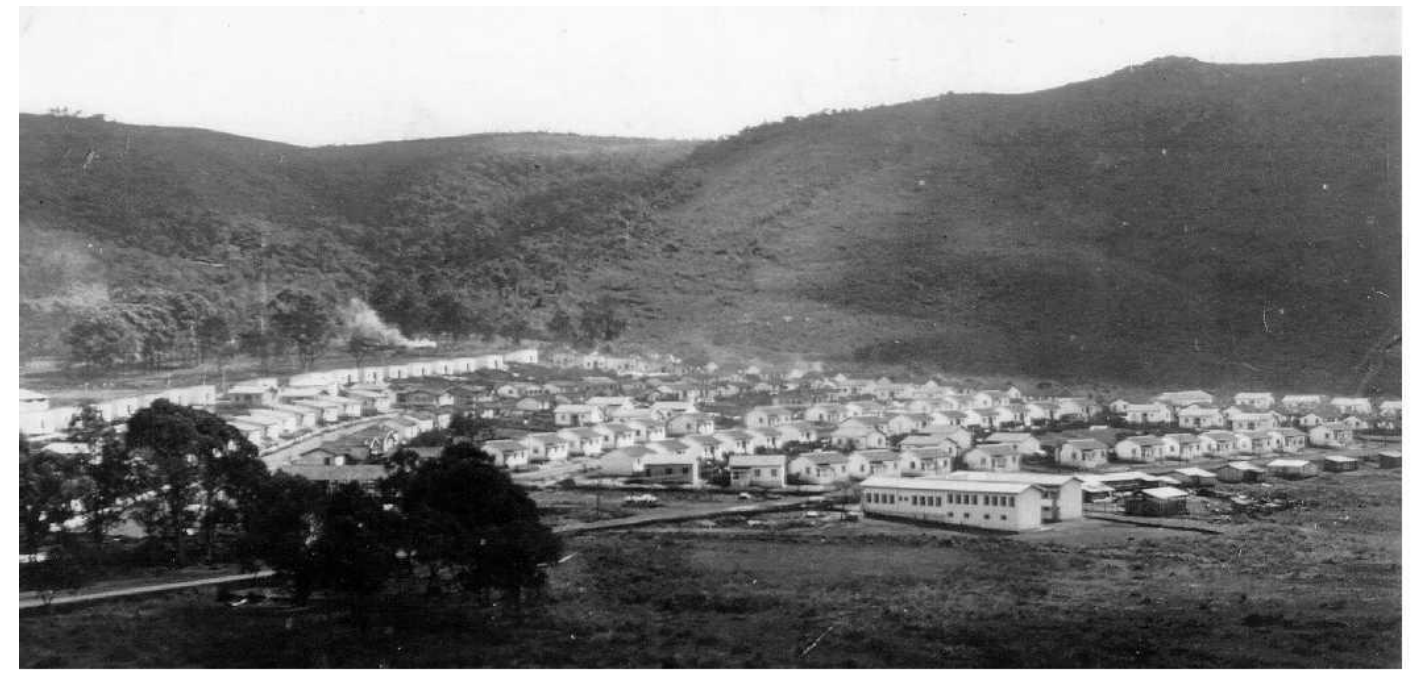

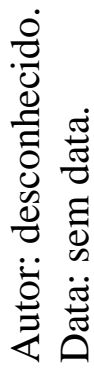

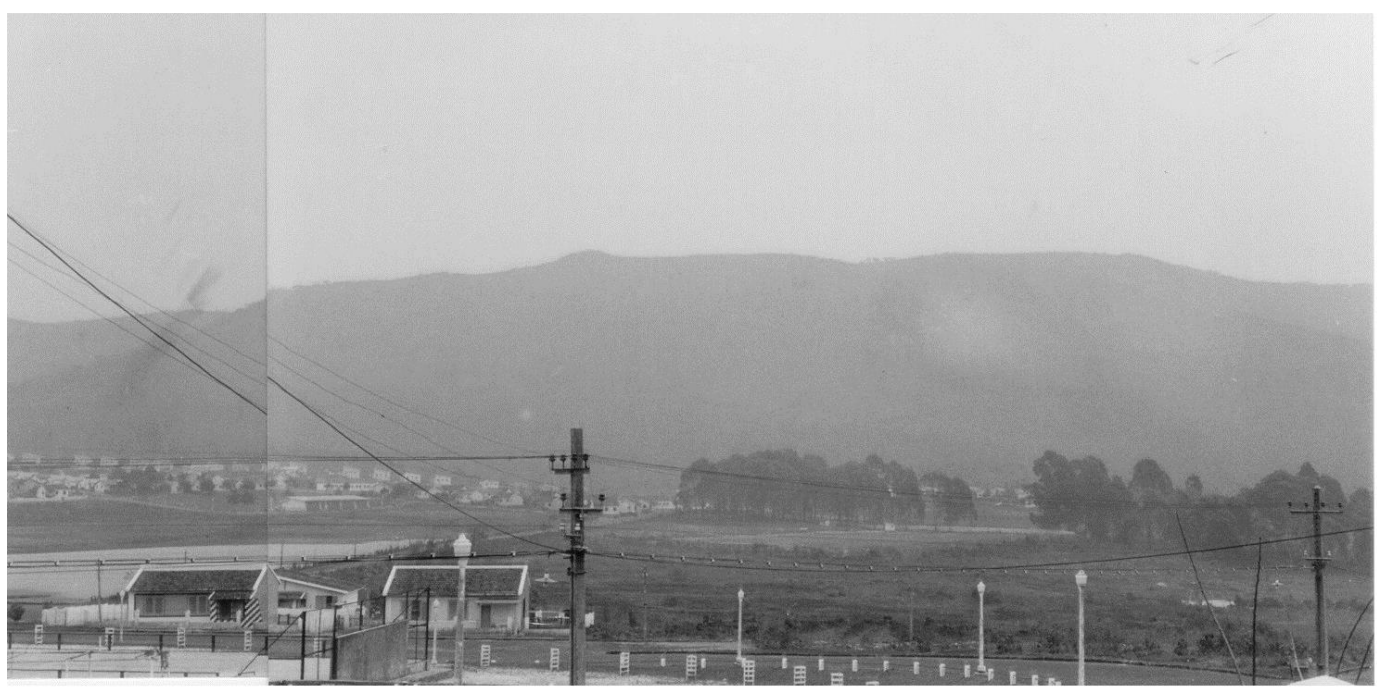

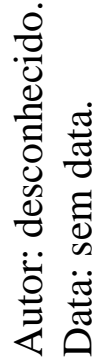

Figura 20 (Anexo 2): O extinto Bairro Casa de Pedra. 


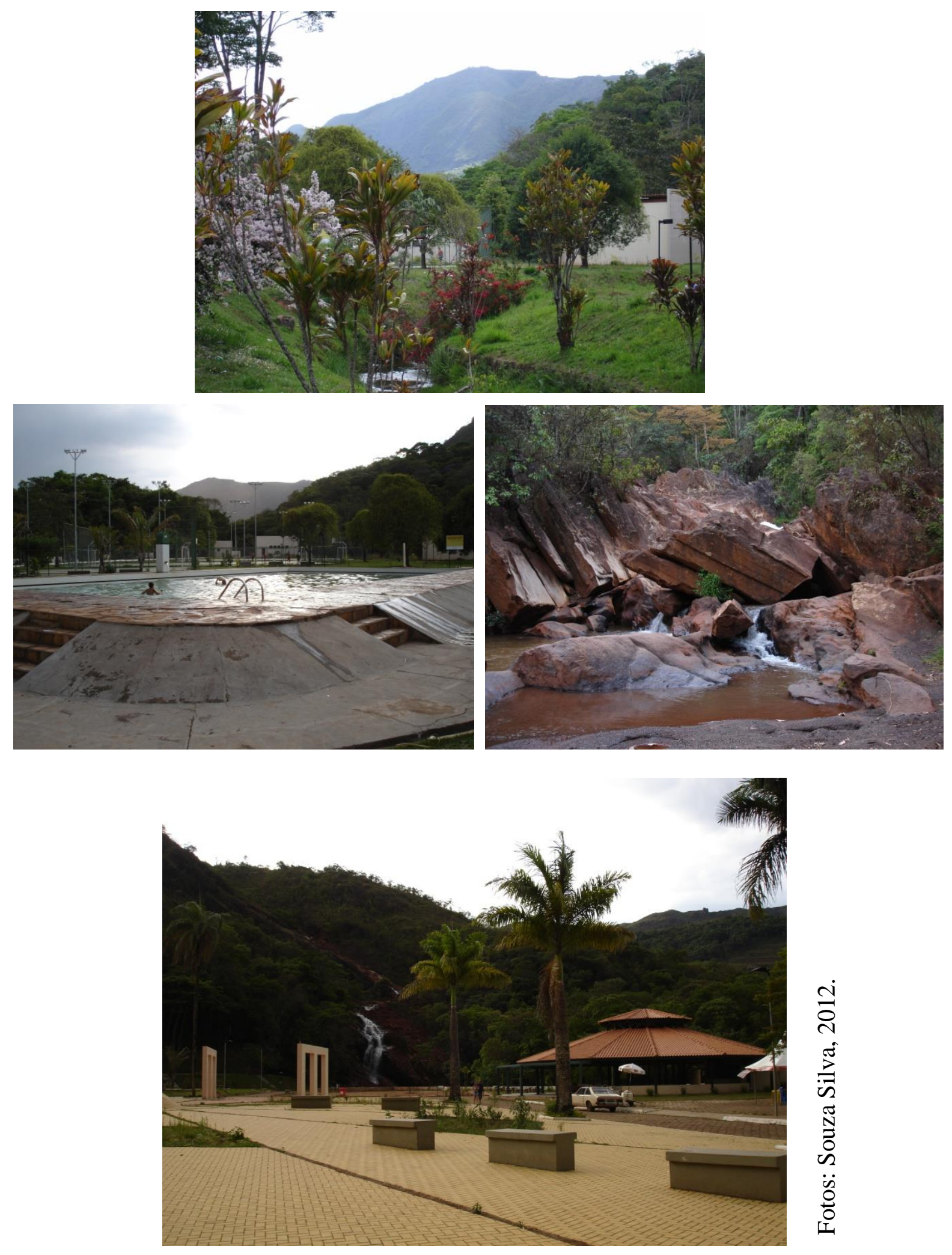

Figura 21 (Anexo 2): Parque Ecológico da Cachoeira. 

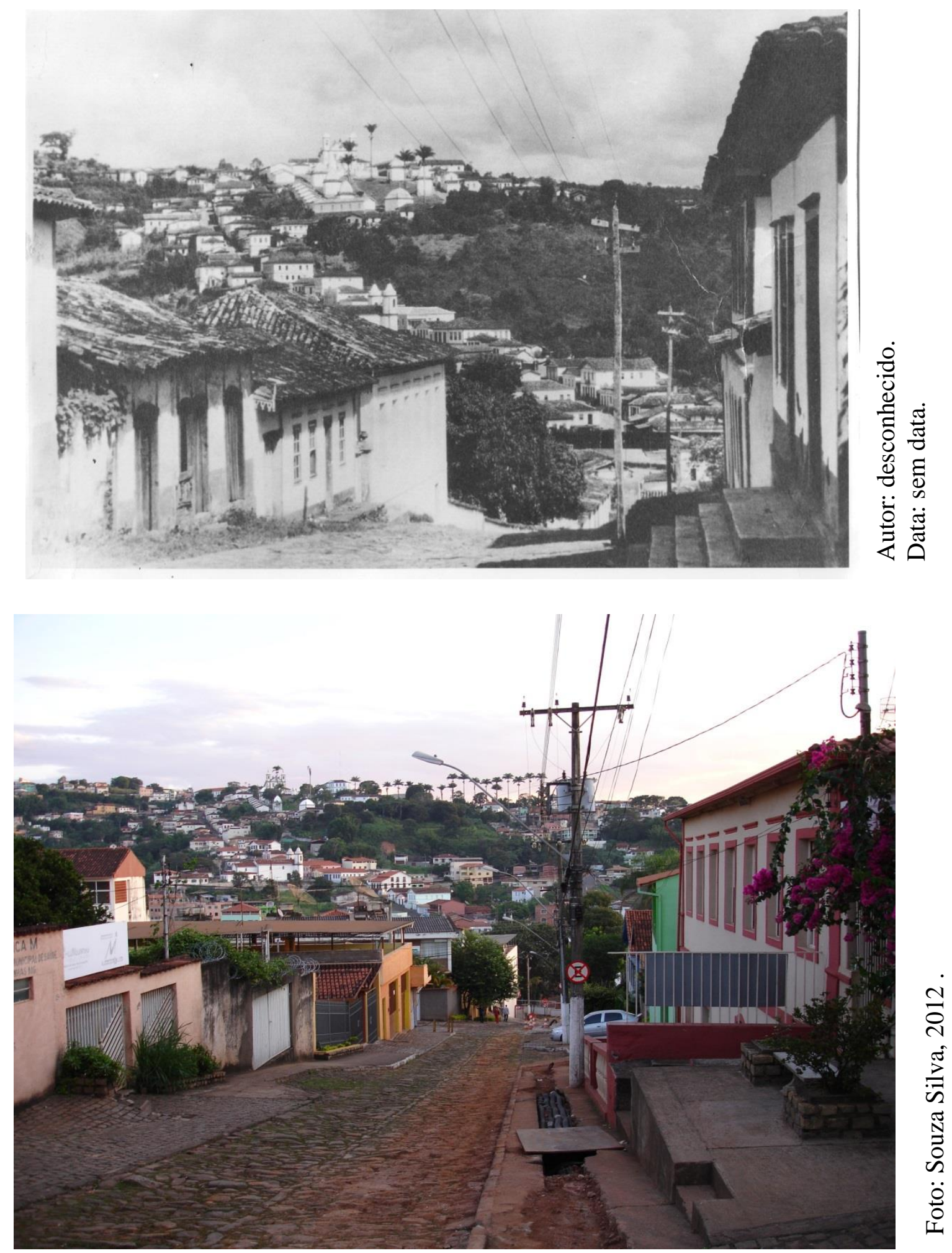

Figura 22 (Anexo 2): Congonhas: contraste entre a cidade colonial e a cidade atual. 

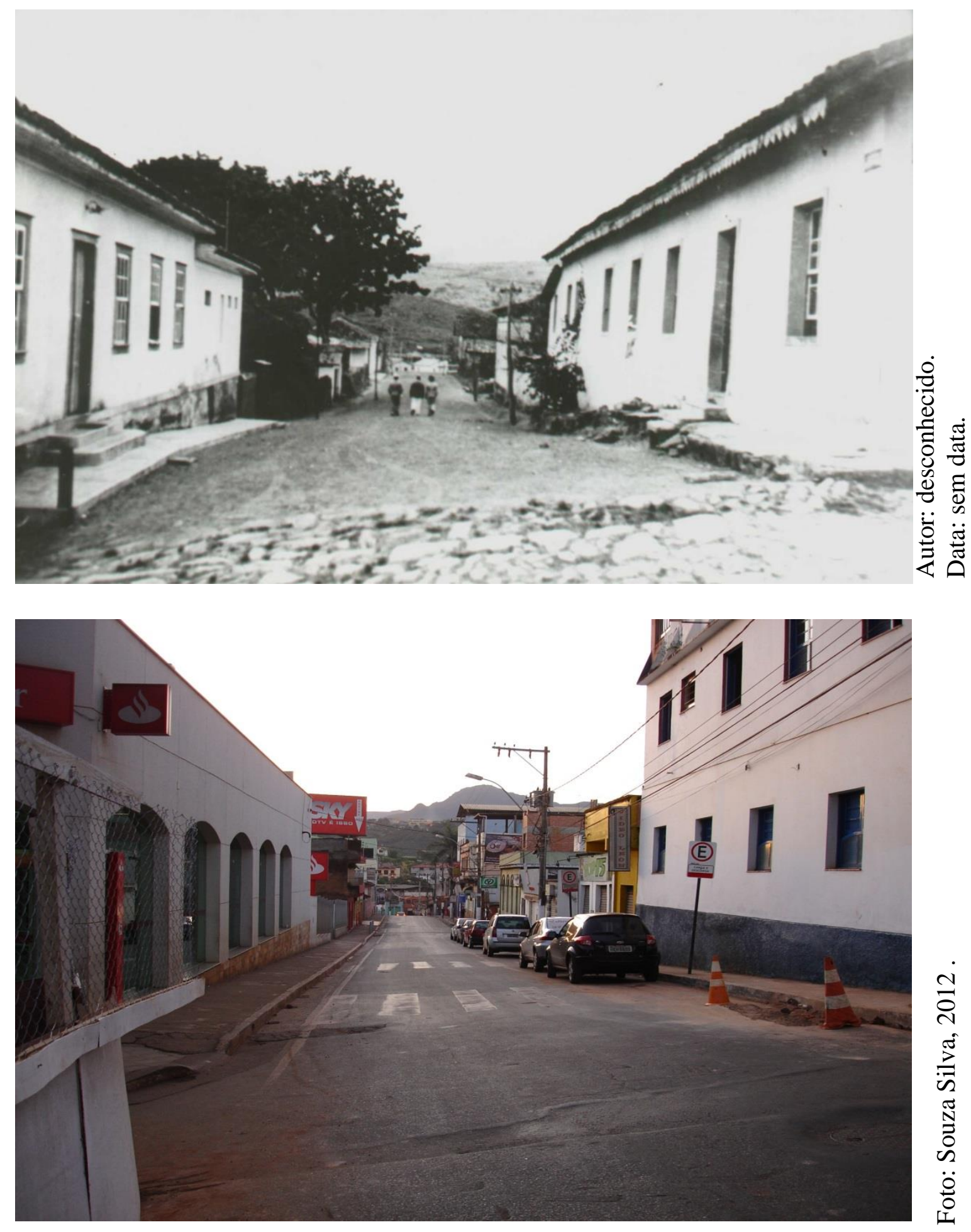

Figura 23 (Anexo 2): Contraste da Rua Getúlio Vargas. 


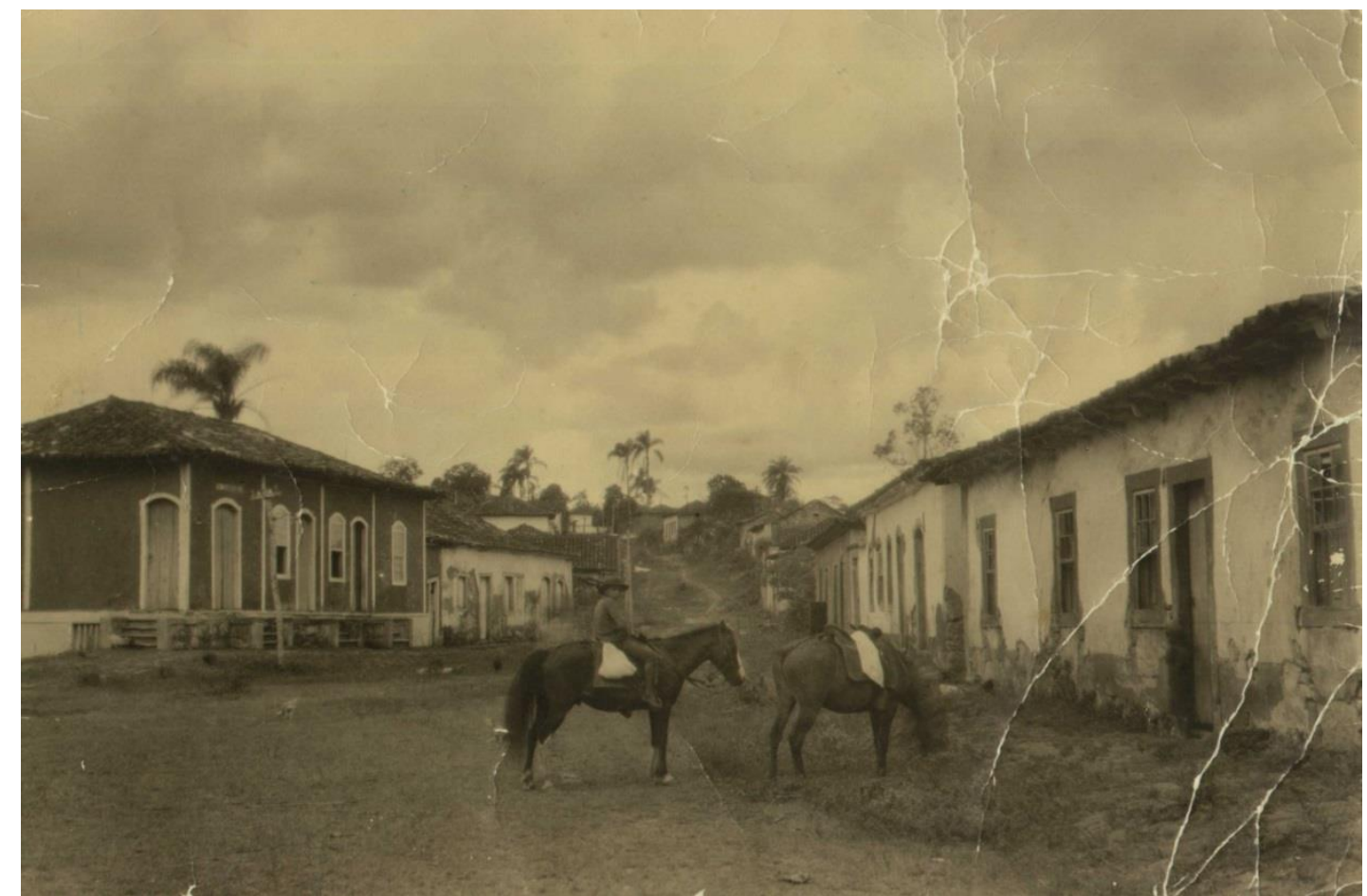

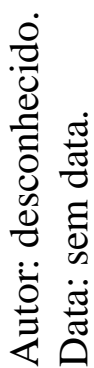

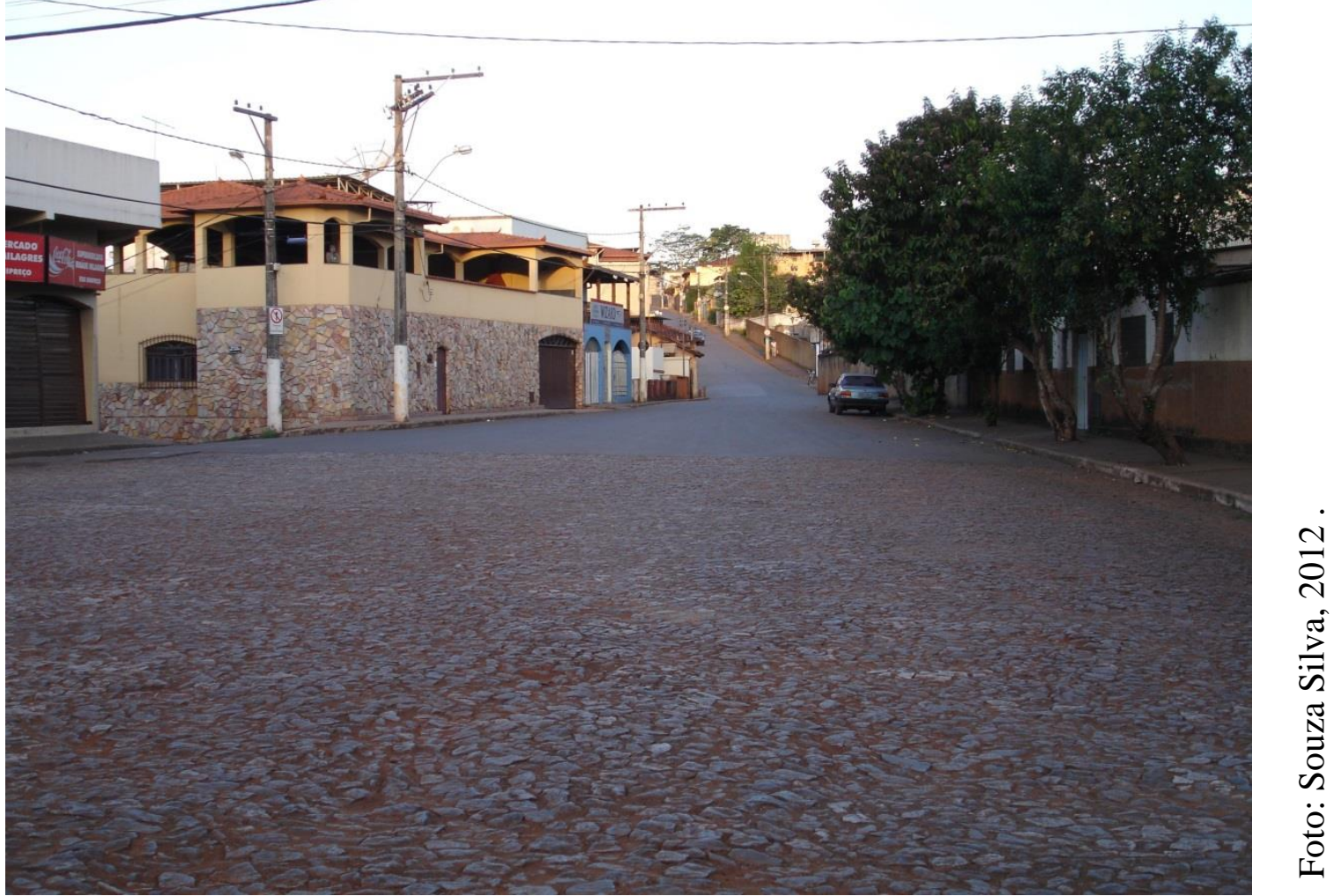

Figura 24 (Anexo 2): Contraste da Praça da Igreja Matriz de Nossa Senhora da Conceição. 

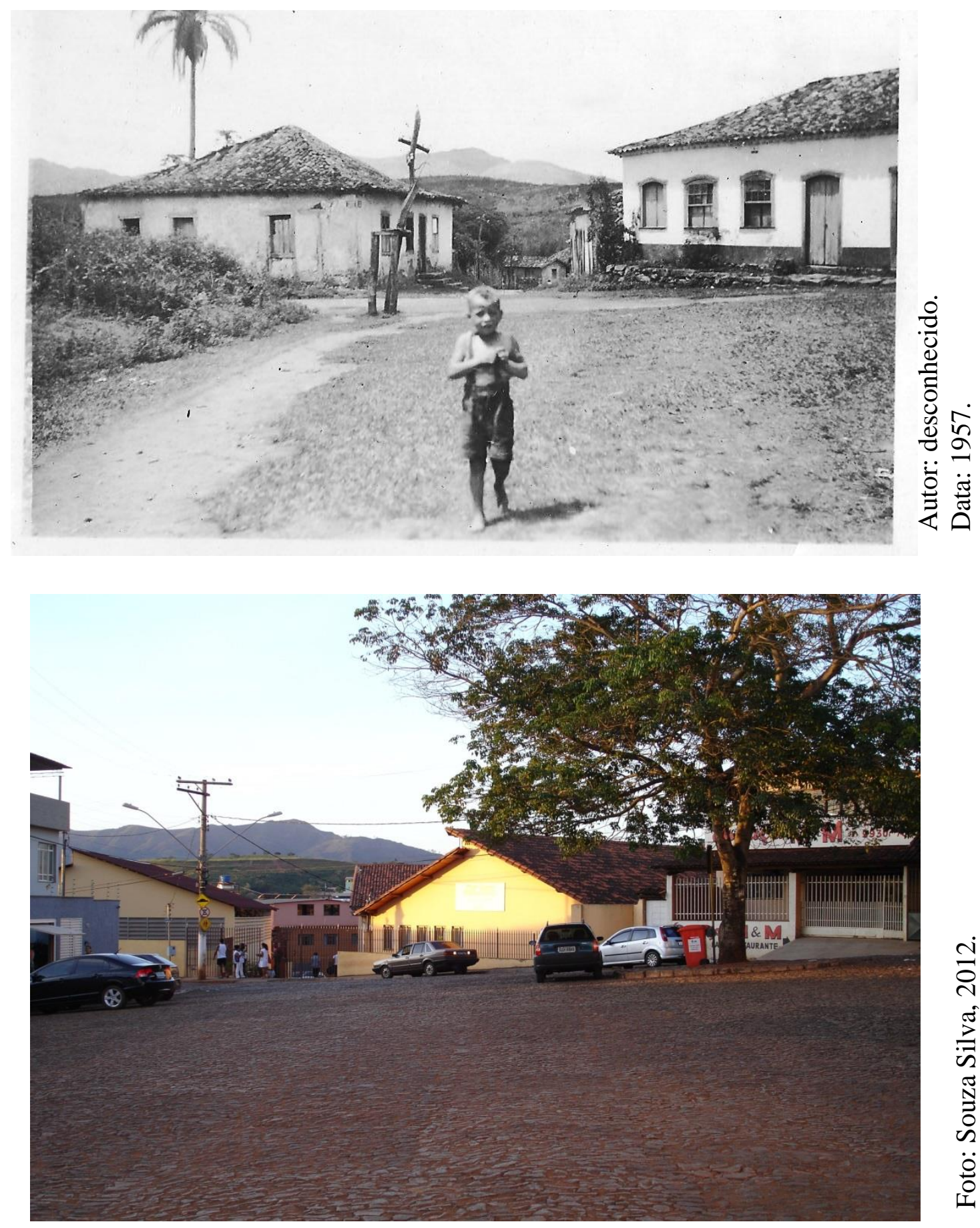

Figura 25 (Anexo 2): Contraste da Praça Sete de Setembro. 


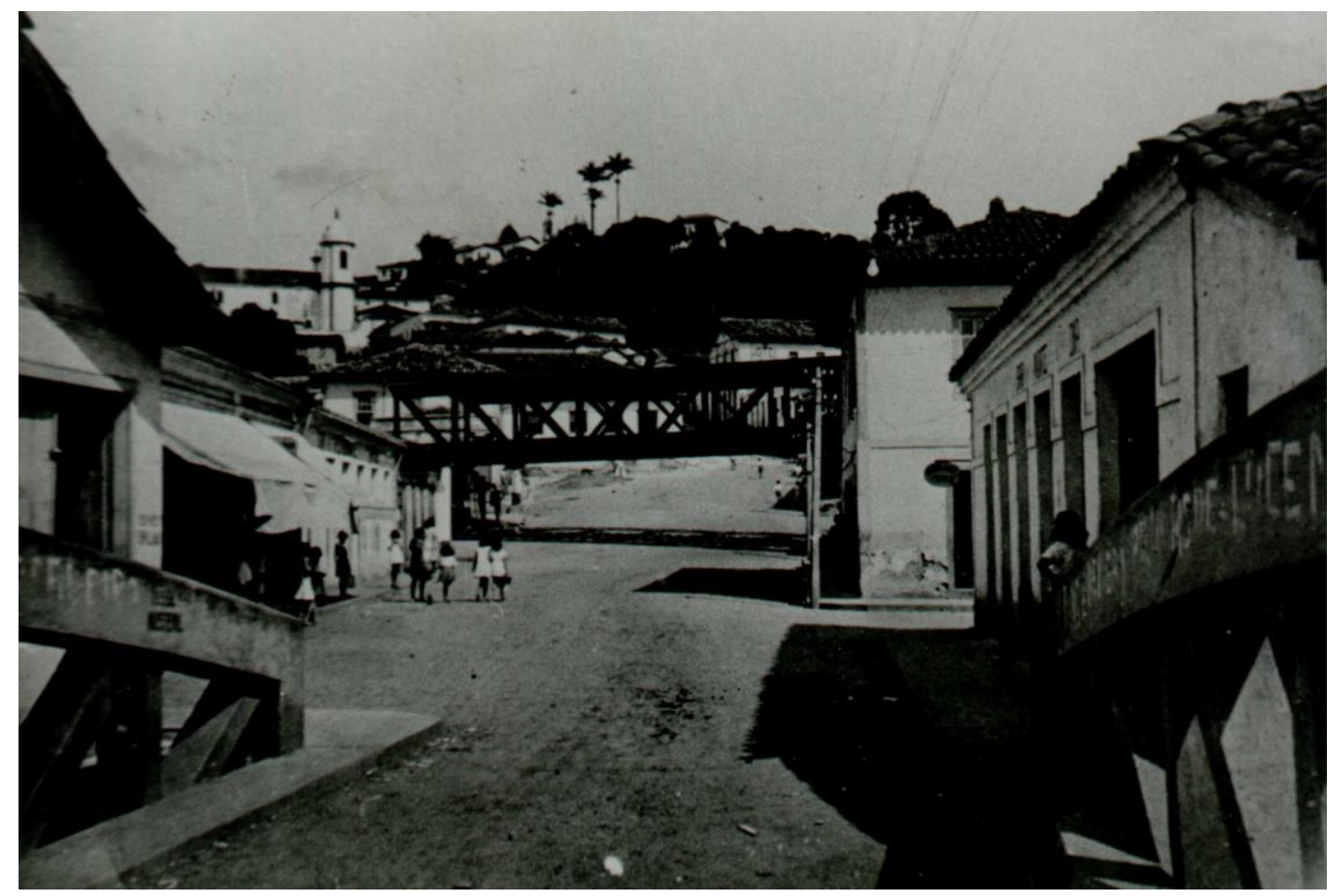

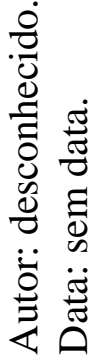

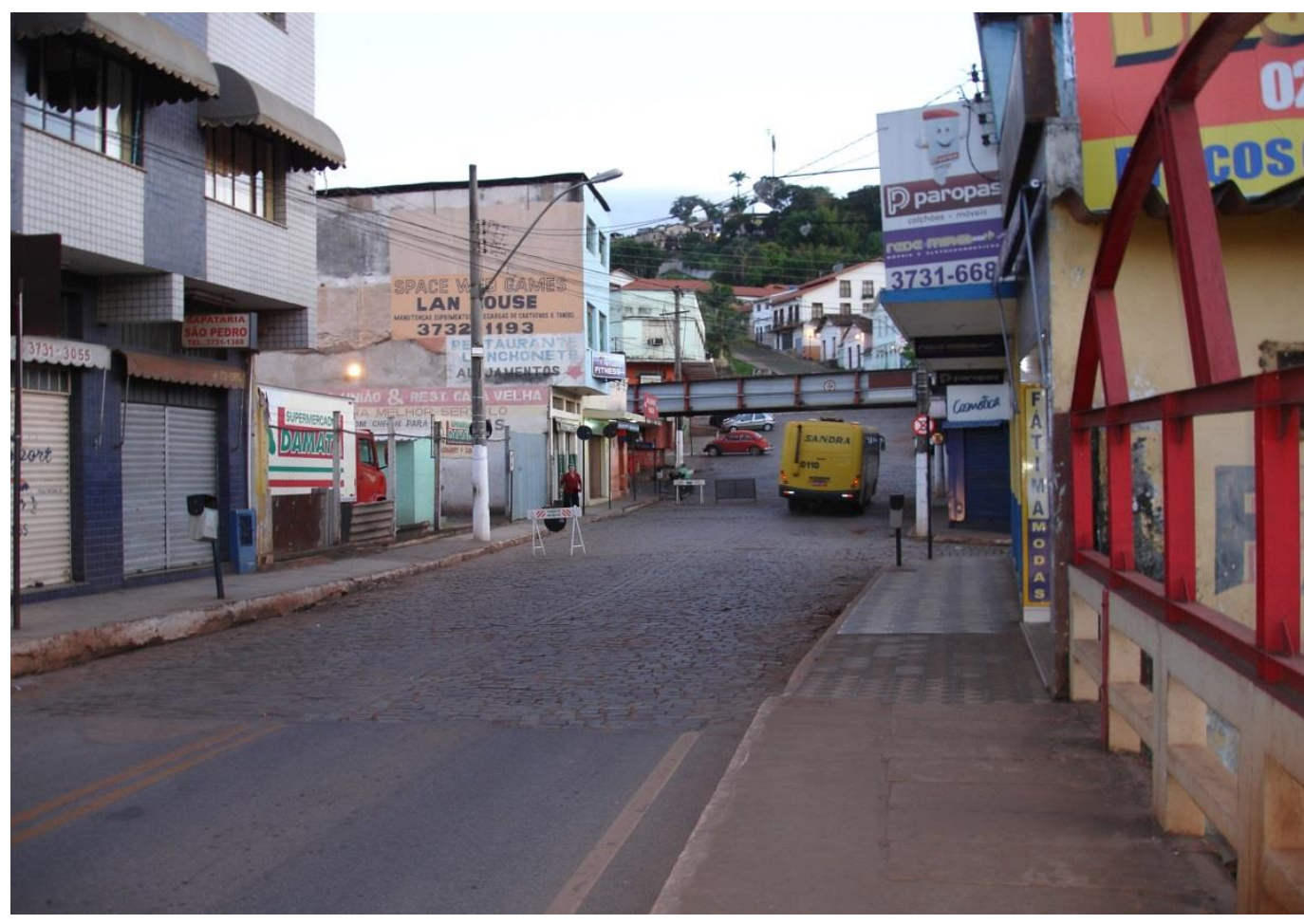

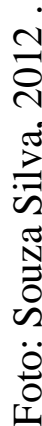

Figura 26 (Anexo 2): Contraste da área central: ponte sobre o Rio Maranhão. 


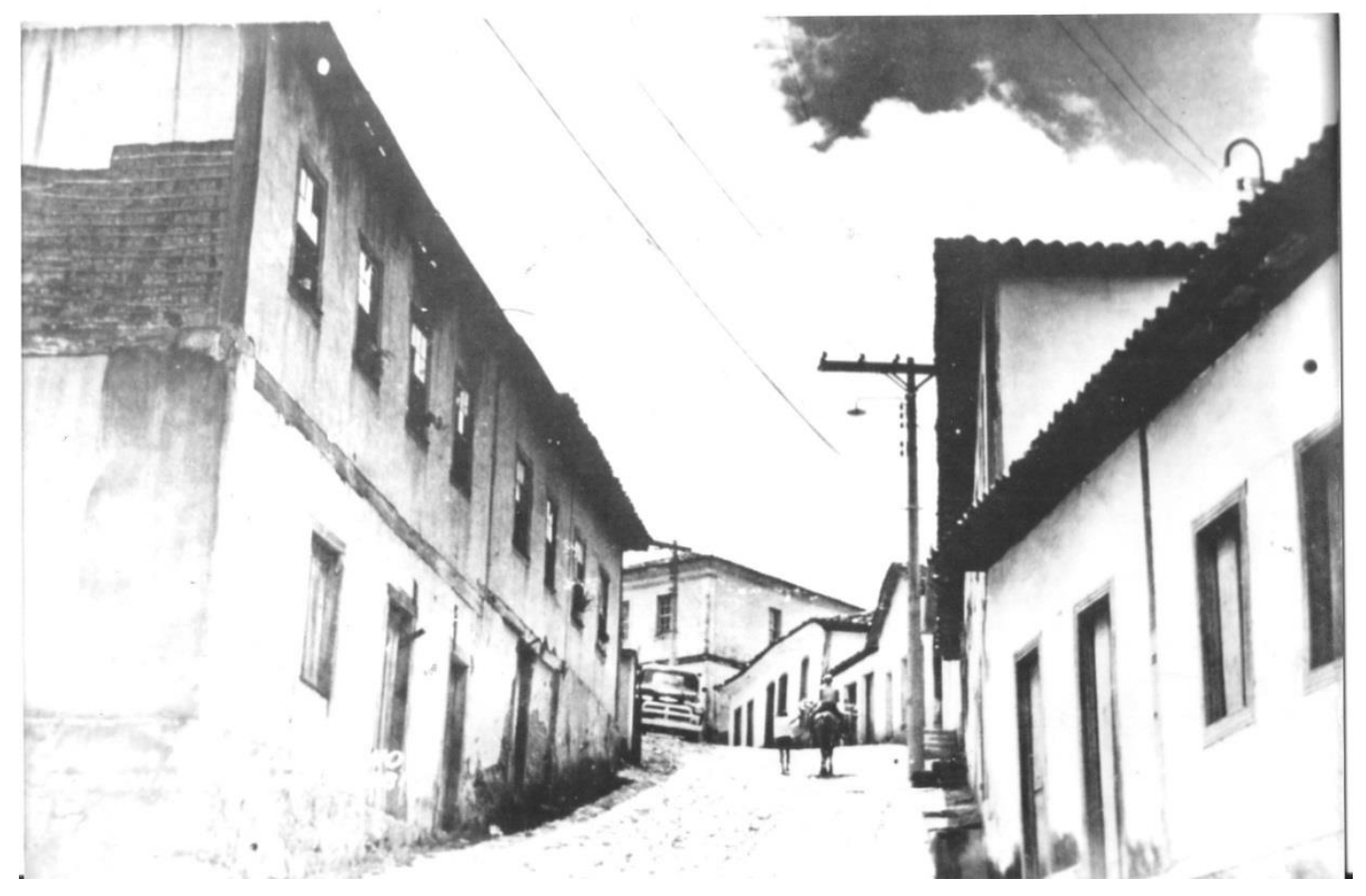

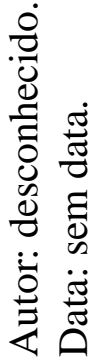

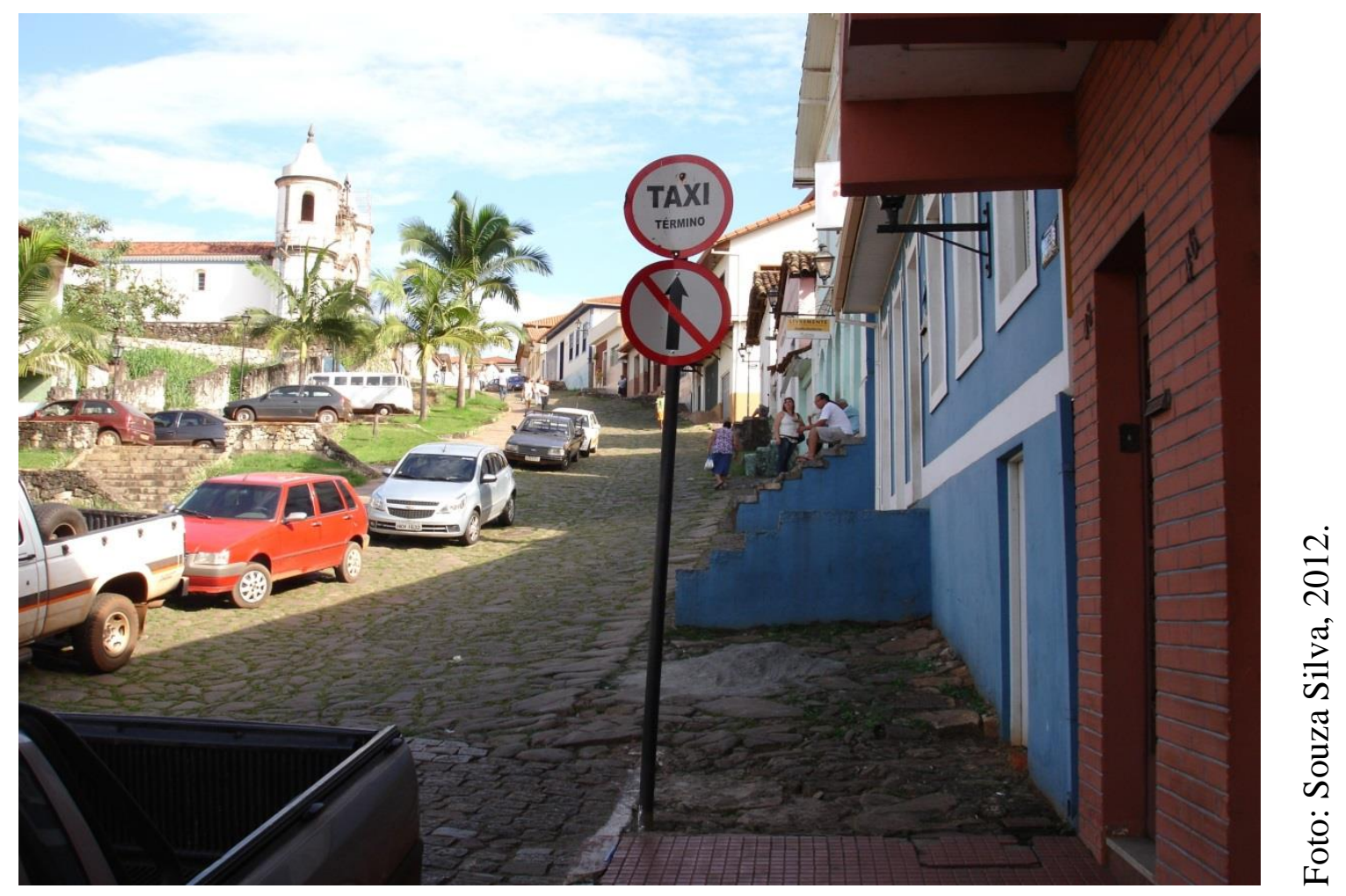

Figura 27 (Anexo 2): Contraste da Ladeira Bom Jesus. 


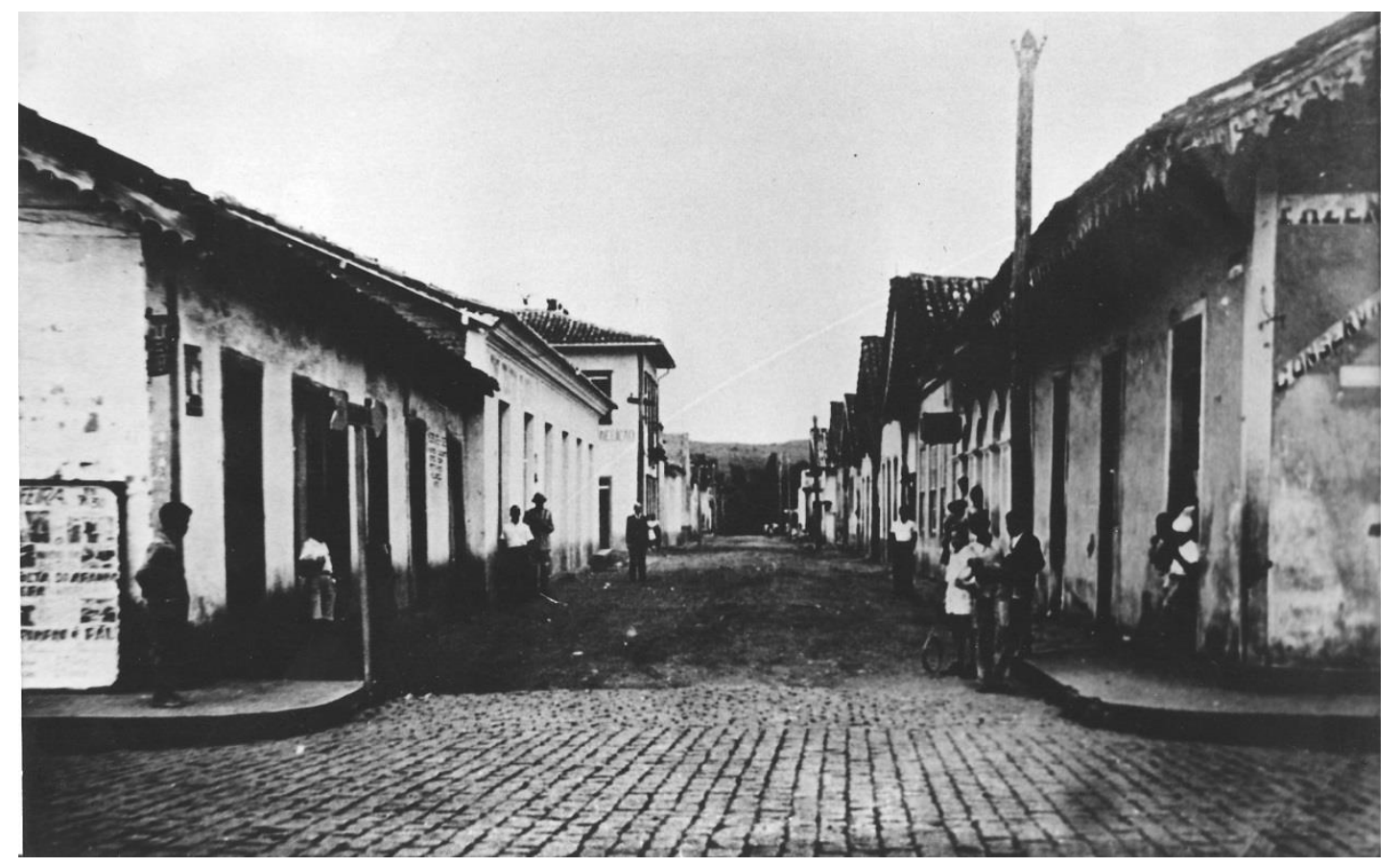

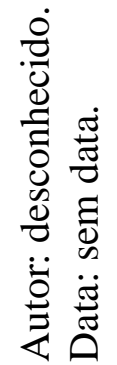

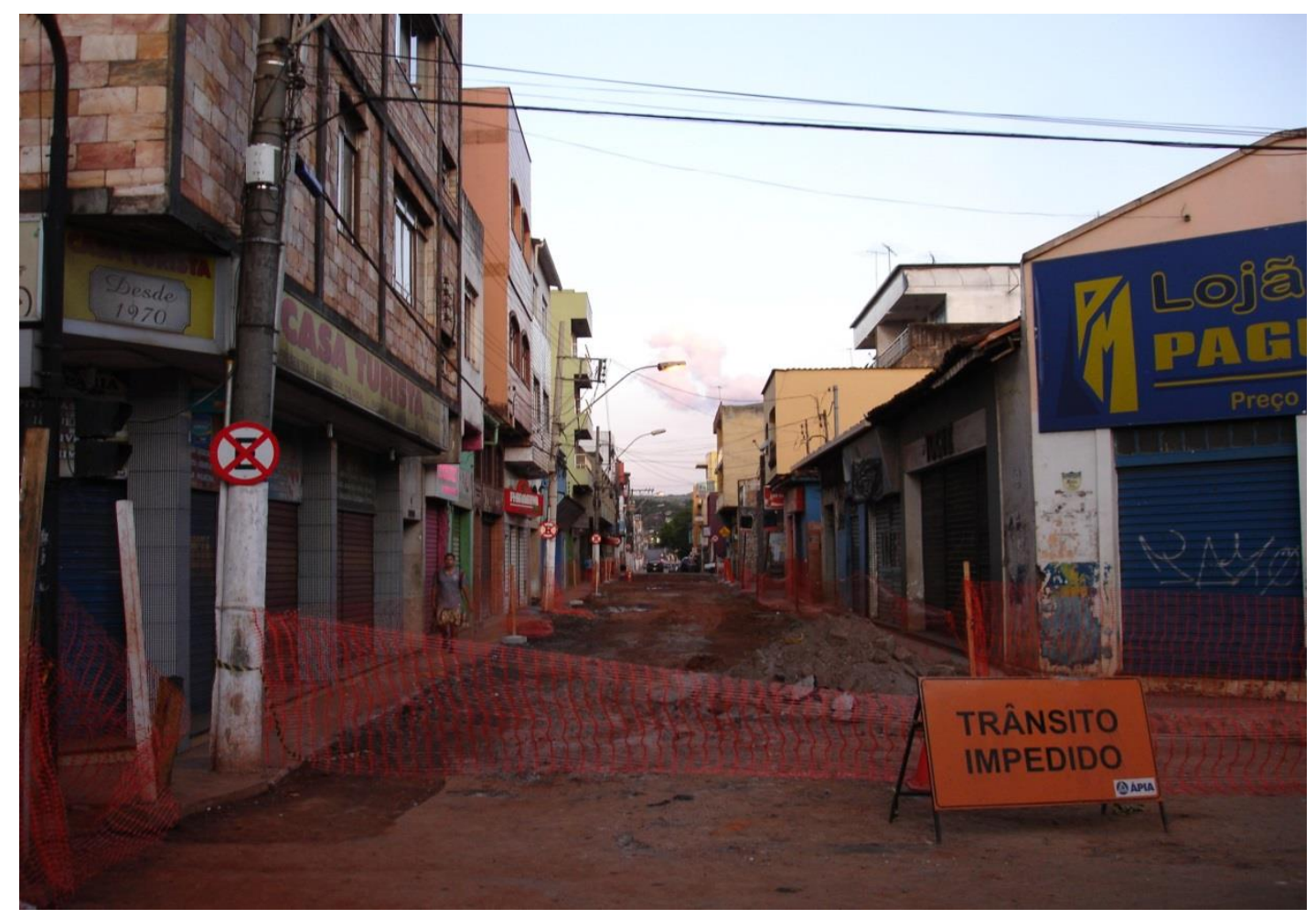

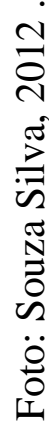

Figura 28 (Anexo 2): Contrate da Rua Marechal Floriano. 

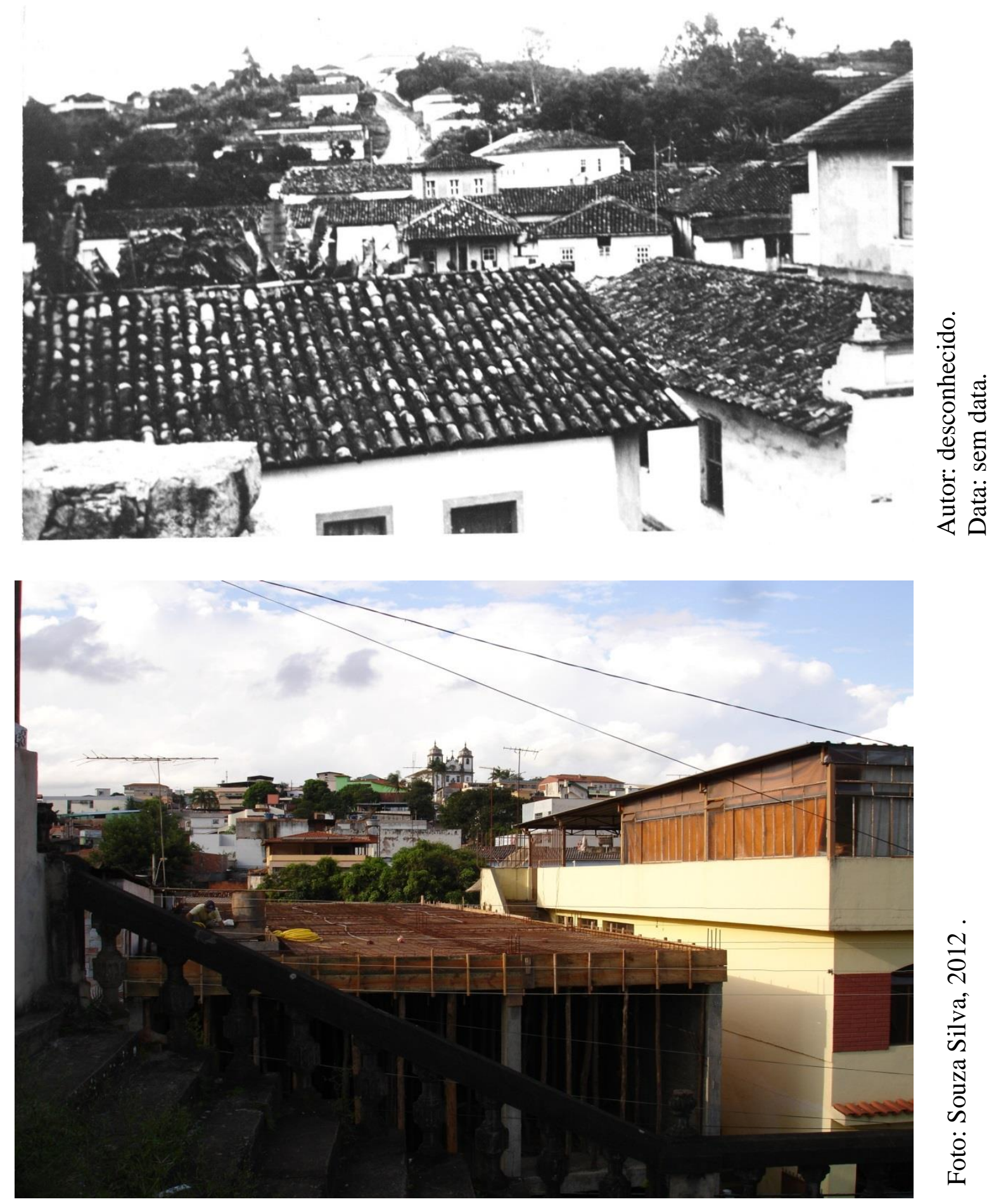

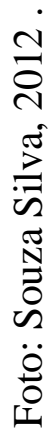

Figura 29 (Anexo 2): Contraste da área da Matriz de Nossa Senhora da Conceição e Centro. 

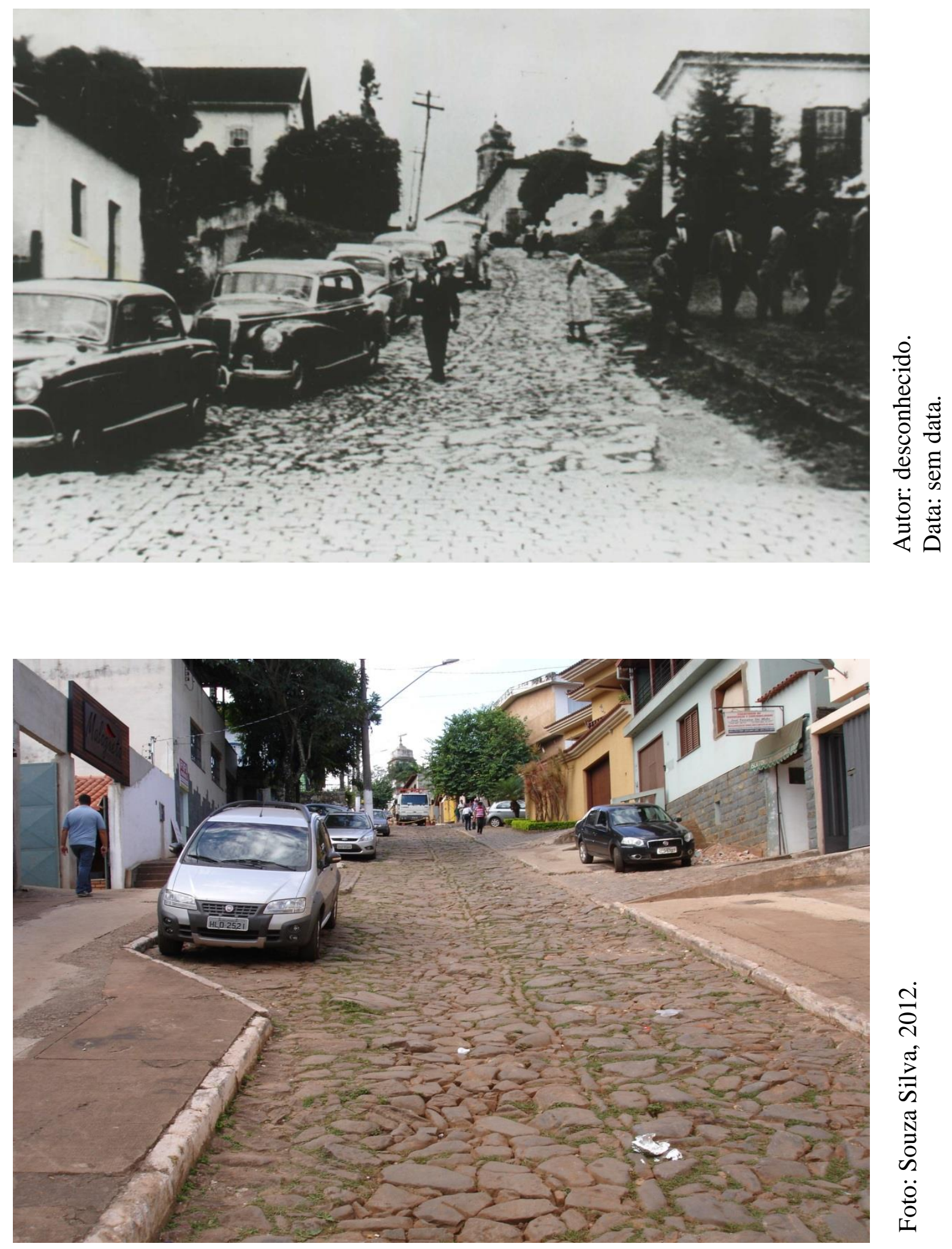

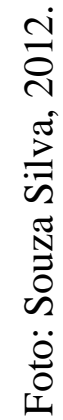

Figura 30 (Anexo 2): Contraste da Rua Padre João Pio. 

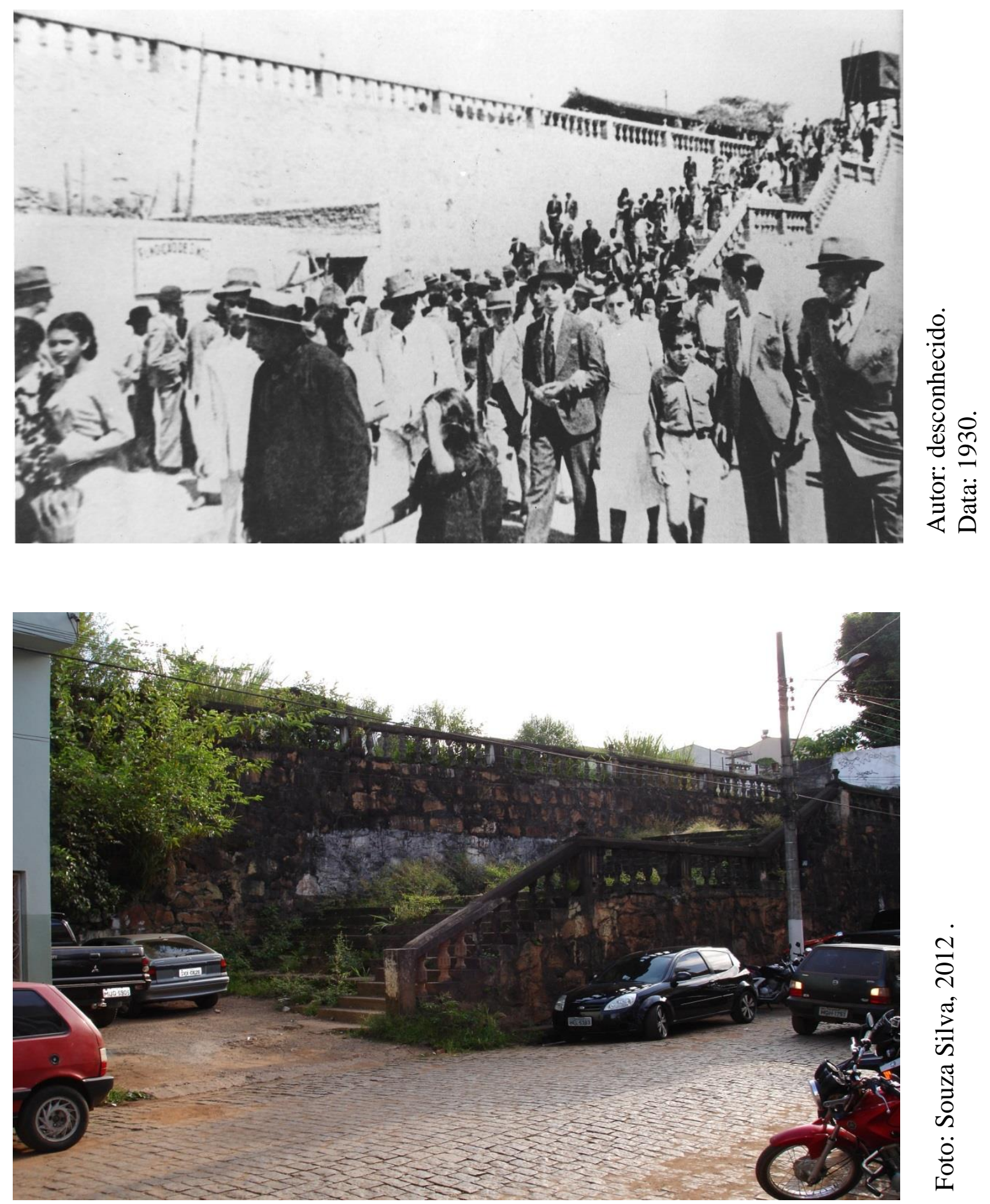

Figura 31 (Anexo 2): Contraste da escadaria da estação ferroviária de Congonhas. 

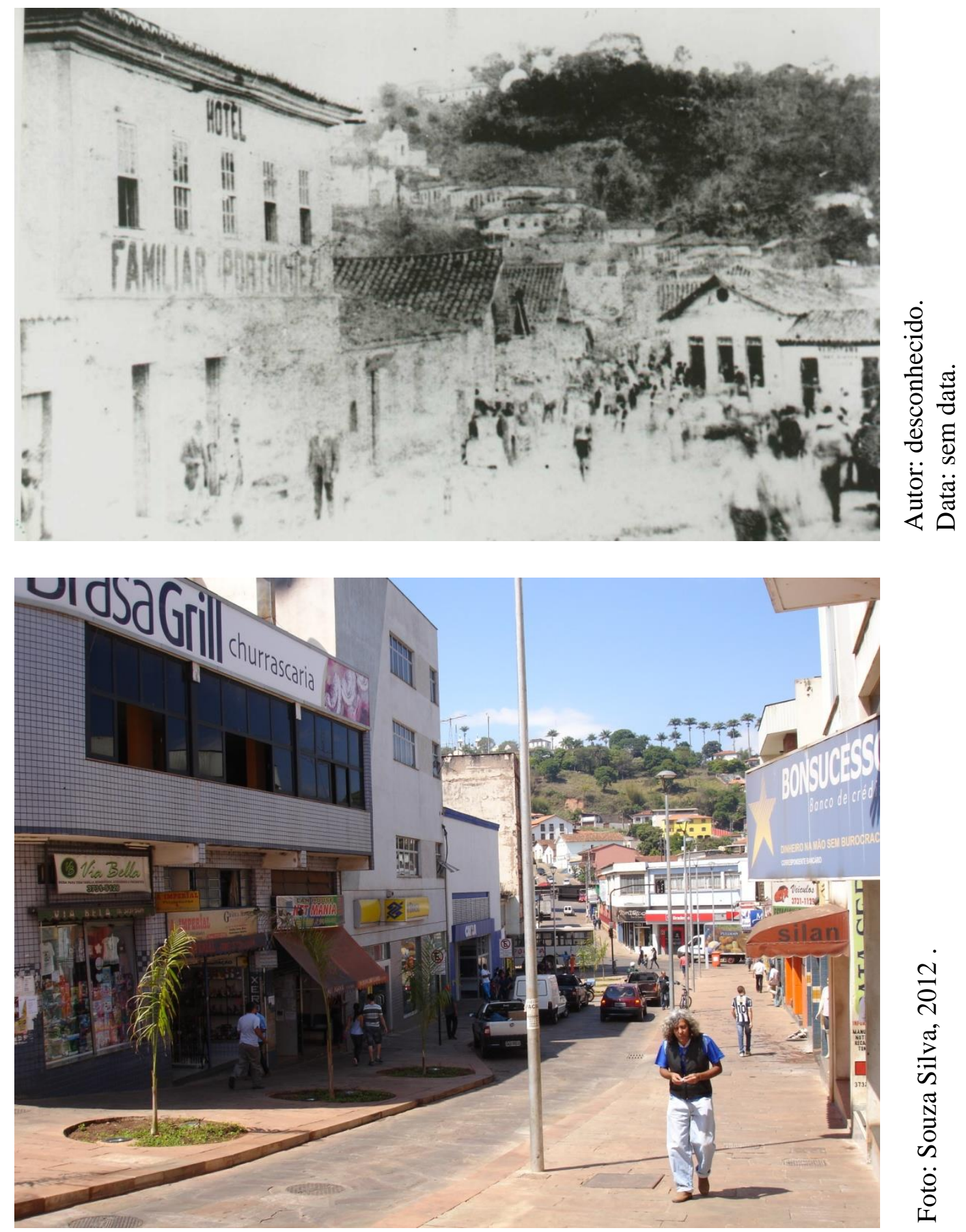

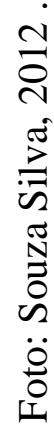

Figura 32 (Anexo 2): Contraste da Praça Dr. Mário Rodrigues Pereira. 

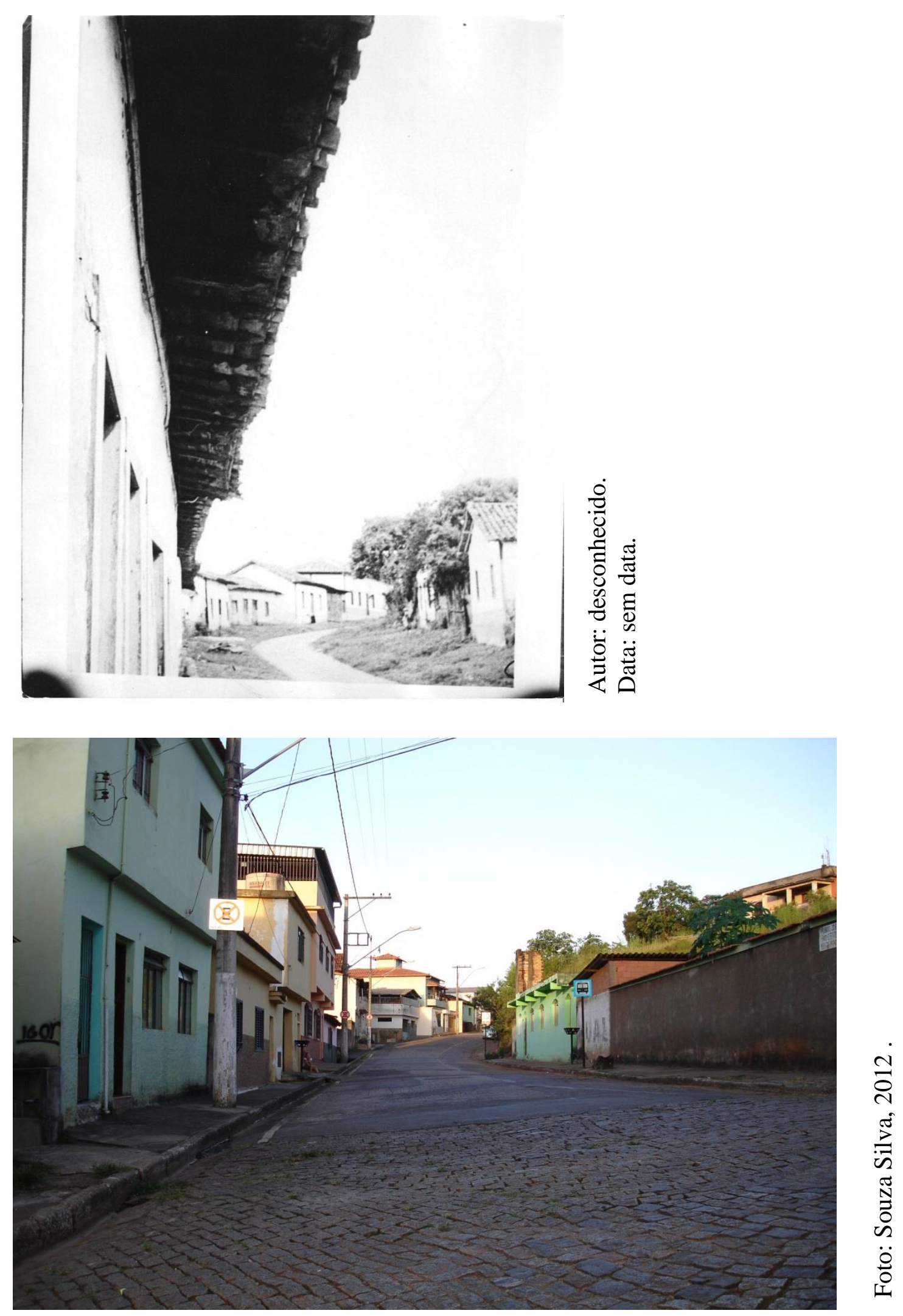

Figura 33 (Anexo 2): Contraste da Rua Visconde de Congonhas. 

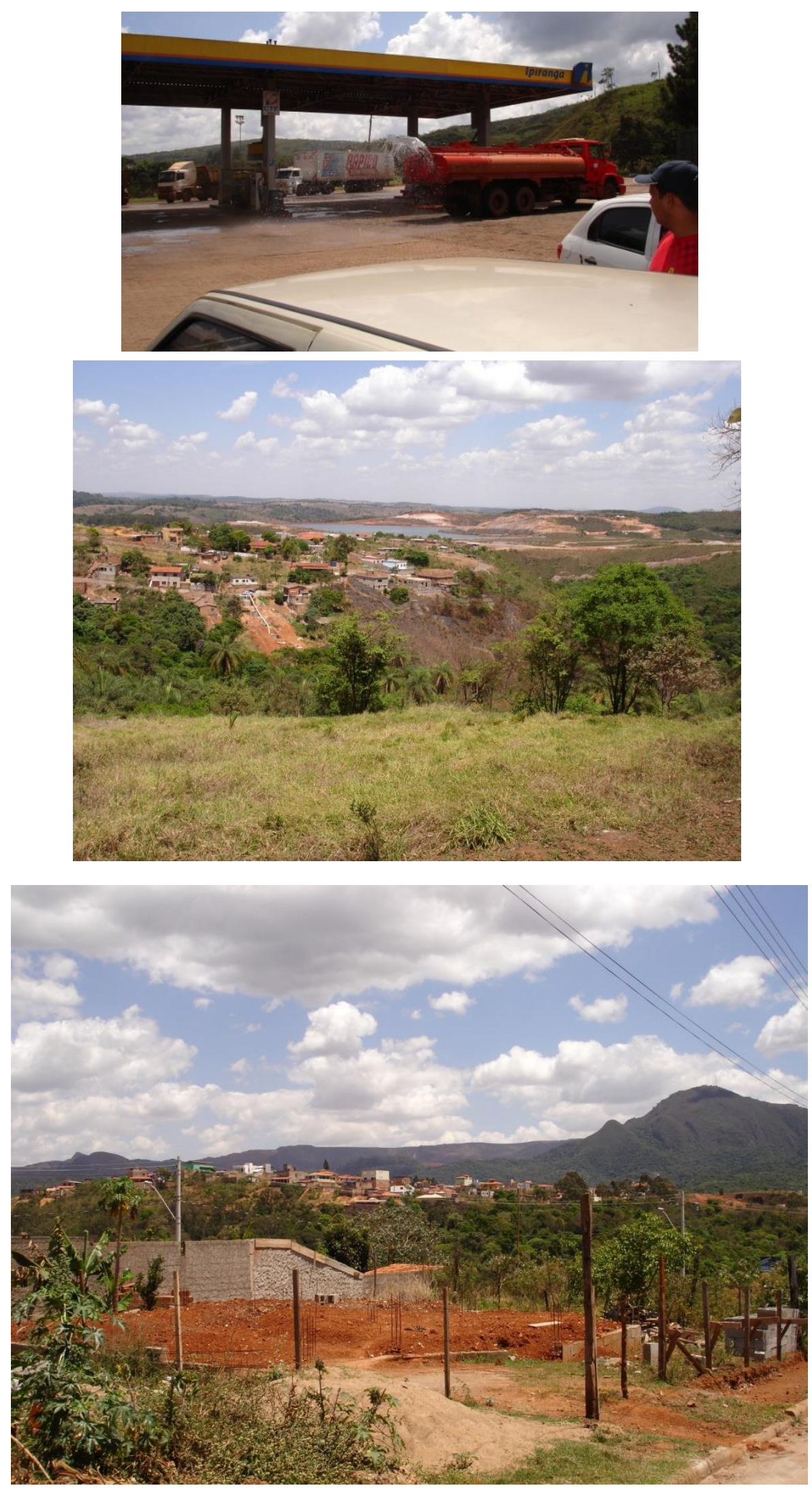

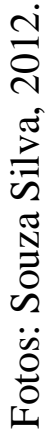

Figura 34 (Anexo 2): De cima para baixo: caminhão pipa jogando água na poeira, encontro entre cidade e mineração e bairro próximo à mineradora. 

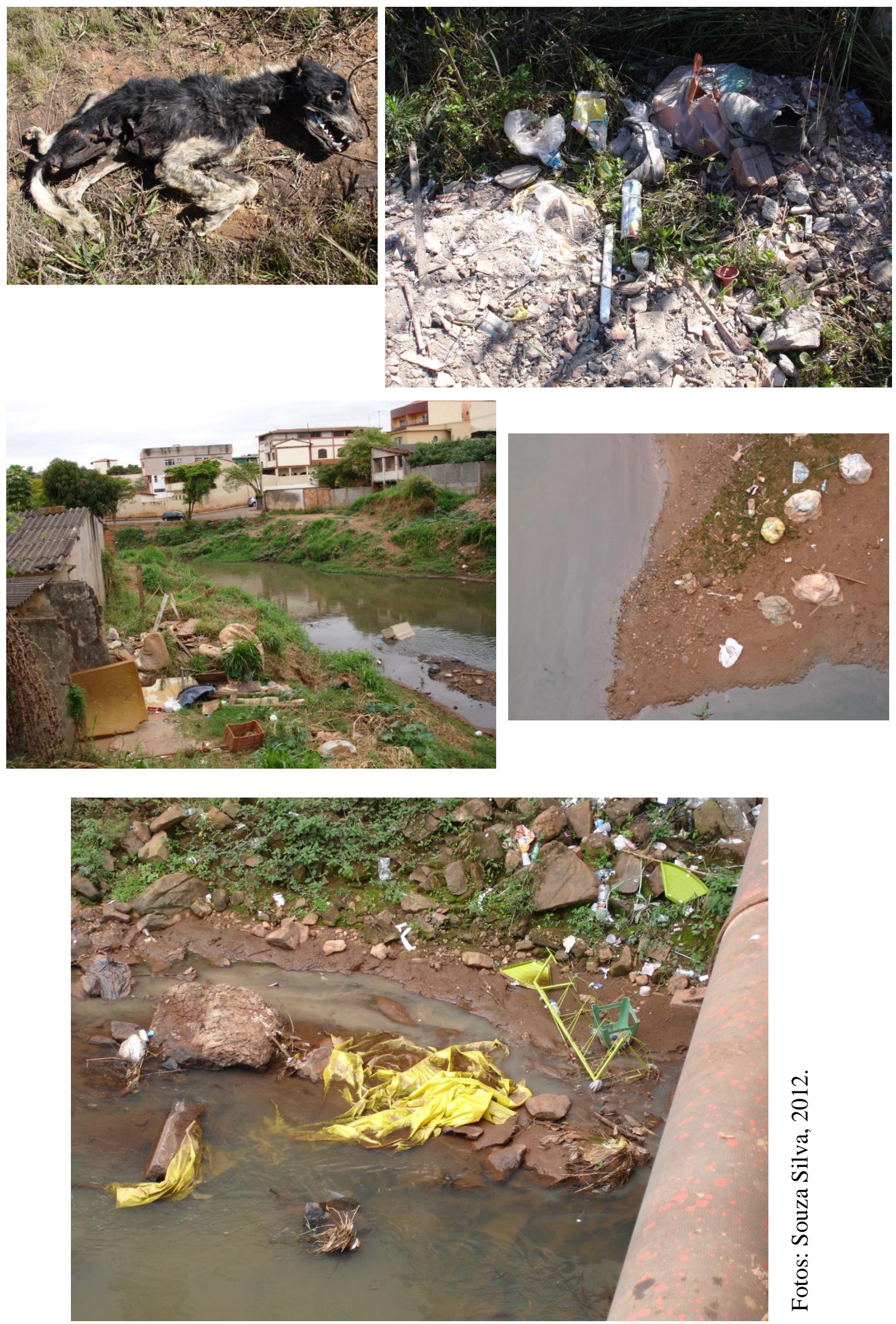

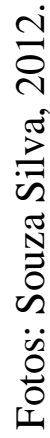

Figura 35 (Anexo 2): Acima: animal morto e lixo próximo ao Córrego dos Macaquinhos. Abaixo: lixo e poluentes no Rio Maranhão. 

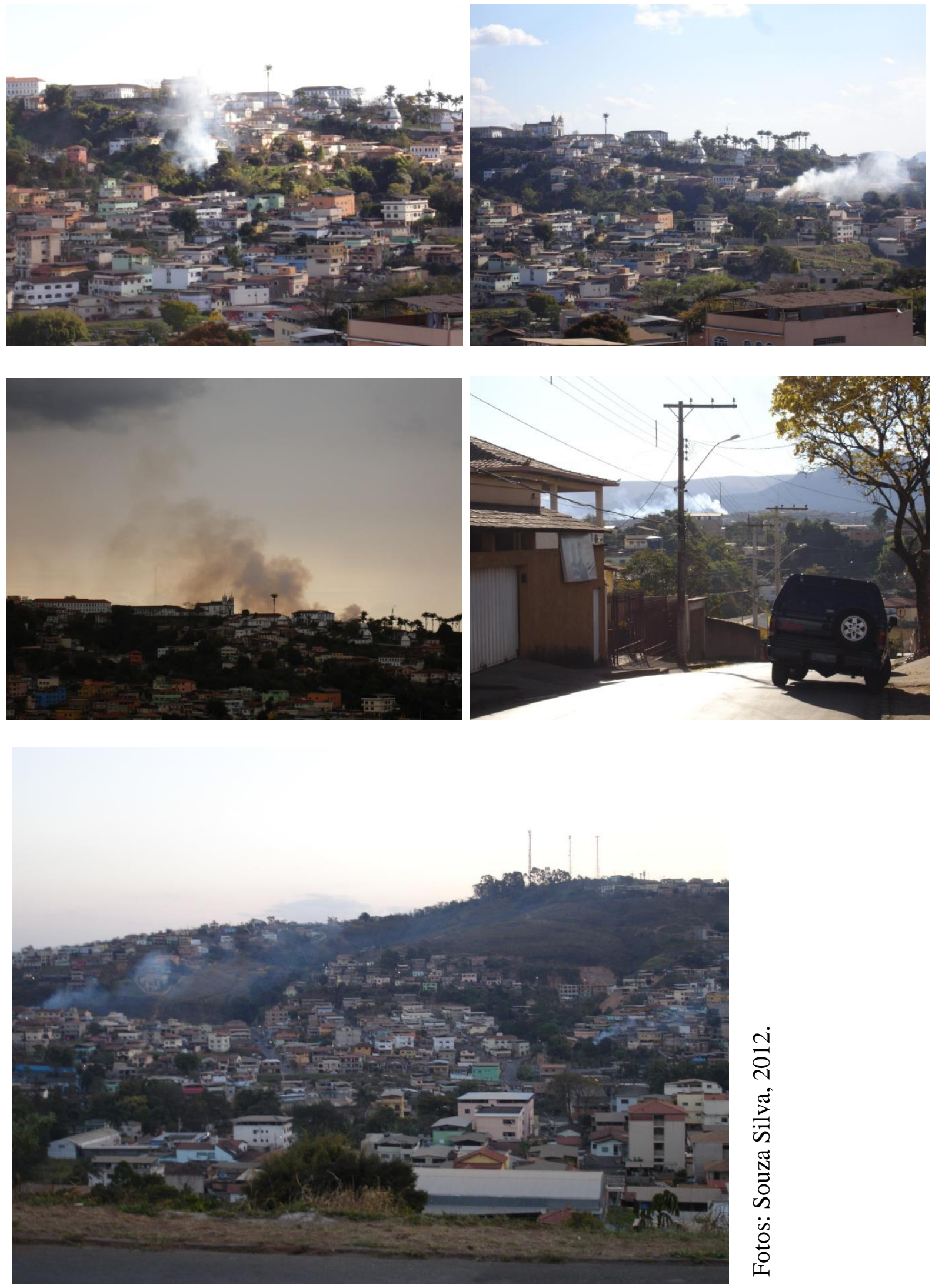

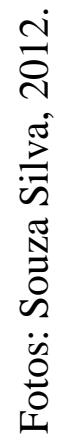

Figura 36 (Anexo 2): Incêndios provocados pela população de Congonhas. 


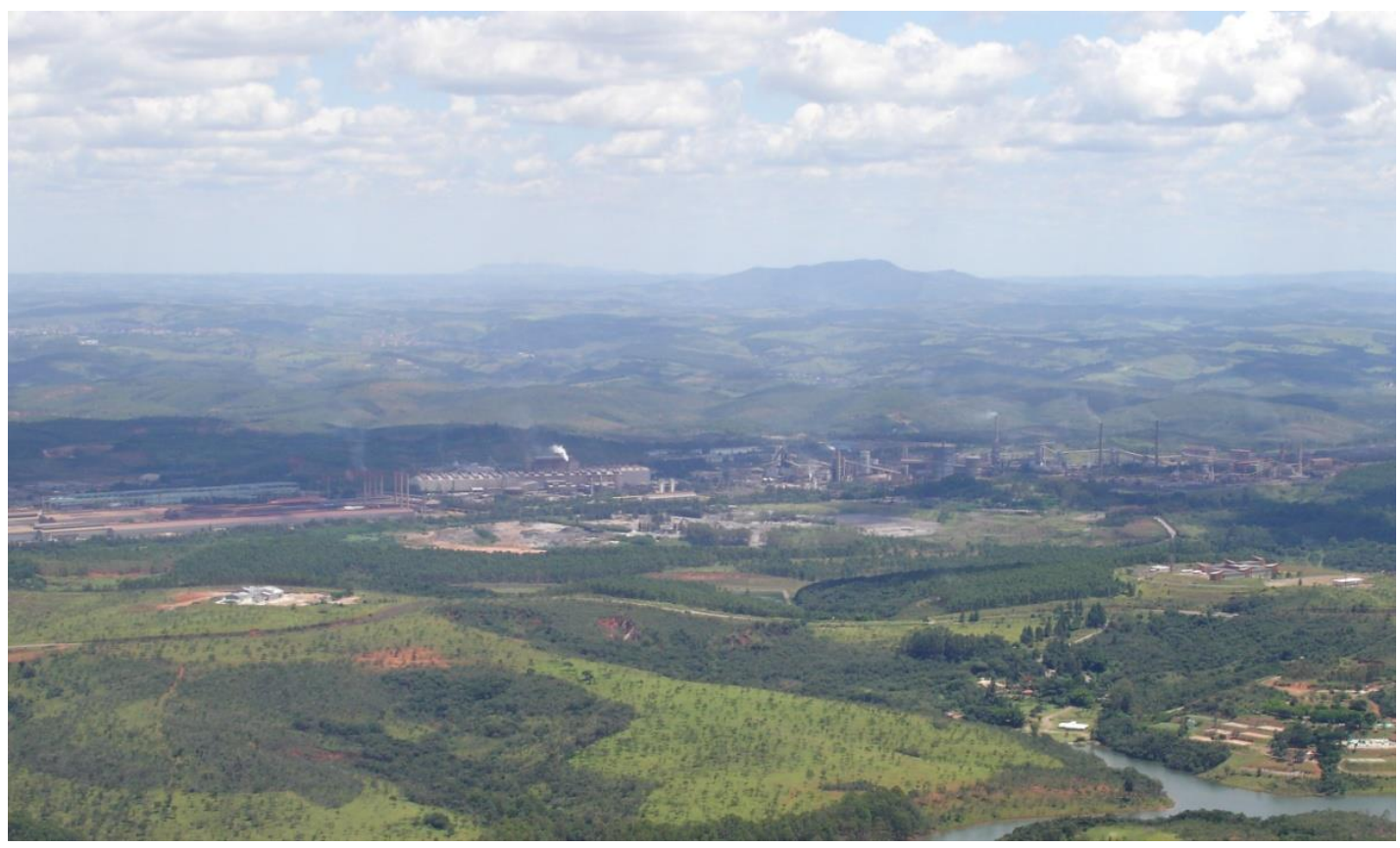

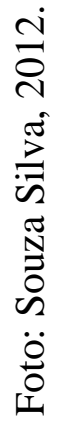

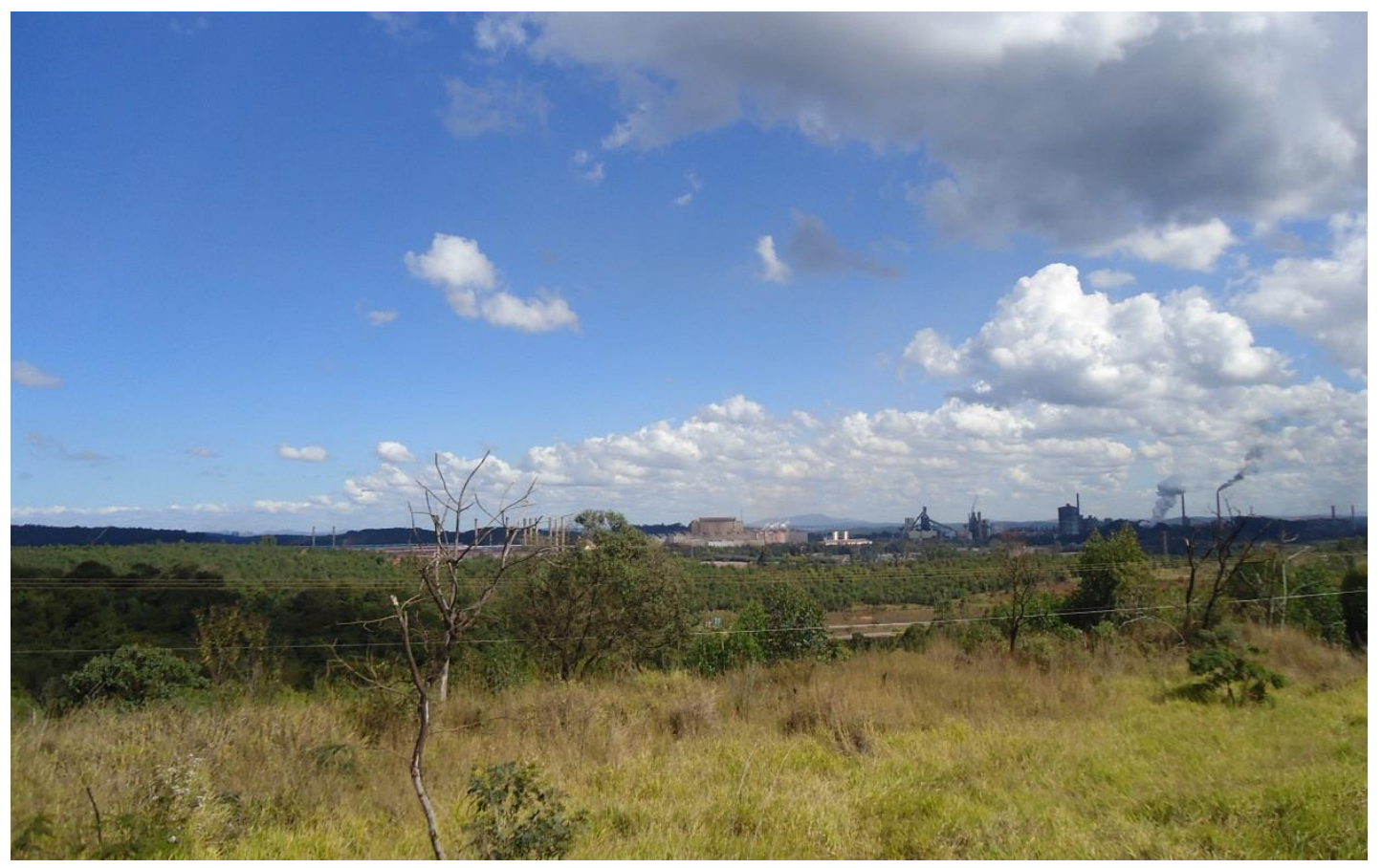

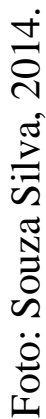

Figura 37 (Anexo 2): Instalações industriais da Gerdau Açominas. 

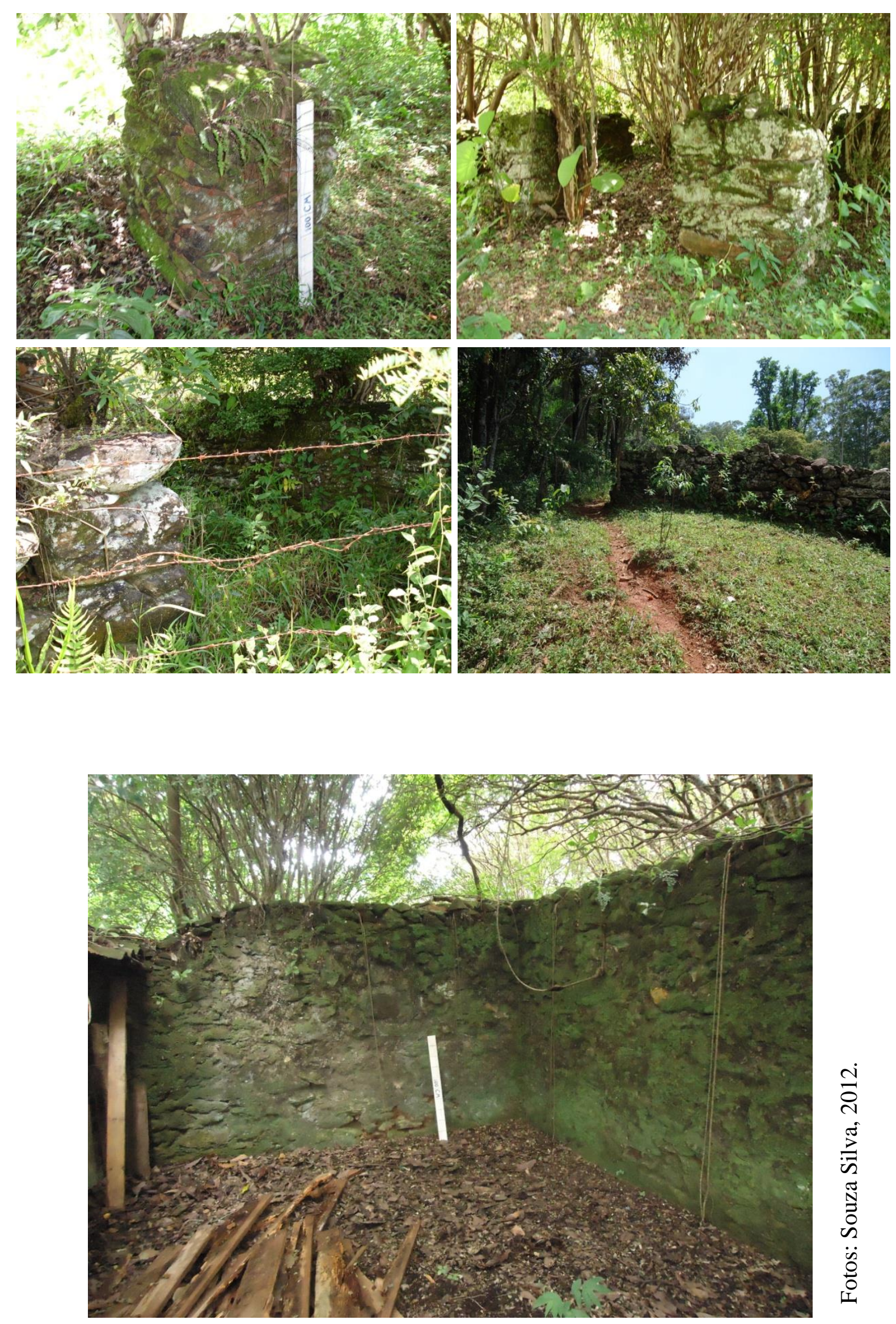

Figura 38 (Anexo 2): Fazenda do Faria: paiol, moinho, curral e senzala. 

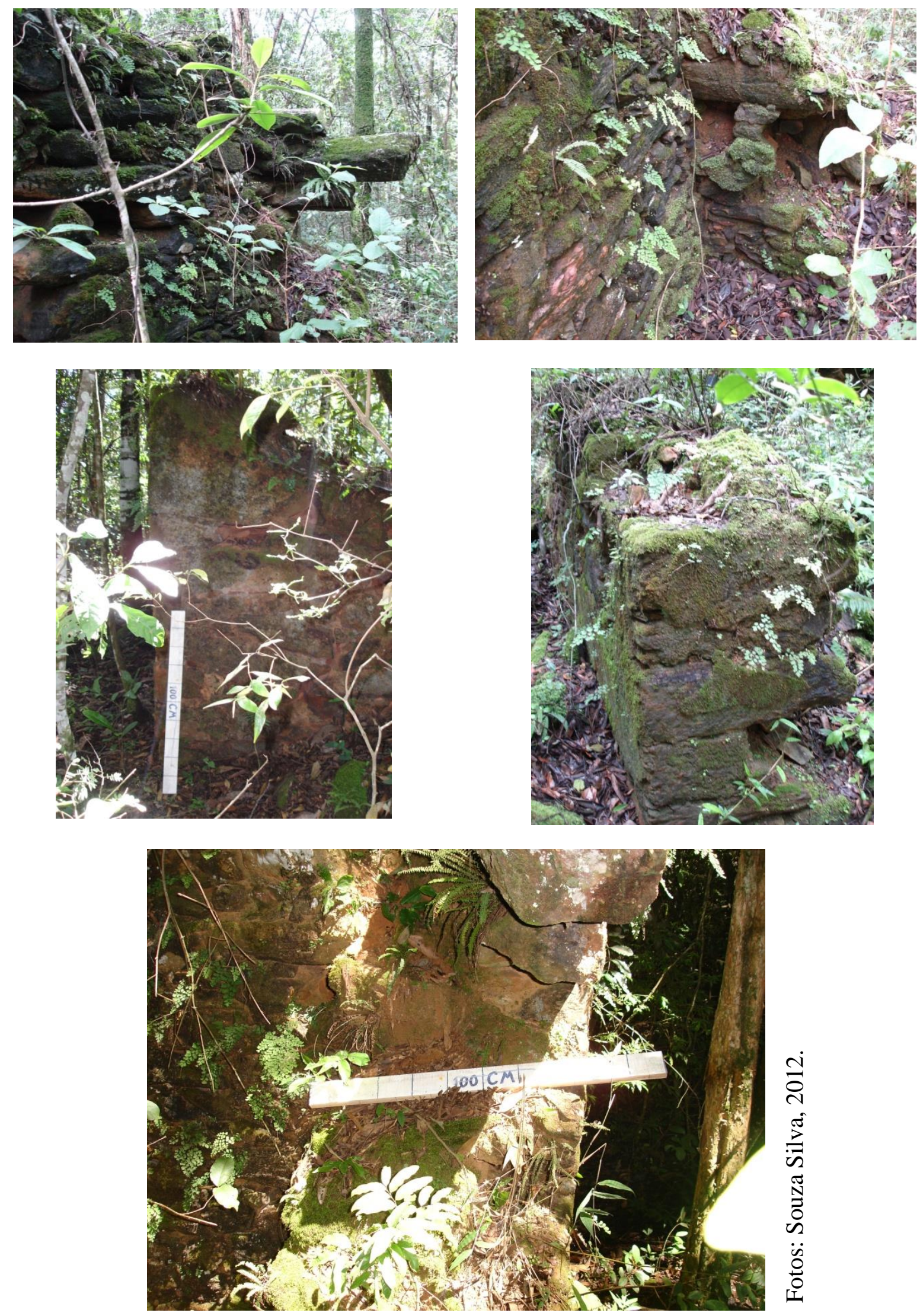

Figura 39 (Anexo 2): Ruínas da Igreja de Santo Antônio em Congonhas. 

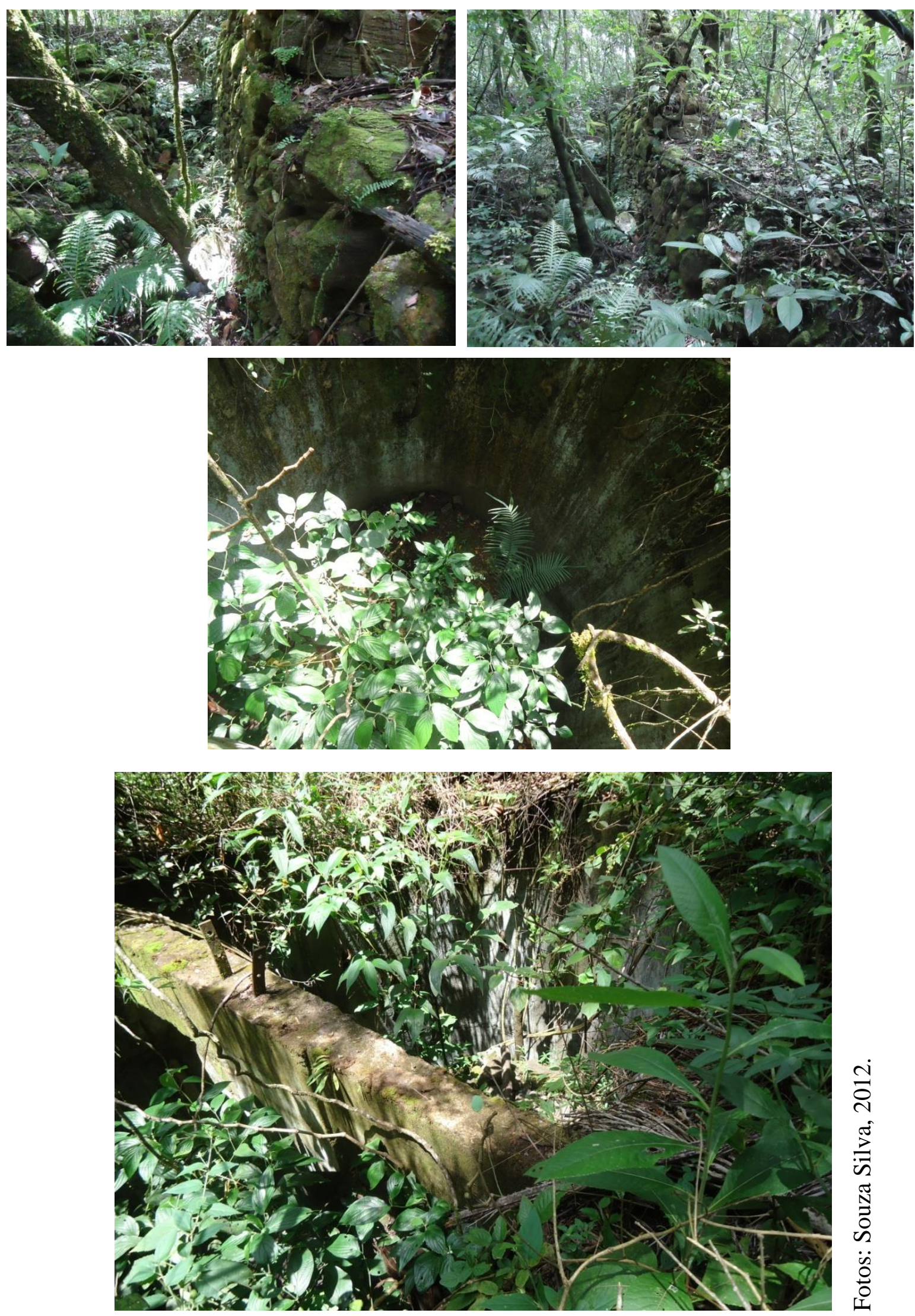

Figura 40 (Anexo 2): Acima - estruturas de garimpo. Abaixo estrutura de concreto. 

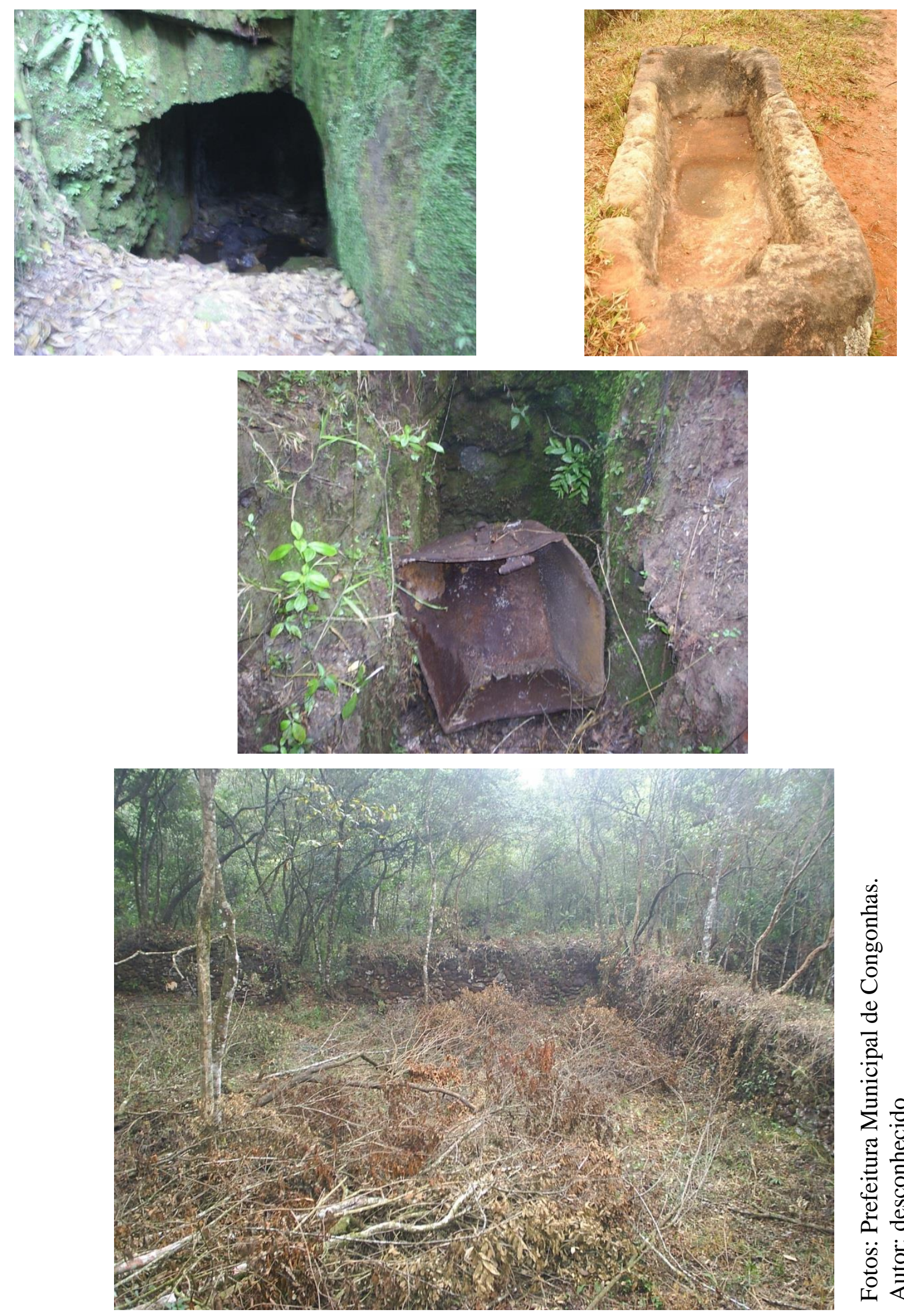

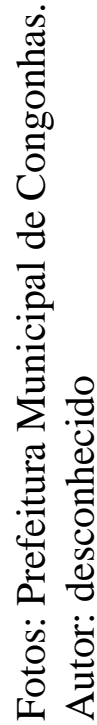

Figura 41 (Anexo 2): Mina do Veeiro. 

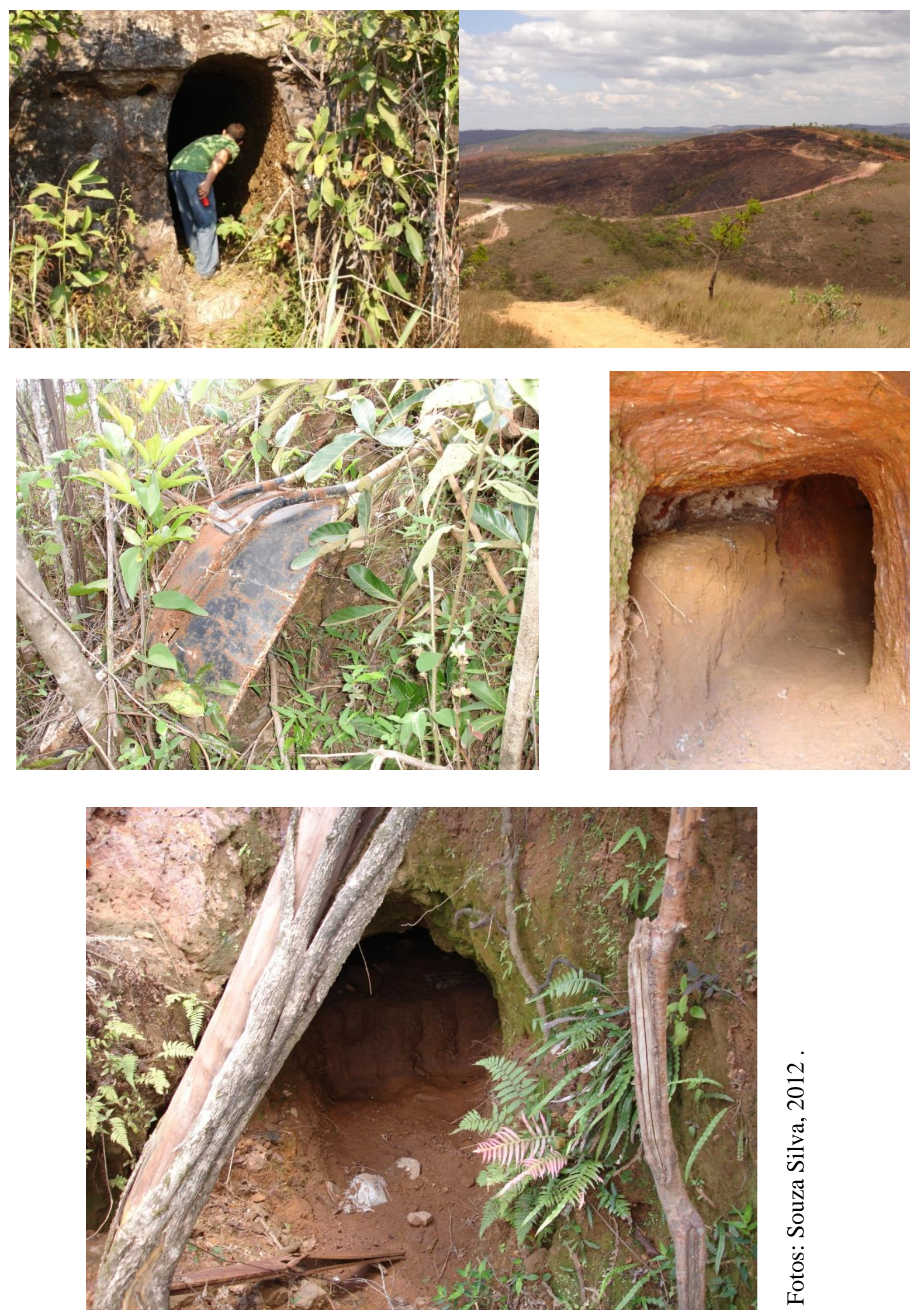

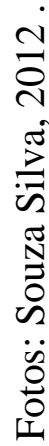

Figura 42 (Anexo 2): Mina da Soledade. 

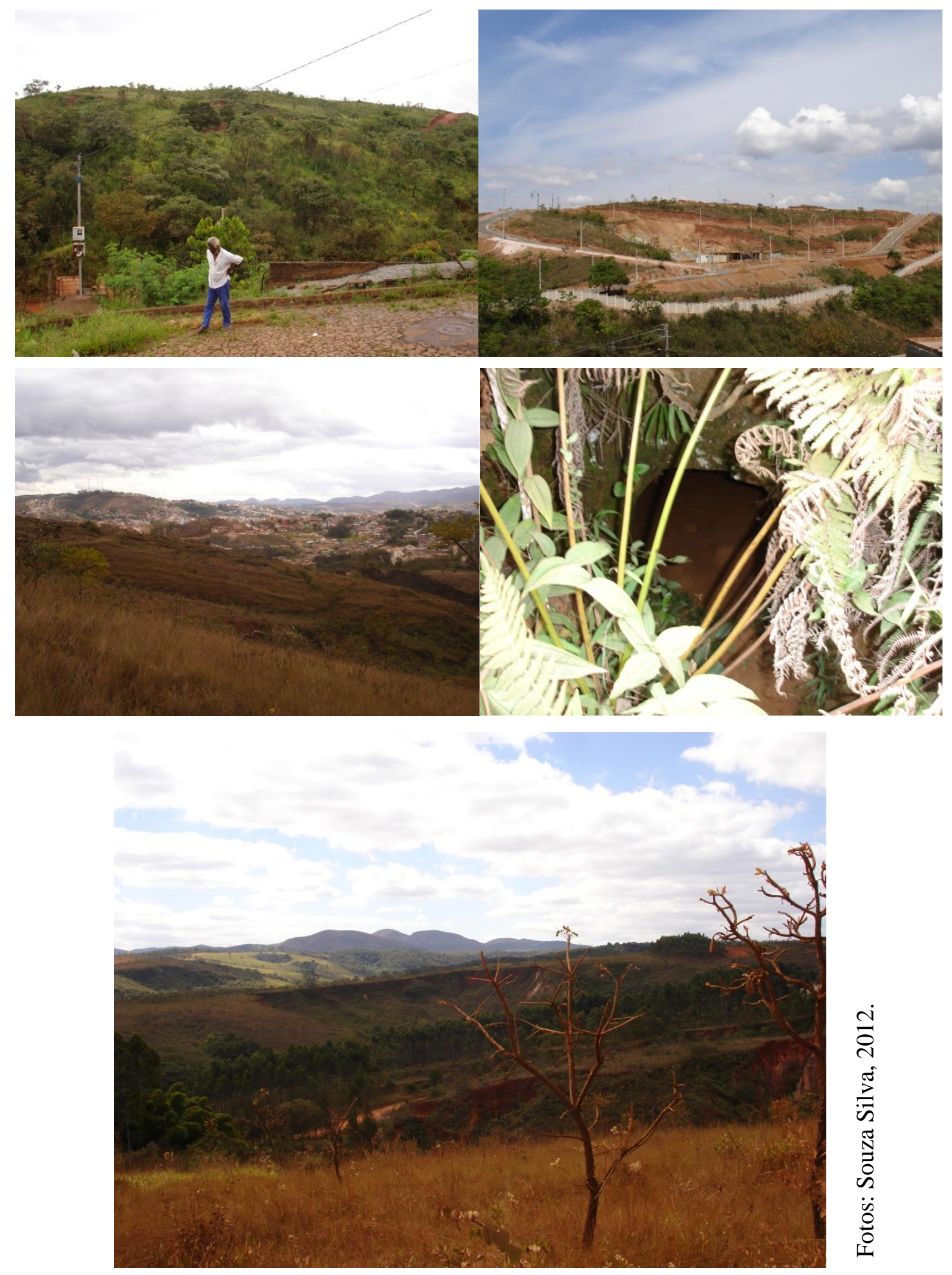

Figura 43 (Anexo 2): Mina das Goiabeiras. 

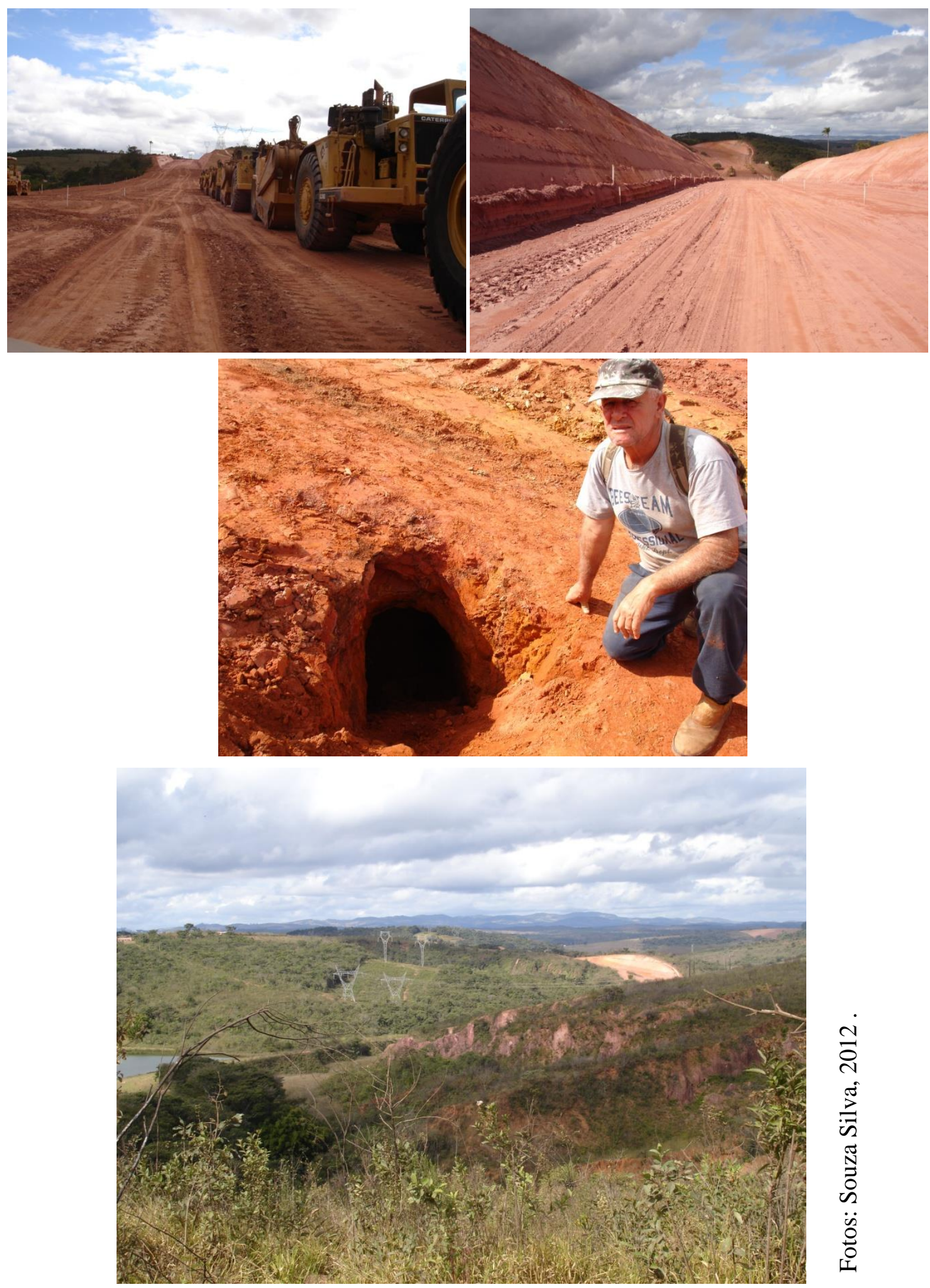

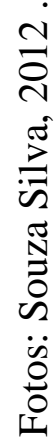

Figura 44 (Anexo 2): Mina do Redondo em Alto Maranhão. 

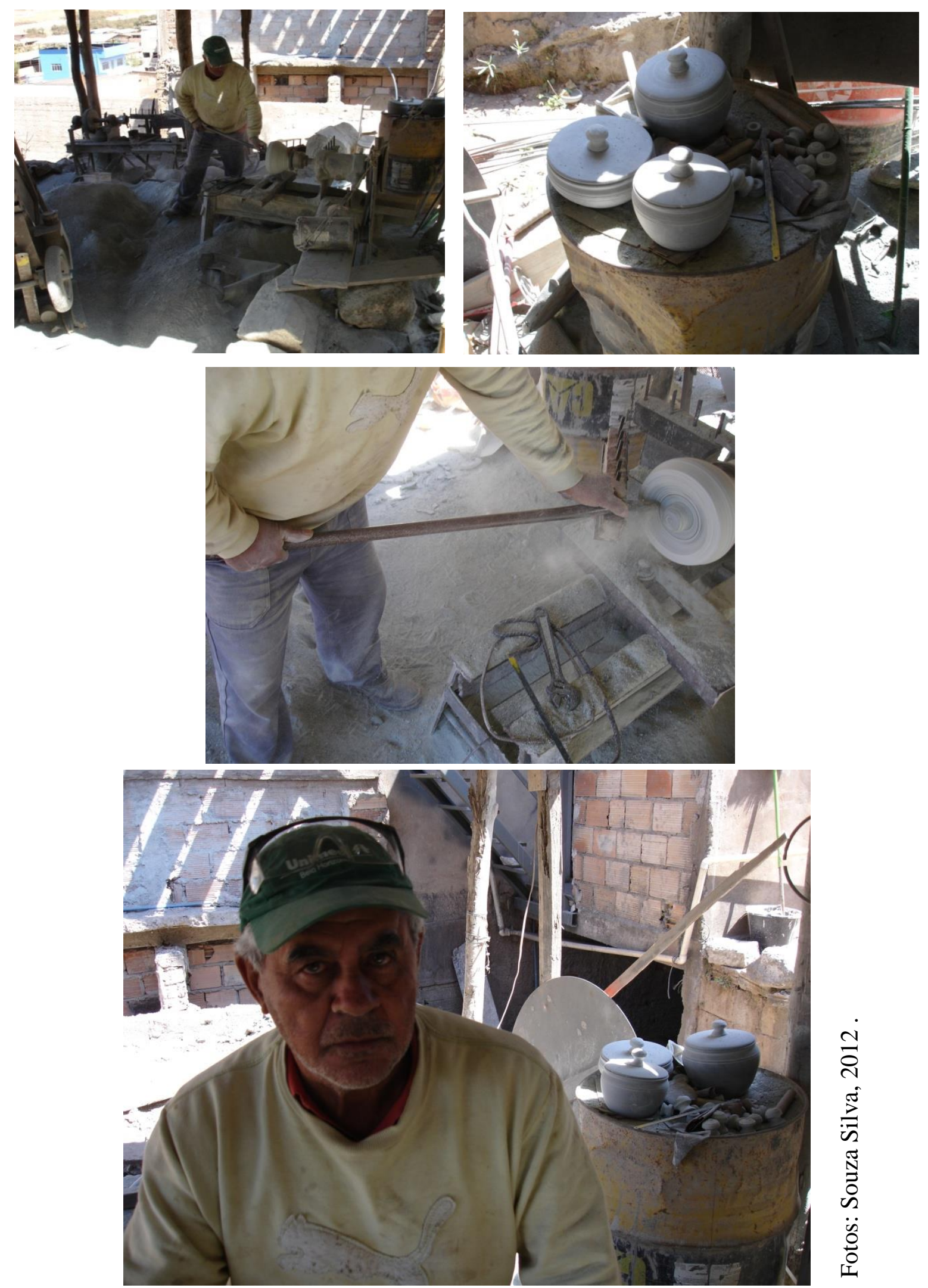

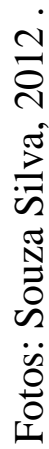

Figura 45 (Anexo 2): Artesão ainda em atividade em Congonhas. 

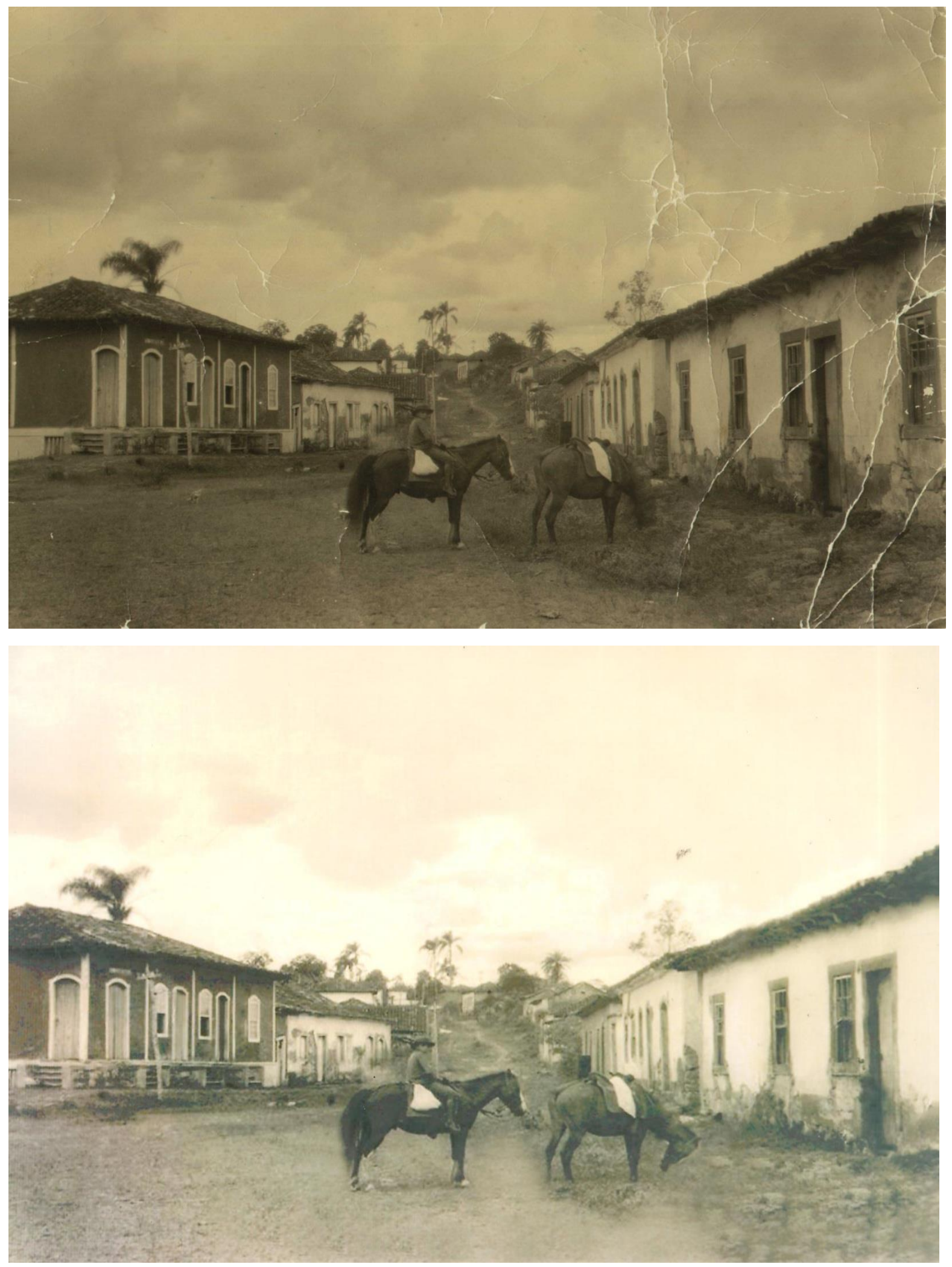

Figura 46 (Anexo 2): Fotografia restaurada da Praça da Matriz em Congonhas ( restauração feita pela empresa de fotografias Foto Profeta, Congonhas, MG). 

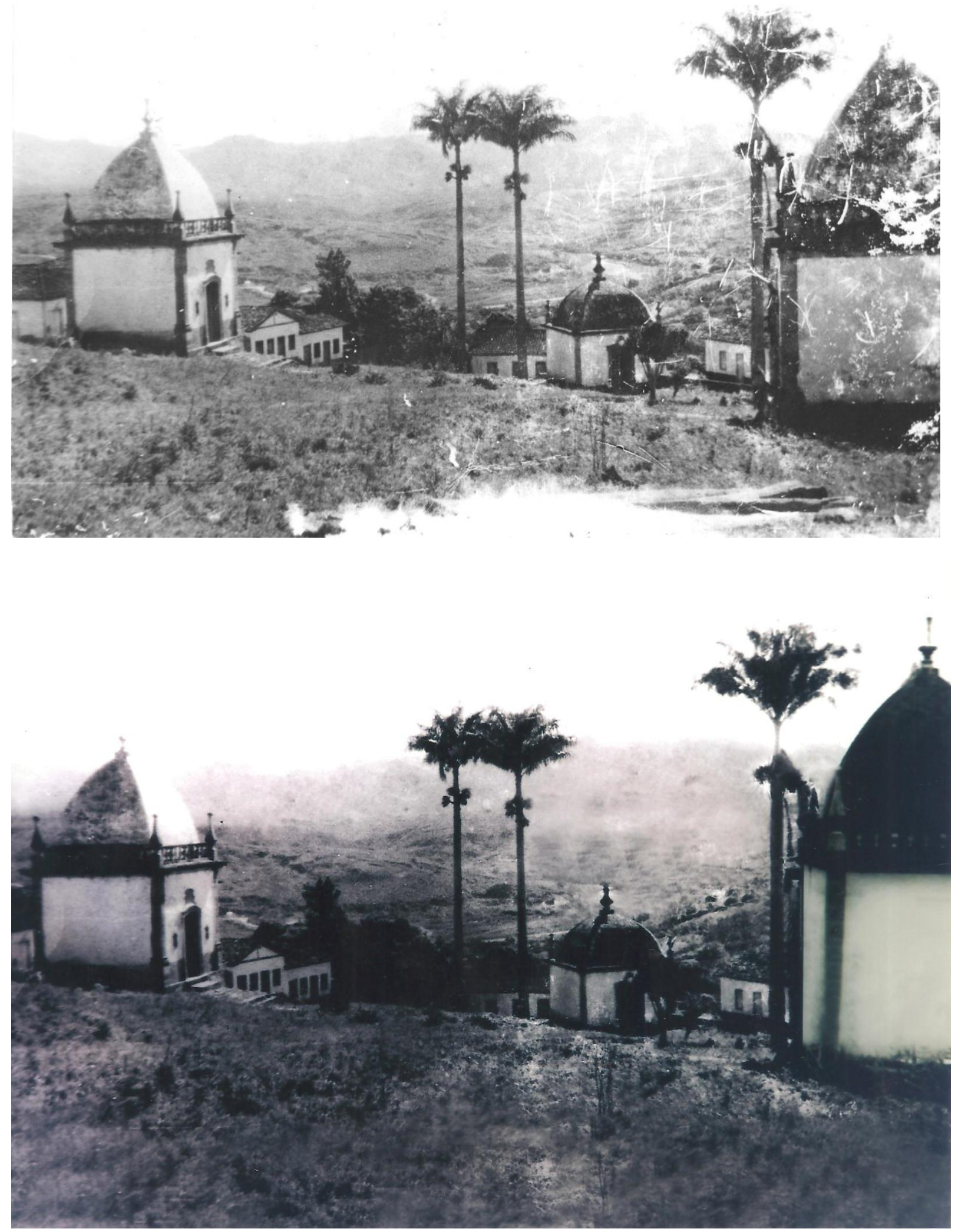

Figura 47: Fotografia restaurada das Capelas dos Passos em Congonhas (restauração feita pela empresa de fotografias Foto Profeta, Congonhas, MG). 


\section{PREFEITURA MUNICIPAL DE CONGONHAS CIDADE DOS PROFETAS}

\section{RELAÇÃO DOS PROPRIETÁRIOS DE IMÓVEIS}

\section{LOTEAMENTO NOVA CONGONHAS (GRAN VIVER)}

NOME: NOVA CONGONHAS EMPREENDIMENTOS IMOBILIÁRIOS S/A.

ÁREA - 442.600,00 $\mathrm{m}^{2}$

CHACREAMENTO DO VIEIRO

NOME: MARIA DO CARMO DA CRUZ

CHÁCARA 07 - DA QUADRA 01 -ÁREA 5.720m²

NOME: CRISTINA SENRA FERNANDES

CHÁCARA 08 DA QUADRA 01 - ÁREA 4.290m²

NOME: ROMULO FERNANDES CARDOSO

CHÁCARA 17 DA QUADRA 02 - ÁREA 3.810m²

$\underline{\text { CHACREAMENTO ÁGUA BOA }}$

NOME: LUIZ RODRIGUES DA SILVA

CHÁCARA 02- QUADRA 11 - ÁREA 2.010m²

NOME: MALVINA LARA DE MOURA E ITAMAR SOARES DE ANDRADE

CHÁCARAS 11e 12 DA QUADRA $02-4.040 \mathrm{~m}^{2}$

NOME: FLÁVIO DE SOUZA ZILLE

CHÁCARAS 13 e 14 DA QUADRA 01 - ÁREA $7.567 \mathrm{~m}^{2}$

Atenciosamente,

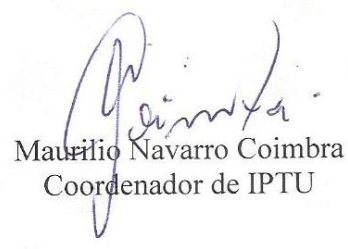

PRAÇA PRESIDENTE KUBITSCHEK, 135 - CENTRO - CONGONHAS - MG - CEP: 36415-000 - TEL.: (31) 3731-1300 - FAX: (31) 3731-1188 - www.congonhas.mg.gov.br

Figura 48 (anexo 2): Lista de moradores de áreas localizadas em sítios arqueológicos. 


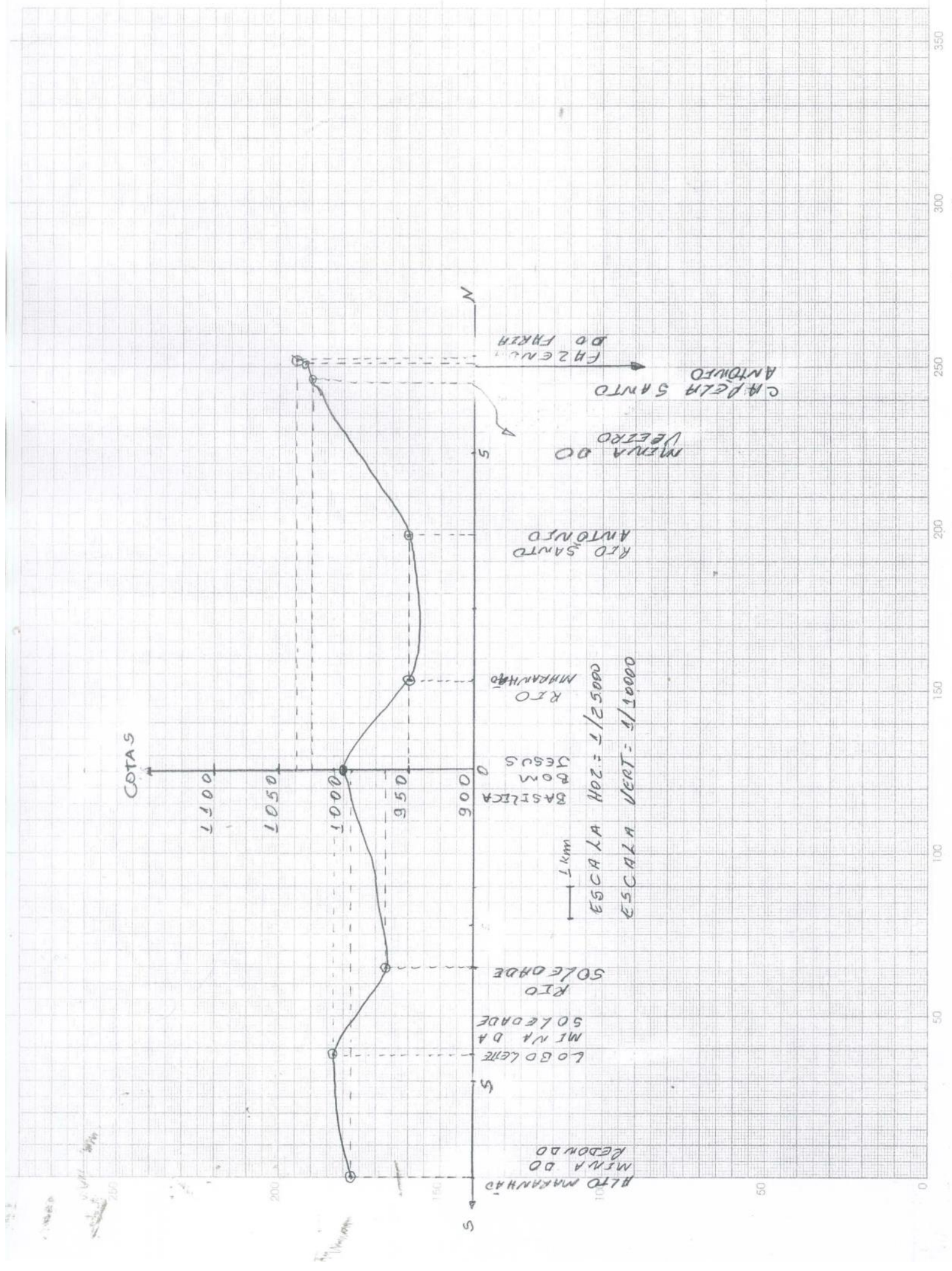

Figura 49 (anexo 2): Planta planialtimétrica dos sítios arqueológicos da pesquisa. 


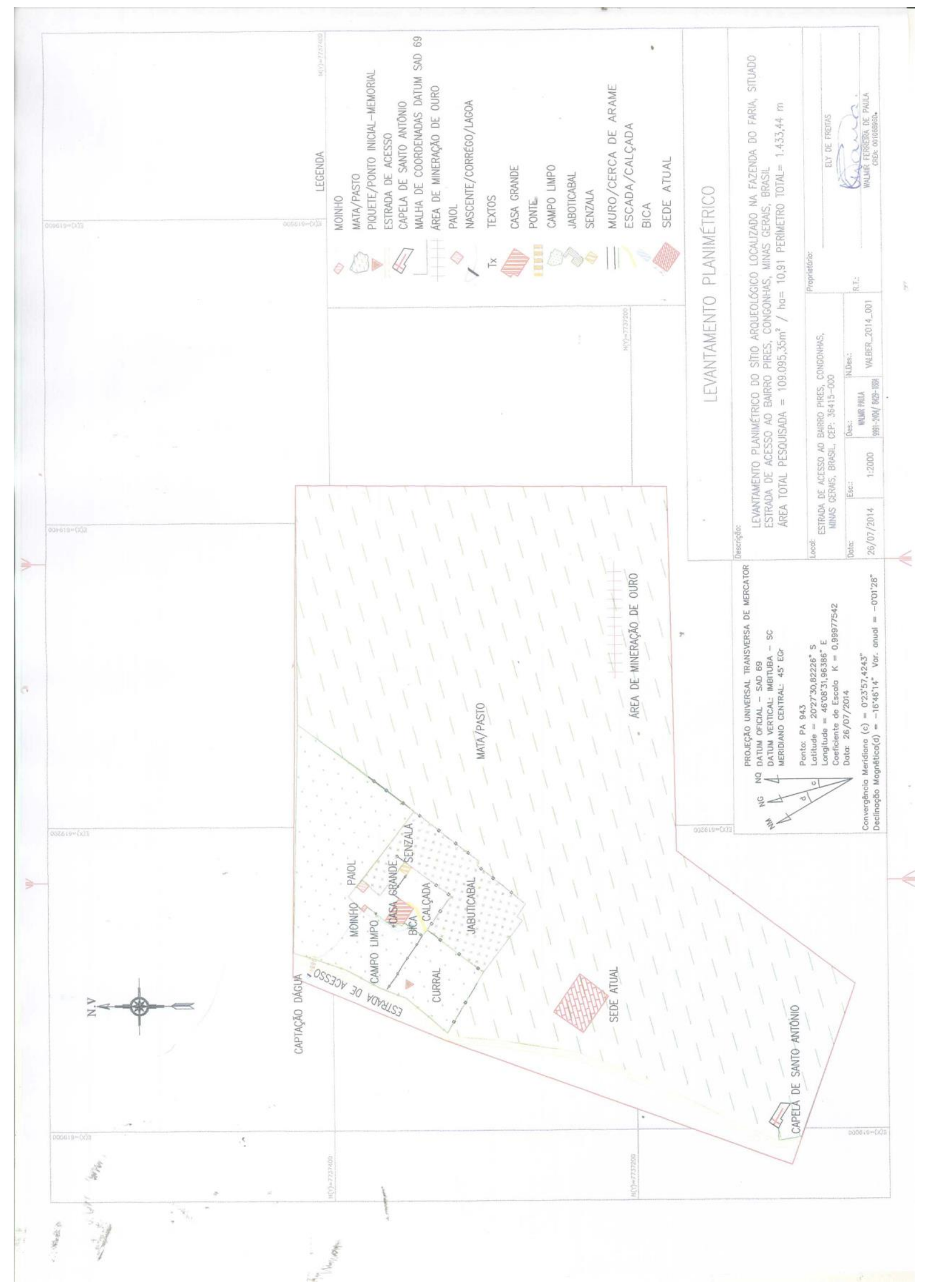

Mapa 1 (anexo 2): Planta da Fazenda do Faria com escala 1:2000. 


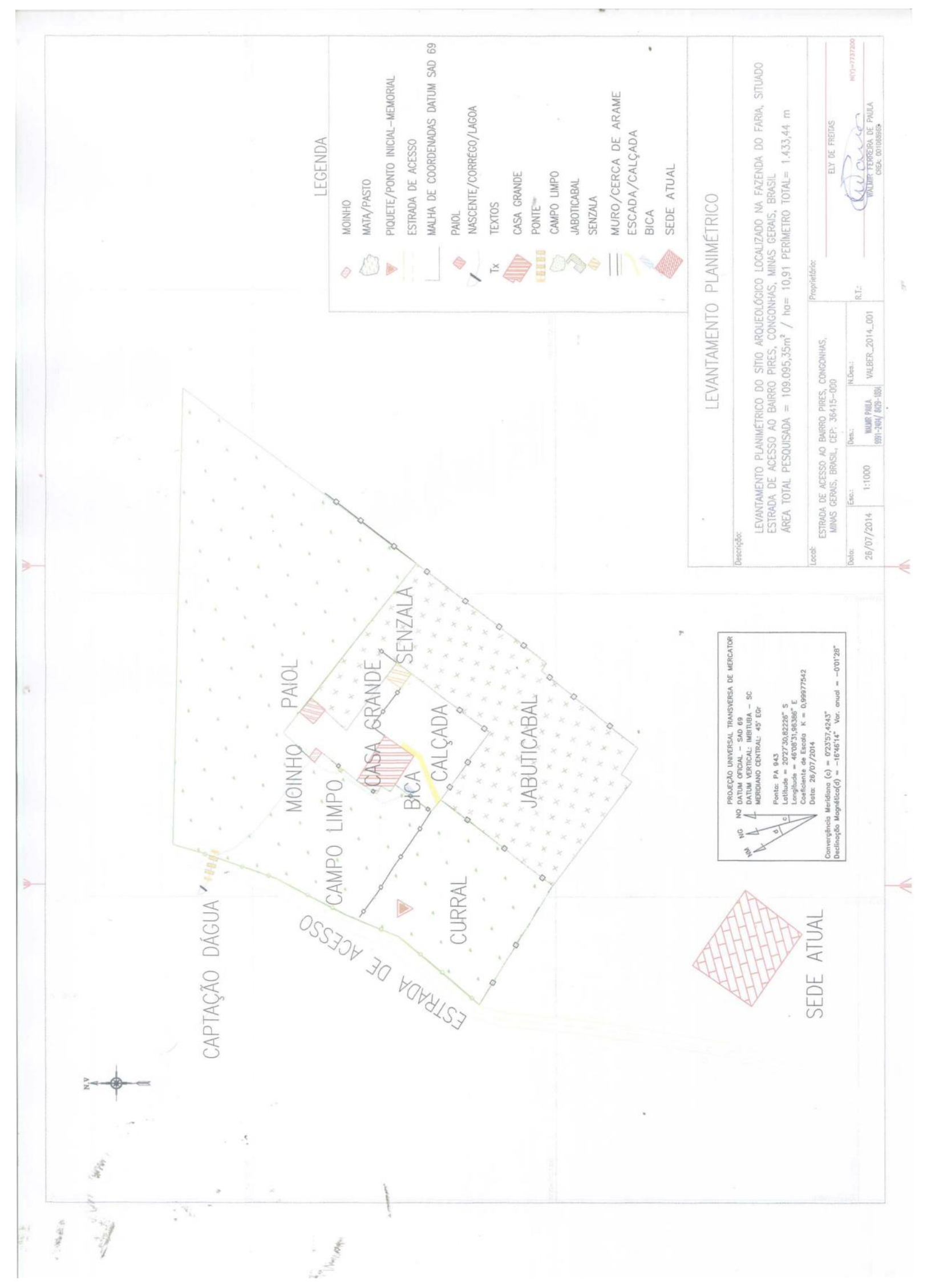

Mapa 2 (anexo 2): Planta da Fazenda do Faria com escala 1:1000. 


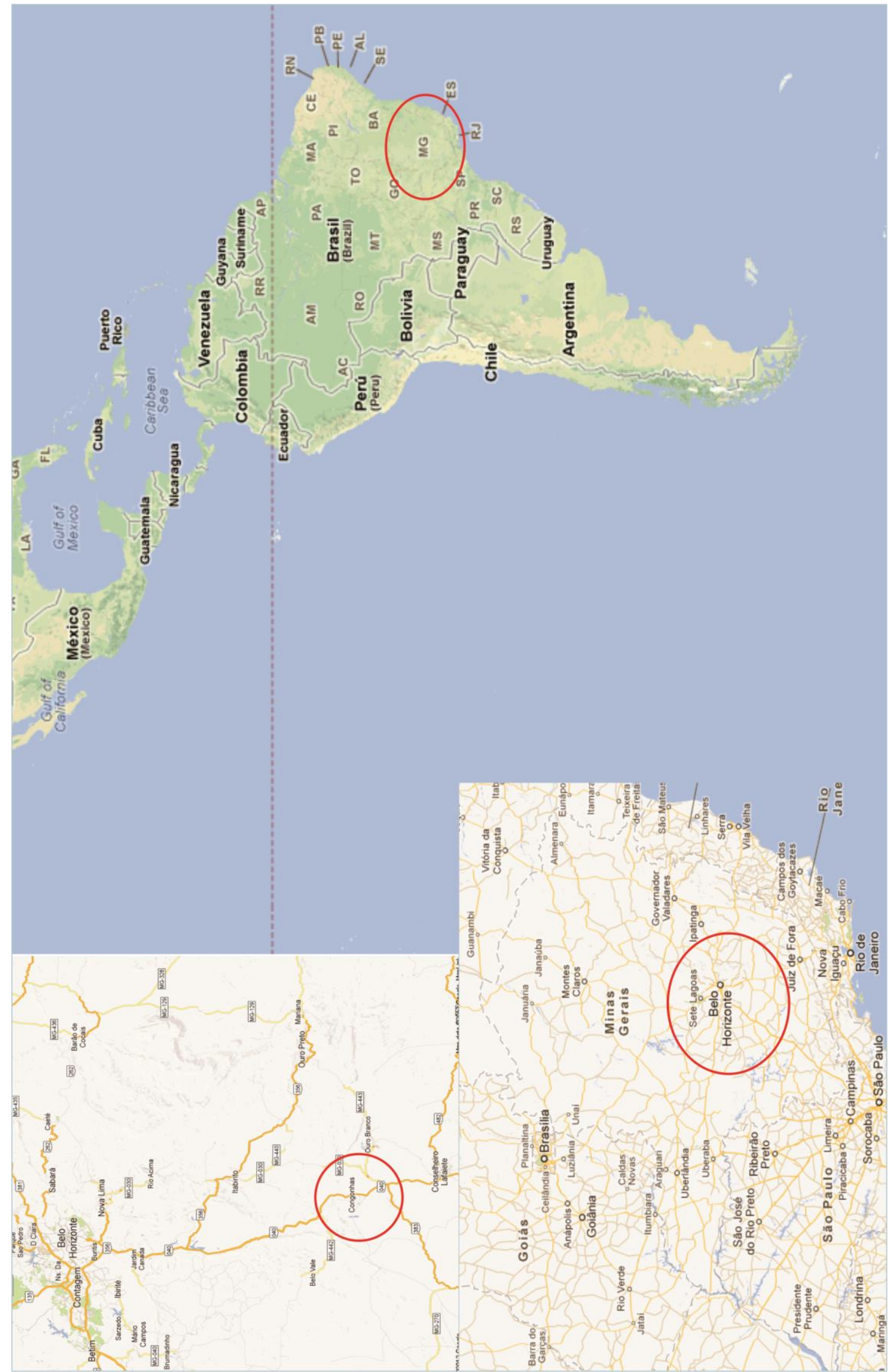

Mapa 3 (Anexo 2): Localização de Congonhas no mapa mundial sobre mapa Google Maps. 
